\title{
Przedsiębiorczość lekarzy dentystów w kontekście relacji z pacjentami
}


$\frac{3}{40}$ 
Agnieszka Bukowska-Piestrzyńska

\section{Przedsiębiorczość lekarzy dentystów w kontekście relacji z pacjentami}


Agnieszka Bukowska-Piestrzyńska - Katedra Funkcjonowania Gospodarki

Wydział Ekonomiczno-Socjologiczny, Uniwersytet Łódzki

90-214 Łódź, ul. Rewolucji 1905 r. nr 41/43

\section{RECENZENT}

Henryk Mruk

\section{KOREKTA}

Jacek Lewandowski

\section{PROJEKT OKŁADKI}

Piotr Piestrzyński

Wydrukowano z gotowych materiałów dostarczonych do Wydawnictwa UŁ

(C) Copyright by Uniwersytet Łódzki, Łódź 2013

Wydane przez Wydawnictwo Uniwersytetu Łódzkiego

Wydanie I. W.06225.13.0.H

ISBN (wersja drukowana) 978-83-7525-901-8

ISBN (ebook) 978-83-7969-192-0

Wydawnictwo Uniwersytetu Łódzkiego

90-131 Łódź, ul. Lindleya 8

www.wydawnictwo.uni.lodz.pl

e-mail: ksiegarnia@uni.lodz.pl

tel. (42) 6655863 , faks (42) 6655862 


\section{Spis treści}

Wstęp

Rozdział I Przedsiębiorczość w kreowaniu przewagi konkurencyjnej ..............25

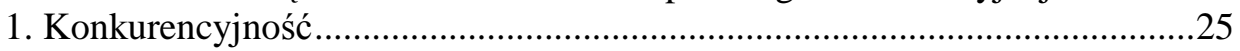

1.1. Wyzwania współczesnej gospodarki - zarys zagadnienia .....................25

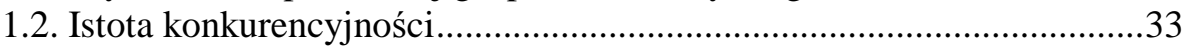

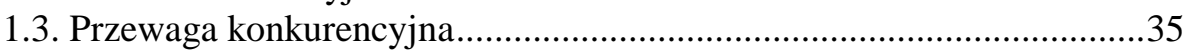

1.4. Konkurencyjność na rynku usług zdrowotnych .....................................

1.4.1. Ekonomizacja działania podmiotów leczniczych .........................45

1.4.2. Specyfikacja konkurencyjności na rynku usług zdrowotnych.....48

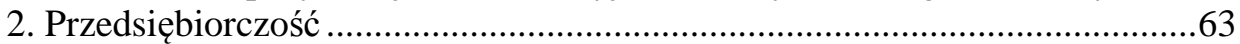

2.1. Przedsiębiorczość $w$ literaturze - zarys zagadnienia...............................63

2.2. Współczesny wymiar przedsiębiorczości............................................66

2.3. Pojęcie przedsiębiorcy - wybrane aspekty ……………………................73

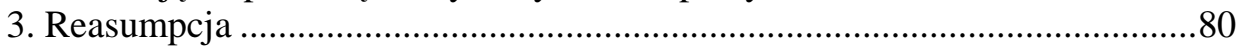

Rozdział II Przedsiębiorcze postawy dentystów ……….......................................83

1. Motywy działania lekarzy dentystów .............................................................83

1.1. Powołanie - determinantą wyboru zawodu............................................83

1.2. Motywy podejmowanych działań - aspekt empiryczny...........................86

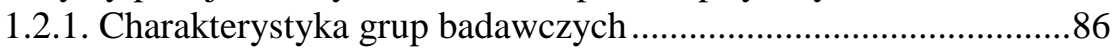

1.2.2. Motywacje stomatologów i studentów - wynik badań..................88

2. Umiejętności i kompetencje stomatologów..................................................95

2.1. Specyficzne cechy lekarzy ...............................................................95

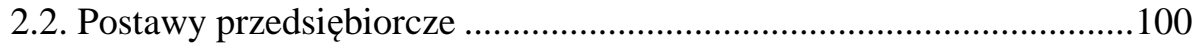

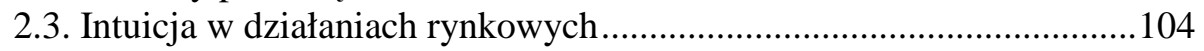

3. Biznesowa rola dentysty w prywatnym gabinecie stomatologicznym ..........107

3.1. Archetypowe role stomatologa ............................................................107

3.1.1. Dentysta jako przedsiębiorca....................................................110

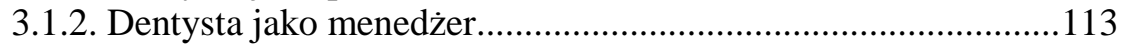

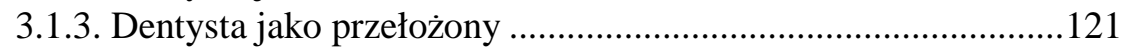

3.2. Dentysta jako partner rynkowy ........................................................... 124

3.3. Umiejętności i kompetencje przedsiębiorcze - wyniki badań...............129

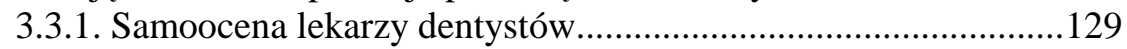

3.3.2. Samoocena studentów stomatologii ..........................................136

3.3.3. Kompetencje idealnego dentysty - perspektywa pacjenta, lekarza

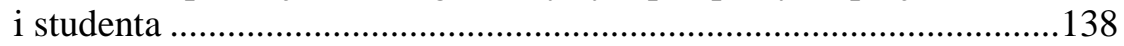

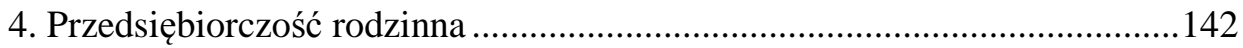

4.1. Istota przedsiębiorstwa rodzinnego ....................................................142 
4.2. Aspekt przedsiębiorczości rodzinnej w gabinetach

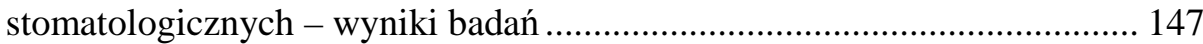

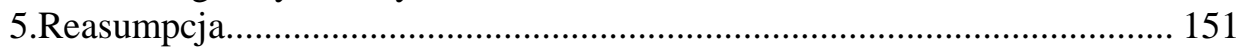

Rozdział III Gabinet stomatologiczny jako podmiot na rynku usług .............. 153

1. Gabinet stomatologiczny podmiotem usługowym ....................................... 153

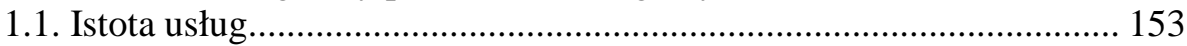

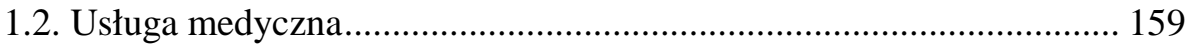

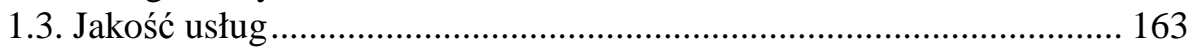

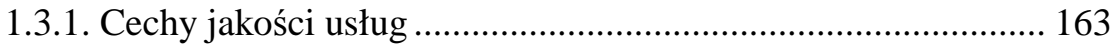

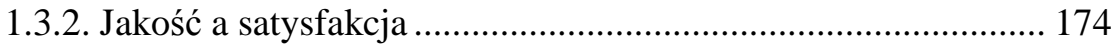

2. Gabinet jako organizacja ucząca się ........................................................... 177

2.1. Innowacja jako instrument przedsiębiorczości .................................. 177

2.2. Wiedza $w$ gabinecie stomatologicznym ............................................ 181

2.2.1. Zarządzanie wiedzą w gabinecie ............................................. 181

2.2.2. Dentysta jako pracownik wiedzy .............................................. 186

2.3. Wiedza w gabinecie - w świetle badań ............................................ 190

2.4. Wiedza akademicka a prowadzenie gabinetu ....................................... 192

3. Funkcjonowanie gabinetów na rynku - wyniki badań ................................. 195

3.1. Rynek działania badanych gabinetów stomatologicznych .................. 195

3.2. Źródła finansowania działalności ...................................................... 199

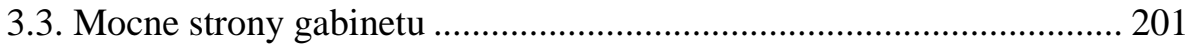

3.4 Kontakty z dostawcami materiałów..................................................... 206

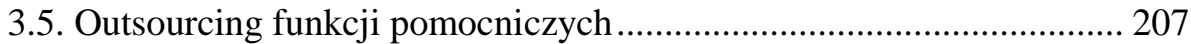

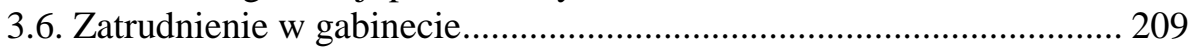

3.7. Miejsce Internetu w gabinecie stomatologicznym................................ 211

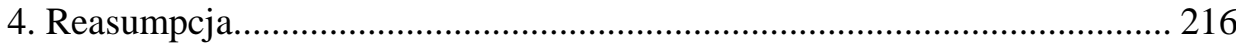

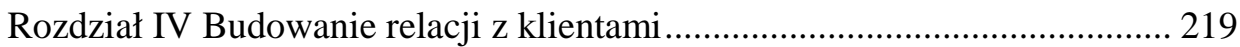

1. Orientacja na klienta ........................................................................... 219

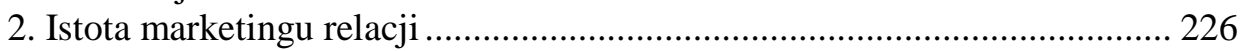

2.1. Ewolucja marketingu - zarys zagadnienia ….................................... 226

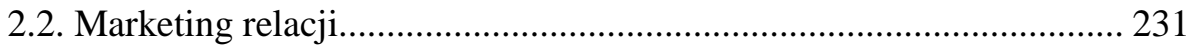

2.3. Marketing w usługach zdrowotnych.................................................. 239

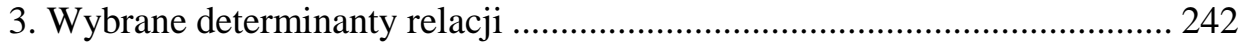

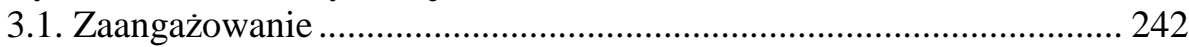

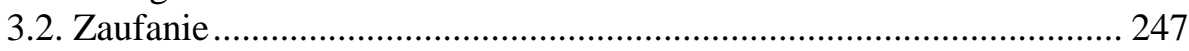

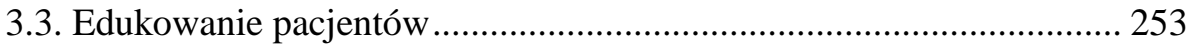

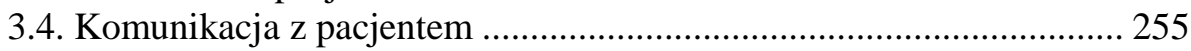

3.4.1. Komunikacja z pacjentem - rys teoretyczny .......................... 255

3.4.2. Komunikacja w gabinecie stomatologicznym - aspekt

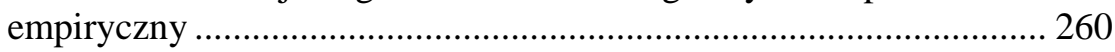


4. Marketing relacji w gabinetach - wyniki badań.......................................268

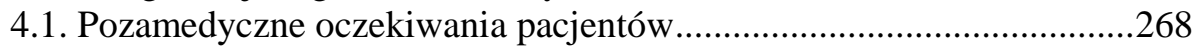

4.1.1. Charakterystyka badanej grupy ..............................................268

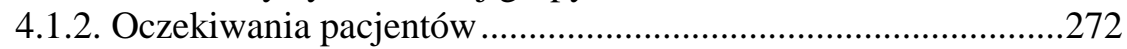

4.1.3. Oczekiwania pacjentów z perspektywy stomatologów ..............276

4.2. Działania marketingowe gabinetów stomatologicznych .......................281

4.3. Poziomy relacji pacjent - lekarz dentysta .........................................291

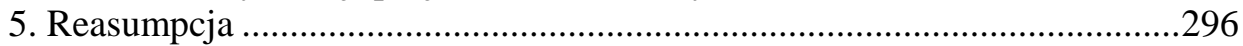

Rozdział V Postawa dentysty a działania z zakresu marketingu relacji

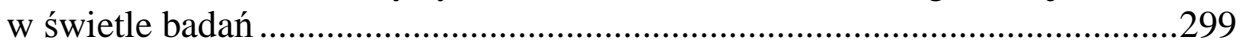

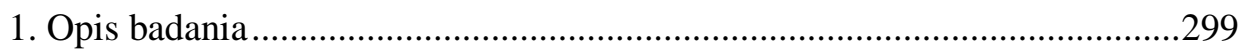

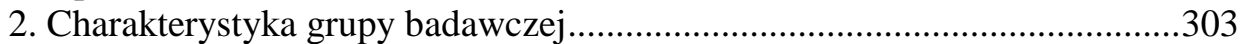

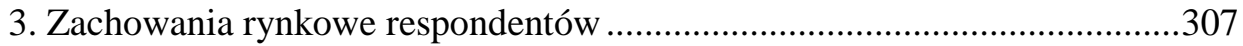

4. Czynniki konkurencyjności gabinetu stomatologicznego ...............................311

5. Samoocena umiejętności i postaw przedsiębiorczych badanych lekarzy

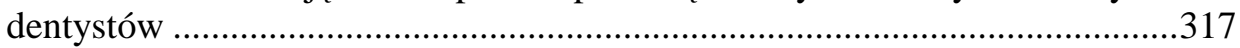

5.1. Samoocena w zakresie umiejętności intrapersonalnych

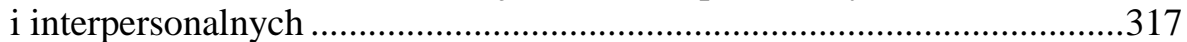

5.2. Samoocena w zakresie postaw prorynkowych ...................................324

6. Wiedza akademicka a działalność rynkowa dentystów................................336

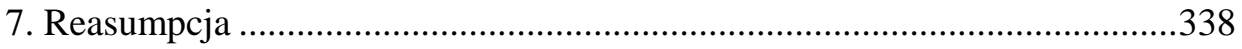

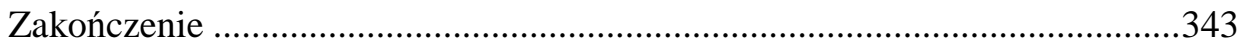

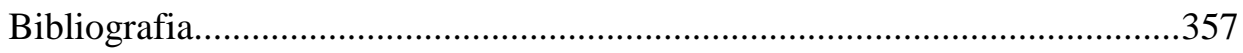

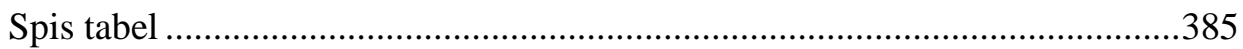

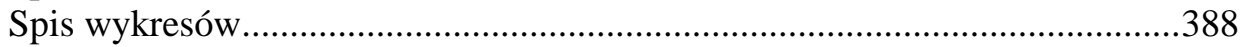

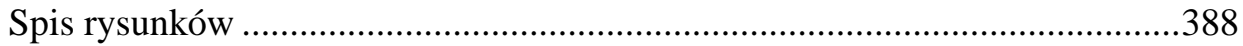

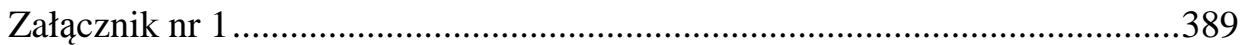

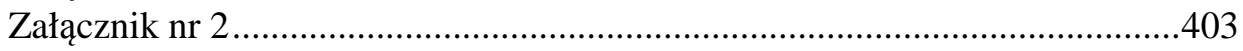





\title{
WSTĘP
}

\author{
... bo najciekawiej jest \\ na styku dyscyplin naukowych \\ G.W. Kołodko ${ }^{1}$
}

We współczesnej gospodarce stawianie dobra nabywcy w centrum uwagi jest ideą filozofii marketingu oraz kluczem do osiągnięcia przewagi konkurencyjnej przez podmiot rynkowy. Zgodnie $\mathrm{z}$ tradycyjną antyczną i średniowieczną deontologią lekarską ${ }^{2}$ - lekarz, jako rzemieślnik, zobowiązany był (i nadal jest) do profesjonalnego spełniania swoich obowiązków i stawiania dobra pacjenta na najwyższym miejscu ${ }^{3}$. Od kilkunastu lat - w literaturze przedmiotu i praktyce działania podmiotów usług medycznych - podejmowane są próby pogodzenia tych dwóch punktów widzenia. Przywołując stanowisko K. Perechudy, można stwierdzić, że we współczesnym świecie coraz silniej obserwujemy uniwersalizację teorii, koncepcji, modeli, metod zarządzania i swoisty ich transfer między organizacjami ${ }^{4}$. Po dokonaniu odpowiedniej adaptacji, istnieje realna możliwość ich zastosowania do osiągania zadanych celów w organizacjach realizujących nie tylko biznesowe zadania (np. gabinetach stomatologicznych).

W pracy podjęto próbę holistycznego ujęcia funkcjonowania gabinetu stomatologicznego ${ }^{5}$ jako uczestnika rynku, wykorzystującego w swoim działaniu współczesne zdobycze nauk ekonomicznych (ze szczególnym uwzględnieniem przedsiębiorczości ${ }^{6}$, jako czynnika wpływającego na pozycję konkurencyjną

\footnotetext{
${ }^{1}$ Kołodko G.W., Wędrujący świat, Prószyński i S-ka, Warszawa 2008, s. 268.

2 Opierała się ona na pismach z Korpus hippocraticum pochodzących częściowo od samego Hipokratesa (ok. 460 - ok. 370), założyciela szkoły lekarskiej z Kos oraz na refleksji etycznej, pochodzącej głównie od stoików.

${ }^{3}$ Mirkiewicz J., Miłość jest najważniejszym lekarstwem - spagiryka, czyli początki nowożytnej farmakologii, w: Płonka-Syroka B. (red.), Relacje lekarz - pacjent $w$ aspekcie spotecznym, historycznym i kulturowym, „Studia z dziejów kultury medycznej”, Katedra Etnologii i antropologii kulturowej Uniwersytetu Wrocławskiego, Wrocław 2005, s. 102.

${ }^{4}$ Perechuda K., Dyfuzja wiedzy jawnej i niejawnej jako instrument sieciowego zarzadzania gmina, „Współczesne Zarządzanie”, 2006 nr 2, s. 5 i nast.

${ }^{5}$ Stomatologia zajmuje się oceną, rozpoznawaniem, profilaktyką i leczeniem chorób, zaburzeń i schorzeń jamy ustnej lub obszaru twarzowo-czaszkowego. Ten aspekt funkcjonowania gabinetu nie będzie przedmiotem rozważań niniejszej pracy - uwaga zostanie skoncentrowana na roli gabinetu, jako uczestnika wymiany rynkowej.

6 Problematyka przedsiębiorczości w systemie ochrony zdrowia podejmowana jest przede wszystkim w literaturze amerykańskiej (por. Philips F.S., Garman A.N., Bariers to entrepreneurship in healthcare organizations, ,Journal of Health and Human Services Administration”, 2006 vol. 28, $\mathrm{nr}$ 4, s. 472 i nast.), ale również w europejskiej (por. Saltman R.B., Busse R., Balancing regulation and entrepreneurialism In Europe's Health sektor: theory and practice, w: Saltman R.B., Busse R.,
} 
podmiotu). Konieczne jest podkreślenie, że - dla opisania funkcjonowania gabinetu stomatologicznego na rynku - wykorzystano przede wszystkim tzw. alternatywne teorie przedsiębiorstwa ${ }^{7}$ (np. nurt behawioralny ${ }^{8}$, teorię biologiczną - z imperatywem ciągłego uczenia się, teorię biznesu P.F. Druckera, rdzeń umiejętności wg C.K. Prahalda) oraz nauki o zarządzaniu (których siłą jest różnorodność ${ }^{9}$, umożliwiająca wszechstronną diagnozę działań podmiotu). Proponowane ujęcie jest oryginalną pracą badawczą (w Polsce tego typu badania nie były prowadzone), pozwalającą uzyskać wiedzę na temat prorynkowych działań podejmowanych przez lekarzy dentystów ${ }^{10}$, ze szczególnym uwzględnieniem roli marketingu relacji ${ }^{11} \mathrm{w}$ praktyce polskich gabinetów stomatologicznych. Wpisuje się w pragmatyczny charakter nauk o zarządzaniu, wzbogacając ich dorobek teoretyczny; przedstawia bowiem wiedzę o charakterze deskryptywnym i normatywnym, pozwalając na sformułowanie rekomendacji dla praktyki organizatorskiej (w ujęciu sektorowym).

Konkurencja jest immanentną cechą gospodarki rynkowej; mechanizmem niejako wymuszającym reorientację zachowań podmiotów rynkowych nie tylko

Mossialos E. (red.), Regulating Entrepreneurial Behavior In European Health Care Systems, European Observatory on Health Care Systems Series, Open University Press, Buckingham, Philadelphia 2002). W ostatnich latach zagadnieniami wprowadzania do systemu ochrony zdrowia mechanizmów rynkowych zajmują się również polscy autorzy $\mathrm{m}$. in.: J. Leowski, I. Rudawska, A. Frączkiewicz-Wronka, J. Suchecka, H. Mruk, B. Nogalski, E. Nojszewska, K. Rogoziński.

7 Teorie alternatywne przedsiębiorstwa to konceptualizacje, wychodzące $\mathrm{z}$ innych niż model przedsiębiorstwa w ekonomii neoklasycznej założeń początkowych i wprowadzające inne zmienne uznane za istotne. Szerzej na ten temat pisze: Gruszecki T., Wspótczesne teorie przedsiębiorstwa, Wydawnictwo Naukowe PWN, Warszawa 2002.

${ }^{8}$ Nurt behawioralny kwestionuje istnienie jednego celu przedsiębiorstwa, wskazując na „wiązkę celów" (w pracy: realizacja w prywatnym gabinecie stomatologicznym i celu medycznego i ekonomicznego). Por. Cyert R.M., March J.G., A Behavioural Theory of Firm, Blackwell Business, Cambridge 1992.

${ }^{9} \mathrm{~W}$ pracy do przedstawienia sylwetki lekarza dentysty jako przedsiębiorcy, wykorzystano - prezentowane w literaturze z zakresu zarządzania - następujące perspektywy:

- funkcjonalny opis działań przedsiębiorczych,

- indywidualne cechy osoby przedsiębiorcy,

- $\quad$ sposoby zachowania przedsiębiorcy.

Por. Piasecki B., Przedsiębiorczość i mała firma: teoria i praktyka, Wydawnictwo UŁ, Łódź 1998.

10 Od 01.05.2004 tytuł zawodowy „lekarza stomatologa” został zastąpiony tytułem „lekarza dentysty" (zgodnie z przepisami Dyrektywy 2005/36/WE w odniesieniu do Polski). Zgodnie z Ustawa $z$ dnia 28 kwietnia 2011 r. o zmianie ustawy o zawodach lekarza i lekarza dentysty (Dz. U. z 2011 r. Nr 113, poz. 658) do 2012r. tytuł lekarza dentysty uzyskiwany był po ukończeniu 5-letnich studiów, odbyciu stażu podyplomowego i zdaniu Lekarsko-Dentystycznego Egzaminu Państwowego (LDEP). Od 2013r. LDEP został zastąpiony Lekarsko-Dentystycznym Egzaminem Końcowym - LDEK (art. 5. ustawy).

W pracy terminy: stomatolog, dentysta, lekarz stomatolog czy lekarz dentysta będą używane zamiennie; a także student stomatologii i student kierunku lekarsko-dentystycznego.

${ }^{11}$ Płaszczyzna ta jest w zarysie pokazywana z punktu widzenia deontologii i etyki lekarskiej, a rozważania zawarte w pracy koncentrują się na pozamedycznych aspektach relacji. 
w kierunku większego wykorzystania możliwości kapitału ludzkiego, wiedzy i innowacji, ale również maksymalizacji wartości dla klienta, zwiększania adaptacyjności i nastawienia na wykorzystywania szans (a więc w kierunku działań przedsiębiorczych). $Z$ badań I.K. Hejduk i in. ${ }^{12}$ wynika, że w budowaniu trwałej przewagi konkurencyjnej w nowoczesnym przedsiębiorstwie - przedsiębiorczość, jako jeden $\mathrm{z}$ trzech (obok wiedzy i innowacji) kluczowych czynników, odgrywa istotną rolę. Można powiedzieć, że przedsiębiorczość stała się warunkiem sine qua non konkurencyjności, czy jak twierdzi I.M. Kirzner: „Przedsiębiorczość i konkurencyjność są dwiema stronami tego samego zjawiska. Działalność przedsiębiorcza zawsze jest konkurencyjna, a działalność konkurencyjna zawsze jest przedsiębiorcza." ${ }^{13} \mathrm{~W}$ pracy przyjęto za T. Listwanem, że przedsiębiorcze działanie to takie, które „,związane jest przede wszystkim z inicjowaniem projektów, twórczym rozwiązywaniem problemów, tworzeniem i wykorzystywaniem okazji oraz elastycznym dostosowaniem się do warunków otoczenia" ${ }^{\text {"14 }}$. Pojęcie przedsiębiorcy jest kategorią par excellance ekonomiczną - przedsiębiorca wynajduje lukę na rynku i powołuje przedsiębiorstwo do życia (funkcja pierwotna). Ta sama osoba może zajmować się prowadzeniem działalności podmiotu na rynku (funkcja wtórna), koordynując zasoby, odkrywając nowe (lub inne) sposoby działania, tak aby osiągać satysfakcjonujący poziom efektów. W gabinetach stomatologicznych obie funkcje najczęściej są pełnione przez jedną osobę - lekarza dentystę, z tego względu w pracy zastosowano kompleksowe podejście: skupiono się zarówno na intencjach przedsiębiorczych, jak i determinantach późniejszych decyzji oraz kierunkach podejmowanych działań $w$ gabinetach stomatologicznych przez lekarzy dentystów w kontekście zmian zachodzących na rynku tych usług. Podejście to wynika z przyjęcia prymatu zasady personalizmu, zgodnie z którą działa/podejmuje decyzje człowiek - lekarz dentysta, a nie gabinet stomatologiczny - podmiot rynku (jest ono zgodne z teorią mikro-mikro Lebensteina ${ }^{15}$ ). Badania nad motywacjami do podjęcia działalności zarobkowej we własnym gabinecie przez lekarzy dentystów skupiono na ich cechach osobniczych, postawach i umiejętnościach, doświadczeniu zawodowym oraz tradycji rodzinnej $^{16}$. Natomiast na poziomie organizacji (gabinetu stomatologicznego) skupiono się na obszarach związanych $\mathrm{z}$ racjonalizacją działań $\mathrm{w}$ świetle oczekiwań pacjentów - przede wszystkim aspektach związanych z jakością

\footnotetext{
${ }^{12}$ Hejduk I.K., Grudzewski W.M., Sankowska A., Wańtuchowicz M., W kierunku zarzadzania drugiej generacji - model diamentu czterech paradygmatów wspótczesnego przedsiębiorstwa, „E-mentor” 2010, nr 1(33), s. 39, www.e-mentor.edu.pl/czasopismo.

${ }_{13}^{13}$ Kirzner I.M., Konkurencja i przedsiębiorczość, Fijorr Publishing, Warszawa 2010, s. 94.

${ }^{14}$ Oleksyn T., Zarzadzanie kompetencjami. Teoria i praktyka, Oficyna Ekonomiczna, Kraków 2006, s. 64.

${ }^{15}$ Por. Leibenstein H., Poza schematem ,homo oeconomicus”, PWN, Warszawa 1988.

16 Por. Evans D.S., Leighton L.S., Some empirical aspects of entrepreneurship, "American Economic Review", 1989, vol. 79, nr 3, s. 519 i nast.
} 
obsługi ( $\mathrm{w}$ tym postawach personelu wobec pacjentów, biznesowej wiedzy lekarzy dentystów, czynnikach materializacji usług), która wpływa na kreowanie i wzmacnianie relacji na płaszczyźnie lekarz dentysta - pacjent.

R.B. Saltman, R. Busse i E. Mossialos ${ }^{17}$ postulują, aby w systemie ochrony zdrowia ( $\mathrm{w}$ tym $\mathrm{m}$. in. $\mathrm{w}$ stomatologii ${ }^{18}$ ) były stosowane zasady przedsiębiorczości. Pobudzanie przedsiębiorczości (rozumianej jako uruchamianie działalności zarobkowej) wśród lekarzy dentystów odbywa się niemal samoistnie wielu młodych ludzi, wybierając kierunek studiów, ma w perspektywie otwarcie własnego gabinetu po zakończeniu studiów. Większe wyzwanie stanowi propagowanie działań przedsiębiorczych (a nie administracyjnych) w trakcie życia rynkowego gabinetu, które wpływają na pozycję konkurencyjną podmiotu. Zmiany zachodzące $w$ usługach stomatologicznych w Polsce m. in. wzrost liczby lekarzy dentystów, rosnące wymagania pacjentów, relatywnie malejący zasób środków finansowych płynących z NFZ do gabinetów (a w konsekwencji konieczność zabiegania o pacjentów, którzy z własnych środków opłacą wizytę), wymagają od lekarzy dentystów zmian w prowadzeniu gabinetów, jako przedsiębiorstw zarobkowych (aktywności rynkowej innej, niż realizowana jeszcze kilka lat temu).

W pracy przyjęto, że lekarz dentysta ${ }^{19}$, prezentujący postawę przedsiębiorczą, będzie mógł budować pozycję konkurencyjną swojego gabinetu również dzięki wykorzystaniu jednego z niematerialnych aktywów swojego podmiotu - relacji $\mathrm{z}$ pacjentami. Przyjęte założenie jest zgodne z prezentowanym w literaturze przedmiotu przekonaniem ${ }^{20}$, że efektywność i pozycja rynkowa współczesnych podmiotów gospodarczych przestała wynikać jedynie z wielkości zgromadzonych zasobów rzeczowych i finansowych; a jej źródłem stał się również sposób

\footnotetext{
${ }^{17}$ Saltman R.B., Busse R., Mossialos E. (red.), Regulating ... op. cit.

${ }^{18} \mathrm{~W}$ warunkach polskich podjęcie wątku przedsiębiorczości w obszarze usług stomatologicznych jest uzasadnione znacznym udziałem sektora prywatnego $w$ oferowaniu świadczeń stomatologicznych.

${ }^{19} \mathrm{~W}$ świetle Ustawy z dania 2 lipca 2004r. o swobodzie działalności gospodarczej (Dz. U. z 2010 r. nr 220, poz. 1447 i nr 239, poz. 1593) głównie mikroprzedsiębiorca, w niewielu przypadkach - mały przedsiębiorca.

20 Por. Rudawska E., Znaczenie relacji z klientami $w$ procesie kształtowania wartości przedsiębiorstwa, Uniwersytet Szczeciński, Rozprawy i Studia t.(DCCXC) 716, Szczecin 2008, s. 8.
} 
wykorzystywania zasobów niematerialnych ${ }^{21}$ (tj. m. in. zgromadzonej i rozwijanej wiedzy, umiejętności i kompetencji pracowników, relacji z klientami ${ }^{22}$ ).

W literaturze można również znaleźć wątpliwości co do tego, czy lekarzy dentystów można uznać za przedsiębiorców w tradycyjnym sensie tego pojęcia; na ich potwierdzenie R. Levin przedstawia następujące argumenty: ${ }^{23}$

- lekarze nie podejmują ryzyka, a ich działalność rynkowa dużo rzadziej kończy się porażką rynkową, niż podmiotów innych branż,

- lekarze mają określoną, jasno sprecyzowaną ofertę i nie prowadzą własnych badań nad jej rozszerzeniem,

- gabinety mają ograniczony potencjał wzrostu.

Przeciwstawiając się tym argumentom, można wskazać, że choć ryzyko jest mniejsze, niż w innych branżach, to jednak jest. Gabinet stomatologiczny działa w warunkach niepewności (np. lekarz dentysta konkuruje nie tylko z gabinettami, które odpłatnie świadczą usługi stomatologiczne, ale również tymi, które mają podpisany kontrakt z NFZ) i stomatolog adaptuje się do otoczenia, by osiągnąć zadowalające rezultaty. Niepewność co do efektów prowadzonej działalności jest związana również ze zmianami w polityce zdrowotnej państwa (i zmniejszeniem zakresu finansowania usług stomatologicznych ze środków publicznych), utraty płynności finansowej w sytuacji przeinwestowania lub problemów z realizacją kontraktu z NFZ; niemożności skutecznego konkurowania wobec zmian zachodzących na rynku (np. w zakresie liczby gabinetów, które działają w pobliżu; czy rosnącej aktywności rynkowej innych podmiotów). Odnosząc się do kolejnego argumentu R. Levina, można się zgodzić, że oferta gabinetów stomatologicznych rzeczywiście nie jest autorskim pomysłem lekarza dentysty (gdyż wykonuje on świadczenia, do realizacji których przygotował się w toku studiów czy specjalizacji). Jednak uwzględniając tempo zmian w zakresie unowocześniania metod leczenia i materiałów, które lekarze wykorzystują, trudno powiedzieć, że oferta usług np. sprzed 5 lat jest w każdym względzie tożsama z dzisiejszą (dentyści podnoszą swoje kwalifikacje, by poprawiać technikę pracy, poznawać nowe metody leczenia, używać lepszych

${ }^{21}$ Jako pierwsi na istotne znaczenie zasobów niematerialnych przedsiębiorstwa w kształtowaniu jego pozycji i wartości rynkowej zwrócili uwagę ekonomiści prezentujący zasobową teorię przedsiębiorstwa m. in.: J. Barney, G. Day, C. Prahald, G. Hamel i in. W polskiej literaturze przedmiotu problematykę wpływu czynników niematerialnych na wartość rynkową przedsiębiorstwa podejmują m. in.: A. Herman, M. Dobija, I. Sobańska, M. Marcinkowska, R. Borowiecki, G.K. Świderska.

${ }^{22}$ G. Hooley, J. Sanders, N. Percy do zasobów niematerialnych zaliczyli m. in. zasoby marketingowe, a więc również relacje z klientami. Por. Hooley G., Saunders J., Piercy N., Marketing Strategy \& Competitive Positioning., Prentice Hall 1998, s. 105.

${ }^{23}$ Levin R., Is the dentist an entrepreneur? „Journal of American Dental Association”, 2004, vol. 135 , nr 12, s. 1733 i nast. 
materiałów itp.). Oferta ulega ewolucyjnym zmianom i to dentyści są głównymi kreatorami tych zmian $\mathrm{w}$ gabinecie (tak na poziomie medycznym, jak i związanym z prowadzeniem gabinetu, jako przedsiębiorstwa zarobkowego). Ostatni z wymienionych argumentów można skonfrontować z faktem, iż wartość rynkowa gabinetu ,na starcie" i tego samego po 10-ciu latach jest inna choćby dzięki reputacji, którą w tym czasie sobie wyrobił. Niektórzy dentyści otwierają kolejne gabinety (również $w$ innych miastach) i zatrudniają w nich innych lekarzy (którzy będą pracować na powiększanie dochodów nie tylko swoich, ale również dentysty-pracodawcy). Jeszcze inni stawiają na turystykę medyczną i np. obsługują pacjentów z Irlandii. Przedstawione uwarunkowania, przemawiające za tym, że lekarza dentystę można nazwać przedsiębiorcą, nie wyczerpują listy argumentów, ale stanowią asumpt do tego, by pokazać szersze spektrum postaw rynkowych stomatologów i przyjąć, że lekarzy dentystów można uznać za przedsiębiorców.

\section{CELE PRACY}

Współczesna koncepcja przedsiębiorczości jest wielowymiarowa i - jak podaje T. Kraśnicka - obejmuje kilka płaszczyzn ${ }^{24}$ :

- ekonomiczną (kryterium efektywności),

- podmiotową (przedsiębiorca),

- edukacyjną (kształcenie),

- instytucjonalną (organizacja),

- otoczenia (otoczenie),

- procesową (realizowane procesy),

- psychologiczną (psychologiczne czynniki przedsiębiorczości),

- osobową (cechy osobowe, wpływające na działania przedsiębiorcze),

- kulturową (ideologie, wartości i normy kulturowe oraz rytuały).

Ponieważ próba zajęcia się problematyką przedsiębiorczości w usługach stomatologicznych $\mathrm{w}$ wymiarze stricte ekonomicznym (tj. podjęcia badań w obszarze efektywności funkcjonowania gabinetów stomatologicznych) zakończyła się niepowodzeniem (podstawową barierą była niechęć dentystów do - nawet anonimowego - przedstawienia wyników finansowych prowadzonej działalności ${ }^{25}$ ), to uwage skoncentrowano na wymiarze: podmiotowym

\footnotetext{
${ }^{24}$ Kraśnicka T., Koncepcja rozwoju przedsiębiorczości ekonomicznej i pozaekonomicznej, Wyd. Akademii Ekonomicznej im. K. Adamieckiego w Katowicach, Katowice 2002, s. 79 i nast.

${ }^{25}$ Ze względu na brak dostępu do wyników finansowych gabinetów stomatologicznych niemożniwym stało się oszacowanie efektywności ich działań, stąd konieczność przyjęcia, jako bezsprzecz-
} 
(rozdział II i V), edukacyjnym (rozdział III i V), instytucjonalnym (rozdział III i IV), osobowym (rozdział II i V), otoczenia (rozdział III) przedsiębiorczości. Ponadto problem przedsiębiorczości został zbadany w kontekście powiązań pomiędzy sylwetką lekarza dentysty (wyrażoną prezentowanym stylem przywództwa powiązanym z postawą przedsiębiorczą) a stosowanymi w gabinecie działaniami z zakresu marketingu relacji (rozdział V). Pozwoliło to na pokazanie, że działania stomatologów w prywatnych gabinetach stomatologicznych wpisują się w koncepcję przedsiębiorczości sensu largo.

Temat został podjęty z myślą zarówno o efektach teoretycznych, jak i praktycznych. Praca ma charakter poznawczy - intencją autorki było pokazanie szerokiego spektrum zagadnień związanych z przedsiębiorczością na rynku usług stomatologicznych. Jej celem jest określenie profilu postawy przedsiębiorczej $^{26}$ dentysty (tak praktykującego lekarza, jak i studenta kierunku lekarsko-dentystycznego) i jego intencji przedsiębiorczych oraz określenie pozamedycznych czynników wpływających na relacje lekarz dentysta - pacjent.

Cele szczegółowe zostały określone następująco:

- zidentyfikowanie przedsiębiorczej postawy lekarza dentysty w świetle dorobku autorów zajmujących się teorią przedsiębiorczości (od R. Cantillona po P.F. Druckera);

- określenie skali przedsiębiorczości jawnej wśród lekarzy dentystów (wraz z charakterystyką rynku, na którym działają) i ukrytej - wśród studentów kierunku lekarsko-dentystycznego;

nego założenia - funkcjonującego od lat w literaturze, że usatysfakcjonowany nabywca (tu: pacjent), staje się lojalnym partnerem biznesowym podmiotu rynkowego (tu: gabinetu stomatologicznego) i źródłem długookresowych strumieni gotówkowych oraz jego ambasadorem, a w konsekwencji przyczynia się do utrzymywania lub poprawiania rentowności podmiotu i jego pozycji konkurencyjnej. Dlatego pokazanie, że w gabinetach stomatologicznych są realizowane idee marketingu relacji (np. poprzez stosowanie narzędzi prorynkowego oddziaływania zgodnego z oczekiwaniami pacjenttów) można utożsamić $\mathrm{z}$ poprawianiem jego konkurencyjności, zgodnie ze spostrzeżeniem P. Doyle'a, że bez wartości dla klientów nie ma wartości dla właścicieli podmiotu.

Por. Doyle P., Marketing wartości, Felberg SJA, Warszawa 2003, s. 28.

${ }^{26}$ Przyjęto, że postawa przedsiębiorcza obejmuje zespół pewnych skłonności organizacyjnych człowieka, przejawiających się w działaniach zmierzających do zapewnienia - w miarę - racjonalnej i efektywnej koordynacji zasobów podmiotu, w dążeniu do uzyskiwania wymiernych korzyści, pozwalających nie tylko na bieżące funkcjonowanie, ale również tworzenie podstaw do dalszego rozwoju. Jest indywidualną cechą ludzkiej osobowości, wyróżniającej się innowacyjnością, umiejętnością dostrzegania uwarunkowań i związków zachodzących między zjawiskami gospodarczymi, zdolnością do organizowania działalności usługowej i dążenia do odmienności w porównaniu z tym, co robią inni.

Por. Walczak W., Miary i kryteria oceny przedsiębiorczości, "Ekonomika i Organizacja Przedsiębiorstwa”, $2010 \mathrm{nr} 3$, s. 5 i nast. 
- określenie uwarunkowań i skali przedsiębiorczości rodzinnej wśród lekarzy dentystów i odpowiedź na pytanie: czy uwarunkowania rodzinne (rodzic/ opiekun jest z zawodu stomatologiem) wzmacniają intencje przedsiębiorcze studentów stomatologii?;

- identyfikacja prorynkowych cech gabinetu stomatologicznego w oczach pacjentów, dentystów i studentów kierunku lekarsko-dentystycznego w ujęciu normatywnym i pozytywnym;

- analiza determinantów wyboru usługodawcy przez pacjentów i określenie oczekiwań pacjentów w zakresie pozamedycznych parametrów usługi stomatologicznej oraz porównanie ich z wiedzą lekarzy dentystów i studentów stomatologii na ten temat;

- przedstawienie działań marketingowych podejmowanych przez lekarzy dentystów, ze szczególnym uwzględnieniem idei marketingu relacji w gabinecie stomatologicznym (scharakteryzowane zostaną główne determinanty relacji oraz jej mierniki - wskaźnik retencji, utraty klientów i skłonności do rekomendacji).

W pracy podjęto próbę weryfikacji hipotezy mówiącej, że postawy lekarzy dentystów w miejscu pracy - prywatnym gabinecie stomatologicznym wpływają na podejmowane przez nich działania prorynkowe i w efekcie na kształtowanie relacji z klientami (w szczególności z pacjentami).

Ponadto przyjęto następujące hipotezy cząstkowe:

- dentyści prezentujący sylwetkę przywództwa transformacyjnego, działają bardziej prorynkowo, niż ci o sylwetce transakcyjnej, mieszanej czy leseferystycznej,

- wśród motywów wyboru zawodu lekarza dentysty dominuje chęć pomocy innym nad względami ekonomicznymi,

- osoby wykonujące zawód lekarza dentysty - oprócz specyficznych cech dla danego zawodu - mają rozwinięte umiejętności interpersonalne, umożliwiające nawiązywanie relacji z klientami gabinetu;

- trwałe relacje z pacjentami są postrzegane przez dentystów, jako podstawowy czynnik konkurencyjności gabinetów;

- wśród dentystów (lekarzy i studentów) istnieje duże (powyżej 50\% badanych) zapotrzebowanie na wiedzę z zakresu biznesowego funkcjonowania gabinetów.

Nakreślony obszar badawczy wynika z chęci przedstawienia możliwie szerokiego spektrum zagadnień związanych $\mathrm{z}$ orientacją rynkową gabinetu stomatologicznego. Zainteresowania naukowe powyższymi polami badawczymi mieszczą 
się w kanonie nauk o przedsiębiorczości i marketingu relacji, ale praca ma charakter interdyscyplinarny, gdyż podejmuje tematy będące $\mathrm{w}$ obszarze zainteresowania nauk o zarządzaniu, deontologii lekarskiej, ekonomii behawioralnej, nauk psychologicznych i socjologii. Zaprezentowane wyniki badań wszechstronnie charakteryzują rynek usług stomatologicznych w Polsce. Są pierwszymi, które łączą problematykę przedsiębiorczej postawy lekarza dentysty z marketingiem relacji.

\section{METODYKA I PRZEDMIOT PRZEPROWADZONYCH BADAŃ}

Praca została przygotowana z myślą zarówno o korzyściach naukowych, jak i praktycznych ${ }^{27}$, dlatego rozważania teoretyczne i materiał empiryczny wzajemnie się przenikają i uzupełniają - w rozdziałach II, III i IV analiza literatury przedmiotu jest ilustrowana wynikami badań własnych.

\section{METODYKA I PRZEDMIOT STUDIÓW LITERATUROWYCH}

$\mathrm{W}$ ramach desk research dokonano przeglądu literatury kilkuset pozycji (polsko- i anglojęzycznych artykułów i opracowań książkowych) z zakresu przedsiębiorczości i jej uwarunkowań jako czynnika konkurencyjności; obsługi nabywcy podmiotu usługowego jako czynnika wpływającego na satysfakcję i lojalność klientów; a także problematyki długookresowych i trwałych więzi z nabywcami (w świetle marketingu relacji).

Pozwoliło to na:

- nakreślenie specyfiki konkurencyjności w opiece zdrowotnej;

- przedstawienie roli przedsiębiorczości w budowaniu konkurencyjności współczesnych podmiotów rynkowych; a także wskazanie determinantów przedsiębiorczości istotnych z punktu widzenia gabinetu stomatologicznego typu profit;

- zaprezentowanie typologii pojęcia przedsiębiorca (wraz z determinantami postawy przedsiębiorczej) wg wybranych badaczy nurtu przedsiębiorczości w gospodarce i wskazanie ich powiązań z sylwetką współczesnego lekarza dentysty;

- zaprezentowanie archetypowych ról dentysty w prywatnym gabinecie stomatologicznym, co umożliwiło pokazanie szerokiego spektrum zachowań lekarzy dentystów w prowadzeniu gabinetu, jako przedsiębiorstwa zarobkującego;

\footnotetext{
${ }^{27}$ Jako metodę badawczą przyjęto podejście empiryczne (zwłaszcza behawiorystyczne). Pozwoliło to na określenie, co lekarze dentyści rzeczywiście robią i sformułowanie wniosków, jakie działania - w świetle marketingu relacji - powinni podejmować.
} 
- zarysowanie problematyki organizacji innowacyjnej i uczącej się, które wraz z przedsiębiorczością, są czynnikami wpływającymi na przewagę konkurencyjną gabinetu stomatologicznego;

- przedstawienie istoty orientacji na klienta oraz uwarunkowań i kluczowych czynników marketingu relacji w usługach stomatologicznych.

Ważnym elementem pracy są rozważania porządkujące sferę terminologiczną istotną dla podjętej tematyki.

\section{METODYKA I PRZEDMIOT BADAŃ EMPIRYCZNYCH}

Materiał empiryczny wykorzystany $\mathrm{w}$ pracy pochodzi przede wszystkim ze źródeł pierwotnych - w celu przygotowania rozprawy zostały zrealizowane badania ilościowe i jakościowe. Były one prowadzone głównie z wykorzystaniem kwestionariuszy ankiet, a także techniką wywiadu (badania pilotażowe) i obserwacji. Otrzymany materiał został poddany analizie za pomocą standardowych narzędzi statystyki opisowej; zastosowano także podejście intepretatywne.

Trzon pracy stanowią wyniki czterech badań pierwotnych. Pierwszym objęto lekarzy dentystów ${ }^{28}$ (ilekroć będą odwołania do wyników tego badania w pracy, będzie ono oznaczone, jako „badanie I”) i przeprowadzono je w okresie maj - wrzesień 2011 r. Dobór próby do badania był losowy, zdeterminowany dostępnością bazy adresowej gabinetów stomatologicznych z województw zachodniopomorskiego, pomorskiego, mazowieckiego, małopolskiego, śląskiego i łódzkiego (nie zakładano zapewnienia reprezentatywności terytorialnej próby). Ankieta pocztowa, licząca 43 pytania (z opcją pojedynczego lub wielokrotnego wyboru i pytania zamknięte skategoryzowane), została rozesłana do 700 lekarzy dentystów. Zwrot uzyskano od 192 ankietowanych, 169 kwestionariuszy ankiet było kompletnych (24,1\% wysłanych) i to one posłużyły do dalszej analizy. Badanie dotyczyło przede wszystkim następujących zagadnień:

- wiedza dentysty na temat (najbliższego) rynku działania,

\footnotetext{
${ }^{28}$ Zgodnie z art. 5.1 Ustawy o zmianie ustawy o zawodach lekarza i lekarza dentysty z 28 kwietnia 2011 r. (Dz. U. nr 113, poz. 658 z 2011 r. z późn. zm.) ORL przyznaje prawo do wykonywania zawodu lekarza dentysty osobie, która: 1) jest obywatelem polskim lub obywatelem innego niż RP państwa członkowskiego UE, 2) posiada: dyplom lekarza dentysty wydany przez polską szkołę wyższą, potwierdzający ukończenie co najmniej pięcioletnich studiów na kierunku lekarskodentystycznym, obejmujących co najmniej dwusemestralne praktyczne nauczanie na 5. roku studiów lub spełnia warunki określone w ust. 2 punkty b-d; 3) posiada pełna zdolność do czynności prawnych; 4) posiada tan zdrowia pozwalający na wykonywanie zawodu lekarza dentysty; 5) wykazuje nienaganną postawę etyczną; 6) odbyła staż podyplomowy lub uzyskała uznanie stażu podyplomowego odbytego poza terytorium RP za równoważny ze stażem podyplomowym odbytym w RP; 7) przedstawi świadectwo złożenia z wynikiem pozytywnym Lekarsko-Dentystycznego Egzaminu Końcowego ( $w$ języku polskim lub w języku, w jakim są prowadzone w polskich uczelniach medycznych studia na kierunku lekarsko-dentystycznym, jeżeli ukończyła studia w tym języku) lub Lekarsko-Dentystycznego Egzaminu Państwowego.
} 
- postawy przedsiębiorcze dentystów,

- wiedza lekarzy dentystów na temat decyzji zakupowych pacjentów ${ }^{29}$,

- stosowanie działań marketingowych w gabinecie,

- problematyka firmy rodzinnej,

- kontakty z dostawcami,

- outsourcing usług pomocniczych,

- zarządzanie personelem.

Drugie badanie również zostało przeprowadzone wśród lekarzy dentystów, którzy wykonują zawód w gabinetach, w których pracują również inne osoby (zarówno na stanowiskach lekarskich, jak i personelu pomocniczego), w pracy określane jest jako: „badanie II”. Zostało ono zrealizowane w okresie listopad 2011 r. - luty 2012 r. techniką pośrednich wywiadów kwestionariuszowych $\mathrm{z}$ wykorzystaniem ankiety $\mathrm{w}$ formie elektronicznej. Podobnie, jak w przypadku poprzedniego pomiaru metodyka badania nie zakładała zapewnienia reprezentatywności terytorialnej próby ( $\mathrm{w}$ praktyce znalazły się $\mathrm{w}$ nim gabinety $\mathrm{z}$ całej Polski). Kwestionariusz ankiety na portalu e-ankiety.pl wypełniło 210 dentystów. Podstawowym czynnikiem, pozwalającym na analizę otrzymanego materiału badawczego, był profil przedsiębiorczej sylwetki respondenta (zdefiniowany przez prezentowany przez niego styl przywództwa). Ankieta liczyła 20 pytań (z opcją pojedynczego lub wielokrotnego wyboru i pytania zamknięte skategoryzowane); a zagadnienia szczegółowe, które były przedmiotem analizy to $\mathrm{m}$. in.:

- reakcja dentysty na zmiany zachodzące w najbliższym otoczeniu gabinetu,

- determinanty sukcesu gabinetu dziś i w przyszłości,

- samoocena umiejętności przedsiębiorczych stomatologa,

- działania zarządcze podejmowane w gabinecie,

- relacje na płaszczyźnie dentysta - personel i dentysta - pacjent.

Kolejnym badaniem (w pracy: „badanie III”) objęto przyszłych dentystów - studentów studiów dziennych wydziału lekarskiego, kierunku lekarsko-dentystycznego Uniwersytetu Medycznego w Łodzi. Zostało ono przeprowadzone

\footnotetext{
${ }^{29}$ Aby określić elementy, które powinny zostać uwzględnione w kwestionariuszu ankiety wcześniej zostało przeprowadzone badanie pilotażowe, którym objęto 30 pacjentów, leczących się w różnych gabinetach. Na podstawie ich wskazań został przygotowany zbiór czynników dotyczących lekarza i personelu oraz gabinetu, który posłużył do sprawdzenia stopnia znajomości oczekiwań pacjentów u lekarzy dentystów (w badaniu I i II) i studentów (badanie III) oraz określenia oczekiwań i ocen pacjentów (badanie IV).
} 
w okresie marzec-kwiecień 2012 r. Badanie zostało zrealizowane techniką bezpośrednich wywiadów kwestionariuszowych $\mathrm{z}$ wykorzystaniem ankiety $\mathrm{w}$ formie papierowej. Badanie ilościowe zostało przeprowadzone na próbie 96 osób, a respondenci byli studentami wszystkich lat studiów (stanowili ok. 25\% studentów studiów dziennych tego kierunku). W kwestionariuszu ankiety wykorzystano wybrane pytania z badania I i II (ogółem 20 pytań z opcją pojedynczego lub wielokrotnego wyboru, a także pytania zamknięte skategoryzowane i otwarte), zajęto się problematyką $\mathrm{m}$. in.:

- samooceny umiejętności przedsiębiorczych studentów,

- postaw studentów wobec pacjentów,

- wiedzy na temat decyzji zakupowych pacjentów,

- wpływu uwarunkowań rodzinnych na wybór drogi zawodowej studentów kierunku lekarsko-dentystycznego,

- stosowania działań marketingowych w gabinecie,

- znaczenia wiedzy ekonomicznej w kształceniu dentystów.

Aby skonfrontować wyobrażenia stomatologów o oczekiwaniach pacjentów względem parametrów optymalnej obsługi w trakcie wizyty w gabinecie stomatologicznym z tymi oczekiwaniami, w okresie październik - listopad 2011 r. przeprowadzono badanie wśród pacjentów ${ }^{30}$ (z województw o największej dostępności do usług stomatologicznych - łódzkiego i mazowieckiego). Badanie to jest określane w pracy, jako „badanie IV”. Przeprowadzono je za pomocą standaryzowanego kwestionariusza. Próbę dobrano na podstawie nielosowego schematu doboru, jako próbę okolicznościową, kierując się strukturą płci i wieku dorosłych Polaków w 2010 r. (punktem wyjścia przy określeniu warstw i odpowiadających im kwot stały się dane na temat populacji mieszkańców Polski dostępne w „Roczniku Statystycznym” 2010 r.). Przygotowano 400 kwestionariuszy, które zostały rozdane respondentom; otrzymano 279 poprawnie wypełnionych kwestionariuszy ankiet i to one stały się przedmiotem dalszej analizy. Kwestionariusz liczył 31 pytań (z opcją pojedynczego lub wielokrotnego wyboru, a także pytania zamknięte skategoryzowane i otwarte), odnoszących się do zagadnień związanych m. in. z:

- oczekiwaniami względem gabinetu stomatologicznego,

- oczekiwaniami w stosunku do personelu gabinetu stomatologicznego,

\footnotetext{
${ }^{30}$ Zgodnie z art. 3 Ustawy o prawach pacjenta i Rzeczniku Praw Pacjenta z 6 listopada 2008 r. (Dz.U. nr 52, poz. 417 z 2008r. z późn. zm.) pacjentem jest osoba zwracająca się o udzielenie świadczeń zdrowotnych lub korzystająca ze świadczeń zdrowotnych, udzielanych przez podmiot udzielający świadczeń zdrowotnych lub osobę wykonującą zawód medyczny.
} 
- oczekiwaniami co do sposobu obsługi w gabinecie stomatologicznym,

- skłonnością pacjentów do rekomendowania usług dentysty i rezygnacji z usług.

\section{STRUKTURA KSIĄŻKI}

Praca składa się z pięciu rozdziałów, zakończenia i dwóch załączników.

Pierwszy rozdział rozpoczynają rozważania na temat konkurencyjności, która stanowi istotę współczesnego rynku i ma wpływ na decyzje podmiotów rynkowych. Przedstawienie wybranych źródeł konkurencyjności ${ }^{31}$ : marketingowych (związanych $\mathrm{m}$. in. $\mathrm{z}$ rozpoznaniem potrzeb rynku, reagowaniem na zmiany rynkowe i lepszą obsługą nabywców), jakości zarządzania (związanej m. in. z umiejętnościami menedżerskimi) i wiedzy, pozwoliło na pokazanie jej związku z przedsiębiorczością. Przedsiębiorczość rozumiana wąsko - jako uruchamianie przedsięwzięcia rynkowego implikuje rosnącą konkurencję na rynku, a ta wymusza na podmiotach działania przedsiębiorcze sensu large rozumiane jako wprowadzanie zmian, aby utrzymać się na rynku i osiągać przewagę konkurencyjną. W rozdziale podjęto studia nad ideą przewagi konkurencyjnej i determinujących ją czynników. Przedstawiono nurt pozycjonowania i koncepcję konkurencyjności opartą na zasobach i kompetencjach, aby pokazać, że są one względem siebie komplementarne, a także istotę koncepcję przewagi konkurencyjnej opartej na orientacji rynkowej. W XXI w. podmioty rynkowe dzięki informacjom i świadomemu stosowaniu wiedzy mogą zmieniać swoje zdolności strategiczne ${ }^{32}$ i tak też się dzieje w podmiotach opieki zdrowonej, dla których orientacja rynkowa staje się koniecznością ${ }^{33}$ (również ze względu na zmiany w dostępności zasobów systemu ochrony zdrowia w obszarze stomatologii - przedstawione w Załączniku nr 1). Lekarze dentyści zakładając prywatne gabinety stomatologiczne, prowadząc je i wykorzystując szanse w zmieniających się warunkach rynkowych, stają się przedsiębiorcami - na podstawie przeglądu różnych teorii przedsiębiorcy wykazano, że lekarz dentysta jest przedsiębiorcą.

Istotą rozważań drugiego rozdziału jest wyeksponowanie pozamedycznych ról pełnionych przez stomatologów w gabinecie (przełożonego, menedżera, partnera w łańcuchu dostaw), ze szczególnym uwzględnieniem jego roli jako przed-

\footnotetext{
${ }^{31}$ Szymański W. (red.), Przedsiębiorstwo, rynek, konkurencja, Wyd. SGH, Warszawa 1995, s. 156.

32 Petit P., The Roots of the New Economy: An Institutional Perspective, CEPREMAP/CNSR, Universite de paris Sud (XI), 17-18 May 2000 za: Skrzypek E., Uwarunkowania jakości klienta w realiach nowej ekonomii, w: Borys T., Rogala P. (red.), Orientacja na klienta jako kryterium doskonałości, „Prace Naukowe Uniwersytetu Ekonomicznego we Wrocławiu” nr 151, Wrocław 2011, s. 556.

${ }^{33}$ Kotler Ph., Shalowitz J., Stevens R.J., Marketing strategiczny w opiece zdrowotnej, Oficyna a Wolters Kluwer business, Warszawa 2011, s. 461 i nast.
} 
siębiorcy. Na podstawie przeprowadzonych badań - wśród lekarzy dentystów i studentów kierunku lekarsko-dentystycznego - wskazano motywy podejmowanych działań (związane $\mathrm{m}$. in. z potrzebami zaspokajanymi w pracy), intencje przedsiębiorcze, umiejętności i kompetencje dentystów, powiązane $\mathrm{z}$ prowadzeniem gabinetu, jako uczestnika rynku. Podkreślono rolę intuicji w kształtowaniu sposobu działania stomatologów, zwracając jednak uwagę, że intuicyjne zarządzanie powinno zostać wsparte bardziej profesjonalnym podejściem. W rozdziale drugim podjęta została również tematyka dentysty - przedsiębiorcy $\mathrm{w}$ przedsiębiorstwie rodzinnym. Przedstawiono istotę przedsiębiorczości rodzinnej, jej zalety i ograniczenia, znaczenie w prowadzeniu działalności przez lekarzy dentystów oraz wpływ uwarunkowań rodzinnych na intencje przedsiębiorcze studentów stomatologii. Rozważania teoretyczne uzupełniono wynikami badań własnych.

Rozdział trzeci przybliża rolę gabinetu, jako podmiotu usługowego. Przedstawiono w nim specyfikę usługi medycznej, znaczenie jakości usług w kreowaniu satysfakcji pacjenta oraz łańcuch jakości w gabinecie stomatologicznym. Ciągłe dążenie do podnoszenia poziomu jakości (zgodnie z oczekiwaniami pacjentów i wymaganiami otoczenia), to wprowadzanie gabinetu na ścieżkę uczenia się (tak adaptacyjnego, jak i kreatywnego - realizowanego przez lekarza dentystę przedsiębiorcę Schumpetera). Wykorzystanie propozycji K. Rogozińskiego ${ }^{34}$, aby działania projakościowe $\mathrm{w}$ usługach były realizowane wg metody $3 \mathrm{M}$ : management, mistrzostwo zawodowe, marketing, stanowiło asumpt do tego, by pokazać - w kolejnym rozdziale - znaczenie marketingu w podnoszeniu poziomu jakości obsługi pacjentów. W trzecim rozdziale zwrócono również uwagę na znaczenie innowacji (np. na płaszczyźnie współpracy z klientem) w przedsiębiorczym działaniu stomatologów - nastawionym na zastępowanie dotychczasowych rozwiązań nowymi. Pozwoliło to na pokazanie, że gabinet stomatologiczny jest organizacją uczącą się, w której dzięki wiedzy pracowników mogą dokonywać się zmiany o charakterze ofensywnym i defensywnym. W aspekcie wiedzy osobistej stomatologa podjęto również kwestię uczestnictwa w szkoleniach oraz roli uczelni medycznych w kształtowaniu umiejętności lekarzy dentystów w zakresie prowadzenia gabinetu, jako przedsiębiorstwa zarobkowego. Istotną część rozdziału stanowi omówienie wyników badań w zakresie rynkowego funkcjonowania gabinetu stomatologicznego, $w$ tym $\mathrm{m}$. in.: czasu trwania kontaktów usługowych z pacjentami, źródeł finansowania działalności, mocnych i słabych stron współczesnych gabinetów (w oczach lekarzy dentystów i studentów kierunku lekarsko-dentystycznego), outsourcingu funkcji pomocniczych.

\footnotetext{
${ }^{34}$ Rogoziński K., Nowy marketing ustug, Wyd. AE w Poznaniu, Poznań 2000, s. 242.
} 
Rozdział czwarty skoncentrowany jest na relacjach ${ }^{35}$ : lekarz dentysta - pacjent. Pokazano, że w podmiotach zorientowanych na klienta - oprócz teorii agencji i teorii interesariuszy - istotną rolę odgrywa współczesny (zgodny z definicją AMA z 2007 r.) marketing. Przegląd definicji marketingu relacji pozwolił na pokazanie roli personelu gabinetu w zatrzymaniu pacjentów, jako klientów gabinetu w długim okresie; a także przedstawienie głównych czynników wpływających na relacje (zaangażowanie, które bazując na zaufaniu, pomaga uwiarygodnić rynkową pozycję gabinetu w oczach interesariuszy - pacjentów i pracowników; optymalną komunikację i edukację prozdrowotną). Zaprezentowano również wyniki badań własnych - dotyczących oczekiwań pacjentów, komunikacji na płaszczyźnie gabinet - pacjent, działań marketingowych gabinetów (w ujęciu normatywnym i pozytywnym), poziomów relacji na płaszczyźnie pacjent - lekarz dentysta, będących egzemplifikacją rozważań teoretycznych.

W rozdziale piątym, dokonano syntezy stylów ze zmodyfikowanej teorii przywództwa transakcyjno-transformacyjnego J.M. Burnsa ${ }^{36} \mathrm{z}$ wybranymi postawami przedsiębiorczymi (prezentowanymi na gruncie nauk o przedsiębiorczości) i otrzymano trzy typy sylwetek lekarzy dentystów - respondentów badania II:

- Sylwetka A - przedsiębiorca inspirator i inicjator zmian (człowiek czujny Kirznera, czy innowator Schumpetera), charakteryzujący się transformacyjnym stylem przywództwa,

- Sylwetka B - osoba skupiona na podejmowaniu decyzji (koordynator Walrasa i decydent Druckera), posługująca się stylem transakcyjnym,

- Sylwetka C - osoba organizująca zasoby (organizator Say’a i człowiek podejmujący umiarkowane ryzyko McClellanda), dla której charakterystyczny jest mieszany styl przywództwa.

Przyjęta typologia pozwoliła na wskazanie - odmiennych w zakresie umiejętności i postaw w miejscu pracy - sylwetek lekarzy dentystów, a w konsekwencji zróżnicowania w podejmowanych działaniach rynkowych. Przedmiotem analizy były następujące obszary:

- postrzeganie czynników konkurencyjności i wyzwań stojących przed gabinetami stomatologicznymi,

\footnotetext{
${ }^{35}$ Przedmiotem zainteresowania pracy są klasyczne relacje dwustronne pomiędzy lekarzem dentystą (realizującym świadczenie zdrowotne) a pacjentem (nabywającym usługę). Jednak znajdują się w niej również odniesienia do innych typów relacji: 1) klasycznych relacji trójstronnych: nabywca dostawca - konkurent, 2) relacji wewnątrz podmiotu, 3) relacji między pacjentami a tzw. personelem pierwszego kontaktu, 4) relacji w ramach układów funkcjonalnych i hierarchicznych, 5) relacji w obrębie marketingu wewnętrznego, 6) relacje związane z pozyskiwaniem wiedzy, 7) relacje ,elektroniczne", 8) relacji z dostawcami usług pomocniczych.

Typy relacji zaczerpnięte z: Gummesson's 30 Rs (30 types of business relationship), www.audiencedialogue.net/30r.html

${ }^{36}$ Burns J.M., Leadership, Harper\&Row, Nowy Jork 1978.
} 
- samoocena umiejętności inter- i intrapersonalnych,

- działania podejmowane $\mathrm{w}$ gabinecie $\mathrm{w}$ odniesieniu do personelu i pacjenttów,

- postrzeganie roli uczelni medycznej w przygotowaniu lekarzy dentystów do prowadzenia gabinetu w pozamedycznym obszarze.

Wykazanie powiązań pomiędzy sylwetką lekarza dentysty a stosowanymi w gabinecie działaniami z zakresu marketingu, pozwoliło na sformułowanie rekomendacji co do zasadności podejmowania praktyk ożywiania przedsiębiorczości wśród lekarzy dentystów w celu umacniania pozycji konkurencyjnej ich gabinetów.

W zakończeniu obok wniosków płynących z przeprowadzonych rozważań, przedstawiono propozycje kierunków dalszych badań związanych z przedsiębiorczością w komercyjnych gabinetach lekarskich.

Chciałabym w tym miejscu wyrazić szczególne podziękowanie - za otwartość i wsparcie - prof. Lucynie Lewandowskiej; prof. Henrykowi Mrukowi za to, że dostrzegł w interdyscyplinarności pracy jej walor. Moim najbliższym, że przejęli na siebie ciężar domowych obowiązków. Moim córkom, że cierpliwie (choć może nie zawsze dość) czekały, aż mama ,napisze w końcu tę książkę”. 


\title{
ROZDZIAŁ I \\ PRZEDSIĘBIORCZOŚĆ \\ W KREOWANIU PRZEWAGI KONKURENCYJNEJ
}

\author{
Przedsiębiorczość i konkurencyjność \\ sa dwoma stronami tego samego zjawiska. \\ Dziatalność przedsiębiorcza \\ zawsze jest konkurencyjna, \\ a działalność konkurencyjna \\ zawsze jest przedsiębiorcza.
}

I.M. Kirzner ${ }^{1}$

\section{KONKURENCYJNOŚĆ \\ 1.1. WYZWANIA WSPÓŁCZESNEJ GOSPODARKI - ZARYS ZAGADNIENIA}

Wydarzenia ostatnich lat dowodzą, że paradygmat ekonomii tradycyjnej - oparty na koncepcji doskonale racjonalnego człowieka gospodarującego (homo economicus) - nie zdaje egzaminu², gdyż decyzje o charakterze ekonomicznym są podejmowane bardzo często w kontekście społecznym, a nie jedynie Robbinsonowskim. Sformalizowana i - jak twierdzi R.H. Thaler - wysoce abstrakcyjna ekonomia tradycyjna ${ }^{3}$ nie potrafi wyjaśniać i przewidywać rzeczywistych zjawisk gospodarczych ${ }^{4}$. Sytuacja ta jest związana również z usunięciem z ekonomii na początku XX w. niemal wszystkich wpływów psychologicznych. Proces ten - rozpoczęty przez V. Pareto ${ }^{5}$ - był kontynuowany

\footnotetext{
${ }^{1}$ Kirzner I.M., Konkurencja i przedsiębiorczość, Fijorr Publishing, Warszawa 2010, s. 94.

2 Thaler R.H., From Homo Economicus to Homo Sapiens, "Journal of Economic Perspectives", 2000, nr 1; Hockuba Z., Pożegnanie z homo economicus, "Rzeczpospolita", 23.12.2008.

${ }^{3}$ Tradycyjna ekonomia - jako nauka pozytywna - jest wolna od wartości. Pewną próbę wyjaśnienia działań gospodarczych w kontekście społecznym stanowi ekonomia instytucjonalna jako kierunek ekonomii heterodoksyjnej od T.B. Veblena przez poglądy J. Commonsa po J. Buchanana, R. Coase'a, O. Williamsona, H. Demsetza i A. Alchiana.

Por. Kątowski T., Zarys historii myśli ekonomicznej, Wyższa Szkoła Finansów i Administracji, Gdynia 2009, s. 74 i nast.

4 Wojtyna A., Wspótczesna ekonomia - kontynuacja czy poszukiwanie nowego paradygmatu, „Ekonomista”, 2008, nr 1.

${ }^{5}$ Tzw. przewrót paretowski (paretian turn) wynikał z założenia, że teorie ekonomiczne powinny być dowodzone na podstawie dobrze ustalonych empirycznych faktów dotyczących obserwowalnych ludzkich wyborów bez użycia psychologicznych pojęć, jak użyteczność, wrażenie, czy szczęście. Por. Wojtyna A., Współczesna ekonomia - kontynuacja czy poszukiwanie nowego paradygmatu, „Ekonomista”, 2008, nr 1; Brzeziński M., Gorynia M., Hockuba Z., Ekonomia a inne nauki spoteczne na początku XXIw. Między imperializmem a kooperacja, „Ekonomista”, $2008 \mathrm{nr} 2$; Polowczyk J., Podstawy ekonomii behawioralnej, „Przegląd Organizacji”, 2009 nr 12, s. 3.
} 
w latach 30-40. ubiegłego wieku przez m. in. J. Hicksa, R. Allena i P. Samuelsona, którzy wyeliminowali z teorii konsumenta pojęcie użyteczności i pokazali, że teorię tę da się stworzyć wyłącznie na podstawie aksjomatów dotyczących obserwowalnych wyborów jednostki. J. Polowczyk ${ }^{6}$ uważa, że najbardziej akceptowaną definicją ekonomii tradycyjnej jest sformułowana w 1932 r. przez L.Ch. Robbinsa: „Ekonomia jest nauką, która bada zachowania człowieka jako związku między celami i ograniczonymi środkami mogącymi mieć alternatywne zastosowania."7 Pierwsza część definicji wyraźnie wskazuje na konieczność zwracania uwagi na zachowania człowieka i badanie ich w kontekście jego funkcjonowania (zarówno na rynku ,tradycyjnym”, jak i w obszarze zaspokajania jego potrzeb społecznych tj. zdrowie, ekologia, do niedawna nie związanych z mechanizmem rynkowym). „Badanie zachowań człowieka” staje się stałym elementem wielu współczesnych definicji ekonomii jako nauki ${ }^{8}$, dlatego można przyjąć, że we współczesnej ekonomii istnieje pewien konsensus co do tego, że podstawowym podmiotem ekonomii jako dyscypliny naukowej jest człowiek i jego zachowania. I właśnie człowiek: lekarz dentysta (zaspokajający własne potrzeby oraz potrzeby innego człowieka) $\mathrm{i}-\mathrm{w}$ pewnym zakresie również pacjent (dokonujący wyboru stomatologa, który może zaspokoić jego potrzeby) oraz determinanty jego decyzji (w zakresie prowadzenia gabinetu stomatologicznego oraz korzystania $\mathrm{z}$ usług stomatologicznych) będzie stanowił punkt centralny niniejszej pracy.

W połowie XX w. pojawiły się głosy, że człowiek gospodarujący to nie tylko „racjonalny wybór”. Twórcą koncepcji tzw. ograniczonej racjonalności ${ }^{9}$ (bounded rationality) był $\mathrm{H}$. Simon ${ }^{10}$, który brał pod uwagę aspekty

\footnotetext{
${ }^{6}$ Polowczyk J., Podstawy ... op. cit., s. 3.

${ }^{7}$ Robbins L.Ch., An Essay on the Nature and Significance of Economic Science, Macmillan, Londyn 1935, s. 16 za: Polowczyk J., Podstawy ... op. cit., s. 3.

${ }^{8}$ Por. Backhouse R.E., Medea S.G., On the Definition of Economics, "Journal of Economic Perspectives", 2009, nr 1.

${ }^{9} \mathrm{Na}$ ten temat pisał również m. in. F.A. Hayek: „Szczególny charakter problemu racjonalnego porządku ekonomicznego wynika właśnie z faktu, że wiedza o warunkach, z której musimy korzystać, nigdy nie występuje w postaci skoncentrowanej czy zintegrowanej, leczy wyłącznie w formie rozproszonych okruchów niepełnej i często sprzecznej wiedzy posiadanej przez wszystkie $\mathrm{z}$ osobna jednostki. Ekonomiczny problem społeczeństwa nie dotyczy zatem po prostu alokacji 'danych' zasobów (...). Jest to raczej problem zapewnienia najlepszego wykorzystania zasobów znanych każdemu spośród członków społeczeństwa w celach, których względne znaczeniu jemu są tylko znane. Krótko mówiąc, jest to problem wykorzystywania wiedzy, która w całej swej pełni nikomu nie jest dana.” I dalej: ,,jeśli chcemy zrozumieć prawdziwą funkcję [rynku], nie można traktować go jak maszyny, ale raczej jak 'mechanizm przekazywania informacji' - rynek jest więc społecznym instrumentem, służącym gromadzeniu wycinków wiedzy rozproszonych po całej gospodarce." Por. Hayek F.A., Wykorzystanie wiedzy w spoteczeństwie, w: Indywidualizm i porzadek ekonomiczny, wydawnictwo ZNAK, 1998, s. 89 i nast.

${ }^{10}$ Simon H.A., Administrative Behavior, Free Press, Nowy Jork 1947.
} 
psychologiczne $^{11}$ i społeczne podejmowania decyzji. Za kamień węgielny ekonomii behawioralnej ${ }^{12}$ uważa się artykuł dwóch amerykańskich psychologów: D. Kahnemana i A. Tversky'ego ${ }^{13}$, którzy nie odrzucali założeń ekonomii tradycyjnej o racjonalności zachowań, ale traktowali je jako punkt wyjściowy do badania odchyleń rzeczywistych zachowań od wzorca. Dążyli do skonstruowania ekonomicznych modeli ludzkiego myślenia i zachowania, które czerpią z osiągnięć psychologii, są bardziej realistyczne i uwzględniają ułomności ludzkiej racjonalności ${ }^{14}$. Odrzucili pojmowanie człowieka jedynie w kategoriach homo economicus (jako działającego w pełni racjonalnie, pod pełną samokontrolą i dążącego do zaspokojenia - wąsko pojmowanego - własnego interesu $^{15}$ ). W efekcie nastąpił powrót do myśli ojca ekonomii klasycznej, który pisał o awersji do strat, ignorowaniu kosztów niejawnych czy o roli poczucia sprawiedliwości $\mathrm{w}$ zachowaniach ekonomicznych ${ }^{16}$. Do istotnych $-\mathrm{z}$ punktu widzenia usług stomatologicznych - osiągnięć tego nurtu można zaliczyć teorię perspektyw $^{17}$, efekt posiadania ${ }^{18}$, a także uwzględnienie emocji i preferencji społecznych w analizie procesów decyzyjnych. Prace z zakresu ekonomii

11 Wykorzystanie psychologii w ekonomii propagowali także: G. Katona, który podkreślał konieczność empirycznych obserwacji, przeprowadzał wiele analiz, wywiadów, aby poznawać ludzkie oczekiwania, zwyczaje i stereotypy (por. Katona G., Essays on Behavioral Economics, Institute for social Research, Ann Arbor 1980) i H. Leibenstein, którego zainteresowania skupiły się na człowieku dążącym do realizacji swoich interesów i będącym niezupełnie racjonalnym z powodu uwarunkowań społecznych, swoich wcześniejszych wyborów czy tożsamości.

por. Leibenstein H., Beyond Economic Man: a New Foundation for Microeconomics, Harvard University Press, Cambridge, MA, 1976.

${ }^{12}$ Za prekursora ekonomii behawioralnej może uchodzić A. Smith, który podjął próbę opisania natury ludzkiej i zasad, które pomagają we właściwym kształtowaniu współżycia ludzi. Rozważał, co jednoczy społeczeństwo wolnych ludzi, dlaczego oprócz egoizmu (miłości własnej) przejawiają również altruizm (miłość do bliźniego).

Por. Smith A., Teoria uczuć moralnych, PWN, Warszawa 1989.

${ }^{13}$ Kahnemen D., Tversky A., Prospect Theory: an analysis of Decision under Risk, "Econometrica" 1979 , nr 47, s. 313 i nast.

${ }^{14}$ Warto zaznaczyć, że ekonomia behawioralna nie jest jednolitą szkołą, lecz stanowi zbiór różnych teorii, do których zalicza się m. in. szkołę Michigan (G. Katona), szkołę makroekonomii behawioralnej (G. Akerlofa), ekonomii eksperymentalnej (V. Smita), ekonomii psychologicznej (C. Camerara, R. Thalera, E. Fehra), ekonomii ewolucyjnej (R. Nelsona, S. Wintera), czy finanse behawioralne (R. Schillera).

${ }^{15} \mathrm{~W}$ podejście to wpisuje się również spojrzenie na dentystę jako na lekarza (który dąży do zaspokojenia potrzeb społecznych związanych ze zdrowiem innych ludzi) i przedsiębiorcę (realizującego własny cel ekonomiczny).

${ }^{16}$ Por. Smith A., Teoria uczuć ... op. cit.

${ }^{17}$ Zakłada ona, że decydent przedkłada mniejszy, lecz pewny zysk nad ryzykowną grę o tej samej wartości oczekiwanej, a jednocześnie woli ryzykowną grę o ujemnej wartości oczekiwanej od pewnej straty tej samej kwoty; ponadto odczuwa silniej stratę niż zysk o tej samej wartości nominalnej, dlatego ma tendencję do utrzymywania status quo.

${ }^{18}$ Zgodnie z nim ludzie wyżej cenią dany obiekt, kiedy znajduje się on już w ich posiadaniu, niż wówczas, gdy nim nie dysponują. 
behawioralnej rozszerzają granice ekonomii w różnych kierunkach i zrywają z opieraniem wyjaśnień na hipotezach racjonalnego wyboru. Badania te często zajmują się tym, co tradycyjnie było uważane za psychologię (jak ludzie podejmują decyzje) lub socjologię (jak wybory są uwarunkowane przez społeczne okoliczności) $^{19}$.

Jeden z głównych współczesnych filozofów polityki - M.J. Sandel, występując przeciw ,jedynie słusznej” logice wyboru ekonomicznego, stawia tezę, że rynek nie jest tylko maszyną racjonalnego wyboru (Veblenowski „kalkulatorem przyjemności i cierpień"), ale mechanizmem, który zaczyna zawłaszczać postawy społeczne (np. altruizm, poczucie obywatelskiego obowiązku) i wpływać na funkcjonowanie wartości trudnych do wycenienia - jak np. wzajemne zaufanie, poczucie obowiązku, odpowiedzialność za słowo czy solidarność społeczna ${ }^{20}$. A przecież gospodarowanie człowieka ma również wymiary pozaekonomiczne, $\mathrm{np}^{21}$ : techniczny, przestrzenny (związany z lokalizacją działalności gospodarczej), ekologiczny, polityczny czy etyczny. Sandel twierdzi, że niektóre obszary życia człowieka nie powinny być dostępne dla rynku, gdyż w grze popytu i podaży człowiek zaczyna gubić człowieczeństwo (i homo sapiens przegrywa $\mathrm{z}$ homo economicus). Jego radykalna postawa względem wolnego rynku jest odpowiedzią na kryzys, z którym świat zmaga się od kilku lat. Niemniej jednak o ile z jego postulatem ,powrotu człowieka” (z jego wartościami i uczuciami wpływającymi na decyzje w obszarze społeczno-ekonomicznego życia) do ekonomii można się zgodzić, o tyle odwrót od ekonomizacji obszarów życia społecznego (np. usług zdrowotnych) wydaje się już niemożliwy (choć oczywiście dyskusja o zasadach jej realizacji w duchu ekonomiczno-społecznoetycznym powinna być podejmowana).

W pracy przyjęto założenie, że lekarz dentysta (prowadzący własny gabinet stomatologiczny) jako człowiek gospodarujący nie jest klasycznym homo economicus, ale podmiotem o ograniczonej racjonalności i z racji specyfiki wykonywanego zawodu jest mu bliżej do sylwetki homo sociologicus ${ }^{22}$. Jest to

${ }^{19}$ Wojtyna A., Wspótczesna ekonomia - kontynuacja czy poszukiwanie nowego paradygmatu, „Ekonomista”, 2008, nr 1; Backhouse R.E., , Medea S.G., On the definition ... op. cit.

${ }^{20}$ Sandel M.J., Czego nie można kupić za pieniadze: moralne granice rynku, Kurhaus Publishing, Warszawa 2012.

${ }^{21}$ Stecewicz J., Stereotypy rozwoju a ekonomia, PWE, Warszawa 1991, s. 48 i nast.

${ }^{22} \mathrm{~W}$ odniesieniu do lekarza dentysty, prowadzącego działalność na własny rachunek, należy zgodzić się z T.B. Veblenem, który odrzucał hedonistyczną i atomistyczną koncepcję natury ludzkiej (leżącą u podstaw klasycznego modelu homo economicus) i postulował uwzględnienie w modelu człowieka gospodarującego psychologii społecznej (dowodzącej, że postawy człowieka nie zawsze są racjonalne) i faktu, iż motywy działania gospodarczego jednostki mogą mieć również wymiar pozaekonomiczny (np. człowiek może kierować się wartościami, emocjami), co sprawia, że człowiek nabiera cech homo sociologicus. Por. Veblen T.B., Why is Economics Not an Evolutionary Science?, "The Quarterly Journal Economics", 1898 nr 12 w: Huebsh B.W. (red.), The Place of Science in Modern Civilization, Nowy Jork 1919. 
podmiot, który stawia sobie do zrealizowania określony cel medyczny i gospodarczy jednocześnie ${ }^{23}$. Na podstawie swojej wiedzy o dostępnych środkach $^{24}$ oraz okolicznościach działania ${ }^{25}$ wybiera najbardziej optymalne sposoby osiągnięcia tego celu. W jego działaniach krzyżują się motywy altruistyczne z ekonomicznymi i te pierwsze (zgodnie z etyką lekarską - obligatoryjnie, a z ekonomią behawioralną - fakultatywnie) powinny przeważać ${ }^{26}$ (i z badań I i III wynika, że tak jest). Ograniczenie racjonalności działania stomatologów wynika nie tylko z ograniczeń wskazanych przez H.A. Simona ${ }^{27}$, ale również z faktu, że usługi medyczne nie są oferowane w warunkach konkurencji doskonałej (o ograniczeniach w traktowaniu świadczeń medycznych jako dóbr rynkowych będzie mowa w dalszej części rozdziału). Można mówić również o ograniczeniach wewnętrznych ( $\mathrm{tj}$. tkwiących $\mathrm{w}$ stomatologu, jako człowieku) w racjonalności działania np. ${ }^{28}$ :

- kierowanie się przesłankami altruistycznymi przez lekarza (może stanowić czynnik wpływający na racjonalność jego ekonomicznych decyzji);

- dążenie do satysfakcjonującego dentystę (a nie zawsze maksymalnego) poziomu realizacji celów;

- ograniczone możliwości percepcji dostępnych informacji i ich przetworzenie w odpowiednie decyzje (w tym stricte ekonomiczne);

${ }^{23}$ Por. koncepcja racjonalności rzeczowej O. Langego - Lange O., Ekonomia polityczna, PWN, Warszawa 1978, s. 140.

${ }^{24}$ Do środków można zaliczyć m. in.: 1) poziom wiedzy i umiejętności stricte medycznych lekarza oraz dostępne metody leczenia, 2) poziom umiejętności interpersonalnych stomatologa; 3) poziom wiedzy i umiejętności personelu, 4) wyposażenie gabinetu, 5) organizację pracy gabinetu (np. praca na jednym vs dwóch fotelach; czas pracy), 6) jakość materiałów stomatologicznych używanych przez stomatologa, 7) kwalifikacje podmiotów współpracujących np. technika dentystycznego, 8) poziom - szeroko pojętej - wiedzy lekarza o funkcjonowaniu podmiotów rynkowych.

${ }^{25}$ Obejmują one m. in.: 1) stan zdrowia pacjenta, 2) status pacjenta - leczenie w ramach ubezpieczenia zdrowotnego (i związane z tym możliwości) czy za prywatne środki pacjenta (i związane z tym możliwości finansowania leczenia), 3) reputację gabinetu, 4) liczbę gabinetów stomatologicznych funkcjonujących w pobliżu, 5) warunki współpracy z organami kontrolnymi (np. Sanepidem), 6) obowiązujące ustawodawstwo w zakresie funkcjonowania gabinetów stomatologicznych i zalecenia Naczelnej Rady Lekarskiej itp.

${ }^{26}$ E. Taylor zauważył, że w działalności gospodarczej nie do uniknięcia jest przeplatanie się motywów gospodarczych z moralnymi, ale pierwszeństwo dawał ekonomicznym, gdyż to one determinują podjęcie działalności gospodarczej.

Por. Taylor E., Wstęp do ekonomiki, Spółdzielnia Wydawnicza „Żeglarz”, Gdynia 1947, s. 48.

W przypadku lekarzy dentystów chęć pomocy innym skłania ich do wyboru zawodu, a powody ekonomiczne - do wykonywania tego zawodu na własny rachunek.

${ }^{27}$ Por. Simon H.A., Rational Decision Making In Business Organizations, „American Economic Review", 1979, vol. 69, nr 4, s. 501 i nast.

${ }^{28}$ Por. Keynes J.M., Ogólna teoria zatrudnienia, procentu i pieniądza, PWN, Warszawa 1956, s. $190 \mathrm{i}$ nast. 
- ograniczona wiedza z zakresu ekonomicznego funkcjonowania podmiotów gospodarczych;

- ograniczenia w trafności przewidywań zmian zachodzących w otoczeniu;

- stan zaufania do państwa tworzącego - odpowiednimi regulacjami prawnymi - warunki do działania lekarza dentysty na rynku.

Podsumowując, zachowania współczesnych podmiotów rynkowych nie da się wytłumaczyć tylko na podstawie zasady maksymalizacji zysku czy - neoklasycznej - zasady racjonalnego gospodarowania. Współczesna ekonomia to również nauka o niepewności i kreacji, nauka o rewitalizacji zasobów oraz nauka o wartościach (m. in. wpływie wartości etycznych, kulturowych, społecznych, religijnych itd. na wartość produktów i usług przedsiębiorstwa dla klienta czy wartości klienta dla przedsiębiorstwa) w prowadzeniu działalności gospodarczej ${ }^{29}$. A. Noga podkreśla, że współczesna teoria ekonomii wręcz dąży do „zbudowania pomostu” między precyzją, elegancją i wewnętrzną zgodnością heurystycznych modeli teorii ekonomii a bogactwem dociekań empirycznych nauk o organizacji i zarządzaniu ${ }^{30}$, czy innych nauk zajmujących się podejmowaniem decyzji przez człowieka. Dlatego mówienie o dzisiejszym rynku (również o rynku, czy - jak niektórzy określają - quasi rynku usług zdrowotnych) wymaga uwzględnienia szerokiego kontekstu - wiedzy zarówno z obszarów ekonomicznych, jak i nauk koncentrujących się na zachowaniu człowieka. Procesy organizowania działań w podmiotach rynkowych znajdują najpełniejszy wyraz na gruncie twierdzeń o organizacji. Z jednej strony dorobek nauki o zarządzaniu zostaje zaadaptowany i rozwijany w ekonomii ${ }^{31}-\mathrm{w}$ końcu XIX w. do ekonomii została wprowadzona przez A. Marshalla - jako czwarty czynnik produkcji - organizacja; a z drugiej strony - dzięki pracom F.W. Taylora i K. Adameckiego - pojawiła się nowa dyscyplina naukowa - naukowa organizacja (współcześnie - nauki o zarządzaniu). Jej istotą - tak w warstwie naukowej, jak i praktycznej - jest redukcja chaosu organizacyjnego i poszukiwanie metod na usprawnienie działań podmiotu ${ }^{32}$. Równolegle $\mathrm{w}$ ekonomii rozwija się - począwszy od T.B. Veblena - tradycyjny i nowoczesny instytucjonalizm, który forsuje potrzebę zintegrowania gospodarowania $\mathrm{z}$ innymi naukami społecznymi (historią, psychologią, socjologia) ${ }^{33}$. P. Samuelson wskazuje, że współczesna gospodarka ma charakter mieszany ${ }^{34}$, a nie w pełni wolnorynkowy,

\footnotetext{
${ }^{29}$ Noga A., Teorie przedsiębiorstw, PWE, Warszawa 2011, s. 42.

${ }^{30}$ Ibidem s. 114.

31 Witczak H., Natura i ksztattowanie systemu zarzadzania przedsiębiorstwem, Wydawnictwo Naukowe PWN, Warszawa 2008, s. 90.

${ }^{32}$ Northouse P.G., Leadership. Theory and Practice, Thousand Oaks, Londyn 2004.

${ }^{33}$ Nasiłowski M., Zarys historii myśli ekonomicznej, Wydawnictwo Key Text, Warszawa 2003, s. 79 .

${ }^{34}$ Gruszecki T., Nagrody Nobla w ekonomii, Oficyna Wydawnicza Verba, Lublin 2001, s. 12.
} 
na skutek działania monopoli i regulacyjnej roli rządu. K.J. Arrow zwraca uwagę na takie czynniki usprawiedliwiające istnienie organizacji (w znaczeniu działań kolektywnych) jak niepewność zachowania się podmiotów, niedoskonała organizacja (w znaczeniu procesu), brak współpracy oraz czynniki niematerialne, jak etyka, kultura organizacji i lojalność administracji ${ }^{35}$.

Mnogość zmian zachodzących zarówno w obszarze funkcjonowania rynku, jak i w teoriach go opisujących zaowocowała nowym spojrzeniem na rynkową aktywność przedsiębiorstw w XXI w., w której - jak twierdzi P. Petit - podmioty gospodarcze mogą uzyskać informacje i stosować wiedzę, zmieniając swoje zdolności strategiczne ${ }^{36}$. Nowa gospodarka ${ }^{37}$ określona została przez A. Glińską-Neweś jako zespół zjawisk i zależności nie tylko o charakterze ekonomicznym, ale i kulturowym, będący efektem współczesnego postępu technicznego $^{38}$. Za cechę nowej ekonomii uważa się koncentrację na zasobach niematerialnych, a szczególnie na kapitale intelektualnym ${ }^{39}$. Tym samym głównym wyznacznikiem wartości w nowej ekonomii staje się wiedza (wartość ekonomiczna powstaje w procesie tworzenia, dystrybucji i konsumpcji wiedzy oraz produktów opartych na wiedzy $)^{40}$. I. Durlik wskazuje na następujące cechy nowej ekonomii w funkcjonowaniu przedsiębiorstw:

- „New economy nie stanowi wytkniętego punktu docelowego w zarządzaniu firmą, to raczej praca twórcza mająca na celu uzyskanie satysfakcji klienta i względnie trwałej egzystencji firmy,

- New economy przedefiniowuje tradycyjne zasady ekonomiczne i posługuje się nowymi kryteriami,

\footnotetext{
${ }^{35}$ Ibidem s. 17.

${ }^{36}$ Petit P., The Roots of ... op. cit., s. 556.

${ }^{37}$ Nowa era nazywana jest również postindustrialną, gospodarką wiedzy, gospodarką elektroniczną, gospodarką sieciową, nową ekonomią czy ekonomią wiedzy (określenia te używane są często jako synonimy). Określenie „nowa gospodarka” utożsamiane bywa także z określeniem „nowy ład ekonomiczny". A. Toffler nową gospodarkę określa jako nowy porządek trzeciej fali rozwoju społecznego i wskazuje, że jej determinantami są: gospodarka światowa (w której dominuje zatrudnienie w sferze usług), gospodarka wiedzy (która zastępuje tradycyjną triadę: praca, kapitał, ziemia) oraz gospodarka nadmiaru lub „,nadmożliwości” określona jako społeczeństwo dobrobytu.

Por. Toffler A., Trzecia fala, PIW, Warszawa 1997,

${ }^{38}$ Glińska-Neweś A., Kulturowe uwarunkowania zarządzania wiedza w przedsiębiorstwie, TNOiK, Toruń 2007, s. 16; por. również: Zienkowski L., Gospodarka „oparta na wiedz” - mit czy rzeczywistość?, w: Zienkowski L. (red.), Wiedza a wzrost gospodarczy, Wydawnictwo Naukowe SCHOLAR, Warszawa 2003, s. 15; Mikuła B., Organizacje oparte na wiedzy, Wydawnictwo Akademii Ekonomicznej w Krakowie, Kraków 2006, s. 19 i nast.

39 Borowiecki R., Romanowska M., System informacji strategicznej, w: Borowiecki R., Romanowska M. (red.), Wywiad gospodarczy a konkurencyjność przedsiębiorstwa, Difin, Warszawa 2001, s. 15.

40 Harris R.G., The Knowledge-Based Economy: Intellectual Origins and New Economic Perspectives, "International Journal of Management Reviews", 2001, vol. 3, s. 21.
} 
- New economy sprzyja nienaruszalności układu, jeśli prowadzi to do osiągnięcia sukcesu w biznesie,

- tradycyjne czynniki produkcji - ziemia, praca, kapitał - gwałtownie stają się raczej zasobami hamującymi niż napędzającymi, a centralnym i kluczowym zasobem staje się wiedza,

- New economy opiera się na najlepszej zgodności i sprzyja zadowoleniu klienta." 41

Wymienione cechy można odnieść również do funkcjonowania gabinetów stomatologicznych - lekarze dentyści przedefiniowują zasady funkcjonowania swoich gabinetów - podmiotów zarobkujących i świadomie poszukują możliwości podejmowania pozamedycznych działań, które poprawiłyby zadowolenie pacjentów i przyczyniły się do trwałej egzystencji gabinetu.

W warunkach nowej ekonomii pojawił się również klient nowej ery ${ }^{42}$, którego cechuje m. in. to, że $\mathrm{e}^{43}$ :

- jest dobrze poinformowany (bo żyje w społeczeństwie informacyjnym),

- staje się partnerem dla przedsiębiorstwa i dysponuje dużą siłą przetargową (nie tylko w postaci pieniędzy, które może zostawić w przedsiębiorstwie, ale również informacji na temat przedsiębiorstwa, którą może przekazać na zewnątrz),

- jest zaangażowany, a decyzje podejmuje z namysłem (szuka potrzebnych informacji, a po zakupie ocenia, czy nabyty przedmiot/usługa spełnia jego potrzeby i w końcu - informuje innych o swoim zadowoleniu lub jego braku),

- jest świadomy swojej wartości i oczekuje od przedsiębiorstwa odpowiedniego traktowania - ze względu na swoją wyjątkowość pragnie, by traktować go indywidualnie, a nie w sposób szablonowy,

- stawia na indywidualność, przyjmuje nowe wartości konsumpcji, co przejawia się w wyższej jakości życia,

- dąży do indywidualnego rozwoju i pełnego realizowania się ${ }^{44}$,

\footnotetext{
${ }^{41}$ Knosala R., Komputerowo zintegrowane zarzadzanie, WNT, Warszawa 2004, s. 282.

${ }^{42}$ Zjawisko to jest widoczne również w usługach stomatologicznych - pacjent $\mathrm{z}$ biernego odbiorcy świadczenia medycznego staje się aktywną stroną kontaktu usługowego; zmienia się jego postawa i oczekiwania (np. w zakresie komunikacji interpersonalnej) wobec lekarza dentysty; dochodzi do ekonomizacji kontaktu lekarz - pacjent.

${ }^{43}$ Skrzypek E., Uwarunkowania jakości klienta w realiach nowej ekonomii, w: Borys T., Rogala P. (red.), Orientacja na ..., op. cit., s. 559.

${ }^{44}$ Od kilku lat rysuje się trend związany ze zwątpieniem w wartości materialne, który prowadzi do tego, że w coraz większej liczbie krajów konsumenci odrzucają mentalność posiadaczy na rzecz
} 
- traktuje konsumpcję jako sprawę prywatną i dąży do ochrony prywatności.

Przedstawione zmiany dotykają przedsiębiorstwa działające zarówno na rynkach globalnych, jak i lokalnych. Podmioty, które chcą utrzymać się na rynku, muszą na nie sprawnie reagować. Ponadto oprócz myślenia w kategoriach „efektywnościowych”, muszą patrzeć na prowadzenie biznesu również przez pryzmat wyzwań społecznych - związanych z jakością warunków pracy personelu, aspektami ekologicznymi czy uczciwością wobec nabywców. Wachlarz czynników, które mogą wspomóc/zahamować rozwój współczesnego przedsiębiorstwa jest i szeroki i różnorodny.

\subsection{ISTOTA KONKURENCYJNOŚCI}

Podmioty rynkowe (zarówno działające w celach biznesowych, jak i organizacje typu non profit) skupiają się w swoich działaniach na realizacji wiązki celów, jakimi mogą być m. in.: zadowolenie klienta, ograniczenie ryzyka, eliminacja marnotrawstwa, wysoka jakość, zadowolenie pracowników, wysoka produktywność, rentowność czy renoma, a w konsekwencji wyższa konkurencyjność rynkowa podmiotu. Konkurencyjność podmiotu to nie tylko jego bezpośredni udział w rynku, ale udział w przyszłych możliwościach ${ }^{45}$, które są konsekwencją wiedzy i kapitału intelektualnego przedsiębiorstwa ${ }^{46}$. Jej istota sprowadza się do tego, że przedsiębiorstwo robi coś więcej, czy inaczej niż inne podmioty, dzięki czemu osiąga lepsze rezultaty. Wybrane definicje pojęcia „konkurencyjność” są zaprezentowane w tabeli 1.

Konkurencyjność można rozpatrywać na płaszczyźnie ${ }^{47}$ : mikro (odnosi się wówczas do przewagi jednego przedsiębiorstwa nad podobną ofertą innego), mezo (odnosi się do towarów i usług poszczególnych branż czy gałęzi, a także regionów) i makro (ma charakter międzynarodowej konkurencyjności gospodarki krajowej). Ponieważ rozważania niniejszej pracy będą koncentrowały się

mentalności osób gromadzących przeżycia (co tworzy podatny grunt dla rozwoju marketingu doświadczeń). Jest to podyktowane z jednej strony trwającym od kilku lat kryzysem, a z drugiej próbą określenia siebie przez to, ,,co robię”, ,kim jestem”, a nie tylko przez to „,co mam”.

${ }^{45}$ G. Hamel i C.K. Prahald twierdzą, że tworzenie przewagi konkurencyjnej jutra to kreowanie i zdominowanie pojawiających się możliwości i szans dla zdobycia przewagi nad nową przestrzenią konkurencyjną.

Por. Hamel G., Prahald C.K., Przewaga konkurencyjna, Business Press, Warszawa 1999, s. 19.

${ }^{46}$ Kreatywność, innowacje i wiedza stanowią klucz do rozwoju przedsiębiorstwa. Jednocześnie, jak wynika z badań Z. Holmberg i J. Rodderstrale, współczesne organizacje wykorzystują zaledwie $10-20 \%$ posiadanej wiedzy i $10-15 \%$ kapitału intelektualnego.

Por. Pawłowski J., Diagnoza potencjału innowacyjności i konkurencyjności przedsiębiorstwa, „Przegląd Organizacji”, 2005 nr 5.

${ }^{47}$ Kożuch B., Inwestycje zagraniczne a wzrost konkurencyjności regionu. w: Olesiński Z. (pod red.) Bezpośrednie inwestycje zagraniczne w Polsce, PWE, Warszawa 1998. 
na funkcjonowaniu poszczególnych podmiotów, to w tabeli 1 przedstawione są przede wszystkim definicje odnoszące się do płaszczyzny mikro.

Tabela 1. Pojęcie ,konkurencyjność” w świetle wybranych pozycji literatury przedmiotu

\begin{tabular}{|c|c|}
\hline Autor & $\begin{array}{c}\text { Proponowane ujęcie zagadnienia } \\
\end{array}$ \\
\hline $\begin{array}{l}\text { A. Ambastha, } \\
\text { K. Momaya }\end{array}$ & $\begin{array}{l}\text { Konkurencyjność przedsiębiorstwa to zdolność firmy do zaprojektowania, } \\
\text { wytworzenia i sprzedaży produktów oraz usług lepszych, niż te oferowane } \\
\text { przez konkurentów, uwzględniając w ocenie cenowe i pozacenowe kryteria } \\
\text { jakościowe. }\end{array}$ \\
\hline $\begin{array}{l}\text { W.M.Grudzewski, } \\
\text { I.K. Hejduk }\end{array}$ & $\begin{array}{l}\text { Konkurencyjność, to „współzawodnictwo między jednostkami gospodarczy } \\
\text { mi, którego celem jest osiągnięcie jak największych korzyści przy sprzedaży } \\
\text { produktów wytworzonych przedsiębiorstwie lub świadczonych usług”. }\end{array}$ \\
\hline $\begin{array}{l}\text { B.Dobiegała-Korona, } \\
\text { S.Kasiewicz }\end{array}$ & $\begin{array}{l}\text { Konkurencyjność przedsiębiorstwa na rynku jest efektem synergicznego } \\
\text { oddziaływania wielu czynników wewnętrznych, tkwiących w przedsiębior- } \\
\text { stwie oraz mechanizmów i uwarunkowań zewnętrznych (istniejących w oto- } \\
\text { czeniu). Można ją rozumieć jako zdolność do rozwoju, osiągania korzyści } \\
\text { i zysków oraz budowania przewagi konkurencyjnej. }\end{array}$ \\
\hline O. Flak, G. Głód ${ }^{d}$ & $\begin{array}{l}\text { Konkurencyjność przedsiębiorstwa to wielowymiarowa cecha firmy, wyni- } \\
\text { kająca zarówno z jej wewnętrznych właściwości, jak i umiejętności radzenia } \\
\text { sobie z uwarunkowaniami zewnętrznymi pochodzącymi z otoczenia. }\end{array}$ \\
\hline M.J.Stankiewicz ${ }^{\mathrm{e}}$ & $\begin{array}{l}\text { Konkurencyjność to zdolność do skutecznego, korzystnego i ekonomicznego } \\
\text { realizowania celów na rynkowej arenie konkurencji. }\end{array}$ \\
\hline M.Gorynia $^{f}$ & $\begin{array}{l}\text { Przedsiębiorstwa są konkurencyjne, jeśli posiadają zdolność do przetrwania } \\
\text { i rozwoju na konkurencyjnym rynku. }\end{array}$ \\
\hline M.Nowakowski ${ }^{\mathrm{g}}$ & $\begin{array}{l}\text { Konkurencyjność to zdolność przedsiębiorstwa do sprostania konkurencji ze } \\
\text { strony rywali, utrzymywania oraz powiększania udziałów rynkowych, a także } \\
\text { osiągania w związku z tym odpowiednich zysków. }\end{array}$ \\
\hline
\end{tabular}

Źródło: opracowanie własne na podstawie: ${ }^{\text {a }}$ Ambastha A., Momaya K., Competitiveness of firms: review of theory, frameworks, and models, "Singapore Management Review", 2004 vol. 26, nr 1, s. 45 i nast.; ${ }^{\text {b }}$ Grudzewski W.M., Hejduk I.K., Innowacyjność w technice i technologii źródtem przewagi konkurencyjnej matych średnich przedsiębiorstw, IFGN SGH, Warszawa 2002, s. 64; ${ }^{\mathbf{c}}$ DobiegałaKorona B., Kasiewicz S., Metody oceny konkurencyjności przedsiębiorstw, w: Kuciński K. (red.), Uwarunkowania konkurencyjności przedsiębiorstw w Polsce, „Materiały i Prace IFGN”, tom LXXIX, Oficyna Wydawnicza SGH, Warszawa 2000; ${ }^{\mathbf{d}}$ Flak O., Głód G., Konkurencyjność przedsiębiorstwa. Pojęcia, definicje, modele, część I, Wyd. Akademii Ekonomicznej w Katowicach, 2009, s. 38; ${ }^{\text {e }}$ Stankiewicz M.J., Konkurencyjność przedsiębiorstwa. Budowanie konkurencyjności przedsiębiorstwa w warunkach globalizacji, Wydawnictwo TNOiK „Dom Organizatora”, Toruń 2005, s. 36; ${ }^{\mathbf{f}}$ Gorynia M. (red.), Luka konkurencyjna na poziomie przedsiębiorstwa a przystapienie Polski do Unii Europejskiej, Wyd. AE w Poznaniu, Poznań, 2002, s. 48; ${ }^{\mathrm{g}}$ Nowakowski M. (red.), Biznes międzynarodowy, Key Text, Warszawa 2000, s. 32.

W pracy przyjęto za B. Dobiegałą-Koroną i S. Kasiewiczem, że konkurencyjność gabinetu stomatologicznego jest efektem oddziaływania różnorakich czynników wewnętrznych (uwaga została skoncentrowana na umiejętnościach, postawach i proklientowskich działaniach lekarzy dentystów) i uwarunkowań zewnętrznych (związanych z działaniami innych gabinetów i - przede wszystkim - oczekiwaniami pacjentów). 
Odzwierciedleniem siły konkurencyjnej danego podmiotu jest jego zdolność skutecznego oddziaływania na innych uczestników rynku (tak konkurentów, jak i klientów czy partnerów biznesowych) oraz odporność na ich oddziaływanie ${ }^{48}$. Można zatem uznać, że konkurencyjne mogą być te przedsiębiorstwa, które mają przewagę konkurencyjną w odpowiednim miejscu i czasie (ujęcie statyczne) oraz umiejętności zdobywania i wzmacniania tej przewagi (ujęcie dynamiczne). Tak więc szeroko rozumiana konkurencyjność może być definiowana jako umiejętność konkurowania - działania i przetrwania w konkurencyjnym otoczeniu $^{49}$. Dlatego można powiedzieć, że konkurencyjność jest atrybutem tylko niektórych podmiotów rynkowych - tych, których działania rynkowe skutecznie pooprawiają ich pozycję względem konkurencji ${ }^{50}$.

\subsection{PRZEWAGA KONKURENCYJNA}

Systemowe podejście do konkurencyjności - prezentowane przez M.J. Stankiewicza - traktuje ją jako sumę czterech podsystemów ${ }^{51}$ :

- pozycji konkurencyjnej, którą można zdefiniować jako osiągnięty przez przedsiębiorstwo wynik konkurowania $\mathrm{w}$ danym sektorze, rozpatrywany w porównaniu z wynikami osiąganymi przez bezpośrednich konkurentów ${ }^{52}$; charakteryzuje przedsiębiorstwo $\mathrm{w}$ danym momencie, ale jest zmienna w czasie (może być poprawiana, utrzymywana lub pogarszana),

- instrumentów konkurowania, które można zdefiniować jako „środki świadomie kreowane przez przedsiębiorstwo w celu pozyskania kontrahentów dla przedstawionej lub projektowanej (przyszłej) oferty",

- potencjału konkurencyjności, który stanowi ogół zasobów ${ }^{53}$ materialnych i niematerialnych niezbędnych do tego, by przedsiębiorstwo mogło funkcjonować na rynkowej arenie konkurencji; charakter jego elementów oraz powiązań pomiędzy nimi decyduje o możliwości budowania przewagi

\footnotetext{
${ }^{48}$ Wrzosek W., Funkcjonowanie rynku, PWE, Warszawa 2002, s. 60.

${ }^{49}$ Gorynia M. (red.), Luka konkurencyjna ... op. cit., s. 48.

${ }^{50}$ Brak skuteczności działania może wynikać z kierowania procesów do wewnątrz - w stronę wydajności, zamiast na zewnątrz (właśnie w kierunku skuteczności).

Por. Swayne L.E., Duncan W.J., Ginter P.M., Zarzadzanie strategiczne w ochronie zdrowia, LEX a Wolters Kluwer business, Warszawa 2012, s. 61

${ }^{51}$ Stankiewicz M.J., Konkurencyjność przedsiębiorstwa. Budowanie konkurencyjności przedsiębiorstwa w warunkach globalizacji, TNOiK, Torun 2005 , s. 89 i nast.

${ }^{52}$ Simmonds K., The Accounting Assessment of Competitive Position, "European Journal of Marketing", 1986, vol. 20, nr 1, s. 16.

${ }^{53}$ Zasoby przedsiębiorstwa można zdefiniować jako wszystko, co może być postrzegane jako silna lub słaba strona danej organizacji np. marka, wewnętrzna wiedza na temat technologii, umiejętności pracowników, kontrakty handlowe, maszyny, procedury, kapitał itp. por. Wernerfelt B., A resourcebased view of the firm, „Strategic Management Journal”, 1984 vol. 5, nr 2, s. 172.
} 
konkurencyjnej oraz o konfigurowaniu możliwych do wykorzystania instrumentów konkurowania,

- przewagi konkurencyjnej będącej zdolnością do wykorzystywania potencjału konkurencyjnego w taki sposób, by możliwe było efektywne generowanie skutecznych instrumentów konkurowania i oferty rynkowej na tyle atrakcyjnej, by przyciągnąc i utrzymać klientów oraz aby zapewnione było powstanie wartości dodanej.

W pracy zostaną przedstawione wybrane instrumenty konkurowania - przede wszystkim z obszaru marketingu i zakres ich wykorzystywania przez lekarzy dentystów do pozyskiwania i utrzymywania indywidualnych nabywców usług stomatologicznych. Pozwoli to na określenie potencjału dentystów w kreowaniu przewagi konkurencyjnej gabinetu.

Koncentrując się na „przewadze konkurencyjnej” należy podkreślić, że jest to złożona kategoria analityczna, której interpretacja podlegała zmianom i która była przedmiotem badań z uwzględnieniem różnych perspektyw badawczych. Korzenie koncepcji przewagi konkurencyjnej sięgają prac W. Aldersona, który już w latach 40. XX w. przekonywał, że przedsiębiorstwo powinno dążyć do osiągnięcia unikatowych cech, zapewniających odróżnienie się od konkurentów ${ }^{54}$. Uważał on, że przewaga zróżnicowania (differential advantage) może być osiągnięta dzięki takim rozłącznym działaniom, jak: obniżanie cen, precyzyjnie ukierunkowana reklama i/lub usprawnienie produktów oraz innowacje. Jeszcze do lat 80 . XX w. - w ramach nurtu pozycjonowania - wystarczającym warunkiem do osiągnięcia przewagi konkurencyjnej była umiejętność skoncentrowania się przedsiębiorstwa na wybranym priorytecie konkurowania. Do takiego jednoznacznego opowiedzenia się nawoływał m. in. M.E. Porter ${ }^{55}$ w swoim modelu konkurowania, przeciwstawiając sobie strategię lidera kosztowego $^{56}$ i strategię dyferencjacji. Wskazywał on jednocześnie, że brak jedno-

\footnotetext{
54 Anderson W., A Marketing View of Competition, „Journal of Marketing”, 1937 nr 1(3), s. 189 i nast.

55 Por. Porter M.E., Porter o konkurencji, PWE, Warszawa 2001; Porter M.E., Strategia konkurencji. Metody analizy sektorów $i$ konkurentów, Wydawnictwo MT Biznes sp. z o.o., Warszawa 2006.

${ }^{56} \mathrm{~W}$ tym miejscu można postawić pytanie: „W jaki sposób podmiot może przewidzieć działania cenowe konkurenta, by nie dopuścić, aby to on stał się liderem kosztowym?” Ph. Kotler, J. Shalowitz, R.J. Stevens odpowiadają, że: „powinien przeanalizować jego aktualną sytuację rynkową” (np. biorąc pod uwagę bieżący poziom sprzedaży, poziom lojalności klientów, misję) i np. jeśli konkurent dąży do zdobycia większych udziałów w rynku, to wówczas istnieje duże prawdopodobieństwo, że zmiana jego cen będzie miała trwały charakter (i dany podmiot powinien tę zmianę $\mathrm{w}$ strategii cenowej konkurenta uwzględnić w swojej strategii cenowej). Z drugiej strony, jeśli konkurent realizuje zadanie krótkoterminowej maksymalizacji swoich zysków, to reakcja firmy może nie być związana z obniżką własnych cen (może polegać np. na zwiększeniu budżetu reklamowego lub na zainwestowaniu w podniesienie jakości produktu). Odpowiedź na agresywne cięcia cenowe
} 
znaczności w tym wyborze poprzez ,efekt ugrzęźnięcia” może zdecydowanie osłabić podmiot na rynku (a w konsekwencji pogorszyć także wyniki jego działalności), czy wręcz wyeliminować go z rynku. M.E. Porter analizując konkurencyjność przedsiębiorstwa, korzystał ze spojrzenia na przewagę konkurencyjną przez pryzmat działań kreujących wartość dla klienta ${ }^{57}$. Podkreślał, że w trakcie wykonywania poszczególnych działań przez przedsiębiorstwo poziom wartości dostarczanej klientowi jest zróżnicowany i aby wykreowało ono wyższą wartość od konkurentów, może się zdecydować na podwyższenie poziomu efektywności operacyjnej albo wykorzystanie lub zmianę pozycji strategicznej ${ }^{58}$.

M. Krzyżanowska ${ }^{59}$ zwraca uwagę, że wobec faktu, iż koncepcja przewagi konkurencyjnej powstała w ramach nurtu badawczego, który koncentruje swoją uwagę na otoczeniu i jego wpływie na sposób funkcjonowania przedsiębiorstwa, to jej początki były związane z próbą identyfikacji takich sposobów postępowania, które zapewniały przedsiębiorstwu większe możliwości realizacji jego celów w danych warunkach (czyli redukowały niesprzyjający wpływ czynników zewnętrznych). I w praktyce bardziej skupiano się na źródłach (lokując je np. w decyzjach dotyczących optymalizacji wielkości produkcji czy ekonomii zakresu działania lub - jak uczynił to M.E. Porter - w zróżnicowaniu czy przy-

konkurentów - zgodnie ze stanowiskiem prezentowanym przez omawianych autorów - następującą postać: 1) utrzymanie ceny i zapewniającej zysk marżę na niezmienionym poziomie (podmiot zakłada, że: a) jeśli zmieni ceny, utraci zbyt dużo korzyści, b) nie straci zbyt wiele udziałów w rynku na rzecz konkurenta, c) ma dość siły, aby odzyskać utracone pole w razie potrzeby); 2) utrzymanie ceny i dodanie nowej wartości, co jest możliwe dzięki ulepszeniu produktu lub systemu komunikacji (pomiot zakłada, że tańszym rozwiązaniem będzie utrzymanie poziomu opłat i przeznaczenie pieniędzy na ulepszenie jakości produktu, zamiast na „wojnę cenową” i działanie w oparciu o niższą marżę, co daje mu szansę na przyciągnięcie klientów, którzy będą lojalni wobec marki); 3) zmiana poziomu ceny i podmiot: a) obniża i dopasowuje swoją cenę do ceny konkurenta (strategia jest optymalna, gdy podmiot musi zachować określony poziom sprzedaży w celu utrzymania zmniejszonego poziomu kosztów bądź gdy przewiduje, że raz utracone udziały w rynku będzie trudno odzyskać); b) zwiększa cenę i dodaje kolejne świadczeń, aby poprawić atrakcyjność oferty.

To, które z rozwiązań okaże się odpowiednie zależy od wielu czynników (m. in.: etapu cyklu życia podmiotu i produktu; istotności roli tej usługi w portfolio produktów podmiotu; intencji i zasobów konkurenta; wrażliwości rynku na cenę i jakość; relacji koszt - ilość; liczby możliwych okazji, jakie pojawiają się przed firmą itp.), dlatego konieczna jest dokładna analiza. Jednak w praktyce często, gdy następuje ,atak cenowy” konkurencji, na szczegółową analizę nie ma czasu, dlatego podmioty (również gabinety stomatologiczne) powinny przewidywać możliwe zmiany cen u rywala i z wyprzedzeniem przygotować zestaw swoich hipotetycznych reakcji.

Por. Kotler Ph., Shalowitz J., Stevens R.J., Marketing strategiczny ... op. cit., s. 461 i nast.

${ }^{57}$ Porter M.E., Porter o ... op. cit., s. 17.

$\mathrm{Z}$ podejścia tego czerpie również marketing wartości, koncentrując się na dostarczaniu klientowi wartości przez niego oczekiwanych (a nie jedynie produktu, czy usługi, jak miało to miejsce w ,tradycyjnym" marketingu masowym).

${ }^{58}$ Porter M.E., Porter o ... op. cit., s. 10.

${ }^{59}$ Krzyżanowska M., Marketing a inne sposoby budowania przewagi konkurencyjnej, „Marketing i Rynek", 2009, nr 1, s. 2. 
wództwie kosztowym), niż na istocie zjawiska. Dlatego - między innymi - koncepcję przewagi konkurencyjnej (zakładającą poszukiwanie przewagi konkurencyjnej przedsiębiorstwa w strukturze sektora ${ }^{60}$ ) poddano krytyce w latach 90 . XX w. Wśród głównych zarzutów można wskazać ${ }^{61}$ :

- pomijanie znaczenia zasobów wewnętrznych przedsiębiorstwa,

- nadmierny sektorowy determinizm i nie uwzględnianie szybkich zmian granic sektorów w zakresie przedmiotowym oraz podmiotowym (jako skutek rozwoju procesów umiędzynarodowienia i globalizacji),

- nie wskazanie konkretnych rekomendacji dotyczących wdrożenia strategii konkurencji w realnym przedsiębiorstwie ${ }^{62}$.

Od połowy lat 80. ubiegłego stulecia zaczęła się rozwijać inna koncepcja konkurencyjności - oparta na zasobach i kompetencjach ${ }^{63}$ (Resource and Competence-based Conception of Competitive Advantage), która stała się dominującą perspektywą badawczą na gruncie zarządzania strategicznego ${ }^{64}$. Jej podstawowym przedmiotem jest przedsiębiorstwo (a nie sektor jak u M.E. Portera). Oznacza to przesunięcie akcentu na wnętrze przedsiębiorstwa i przywrócenie zainteresowania jego zasobami i kompetencjami. Zgodnie z zasadą przewagi konkurencyjnej opartej na zasobach, przedsiębiorstwo jest unikatową wiązką materialnych i niematerialnych zasobów ${ }^{65}$ i kompetencji.

\footnotetext{
${ }^{60}$ Podejmowanie decyzji rynkowych wymaga analizy otoczenia, która może być przeprowadzona m. in. z wykorzystaniem metod: 1) badania otoczenia w zakresie odbiorców produktów/usług (np. potrzeb, jakie charakteryzują rzeczywistych i potencjalnych klientów), 2) badania otoczenia konkurencyjnego (np. za pomocą niesformalizowanej obserwacji, wykorzystania benchmarkingu itp. dokonuje się oceny firm, które bezpośrednio i/lub pośrednio wpływają także na pozycję firmy na rynku), 3) badania otoczenia ekonomicznego (np. systemu podatkowego czy możliwości dofinansowania działalności jednostki ze środków lokalnych, rządowych i unijnych), 4) badania otoczenia pośredników rynkowych (np. podmiotów zaopatrujących w czynniki produkcji), 5) badania otoczenia społecznego i prawnego (np. zmian prawnych w zakresie sprzedaży, trendów rynkowych), 6) badania otoczenia technologicznego (ze szczególnym zwróceniem uwagi na pojawiający się na rynku nowoczesny sprzęt), 7) badania otoczenia socjokulturowego (szczególnie zmian kulturowych, które najczęściej mają charakter długofalowy).

Por. Binsztok A., Instrumenty marketingowe pozyskiwania, obstugi i utrzymania klienta w komercyjnej firmie medycznej, w: Perechuda K., Kowalewski M., Zarzadzanie komercyjna firma medyczna, Wolters Kluwer business, Warszawa 2008, s. 52.

${ }^{61}$ Macias J., Nowe koncepcje przewagi konkurencyjnej wspótczesnych przedsiębiorstw, „Przegląd Organizacji”, 2008, nr 9, s. 11.

${ }^{62}$ Kogut B., Designing global strategies: Comparative and competitive value-added chains, "Sloan Management Review", 1985, vol. 24, nr 4, s. 16.

63 Obłój K., Strategia organizacji. W poszukiwaniu trwałej przewagi konkurencyjnej, PWE, Warszawa 2007, s. 127.

${ }^{64}$ Fey C.F., Birkinshaw J., External Sources of Knowledge, Governance Made and $R+D$ Performance, "Journal of Management" 2005, nr 4, s. 598.

${ }^{65}$ Zasoby niematerialne (intangible resources) obejmują m.in.: wiedzę, kulturę organizacyjną, reputację przedsiębiorstwa, marki produktów, kreatywność i przedsiębiorczość, sieć relacji, prawa
} 
Głównym założeniem zasobowej teorii przedsiębiorstwa jest teza, że cenne, rzadkie, trudne do imitacji i dobrze zorganizowane zasoby i umiejętności tworzą tzw. aktywa strategiczne ${ }^{66}$, umożliwiające przedsiębiorstwom uzyskiwanie trwałej przewagi konkurencyjnej i w efekcie stałych, ponadprzeciętnych dochodów (zasobami firmy są zatem wyłącznie jej silne strony, które mają przyczynić się do stworzenia i wdrożenia strategii) ${ }^{67}$. Przyjmuje się, że przedsiębiorstwo posiada przewagę konkurencyjną, jeśli jest w stanie wytworzyć więcej wartości ekonomicznej, niż najsłabszy konkurent na określonym rynku produktowym/usługowym osiągający wyniki powyżej progu rentowności ${ }^{68}$. Dlatego aby wytworzyć wyższą wartość od konkurentów, przedsiębiorstwo musi albo generować większe korzyści przy tych samych kosztach (różnicować produkt/usługę, by być w stanie zażądać wyższą cenę ${ }^{69}$ ), albo te same korzyści przy niższych kosztach (przywództwo kosztowe) ${ }^{70}$.

F. Luthans i C.M. Youssef ${ }^{71}$, analizując kwestię zasobowej konkurencyjności organizacji, wskazują na cztery potencjalne źródła, które tę konkurencyjność tworzą:

- zasoby „tradycyjne”, które zwykle nie stanowią unikalnej właściwości podmiotu i w krótkim czasie mogą zostać skopiowane przez konkurencję; obejmują one:

- zasoby finansowe (np. dostęp do kredytów),

- zasoby strukturalne (np. zasoby fizyczne, procedury, systemy modele podejmowania decyzji),

własności intelektualnej, kapitał intelektualny, kapitał społeczny, innowacyjność, kapitał strukturany, informację i bazy danych, umiejętności i doświadczenie, stosunki międzyludzkie w organizacji, zaufanie i wiarygodność, lojalność, technologie informacyjne, zdolności, postawy i zaangażowanie. Na podstawie: Bryan L., Kay J., Dialogue: Can a Company Be Too Big? „The McKinsey Quarterly” 1999, nr 4, s. 102 i nast.; Głuszek E. Zarzadzanie zasobami niematerialnymi, Wyd.AE im. O.Langego, Wrocław 2004, s. 235 i nast.; Kostro K., Kapitat spoteczny w teorii ekonomicznej, „Gospodarka Narodowa”, 2005, nr 7-8, s. 3 i nast.; Stobińska K., Zarzadzanie wiedza. Wyzwania dla zarzadzania zasobami ludzkimi, „Organizacja i Kierowanie”, 2004, nr 1, s. 33.

${ }^{66}$ Barney J.B., Firm resources and sustained competitive advantage, "Journal of Management", 1991 vol. 17 , nr 1, s. 99 i nast.

${ }^{67}$ Barney J.B., Firm resources and sustained competitive advantage, "Journal of Management", 1991 vol. 17, nr 1, s. 101.

${ }^{68}$ Petera M.A., Barney J.B., Unraveling the Resource-based Triangle, "Managerial and Decision Economics", 2003 vol. 24, nr 4, s. 314.

${ }^{69}$ Barney J.B., Wright P.M., On Becoming a Strategic Partner: The Role of Human Resources in Gaining Competitive Advantage, "Human Resource Managament", 1998 vol. 37, nr 1, s. 32.

70 Barney J.B., Clark D.N., Resource-Based Theory. Creating and Sustaining Competitive Advantage, Oxford University Press, Oxford, Nowy Jork 2009, s. 25.

${ }^{71}$ Luthans F., Youssef C.M., Human, social, and now positive psychological capital management: Investing in people for competitive advantage, Organizational Dynamics, 2004, $\mathrm{nr}$ 33, s. 143 i nast. za: Łaguna M., Nowe tendencje w podejściu do szkoleń w organizacji w: Zawadzka A.M. (red.), Psychologia zarzadzania w organizacji, Wydawnictwo Naukowe PWN, Warszawa 2010, s. 121. 
- zasoby technologiczne (np. technologie informatyczne),

- zasoby ludzkie, do których zalicza $\operatorname{się}^{72}$ :

- wiedzę jawną (explicite knowledge), która jest zdobywana np. podczas szkoleń i może być w pewnym stopniu przejęta przez konkurencję,

- wiedzę utajoną (tacit knowledge) pracowników danej firmy, stanowiącą zasób specyficzny dla danej organizacji, który nie tak łatwo imitować; składa się na nią zrozumienie struktury i dynamicznych procesów zachodzących w organizacji (które trudno jest przekazać werbalnie na przykład podczas wykładu), jej zdobywanie wymaga osobistego doświadczenia i treningu; podmiot traci ją, gdy nie jest w stanie zatrzymać swoich pracowników,

- kapitał społeczny ${ }^{73}$ - obejmujący wspierające relacje międzyludzkie, międzygrupowe (np. między działami przedsiębiorstwa) oraz międzyorganizacyjne; stanowi także panujące w organizacji normy społeczne i podzielane wartości oraz zaufanie społeczne, jakim się cieszy. W jego tworzeniu można wykorzystać szkolenia wewnętrzne dostarczające okazji uczenia się efektywnej komunikacji, budowania wzajemnego zaufania, gospodarowania czasem i ustalania priorytetów, które mogą pomóc zachować równowagę między życiem prywatnym a zawodowym (np. dzięki znalezieniu czasu na relacje z bliskimi, które dają wsparcie społeczne),

- pozytywny kapitał psychologiczny ${ }^{74}$, jaki stanowią pozytywne przekonania pracowników, które dają im unikalną siłę radzenia sobie z przeciwnościami i motywują do działania; do przekonań tych należą:

- przeświadczenie o własnej skuteczności w danym obszarze działania ${ }^{75}$,

- nadzieja na osiągnięcie sukcesu i znalezienie dróg do celu, która daje energię do działania ${ }^{76}$,

- optymizm rozumiany jako sposób wyjaśniania przyczyn własnych sukcesów, upatrywanie ich wewnątrz osoby, w jej stałych i uogólnionych dyspozycjach ${ }^{77}$,

- prężność osobowości, czyli zdolność podnoszenia się, a nawet wzrostu po doświadczeniu porażki ${ }^{78}$.

\footnotetext{
${ }^{72}$ Nonaka I., Takeuchi H., Kreowanie wiedzy w organizacji, Polska Fundacja Promocji Kadr, Warszawa 2000.

${ }^{73}$ Luthans F., Youssef C.M., Human, social, and ... op. cit., s. 143 i nast.

${ }^{74}$ Ibidem s. 143 i nast.

${ }^{75}$ Bandura A., Self-efficacy: The exercise of control, Frejman\&Co, Nowy Jork 1997.

${ }^{76}$ Synder C.R., Hope theory: Rainbows in the mind. Psychological Inquiry, $2002 \mathrm{nr}$ 13, s. 249 i nast.

${ }^{77}$ Seligmann M.E.P., Optymizmu można się nauczyć, Media Rodzina of Poznań, Poznań 1999.

${ }^{78}$ Masten A., Ordinary magic: resilience processes in development, "American Psychologist", 2001 nr 56, s. 227 i nast.; Bandura A., Cultivate self-efficacy for personal and organizational effecti-
} 
Przekonania te nie są tak stałe, jak cechy osobowości; mogą być nie tyle traktowane jako kryteria selekcji przy rekrutacji pracowników, ile rozwijane przez trening i szkolenia i przyczyniać się do budowania konkurencyjności podmiotu. Postrzeganie siebie jako osoby skutecznej w danej dziedzinie, sprzyja podejmowaniu zadań o wysokim poziomie trudności, stawianiu sobie ambitnych celów; pozwala także określić, jak duży wysiłek zostanie włożony w daną aktywność i jak długo będzie on podtrzymywany, mimo napotykanych przeszkód, co może przyczyniać się do osiągnięcia sukcesu w działaniu ${ }^{79}$.

Inna z klasyfikacji zasobów przedsiębiorstwa - autorstwa B. deWitta i R. Meyera - ujmuje je jako ${ }^{80}$ :

- zasoby niematerialne (są urzeczywistnianie przez ludzi), obejmujące kompetencje:

- wiedzę, rozumianą jako całość reguł (uczestnicy organizacji wiedzą: jak? co? gdzie? kiedy?) i prawidłowości (wiedzą: dlaczego?), które są zawarte $\mathrm{w}$ informacjach oraz pozwalają ustalić ich sens; wiedza powstaje $\mathrm{z}$ interpretowania informacji, jednocześnie wpływając na ten proces,

- zdolności, czyli możliwości organizacji w zakresie wykonywania określonych zadań,

- $\operatorname{postawy}^{81}$ utożsamiane z dominującą w organizacji mentalnością,

- zasoby relacyjne (są urzeczywistniane przez ludzi), obejmują relacje i reputację,

- zasoby materialne: grunty, budynki, materiały, gotówka.

W warunkach współczesnej gospodarki, charakteryzującej się dużą dynamiką zmian, zasoby niematerialne i relacyjne zyskują na strategicznym znaczeniu (i wykorzystywanie tych grupy zasobów będzie przedmiotem dalszej analizy, jako przejaw postaw przedsiębiorczych stomatologów), natomiast rola materialnych staje się ograniczona.

W kontekście przewagi konkurencyjnej można zauważyć, że prawie wszystkie z zasobów rynkowych ${ }^{82}$, które - z racji posiadanych cech, własności i właści-

veness, w: Locke A. (red.), Handbook of principles of organization behavior, Blackwell, Oxford 2000, s. 120 i nast.

${ }^{79}$ Bandura A., Self-efficacy ... op. cit.; Stajkovic A.D., Luthans F., Social cognitive theory and selfefficacy: going beyond traditional motivational and behavioral approaches, "Organizational Dynamics" 1998, nr 26, s. 62 i nast.

${ }^{80}$ de Witt B., Meyer R., Synteza strategii. Tworzenie przewagi konkurencyjnej przez analizowanie paradoksów, PWE, Warszawa 2007, s. 163.

${ }^{81}$ Do charakterystyki postaw używa się również określeń, takich jak „usposobienie” czy „,podejście", świadczących o tym, jaki przedsiębiorstwo postrzega otoczenie, jak się do niego ustosunkowuje. 
wości - potencjalnie mogą stać się aktywami konkretnego przedsiębiorstwa ${ }^{83}$ : udział w rynku, firma, reputacja przedsiębiorstwa, dominacja rynkowa, atrakcyjność ofert, posiadane marki, pozycja ceowa, sieć dystrybucji, unikalność dystrybucji, warunki dystrybucji, warunki dostawy, komunikacja z klientami, system informacyjny i wiedza marketingowa, prawa autorskie i patenty, kultura firmy, zdolności marketingowe, kompetencje marketingowe itp.; są ściśle związane $\mathrm{z}$ orientacją proklientowską przedsiębiorstwa.

Koncepcja przewagi konkurencyjnej oparta na orientacji rynkowej pojawiła się w literaturze na przełomie XX i XXI w. J.C. Narver i S.F. Slater postrzegali orientację rynkową jako kulturę organizacyjną, zawierającą następujące elementy ${ }^{84}$ :

- orientację na klienta (w sensie zrozumienia rynku docelowego),

- zorientowanie na kluczowych konkurentów (zrozumienie ich mocnych i słabych stron oraz podejmowanych przez nich zadań),

- koordynację interfunkcjonalną, rozumianą jako używanie wszystkich zasobów przedsiębiorstwa $\mathrm{w}$ celu stworzenia wartości pożądanej przez docelową grupę klientów.

\footnotetext{
${ }^{82}$ Por. Niestrój E., Zarządzanie marketingiem. Aspekty strategiczne, Wydawnictwo Naukowe PWN, Warszawa 1996, s. 79 i nast.; Szymura-Tyc M., Zasoby $i$ kompetencje marketingowe przedsiębiorstwa, „Marketing i Rynek”, $2001 \mathrm{nr} 5$.

${ }^{83} \mathrm{~W}$ tym miejscu można wskazać, że pojęcie ,,aktywów rynkowych” zostało po raz pierwszy użyte przez H. Davidsona, który zdefiniował je jako zasoby posiadane przez przedsiębiorstwo, zwykle o charakterze niematerialnym, które mogą być użyte do osiągania przewagi na rynku. Por. SzymuraTyc M., Zasoby ... op. cit.

Inną interpretację pojęcia ,aktywa rynkowe” proponują P. Hadrian i M. Rawski - lokują je na continuum, którego domknięciem z jednej strony jest pogląd, zgodnie z którym uważa się, że aktywa przedsiębiorstwa obejmują strategie produktu, ceny, dystrybucji, promocji i segmentacji (ujęcie sensu stricte); a z drugiej - pogląd, zgodnie z którym aktywa rynkowe przedsiębiorstwa obejmują wszystkie materialne i niematerialne zasoby posiadane bądź kontrolowane przez przedsiębiorstwo, także umiejętności, zdolności i kompetencje ich wykorzystania, które mogą być przez nie efektywnie użyte $w$ celu dostarczenia wybranym klientom oczekiwanej przez nich wiązki wartości (ujęcie sensu largo). Por. Hadrian P., Rawski M., Możliwości wykorzystania metody refleksji strategicznej w marketingu relacyjnym, „Marketing i Rynek”, 2009 nr 10, s. 4.

Pojęciu ,aktywa rynkowe” w literaturze przedmiotu przypisuje się różne znaczenia np. aktywa rynkowe obejmują wszystkie elementy współtworzące siłę konkurencyjną i rynkową wartość przedsiębiorstwa, a więc nie tylko kategorie księgowo-bilansowe, odzwierciedlające wielkość i strukturę będących w dyspozycji przedsiębiorstwa zasobów kapitałowych, ale także składniki pozaewidencyjne, które można ująć w trzy grupy: 1) kadra zarządzająca i system zarządzania przedsiębiorstwem, 2) składniki organizacyjne i techniczne (np. wielkość i struktura zasobów pracy będących w dyspozycji przedsiębiorstwa, poziom zastosowania technologii, organizacja pracy), 3) aktywa określające pozycję rynkową przedsiębiorstwa (np. udział w rynku, atrakcyjność programu asortymentowego, cenowa pozycja produktów, system dystrybucji, aktywa rynkowe). Por. Niestrój R., Zarzadzanie marketingiem... op. cit., s. 59.

${ }^{84}$ Narver J.C., Slater S.F., The effect of a market orientation on business profitability, "Journal of Marketing”, 1999, nr 54, s. 20 i nast.
} 
Do szczegółowych elementów przewagi konkurencyjnej charakterystycznej dla podmiotu przykładającego wagę do dobrej obsługi klienta ${ }^{85}$, należy zaliczyćc ${ }^{86}$ :

- podejmowanie decyzji uwzględniających przede wszystkim dobro klienta,

- przyjęcie przez każdego pracownika postawy „klient jest najważniejszy” (wartość ta powinna być zawarta w misji i wizji podmiotu, a także w procedurach postępowania),

- ciągłe informowanie o kluczowej roli obsługi klienta w sukcesie podmiotu,

- (rozbudowany) system szkoleń pracowników z zakresu obsługi klienta,

- umiejętność zdobywania informacji, jakie są potrzeby klienta i w jaki sposób można je zaspokoić,

- pozyskiwanie i analizowanie informacji zwrotnej od klienta,

- elastyczny sposób zaspokajania potrzeb klientów,

- usługi przekraczające oczekiwania klientów, a nie tylko zaspokajające je,

- filozofię przedsiębiorstwa, stawiającą na pierwszym miejscu zapobieganie problemom w kontaktach z nabywcami, a nie ich rozwiązywanie,

- szybkie i sprawne rozpatrywanie reklamacji w przypadku, gdy wystąpią jakieś niedociągnięcia ze strony przedsiębiorstwa i/lub niezadowolenie klienta ze sposobu zaspokojenia jego potrzeb.

Orientacja na klienta nie polega zatem jedynie na dostarczaniu mu produktów o wymaganej jakości (np. stricte medycznej). Troska o klienta wyraża się również w dbałości o jakość obsługi we wszystkich fazach nabywania i użytkowania produktu - działania te podnoszą wartość produktu z punktu widzenia klienta i są postrzegane jako jeden z istotnych wyznaczników jakości działania podmiotu, który wpływa na jego przewagę konkurencyjną. I pozamedyczne czynniki obsługi pacjentów będą przedmiotem zainteresowania kolejnych rozdziałów.

Konkludując, warto podkreślić, że dziś już nie wystarczy, aby do osiągania przewagi konkurencyjnej i związanych z nią celów efektywnościowych forsować tylko jeden wyraźnie wyartykułowany kierunek działania: sektorowy vs zasobowy; np. W. Jenkins ${ }^{87}$ stwierdza, że dwie pierwsze $\mathrm{z}$ wymienionych wcześniej koncepcji są ze sobą ściśle powiązane:

\footnotetext{
${ }^{85}$ Do takich podmiotów można zaliczyć prywatne gabinety stomatologiczne.

86 Rachwał M., Znaczenie obstugi klienta $w$ osiaganiu przewagi konkurencyjnej, www.mfp.org.pl/publicystyka.php?id=19

${ }^{87}$ Jenkins W., Competing in Times of Evolution and Revolution. An Essay on Long - Term Firm Survival, "Management Decision", 2005 nr 1, s. 26.
} 
- koncepcja przewagi konkurencyjnej oparta na zasobach i kompetencjach przedsiębiorstwa dostarcza pierwszej część kompleksowej analizy strategicznej SWOT - czyli „,siły i słabości przedsiębiorstwa”,

- koncepcja M.E. Portera wskazuje na „szanse i zagrożenia” płynące z otoczenia przedsiębiorstwa (drugą część analizy SWOT).

Rozwój teorii konkurencyjności przedsiębiorstwa w ramach nurtów pozycjonowania i zasobowego można postrzegać jako dorobek o właściwościach względem siebie komplementarnych. W konsekwencji dla przeprowadzenia pogłębionej analizy konkurencyjności przedsiębiorstwa ważne jest uwzględnienie nie tylko samych działań podejmowanych lub zasobów posiadanych przez podmioty gospodarcze, ale obu tych obszarów potencjału konkurencyjnego jednocześnie oraz interakcji zachodzących pomiędzy pozostałymi wymiarami konkurencyjności w ujęciu dynamicznym. Pozwoli to na optymalną realizację orientacji na klienta - w praktyce, obecne warunki funkcjonowania na rynku ${ }^{88}$, do zapewnienia rozwoju firmy egzekwują jej zdolność do działania z uwzględnieniem kilku priorytetów równocześnie (mamy tu zatem do czynienia z ambiwalencją, która nie dotyczy tylko sposobów osiągania danego celu, ale także samych celów), w tym:

- szybkiego dostarczania danej ofert,

- utrzymywania odpowiednio niskich kosztów,

- zapewnienia relatywnie wysokiej jakości,

- respektowania zindywidualizowanych oczekiwań, co przekłada się na konieczność zapewnienia kompleksowej oferty, czyli zróżnicowania profilu działania przedsiębiorstwa.

Jak pisze G. Osbert-Pociecha ,na pierwszy rzut oka priorytety są sprzeczne ze sobą, czy nawet częściowo wykluczają się, a tym samym są trudne do realizacji w tym samym czasie" ${ }^{\not 9}$. Okazuje się jednak, że poprzez podejmowanie określonych działań (o przekrojowym charakterze, zorientowanym procesowo, uwzględniających różne horyzonty czasowe itp.) na rzecz szeroko rozumianej elastyczności, możliwe jest neutralizowanie konfliktu między nimi ${ }^{90}$. Na takie możliwości w odniesieniu do podstawowego dylematu każdego przedsiębiorstwa, tj. jak funkcjonować tu i teraz, a jednocześnie patrzeć w przód, by być przygotowanym na to, co przyniesie przyszłość - wskazują Ch.A. O’Reilly

\footnotetext{
${ }^{88}$ Wadhawa S., Rao K.S., Towards a Proactive Flexibility Management, "Global Journal of Flexible System Management”, 2002 nr 2-3, s. 11.

${ }^{89}$ Osbert-Pociecha G., Ambiwalencja zarzadzania organizacja - zagrożenie czy szansa, „Przegląd Organizacji”, $2009 \mathrm{nr}$ 6, s. 15.

90 Osbert-Pociecha G., Relacja między efektywnościa a elastycznościa organizacji, Prace Naukowe Akademii Ekonomicznej nr 1183, Wrocław, 2007, s. 337.
} 
i M.L. Tushman ${ }^{91}$, przedstawiając ideę ambidextrous organizations (tj. firmy „oburęcznej”, która ma oddzielone w swojej strukturze jednostki zajmujące się eksploatacją - aktualnymi produktami i procesami od jednostek zajmujących się poszukiwaniem nowych koncepcji biznesowego działania). Jednak takie rozwiązanie sprawdzi się $\mathrm{w}$ średnich i dużych przedsiębiorstwach, pozostałe bardzo często są niejako skazane na bycie „firmami jednoręcznymi” (zdecydowana większość gabinetów stomatologicznych - ze względu na swoją wielkość - jest tak zorganizowana, że dentysta zajmuje się i aktualną działalnością i - ewentualnie - poszukiwaniem nowych koncepcji biznesowego działania). Wówczas i myślenie o przyszłości przedsiębiorstwa i bieżące prowadzenie biznesu spoczywa na jednostce (zgodnie z przyjętą zasadą personalizmu).

\subsection{KONKURENCYJNOŚĆ NA RYNKU USŁUG ZDROWOTNYCH}

\subsubsection{EKONOMIZACJA DZIAŁANIA PODMIOTÓW LECZNICZYCH}

Pytanie postawione przez - wspomnianego już - M.J. Sandela: „Czego nie można kupić za pieniądze?" ${ }^{92}$ może stać się asumptem do refleksji nad ekonomizacją $^{93}$ świadczeń zdrowotnych. Autor ten dostrzega zagrożenie w coraz szybszej i coraz szerszej ekspansji mechanizmów rynkowych w obszary życia społecznego związanego z dobrami - dotychczas nierynkowymi - takimi jak zdrowie, nieskażona przyroda czy nawet msza odprawiana przez papieża. Rynki wg M.J. Sandela korumpują i/lub niszczą wartości nierynkowe - edukację, zdrowie, altruizm, solidarność społeczną itp. Czy tak rzeczywiście jest? Obszernej odpowiedzi na to pytanie udziela I. Rudawska (której głos w polskim piśmiennictwie w tym zakresie był jednym z pierwszych): „Biorąc pod uwagę

\footnotetext{
${ }^{91}$ O’Reilly Ch.A., Tushman M.L., Oburęczna firma, "Harvard Business Review Polska”, 2004, nr 7, s. 48.

${ }^{92}$ Por. Sandel M.J., Czego nie ... op. cit.

${ }^{93}$ W myśl prakseologii „ekonomizacja” jest jedną z dyrektyw sprawnego działania i oznacza dążenie do znalezienia bardziej ekonomicznego sposobu funkcjonowania (oszczędniejszego bądź wydajniejszego). Por. Kieżun W., Sprawne zarzadzanie organizacją, Wyd. SGH, Warszawa 1997, s. 20.

W naukach ekonomicznych ,ekonomizacja” jest pojmowana jako zasada zachowań ludzkich w różnych dziedzinach życia, a jej naczelnym wyznacznikiem jest podporządkowanie tych zachowań pojęciom i kategoriom ekonomicznym. Konsekwencją tej interpretacji jest opisywanie aktywności ludzkiej w kategoriach skuteczności, efektywności, profesjonalizmu czy konkurencyjności. Por. Iwankiewicz-Rak B., Marketing organizacji niedochodowych. Wybrane problemy adaptacji $w$ warunkach polskich, Monografie i Opracowania nr 121, Wyd. Akademii Ekonomicznej we Wrocławiu, Wrocław 1997, s. 132; Dunaj B. (red.), Stownik wspótczesnego języka polskiego, Wyd. SMS, Kraków 2000, s. 374; Rudawska I., Ekonomizacja relacji pacjent - ustugodawca $w$ opiece zdrowotnej, Studia i rozprawy T. 602, wyd. Uniwersytetu Szczecińskiego, Szczecin 2006, s. 55.

Natomiast w nauce o organizacji i zarządzaniu pojęcie ,ekonomizacja” definiuje się jako zmianę sposobu działania (usprawnienie działania), powodującą zwiększenie stosunku między wynikiem użytecznym a kosztem działania. Por. Micherda B., Analityczna funkcja rachunkowości, Wyd. Akademii Ekonomicznej w Krakowie, Kraków 2001, s. 13.
} 
rzadkość zasobów opieki zdrowotnej, to wybory dokonywane w imieniu pacjentów muszą uwzględniać dylemat: 'w jakie szczegółowe formy leczenia inwestować' i 'kogo leczyć', skoro nie wystarcza dla wszystkich środków. Imperatyw racjonalizacji działań z jednej strony ogranicza wybory pacjentów, a z drugiej zmusza lekarzy do dokonywania tych wyborów" "94. Ale w żaden sposób nie skłania do wybierania złych (krzywdzących pacjentów) rozwiązań. Wprost przeciwnie, deontologia lekarska wyraźnie wskazuje na konieczność zachowania skuteczności klinicznej i bezpieczeństwa chorego. I. Rudawska traktuje ekonomizację relacji pacjent - usługodawca „w kategoriach wprowadzania do niej mechanizmów ekonomicznych oraz logiki i reguł rynkowych ${ }^{95}$, w tym marketingowych ${ }^{96}$, wraz z odpowiednimi instrumentami. ${ }^{.97}$ Mechanizmy te mają pozwolić na znalezienie sposobów racjonalizacji działań systemu ochrony zdrowia czy poszczególnych jego podmiotów. Jak podkreśla ta sama autorka rynek usług medycznych - w rozumieniu klasyków ekonomii - nie jest wolnym rynkiem $^{98}$. W żadnym demokratycznym kraju nie wysuwa się postulatów regulacji kwestii zdrowia przez „niewidzialną rękę rynku”. Zdrowie jest $-\mathrm{z}$ jednej strony - dobrem prywatnym, będącym w centrum zainteresowania każdej osoby, a także dobrem publicznym, za które odpowiada władza publiczna. Nie wyklucza to stosowania marketingowej orientacji, rozumianej jako uznanie reguł postępowania na rynku, których wdrożenie może przyczynić się do realizacji celów ekonomicznych (podnoszenie skuteczności i efektywności działania, poprawa jakości relacji z pacjentem-klientem) i społecznych (respektowanie sprawiedliwości w dostępie do usług). Dlatego - dla dobra społecznego - pieniądze wydatkowane $\mathrm{w}$ systemie ochrony zdrowia powinny być wydawane racjonalnie (z regulacyjnym wsparciem państwa). Można zgodzić się z M.J. Sandelem, że w odniesieniu do dóbr rzadkich analiza rynkowej efektywności wymaga uzupełnienia refleksją moralną. I takie spojrzenie jest zachowane w ochronie zdrowia: dentyści podkreślają, że najpierw są lekarzami (z bagażem wartości wnoszonym przez deontologię lekarską), a dopiero później właścicielami gabinetów (z myśleniem w kategoriach osiąganych wyników ekonomicznych). Oczywiście można wskazać przykłady niszczenia pewnych wartości

\footnotetext{
${ }^{94}$ Rudawska I., Między ekonomia a deontologia lekarska - konflikt wartości na rynku ustug zdrowotnych, „Antidotum”, $2002 \mathrm{nr}$ 6, s. 43 i nast.

${ }_{95}$ Orientacja na rynek wymaga od placówki zdrowotnej dwojako rozumianej otwartości: 1) jako gotowość podmiotu do modyfikacji swych działań wraz ze zmianami zachodzącymi na rynku, 2) jako deklaracja chęci uczenia się - ciągłego nabywania i doskonalenia umiejętności adaptacyjnych oraz kształtowania szerokiego pojętej kultury organizacji.

Por. Rudawska I., Podstawy marketingu ustug zdrowotnych, w: Kautsch M. (red.), Zarzadzanie w opiece zdrowotnej. Nowe wyzwania, Wolters Kluwer Polska sp. z o.o., Warszawa 2010, s. 176.

96 Orientacja marketingowa oznacza nie tylko akceptację wiodącej roli pacjenta, ale przede wszystkim postrzeganie jego potrzeb w szerszej perspektywie środowiskowej.

${ }^{97}$ Rudawska I., Ekonomizacja relacji ... op. cit., s. 57.

${ }^{98}$ Rudawska I., Podstawy marketingu ... op. cit., s. 175.
} 
- łapówki wręczane lekarzom, ale są to wyjątki, a nie nowo ukształtowana pod presją rynku - reguła (przecież problem ten istniał również, gdy w Polsce nie mówiło się o rynku w odniesieniu do usług zdrowotnych).

Reasumując, należy podkreślić, że specyfika usług zdrowotnych i znaczenie sektora opieki zdrowotnej nie pozwalają na odizolowanie efektywności ekonomicznej od społecznej (ich wzajemna współzależność wpływa na ogólną efektywność systemu ocenianą przez pacjenta). Efektywność ekonomiczna służy ocenie procesów gospodarowania podmiotów funkcjonujących na rynku, a składają się na nią dwa komponenty ${ }^{99}$ :

- skuteczność - odnosząca się do poziomu zrealizowania założonego celu działania przedsiębiorstwa,

- ekonomiczność - odzwierciedlająca różnicę pomiędzy osiągniętymi efektami a poniesionymi nakładami.

Natomiast efektywność w aspekcie społecznym, analizowana w szerokiej perspektywie, odnosi się do stopnia realizacji celów społecznych (najczęściej wymienia się: sprawiedliwość społeczną ${ }^{100}$ ) w stosunku do poniesionych nakładów. Oprócz - ogólnie zdefiniowanego - celu sprawiedliwości w sektorze opieki zdrowotnej, którego realizacja ma się przełożyć na efektywność społeczną sektora, wyodrębnia się również ${ }^{101}$ : dostępność i wzrost jakości świadczeń zdrowotnych.

Nowa rzeczywistość ekonomiczno-prawna powoduje, że podmioty lecznicze mogą być postrzegane jako typowe przedsiębiorstwa (w szczególności dotyczy to podmiotów prowadzących działalność w oparciu o środki własne pacjentów), w których duży nacisk kładzie się na jakość, racjonalność gospodarowania posiadanymi zasobami i efektywność działania. W zreformowanym systemie opieki zdrowotnej istotnie wzrosła rola pacjenta-klienta, który uzyskał możliwość wolnego wyboru świadczeniodawcy. Dlatego analiza i ocena potrzeb pacjentów, zwiększająca szansę na ich satysfakcję z otrzymanych usług oraz ciągłe podnoszenie jakości udzielanych świadczeń stały się szansą wygrania rywalizacji o nabywcę (a nie jedynie dążenie do obniżania kosztów działania).

\footnotetext{
${ }^{99}$ Grzesiak S., Efektywność funkcjonowania przedsiębiorstwa - aspekty prakseologiczne i ekonomiczne, w: Przedsiębiorstwo na rynku. Gospodarka polska w procesie transformacji systemowej, materiały konferencyjne Uniwersytetu Szczecińskiego nr 17, Szczecin 1996, s. 62.

100 Aspekt sprawiedliwości społecznej w sektorze opieki zdrowotnej może być analizowany w trzech obszarach: stanu zdrowia, alokacji środków i korzystania.

101 Golinowska S., Polityka społeczna państwa w gospodarce rynkowej: studium ekonomiczne, Wydawnictwo Naukowe PWN, Warszawa 1997, s. 101.
} 


\subsubsection{SPECYFIKA KONKURENCYJNOŚCI NA RYNKU USEUG ZDROWOTNYCH}

Od wielu lat popyt na usługi zdrowotne rośnie. Jednym z powodów tego wzrostu - w obszarze odpłatnych usług zdrowotnych - jest wzrost dochodów ludności, odzwierciedlający poprawę warunków życia. Wzrost dochodu idzie w parze ze wzrostem wykształcenia, co zwiększa świadomość zdrowotną w społeczeństwie (health literacy) oraz wiedzę na temat funkcjonowania własnego organizmu, a także oddziaływania nań środowiska i stylu życia ${ }^{102}$. Kolejną determinantą popytu są przemiany demograficzne oraz epidemiologiczne, wyrazem których jest wydłużenie przeciętnego trwania życia i dominacja chorób charakterystycznych dla starszego wieku. Popyt na usługi zdrowotne mogą tworzyć również usługodawcy (lekarze i pozostały personel medyczny), wykorzystując silną asymetrię informacji wobec pacjenta ${ }^{103}$ - gdy zjawisku oczywistej przewagi informacyjnej oraz kompetencyjnej lekarza nad pacjentem towarzyszy motywacja finansowa do zwiększania świadczeń ${ }^{104}$ (zjawisko to może być szczególnie widoczne w gabinetach stomatologicznych, biorąc pod uwagę fakt, że ok. $80 \%$ świadczeń stomatologicznych jest opłacanych z prywatnych środków pacjentów).

I. Rudawska klasyfikuje w następujący sposób determinanty popytu na usługi zdrowotne: ${ }^{105}$

- ekonomiczne, obejmujące:

- czynniki pieniężne - to ceny innych - również niekonwencjonalnych dóbr i usług, poziom dochodów pacjenta,

- czynniki niepieniężne - obejmujące np.: koszty utraconego przez pacjenta czasu (na dotarcie do lekarza i oczekiwanie przed gabinetem, a także czasu, jaki mija od momentu wyznaczenia terminu wizyty do chwili świadczenia usługi); czy koszty natury psychicznej (związane z koniecznością pokonania bariery informacyjnej, przebrnięcia przez procedury biurokratyczne, a także bariery natury kulturowej i etycznej),

- demograficzne - obejmujące wiek, poziom wykształcenie pacjenta,

- zdrowotne - odnoszące się do „wyjściowego” stanu zdrowia pacjenta,

- psychologiczne - obejmujące system wartości pacjenta, jego chęć bycia zdrowym, czy związana z poprawą wyglądu.

\footnotetext{
${ }^{102}$ Golinowska S., Rynek pracy w sektorze zdrowotnym - zaniedbany obszar zarzadzania, "Polityka Społeczna", $2008 \mathrm{nr}$ 7, s. 3.

${ }^{103}$ Zagadnienie asymetrii zostanie omówione szerzej w punkcie 1.2 trzeciego rozdziału.

${ }^{104}$ Golinowksa S., Rynek ... op. cit., s. 3.

${ }^{105}$ Rudawska I., Ekonomizacja relacji ... op. cit., s. 30 i nast.
} 
Natomiast podaż usług związanych ze zdrowiem uzależniona jest przede wszystkim od ${ }^{106}$ :

- wielkości środków finansowych wpływających do systemu opieki zdrowotnej $^{107}$ danego państwa (zarówno ze źródeł publicznych, jak i prywatnych środków pacjentów),

- kadry medycznej $^{108}$ (jej liczby, kwalifikacji, przestrzennego rozmieszczenia i sprawności działania),

${ }^{106}$ Sobiech J., Warunki wyboru ekonomiczno-finansowych mechanizmów kierowania opieka zdrowotna, Zeszyty Naukowe nr 109, Wyd. Akademii Ekonomicznej w Poznaniu, Poznań 1990, s. 10.

${ }^{107}$ Opiekę zdrowotną można zdefiniować jako system podmiotów wykonujących działalność leczniczą i świadczonych przez nie usług, których celem jest umacnianie i poprawa zdrowia jednostek oraz społeczeństwa przez zapobieganie chorobom, wczesne ich wykrywanie, leczenie i rehabilitację. Celem tego systemu jest: 1) zabezpieczenie i dostarczenie całej populacji możliwie pełnego zakresu świadczeń medycznych, których ona wymaga, bez względu na różnicujące ją kryteria ekonomiczne, społeczne, kulturowe i geograficzne (dostępność opieki) np. w Polsce obowiązuje konstytucyjna (art. 68) zasada równego dostępu obywateli do świadczeń opieki zdrowotnej finansowanych z pieniędzy publicznych. $\mathrm{O}$ tym, że podstawowym zadaniem władz publicznych jest zapewnienie równego dostępu obywateli do świadczeń opieki zdrowotnej mówi również art. 5 Ustawy o świadczeniach opieki zdrowotnej finansowanych ze środków publicznych z 27 sierpnia 2004 (Dz. U. nr 210, poz. 2135 z późn. zm.); 2) zapewnienie usług i świadczeń profilaktyczno-leczniczych rehabilitacyjnych na możliwie najwyższym poziomie, adekwatnie do poziomu wiedzy i sztuki medycznej oraz zasad dobrej praktyki (jakość opieki medycznej z uwzględnieniem zasad jej ciągłości i globalnego podejścia); 3) organizowanie opieki w możliwie najlepszy sposób, aby zapewnić optymalne wykorzystanie innych zasobów materialnych, finansowych i osobowych - bazy ochrony zdrowia oraz ich kwalifikacji (efektywność opieki zdrowotnej - produktywność, racjonalność, skuteczność); 4) konsekwentne wdrażanie rozwiązań doskonalących system oraz umożliwiających satysfakcję użytkowników systemu (biorców świadczeń medycznych) i personelu realizującego usługi i świadczenia medyczne.

Opieka zdrowotna obejmuje wprowadzenie nie tylko usługi, lecz i dobra, które służą promocji zdrowia i/lub prewencji, ulżeniu w chorobie bądź jej usunięciu, a przynajmniej zmniejszeniu dyskomfortu, najczęściej jest jednak definiowana właśnie jako działalność usługowa, polegająca na świadczeniu usług medycznych, mimo że dóbr (w tym zwłaszcza leków) zużywa się coraz więcej.

por. Kalisiewicz D. (red. nacz.), Encyklopedia PWN, t. II, Wydawnictwo Naukowe PWN, Warszawa 1999; Poznański P., Konracka D., Skolimowska J., Gałczyński K., Zbylut J., Analiza gospodarki finansowej Kas Chorych $w$ aspekcie zapewnienia dostępności do wybranych świadczeń zdrowotnych, „Antidotum” 2000, nr 6, s. 6; Money G., Economics, Medicine and Health Care, Englewood Cliffs, Nowy Jork, 2003, s. 17 i nast.

${ }^{108}$ Podażową stronę relacji usługowej cechuje duże uzależnienie od czynnika ludzkiego. H. Mruk podkreśla, że od kwalifikacji kadr (zdolności usługowych) i ich gotowości do świadczenia usług zależy jakość relacji ze stroną popytową. Osoba wykonująca określoną usługę medyczną staje się niejako ,jej częścią" - to m. in. od jej umiejętności, doświadczenia zawodowego, przygotowania teoretycznego, organizacji pracy i stosunku do niej, a także zdolności komunikacyjnych zależy efekt końcowy kontaktu usługowego. Pacjenci „kupują” kontakt z konkretnym lekarzem, a nie „wizytę”; operację wykonaną rękami wybitnego specjalisty, a nie interwencję medyczną itp.

Por. Mruk H., Marketing ustug profesjonalnych, „Marketing serwis”, 1996 nr 8, s. 20. 
- dostępności techniki medycznej, dystrybucji jej zdobyczy (sprzęt i aparatura medyczna) oraz stopnia wykorzystania i wydajności aparatury,

- dostępu do specjalistycznej wiedzy medycznej (know how).

Istotną cechą współczesnej gospodarki rynkowej jest prywatna własność środków produkcji, która dominuje w jej strukturze własnościowej. Podstawowym regulatorem alokacji zasobów (które umożliwiają produkcję dóbr, zaspokajających zmienne i zdywersyfikowane potrzeby ludzkie) jest konkurencja. Jeśli spojrzy się na funkcjonowanie systemu ochrony zdrowia w zakresie stomatologii, to można zauważyć, iż:

- dominuje prywatna własność wśród podmiotów prowadzących działalność w tym obszarze ${ }^{109}$,

- liczba gabinetów pozwala na mówienie o warunkach konkurencji (por. Załącznik nr 1),

- pacjenci mają zmienne i zdywersyfikowane potrzeby (m. in. uzależnione od wieku, wysokości dochodów, kultury bycia związanej z higieną jamy ustnej, problemów zdrowotnych - w tym wrodzonych itp.),

- pacjenci w ok. 80\% nabywają świadczenia zdrowotne, opłacając je $\mathrm{z}$ własnych dochodów.

Powyższe powody uzasadniają istnienie mechanizmu rynkowego $\mathrm{w}$ obszarze usług stomatologicznych. A konkurencja - rozumiana jako proces, za pomocą którego uczestnicy rynku, dążąc do realizacji swych interesów, próbują przedstawić oferty korzystniejsze od innych, wpływając na decyzję nabywcy o zawarciu transakcji - jest immanentną cechą gospodarki rynkowej ${ }^{10}$. Stomatologia jest sektorem charakteryzującym się wysoką konkurencyjnością i niskim

\footnotetext{
${ }^{109}$ Świadczeniodawcami - w świetle Ustawy o działalności leczniczej oraz Ustawy o świadczeniach opieki zdrowotnej finansowanych ze środków publicznych - są tzw. podmioty lecznicze (zobowiązzane do udzielania świadczeń zdrowotnych tylko i wyłącznie przez osoby wykonujące zawód medyczny).

Podmioty wykonujące działalność leczniczą można podzielić na dwie grupy: 1) podmioty lecznicze, chodzi tu o: przedsiębiorstwa - definiowane na podstawie art. 4 Ustawy o swobodzie dziatalności gospodarczej z 15 kwietnia 2011 r. (Dz. U. nr 112, poz. 654 z 2011 r. z późn. zm.); samodzielne publiczne zakłady opieki zdrowotnej - tj. podmioty nie będące przedsiębiorcami i tworzone w myśl art. 7 Ustawy o działalności leczniczej - przez jednostki samorządu terytorialnego, Skarb Państwa i uczelnie medyczne); jednostki budżetowe tworzone przez organy administracji rządowej lub samorządowej i instytuty badawcze, fundacje i stowarzyszenia (które - zgodnie z art. 5 Ustawy o działalności leczniczej - w statucie mają zapis o wykonywaniu zadań z zakresu ochrony zdrowia), kościoły i związki wyznaniowe (ze wskazaniem obszaru, w jakim wykonują działalność leczniczą); 2) indywidualne i grupowe praktyki zawodowe.

110 Kamerschen D.R., McKenzie R.B., Nordinelli C., Ekonomia, Fundacja Gospodarcza „Solidarność“, Gdańsk 1990, s. 47.
} 
udziałem w rynku poszczególnych podmiotów (najczęściej na danym obszarze działa kilku stomatologów) ${ }^{111}$.

Z ekonomicznego punktu widzenia opieka zdrowotna może być rozpatrywana, jako działalność usługowa służąca zaspokajaniu - szczególnie zindywidualizowanych - potrzeb człowieka. Gospodarowanie w opiece zdrowotnej (rozumianej jako działalność usługowa) polega na wykorzystaniu czynników świadczenia usług ${ }^{112}$ (czynników produkcji - pracy, kapitału, ziemi ${ }^{113}$ oraz organizacji) w celu osiągnięcia zamierzonego rezultatu tej działalności ${ }^{114}$. J. Sobiech stwierdza, że ochrona zdrowia to działalność sui generis gospodarcza ${ }^{115}$, w ramach której, w oparciu o ograniczone środki (rzeczowe i pracy), zmierza się do zaspokajania specyficznych potrzeb człowieka, jakimi są potrzeby zdrowotne $^{116}$.

W tym miejscu należy wyraźnie podkreślić, że zdrowie człowieka nie jest towarem $^{117}$, nie podlega ono mechanizmom rynkowym, prawnym czy ekonomicz-

${ }^{111}$ Swayne L.E., Duncan W.J., Ginter P.M., Zarzadzanie ... op. cit., s. 112.

${ }^{112}$ Czynniki te w opiece zdrowotnej mają swoją specyfikę, a ich substytucyjność i komplementarność także nabiera specyficznego charakteru.

${ }^{113}$ Rozumianej jako ograniczona przestrzeń.

114 Dobska M., Rogoziński K. (red.), Podstawy zarzadzania zakładem opieki zdrowotnej, Wydawnictwo Naukowe PWN, Warszawa 2008, s. 67 i nast.

${ }^{115} \mathrm{Z}$ utrwalonego orzecznictwa Europejskiego Trybunału Sprawiedliwości wynika, że działalność gospodarczą stanowi każda działalność polegająca na oferowaniu usług na danym rynku. W orzecznictwie i dokumentach Komisji Europejskiej funkcjonuje wąskie ujęcie pojęcia „działalność gospodarcza”, które można utożsamić z „wszelką działalnością komercyjną sensu stricte”. Wśród usług o ogólnym interesie jako działalności o charakterze niegospodarczym wymienia się usługi z zakresu opieki społecznej, zdrowotnej, kultury, edukacji czy też usługi polegające na nadawaniu programów telewizyjnych i radiowych; natomiast wśród usług niegospodarczych wymienia się prerogatywy państwowe, takie jak działalność policji, wymiaru sprawiedliwości, systemu opieki społecznej, poprawa i utrzymywanie bezpieczeństwa ruchu lotniczego, nadzór w zakresie ochrony środowiska przed zanieczyszczeniem obszarów morskich, standaryzacja i związana z nią działalność badawczorozwojowa.

Por. Dokument roboczy uzupełniający Komunikat Komisji Europejskiej do Parlamentu Europejskiego, Rady Komitetu Ekonomiczno-Społecznego oraz Komitetu Regionów: Accompanying the Communication on "A single market for $21^{\text {th }}$ century Europe”. Services of general interest, including social services of general interest: a new European commitment, COM (2007)725 final za: Skoczny T., Jurkowska A., Bernatt M., Charakter ustug świadczonych przez podmioty sektora pozarzadowego $w$ Polsce na tle definicji ustug ekonomicznych i nieekonomicznych $w$ prawie wspólnotowym $w$ szczególności $w$ świetle zakresów Dyrektywy o ustugach na rynku wewnętrznym 2006/123/WE z uwzględnieniem orzecznictwa ETS, Warszawa 2008, s. 17.

${ }^{116}$ Sobiech J., Warunki wyboru ... op. cit., s. 10.

${ }^{117}$ Już pięćdziesiąt lat temu K.J. Arrow podkreślał, że świadczenia medyczne są jedyne w swoim rodzaju ze względu na znaczenie, jakie każdy przypisuje zdrowiu i jego utracie, a rynek świadczeń medycznych różni się od ryków wszystkich innych dóbr i usług, ponieważ wśród wartości indywidualnych i społecznych zdrowie należy do najważniejszych.

Por. Arrow K.J., Uncertainty and the Welfare Economics of Medical Care, "The American Economic Review", December 1963, vol. LIII, nr 5, s. 941 i nast. 
nym. Podlegają im natomiast wszelkie usługi polegające na świadczeniu opieki zdrowotnej. Podstawowa regulacja dotyczy tego, iż usługę medyczną mogą wykonywać jedynie uprawnione osoby, co wynika z reglamentacji usług medycznych i dotyczy wszystkich zawodów medycznych ${ }^{118}$ (lekarzy, pielęgniarek, ratowników). Wyjątkowość usługi medycznej wynika z użyteczności i znaczenia przypisywanych jej przez pacjentów, co przekłada się na popyt na daną usługę medyczną (określoną procedurę) oraz jej cenę na wolnym rynku ${ }^{119}$. Cena usługi medycznej podlega wahaniom, a jej poziom ulega zmianom w zależności od warunków kształtowanych na rynku, na które decydujący wpływ ma państwo i wybrany system finansowania usług medycznych ${ }^{120}$.

W teorii ekonomii zdrowia ${ }^{121}$ istnieje kilka podstawowych cech rynku zdrowia, które różnicują go od innych sfer działalności ekonomicznej, a jednocześnie powodują, że ten rynek jest na tyle daleki od wzorca tzw. rynku doskonałego, że niektórzy nazywają go ,quasi rynkiem”. Wśród cech upośledzających relacje rynkowe w ochronie zdrowia najważniejsze to: dysproporcja informacyjna między lekarzem a pacjentem oraz - wspomniane wcześniej - ograniczenia dostępu do rynku nowych świadczeniodawców ${ }^{122}$. Skutkiem tych dwóch cech jest:

\footnotetext{
${ }^{118}$ Ograniczenia te wynikają z restrykcyjnych ograniczeń prawnych i wymogów nakładanych na osoby wykonujące zawody medyczne (wysokie wymogi proceduralne oraz długi okres kształcenia specjalistów dodatkowo zwiększa tzw. monopolistyczną konkurencję na rynku usług medycznych). Por. Chamberlin E.H., The Theory of Monopolistic Competition, A Re-orientation of the Theory of Value, "Harvard University Press", wydanie 8, 1962 za: Czaja I., Przedsiębiorczość na rynku ustug medycznych procesie przeksztatceń organizacyjnych $i$ wtasnościowych $w$ Polsce, w: Rudawska I., Urbańczyk E., Ekonomiczno-organizacyjne problemy zarzadzania jednostkami stużby zdrowia, „Studia i materiały Polskiego Stowarzyszenia Zarządzania Wiedzą”, Bydgoszcz 2010, s. 54.

${ }^{119} \mathrm{~W}$ systemach jednego płatnika (jak NFZ), cena jest ustalana przez silniejszą ze stron - w Polsce wartość procedur ustalana jest bardzo często na zasadzie „ile NFZ jest w stanie za usługę zapłacić”; natomiast w prywatnym obszarze usług zdrowotnych decydują podaż (reprezentowana przez prywatne gabinety i kliniki) i popyt na daną usługę zgłaszany przez pacjentów.

${ }^{120}$ Czaja I., Przedsiębiorczość na rynku ... op. cit., s. 54.

${ }^{121}$ Kozierkiewicz A., Wzmacnianie świadomej decyzji pacjentów jako narzędzie wspomagania konkurencji, w: Standaryzacja w materiały z Szóstej Ogólnopolskiej Konferencji Jakość w systemie opieki zdrowotnej, Centrum Monitorowania Jakości w Ochronie Zdrowia, Kraków 2001, s. 198.

${ }^{122}$ Do barier, jakie nowi uczestnicy rynku muszą pokonać, jeśli chcą dostać się na rynek, można zaliczyć m. in.: 1) ekonomię skali i zasięgu - pozwala dotychczasowym uczestnikom rynku świadczyć usługi przy niższym średnim koszcie i z wiedzą oraz doświadczeniem, których nie mają wchodzące na rynek jednostki; 2) wymagania kapitałowe - mogą dotyczyć zarówno wyposażenia w podstawowy sprzęt, jak i specjalistyczne urządzenia; 3 ) dostępność kluczowych zasobów (np. ludzkich) lub kanałów dystrybucyjnych (np. opieka stomatologiczna dla osób starszych, niebędących w stanie opuścić swojego domu); 4) ograniczenia prawne - wymagania co do stażu, doświadczenia, zasad działania w określonej formie organizacyjnej; 5) istniejące podmioty z nadwyżką zdolności produkcyjnej - mogą mieć tendencję do używania redukcji cen, jako strategii konkurencyjnej; 6) rynkową reputację działających podmiotów.
}

Por. Kotler Ph., Shalowitz J., Stevens R.J., Marketing strategiczny ... op. cit., s. 191 i nast. 
- brak możliwości oceny przez pacjenta faktycznej wartości uzyskanych dóbr,

- brak możliwości porównania dóbr oferowanych przez różnych świadczeniodawców,

- łatwa możliwość generowania popytu przez dostawców dóbr,

- występowanie pacjenta w roli klienta monopolu (co najmniej lokalnego),

- łatwość tworzenia regionalnych trustów i sojuszów rynkowych wielu świadczeniodawców,

- usługodawcy, płatnicy oraz pacjenci w wielu wypadkach posiadają funkcje celu odbiegające od maksymalizacji zysku (non-profit) i własnej użyteczności (preferencje altruistyczne),

- niepewność towarzysząca procesowi leczenia wraz z asymetrią informacyjną ${ }^{123}$, które czynią kontakty niepełnymi, co sprzyja powstawaniu kosztów transakcyjnych (problem pokusy nadużycia ${ }^{124}$, selekcji negatywnej, kosztów przetargów) i kosztów agencji (rozbieżnych interesów agenta i pryncypała ${ }^{125}$, monitoringu, ryzyka i renty informacyjnej).

\footnotetext{
${ }^{123}$ Za najważniejsze czynniki wpływające na poziom asymetrii w komunikacji lekarz - pacjent należy uznać: 1) wiek lekarza - kojarzony jest z doświadczeniem i dużym zasobem wiedzy, może być czynnikiem zwiększającym asymetrię; dlatego młodszy lekarz musi mocniej pracować nad utrzymaniem swojej instytucjonalnej asymetrii, zwłaszcza w konsultacji ze starszym i doświadczonym pacjentem, niż lekarz starszy, u którego już sam wiek wzbudza zaufanie i respekt pacjenta; generalnie im większa jest różnica wieku na korzyść lekarza, tym większa asymetria (wyjątkiem są konsultacje z udziałem dzieci, gdyż dziecku-pacjentowi zazwyczaj towarzyszy dorosły opiekun i większa część interakcji odbywa się między nim a lekarzem; 2) płeć lekarza, 3) wiek i płeć pacjenta, 4) specjalizację lekarza i jego doświadczenie, a co za tym idzie pozycję w hierarchii medycznej, 5) cel wizyty pacjenta i związaną z tym wagę, jaką przypisuje swoim problemom, 6) obecność osoby trzeciej podczas konsultacji (zarówno ze strony lekarza, jak i pacjenta), 7) fazę konsultacji oraz jej otoczenie instytucjonalne.

Por. Stefaniak K., Władza I tożsamość w komunikacji lekarz pacjent, Oficyna Wydawnicza ATUT, Wrocławskie Wydawnictwo Oświatowe, Wrocław 2011, s. 158 i nast.

${ }^{124}$ Pokusa nadużycia (moral hazard) dla obszaru opieki zdrowotnej może być zdefiniowana jako „różnica w zachowaniach zdrowotnych i konsumpcji opieki zdrowotnej wywołana faktem ubezpieczenia." Por. Zweifel P., Manning W.G., Moral hazard and consumer incentives in health care, w: Culyer A.J., Newhouse J.P., Handbook of Health Economics, Nowy Jork 2000, s. 416.

${ }^{125}$ Nowoczesna teoria agencji koncentruje się na analizie bodźców, wynikających z delegowania praw i obowiązków w organizacjach ekonomicznych, a relacja agencji pojawia się jako jeden z zasadniczych komponentów wszystkich rynkowych transakcji (w tym również transakcji w sektorze opieki zdrowotnej). Może wyjaśnić specyfikę relacji lekarz - pacjent, gdyż zakłada delegowanie przez pacjenta (pryncypała) na lekarza (agenta) uprawnień do decydowania o rodzaju wykonywanych świadczeń medycznych. Teoria agencji zajmuje się wieloma aspektami relacji pryncypał agent. Badania nad rozwiązywaniem konfliktów wynikających z tej relacji koncentrują się jednak przede wszystkim na zakresie i skutkach asymetrii informacyjnej.
} 
$\mathrm{Z}$ powyższych powodów zagadnienia konkurencji w ochronie zdrowia należy traktować ze szczególną ostrożnością, pamiętając, że konkurencja nie stanowi wartości per se, może być jedynie jednym z instrumentów osiągania społecznie pożądanych celów.

Równość w dostępie do świadczeń zdrowotnych to jedno z głównych praw ludzi, a jej zapewnienie powinno być podstawowym celem systemu opieki zdrowotnej. Polityka zdrowotna każdego państwa ${ }^{126} \mathrm{i} \mathrm{WHO}^{127}$ winna zmierzać zatem do tak postawionego celu poprzez odpowiedni system regulacji prawnych, finansowych strukturalnych, a także poprzez propagowanie zasad bioetyki (równość w dostępie do opieki zdrowotnej dla osób o identycznych potrzebach zdrowotnych, zapewnienie takiej samej jakości usług medycznych, jednakowe użytkowanie zasobów i pracy służącej zdrowiu) ${ }^{128}$.

Dostępność w odniesieniu do usług medycznych związana jest z takimi czynnikami, jak ${ }^{129}$ :

- lokalizacja - nie tylko zespoły medyczne muszą znajdować się fizycznie blisko aktualnych i przyszłych pacjentów, lecz także sami pacjenci muszą być w stanie do nich dotrzeć (czynniki: czas podróży, odległość od transportu publicznego, czy dostępność parkingów mogą mieć istotne znaczenie dla tego aspektu),

Por. Misiński W., Modelowanie sytemu powszechnych ubezpieczeń zdrowotnych w Polsce, Wyd. Akademii Ekonomicznej im. O. Langego we Wrocławiu, Wrocław 2007, s. 86; Caers R., Du Bois C., Jegers M., De Gieter S., Schepers C., Peperma R., Principal-Agent Relationships on the Stewardship-Agency Axis, Nonprofit Management \& Leadership, 2006 nr 1, s. 25 i nast.

${ }^{126}$ Jeśli chodzi o kraje UE, to np. artykuł 129.1 Układu z Maastricht z 1993 r. stwierdza, że: „Wspólnota będzie współdziałała w celu zapewnienia wysokiego poziomu ochrony zdrowia obywateli. Działania Wspólnoty będą ukierunkowane na zapobieganie chorobom, w szczególności najważniejszym zagrożeniom zdrowotnym łącznie z uzależnieniami lekowymi, poprzez promowanie badań naukowych ukierunkowanych na ich przyczyny i rozprzestrzenianie, jak również na informacją zdrowotną i nauczanie. Potrzeby ochrony zdrowia ludzi stanowią istotną część polityki Wspólnoty”.

${ }^{127}$ Strategia WHO „Zdrowie dla Wszystkich”, przyjęta w 1978 r. na międzynarodowej konferencji w Ałma Acie, była wyrazem uznania przez najwyższe światowe forum zdrowia podstawowej zasady równości i sprawiedliwości społecznej w odniesieniu do spraw zdrowia. Główne jej przesłania to: 1) równość społeczna w dostępie do podstawowej opieki zdrowotnej wg potrzeb, 2) współuczestnictwo i współodpowiedzialność za zdrowie społeczeństwa. Strategia stała się programem wdrażania idei bezpieczeństwa zdrowotnego w skali świata i w tym znaczeniu została zaakceptowana przez rządy wszystkich 191 krajów członkowskich WHO. Przyjmując strategię „Zdrowie dla Wszystkich” zaakceptowano tym samym główny cel krajów członkowskich WHO na nadchodzące dekady osiągnięcie przez wszystkich ludzi świata poziomu zdrowia, który pozwoli im wieść społecznie i ekonomicznie wydajne życie.

za: Leowski J., Polityka zdrowotna a zdrowie publiczne, CeDeWu, Warszawa 2009, s. 27.

${ }^{128}$ Suchecka J., Regulacje publiczne i prawne, równość sektorów w ochronie zdrowia, w: Ryć K., Skrzypczak Z., Ochrona zdrowia i gospodarka. Mechanizmy rynkowe a regulacje publiczne, Wyd. Nauk. WZ UW, Warszawa 2008, s. 24.

${ }^{129}$ Kotler Ph., Shalowitz J., Stevens R.J., Marketing strategiczny... op. cit., s. 187 i nast. 
- dostarczanie usług - to analizowanie sposobów, na jakie zespół medyczny może pomagać bezpośrednio (np. wizyty domowe) lub wirtualnie (np. telemedycyna) pacjentom,

- wygoda - skupia się na dostarczeniu usług, kiedy pacjenci ich potrzebują lub zażądają (np. dostępność poza typowymi godzinami przyjęć),

- status kontaktu z ubezpieczycielem - w celu zapewnienia odpowiedniej liczby pacjentów placówki zdrowia podpisują kontrakty z ubezpieczycielem (w warunkach polskich głównie NFZ); firmy farmaceutyczne stają przed podobnymi ograniczeniami, gdy próbują wpisać swoje produkty na listy refundacyjne.

W polskim systemie opieki zdrowotnej pojęcie dostępności ochrony zdrowia A. Frączkiewicz-Wronka definiuje na dwóch poziomach ${ }^{130}$ :

- na poziomie systemu - prawo do korzystania z opieki zdrowotnej daje tytuł ubezpieczeniowy (ubezpieczenie zdrowotne jest powszechne i obowiązkowe),

- na poziomie instytucji - pacjent ma prawo do korzystania z wszystkich faz opieki zdrowotnej (od promocji zdrowia, poprzez świadczenia profilaktyczne, diagnostykę i leczenie, rehabilitację po opiekę paliatywno-hospicyjną). Jeśli jest ubezpieczony, to nieodpłatnie, jeśli nie przedstawi dowodu ubezpieczenia, to świadczenie jest udzielane na jego koszt. Ograniczeniem zasady dostępności na tym poziomie jest również wymóg posiadania skierowania do lekarza specjalisty ${ }^{131}$ i do szpitala ${ }^{132}$.

R. Holly zwraca uwagę, że o celach i charakterze systemu ochrony zdrowia przesądza polityka zdrowotna danego kraju. Jej kształt wpływa również na sprawność i koszty funkcjonowania systemu ochrony zdrowia, a więc na jego efektywność. Polityka zdrowotna tworzy zinstytucjonalizowaną formę urzeczywistniania jednej z najważniejszych wartości w życiu człowieka - zdrowia. Jej celem jest formułowanie i wdrażanie takich rozwiązań, które w stosunkowo największym stopniu okażą się możliwe do zaakceptowania przez możliwie największą liczbę ludzi, których dotyczą ${ }^{133}$. Rozwiązania te mają zapewnić m. in. równą dostępność obywateli do świadczeń zdrowotnych (a świadczeń medycznych w szczególności). Przy czym dostępność opieki medycznej to nie

\footnotetext{
${ }^{130}$ Frączkiewicz-Wronka A., Dostępność ustug zdrowotnych - racjonalizacja czy wykluczenie, „Polityka Zdrowotna”, 2004 tom I, s. 72.

${ }^{131}$ Wymóg ten nie dotyczy m.in. wizyty u ginekologa i położnika, lekarza dentysty, dermatologa, psychiatry i leczenia chorób wenerycznych, a także nosicieli HIV i gruźlicy.

${ }^{132} \mathrm{Z}$ wyjątkiem nagłych przypadków, wypadków, porodów itp.

${ }^{133}$ Holly R., Racjonalna polityka zdrowotna a procedury $i$ standardy medyczne w systemie ochrony zdrowia, „Polityka Zdrowotna”, 2004 tom I, s. 9.
} 
tylko bliskość placówek ochrony zdrowia w sensie geograficznym (odległość, czas dotarcia, środki transportu). J. Leowski podkreśla, że opieka medyczna musi być dostępna $\mathrm{w}$ sensie ${ }^{134}$ :

- funkcjonalnym, co oznacza dostępność właściwego rodzaju ciągłej opieki dla wszystkich (dostarczanej przez zespół odpowiednio przygotowany i wyposażony),

- kulturowym, a więc w metodach jej udostępniania i w procesie udzielania świadczeń powinien być uwzględniony akceptowany przez dane społeczeństwo systemu wartości kulturowych, religijnych, etycznych,

- finansowym, który oznacza stopień w jakim dane społeczeństwo i dany kraj stać na opiekę medyczną (w tym aspekcie pojawiają się również problemy: kto będzie ponosił odpowiedzialność, kto będzie podejmował decyzje o udzieleniu lub nie udzieleniu opieki ${ }^{135}$ ).

Biorąc pod uwagę fakt, że dostępność usług medycznych jest jednym z warunków dobrze zorganizowanej opieki zdrowotnej A. Frączkiewicz-Wronka rozpatruje dostępność, jako kategorię techniczną i wskazuje jej pięć obszarów ${ }^{136}$ :

- osiągalność - rozumianą jako relacja między wielkością i strukturą zasobów znajdujących się w dyspozycji systemu a wielkością i strukturą potrzeb zdrowotnych określonej populacji,

- dostępność przestrzenną - określoną jako relacja między przestrzenną dystrybucją zasobów a terytorialnym rozmieszczeniem osób, które mają korzystać ze świadczeń,

- dostępność organizacyjną - zdefiniowaną przez stopień dostosowania organizacyjnych warunków udostępniania świadczeń i praktycznych możliwości korzystania przez pacjentów ze stosowanych rozwiązań,

- dostępność kosztową - która powinna być analizowana na poziomie makro (dotyczy zasad przyznawania uprawnień do korzystania ze świadczeń) i mikro (postrzegana przez pacjenta jego zdolność do poniesienia kosztu związanego z kontaktem z systemem ochrony zdrowia),

\footnotetext{
${ }^{134}$ Leowski J., Polityka zdrowotna ... op. cit., s. 115-116.

${ }^{135} \mathrm{~W}$ systemie publicznej służby zdrowia zarówno decyzje, jak i odpowiedzialność spoczywają na ciałach zbiorowych - wybieranych władzach, radach i powołanych do tych celów zespołach, które formułują politykę zdrowotną, podejmują decyzje i odpowiadają za realizację nie tylko w zakresie medycyny zapobiegawczej i zdrowia publicznego (np. jakim szczepieniom ochronnym i w jakim wieku podlegają wszystkie dzieci, czy i jaka liczba pałeczek coli jest dopuszczalna w wodzie do picia, mleku czy kąpieliskach), ale również kto jest odpowiedzialny za finansowanie i dostarczanie świadczeń medycznych.

${ }^{136}$ Frączkiewicz-Wronka A., Dostęność ustug zdrowotnych ... op. cit., s. 71.
} 
- akceptowalność - rozumianą jako relacja między oczekiwaniami pacjenta dotyczącymi technicznych, psychologicznych i kulturowych aspektów zaspokajania potrzeb a stopniem spełnienia tych oczekiwań w warunkach konkretnego kontaktu z systemem ochrony zdrowia.

Ocenę dostępności można przeprowadzać na wiele sposobów, stosując miary:

- obiektywne np. nakłady na służbę zdrowia, liczba lekarzy przypadająca na 10 tyś. mieszkańców, liczba udzielonych porad ${ }^{137}$ itp.

- subiektywne - ocena dostępności dokonana przez pacjentów (np. częstość i przyczyny rezygnacji z wizyt u lekarza, czas oczekiwania na uzyskanie porady itp.) na podstawie badań ankietowych.

Szczegółowe zmiany w zakresie dostępności usług stomatologicznych w latach 2003-2012 przedstawione są w Załączniku nr 1. Ogólnie kierunek zmian w tym zakresie należy ocenić jako wzrost liczby podmiotów oferujących świadczenia przy niewielkich (lub żadnych) zmianach nasycenia ${ }^{138}$ (wyjątek stanowiły przychodnie stomatologiczne HP.3.2 - wzrost z 6,8 do 10,0) oraz wzrost liczby osób uprawnionych do wykonywania zawodu lekarza dentysty. Przykładowe zmiany przedstawiają się następująco:

- liczba zakładów opieki zdrowotnej zajmujących się stomatologicznym leczeniem ambulatoryjnym wzrosła o $13,5 \%$; średnie nasycenie wyniosło w 2010 r. - 4,2 (największe było w województwie mazowieckim, a najmniejsze w opolskim - 1,6) i wzrosło o 0,6 w porównaniu z 2003 r.;

- liczba zakładów oferujących leczenie szpitalne na oddziałach chirurgii szczękowo-twarzowej wzrosła o 77\%; komórek - o 37\%, a łóżek - o 6,6\%, choć średnie nasycenie $\mathrm{w}$ analizowanym okresie pozostało na niezmienionym poziomie - 0,1 (największe - 0,2 odnotowały województwa: dolnośląskie, lubelskie, łódzkie, mazowieckie, podlaskie, wielkopolskie, warmińsko-mazurskie; a najmniejsze - 0,0 - lubuskie i świętokrzyskie);

- liczba poradni stomatologicznych dla dzieci wzrosła o 46\%, a średnie nasycenie wzrosło z 0,2 do 0,4 w 2010 r. (maksymalne było w województwie mazowieckim $-1,4$, a minimalne $-0,0 \mathrm{w}$ lubelskim, lubuskim, śląskim i opolskim);

- liczba poradni ortodontycznych wzrosła o $36 \%$, a nasycenie wynosiło w 2010 r. - 0,4 (maksymalne było w województwach: łódzkim, mazowieckim i zachodniopomorskim, a minimalne $-0,1 \mathrm{w}$ podkarpackim, świętokrzyskim i warmińsko-mazurskim);

\footnotetext{
${ }^{137}$ Access to Health Care, www.ucatlas.ucsc.edu/access.php.

138 Nasycenie to liczba komórek organizacyjnych placówek ochrony zdrowia (np. poradni, oddziałów szpitalnych, pracowni itp.) przypadających na 10 tyś. mieszkańców.
} 
- liczba poradni protetyki stomatologicznej wzrosła o 32\%, a średnie nasycenie w 2010 r. wynosiło 0,5 (najwyższą wartość miał ten wskaźnik w województwie zachodniopomorskim - 1,3, a najniższą w kujawsko-pomorskim, małopolskim, świętokrzyskim i warmińsko-mazurski - 0,1);

- liczba zakładów opieki zdrowotnej świadczących usługi z zakresu periodontologii wzrosła o $82 \%$, a nasycenie w badanym okresie z 0,4 do 0,6 (największe było w województwie mazowieckim - 1,5, a najmniejsze w podlaskim - 0,0);

- liczba osób uprawnionych do wykonywania zawodu lekarza dentysty w latach $2000-2010^{139}$ wzrosła o $10,85 \%$, co wpłynęło na wzrost wartości wskaźnika nasycenia - z 8,5 w 2001 r. do 9,8 w 2010 r.; jednak jeśli uwzględni się, że w 2010 r. 16,14\% lekarzy dentystów uprawnionych do wykonywania zawodu nie wykonywało go, to wskaźnik nasycenia wynosi 8,2; a uwzględnienie stażystów (w 2010 r. - 951 osób) obniża wartość wskaźnika do poziomu - 7,97;

- spadek wartości wskaźnika: liczba zatrudnionych dentystów na 10 tyś. mieszkańców z 1,2 w 2002 r. do 0,5 w 2010 r. (zróżnicowanie między województwami w $2010 \mathrm{r}$. było na poziomie 1,1: od 1,2 w województwie łódzkim do $0,1 \mathrm{w}$ województwie lubuskim i warmińsko-mazurskim); można zatem wnioskować, że znaczna część tych lekarzy znalazła zatrudnienie $\mathrm{w}$ sektorze prywatnych usług stomatologicznych np. w drodze samozatrudnienia (co doprowadziło do wzrostu konkurencji na tym rynku), a część z nich mogła „zniknąć ze statystyk” odchodząc z zawodu lub wyjeżdżając za granicę (zmniejszając dostępność do świadczeń stomatologicznych oferowanych przez podmioty publiczne),

- uwzględniając zmiany w zakresie liczby dentystów ze specjalizacją w latach 1992-2010 należy zauważyć, że w 2010 r. odnotowano najniższą (niższa była tylko w 2000 r.) liczbę lekarzy dentystów pracujących w placówkach ochrony zdrowia wg podstawowego miejsca zatrudnienia; tendencję malejącą wskazywały wszystkie grupy specjalności (chirurgia stomatologiczna, chirurgia szczękowo-twarzowa, protetyka, stomatologia dziecięca, stomatologia zachowawcza), z wyjątkiem liczby specjalistów w zakresie ortodoncji i periodontologii.

Mówiąc o konkurencji w sferze usług zdrowotnych, Ch. Wolfe Jr. zwraca uwagę na to, że ${ }^{140}$ :

\footnotetext{
${ }^{139}$ Dane bez MON, MSWiA, MS.

${ }^{140}$ Wolfe Ch. Jr., Markets or governments: choosing between imperfect alternatives, MIT Press, Cambridge 1994, za: Getzen T., Ekonomika zdrowia, Wydawnictwo Naukowe PWN, Warszawa 2000, s. 403.
} 
- etyka konkurencji nie harmonizuje z etyką profesjonalistów medycznych, wykonujących zawód opiekuńczy (dążenie do maksymalizacji zysku kosztem dobra pacjenta); funkcja lekarza-przedsiębiorcy stoi w sprzeczności $\mathrm{z}$ deontologią lekarską ${ }^{141}$,

- sfera usług medycznych nie jest szczególnie wrażliwa na ceny, prawdopodobnie na skutek problemów informacyjnych. Również I. Rudawska ${ }^{142}$ stwierdza, że „należy się zgodzić z hipotezą, że w podstawowym, standardowym wymiarze usług wykorzystanie cen do zmiany zachowania klientów nie jest dobrym rozwiązaniem. Nawet wtedy, gdy ludzie będą mogli posługiwać się cenami i będą mieli siłę nabywczą, z dużym prawdopodobieństwem można stwierdzić, że będą chcieli uniknąć wpływu cen na swoje decyzje dotyczące usług zdrowotnych." W odniesieniu do usług stomatologicznych stwierdzenie to okazuje się nieuzasadnione w odniesieniu do niektórych pacjentów, czego przykładem może być korzystanie przez pacjenttów z zakupów grupowych. Pacjent kierując się niską ceną (obniżoną o min. 50\% w stosunku do poziomu podstawowego) wykonuje zabieg w gabinecie, w którym nigdy wcześniej nie korzystał z usług zdrowotnych (temat ten będzie poruszony w dalszej części pracy).

$\mathrm{Na}$ ograniczenie konkurencji w systemie ochrony zdrowia ${ }^{143}$ wpływa przede wszystkim fakt, że występuje w nim wiele czynników wytłumiających zachowania prokonkurencyjne. Można je podzielić na następujące obszary ${ }^{144}$ :

- czynniki systemowe, które związane są z ogólną konstrukcją systemu ochrony zdrowia w danym kraju (instytucje, regulacje, kontrola, nadzór),

\footnotetext{
${ }^{141}$ Gabinety stomatologiczne mają dualny charakter: są nie tylko zarobkującymi usługodawcami, ale również instytucjami zaufania publicznego, oferującymi świadczenia zdrowotne. Dlatego dentyści stają przed swoistym wyzwaniem: znalezieniem punktu równowagi między efektywnością (czy konkurencyjnością, dochodowością itp.) a szeroko rozumianym bezpieczeństwem (stabilnością, etyką itp.). Dlatego tak jednoznacznie postawiona kwestia działań lekarza-przedsiębiorcy: „Dążenie do maksymalizacji zysku kosztem dobra pacjenta" jest jedną (i do tego skrajną) z możliwości. Lekarz może zarabiać (niekoniecznie maksymalizując korzyść finansową) i maksymalizować satysfakcję z wykonywania udanych zabiegów trudnych przypadków medycznych i działać dla dobra pacjenta (dążąc w ten sposób do równowagi między etyką lekarską i etyką biznesu).

${ }^{142}$ Rudawska I., Ekonomizacja relacji ... op. cit., s. 42.

${ }^{143}$ Ochrona zdrowia jest to wszelka społeczna działalność, podejmowana z wykorzystaniem odpowiednich urządzeń, norm prawnych i instytucji, której celem jest zapobieganie chorobom i ich leczenie, utrzymanie rozwoju psychicznego, fizycznego i społecznego człowieka, przedłużenie życia, zapewnienie zdrowego rozwoju następnych pokoleń.

por. Kalisiewicz D. (red. nacz.), Encyklopedia PWN, t. II, Wydawnictwo Naukowe PWN, Warszawa 1999.

${ }^{144}$ Adamczyk-Kloczkowska B., Wojna M., Czynniki wspierające i osłabiajace konkurencję w systemie ochrony zdrowia, w: Ryć K., Skrzypczak Z. (red.), Ochrona zdrowia i gospodarka. Mechanizmy rynkowe i gospodarka. Mechanizmy rynkowe a regulacje publiczne, Wydawnictwo Naukowe Wydziału Zarządzania Uniwersytetu Warszawskiego, Warszawa 2008, s. 78.
} 
- czynniki organizacyjne, związane ze szczegółowymi rozwiązaniami stosowanymi przez podmioty, zwłaszcza usługodawców, z obszaru ochrony zdrowia, praktycznym przestrzeganiem regulacji przez te podmioty itd.,

- czynniki wynikające ze specyfiki ochrony zdrowia oraz usług medycznych.

W neoklasycznej teorii ekonomii niesprawność rynkowa spowodowała pojawienie się argumentacji za interwencją sił innych niż rynkowe, które przez odpowiednie mechanizmy regulacyjne mogłyby skutecznie jej przeciwdziałać ${ }^{145}$. A. Wojtyna podkreśla, że przede wszystkim chodzi tu o państwo, które pełniąc swoje funkcje, ma za zadanie zapobiegać powstawaniu ,wad rynku” lub łagodzić ich negatywne skutki. W teorii neoklasycznej państwo jawi się jako wyraziciel ogólnych interesów społeczeństwa. Odgrywając rolę pełnomocnika swych mocodawców (nabywców usług), ma na celu redukcję kosztów transakcji, a przez to zwiększenie efektywności alokacji zasobów i tym samym przyczynienie się do maksymalizacji użyteczności klientów ${ }^{146}$. $Z$ drugiej strony warunkiem stosowania reguł rynkowych $\mathrm{w}$ gospodarce jest prywatyzacja jej podmiotów (sprzyjająca rozwojowi przedsiębiorczości). Dlatego dążenie do znalezienia punktu równowagi między siłami rynkowymi a oddziaływaniem innych mechanizmów staje się wyzwaniem szczególnie istotnym dla systemu ochrony zdrowia (stając się procesem ciągłego dążenia do znalezienia optimum deontologgicznego i ekonomicznego), zwłaszcza, że świadczenia są realizowane zarówno przez podmioty publiczne, jak i prywatne (tak z wykorzystaniem środków publicznych, jak i prywatnych - pochodzących od pacjentów lub z abonamentów pracodawców). Znalezienie wspólnego mianownika działań ekonomicznych dla podmiotów, które działają w celu zarobkowym i non profit jest trudnym zadaniem ze względu na różne przepisy, określające praktykę ich funkcjonowania, różne sposoby finansowania ${ }^{147}$, również - ciągle jeszcze - odmienną mentalność decydentów w tych podmiotach. Odpowiedzią na wyzwania rynku staje się aplikowanie - odpowiednio dostosowanych do specyfiki branży - rozwiązań, które sprawdziły się wcześniej $\mathrm{w}$ innych branżach $\mathrm{w}$ jednych podmiotach i wdrażanie zasad New Public Management w innych oraz poszukiwanie nowych działań dedykowanych usługom zdrowotnym. Stomatologia jest tym

\footnotetext{
${ }^{145}$ Sadowski Z., Podstawowe założenia strategii rozwoju Polski, „Ekonomista” 1993 nr 12, s. 143 za: Rudawska I., Ekonomizacja relacji ... op. cit., s. 46 i nast.

${ }^{146}$ Wojtyna A., Rola państwa we wspótczesnej ekonomii, „Ekonomista” 1992 nr 3, s. 356.

${ }^{147}$ Współuczestniczenie pacjentów $\mathrm{w}$ finansowaniu opieki medycznej jest jednym $\mathrm{z}$ istotnych elementów w wielu systemach ochrony zdrowia. Głównym założeniem jest modyfikowanie popytu na usługi medyczne i ograniczenie nadmiernej skłonności do konsumpcji świadczeń tzw. pokusy nadużycia (moral hazard). Jednak w Polsce w odniesieniu do usług stomatologicznych zrezygnowano ze współpłacenia (pacjent dopłacał do lepszych materiałów lub procedur nieobjętych kontraktem z NFZ w gabinecie) i pacjent może korzystać nieodpłatnie - w zakresie przewidzianym obowiązującym prawodawstwem - ze świadczeń stomatologicznych w gabinetach, które mają podpisane umowy z NFZ lub może opłacać bezpośrednio usługi świadczone prywatnie.
} 
szczególnym obszarem usług zdrowotnych, który od lat pozostaje - w dużej części - w rękach prywatnych podmiotów i godząc zasady pracy lekarza z mechanizmami rynkowymi ${ }^{148}$ ma w tym już znaczne doświadczenie i sporą - jak się okazuje - intuicyjną wiedzę na ten temat. Z tego względu odpowiedzią na coraz szybciej postępujące zmiany w otoczeniu, sposobem na osiągnięcie przewagi konkurencyjnej i skutecznego wyróżnienia się na rynku, w podmiotach świadczących usługi zdrowotne może stać się (i staje się) przyjęcie orientacji prorynkowej i zastosowanie marketingu relacji ${ }^{149}$ (więcej na ten temat w odniesieniu do specyficznych podmiotów usługowych, jakimi są gabinety stomatologiczne będzie w IV i V rozdziale).

Ph. Kotler, J. Shalowitz i R.J. Stevens wyraźnie podkreślają, że wprowadzanie orientacji prorynkowej w podmiotach świadczących usługi medyczne jest możliwe i dziś wręcz konieczne. W praktyce może dojść do tego m. in. dzięki ${ }^{150}$ :

- wewnętrznemu przekonaniu dentysty-menedżera, że gabinet powinien być skoncentrowany na pacjencie-kliencie, jako osobie (a nie tylko przypadku medycznym); przyjęcie proklientowskiej orientacji w podmiocie opieki zdrowotnej pozwoli na prawdziwe zaangażowanie lekarza w przekonywanie pozostałych członków personelu o korzyściach płynących z tego, że pacjenci czują się komfortowo podczas pobytu w gabinecie,

\footnotetext{
${ }^{148}$ Władza publiczna zapewnia obywatelom dostęp do usług publicznych, jakimi są usługi stomatologiczne, zgodnie z przyjętymi sposobami i zakresem ich finansowania ze środków publicznych. Dyskusyjną kwestią z punktu widzenia lekarzy dentystów może być kwestia wysokości wyceny procedur proponowana przez NFZ, czy problem nadwykonań. Z punktu widzenia pacjentów można byłoby stawiać pytania dotyczące zakresu świadczeń i rodzaju materiałów, które mogą być używane w ramach opłaty ponoszonej przez NFZ. Obowiązujące przepisy w tym zakresie nie stanowią jednak przedmiotu zainteresowania niniejszej pracy. Istotne jest to, że dentyści świadczą usługi, które pacjent opłaca $\mathrm{z}$ własnych środków i wówczas mechanizm rynkowy staje się regulatorem kontaktów stomatolog - pacjent. Wówczas znaczenia nabiera cena usługi, liczba podmiotów oferujących usługę na danym rynku, liczba osób chcących skorzystać z danej usługi, szerokość i głębokość oferowanych usług, jakość świadczenia i obsługi, reputacja dentysty/gabinetu itp.

${ }^{149}$ Pojęcie „relacja” pomiędzy podmiotami odnosi się do sposobu, w jakim dwie osoby lub grupy osób postrzegają się i zachowują wobec siebie. Dla celów marketingu relacji termin ,relacja” rozumiany jest jako suma kontaktów i transakcji pomiędzy dostawcą i klientem, realizowanych w czasie z uwzględnieniem wzajemnych interesów, a więc dobrowolnie, zaplanowane, powtarzalne transakcje pomiędzy dostawcą a klientem, realizowane z zamiarem kontynuowania w przyszłości dla osiągnięcia wzajemnych korzyści.

Konkurencję należy uznać za mechanizm wymuszający reorientację zachowań usługodawców w kierunku proklientowskim, lecz w procesie kreacji relacji pacjent-usługodawca istotne znaczenie należałoby przypisywać współpracy - wszyscy uczestnicy procesu usługowego przyjmują na siebie odpowiedzialność za satysfakcjonujący rozwój relacji.

Por. Hougaard S., Bjerre M., Strategic relationship marketing, Springer, Berlin 2003, s. 32; Little E., Marandi E., Relationship marketing management, Thomson 2003, s. 23.

${ }^{150}$ Kotler Ph., Shalowitz J., Stevens R.J., Marketing strategiczny ... op. cit., s. 636.
} 
- zwracaniu uwagi na przykłady zachowań, do których naśladowania dentysta chce nakłonić innych (powinien on osobiście dawać dowody troski nad pacjentem np. poprzez pozamedyczne rozmowy z nim, ułatwianie komfortowego pobytu na terenie podmiotu - w poczekali, gabinecie, inwestowanie w ulepszanie i zwiększanie estetyki pomieszczeń itp.),

- zdobyciu pomocy z zewnątrz - udział w szkoleniach z zakresu pozamedycznych obszarów funkcjonowania gabinetu, zatrudnienie firmy konsultingowej, mającej wiedzę z zakresu ulepszania jakości usług placówek zdrowotnych, kreowania wizerunku itp.,

- wprowadzeniu lub rozwinięciu systemu informacji dotyczącej pacjentów (na temat ich zadowolenia lub niezadowolenia z pobytu w gabinecie),

- zmianie systemu motywowania i nagradzania (w celu nagradzania właściwych zachowań pracowników),

- stworzeniu wewnętrznych programów szkoleniowych (mających na celu uwrażliwienie pracowników kontaktujących się z pacjentami na problemy pacjentów np. szkolenia z zakresu komunikacji interpersonalnej, przeciwdziałania wypaleniu zawodowemu itp.),

- przekazaniu większej władzy w ręce pracowników, aby współuczestniczyli w ulepszaniu obsługi pacjentów (np. umożliwianiu szybkiego rozpatrywania zażaleń).

Podsumowując, można powtórzyć za I.M. Kirznerem: „By proces rynkowy się pojawił potrzebny jest dodatkowy składnik, nieobecny w wąskich granicach zachowania ekonomizującego. Ten komponent (...) najlepiej scharakteryzować jako przedsiębiorczość; zajmuje taką samą pozycję w stosunku do węższego 'ekonomizującego' elementu rynku, jaką w jednostkowym działaniu zajmują elementy przedsiębiorczości w stosunku do efektywności decyzyjnej." Ponadto I.M. Kirzner dowodzi, że „konkurencyjny proces rynkowy jest koniecznie przedsiębiorczy”; używając następujących argumentów: „wzorzec decyzji w każdym zakresie różni się od wzorca z poprzedniego okresu, ponieważ uczestnicy rynku zdają sobie sprawę z nowych możliwości. Po tym jak wykorzystają te szanse, ich konkurencja kieruje ceny w stronę, gdzie stopniowo maleje możliwość zarobku. Element przedsiębiorczy w ekonomicznym zachowaniu polega na (...) wzmożonej czujności wobec wcześniej niedostrzeżonych zmian w warunkach, które umożliwiają osiągnięcie większego zysku niż dotychczas." w ekonomii. Jednak Robbinsonowskie ujęcie ekonomii, najbardziej doniośle poddawał w wątpliwości J.A. Schumpeter, który nadawał priorytetowe znacze-

${ }^{151}$ Kirzner I.M., Konkurencja ... op. cit., s. 38.

152 Ibidem s. 24. 
nie przedsiębiorcom i przedsiębiorstwom, jako głównym kreatorom rozwoju ${ }^{153}$. Według tego autora kreacja jest najogólniejszym polem zainteresowań ekonomii ergo teorii przedsiębiorstwa jako jej holonu, natomiast alokacja jest węższym polem badawczym, zajmującym się względnie nietrwałymi i krótkookresowymi stanami w gospodarce ${ }^{154}$. I w dalszej części pracy uwaga zostanie skoncentrowana na „elemencie przedsiębiorczym” lekarzy dentystów, który pozwala im wykorzystywać zdobycze marketingu relacji w prowadzeniu gabinetu, jako przedsiębiorstwa zarobkującego.

\section{PRZEDSIĘBIORCZOŚĆ \\ 2.1. PRZEDSIĘBIORCZOŚĆ W LITERATURZE - ZARYS ZAGADNIENIA}

Współcześnie przedsiębiorczość (enterprise, enterpreneurship) jest przedmiotem zainteresowania wielu dziedzin nauki: ekonomii i nauk o zarządzaniu, psychologii i socjologii, prawa, etyki itp. Powoduje to trudności w jednoznacznym zdefiniowaniu tego pojęcia, ale jego korzeni można upatrywać wśród osiemnastowiecznych ekonomistów - jako pierwszy wyróżnił je R. Cantillon w 1755 r., określając ,przedsiębiorczość”, jako ,zdolność do przewidywania, skłonność do podejmowania ryzyka”, a „przedsiębiorcę” jako osobę, która „dobrze znając określony rynek, wykorzystuje pojawiającą się na nim okazję, stworzoną przez brak popytu i równowagi pomiędzy popytem a podażą," Przedsiębiorca Cantillona to arbitrażysta, który zauważając nierównowagę na rynku (która może zapewnić mu zysk), wykorzystuje ją i przywracając równowagę rynkowi (ale na innym, wyższym poziomie) - zarabia.

A. Smith odróżniał funkcję kapitalisty od funkcji kierownika, ale nie odróżniał kapitalisty dostarczającego zasobów do firmy od przedsiębiorcy podejmującego ostateczne decyzje (określenia przedsiębiorca używał jako synonimu właściciela przedsiębiorstwa $)^{156}$.

Kolejnym ekonomistą, zajmującym się problematyką przedsiębiorczości, był J. Say, który w działaniu przedsiębiorczym widział przenoszenie zasobów ekonomicznych z obszaru o niższej do obszaru o wyższej wydajności i zysku ${ }^{157}$.

\footnotetext{
${ }^{153}$ Schumperer J.A., Teoria rozwoju gospodarczego, PWN, Warszawa1960.

${ }^{154}$ Alokacja dokonuje się w wyniku kreacji, która kieruje się swoimi autonomicznymi czynnikami sprawczymi, trudnymi do skodyfikowania, jak każdy akt twórczy.

Por. Noga A., Teorie przedsiębiorstw, PWE, Warszawa 2011, s. 59.

${ }^{155}$ Cantillon R., Assai sur la nature du commerce en general, za: Łuczak M., Przedsiębiorczość $w$ zarzadzaniu firma, Wydawnictwo WSzE w Warszawie, Warszawa, 2003, s. 11.

${ }^{156}$ Blaug M., Teoria ekonomii: ujęcie retrospektywne, Wydawnictwo Naukowe PWN, Warszawa 1994, s. 467.

${ }^{157}$ Gruszecki T., Przedsiębiorca w teorii ekonomii, CEDOR, Warszawa 1994, s. 32.
} 
W przedsiębiorcy (rzemieślniku, kupcu) widział osobę, która tworzy produkt użyteczny tj. powiększający użyteczność dla jego nabywcy.

Po przerwie w zajmowaniu się problematyką przedsiębiorczości w XIX w. (spowodowanej wg. M. Blauga „rosnącą popularnością doktryny równowagi ogólnej, która ostatecznie wykluczyła możliwość teoretycznych rozważań nad przedsiębiorczością"158), wiek XX przyniósł eksplozję zainteresowania tematem $^{159}$. Swoje teorie przedstawili m. in. J.A. Schumpeter, F. Knight, I.M. Kirzner, a ich silny wpływ można nadal obserwować w literaturze dotyczącej problematyki przedsiębiorczości.

J.A. Schumpeter ${ }^{160}$ postawił tezę, że dynamiczna nierównowaga, wywołana przez innowacyjnego przedsiębiorcę ${ }^{161}$, jest objawem zdrowej gospodarki, a zarazem osią teorii i praktyki ekonomicznej, w większym stopniu niż równowaga i optymalizacja. Dowodził, że głównymi argumentami wzrostu gospodarczego są przedsiębiorcy, którzy wprowadzają nowe produkty i nowe metody wytwarzania stymulujące aktywność gospodarczą. Przedsiębiorczość opisał jako proces „kreatywnej destrukcji”, w którym przedsiębiorca ciągle zastępuje stare produkty nowymi ${ }^{162}$. Zjawisko to ma pozytywny wpływ na rozwój, ponieważ powstają nowe technologie i coraz doskonalsze produkty, a to z kolei pobudza do kupowania i ekonomicznej aktywności konsumentów. Jednak według Schumpetera ${ }^{163}$ zadaniem przedsiębiorcy nie jest jedynie wynajdywanie nowych rozwiązań (w tym m. in.: tworzenie nowych dóbr, nowych metod

\footnotetext{
${ }^{158}$ Blaug M., Teoria ekonomii ... op. cit., s. 469.

${ }^{159} \mathrm{~W}$ historycznym rozwoju badań nad przedsiębiorczością wyłoniło się kilka szkół: 1) neoklasyczna teoria równowagi (R.E. Khilstrom, J.J. Laffont), 2) teoria psychologiczna (T.M. Begley, D.P. Boyd), 3) ekonomiczna szkoła austriacka (I.M. Kirzner, F.A. Hayek). Każda z nich przyjmuje różne założenia i definicje przedsiębiorczości.

${ }^{160}$ Schumpeter J.A., Teoria rozwoju gospodarczego, PWN, Warszawa 1960.

${ }^{161}$ Dziś również podkreśla się silny związek między przedsiębiorczością i innowacjami (traktując je jako szczególne i podstawowe narzędzie, a także przejaw przedsiębiorczości). Innowacja jest specyficzną cechą przedsiębiorczości - działaniem, które nadaje zasobom nowe możliwości tworzenia bogactwa np. dzięki wykorzystaniu reguł marketingu relacji. Niektórzy autorzy (por. Robbins S.P., DeCenzo D.A., Podstawy zarządzania, PWE, Warszawa 2002, s. 164) uważają, że nie ma przedsiębiorczości bez innowacji.

Według P.F. Druckera (por. Drucker P.F., Innowacja i przedsiębiorczość. Praktyka i zasady, PWE, Warszawa 1992, s. 30) nie każde nowe, małe przedsiębiorstwo ma charakter przedsiębiorczy lub reprezentuje przedsiębiorczość, gdyż efektem przedsiębiorczości powinny być nowe sposoby zaspokajania potrzeb czy wykreowanie nowego popytu. Perspektywa tej definicji może budzić pewne wątpliwości co do tego, czy gabinet stomatologiczny jest podmiotem przedsiębiorczym, ale wydaje się, że biorąc pod uwagę nowe rozwiązania w zakresie stosowanych metod leczenia, nowe sposoby pozyskiwania pacjentów przez gabinety (np. turystyka medyczna) i fakt swoistej mody na noszenie aparatów korygujących zgryz przez osoby w różnym wieku, można go tak nazwać nawet w świetle obostrzeń zgłaszanych przez Druckera.

${ }^{162}$ Schumpeter J.A., Kapitalizm, socjalizm, demokracja, PWN, Warszawa 1995, s. 102.

${ }^{163}$ Ibidem s. 161 i nast.
} 
produkcji i transportu oraz nowych rynków, a także twórcze zaangażowanie się jednostki w rozwój osobisty oraz zawodowy na rzecz społeczeństwa, przedsiębiorstwa i gospodarki ogółem ${ }^{164}$ ), ale przede wszystkim wprowadzanie ich w życie (co przyczynia się do powstawania „powtarzających się fal 'prospetrity', które wpływają pozytywnie na gospodarkę i nawracających 'recesji', wywołanych wpływem nowych produktów i metod, zakłócających dotychczasową równowagę"). I właściwie tylko szkoła austriacka ${ }^{165}$ nadała przedsiębiorcy centralną rolę w ekonomii (późniejsze definicje przedsiębiorczości uwzględniają Schumpeterowskie ukierunkowanie przedsiębiorcy na zmiany, które traktowane są jako naturalny atrybut jego działania).

F.H. Kinght utożsamiał przedsiębiorczość z kontrolą działalności przedsiębiorstwa i odpowiedzialnością za jego wynik. Podstawą jego podejścia do przedsiębiorczości jest uznanie przedsiębiorcy, jako osoby ponoszącej ryzyko z tytułu niepewności ${ }^{166}$ (pozwala ona na osiąganie zysku, nawet $w$ warunkach doskonałej konkurencji i długookresowej równowagi). Przedsiębiorca dostosowuje produkcję do zmieniających się warunków rynkowych (podejście makroekonomiczne) i podejmuje decyzje związane $\mathrm{z}$ codziennym funkcjonowaniem podmiotu (podejście mikroekonomiczne). Ale zysk przedsiębiorstwa jest efektem nie tylko działań przedsiębiorczych (wynikających ze zdolności przedsiębiorcy w dostrzeganiu szansy), ale również szczęścia (niezbędnego w warunkach ciągłych zmian otoczenia oraz niepewności co do przyszłego poziomu cen) i ogólnej sytuacji na rynku ${ }^{167}$.

L. von Mises stawiał bardzo wygórowane oczekiwania przed przedsiębiorcą, mówiąc, że ,przedsiębiorca może osiągnąć zysk jedynie wtedy, gdy przewiduje przyszłe warunki trafniej niż inni" "168, a więc antycypuje przyszłość najlepiej ze wszystkich obecnych na rynku podmiotów. Podejmowane przez niego decyzje powinny być skoncentrowane na osiągnięciu zysków z dostosowania działań do przewidywanych $z \operatorname{mian}^{169}$. Radzenie sobie ze zmianami zachodzącymi w otoczeniu (czy to przez wyprzedzanie ich, czy dostosowywanie się do nich), wymaga myślenia o długookresowym horyzoncie i nabiera szczególnego znaczenia $\mathrm{w}$ aktywności przedsiębiorcy.

\footnotetext{
${ }^{164}$ Haltiwanger J., Aggregate growth: what hale we learned from microeconomic evidence?, "Economics Department Working Papers", 2000, nr 267, s. 5.

${ }^{165}$ Do jej głównych przedstawicieli należą: C. Menger, E. von Bohm-Bawerk, J.A. Schumpeter, L. von Mises, M. Rothbardi, I.M. Kirzner.

${ }^{166}$ Wprowadził rozróżnienie ryzyka, od którego można się ubezpieczyć i niepewności, której nie można zniwelować. Por. Gruszecki T., Przedsiębiorca w ... op. cit., s. 37.

${ }^{167}$ Knight F.H., Risk, Uncertainly and Profit, Houghton\&Mifflin, Boston 1921 za: Piasecki B., Przedsiębiorczość $i$... op. cit., s. 21.

${ }^{168}$ von Mises L., Ludzkie działanie, Instytut Ludwiga von Milesa, Warszawa 2007, s. 254.

${ }^{169}$ Ibidem s. 220.
} 
I.M. Kirzner (kontynuator myśli R. Cantillona) wskazuje, że działanie przedsiębiorcze prowadzi do przywrócenia równowagi rynkowej ${ }^{170}$. Przedsiębiorca ma dostrzegać okazje (niezauważane przez innych) i wykorzystywać je; pomocna w tym celu może być wiedza, której nie posiadają inni uczestnicy rynku. Z tego podejścia wyrasta imperatyw nieustannego monitorowania otoczenia i ciągłego analizowania sygnałów płynących z otoczenia, a także uczenia się - tak na własnych doświadczeniach, jak i z wykorzystaniem benchmarkingu. Spojrzenie I.M. Kirznera na rynkową rolę przedsiębiorcy będzie szerzej omówione w następnym rozdziale.

Podsumowując, w ujęciu historycznym można wyróżnić trzy główne podejścia do przedsiębiorczości ${ }^{171}$ :

- przedsiębiorczość, jako rola podmiotu prowadzącego przedsiębiorstwo (działalność gospodarczą),

- przedsiębiorczość jako proces tworzenia nowych przedsiębiorstw,

- przedsiębiorczość, jako tworzenie i wykorzystywanie szans i szczególnych okazji w istniejących warunkach gospodarowania, zawierających w sobie odnowę strategiczną funkcjonujących organizacji.

$\mathrm{Na}$ grunt literatury z zakresu zarządzania jako pierwszy istotę przedsiębiorczości wniósł P.F. Drucker, tworząc podwaliny teorii biznesu.

\subsection{WSPÓŁCZESNY WYMIAR PRZEDSIĘBIORCZOŚCI}

Po usunięciu $\mathrm{z}$ ekonomii niemal wszystkich wpływów psychologicznych w pierwszej połowie XX w. (o czym była mowa w punkcie 1.1) stan taki $\mathrm{w}$ literaturze przedmiotu utrzymywał się przez blisko pół wieku. Zainteresowanie tym, dlaczego jedni ludzie są mniej przedsiębiorczy, a inni bardziej znalazło swoje odzwierciedlenie w podejściu psychologii (Trait Theory), która w latach 60. XX w. przyjęła, że zachowanie człowieka wynika z cech osobowości (takich jak: kreatywność, otwartość na zmiany, dążenie do niezależności $)^{172}$. Kolejnym krokiem w badaniach nad przedsiębiorczością było podejście zaproponowane przez W. Gartnera ${ }^{173}$ (podejście behawioralne), zgodnie z którym ważniejsze w zdefiniowaniu przedsiębiorcy jest spojrzenie na jego zachowanie (np. zakładanie przedsiębiorstwa, podejmowanie ryzyka). W połowie lat 90 . XX w. rozwinął się nurt, w którym zaczęto coraz wyraźniej

\footnotetext{
${ }^{170}$ Piasecki B., Przedsiębiorczość $i$... op. cit., s. 24 i nast.

${ }^{171}$ Bratnicki M., Konfiguracyjne ujęcie przedsiębiorczości organizacyjnej, „Ekonomika i Organizacja Przedsiębiorstwa”, $2008 \mathrm{nr}$ 6, s. 17 i nast.

172 McClelland D., The achieving society, "The Free Press", Londyn 1961.

173 Gartner W., Who is an Entrepreneur? Is the wrong question, "Entrepreneurship Theory and Practice", 1989, nr 5, s. 47 i nast.
} 
dostrzegać człowieka i jego indywidualizm w myśleniu, jako centrum procesu przedsiębiorczego (podejście kognitywne) ${ }^{174}$. Dorobek psychologii i edukacji wdrożono do nauk o przedsiębiorczości (i w konsekwencji oprócz czynników zewnętrznych, kształtujących zachowanie człowieka, zajęto się czynnikami psychologicznymi i kognitywnymi). Zaczęto badać kształtowanie się intencji przedsiębiorczych. Powstało kilka modeli próbujących je zbadać. A. Kurczewska wymienia dwa, jako dobrze wyjaśniające mechanizm intencji i wynikających $\mathrm{z}$ nich działań $^{175}$ :

- Model Zdarzenia Przedsiębiorczego (Model of the Entrepreneurial Event ${ }^{176}$ ) zakłada, że intencja ${ }^{177}$ jest pewnego rodzaju stanem, poprzedzającym zachowanie przedsiębiorcze, które może mieć miejsce, jeśli będzie istniała taka możliwość. Realizacja „możliwości” zależy od tego, jak jednostka postrzega i ocenia swoje chęci oraz wykonalność swoich zamierzeń (oba czynniki uzależnione są od wpływów zewnętrznych), a także od jej skłonności do działania ${ }^{178}$;

- Teoria Planowanego Zachowania (Theory of Planned Behavior ${ }^{179}$ ), która jest w dużym stopniu wynikiem dorobku psychologii - łączy koncepcję postaw i nastawienia człowieka z jego zachowaniem. Zakłada, że zachowanie człowieka jest wynikiem jego intencji, które z kolei determinowane są przez trzy czynniki związane z percepcją:

- postrzeganą atrakcyjność obiektu lub postawy, jakie wobec tych obiektów lub czynności człowiek przyjmuje,

- postrzegane normy społeczne, tj. przeświadczenia o akceptacji lub braku akceptacji społeczeństwa wobec danego zachowania,

\footnotetext{
${ }^{174}$ Tounés A., L'intention entrepreneuriale des étudiants: les cas français, „La Revue des Sciences de Gestion, Direction et Gestion“, 2006, nr 219 za: Kurczewska A., Intencje przedsiębiorcze, czyli co decyduje o przedsiębiorczości człowieka, „Przegląd Organizacji”, 2010, nr 10, s. 20.

${ }^{175}$ Kurczewska A., Intencje przedsiębiorcze ... op. cit., s. 22.

${ }^{176}$ Shapero A., Sokol L., Social Dinensions of Entrepreneurship, w: Kent C., Sexton D., Vespers K., The Encyclopedia of Entrepreneurship, Prentice-Hall: Englewood Cliffs, Nowy Jork 1982.

${ }^{177}$ Antecedencjami mogą być: potrzeby, wartości, chęci, wierzenia czy przyzwyczajenia danej osoby. Sa one rezultatem procesu kognitywnego (percepcji), wierzeń, oczekiwań i wartości człowieka. Por. Liñán F., Chen Y.-W., Development and Cross-Cultural Application of a Specific Instrument to Measure Entrepreneurial Intentions, "Entrepreneurship Theory and Practice", $2009 \mathrm{nr}$ 5; Chattopadhyay R., Ghosh A.K., Entrepreneurial Intention Model-Based quantitative Approach to Estimate Entrepreneurial Success, "Journal of Small Business and Entrepreneurship", 2008 za: Kurczewska A., Intencje przedsiębiorcze ... op. cit., s. 22.

${ }_{178}$ Twórcy teorii szczególną rolę nadali tzw. zdarzeniom przemieszczającym, czyli pewnego rodzaju bodźcom, które pobudzają do podjęcia działalności gospodarczej (uznając je za katalizatory zachowania przedsiębiorczego), np. dla stomatologów bodźcem do podjęcia pracy we własnym gabinecie może być ,chęć ucieczki przed pacjentami z NFZ” (jest to jeden z motywów wskazany w trakcie prowadzonych badań).

179 Ajzen I., The theory of planned behavior, "Organizational Behavior and Human Decision Processes", 1991, t. 50.
} 
- postrzeganą kontrolę nad zachowaniem (tzw. kontrolę behawioralną), czyli poczucie możliwości i ograniczeń (łatwości i trudności) związanych $\mathrm{z}$ danym zachowaniem.

Badacze problemu są zgodni, że działania przedsiębiorcze (prowadzące na przykład do rozpoczęcia działalności gospodarczej) są przejawem planowanego, zamierzonego zachowania ${ }^{180}$. Stanowisko to potwierdzają wyniki badania III, zgodnie z którymi student stomatologii już na etapie studiów planuje swoją karierę zawodową we własnym gabinecie jako przedsiębiorstwie zarobkującym. Jeśli założy się, że przedsiębiorczość jest procesem, który ma miejsce przez pewien okres, to intencje przedsiębiorcze są pierwszym etapem rozwoju pomysłu posiadania własnego biznesu (tym samym są decydującym elementem kształtującym zachowanie przedsiębiorcze, prowadzącym do założenia firmy $)^{181}$. W II rozdziale zostaną przedstawione motywy, które wpłynęły na decyzje przedsiębiorcze stomatologów.

Wracając do istoty przedsiębiorczości, można przyjrzeć się zestawieniu zawartemu w tabeli 2, przedstawiającemu wybrane definicje pojęcia ,przedsiębiorczość”, proponowane we współczesnej literaturze. Jak wynika z zaprezentowanych definicji, przedsiębiorczość jest wielowymiarowym zjawiskiem wymagającym interdyscyplinarnego oglądu i przez to tworzącego konieczność zawarcia pewnego kompromisu przez przedstawicieli różnych dziedzin naukowych w formułowaniu jego określenia. Większość współczesnych definicji przedsiębiorczości formułowana na gruncie ekonomii utrzymywana jest w konwencji definicji J.A. Schumpetera - odwołują się one do określania jej jako czynnego sposobu działania $\mathrm{w}$ gospodarce rynkowej i poza nią oraz podkreślają rolę pewnych cech homo economicus (np. jego racjonalność w podejmowaniu decyzji ${ }^{182}$. Ponadto część definicji skupia się również na cechach prezentowanych przez homo empaticus (dając wyraz temu, że nie wszystkie decyzje związane z zawarciem transakcji przez człowieka są racjonalne, a czynniki związane z relacjami międzyludzkimi - szczególnie w usługach - stają się równie ważne). Natomiast definicje przedsiębiorczości w literaturze z zakresu zarządzania ujęte są w trzech obszarach ${ }^{183}$ :

- funkcjonalnego opisu działań przedsiębiorczych,

- indywidualnych cech osoby przedsiębiorcy,

- sposobach zachowania przedsiębiorcy.

\footnotetext{
${ }^{180}$ Kurczewska A., Intencje przedsiębiorcze ... op. cit., s. 20.

${ }^{181}$ Ibidem s. 21.

182 Gieorgica J.P. (red.), Studia nad przedsiębiorczościa generacyjna, regionalna, ogólnopolska, Wyd. Uniwersytetu w Białymstoku, Białystok 2009, s. 10.

${ }^{183}$ Piasecki B., Przedsiębiorczość ... op. cit.
} 
Tabela 2. Pojęcie ,przedsiębiorczość” w świetle współczesnych, wybranych pozycji literatury przedmiotu

\begin{tabular}{|c|c|}
\hline Autor & Proponowane ujęcie zagadnienia \\
\hline F. Znaniecki ${ }^{\mathrm{a}}$ & $\begin{array}{l}\text { Zgodnie z ujęciem socjologicznym przedsiębiorczość jest wynikiem działań } \\
\text { człowieka pracy, którego charakteryzuje łatwość przystosowania się do odmiennych } \\
\text { warunków społecznych (m. in. dzięki społecznemu uczeniu się poprzez obserwacje } \\
\text { środowiska osób zajmujących się pracą) oraz podejmowanie nowych inicjatyw. }\end{array}$ \\
\hline P.F. Drucker & $\begin{array}{l}\text { Przedsiębiorczość można utożsamiać z poszukiwaniem zmiany, reagowaniem na nią } \\
\text { oraz jej wykorzystaniem jako okazji, z działaniem opartym na celowej innowacji } \\
\text { (która stanowi specyficzne narzędzie przedsiębiorczości, nadające zasobom nowe } \\
\text { możliwości pomnażania bogactwa, przy czym przedsiębiorczość nie ogranicza się do } \\
\text { organizacji gospodarczych - może dotyczyć organizacji pożytku publicznego, szkół, } \\
\text { szpitali itp.). } \\
\text { Jest określonym sposobem zachowania, funkcjonowania; jest pewną koncepcją } \\
\text { i praktyką działania, której nie należy łączyć jedynie z biznesem. } \\
\text { Nie jest cechą wrodzoną - można się jej nauczyć i doskonalić - ,przedsiębiorczość } \\
\text { jest cechą danej osoby czy instytucji, ale nie jest cechą osobowości (...). Każdy kto } \\
\text { potrafi sprostać podejmowaniu decyzji może nauczyć się być przedsiębiorcą i działać } \\
\text { przedsiębiorczo. Przedsiębiorczość jest więc raczej sposobem zachowania niż cechą } \\
\text { osobowości.” }\end{array}$ \\
\hline $\begin{array}{l}\text { H.H. Stevensc } \\
\text { J.C. Jarilloc }\end{array}$ & $\begin{array}{l}\text { Przedsiębiorczość jest procesem, który ma motywować jednostki do tworzenia } \\
\text { wartości dodatkowej i ważnym elementem zarządzania strategicznego. }\end{array}$ \\
\hline T. Listwan ${ }^{\mathrm{d}}$ & $\begin{array}{l}\text { Przedsiębiorcze działanie to takie, które „Związane jest przede wszystkim z ini- } \\
\text { cjowaniem projektów, twórczym rozwiązywaniem problemów, podejmowaniem } \\
\text { ryzyka, tworzeniem i wykorzystywaniem okazji oraz elastycznym dostosowaniem } \\
\text { się do warunków otoczenia.” }\end{array}$ \\
\hline R.W. Griffin ${ }^{\mathrm{e}}$ & $\begin{array}{l}\text { Przedsiębiorczość może być rozumiana jako proces organizowania, prowadzenia } \\
\text { działalności gospodarczej oraz podejmowania związanego z nią ryzyka. } \\
\text { Przedsiębiorca podejmuje działania objęte mianem przedsiębiorczości, organizuje } \\
\text { i prowadzi działalność gospodarczą oraz podejmuje ryzyko. }\end{array}$ \\
\hline J. Jezior ${ }^{f}$ & $\begin{array}{l}\text { Przedsiębiorczość może być definiowana jako cecha osoby, sposobu jej działania } \\
\text { oraz stosunku do pracy. Jest to cecha wielowymiarowa i zarazem realizująca się na } \\
\text { wielu polach i płaszczyznach ludzkiej działalności. } \\
\text { „Wiele zachowań przedsiębiorców w środowisku pracy ma charakter ciągły, } \\
\text { w sensie koncepcyjnym i wykonawczym, wymaga stałego zaangażowania } \\
\text { intelektualnego i aktywności w zakresie przedsięwzięcia gospodarczego, } \\
\text { organizowania warsztatu pracy dla siebie, a często także dla innych osób, ponoszenia } \\
\text { odpowiedzialności za firmę i ryzyka, umiejętności dostosowywania się do zdarzeń } \\
\text { w otoczeniu w warunkach niepewności rynkowej.” }\end{array}$ \\
\hline A.J. Timmons ${ }^{\mathrm{g}}$ & $\begin{array}{l}\text { Przedsiębiorczość może być postrzegana jako sposób myślenia i działania } \\
\text { ukierunkowany na wyszukiwanie szans, identyfikację okazji, bez względu na } \\
\text { posiadane czy kontrolowane zasoby. }\end{array}$ \\
\hline T. Kraśnicka ${ }^{h}$ & $\begin{array}{l}\text { Przedsiębiorczość jest rozumiana jako szczególny typ aktywności ludzi działających } \\
\text { indywidualnie lub wewnątrz organizacji, polegającej na wykorzystywaniu postrze- } \\
\text { ganych w otoczeniu okazji poprzez realizację przedsięwzięć (o charakterze } \\
\text { innowacji, tworzenia nowych organizacji lub rewitalizacji już istniejących), które } \\
\text { przynoszą efekty ekonomiczne i/lub pozaekonomiczne. }\end{array}$ \\
\hline J. Siekierski ${ }^{i}$ & $\begin{array}{l}\text { Przedsiębiorczość polega na umiejętności indywidualnego lub zespołowego działania } \\
\text { w określonej dziedzinie, a jej nieodłącznym elementem jest innowacyjność } \\
\text { i kreowanie nowych przedsięwzięć gospodarczych (obok strategii marketingowej, } \\
\text { doradztwa i konkurencyjności). }\end{array}$ \\
\hline
\end{tabular}




\begin{tabular}{|l|l|}
\hline A. Klasik & $\begin{array}{l}\text { Przedsiębiorczość można scharakteryzować jako uwarunkowany społecznie proces } \\
\text { tworzenia szans na kreowanie bogactwa oraz ich twórcze wykorzystanie poprzez } \\
\text { użytkowanie zasobów finansowych, materialnych oraz kapitału ludzkiego i społecz- } \\
\text { nego w sposób innowacyjny. }\end{array}$ \\
\hline T.Zalaśkiewicz & $\begin{array}{l}\text { W myśl ujęcia psychologicznego przedsiębiorczość jest zbiorem cech jednostki, } \\
\text { będącym wynikiem interakcji, jaka zachodzi między wrodzonymi cechami osobowości } \\
\text { a stymulacją pochodzącą z otoczenia (stanowi indywidualny wyróżnik przypisany do } \\
\text { określonej osoby). }\end{array}$ \\
\hline $\begin{array}{l}\text { Słownik języka } \\
\text { polskiego }\end{array}$ & $\begin{array}{l}\text { Przedsiębiorczość to „zdolność do tego, aby być przedsiębiorczym, posiadanie ducha } \\
\text { inicjatywy; obrotność, rzutkość, zaradność.” }\end{array}$ \\
\hline Komisja & $\begin{array}{l}\text { Przedsiębiorczość oznacza zdolność osoby do wcielania pomysłów w czyn; } \\
\text { obejmującą: twórczość, innowacyjność i podejmowania ryzyka, a także zdolność do } \\
\text { planowania przedsięwzięć i kierowania nimi dla osiągnięcia zamierzonych celów. } \\
\text { Stanowi wsparcie w życiu prywatnym, zawodowym i społecznym - jest podstawą } \\
\text { konkretnych umiejętności i wiedzy potrzebnych osobom podejmującym przedsię- } \\
\text { wzięcia o charakterze komercyjnym i społecznym. }\end{array}$ \\
\hline
\end{tabular}

Źródło: opracowanie własne na podstawie: ${ }^{a}$ Znaniecki F., Ludzie teraźniejsi a cywilizacja przyszłości, Państwowe Wydawnictwo Naukowe, Warszawa 2001, s. 204; ${ }^{b}$ Drucker P.F., Innowacje i przedsiębiorczość. Praktyka i zasady, PWE, Warszawa 1992, s. 156 i nast.; ' Stevenson H.H., Jarillo J.C., A paradigm of entrepreneurship: entrepreneurial management, "Strategic Management Journal", 1990, $\mathrm{nr} 11 \mathrm{za}$

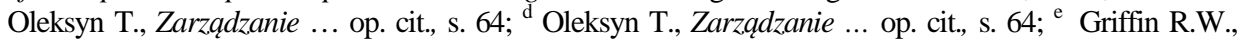
Podstawy zarzadzania organizacjami, Wydawnictwo Naukowe PWN, Warszawa 1996, s. 730 i nast.; ${ }^{\mathrm{f}}$ Jezior J., Społeczno-kulturowe i rynkowe czynniki kształtowania sytuacji pracy przedsiębiorców. Na podstawie badań matych firm w woj. lubelskim, Wydawnictwo Uniwersytetu M. Curie-Skłodowskiej, Lublin 2009, s. 73; ${ }^{\mathrm{g}}$ Timmons J.A., New venture creation. Entrepreneurship for the $21^{\text {st }}$ century, Irwion McGraw-Hill, Singapore 1999, za: Glinka B., Kulturowe uwarunkowania przedsiębiorczości w Polsce, PWE, Warszawa 2008, s. 20 i nast.; ${ }^{\mathrm{h}}$ Kraśnicka T., Koncepcje rozwoju ... op. cit.; ${ }^{\mathrm{i}}$ Kapusta F., Przedsiębiorczość. Teoria i praktyka, Wydawnictwo Forum Naukowe, Poznań 2006, s. 22; ${ }^{j}$ Klasik A., Przedsiębiorczość i konkurencyjność a rozwój regionalny, Wydawnictwo AE w Katowicach, Katowice 2006, s. 279.; ${ }^{\mathrm{k}}$ Zalaśkiewicz T., Przedsiębiorczość $i$ podejmowanie ryzyka, w: Tyszka T. (red.), Psychologia ekonomiczna, GWP, Gdańsk 2004, s. 308; ${ }^{1}$ Sobol E. (red.) Stownik języka polskiego, Wydawnictwo Naukowe PWN, Warszawa 2005, s. 775; ${ }^{1}$ Wniosek dotyczacy zalecenia Parlamentu Europejskiego i Rady w sprawie kluczowych kompetencji w uczeniu się przez cate życie, COM 548 z 2005, załącznik (pkt 7), www.eur-lex.europa.eu/LexUriServ/LexUriServ.do? uri=OJ:C:2008:044:0084: 0090: PL:PDF za: Duraj J., Papiernik-Wojdera M., Przedsiębiorczość i inno-wacyjność, Difin, Warszawa 2010, s. 24.

W pracy zostało przyjęte podejście, że przedsiębiorczość jest związana z utworzeniem nowego podmiotu rynkowego oraz uzyskaniem korzyści (nie tylko finansowej, ale również związanej z rozwojem przedsiębiorcy), z posiadaniem pewnych cech osobowościowych i posługiwaniem się wiedzą oraz bezpośrednimi kontaktami rynkowymi. I z tej perspektywy były prowadzone badania, których wyniki przedstawione są w kolejnych rozdziałach.

Bazując na klasycznej koncepcji przedsiębiorczości H.H. Stevensona i J. Jarillo ${ }^{184}$, można wyróżnić dwa rodzaje zachowań organizacji: przedsiębior-

${ }^{184}$ Stevenson H.H., Jarillo J.C., A paradigm ... op. cit. 
cze i administracyjne, które stanowią dwa przeciwstawne typy zachowań - ich charakterystyka przedstawiona jest w tabeli 3.

Tabela 3. Wybrane cechy zachowań przedsiębiorczych i administracyjnych organizacji

\begin{tabular}{|c|c|c|}
\hline Cechy & Zachowania administracyjne & Zachowania przedsiębiorcze \\
\hline $\begin{array}{l}\text { Główny cel } \\
\text { działania }\end{array}$ & $\begin{array}{l}\text { Dążenie do tego, aby jak najefektyw- } \\
\text { niej wykorzystywać posiadane zaso- } \\
\text { by. }\end{array}$ & $\begin{array}{l}\text { Poszukiwanie i wykorzystywanie szans, } \\
\text { niezależnie od posiadanych na własność } \\
\text { zasobów. }\end{array}$ \\
\hline $\begin{array}{l}\text { Orientacja } \\
\text { strategiczna }\end{array}$ & $\begin{array}{l}\text { Na zasoby, które leżą u podstaw } \\
\text { wyboru strategii }\end{array}$ & Na szanse „napędzające” strategię. \\
\hline $\begin{array}{l}\text { Kultura } \\
\text { organizacyjna }\end{array}$ & $\begin{array}{l}\text { Ma cechy biurokratyczne (wdrażanie } \\
\text { zmian, nowych idei musi pasować do } \\
\text { posiadanych zasobów). }\end{array}$ & $\begin{array}{l}\text { Zachęca do innowacyjności, kreatywności } \\
\text { czy zgłaszania pomysłów. }\end{array}$ \\
\hline $\begin{array}{l}\text { Orientacja } \\
\text { zasobowa }\end{array}$ & $\begin{array}{l}\text { Dążenie do posiadania relatywnie du- } \\
\text { żych zasobów własnych (zapewnienie } \\
\text { ich produktywności } \quad \text { staje ręę } \\
\text { kluczową kwestią zarządzania). }\end{array}$ & $\begin{array}{l}\text { Dążenie do wykorzystania szans z jedno- } \\
\text { czesnym zmniejszeniem ilości potrzeb- } \\
\text { nych zasobów własnych. }\end{array}$ \\
\hline $\begin{array}{l}\text { Struktura } \\
\text { zarządzania }\end{array}$ & $\begin{array}{l}\text { Sformalizowana hierarchia, często } \\
\text { rozbudowane struktury o charakterze } \\
\text { biurokratycznym (zorientowane na } \\
\text { kontrolę i pomiar poziomu produkt- } \\
\text { tywności). }\end{array}$ & $\begin{array}{l}\text { Płaska i elastyczna, często obejmująca } \\
\text { liczne sieci powiązań nieformalnych. }\end{array}$ \\
\hline $\begin{array}{l}\text { Filozofia } \\
\text { wynagradzania }\end{array}$ & $\begin{array}{l}\text { Wynagrodzenie zależy od ilości zaso- } \\
\text { bów będących pod kontrolą danego } \\
\text { pracownika i jego stażu pracy. }\end{array}$ & $\begin{array}{l}\text { Pracownicy są wynagradzani w zależności } \\
\text { od ich udziału w tworzeniu wartości dla } \\
\text { klienta (pracownicy mają poczucie nieza- } \\
\text { leżności i odpowiedzialności). }\end{array}$ \\
\hline $\begin{array}{l}\text { Orientacja na } \\
\text { wzrost }\end{array}$ & $\begin{array}{l}\text { Powolne, etapowe dążenie do wzros- } \\
\text { tu. Celem jest utrzymanie jego stałego } \\
\text { tempa i zrównoważonego rozwoju. }\end{array}$ & $\begin{array}{l}\text { Orientacja na szybki wzrost i rosnącą jego } \\
\text { dynamikę. }\end{array}$ \\
\hline
\end{tabular}

Źródło: opracowanie na podstawie: Stevenson H.H., Jarillo J.C., A paradigm ... op. cit.

Te dwa odmienne typy zachowań można wskazać w gabinetach stomatologicznych, przy czym zachowania administracyjne występują częściej w podmiotach publicznych i gabinetach, które mają monopolistyczną lub oligopolistyczną pozycję rynkową (np. w małych miejscowościach) i są prowadzone przez stomatologów z długoletnim stażem ${ }^{185}$, a także przez lekarzy dentystów o Sylwetce typu B z badania II (por. rozdział V). Zdaniem niektórych badaczy ${ }^{186}$ orientacja przedsiębiorcza ma pozytywny wpływ na efektywność organizacyjną (zarówno finansową, jak i pozafinansową), $\mathrm{z}$ tego względu pożądaną zmianą w gabinetach byłoby podejmowanie działań o charakterze przedsiębiorczym (i w wielu podmiotach są podejmowane ${ }^{187}$ ). Tym bardziej, że jak to jest pod-

${ }^{185}$ Tyle lat prowadze gabinet, że nie muszę niczego w nim zmieniać. Jest dobrze tak, jak jest - jest to wypowiedź jednej z lekarek w kontekście propozycji pewnych zmian w funkcjonowaniu gabinetu.

${ }^{186}$ Por. Zahra S.A., Jennings D.F., Kuratko D., Antecedents and consequences of firm level entrepreneurship: The state of the field, "Entrepreneurship Theory \& Practice" 1999, nr 24.

187 Jeśli nie przekonam pacjenta, że mój gabinet jest dla niego dobry, to może się zaczać robić krucho - jest to wypowiedź jednego z dentystów w kontekście zmian w popycie na usługi stomatologiczne pod wpływem kryzysu - związana z zauważalnym odpływem części pacjentów z gabinetu. 
kreślane w literaturze przedmiotu ${ }^{188}$, identyfikowanie przedsiębiorczości wyłącznie $\mathrm{z}$ organizacjami typu profit (a przecież prywatne gabinety stomatologiczne ewidentnie należą do tej grupy) jest coraz rzadsze i termin ten jest używany również na określenie działalności także $\mathrm{w}$ innych obszarach ludzkiej aktywności - w sektorze publicznym i społecznym (tym samym może dotyczyć publicznych gabinetów stomatologicznych, choć w praktyce w odniesieniu do nich - jak już zostało wcześniej powiedziane - raczej należy mówić o administrowaniu).

Przyglądając się funkcjonowaniu prywatnych gabinetów stomatologicznych przez pryzmat ich przedsiębiorczych działań, można wskazać dwa typy ${ }^{189}$ :

- gabinety o tzw. małej przedsiębiorczości, które są nastawione na teraźniejszość i stabilność funkcjonowania; często są to indywidualne praktyki lekarskie lub gabinety prowadzone przez członków rodziny (można wówczas mówić o przedsiębiorczości rodzinnej); mają niewielką i - raczej niezmienną w czasie liczbę członków personelu; jest ich najwięcej,

- gabinety innowacyjne, które rynkowo są bardzo aktywne (identyfikują i wykorzystują nadarzające się okazje), funkcjonują z myślą o przyszłości o rozwoju, dlatego zatrudniają personel niemedyczny (np. osoby odpowie dzialne za działania z zakresu PR, do opieki nad dziećmi pacjentów, specjalistów ds. turystyki medycznej), tworzą sieci gabinetów pod wspólną marką itp.

Ze względu na motywy podejmowania działalności gospodarczej, można mówić ${ }^{190}$ :

- przedsiębiorczości zorientowanej na wykorzystywanie szans, która ma źródła w pozytywnych motywach zakładania i prowadzenia przedsiębiorstwa, chęci uniezależnienia się, samorealizacji, podejmowania nowych wyzwań - i taką głównie postawę prezentowali badani dentyści, prowadzący swoje gabinety,

${ }^{188}$ Por. Dess J.G., Emmerson J., Economy P., Enterprising nonprofits, John\&Wiley Sons, Nowy Jork 2001; Kraśnicka T., Koncepcja rozwoju ... op. cit.

${ }^{189}$ Duraj J., Papiernik-Wojdera M., Przedsiębiorczość ... op. cit., s. 46.

${ }^{190}$ Ta klasyfikacja ma znaczenie z uwagi na korelację rodzajów przedsiębiorczości z postawami, zachowaniami i oczekiwaniami przedsiębiorców (w przypadku przedsiębiorczości wymuszonej postawa jest bardziej bierna, pozbawiona entuzjazmu i energii w działaniu; przedsiębiorcy zorientowani na wykorzystywanie szans są w większym stopniu aktywni, zorientowani na przyszłość, poszukują rozwiązań pozwalających na przezwyciężenia zaistniałych trudności).

Por. Glinka B., Konecki K. (red.), Wspótczesne problemy socjologii organizacji i zarzadzania. Wybrane zagadnienia, Wyd. UŁ, Łódź 2006, s. 29 i nast. 
- przedsiębiorczości wymuszonej, która podejmowana jest głównie z konieczności pozyskania środków finansowych na utrzymanie własne i rodziny, przy braku innych możliwości ekonomicznego zabezpieczenia bytu.

Przedsiębiorczość dentystów charakteryzuje również to, że jest (na pewno powinna być) etyczna, gdyż wynika z przyjmowania przez stomatologów i pozostały personel wartości, norm, poglądów, zasad społecznych, kulturowych zgodnych z Kodeksem etyki lekarskiej i zasadami deontologii lekarskiej.

Podsumowując, przedsiębiorcze gabinety stomatologiczne to takie, które ${ }^{191}$ :

- są nastawione na maksymalizację wartości dla nabywcy usługi zdrowotnej zarówno na płaszczyźnie stricte medycznej, jak i pozamedycznej (co oznacza ich skłonność i gotowość do zmian w funkcjonowaniu podmiotu),

- cechuje elastyczność i adaptacyjność, dzięki czemu szybko dostosowują się do zmiennych warunków rynkowych,

- są oparte na kapitale ludzkim i wiedzy, preferują bardziej partnerski, partycypacyjny system zarządzania, dzięki czemu wyzwalają inicjatywę i integrują pracowników z gabinetem (co jest związane np. z - omówionym w IV rozdziale - zaangażowaniem),

- w rezultacie permanentnego poszukiwania i wdrażania innowacji (zarówno produktowych, jak i procesowych) naruszają rzeczywistość, poszukując coraz nowych punktów równowagi,

- cechuje swoboda działania i płaska struktura.

\subsection{POJECIE PRZEDSIĘBIORCY - WYBRANE ASPEKTY}

Jak już zostało wcześniej powiedziane pojęcie „,przedsiębiorcy” do współczesnej ekonomii na stałe wprowadził w latach XX w. J.A. Schumpeter, stwierdzając, że przedsiębiorca-innowator zakłóca stały cykl produkcji i rynku, odkrywając oryginalne sposoby wyrabiania i nowe rzeczy do produkowania. Spełniając tę rolę, osiąga zysk dla siebie. Schumteterowski przedsiębiorca, odchodząc od swoich zwykłych działań, może stworzyć tymczasowe luki między cenami czynników i ceną produktu”"192 (przynajmniej „do czasu aż naśladowcy ponownie dostosują ceny i koszty do siebie, prekursor może czerpać

\footnotetext{
${ }^{191}$ Targalski J. (red.), Przedsiębiorczość i rozwój firmy, Wyd. Akademii Ekonomicznej w Krakowie, Kraków 1999, s. 167 i nast.

${ }^{192}$ Kirzner I.M., Konkurencja ... op. cit., s. 80.
} 
czysty zysk"193). Jest decydentem, którego czujność na niezauważone okazje umożliwia mu odejście od rutyny pracy przy dobrze znanych możliwościach ${ }^{194}$.

Przedsiębiorca Schumpetera jest zaangażowany w 'proces twórczej destrukcji'. W procesie tym przedsiębiorczą działalnością jest zachowanie liderów - innowatorów i pionierów; z drugiej strony na rynku występuje tłum „naśladowców” imitujących przedsiębiorców. „Podczas gdy liderzy tymczasowo tworzą zysk poprzez zaburzenie stanu równowagi (...), to masa naśladowców przywraca gospodarkę w stan spoczynku na nowym poziomie równowagi. Ich działalność, polegająca na przywracaniu równego okrężnego ruchu, nie jest przedsiębiorcza; są oni tylko przeciętnymi ludźmi, którzy z chwilą, gdy nauczyli się naśladować liderów, popadają w kolejną niedochodową rutynę."195 Patrząc na rynek usług stomatologicznych, niewątpliwie można wskazać na pionierów wprowadzania pewnych rozwiązań (np. nowa metoda leczenia - swego czasu taką nowinką były implanty; nowe narzędzia - pierwsze zastosowania mikroskopu w leczeniu zachowawczym; zastosowanie nowych materiałów - używanie włókien nowej generacji do odbudowy zębów; nowy sposób obsługi pacjenta - np. przypomninanie SMSem o terminie wizyty; nowy sposób docierania do pacjenta - umieszczanie oferty na portalu zakupów grupowych) i ich naśladowców (o czym będzie mowa w $\mathrm{V}$ rozdziale).

W teorii I.M. Kirznera ważną cechą przedsiębiorczości jest nie tyle możliwość oderwania się od rutyny (jak u J.A. Schumpetera), co zdolność zauważenia nowych sposobności, których inni nie dostrzegli - gdzie nowe produkty stały się wyjątkowo wartościowe dla nabywców i gdzie nowe metody świadczenia usług są możliwe do wprowadzenia ${ }^{196}$.

Lekarz dentysta osiąga zysk w sensie Robbinsonowskim, posiadając sprzęt i urządzenia potrzebne do świadczenia usług stomatologicznych i/lub - czasami - jako przedsiębiorca I.M. Kirznera. Wykorzystując przykład, którym posłużył się I.M. Kirzner ${ }^{197}$, można tę sytuację przedstawić w następujący sposób: na danym rynku wysoka cena określonej usługi stomatologicznej sprawia, że jej świadczenie wydaje się w ocenie dentysty A dochodowym przedsięwzięciem (potrzebne są do jej wykonywania: specjalistyczny sprzęt i praca stomatologa).

Wariant I. Można sobie wyobrazić, że dentysta A decyduje się sam zaangażować w realizację nowej usługi, dlatego kupuje (lub wypożycza po cenie rynkowej) potrzebne narzędzia i urządzenia oraz kupuje (wynajmuje, dostoso-

\footnotetext{
${ }^{193}$ Ibidem s. 80.

${ }^{194}$ Schumpeter J.A., Theory of Economic Development: An Inquiry into Profits, Capital, Credit, Interest and the Business Cycle, Transaction Publishers, Londyn 2008, s. 137.

${ }^{195}$ Kirzner I.M., Konkurencja ... op. cit., s. 125.

196 Ibidem s. 82.

${ }^{197}$ Ibidem s. 61 i nast.
} 
wuje posiadane do specyfiki nowego sprzętu itp.) pomieszczenie do prowadzenia działalności, a w sytuacji braku wiedzy i umiejętności w zakresie świadczenia nowej usługi kupuje również wiedzę na ten temat (uczestnicząc w szkoleniach specjalistycznych). Ta decyzja ma charakter przedsiębiorczy (to Kirzerowska czujność - dentysta zauważył możliwość zysku). Jeśli przychód z realizowanych świadczeń stomatologicznych, po odjęciu wartości wynagrodzenia dentysty, przekracza koszt kupna/wypożyczenia sprzętu, wynajęcia gabinetu, czy zdobycia wiedzy w zakresie nowych metod leczenia (również zdobycia specjalizacji), to ta nadwyżka jest stricte przedsiębiorczym zyskiem przypisywanym pozyskaniu narzędzi i urządzeń oraz lokalu, a także zdobyciu nowej wiedzy. Gdy inni dentyści na rynku zauważą zyskowność prowadzonej przez dentystę A działalności, wejdą na rynek, by świadczyć usługi stomatologiczne, co spowoduje spadek wartości rynkowej świadczenia medycznego, aż stricte przedsiębiorczy zysk przestanie istnieć, gdyż np. miesięczny koszt wynajęcia gabinetu i wyposażenia go razem z wynagrodzeniem dentysty wyczerpie całkowity przychód z prowadzonej działalności.

Wariant II. Można rozważyć również sytuację, gdy dentysta A nie tylko pierwszy otworzył gabinet stomatologiczny, ale również lepiej wyczuwa (np. dzięki rozpoznaniu sytuacji ekonomicznej uczestników rynku), którzy potencjalni pacjenci dadzą większą szansę na dochód (np. komercyjni vs pacjenci, których wizyty opłaca NFZ). Obsługuje więc pacjentów, którzy przynoszą większy dochód, niż inni - obsługiwani rzez konkurencyjne gabinety. Dentysta A zdobywa przedsiębiorczy zysk, ponieważ koszt zdobycia niezbędnej wiedzy (np. z zakresu ortodoncji), wynajęcia wyposażonego gabinetu i jego płaca nie wyczerpują całkowitego przychodu z prowadzonej działalności.

Wariant III. Załóżmy, że dentysta A nie jest bardziej czujnym przedsiębiorcą niż inni, jeśli chodzi o zdolność pozyskiwania „cenniejszych” pacjentów. Niemniej wynajął dentystę B, który nie jest lepszym dentystą niż inni, ale posiada rzadką zdolność (która stanowi o jego potencjale w kreowaniu przewagi konkurencyjnej), polegającą na proklientowskim podejściu do pacjentów (pozwalającym w sposób szczegółowy na pozyskanie i utrzymanie zaufania nabywców usługi stomatologicznej). Dentysta B nie musi pracować więcej (spędzać w miejscu pracy więcej czasu), niż przeciętny stomatolog, aby dobrze zarabiać. Pracodawca - dentysta A, może zauważyć, że nadal posiada nadwyżkę, kiedy odejmie od przychodu brutto koszt wynajęcia wyposażonego gabinetu i średnią płacę, którą otrzymuje pracownik - dentysta B. Tę nadwyżkę I.M. Kirzner nazywa przedsiębiorczym zyskiem dentysty A za to, że dalekowzrocznie (lub dzięki szczęściu) zatrudnił dentystę B zamiast innych lekarzy. W rzeczywistości można postrzegać umiejętność świadczenia usług stomatologicznych jako element nieodłączny czujności na bardziej dochodowe możliwości (związane z wykorzystywaniem umiejętności nawiązywania i utrzymywania relacji z pac- 
jentami) i dlatego można uznać dentystę B za lepszego ${ }^{198}$ i przewidywać, że cena rynkowa usług przez niego świadczonych będzie, w rezultacie konkurencji między pracodawcami, rosła aż nadwyżka dentysty A zniknie. W tej sytuacji skoro dentysta B pracuje jako pracownik najemny i nie wykorzystuje swoich obu umiejętności do osiągnięcia przedsiębiorczego zysku, a tylko do dobrej realizacji zleconych zadań, to tylko dentystę A można nazwać przedsiębiorcą Kirznera, gdyż wykazuje większą czujność na wyjątkowe sposobności do zwiększenia wpływów z prowadzonej działalności i zwiększania potencjału konkurencyjnego swojego gabinetu, a w konsekwencji tworzenia warunków do poprawiania pozycji konkurencyjnej gabinetu.

W omawianym przykładzie można dopatrzeć się również problemu etycznego. Co w sytuacji, gdy dentysta B nie wypełnia swojej części umowy i jednocześnie odkryje możliwość do wykorzystania swojej wyjątkowej zdolności w celu osobistego zarobku? Co, jeśli etyka dentysty B (lub w istocie jej brak) skłania go do wzbogacania siebie, a nie pracodawcy - dentysty A?, zdobywania prestiżu tylko dla siebie, zamiast dokładania się do zysku i prestiżu gabinetu pracodawcy? Dentysta A nie osiąga przedsiębiorczego zysku ze zdolności dentysty $\mathrm{B}$, ponieważ nie był w stanie skłonić B do wykorzystania tych zdolności do realizacji własnych celów, jako pracodawcy. Można powiedzieć, iż dentysta A nie wykazał się przedsiębiorczością w tym względzie, że nie odkrył sposobu działania, który byłby lepszy od metod stosowanych przez inne podmioty. Ponadto nie udało mu się wykorzystać umiejętności dentysty B. Dentysta B nie uruchamia swojego własnego gabinetu, żeby samemu czerpać przedsiębiorczy zysk ze swojej czujności - on już osiąga go, używając zasobów dentysty A w najlepszy możliwy dla siebie sposób ${ }^{199}$. I będąc pracownikiem najemnym,

\footnotetext{
${ }^{198}$ Jeśli zdolności dentysty B podzieli się na dwie części: umiejętności stricte medyczne (które nie wyróżniają go spośród innych stomatologów) oraz umiejętności interpersonalne (pozwalające mu wywierać pozytywny wpływ na pacjentów, w czym jest zdecydowanie lepszy od innych dentystów), to można spekulować dlaczego B został wynajęty za przeciętną płacę dentysty. Jeśli jest zatrudniony wyłącznie po to, aby leczyć, wtedy nie może wykazać się drugą zdolnością i jego pracodawca nie będzie miał zysków (a płaca B nie wzrośnie). Jeśli B ma leczyć, ale wyraźnie nie ma wskazane, aby stosował instrumentarium marketingu relacji w kontaktach z pacjentami, wtedy tylko przypadkowo może przynieść większy przychód niż inni pracownicy. Jeśli dentysta B jest zatrudniony, aby działał proklientowsko, to można stwierdzić, że został zatrudniony, aby wykorzystywał swoje obie umiejętności na stanowisku pracy. Jednak jego wynagrodzenie w wyniku jego ogólnej rynkowej nieświadomości drugiej posiadanej przez niego zdolności nie jest wyższe niż płacone innym dentystom wyłącznie za pierwszą zdolność. Czujność dentysty B nie jest przedsiębiorcza, tzn. dla B świadomość lepszych możliwości wystarcza do sprzedawania swoich usług za płacę, ale nie jest dla niego dostatecznie przekonująca, aby sam ,poszedł za zyskiem” (założył własny gabinet), który dostrzega.

${ }^{199}$ Dentysta B wie, jak używać zasobów gabinetu w szczególnie korzystny sposób (nieznany dentyście A ani innym dentystom, prowadzącym w pobliżu działalność), zauważa, że aby pobierać przedsiębiorczy zysk, który uznaje się za osiągalny, nie jest konieczne wynajmowanie/kupowanie gabinetu i wyposażenia i zakładanie własnej firmy. Osiąga zysk zatrudniając się u dentysty A za
} 
działa jak Kirznerowski przedsiębiorca. W takiej sytuacji decyzja dentysty A o dalszym zatrudnianiu dentysty B nie przynosi mu przedsiębiorczego zysku (co nie oznacza, że nie może go dalej zatrudniać).

Z przedstawionego przykładu wynika, że zysk zawsze przypada przedsiębiorcy. I albo dentyście A udało się zatrudnić czujność B i wówczas tylko A jest przedsiębiorcą (i zatrzymuje zysk); albo się nie udało i dentysta B sam wykorzystuje możliwości, które zauważa - w tej sytuacji czujność B jest przedsiębiorcza (i dentysta B otrzymuje zysk), a dentysta A nie jest przedsiębiorcą w stosunku do czujności stomatologa B. Ten przykład pokazał również, że przedsiębiorczość sensu stricte nie musi polegać na zakupie wszystkich czynników produkcji. Przedsiębiorca - dentysta B może mieć jeden czynnik pracę, sprzedać go innemu przedsiębiorcy - dentyście A, który jest w posiadaniu drugiego składnika - narzędzi i sprzętu w gabinecie stomatologicznym i mieć okazję osiągnięcia zysku, który uważa za możliwy (wykorzystując niezauważony przez innych układ czynników) ${ }^{200}$.

Aby nie rozszerzać nadmiernie omówienia istoty pojęcia ,przedsiębiorca” w ujęciu różnych autorów i w pewien sposób nie powielać myśli przedstawionych w poprzednich dwóch punktach, w tabeli 4 zaprezentowane jest syntetyczne spojrzenie na rynkową rolę przedsiębiorcy wraz z wskazaniem, czy można mówić o pełnieniu takiej roli przez lekarza dentystę.

Tabela 4. Typologia pojęcia ,przedsiębiorca” i jego związek z współczesnym stomatologiem

\begin{tabular}{|l|l|l|}
\hline \multicolumn{1}{|c|}{ Przedsiębiorca } & $\begin{array}{c}\text { Autor/ } \\
\text { przedsatwiciel } \\
\text { podejścia }\end{array}$ & \multicolumn{1}{|c|}{ Występowanie dentysty w danej roli } \\
\hline Arbitrażysta & $\begin{array}{l}\text { R.Cantillon, } \\
\text { I.M. Kirzner }\end{array}$ & $\begin{array}{l}\text { Tak, gdy dentysta znając rynek działania, wykorzystuje po- } \\
\text { jawiającą się na nim okazję - np. brak lekarzy świadczących } \\
\text { określone usługi (co wpływa na brak równowagi między po- } \\
\text { pytem i podażą) i zdobywa odpowiednią wiedzę i kwali- } \\
\text { fikacje, by je świadczyć. Należy jednak pamiętać, że zdoby- } \\
\text { wanie specjalizacji, to lata działań, a nie jednorazowy akt } \\
\text { i zrównoważenie rynku nie nastąpi natychmiast. }\end{array}$ \\
\hline $\begin{array}{l}\text { przywódca (lider) } \\
\text { i menedżer }\end{array}$ & J.B. Say & $\begin{array}{l}\text { Tak, gdy jest właścicielem gabinetu zatrudniającego } \\
\text { personel. }\end{array}$ \\
\hline $\begin{array}{l}\text { koordynator } \\
\text { i arbitrażysta }\end{array}$ & $\begin{array}{l}\text { Tak, koordynuje zasoby ekonomiczne, aby osiągnąć określo- } \\
\text { ny efekt (tak w wymiarze medycznym, jak i biznesowym). }\end{array}$ \\
\hline $\begin{array}{l}\text { osoba specjalizująca } \\
\text { się w podejmowaniu } \\
\text { rozstrzygających decy- } \\
\text { zji dotyczących kordy- } \\
\text { nacji rzadkich zasobów }\end{array}$ & M. Casson & $\begin{array}{l}\text { Rzadko, chyba że mówimy o dentyście - dyrektorze dużej } \\
\text { kliniki stomatologicznej, ewentualnie ordynatorze w szpitalu } \\
\text { (intraprzedsiębiorca), który uzupełnił swoją wiedzę (np. na } \\
\text { studiach podyplomowych) w zakresie zarządzania podmio- } \\
\text { tami opieki zdrowotnej. }\end{array}$ \\
\hline
\end{tabular}

przeciętne wynagrodzenie i oddając pracodawcy standardowy przychód, a dodatkowy dochód, który jako jedyny jest w stanie zdobyć, zatrzymując dla siebie.

${ }^{200}$ Kirzner I.M., Konkurencja ... op. cit. s. 65. 


\begin{tabular}{|c|c|c|}
\hline $\begin{array}{l}\text { właściciel } \\
\text { przedsiębiorstwa }\end{array}$ & F. Quasney & $\begin{array}{l}\text { Tak, w przypadku podjęcia praktyki we własnym gabinecie, } \\
\text { a w przypadku grupowych praktyk - współwłaściciel. }\end{array}$ \\
\hline $\begin{array}{l}\text { osoba odkrywająca } \\
\text { możliwość zysku }\end{array}$ & I.M. Kirzner & $\begin{array}{l}\text { Tak, gdy poszukuje i wykorzystuje okazje do osiągnięcia } \\
\text { zysku - omówienie: przykład nad tabelą. }\end{array}$ \\
\hline innowator & J.A. Schumpeter & $\begin{array}{l}\text { Tak, pod warunkiem, że rozwiązania w swoim gabinecie } \\
\text { wprowadza jako pierwszy, często nie wiedząc, czy pacjenci } \\
\text { będą zainteresowani taką ofertą. } \\
\text { Tak, gdyż angażuje się w rozwój zawodowy na rzecz } \\
\text { pacjentów (a w konsekwencji dla dobra społeczeństwa - } \\
\text { podnosi poziom zdrowia). }\end{array}$ \\
\hline $\begin{array}{l}\text { osoba ponosząca } \\
\text { ryzyko związane z } \\
\text { niepewnością }\end{array}$ & $\begin{array}{l}\text { R.Cantillon, } \\
\text { F.H.Knight, } \\
\text { L. vonMises, }\end{array}$ & $\begin{array}{l}\text { Tak - dentysta najczęściej jest właścicielem (ewentualnie } \\
\text { kredytobiorca) środków finansowych, służących urucho- } \\
\text { mieniu gabinetu, dlatego w sytuacji rynkowego niepowo- } \\
\text { dzenia* ryzyko spada na niego. Niepewność może dotyczyć } \\
\text { również warunków prowadzenia działalności w oparciu } \\
\text { o kontrakt z NFZ (np. co do wysokości stawki za punkt). }\end{array}$ \\
\hline $\begin{array}{l}\text { osoba dostarczająca } \\
\text { kapitał }\end{array}$ & $\begin{array}{l}\text { A.Smith, } \\
\text { L.vonMises, } \\
\text { F.H. Knight }\end{array}$ & $\begin{array}{l}\text { Tak, uruchomienie prywatnego gabinetu wiąże się z dostar- } \\
\text { czeniem przez dentystę (dentystów w przypadku grupowej } \\
\text { praktyki) środków finansowych (nawet jeśli są pożyczone, to } \\
\text { będą wymagała spłaty i stomatolog będzie odpowiedzialny } \\
\text { za tę spłatę), a w konsekwencji z odpowiedzialnością za } \\
\text { wynik ekonomiczny funkcjonowania gabinetu. }\end{array}$ \\
\hline $\begin{array}{l}\text { osoba podejmująca } \\
\text { decyzje }\end{array}$ & $\begin{array}{l}\text { R.Cantillon, } \\
\text { A.Marshall, } \\
\text { J.M.Keynes, } \\
\text { L.vonMises, }\end{array}$ & $\begin{array}{l}\text { Tak, dentysta - właściciel gabinetu decyduje o zatrudnieniu } \\
\text { personelu, o wyborze dostawcy materiałów stomatologicz- } \\
\text { nych, o zleceniu pozamedycznych funkcji gabinetu na } \\
\text { zewnątrz itp. }\end{array}$ \\
\hline $\begin{array}{l}\text { organizator i } \\
\text { koordynator zasobów } \\
\text { ekonomicznych }\end{array}$ & $\begin{array}{l}\text { J.B.Say, } \\
\text { J.A.Schumpeter, } \\
\text { M.Casson }\end{array}$ & $\begin{array}{l}\text { Tak, decyduje o lokalizacji gabinetu; organizuje środki } \\
\text { finansowe umożliwiające wyposażenie gabinetu; wybiera } \\
\text { osoby, które będą pracowały w gabinecie; decyduje, w jakich } \\
\text { kursach (medycznych, biznesowych) będzie brał udziat } \\
\text { personel, by zdobyć/powiększyć wiedzę. }\end{array}$ \\
\hline $\begin{array}{l}\text { osoba zatrudniająca } \\
\text { czynniki produkcji }\end{array}$ & J.M. Keynes & $\begin{array}{l}\text { Tak, kupuje/bierze w leasing specjalistyczny sprzęt; nabywa } \\
\text { materiały wykorzystywane w gabinecie; zatrudnia personel; } \\
\text { „,zatrudnia” wiedzę } \quad \text { (zatrudniając wykwalifikowany } \\
\text { personel). }\end{array}$ \\
\hline $\begin{array}{l}\text { osoba energiczna, } \\
\text { podejmująca } \\
\text { umiarkowane ryzyko }\end{array}$ & D.McClelland & $\begin{array}{l}\text { Raczej tak - dentyści bardzo często są pasjonatami swojego } \\
\text { zawodu i dążą do rozwoju i samorealizacji (choć jak } \\
\text { w każdym zawodzie będą również flegmatycy, ceniący sobie } \\
\text { zachowanie status quo w funkcjonowaniu gabinetu). }\end{array}$ \\
\hline $\begin{array}{l}\text { osoba kreująca coś } \\
\text { odmiennego z uwagi } \\
\text { na wartość, coś wyma- } \\
\text { gającego niezbędnego } \\
\text { nakładu czasu i wysił- } \\
\text { ku i zakładającego } \\
\text { finansowe, psychiczne } \\
\text { i społeczne ryzyko, } \\
\text { przy oczekiwaniu w } \\
\text { zamian nagrody } \\
\text { finansowej i osobistej } \\
\text { satysfakcji }\end{array}$ & $\begin{array}{l}\text { R.D.Hisrich, } \\
\text { M.P.Peters } \\
\\
\\
\end{array}$ & $\begin{array}{l}\text { Tak, most założony pacjentowi zwiększa jego dobrostan } \\
\text { psychiczny, a jego przygotowanie wymaga czasu i wysiłku } \\
\text { ze strony dentysty, który oczekuje nie tylko zapłaty za } \\
\text { wykonaną pracę, ale również satysfakcji z dobrze } \\
\text { zrealizowanego planu leczenia. }\end{array}$ \\
\hline
\end{tabular}




\begin{tabular}{|c|c|c|}
\hline $\begin{array}{l}\text { Osoba, która wyka- } \\
\text { zuje w swoim zacho- } \\
\text { waniu ,przedsiębior- } \\
\text { cze atrybuty“** i wy- } \\
\text { korzystuje ich } \\
\text { kombinację. }\end{array}$ & A.A.Gibb & 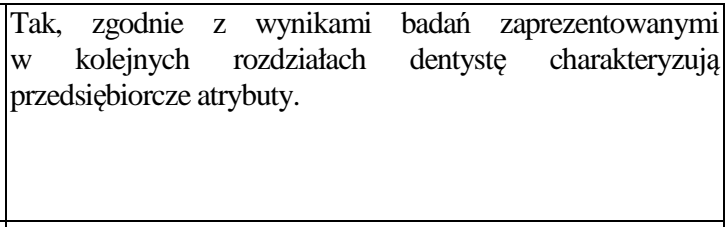 \\
\hline $\begin{array}{l}\text { Osoba „,goniąca za } \\
\text { okazjami, pomijając } \\
\text { zasoby aktualnie } \\
\text { posiadane”. }\end{array}$ & $\begin{array}{l}\text { H.H.Stevenson, } \\
\text { M.J.Roberts, } \\
\text { H.I.Grousbeck }\end{array}$ & $\begin{array}{l}\text { Rzadko, najczęściej stomatolodzy skupiają się na „dniu } \\
\text { dzisiejszym”; choć oczywiście są wizjonerzy, którzy myślą } \\
\text { w perspektywie 2-3 lat o kierunkach rozwoju swojej } \\
\text { praktyki. }\end{array}$ \\
\hline $\begin{array}{l}\text { Osoba } \\
\text { „maksymalizująca } \\
\text { okazję" }\end{array}$ & P.F.Drucker & $\begin{array}{l}\text { Nie, choć mogą się zdarzyć osoby przedkładające optykę } \\
\text { biznesową gabinetu nad stricte lekarską (przykład: wyniki } \\
\text { badania III). }\end{array}$ \\
\hline $\begin{array}{l}\text { Osoba } \\
\text { samozmotywowana }\end{array}$ & $\begin{array}{l}\text { S.L.Mueller, } \\
\text { T.S.Anisya }\end{array}$ & $\begin{array}{l}\text { Tak, dentysta jest osobą tworzącą nowe przedsięwzięcie, } \\
\text { która podejmuje inicjatywę, polegając przede wszystkim na } \\
\text { sobie (w formułowaniu i wcielaniu w życie swoich celów). }\end{array}$ \\
\hline
\end{tabular}

Źródło: opracowanie własne na podstawie: Piasecki B., Przedsiębiorczość ... op. cit., s. 12 i nast.; Mueller S.L., Anisya T.S., Culture and Entrepreneurial Potential: a Nine Country Study of Locus of Control and Innovativeness, „Journal of Business Venturing”, 2001, t. 16, $\mathrm{nr} 1$.

* W praktyce trudno sobie wyobrazić taką sytuację, chyba, że umiejętności stomatologa będą na takim poziomie, iż po prostu w średnim/długim okresie nie będzie miał pacjentów. Innym przykładem może być sytuacja warszawskiego gabinetu, który poprzez portal zakupów grupowych chciał pozyskiwać nowych pacjentów, ale zaproponowana - niska - cena wysokospecjalistycznych świadczeń oraz - znaczna - liczba pacjentów, którzy dokonali zakupu przyczyniły się do bankructwa gabinetu. ** Np. inicjatywa, silna zdolność przekonywania, umiarkowana skłonność do podejmowania ryzyka, elastyczność, kreatywność, niezależność, zdolność rozwiązywania problemów, potrzeba osiągnięć, wyobraźnia, wysokie przekonanie o kontroli własnego przeznaczenia, przywództwo, umiejętność ciężkiej pracy.

Zawarte w tabeli 4 definicje nie stanowią oddzielnych (istotnie odmiennych) określeń omawianego pojęcia. Niektóre znaczenia są zbieżne lub pokrywają się, inne opisują tylko część funkcji, dając tym samym wyraz wielostronności natury przedsiębiorcy. Kompleksowa prezentacja pojęcia „przedsiębiorca”, pozwala na ukazanie działań dentysty w różnych aspektach, co daje asumpt do mówienia o lekarzu dentyście jako o przedsiębiorcy. Podejście to stanowi nie tylko dalszą polemikę z wątpliwościami R. Levina, przedstawionymi we wstępie, ale pokazuje również, że działania przedsiębiorcze podejmowane na różnych płaszczyznach $w$ gabinecie stomatologicznym nie muszą być sprzeczne $\mathrm{z}$ etyką lekarską. 


\section{REASUMPCJA}

Przewaga konkurencyjna podmiotów rynkowych wynika zarówno z rozwijania kompetencji wewnętrznych ${ }^{201}$, jak i ze zmieniających się warunków w otoczeniu organizacji ${ }^{202}$. Ma swoje korzenie zarówno $\mathrm{w}$ zachowaniach nabywców, jak i działaniach konkurentów ${ }^{203}$ (jest rezultatem zachowań konkurencyjnych i współpracy). Konkurencja lekarzy (o pacjentów) jest ważna z punktu widzenia realizacji celów pacjenta - im konkurencja jest silniejsza, tym większą wagę lekarze przywiązują do celów pacjenta (dostępność świadczeń, jakość świadczenia i obsługi) ${ }^{204}$.

Niektórzy dentyści ciągle postrzegają swoją rolę wyłącznie w kategoriach społecznych tj. opieki zdrowotnej (realizacji doradztwa i wykonywania świadczeń stricte stomatologicznych) i dlatego nie widzą potrzeby rozwijania dodatkowych umiejętności, wychodzących poza stricte medyczną specyfikę ich pracy. Tymczasem rynek narzuca konieczność podejmowania działań, mających na celu m. in.:

- pozyskiwanie nowych pacjentów - nabywców usług gabinetu stomatologicznego,

- usatysfakcjonowanie obecnych pacjentów (co przyczyni się nie tylko do zatrzymania ich w gabinecie, jako lojalnych nabywców, ale również do tego, że będą rekomendować stomatologa innym - potencjalnym nabywcom),

\footnotetext{
${ }^{201}$ W literaturze podkreśla się znaczenie konfiguracji działań organizacji oraz ich koordynacji jako sposobów osiągania przewagi konkurencyjnej. Z drugiej strony mówi się o umiejętnościach wyróżniających jako źródłach przewagi lub o znaczeniu identyfikacji i rozwijaniu kluczowych kompetencji w celu wzmocnienia potencjału przedsiębiorstwa. Kluczowe kompetencje powinny prowadzić do kluczowych produktów, które z kolei umożliwiają osiągnięcie przewagi konkurencyjnej. Por. Krupski R., Niemczyk J., Stańczyk-Hugiet E., Koncepcje strategii organizacji, PWE, Warszawa 2009, Colgate M., Creating Sustainable Competitive Advantage through Marketing Information System Technology - a Triangulation Methodology within the Banking Industry, "International Journal of Bank Marketing", 1998, nr 2.

Osiąganie przewagi konkurencyjnej jest rezultatem m.in. procesów organizacyjnego uczenia się, pozyskiwania i rozwijania wiedzy, kreowania unikatowych kompetencji. Również przedsiębiorstwo rozwija się dzięki nagromadzonej i umiejętnie wykorzystywanej wiedzy. Por. Grossman G.M., Helman E., Innovation and Growth, MIT Press, Cambridge, Mass. 1995.

${ }^{202}$ Mastyk E., Organizacja w ruchu, Oficyna Ekonomiczna, Kraków 2003.

${ }^{203}$ Kompozycja oferty rynkowej konkurentów oraz specyficznych zachowań nabywców decyduje, że metody czy narzędzia budujące przewagę konkurencyjną na jednym rynku, wcale nie muszą przynieść korzyści w innych uwarunkowaniach.

${ }^{204}$ Por.von Schulenburg J.M., Greiner W., Gesundheitsökonomie, Mohr Siebeck, Tubingen 2000, za: Sowada C., Wptyw metod finansowania na zachowania lekarzy - aspekty ekonomiczne, zdrowotne i spoteczne, „Zeszyty Naukowe Ochrony Zdrowia. Zdrowie Publiczne i Zarządzanie”, $2005 \mathrm{nr}$ 1, t. III, s. 72.
} 
- zarządzanie relacjami z nabywcami usług zdrowotnych (szczególnie w podmiotach typu profit) w celu utrzymania ich jako nabywców usług w długim okresie,

- kreowanie pożądanego wizerunku podmiotu w świadomości klientów (tak wewnętrznych, jak i zewnętrznych ${ }^{205}$ ),

- stałe podnoszenie jakościowych standardów obsługi i komunikowanie o tym procesie na zewnątrz podmiotu.

Jeśli przyjąć, że przedsiębiorczość polega na umiejętności (indywidualnego lub zespołowego) działania w określonej dziedzinie w sposób nowatorski ${ }^{206}$, to wymaga przyjęcia postawy kreatywnej i zaangażowanej (aby wyszukiwać i wykorzystywać okazje rynkowe i dążyć do osiągnięcia przewagi konkurencyjnej). $\mathrm{Z}$ tego względu przedstawione powyżej cele rynkowe mogłyby się stać inspiracją dla dentystów do zmiany sposobu postrzegania otoczenia rynkowego ${ }^{207}-$ do traktowania zmian zachodzących na rynku, jako okazji do wprowadzenia zmian w funkcjonowaniu swojego gabinetu.

W rozdziale pokazano, że współczesne podmioty rynkowe (również gabinety stomatologiczne) powinny dla osiągnięcia przewagi konkurencyjnej uwzględniać zasoby i kompetencje przedsiębiorstwa. Specyfika usług zdrowotnych sprawia, że przed gabinetami stomatologicznymi staje konieczność dążenia do osiągania efektywności na płaszczyźnie ekonomicznej i społecznej. Osiągnięcie jej będzie możliwe nie tylko dzięki działaniom stricte medycznym, ale również pozamedycznym. Dentysta jest nie tylko lekarzem, ale w wielu przypadkach również przedsiębiorcą - rozpoczynając działalność na własny rachunek; prowadząc gabinet, jako podmiot zarobkujący; a także prezentując postawy, czy

\footnotetext{
${ }^{205}$ Tym bardziej, że w gabinecie stomatologicznym dochodzi do zależności, która może stać się niekończącą spiralą zależności: przyjazny pacjentowi gabinet może stać się najbardziej pożądanym miejscem pracy dobrych pracowników (może przyciągać talenty i wiedzę), dobry personel będzie przyciągał kolejnych pacjentów itp. (por. rysunek 7).

${ }^{206}$ Najczęściej w literaturze uznaje się złożoną istotę przedsiębiorczości i wyróżnia się trzy kluczowe jej komponenty: 1) innowacyjność, 2) przyjmowanie ryzyka, 3) proaktywność (jest wymiarem orientacji przedsiębiorczej, która na poziomie podmiotu odnosi się do podejmowania szans oraz aktywności organizacji na rynku w stosunku do jej konkurentów, a na płaszczyźnie jednostki wiąże się z wizją i wyobraźnią przedsiębiorcy). Por. Gonzales-Benito O., Gonzales-Benito P., MunozGallego P.A., Role of Entrepreneurship and Market orientation in Firm's Success, "European Journal of Marketing", 2009, nr 3-4, s. 502; Lumpkin G.T., Dess G.G., Linking two dimensions of entrepreneurial orientation to firm performance: The moderating role of environment and industry life cycle, "Journal of Business Venturing", $2001 \mathrm{nr} 16$.

${ }^{207}$ W. Kapała i P. Drygas mówią, że poczucie mylnego bezpieczeństwa, wynikające z przekonania lekarzy, iż pacjenci zawsze się znajdą oraz braku na rynku alternatywnych wobec NFZ instytucji finansowania działalności medycznej, doprowadza wręcz do swoistej stagnacji myślowej decydentów placówek opieki zdrowotnej. Por. Kapała W., Drygas P., Marketing w ustugach medycznych. Marketing relacyjny, „Antidotum”, $2001 \mathrm{nr} 2$.
} 
podejmując działania w gabinecie, które można odnaleźć w definicjach słowa „przedsiębiorca”. Rola dentysty, jako przedsiębiorcy szerzej zostanie omówiona w następnym rozdziale. 


\title{
ROZDZIAŁ II \\ PRZEDSIĘBIORCZE POSTAWY DENTYSTÓW
}

\author{
Jedynie wprowadzenie niewiedzy \\ stwarza prawdopodobieństwo zaistnienia \\ niewykorzystanych okazji \\ (i, co za tym idzie, czystego zysku) \\ i sposobności, że pierwszy uczestnik rynku, \\ który zauważy prawdziwy stan rzeczy, \\ będzie mógt osiagnać zysk \\ dzięki innowacjom, zmianom i tworzeniu. \\ I.M. Kirzner ${ }^{l}$
}

\section{MOTYWY DZIAŁANIA LEKARZY DENTYSTÓW}

\subsection{POWOLANIE - DETERMINANTĄ WYBORU ZAWODU}

Hipokrates twierdził, że „najpierwszym warunkiem przy wyborze zawodu lekarskiego, powinno być wrodzone usposobienie. Kandydat na lekarza powinien więc zadać sobie pytanie, czy będzie miał dość hartu ducha, aby podołać ciężkim, choć wzniosłym zadaniom lekarza. Kogo nie wzrusza niedola ludzka, kto nie ma dość siły woli, aby zawsze i wszędzie panować nad sobą ten, niech lepiej obierze sobie inny zawód, gdyż nigdy dobrym lekarzem nie będzie. Wybór zawodu tak, jak wybór w małżeństwie, powinien wynikać jedynie z miłości i przywiązania. Zawód ten, jak żona idzie z nami nierozłącznie przez całe życie, aż do grobu i zawód życie lekkim lub ciężkim uczynić może. Znałem lekarzy, którzy nie cierpieli swojego zawodu. Ludzie ci byli podwójnie nieszczęśliwi: najprzód dlatego, że nie mieli powodzenia w swoim zawodzie, następnie dlatego, że żyli w wiecznej rozterce moralnej. Czy może coś więcej ciążyć człowiekowi, jak przymus wykonywania przez całe życie tego, do czego czuje się wstręt nie przezwyciężony. Wybierając ten zawód, można dać radę: iść tylko za głosem powołania na nic innego nie zważać. Człowiek, który lubi swój zawód, przy odrobinie zdolności zawsze wybić się musi. Przeciwnie człowiek nie lubiący swego zawodu i przy dużych zdolnościach do niczego nie dojdzie. Kto szuka tylko chleba w swoim zawodzie, ten chleb może znajdzie, ale pustki życia tym sposobem nie wypełni. A wypełnić życie tak, żeby w nim żadnej pustki nie pozostawało, stanowi całą sztukę życia bodaj czy nie całe szczęście człowieka."2 Miłość, głos serca, przywiązanie i powołanie to Hipokratesowskie drogowskazy, które mają przyczynić się do tego, żeby zawód lekarza

\footnotetext{
${ }^{1}$ Kirzner I.M., Konkurencja ... op. cit., s. 69.

${ }^{2}$ Ibidem s. 85.
} 
wykonywała odpowiednia osoba. Przez setki lat ${ }^{3}$ ta receptura właściwie niemal się nie zmieniła ${ }^{4}$. Nadal w odniesieniu do zawodu lekarza mówi się o powołaniu; ale pojawiły się również odniesienia do predyspozycji (np. interpersonalnych), wartości (np. wyznawanych poglądów, etyki), które sprawiają, że dana osoba będzie dobrym lekarzem. Dziś lekarze wykonujący swój zawód ${ }^{5} \mathrm{w}$ ramach prywatnej praktyki, oprócz chęci pomagania innym, kierują się w swoich wyborach również rachunkiem ekonomicznym. I w odniesieniu do nich szczególnie aktualną pozostaje myśl, aby powołanie stało wyżej, niż pobudki wyłącznie finansowe. Środowisko lekarzy dentystów od lat jest związane z komercyjnym wykonywaniem swojego zawodu ${ }^{6}$, dlatego warto przyjrzeć się motywom pracy stomatologów - czy ciągle w centrum uwagi jest chęć pomocy innym, czy też dominują pobudki finansowe.

\footnotetext{
${ }^{3}$ Również wśród średniowiecznych etyków można znaleźć m. in. opinię Hiszpana Arnolda de Villanovy, który twierdził - może nieco brutalnie - że „kto się uczy na wydziale medycyny, jaki wybrał nie dla wiedzy, lecz dla zysku, z tego się wytwarza płód nie donoszony."

Por. Seyda B., Dzieje medycyny w zarysie, Warszawa 1973, s. 123, za: Gilewska-Dubis J., Etos zawodu ... op. cit., s. 86.

${ }^{4}$ Współcześnie można spotkać się z takim podejściem do omawianego zagadnienia: każdy lekarz musi zdawać sobie sprawę z tego, że nie jest możliwe wykonywanie zawodu wyłącznie z pobudek finansowych, bowiem powołanie to satysfakcja i chęć pomocy drugiemu człowiekowi, który jej potrzebuje. Lekarz będący zwykłym usługodawcą, sprzedającym swoje usługi w wyznaczonych godzinach za określoną stawkę, w gruncie rzeczy sprzeniewierz się etosowi.

Por. Por. Hartman J., Bioetyka dla lekarzy, Wolters Kluwer Polska, Warszawa 2009, s. 5 i nast.; Nawrocka A., Etos w za-wodach medycznych, WAM, Kraków 2008, s. 59 i nast.

${ }^{5}$ Zgodnie z art. 2 Ustawy o zawodzie lekarza i lekarza dentysty z 5 grudnia 1996 r. (t. j. Dz. U. nr 277, poz. 1634 z 2011 r., brzmienie od 01.01.2013 r.) wykonywanie zawodu lekarza dentysty, polega na: 1) udzielaniu przez osobę posiadającą wymagane kwalifikacje, potwierdzone odpowiednimi dokumentami, świadczeń zdrowotnych (w szczególności: badaniu stanu zdrowia, rozpoznawaniu chorób i zapobieganiu im, leczeniu i rehabilitacji chorych, udzielaniu porad lekarskich, a także wydawaniu opinii i orzeczeń lekarskich) w zakresie chorób zębów, jamy ustnej, części twarzowej czaszki oraz okolic przyległych; 2) prowadzeniu przez lekarza prac badawczych w dziedzinie nauk medycznych; 3) promocji zdrowia; 4) nauczaniu zawodu lekarza dentysty; 5) kierowania podmiotem leczniczym, o którym mowa w art. 4 Ustawy o dziatalności leczniczej; 6) zatrudnieniu w podmiotach zobowiązanych do finansowania świadczeń opieki zdrowotnej finansowanych ze środków publicznych w rozumieniu przepisów Ustawy o świadczeniach opieki zdrowotnej finansowanych ze środków publicznych (Dz. U. nr 164, poz. 1027 z 2008 r. z późn. zm.) lub urzędach te podmioty obsługujących, w ramach którego wykonuje czynności związane z przygotowaniem, organizowaniem lub nadzorem nad udzielaniem świadczeń opieki zdrowotnej.

${ }^{6} \mathrm{~W}$ gospodarce centralnie planowanej oprócz państwowej służby zdrowia funkcjonowały prywatne gabinety, prowadzące działalność w oparciu o prywatne sroki pacjentów, więc pewne mechanizmy rynkowe towarzyszą świadczeniom stomatologicznym od kilkudziesięciu lat. W XXI w. NFZ - w ramach ubezpieczenia zdrowotnego - zapewnia finansowanie procedur stomatologicznych w podstawowym zakresie (na podstawie rozporządzenia Ministra Zdrowia z 30 sierpnia $2009 \mathrm{r}$. w sprawie świadczeń gwarantowanych z zakresu leczenia stomatologicznego Dz. U. nr 140, poz. 1144 z 2009 r. z późn. zm.) i jak twierdzą lekarze dentyści „wpycha” pacjentów do komercyjnych gabinetów. W 2010 r. Polacy wydali na usługi stomatologiczne ok. 8 mld zł (szacunki firmy analitycznej PMR z Krakowa).
} 
W pracy lekarze mogą zaspokajać nie tylko - pierwotną dla tego zawodu - potrzebę niesienia pomocy innym, ale również inne potrzeby. Do najczęściej wymienianych potrzeb, jakie ludzie zaspokajają w pracy, B. Kożusznik zaliczyła ${ }^{7}$ :

- potrzebę bezpieczeństwa - jest to fundamentalna potrzeba człowieka, który poszukuje bezpiecznych i niezmiennych warunków życia, dlatego oczekuje godziwych zarobków (pozwalających na utrzymanie siebie oraz rodziny) i stałego miejsca pracy;

- potrzebę afiliacji - zaspokojenie tej potrzeby jest możliwe dzięki utrzymywaniu i nawiązywaniu pozytywnych relacji z innymi ludźmi - człowiek chce czuć, że uczestniczy w życiu społecznym, a jego osoba jest w pełni akceptowana przez otoczenie;

- potrzebę władzy - ludzie poszukują możliwości uzyskiwania wpływów oraz zajmowania wysokich stanowisk w miejscu pracy, z których mogą wpływać na decyzje i zachowania osób na stanowiskach niższych w hierarchii;

- potrzebę osiągnięć - źródłem zaspokojenia tych potrzeb jest uzyskiwanie coraz to lepszych wyników w wykonywanych działaniach, robienie czegoś nowego; osoby odczuwające tę potrzebę stawiają sobie ,wysoko poprzeczkę", która ich motywuje do pracy i dzięki temu starają się osiągać coraz to nowe i o wyższym poziomie trudności cele (wymaga to od nich pewnej inicjatywy, inwencji oraz chęci podjęcia pewnego ryzyka).

W odniesieniu do pracy stomatologa E. $\operatorname{Kosak}^{8}$ - jako czynniki wpływające na motywację - wymienia:

- samorealizację, związaną $\mathrm{z}$ zaspokojeniem potrzeb wyższego rzędu z rozwojem, z dążeniem do satysfakcji z wykonywanych zadań (a więc Hipokratesowskie powołanie);

- atmosferę pracy (zwiększającą zaangażowanie), obejmującą otwartą komunikację ze współpracownikami i dopingujący stosunek przełożonego;

- warunki pracy (związane z wyposażeniem gabinetu, stosowanymi narzędziami, materiałami czy odpowiednią odzieżą roboczą) dające poczucie bezpieczeństwa; pokazując, że - w dużej mierze - elementy pozafinansowe stanowią intencje działań stomatologów.

Wymienione powyżej czynniki stały się elementami oceny w badaniu przeprowadzonym wśród praktykujących lekarzy dentystów i przyszłych stomatologów - tj. studentów kierunku lekarsko-dentystycznego UM w Łodzi.

\footnotetext{
${ }^{7}$ Kożusznik B., Zachowania człowieka w organizacji, PWE, Warszawa 2007, s. 45.

${ }^{8}$ Kosak E., Motywacje stomatologów, „Magazyn Stomatologiczny”, 2000, nr 1, s. 32.
} 


\subsection{MOTYWY PODEJMOWANYCH DZIAŁAŃ - ASPEKT EMPIRYCZNY}

\subsubsection{CHARAKTERYSTYKA GRUP BADAWCZYCH}

Badanie I zostało przeprowadzone w okresie maj - wrzesień 2011 r. Jego celem było określenie zakresu przedsiębiorczości (postawy, umiejętności, działania) polskich stomatologów. Dobór do badania był losowy, zdeterminowany dostępnością bazy adresowej gabinetów stomatologicznych z województw: zachodniopomorskiego, pomorskiego, mazowieckiego, małopolskiego, śląskiego i łódzkiego. W badaniu wykorzystano 169 poprawnie wypełnionych ankiet pocztowych. Wśród respondentów było 137 kobiet i 32 mężczyzn, co odpowiada wiedzy płynącej z zestawień statystycznych GUS na temat stopnia feminizacji tego zawodu (por. Załącznik 1, tabela $\mathrm{nr}$ 1.16). Biorąc pod uwagę staż pracy w zawodzie, struktura badanych przedstawiała się, jak w tabeli 5.

Tabela 5. Respondenci badania I wg czasu jaki upłynął od ukończenia studiów

\begin{tabular}{|c|c|c|}
\hline Liczba lat, jakie upłynęły od & \multicolumn{2}{|c|}{ Respondenci } \\
\cline { 2 - 3 } ukończenia przez lekarza studiów & Wskazania & $\%$ \\
\hline 5 i mniej & 16 & 9,47 \\
\hline 6-14 & 36 & 21,30 \\
\hline 15-21 & 50 & 29,59 \\
\hline 22 i więcej & 67 & 39,64 \\
\hline
\end{tabular}

Źródło: opracowanie własne na podstawie przeprowadzonego badania.

Zdecydowaną większość badanych stanowiły osoby wykonujące zawód 15 lat i dłużej (tylko co dziesiąty badany miał staż krótszy niż 5 lat), dlatego prezentowane wyniki można uznać, jako dobrze pokazujące stanowisko dentystów, znających realia wykonywanego zawodu.

Większość respondentów - 81,33\% była właścicielami gabinetów/klinik stomatologicznych, w których pracowali; pozostała grupa respondentów $(16,67 \%)$ stanowiła grupę pracowników. Wynik ten pokazuje skalę przedsiębiorczości jawnej - rozumianej jako rozpoczynanie i prowadzenie działalności gospodarczej - polskich stomatologów.

Zróżnicowanie odpowiedzi na pytanie, jak długo respondent pracuje w obecnym gabinecie przedstawia tabela 6 .

Tabela 6. Respondenci badania I wg czasu od jakiego pracują w obecnym gabinecie

\begin{tabular}{|c|c|c|}
\hline Liczba lat, od ilu lekarz pracuje & \multicolumn{2}{|c|}{ Respondenci } \\
\cline { 2 - 3 } w obecnym gabinecie & Wskazania & $\%$ \\
\hline 5 i mniej & 43 & 25,45 \\
\hline $6-14$ & 25 & 14,79 \\
\hline $15-21$ & 78 & 46,15 \\
\hline 22 i więcej & 23 & 13,61 \\
\hline
\end{tabular}

Źródło: opracowanie własne na podstawie przeprowadzonego badania. 
Biorąc pod uwagę fakt, że większość respondentów ukończyła studia przeszło 15 lat temu i jest właścicielami gabinetów, zrozumiały jest relatywnie długi czas pracy w danym podmiocie. Niemniej jednak nie pracują tylko w jednym gabinecie $-35,71 \%$ respondentów stwierdziło, że pracuje w więcej niż jednym gabinecie. $\mathrm{Z}$ jednej strony może to być przejawem przedsiębiorczości wewnętrznej dentystów: „pracuje $w$ kilku miejscach, bo chce więcej zarobić” - kilka tego typu uzasadnień pojawiło się w badaniu. Z drugiej strony można również mówić o pewnej "wymuszonej" przedsiębiorczości - zewnętrznej: ,ze względu na przepisy podatkowe pracuję u kogoś, choć mam swój gabinet" twierdzili respondenci.

Większość gabinetów - 65,87\% to gabinety, w których praca odbywa się na jednym fotelu, tylko w niespełna $1 / 3$ podmiotów prowadzona jest na dwóch stanowiskach. Potwierdza to - przedstawione we wstępie stanowisko R. Levina o stosunkowo niskim potencjale rozwoju stworzonych przez lekarzy dentystów przedsiębiorstw. Z drugiej strony może również świadczyć o pewnej niechęci do wprowadzania zmian: stomatolodzy twierdzą, że ,polski pacjent jest nieprzyzwyczajony do pracy na dwóch fotelach" (bariera leżąca po stronie popytu), ale jeszcze kilka lat temu mówili tak o pracy z pacjentem w pozycji leżącej. Można postawić tezę, że to nie tylko przyzwyczajenia pacjentów decydują o organizacji pracy gabinetu stomatologicznego, ale również nastawienie lekarza dentysty do nowego rozwiązania (bariera mentalna). Nastawienie to może wynikać nie tylko z powodu - deklarowanych najczęściej - obaw, jak zareagują pacjenci, ale również może być wynikiem np.:

- braku miejsca w obecnym gabinecie (bariera organizacyjna),

- braku umiejętności lekarza dentysty i asysty stomatologicznej w tym zakresie (bariera związana z wiedzą i umiejętnościami),

- braku środków finansowych na inwestycje związane ze zmianą (bariera finansowa).

Jak widać barier - nie zmieniania organizacji pracy w gabinecie na dwustanowiskową - leżących po stronie podaży, można wskazać wiele, co pokazuje złożony charakter niskiego potencjału rozwoju gabinetów.

Większość respondentów - 60,48\% zadeklarowała, że pracuje z asystą, pozostali - że bez. Można byłoby się zastanowić nad efektywnością pracy lekarza dentysty (np. w zakresie wykorzystania czasu wizyty), który wszystkie czynności wykonuje sam. Lekarze taką organizację pracy uzasadniali najczęściej (92\% wskazań) wysokim kosztem zatrudnienia pracownika (bariera finansowa).

Kolejnym badaniem (badanie III) objęto przyszłych lekarzy dentystów - studentów studiów dziennych wydziału lekarskiego, kierunku lekarsko-dentystycznego Uniwersytetu Medycznego w Łodzi. Zostało ono przeprowadzone 
- techniką bezpośrednich wywiadów kwestionariuszowych z wykorzystaniem techniki Paper and Pencil Interview - w okresie marzec-kwiecień 2012r. Objęto nim 96 osób (studentów wszystkich lat studiów), co stanowiło ok. 25\% wszystkich osób studiujących na kierunku lekarsko-dentystycznym w trybie dziennym w roku akademickim 2011/12. Respondenci byli w wieku 19-26 lat, a $64,6 \%$ badanych stanowiły kobiety. Strukturę badanej grupy z punktu widzenia roku studiów, na którym był student w trakcie badania przedstawia tabela 7 .

Tabela 7. Respondenci badania III a rok studiów

\begin{tabular}{|c|c|c|}
\hline $\begin{array}{c}\text { Rok } \\
\text { studiów }\end{array}$ & $\begin{array}{c}\text { Liczba } \\
\text { respondentów }\end{array}$ & $\%$ \\
\hline I & 1 & $1 \%$ \\
\hline II & 43 & $45 \%$ \\
\hline III & 16 & $17 \%$ \\
\hline IV & 23 & $24 \%$ \\
\hline V & 13 & $14 \%$ \\
\hline
\end{tabular}

Źródło: Opracowanie własne na podstawie przeprowadzonego badania.

Ze względu na zbyt małe liczebności poszczególnych podgrup (rozumianych jako liczba studentów określonego roku studiów) wyniki badania nie będą filtrowane i cała badana grupa będzie przedmiotem dalszej analizy (choć autorka badania ma świadomość, że wyniki otrzymywane wśród studentów np. II i V roku mogłyby być odmienne).

\subsubsection{MOTYWACJE STOMATOLOGÓW I STUDENTÓW - WYNIKI BADAŃ}

W celu określenia priorytetów w prowadzeniu gabinetu, motywacje stomatologów zostały podzielone na wewnętrzne - dotyczące lekarza, jako człowieka wykonującego określoną pracę i zewnętrzne - powiązane ze specyfiką pracy. I choć umieszczenie poszczególnych czynników motywacyjnych w jednej z dwóch grup można uznać za dyskusyjne (np. respondent, jako dobry szef motywacja wewnętrzna czy motywacja związana $\mathrm{z}$ wykonywanym zawodem), to autorka przyjęła, określony punkt widzenia i zgodnie z nim dokonała analizy wiązki głównych motywatorów w działaniach stomatologów. Spojrzenie na dane zawarte w tabeli 8 i 9 pozwala na kompleksowe odniesienie się do motywów, jakimi respondenci badania I kierowali się przy wyborze zawodu i pracy na własny rachunek.

Intrapersonalne motywacje stomatologów przedstawia tabela 8 . Badani wyrażali swoje opinie posługując się skalą od 1 (nieważne, nie dotyczy itp.) do 5 (bardzo ważne, na pewno tak itp.), a w opracowaniu przedstawiono wyniki badań wykorzystując częstotliwość udzielanej odpowiedzi

\footnotetext{
${ }^{9}$ Takie podejście zostało zastosowane we wszystkich przeprowadzonych dla potrzeb pracy badaniach ilościowych.
} 
Tabela 8. Ranking intrapersonalnych motywacji lekarzy dentystów

\begin{tabular}{|c|c|c|c|c|c|c|c|c|c|}
\hline \multirow[b]{2}{*}{ Czynnik motywacyjny } & \multicolumn{5}{|c|}{$\begin{array}{l}\text { Stanowisko respondenta } \\
\text { (procent wskazań) }\end{array}$} & \multirow[b]{2}{*}{$\bar{x}$} & \multirow[b]{2}{*}{ Do } & \multirow[b]{2}{*}{ Me } & \multirow[b]{2}{*}{$\mathbf{S}(\mathbf{x})$} \\
\hline & \begin{tabular}{|c|} 
na \\
pewno \\
nie \\
$(1)$ \\
\end{tabular} & $\begin{array}{c}\text { raczej } \\
\text { nie } \\
(2) \\
\end{array}$ & \begin{tabular}{|c|}
$\begin{array}{c}\text { trudno } \\
\text { powie- } \\
\text { dzieć } \\
(3)\end{array}$ \\
\end{tabular} & $\begin{array}{c}\text { raczej } \\
\text { tak } \\
(4) \\
\end{array}$ & $\begin{array}{c}\text { na } \\
\text { pewno } \\
\text { tak } \\
(5) \\
\end{array}$ & & & & \\
\hline Satysfakcja z wykonywanej pracy & 0,0 & 0,0 & 0,61 & 21,82 & 77,58 & 4,77 & 5 & 5 & 0,44 \\
\hline $\begin{array}{l}\text { Rozwój własnych kwalifikacji } \\
\text { medycznych }\end{array}$ & 0,0 & 1,88 & 3,75 & 23,13 & 71,25 & 4,64 & 5 & 5 & 0,65 \\
\hline Robienie tego, co lubię & 0,0 & 0,61 & 8,59 & 27,61 & 63,19 & 4,53 & 5 & 5 & 0,68 \\
\hline $\begin{array}{l}\text { Dochody pozwalające na godne } \\
\text { życie }\end{array}$ & 0,61 & 0,61 & 8,64 & 37,67 & 52,47 & 4,41 & 5 & 5 & 0,73 \\
\hline $\begin{array}{l}\text { Organizacja pracy dająca więcej } \\
\text { czasu na realizację własnych pasji }\end{array}$ & 1,28 & 3,21 & 17,95 & 31,41 & 46,15 & 4,18 & 5 & 4 & 0,93 \\
\hline $\begin{array}{l}\text { Bycie poważanym przez rodzinę, } \\
\text { znajomych }\end{array}$ & 5,59 & 11,18 & 26,71 & 34,16 & 22,36 & 3,57 & 4 & 4 & 1,12 \\
\hline
\end{tabular}

Źródło: opracowanie własne na podstawie przeprowadzonych badań.

Dla respondentów najważniejszą kwestią związaną z pracą zawodową jest satysfakcja $\mathrm{z}$ jej wykonywania (dla 99,4\% respondentów był to ważny lub bardzo ważny motywator) oraz rozwój zawodowy $(94,4 \%$ badanych uznało go za ważny lub bardzo ważny element). Ponadto istotne jest również robienie $\mathrm{w}$ życiu tego, co się lubi $(90,8 \%$ respondentów uznało to za ważny lub bardzo ważny czynnik), a praca $\mathrm{w}$ zawodzie lekarza dentysty umożliwia taką organizację czasu, aby realizować własne pasje $-77,6 \%$ badanych uznało ten czynnik za ważny lub bardzo ważny motywator. Zgodnie z przedstawioną wcześniej hierarchią potrzeb zaspokajanych w miejscu pracy - ważniejsze jest osiąganie dochodów pozwalających na godne życie $(90,1 \%$ respondentów uznało ten czynnik za ważny lub bardzo ważny), niż uznanie w oczach znajomych (czynnik ważny lub bardzo ważny dla 56,5\% respondentów). Duże znaczenie, jakie lekarze dentyści przypisali intrapersonalnym motywatorom, pozwala wnioskować o znacznym zaangażowaniu w wykonywanie zawodu. Jest to o tyle istotne, że pasja jest motorem zmian - pozwala wyznaczać nowe (często bardzo ambitne) cele, realizacja których może prowadzić do kompleksowego rozwoju tak na płaszczyźnie stricte medycznej, jak i biznesowej.

Motywacje lekarzy dentystów powiązane z obszarem interpersonalnym funkcjonowania gabinetu (zarówno w odniesieniu do personelu, jak i do pacjenttów) i wpływające na decyzję o wyborze zawodu przedstawia tabela 9. Motywatorami związanymi ze specyfiką zawodu były przede wszystkim:

- wyleczenie pacjenta (czynnik ważny i bardzo ważny dla 98,79\% badanych),

- pozyskanie zaufania pacjenta (czynnik ważny lub bardzo ważny dla 98,7\% badanych lekarzy), 
- satysfakcja pacjenta (czynnik ważny lub bardzo ważny dla $98 \%$ respondentów).

Te trzy czynniki miały najwyższą średnią w rankingu motywatorów ogółem, dlatego z całą pewnością można powiedzieć, że powołanie do bycia lekarzem wpłynęło na wybór drogi zawodowej badanych. Pielęgnowanie w sobie tych motywów w trakcie trwania pracy zawodowej i dbałość o ich realizację na wysokim poziomie, powinno umożliwić utrzymanie stałej grupy lojalnych pacjentów (co jest kluczowym zagadnieniem marketingu relacji) i stwarzać szanse dla pozyskiwania nowych. Niemniej jednak czynnik ,utrzymywanie określonej grupy lojalnych pacjentów" cieszył się już nieco mniejszym bezpośrednim zainteresowaniem respondentów (czynnik ważny lub bardzo ważny dla 93,13\% badanych), podobnie, jak ,ppozyskiwanie nowych pacjentów” (czynnik ważny lub bardzo ważny dla 86,73\% respondentów). Można pokusić się o stwierdzenie, że ,lekarz" (zorientowany na pacjenta) wygrywa z ,przedsiębiorcą" (zorientowanym na pozyskiwanie nowych nabywców usług) w myśleniu i działaniu stomatologów.

Dobra atmosfera pracy jest istotna dla 96,88\% badanych, ale już bycie dobrym szefem dla 76,72\%. Takie stanowisko może wynikać $\mathrm{z}$ faktu, że część respondentów była pracownikami i nie traktowała ,bycia przełożonym”, jako priorytetu; ale $\mathrm{z}$ drugiej strony może być - prawdopodobnie - sygnałem nie zauważania rangi powiązania pomiędzy postawą przełożonego względem podwładnych a atmosferą pracy. Ciekawym spostrzeżeniem jest to, że respondenci są zainteresowani wzrostem rentowności gabinetu - 87,14\% wskazań, ale bycie dobrym menedżerem jest ważne dla 57,52\% respondentów (a dla pozostałej grupy - nie lub nie mają zdania w tej sprawie). Otwartym pozostaje pytanie: jak ok. 1/3 badanych zamierzałaby zrealizować cel: wzrost rentowności gabinetu bez dążenia do poprawienia swoich umiejętności zarządzania gabinetem, jako podmiotem zarobkującym.

Tabela 9. Ranking interpersonalnych motywacji lekarzy dentystów

\begin{tabular}{|c|c|c|c|c|c|c|c|c|c|}
\hline \multirow[b]{2}{*}{ Czynnik motywacyjny } & \multicolumn{5}{|c|}{$\begin{array}{c}\text { Stanowisko respondenta } \\
\text { (procent wskazań) }\end{array}$} & \multirow[b]{2}{*}{$\bar{x}$} & \multirow[b]{2}{*}{ Do } & \multirow[b]{2}{*}{ Me } & \multirow[b]{2}{*}{$\mathbf{S}(\mathbf{x})$} \\
\hline & $\begin{array}{c}\text { na } \\
\text { pewno } \\
\text { nie } \\
(1)\end{array}$ & $\begin{array}{c}\text { raczej } \\
\text { nie } \\
(2)\end{array}$ & $\mid \begin{array}{c}\text { trudno } \\
\text { powie- } \\
\text { dzieć } \\
(3)\end{array}$ & $\begin{array}{c}\text { raczej } \\
\text { tak } \\
(4)\end{array}$ & $\begin{array}{c}\text { na } \\
\text { pewno } \\
\text { tak } \\
(5)\end{array}$ & & & & \\
\hline Wyleczenie pacjenta & 0,61 & 0,61 & 0,0 & 7,88 & \begin{tabular}{|l|}
90,91 \\
\end{tabular} & 4,88 & 5 & 5 & 0,47 \\
\hline Satysfakcja pacjenta & 0,0 & 0,0 & 1,85 & 11,73 & 86,22 & 4,85 & 5 & 5 & 0,41 \\
\hline Pozyskanie zaufania pacjentów & 0,0 & 0,0 & 1,27 & 17,83 & 80,89 & 4,80 & 5 & 5 & 0,43 \\
\hline Dobra atmosfera pracy & 0,0 & 0,0 & 3,13 & 24,38 & 72,5 & 4,69 & 5 & 5 & 0,53 \\
\hline $\begin{array}{l}\text { Utrzymywanie grupy lojalnych } \\
\text { pacjentów }\end{array}$ & 0,61 & 1,88 & 4,40 & 41,88 & 51,25 & 4,41 & 5 & 5 & 0,72 \\
\hline Wzrost rentowności gabinetu & 0,61 & 5,16 & 7,10 & 36,82 & 50,32 & 4,41 & 5 & 5 & 0,87 \\
\hline Pozyskiwanie nowych pacjentów & 0,61 & 5,06 & 7,59 & 36,1 & 50,63 & 4,31 & 5 & 5 & 0,87 \\
\hline
\end{tabular}




\begin{tabular}{|l|c|c|c|c|c|c|c|c|c|}
\hline $\begin{array}{l}\text { Budowa (poprawa) wizerunku } \\
\text { gabinetu }\end{array}$ & 1,32 & 5,3 & 7,95 & 40,4 & 45,03 & 4,23 & 5 & 4 & 0,90 \\
\hline $\begin{array}{l}\text { Pomoc pacjentowi w zwiększeniu } \\
\text { wiary w siebie }\end{array}$ & 0,61 & 2,53 & 16,48 & 42,41 & 37,97 & 4,15 & 4 & 4 & 0,83 \\
\hline $\begin{array}{l}\text { Wprowadzanie nowych usług do } \\
\text { oferty gabinetu }\end{array}$ & 0,61 & 6,96 & 12,03 & 43,69 & 36,71 & 4,09 & 4 & 4 & 0,91 \\
\hline Bycie dobrym szefem & 4,79 & 4,11 & 14,38 & 31,51 & 45,21 & 4,08 & 5 & 4 & 1,09 \\
\hline Bycie sprawnym menedżerem & 3,27 & 11,8 & 27,41 & 32,68 & 24,84 & 3,64 & 4 & 4 & 1,08 \\
\hline
\end{tabular}

Źródło: opracowanie własne na podstawie przeprowadzonych badań.

Pacjenci, obserwując swoich dentystów - wyniki badania IV ${ }^{10}$, też mają pewne wyobrażenia o motywach postępowania stomatologów. Ich ranking jest następujący $^{11}$ :

- wyleczenie pacjenta - 73,5\% wskazań,

- osiągnięcie dochodów pozwalających na godne życie - 41,4\%,

- satysfakcja pacjenta - 39,6\%,

- pozyskanie nowych pacjentów - 38,8\%,

- oferowanie usług wysokiej jakości-31,7\%,

- dobra atmosfera pracy - 21,6\%,

- budowa (ewentualnie poprawa) wizerunku gabinetu w otoczeniu - 20,9\%,

- rozwój własnych kwalifikacji medycznych - 20,5\%,

- szybki zysk - 11,6\%,

- $\quad$ wprowadzanie nowych usług $-9,3 \%$,

- inne $-0,4 \%$.

Pacjenci są w większości przekonani $(73,5 \%)$, że lekarze dentyści dążą do wyleczenia pacjentów - widzą główny motyw podejmowanych przez stomatologów działań związany z pomocą pacjentowi, a nie głównie ekonomiczny ${ }^{12}$. Wyniki te mogą świadczyć, że opieka zdrowotna zapewniana przez gabinety komercyjne może być (i jest) realizowana w duchu etyki lekarskiej (zarówno w przekonaniu osoby realizującej świadczenie, jak i z niego korzystającej). $\mathrm{Z}$ tego względu zapewnienie równowagi pomiędzy etyką lekarską a etyką biznesu, staje się gwarantem odpowiedniego postępowania stomatologów, prowadzących własne gabinety.

\footnotetext{
${ }^{10}$ Więcej na temat badania IV w Rozdziale IV, punkt 4.1.1.

${ }^{11}$ Odpowiedzi nie sumują się do $100 \%$, ponieważ respondenci mogli zaznaczyć 3 odpowiedzi.

${ }^{12}$ Cztery razy więcej pacjentów dostrzega w działaniach lekarzy stomatologów normalne ekonomiczne motywy związane z prowadzoną działalnością, niż chęć realizacji szybkiego zarobku (choć $10 \%$ pacjentów taki motyw wskazało).
} 
Jeśli chodzi o przyszłych dentystów - motywacje rozpoznane w ramach badania III - to za najważniejszy czynnik intrapersonalnej motywacji (por. tabela 10) studenci uważają rozwój własnych kwalifikacji medycznych (u dentystów - średnia wskazań taka sama, ale drugie miejsce w rankingu), a satysfakcja $\mathrm{z}$ wykonywanej pracy (pierwsze miejsce u dentystów) plasuje się dopiero na czwartym miejscu. Większą wagę, niż dentyści przywiązują również do organizacji pracy dającej więcej czasu na realizację własnych pasji - czynnik ważny dla $86,31 \%$ badanych. Znakiem czasów jest wskazanie czynnika stricte ekonomicznego jako ważnego (dla 93,75\% badanych) w wyborze zawodu drugie miejsce $\mathrm{w}$ rankingu, podczas gdy u praktyków stomatologii czynnik ten zajął czwarte miejsce.

Tabela 10. Intrapersonalne motywacje studentów kierunku lekarsko-dentystycznego

\begin{tabular}{|c|c|c|c|c|c|c|c|c|c|}
\hline \multirow[b]{2}{*}{ Czynnik motywacyjny } & \multicolumn{5}{|c|}{$\begin{array}{c}\text { Stanowisko respondenta } \\
\text { (procent wskazań) }\end{array}$} & \multirow[b]{2}{*}{$\bar{x}$} & \multirow[b]{2}{*}{ Do } & \multirow[b]{2}{*}{ Me } & \multirow[b]{2}{*}{$\mathbf{S}(\mathbf{x})$} \\
\hline & $\begin{array}{c}\text { na } \\
\text { pewno } \\
\text { nie } \\
\\
(1)\end{array}$ & $\begin{array}{c}\text { raczej } \\
\text { nie } \\
(2)\end{array}$ & $\begin{array}{l}\text { trudno } \\
\text { powie- } \\
\text { dzieć } \\
(3)\end{array}$ & $\begin{array}{c}\text { raczej } \\
\text { tak } \\
(4)\end{array}$ & $\begin{array}{c}\text { na } \\
\text { pewno } \\
\text { tak } \\
(5)\end{array}$ & & & & \\
\hline $\begin{array}{l}\text { Rozwój własnych kwalifikacji } \\
\text { medycznych }\end{array}$ & 0,0 & 0,0 & 3,13 & 30,21 & 66,67 & 4,64 & 5 & 5 & 0,54 \\
\hline $\begin{array}{l}\text { Dochody pozwalające na godne } \\
\text { życie }\end{array}$ & 0,0 & 0,0 & 6,25 & 27,08 & 66,67 & 4,60 & 5 & 5 & 0,60 \\
\hline Robienie tego, co lubię & 0,0 & 1,05 & 8,42 & 23,16 & 67,37 & 4,57 & 5 & 5 & 0,69 \\
\hline Satysfakcja z wykonywanej pracy & 0,0 & 0,0 & 7,29 & 29,17 & 63,54 & 4,56 & 5 & 5 & 0,63 \\
\hline $\begin{array}{l}\text { Organizacja pracy dająca więcej } \\
\text { czasu na realizację własnych pasji }\end{array}$ & 0,0 & 5,26 & 8,42 & 33,68 & 52,63 & 4,34 & 5 & 5 & 0,84 \\
\hline $\begin{array}{l}\text { Bycie poważanym przez rodzinę, } \\
\text { znajomych }\end{array}$ & 3,16 & 8,42 & 24,21 & 26,32 & 37,80 & 3,87 & 5 & 4 & 1,11 \\
\hline
\end{tabular}

Źródło: Opracowanie własne na podstawie przeprowadzonego badania.

Otrzymane wyniki są zbliżone do wyników badań nad przedsiębiorczością polskich studentów (studiów dziennych innych kierunków) prowadzonych przez M. Kunasz ${ }^{13}$. Za główne walory wynikające $\mathrm{z}$ podjęcia własnej działalności gospodarczej uznali: możliwość samorealizacji, podnoszenia kwalifikacji, osiągnięcia satysfakcji z pracy zawodowej, a także wysokość możliwych do uzyska nia zarobków. Jako najważniejsze bariery, które mogą uniemożliwić założenie własnej firmy, podali brak środków finansowych oraz nieznajomość procedur tworzenia podmiotu gospodarczego. Wydaje się, że z dużą dozą prawdopodobieństwa można byłoby te ograniczenia przypisać również badanym studentom.

13 Kunasz M., Przedsiębiorczość studentów studiów dziennych - wyniki badań, „Przegląd Organizacji”, 2008, nr 1, s. 29, s. 14 i nast. 
Jeśli chodzi o interpersonalne motywacje przyszłych lekarzy dentystów (por. tabela 11), to najważniejsze (i najważniejsze w ogóle) jest dla nich wyleczenie pacjenta. Dwa kolejne miejsca w rankingu - satysfakcja pacjenta (ważna lub bardzo ważna dla $95,79 \%$ badanych) i pozyskanie zaufania pacjenta (ważne dla 93,18\% badanych) są takie, jak praktyków zawodu, a więc wniosek sformułowany w odniesieniu do studentów, że powołanie motywuje do wyboru zawodu jest również uprawniony. Można byłoby postawić pytanie dlaczego taka kolejność tych dwóch priorytetów? Czy - z punktu widzenia logiki organizacji usługowej - priorytetem ważniejszym nie powinno być pozyskanie zaufania pacjenta? Czy pacjent, mający zaufanie do personelu gabinetu (a dentysty w szczególności), nie byłby bardziej zadowolony z leczenia, a w konsekwencji bardziej usatysfakcjonowany? (rozważania na ten temat będą podjęte w IV rozdziale).

Tabela 11. Interpersonalne motywacje studentów kierunku lekarsko-dentystycznego

\begin{tabular}{|c|c|c|c|c|c|c|c|c|c|}
\hline \multirow[b]{2}{*}{ Czynnik motywacyjny } & \multicolumn{5}{|c|}{$\begin{array}{l}\text { Stanowisko respondenta } \\
\text { (procent wskazań) }\end{array}$} & \multirow[b]{2}{*}{$\bar{x}$} & \multirow[b]{2}{*}{ Do } & \multirow[b]{2}{*}{ Me } & \multirow[b]{2}{*}{$\mathbf{S}(\mathbf{x})$} \\
\hline & \begin{tabular}{|c|} 
na \\
pewno \\
nie \\
$(1)$
\end{tabular} & $\begin{array}{c}\text { raczej } \\
\text { nie } \\
\\
(2)\end{array}$ & $\begin{array}{c}\text { trudno } \\
\text { powie- } \\
\text { dzieć } \\
\text { (3) }\end{array}$ & $\begin{array}{c}\begin{array}{c}\text { raczej } \\
\text { tak }\end{array} \\
\text { (4) }\end{array}$ & \begin{tabular}{|c|} 
na \\
pewno \\
tak \\
$(5)$
\end{tabular} & & & & \\
\hline Wyleczenie pacjenta & 0,0 & 1,04 & 1,04 & 13,54 & 84,38 & 4,81 & 5 & 5 & 0,49 \\
\hline Pozyskanie zaufania pacjentów & 0,0 & 1,08 & 5,38 & 23,66 & 69,89 & 4,62 & 5 & 5 & 0,57 \\
\hline Satysfakcja pacjenta & 0,0 & 0,0 & 4,21 & 29,47 & 66,32 & 4,62 & 5 & 5 & 0,65 \\
\hline Dobra atmosfera pracy & 0,0 & 0,0 & 5,21 & 29,17 & 65,63 & 4,60 & 5 & 5 & 0,59 \\
\hline Pozyskiw & 0,0 & 1,04 & 6,25 & 27,08 & 65,63 & 4,57 & 5 & 5 & 0,66 \\
\hline Bycie dobrym szefem & 0,0 & 1,05 & 17,71 & 35,42 & 45,82 & 4,26 & 5 & 4 & 0,78 \\
\hline $\begin{array}{l}\text { Wprowadzanie nowych usług do } \\
\text { oferty gabinetu }\end{array}$ & 0,0 & 0,0 & 18,75 & 40,63 & 40,63 & 4,22 & $4 ; 5$ & 4 & 0,74 \\
\hline $\begin{array}{l}\text { Utrzymywanie grupy lojalnych } \\
\text { pacjentów }\end{array}$ & 1,05 & 0,0 & 18,95 & 36,84 & 43,16 & 4,21 & 5 & 4 & 0,82 \\
\hline $\begin{array}{l}\text { Budowa (poprawa) wizerunku } \\
\text { gabinetu w otoczeniu }\end{array}$ & 0,0 & 4,26 & 14,89 & 40,43 & 40,43 & 4,17 & $4 ; 5$ & 4 & 0,84 \\
\hline Wzrost rentowności gabinetu & 1,06 & 1,06 & 14,89 & 48,94 & 34,04 & 4,14 & 4 & 4 & 0,78 \\
\hline Bycie sprawnym menedżerem & 1,04 & 3,13 & 20,83 & 38,54 & 36,46 & 4,06 & 4 & 4 & 0,89 \\
\hline $\begin{array}{l}\text { Pomoc pacjentowi w zwiększeniu } \\
\text { wiary w siebie }\end{array}$ & 1,05 & 6,32 & 25,26 & 47,37 & 20,0 & 3,79 & 4 & 4 & 0,87 \\
\hline
\end{tabular}

Źródło: Opracowanie własne na podstawie przeprowadzonego badania.

Reasumując, warto podkreślić, że respondenci - zarówno z badania I, jak i z III - za najważniejszy motywator swojej pracy uznali wyleczenie pacjenta. Dentyści postawili pacjenta w centrum uwagi, wskazując, że ważna jest dla nich satysfakcja pacjenta i pozyskanie jego zaufania; dopiero na czwartym miejscu postawili siebie (wyraziło się to $\mathrm{w}$ satysfakcji z wykonywanej pracy). Widać więc Hipokratesowskie powołanie w postawach respondentów. Dla studentów 
ważny jest samorozwój w zakresie kwalifikacji zawodowych (specyfika pracownika wiedzy), a dopiero później satysfakcja pacjenta i jego zaufanie ${ }^{14}$.

Patrząc na hierarchię motywatorów wewnętrznych i zewnętrznych dentystów i studentów, nie sposób nie przywołać słów J.A. Schumpetera ${ }^{15}$, który twierdzi, że motywem działań przedsiębiorcy jest nie tylko chęć uzyskania dla siebie korzyści materialnych i zaspokojenia swych potrzeb konsumpcyjnych, ale także zdobycia satysfakcjonującej pozycji społecznej oraz ,pragnienie zdobywania: chęć do walki (...), do zwyciężania nie dla jego owoców, lecz dla samego zwyciężania. Na koniec istnieje radość tworzenia, dokonywania czegoś lub po prostu ćwiczenia swojej energii i pomysłowości." Przedstawione motywy działań lekarzy dentystów i studentów kierunku lekarsko-dentystycznego pokazują, że postawy zawodowe stomatologów pozostają w zgodzie nie tylko z Hipokratesowskim postrzeganiem zawodu lekarza, ale również Schumpeterowskim motywem działań przedsiębiorcy.

Z drugiej strony - nie kwestionując znaczenia powołania lekarskiego - nie można traktować lekarzy, jako grupy zawodowej, która nie realizuje własnych celów finansowych, bo - jak wynika z przeprowadzonych badań - tak nie jest. Lekarze dentyści $w$ granicach posiadanych kompetencji stricte biznesowych, prowadząc swoje gabinety, podejmują decyzje, które mają na celu realizację korzyści ekonomicznej ${ }^{16}$.

\footnotetext{
${ }^{14}$ Istotnym jest, aby myślenie o własnym rozwoju pozostawało działaniem podejmowanym dla dobra pacjenta, aby doskonały specjalista (z szeroką wiedzą i umiejętnościami na wysokim poziomie) skupiony był na pacjencie (a nie jedynie na rozwiązywaniu problemu medycznego).

${ }^{15}$ Schumpeter J.A., Teoria rozwoju ... op. cit., s. 149.

${ }^{16}$ F. Breyer, P. Zweifel, M. Kifmann przedstawili model satysfakcjonującego dochodu, opisujący zachowania lekarzy. Osiągnięcie satysfakcjonującego poziomu dochodu pozwala skierować się w stronę realizacji innych celów, także tych związanych z pracą zawodową (np. uzyskiwanie satysfakcji z faktu niesienia pomocy innym). Dopóki cel dochodowy nie zostanie osiągnięty, istnieje zagrożenie w postaci oportunizmu i kreacji sztucznego popytu. Przy bardzo niskich dochodach takie bariery, jak koszt alternatywny w postaci mniejszej ilości czasu wolnego i większego obciążenia pracą, koszty psychiczne, konieczność inwestowania we własne wykształcenie przestają funkcjonować. Przy wyższych dochodach można je traktować jako uzupełniający cel lekarza - określony minimalizacją własnych nakładów pracy. Por. Breyer F., Zweifel P., Kifmann M., Gesundheitsökonomie, Springer Verlag, Berlin, Heidelberg, Nowy Jork, 2003 za: Sowada C., Wptyw metod finansowania na zachowania lekarzy - aspekty ekonomiczne, zdrowotne i spoteczne, „Zeszyty Naukowe Ochrony Zdrowia. Zdrowie Publiczne i Zarządzanie”, 2005 nr 1, t. III, s. 70.
} 


\section{UMIEJĘTNOŚCI I KOMPETENCJE STOMATOLOGÓW 2.1. SPECYFICZNE CECHY LEKARZY}

Już we wczesnym średniowieczu istniały teksty deontologiczne ${ }^{17}$, które określały pożądane zachowanie lekarzy wobec pacjentów, a także cechy charakteru, którymi powinni odznaczać się medycy. I tak np. w anonimowym liście do Arseniusza (z ok. IX w.) można przeczytać m.in.: „Przede wszystkim lekarz powinien sprawdzić swoją osobowość, by zobaczyć, czy jest przyzwoitego i dobrego charakteru, zdolny i skłonny do nauki, wstrzemięźliwy, i zrównoważony, skrupulatny, inteligentny, uprzejmy, czujny, skromny i łaskawy"18. Minęło tysiąc lat i lista ta jest ciągle aktualna - można znaleźć jej echo m. in. w koncepcji zarządzania kapitałem ludzkim organizacji, zarządzania wiedzą, zarządzania relacjami itp.

Również dziś podejmowane są badania, mające na celu określenie cech charakterystycznych lekarzy ${ }^{19}$. Światowa Organizacja Zdrowia, definiując atrybuty współczesnego lekarza, posługuje się pojęciem tzw. „lekarza pięciogwiazdkowego" (the five-star doctor); należą do nich ${ }^{20}$ :

- świadczenie usług medycznych o wysokiej jakości,

17 „Deontologia” (gr. deon - oznacza obowiązek, a logos - nauka, mowa); deontologia lekarska, jako gałąź medycyny powstała w wyniku rosnącego zainteresowania filozofów-etyków, historyków medycyny, teologów oraz lekarzy etyką zawodu lekarskiego. Por. Kielanowski T., Wprowadzenie do nauki o etyce i deontologii lekarskiej, w: Kielanowski T. (red.) Wybrane zagadnienia z etyki i deontologii lekarskiej, Warszawa 1980, s. 11.

${ }^{18}$ Galvao-Sobrinho C.R., Hippocraticc Ideale, Medical Ethics, and Practice of Medicine In the Early Middle Ages: The Legacy of the Hippocratic Oath, "Journal of the History Medicine", 1996 t. 51, s. 445 i nast. za: Chmielnicki B., Oczekiwania pacjenta wobec lekarza w średniowiecznej medycynie europejskiej, w: Płonka-Syroka B. (red.), Relacje lekarz-pacjent ... op. cit., s. 97.

${ }^{19} \mathrm{O}$ postawach lekarza względem pacjenta - wynikających z deontologii lekarskiej - pisali $\mathrm{m}$. in.: Parsons T., The sick role and the role of the physician reconsidered, "Health and Society", 1975 nr 53; Brzeziński T., Tradycyjne zasady deontologii lekarskiej, w: Kielanowski T. (red.), Etyka ... op. cit., s. 27 i nast.; Gordon T., Pacjent jako partner, Instytut Wydawniczy PAX, Warszawa 1999; Heszen-Niejodek I., Lekarz i pacjent. Badania psychologiczne, Wyd. UJ, Kraków 1992.

O postawach wobec pacjentów, dla których główną przesłanką była poprawa komunikacji lekarz pacjent pisali m. in.: Ley P., Communicating with patients: Improving communication, satisfaction and compliance, Croom Helm, Londyn 1988; Quill T.E., Recognizing and Adjusting to Barriers In Doctor-Patient Communication, "Annals of Internal Medicine", $1989 \mathrm{nr}$ 111; Ibrahim Y., Doctor and patient questions as a measure of doctor-centeredness in UAE hospitals, "English for Specific Purposes", 2001 nr 20; Barański J., Waszyński E., Steciwko A., Komunikowanie się lekarza z pacjentem, Wydawnictwo ASTRUM, Wrocław 2000; Rollnick S., Miller W.R., Butler Ch.C., Wywiad motywujacy $w$ opiece zdrowotnej, Wydawnictwo Szkoły Wyższej Psychologii Społecznej Academica, Warszawa 2010; Stefaniak K., Władza i tożsamość w komunikacji lekarz - pacjent, Oficyna Wydawnicza ATUT, Wrocławskie Wydawnictwo Oświatowe, Wrocław 2011.

${ }^{20}$ Doctors for Health, WHO global strategy for changing medical education and medical practice for health for ali, WHO, Genewa 1996, s. 8 za: Rudawska I., Jakość relacji pacjent-profesjonalista w sektorze ustug medycznych, „Problemy Jakości”, 2005 nr 3, s. 15. 
- podejmowanie decyzji w aspektach: etycznym i ekonomicznym,

- skuteczne komunikowanie się z innymi uczestnikami rynku,

- przewodzenie społeczności lokalnej,

- zarządzanie systemem zaspokajania potrzeb zdrowotnych jednostek i całych zbiorowości.

Druga i trzecia „gwiazdka” - jako działania, które mogą być podejmowane przez dentystę-przedsiębiorcę - stały się przedmiotem uwagi niniejszego opracowania. Podjęte badania koncentrują się $\mathrm{m}$. in. na determinantach jakości obsługi, priorytetach w prowadzeniu prywatnego gabinetu stomatologicznego, roli komunikacji w nawiązywaniu trwałej relacji na płaszczyźnie lekarz dentysta - pacjent oraz biznesowym obszarze prowadzenia gabinetu stomatologicznego typu profit.

A. Borkowska i A. Czerw piszą, że specyfika pracy lekarza nie wynika wyłącznie $\mathrm{z}$ jej przedmiotu ${ }^{21}$ ( $\mathrm{w}$ tym obszarze nie jest analizowana $\mathrm{w}$ niniejszej pracy), wiele innych kwestii (zarówno obiektywnych, jak i związanych ze społecznym obrazem tej profesji) stanowi o jej odrębnym charakterze:

- wymaga znacznego zaangażowania oraz szczególnej odpowiedzialności za innych ludzi ${ }^{22}$,

- aktywność w tym zawodzie poprzedza długi okres kształcenia i przygotowania do pełnienia obowiązków zawodowych (dzięki kształceniu uzyskuje się wiedzę i kompetencje potwierdzone państwowym egzaminem - por. przypis 10 we wstępie);

- profesja ta jest wysoce specjalistyczna, a cała grupa zawodowa składa się z wielu różnych i osobnych specjalności lekarskich;

- praca wykonywana przez lekarzy jest potrzebna każdemu człowiekowi - każdy w swoim życiu wielokrotnie styka się z lekarzami i korzysta z ich pomocy;

- rola lekarza ma bardzo silny etos w kulturze polskiej (jest to część szerszego etosu inteligenckiego),

21 Borkowska A., Czerw A., Psychologiczny portret zawodu lekarza, w: Walkowiak R., Lewandowski R. (red.), Wspótczesne wyzwania strukturalne i menedżerskie w ochronie zdrowia. Problematyka zasobów i przeksztatceń, Wydawnictwo OWSzliZ im. prof. T. Kotarbińskiego, Olsztyn 2010, s. 17.

${ }^{22}$ Praca w zawodzie lekarza należy do profesji obciążających pod względem emocjonalnym. Wpływ ma na to przede wszystkim stykanie się na co dzień z cierpieniem innych ludzi i odpowiedzialność za nich. Równie wyczerpująca może być konieczność radzenia sobie z emocjami pacjentów (nierzadko intensywnie przez nich odczuwanymi i wyrażanymi). 
- pomimo nierzadkich konfliktów społecznych z udziałem lekarzy (zarówno jednostek, jak i całych grup) zawód ten nieodmiennie cieszy się wysokim prestiżem społecznym ${ }^{23} \mathrm{i}$ w sondażach utrzymuje się w czołówce zawodów wybieranych, jako najbardziej atrakcyjny dla własnych dzieci ${ }^{24}$.

W tabeli 12 zostały przedstawione specyficzne cechy lekarzy, które w sposób istotny statystycznie różnią grupę lekarzy od przedstawicieli innych zawodów ${ }^{25}$. Zaprezentowane szerokie spektrum cech charakterystycznych dla lekarzy skonfrontowane $\mathrm{z}$ wynikami badań własnych autorki, pozwala na sformułowanie wniosku, że wyzwanie stojące przed współczesnymi podmiotami opieki zdrowotnej, jakim jest próba pogodzenia podejścia stricte medycznego (lekarz wypełniając swoje obowiązki zawodowe, kieruje się chęcią pomocy innemu człowiekowi, zaangażowaniem i odpowiedzialnością za zdrowie i życie chorego) z rynkowym (lekarz-profesjonalista dysponując wiedzą medyczną, informacjami na temat sposobu finansowania określonych procedur medycznych, dostępem do systemu eWUŚ, działa zgodnie z rachunkiem ekonomicznym i filozofią marketingu $)^{26}$ jest możliwe do realizacji. Przykłady funkcjonowania znacznej części prywatnych gabinetów stomatologicznych potwierdzają ten wniosek - oba filary: medyczny i rynkowy mogą pozostawać z sobą w symbiozie, dając zadowalające efekty na obu płaszczyznach.

\footnotetext{
${ }^{23}$ Zawód lekarza od lat należy do czołówki zawodów prestiżowych - w 2009 r. zajął piąte miejsce w rankingu (jego miejsce w rankingu powoli ale systematycznie spada). w: Prestiż zawodów. Komunikat z badań, CBOS, Warszawa 2009, www.cbos.pl; za: Borkowska A., Czerw A., Psychologiczny ... op. cit., s. 19.

${ }^{24}$ W badaniach CBOS $22 \%$ respondentów pytanych o upragniony zawód dla córki wskazało na zawód lekarza, w przypadku upragnionego zawodu dla syna - 13\% respondentów. w: Aspiracje zawodowe Polaków. Komunikat z badań, CBOS, Warszawa 2009, www.cbos.pl; za: Borkowska A., Czerw A., Psychologiczny ... op. cit., s. 19. Z badań własnych wynika, że: 18,3\% dzieci dentystów pracuje jako dentyści. Więcej na ten temat w punkcie 4.2. tego rozdziału).

${ }^{25}$ Są to wyniki badań A. Borkowskiej i A. Czerw pozyskanych w trakcie realizacji projektu „Zainteresowania zawodowe i strategie funkcjonowania w zawodach z misją społeczną". W przeprowadzonych badaniach dokonano pomiaru wielu zmiennych psychologicznych, warunkujących funkcjonowanie w zawodzie lekarza. Ze względu na szerokie spektrum badań i ciekawe poznawczo - z perspektywy niniejszej pracy - wyniki, autorka zdecydowała się przywołać je w całości (by na ich tle przedstawić wyniki badań własnych). W grupie diagnozowanych zmiennych znalazły się: 1) zainteresowania zawodowe, 2) style myślenia i działania, 3) inteligencja emocjonalna, 4) optymizm, wartości i motywy pracy, 5) poczucie misji, 6) satysfakcja z pracy. Wybór tych zmiennych podyktowany został założeniami autorek o wpływie wewnętrznych cech człowieka na jakość jego funkcjonowania w zawodach z misją społeczną. por. Borkowska A., Czerw A., Psychologiczny ... op. cit., s. 25. ${ }^{26}$ Stanowisko takie jest prezentowane w literaturze m. in. przez I. Rudawską, A. Borkowską, A. Czerw, H. Mruka, K. Rogozińskiego, A. Frączkiewicz-Wronkę.
} 
Tabela 12. Wybrane charakterystyki lekarzy

\begin{tabular}{|c|c|c|}
\hline $\begin{array}{c}\text { Obszar } \\
\text { badania }\end{array}$ & $\begin{array}{c}\text { Zmienna } \\
\text { psychologiczna }\end{array}$ & Charakterystyka lekarzy \\
\hline \multirow[t]{4}{*}{$\begin{array}{l}\text { Zainteresowania } \\
\text { zawodowe }\end{array}$} & $\begin{array}{l}\text { Zainteresowania } \\
\text { badawcze }\end{array}$ & $\begin{array}{l}\text { Wysoki poziom zainteresowań związanych z wnikliwym } \\
\text { i otwartym spojrzeniem na rzeczywistość oraz z wysokim } \\
\text { potencjałem umysłowym świadczy o analityczności, umiejęt- } \\
\text { ności poprawnego wnioskowania oraz poprawnym formułowa- } \\
\text { niu problemów abstrakcyjnych i umiejętności ich rozwiązły- } \\
\text { wania. Lekarze wydają się być grupą bez większych trudności } \\
\text { przyswajającą wiedzę, co może być efektem ciągłego dokształ- } \\
\text { cania się i wskazuje na pozytywny efekt tego treningu. }\end{array}$ \\
\hline & $\begin{array}{l}\text { Zainteresowania } \\
\text { handlowe }\end{array}$ & $\begin{array}{l}\text { Lekarze wydają się być relatywnie mało zainteresowani komer- } \\
\text { cyjnym aspektem swojej aktywności (co - w pewnym zakresie } \\
\text { - potwierdzają wyniki badan przedstawione w punkcie 1.2.2 } \\
\text { niniejszego rozdziału). Nie skupiają uwagi, a zapewne tak-że } \\
\text { nie preferują wymiernego aspektu relacji społecznych, nie } \\
\text { traktują swoich kontaktów (w tym kontaktów z pacjentami), } \\
\text { jako transakcji handlowych (pacjenci są osobami, które trzeba } \\
\text { diagnozować, leczyć, a nie zawierać z nimi transakcje). }\end{array}$ \\
\hline & $\begin{array}{l}\text { Zainteresowania } \\
\text { komunikacyjne } \\
\text { i społeczne }\end{array}$ & $\begin{array}{l}\text { Lekarze uzyskali niższe wyniki, niż pozostałe grupy zawodo- } \\
\text { we w zakresie umiejętności komunikacyjnych (przeprowadzo- } \\
\text { ne badania potwierdzają, że lekarze - we własnej ocenie - dys- } \\
\text { ponują umiejętnościami z tego zakresu na stosunkowo niskim } \\
\text { poziomie - punkt 3.3.1. tego rozdziału). Niski stopień zaintere- } \\
\text { sowania relacjami (równorzędnymi i partnerskimi), przestrze- } \\
\text { gania konwencji i zasad społecznych oraz jakości komuniko- } \\
\text { wania się z innymi (tzw. kompetencje miękkie) wpływa na } \\
\text { kształtowanie relacji lekarz - pacjent (na - często - } \\
\text { niesatysfakcjonującym pacjentów poziomie). Wyniki badań } \\
\text { własnych nie potwierdzają tego spostrzeżenia - por. rozdział IV. }\end{array}$ \\
\hline & $\begin{array}{l}\text { Skala aprobaty } \\
\text { społecznej }\end{array}$ & $\begin{array}{l}\text { Lekarze mają szczególną potrzebę uznania społecznego i ak- } \\
\text { ceptacji ze strony innych. Z tego powodu deklarują się jako } \\
\text { osoby szczególnie uczciwe i wierne zasadom (co może być } \\
\text { nieświadomym zaspokojeniem tych potrzeb). } \\
\text { Z badań własnych autorki wynika, że uznanie w oczach rodziny } \\
\text { i znajomych nie jest głównym motywatorem (choć dla przeszło } \\
50 \% \text { respondentów jest to ważny lub bardzo ważny czynnik - } \\
\text { por. tabela 18). }\end{array}$ \\
\hline \multirow[t]{2}{*}{$\begin{array}{l}\text { Style myślenia i } \\
\text { działania }\end{array}$} & \begin{tabular}{|l|} 
Skala \\
reagowania na \\
niepewność
\end{tabular} & $\begin{array}{l}\text { Lekarze nie boją się podejmować ryzyka, nie boją się zmian } \\
\text { i są na nie otwarci (co jest wyrazem ich przedsiębiorczych } \\
\text { postaw). }\end{array}$ \\
\hline & $\begin{array}{l}\text { Planowanie i } \\
\text { analiza } \\
\text { strategiczna }\end{array}$ & $\begin{array}{l}\text { Lekarze charakteryzują się skłonnością do planowania działań } \\
\text { przynoszących rezultaty nawet w odległej przyszłości. Takie } \\
\text { planowanie związane jest z tendencją do przeprowadzania } \\
\text { analiz własnych działań i efektów (sukcesów i porażek) pod } \\
\text { względem konieczności i sensowności wykorzystania własnego } \\
\text { czasu czy energii. } \\
\text { Z badań własnych autorki wynika, że planowanie nie jest mocną } \\
\text { stroną lekarzy dentystów (choć wyżej oceniają oni swoje } \\
\text { umiejętności planowania długoterminowego, niż krótkotermi- } \\
\text { nowego - por. tabela } 18 \text { i 20). }\end{array}$ \\
\hline
\end{tabular}




\begin{tabular}{|c|c|c|}
\hline & Analityczność & $\begin{array}{l}\text { Lekarze posiadają umiejętność analizowania silnych i słabych } \\
\text { stron problemów oraz oceny szans ich rozwiązania. } \\
\text { Znalazło to potwierdzenie w badaniach własnych autorki - por. } \\
\text { tabela } 18 \text { i } 20 .\end{array}$ \\
\hline & $\begin{array}{l}\text { Globalność } \\
\text { myślenia }\end{array}$ & $\begin{array}{l}\text { Lekarze mają łatwość przewidywania następstw zdarzeń zarówno } \\
\text { w perspektywie osobistej, jak i globalnej. Myślą szerokimi } \\
\text { kategoriami i łatwo przyjmują szeroką perspektywę w ocenie } \\
\text { podejmowanych zadań i dążeniu do celów. Pozwala im to na } \\
\text { świadomą i pełną refleksję nad tym, co robią, co trzeba zrobić } \\
\text { i jak to wykonać skutecznie. }\end{array}$ \\
\hline & Kreatywność & $\begin{array}{l}\text { Lekarzy charakteryzuje skłonność do poszukiwania nowych } \\
\text { możliwości działania i generowania nowych, niestereotypowych } \\
\text { rozwiązań. Co dowodzi, że lekarze są innowacyjni, a więc } \\
\text { potwierdza ich przedsiębiorcze umiejętności. }\end{array}$ \\
\hline & $\begin{array}{l}\text { Orientacja na } \\
\text { działanie }\end{array}$ & $\begin{array}{l}\text { Lekarzy charakteryzuje umiejętność podejmowania inicjatywy } \\
\text { w działaniu oraz wytrzymałość i długotrwałe utrzymywanie } \\
\text { takiego zachowania, a także uporczywe dążenie do realizowania } \\
\text { podjętych działań. } \\
\text { Postawa proaktywna jest kolejnym czynnikiem potwierdza- } \\
\text { jącym przedsiębiorczość wielu lekarzy. }\end{array}$ \\
\hline $\begin{array}{l}\text { Poziom } \\
\text { optymizmu }^{\text {a }}\end{array}$ & Optymizm & $\begin{array}{l}\text { Lekarze cechują się średnim poziomem optymizmu. Są przeko- } \\
\text { nani, że podejmowane przez nich działania powinny być } \\
\text { skuteczne, dlatego nie mają problemów z podtrzymywaniem } \\
\text { swojego dążenia do celu, nawet w sytuacjach, gdy pojawiają się } \\
\text { nieprzewidziane przeszkody. Zdarza się im oczekiwać pozytyw- } \\
\text { nych zdarzeń niezależnie od podejmowanych działań własnych, } \\
\text { czy też braku takich działań. }\end{array}$ \\
\hline \multirow[t]{2}{*}{$\begin{array}{l}\text { Poziom } \\
\text { inteligencji } \\
\text { emocjonalnej }\end{array}$} & $\begin{array}{l}\text { Inteligencja } \\
\text { emocjonalna }\end{array}$ & $\begin{array}{l}\text { Lekarzy charakteryzuje wysoki poziom inteligencji emocjonalnej. } \\
\text { Pod względem umiejętności rozpoznawania emocji własnych oraz } \\
\text { innych ludzi, a także pod względem zdolności do rozumienia } \\
\text { uczuć i współodczuwania z innymi ludźmi lekarze nie różnią się } \\
\text { od innych badanych. }\end{array}$ \\
\hline & $\begin{array}{l}\text { Wiedza } \\
\text { emocjonalna i } \\
\text { regulacja } \\
\text { nastroju }\end{array}$ & $\begin{array}{l}\text { Lekarze są wnikliwi i analityczni w obszarze własnych i cudzych } \\
\text { emocji. Posiadają umiejętność inicjowania i podtrzymywania } \\
\text { pozytywnego nastroju, co stanowi ważny mechanizm radzenia } \\
\text { sobie z rzeczywistością (przede wszystkim społeczną). } \\
\text { Potwierdzają to wyniki badań własnych - por. tabela } 19 \text { i } 21 \text {. }\end{array}$ \\
\hline \multirow[t]{3}{*}{$\begin{array}{l}\text { Wartości i } \\
\text { motywy } \\
\text { realizowane w } \\
\text { pracy }\end{array}$} & $\begin{array}{l}\text { Samorealizacja } \\
\text { poprzez pracę }\end{array}$ & $\begin{array}{l}\text { Lekarze od własnej aktywności zawodowej oczekują i starają się } \\
\text { realizować przede wszystkim osiągnięcie własnych planów, } \\
\text { niezależność, a także zapewnić sobie istotne i rozwijające } \\
\text { wyzwania. Realizują etos profesjonalisty otwartego na nowe } \\
\text { wyzwania, inwestującego we własne kompetencje i ceniącego } \\
\text { własną niezależność w pracy. Potwierdzają to wyniki badań } \\
\text { własnych - por. tabela 8 i 10. }\end{array}$ \\
\hline & $\begin{array}{l}\text { Bezpieczeństwo } \\
\text { i sprawiedliwość } \\
\text { w pracy }\end{array}$ & $\begin{array}{l}\text { Lekarze przez dążenie do bezpieczeństwa, godności i egalita- } \\
\text { ryzmu realizują etos związany z rolą inteligenta, dążącego } \\
\text { w imieniu społeczeństwa do równości i sprawiedliwości. }\end{array}$ \\
\hline & prospołeczność & $\begin{array}{l}\text { Nastawienie na innych, na wspólnotę i dbanie o nią, jest } \\
\text { przeciętne (podczas gdy - dość powszechnie - oczekuje się od } \\
\text { lekarzy zaangażowania w sprawy społeczne i działania } \\
\text { prowspólnotowe). }\end{array}$ \\
\hline
\end{tabular}




\begin{tabular}{|l|l|l|}
\hline $\begin{array}{l}\text { Poziom misji } \\
\text { realizowanej w } \\
\text { pracy }\end{array}$ & $\begin{array}{l}\text { Użyteczność } \\
\text { społeczna }\end{array}$ & $\begin{array}{l}\text { Lekarze są głęboko przekonani o istotnym zaporzebowaniu } \\
\text { społecznym na swoją pracę, wiedzę, że bez niej jakość życia ludzi } \\
\text { znacznie by się pogorszyła. }\end{array}$ \\
\cline { 2 - 3 } & $\begin{array}{l}\text { Uznanie } \\
\text { społeczne }\end{array}$ & $\begin{array}{l}\text { Lekarze uważają swój zawód za godny szacunku i prestiżowy (co } \\
\text { niewątpliwie pociąga za sobą oczekiwanie od innych uznania } \\
\text { owego prestiżu, choć wśród intrapersonalnych motywów wyboru } \\
\text { zawodu czynnik ten zajął ostatnie miejsce - por. tabela 8 i 10). }\end{array}$ \\
\hline
\end{tabular}

Źródło: Borkowska A., Czerw A., Psychologiczny ... op. cit., s. 22 i nast.

${ }^{a}$ Różnice między lekarzami a innymi grupami zawodowymi w tym zakresie były nieistotne statystycznie.

${ }^{\mathrm{b}}$ Optymizm rozumiany jest $\mathrm{w}$ badaniu jako czynnik silnie motywujący do podejmowania wszelkich działań. Pełni szczególną rolę w sytuacjach trudnych, problemowych. Jego poziom jest istotny w codziennym funkcjonowaniu każdego człowieka, a w relacji lekarz - pacjent wpływa na budowanie poprawnych i/lub satysfakcjonujących dla obu stron (szczególnie dla pacjenta i jego rodziny) wrażeń.

c Jest to zaskakujący wynik, zważywszy, iż rozumienie wewnętrznych stanów pacjenta i trafne rozpoznawanie jego emocji jest istotne w relacji lekarz - pacjent. Wynik ten Autorki badania próbują zinterpretować w kategoriach rodzaju samoobrony przed jeszcze większym obciążeniem emocjonalnym, wynikającym z empatii z cierpiącymi pacjentami, z którymi lekarze stykają się na co dzień. Za: Borkowska A., Czerw A., Psychologiczny... op. cit., s. 25.

\subsection{POSTAWY PRZEDSIĘBIORCZE}

Podmiot powinien być proaktywny w stosunku do nowych możliwości (tak wewnętrznych, jak i płynących z zewnątrz), jeśli chce pozostać konkurencyjny. Aktywność rynkową podmiotów można utożsamiać z zachowaniem przedsiębiorczym (związanym ze strategiczną orientacją, angażowaniem się w okazje, efektywnym wykorzystywaniem zasobów, kontrolą nad posiadanymi środkami, bezpośrednim kontaktem $\mathrm{z}$ otoczeniem podmiotu ${ }^{27}$ ) osób odpowiedzialnych za ich funkcjonowanie (zgodnie $\mathrm{z}$ przyjętą we wstępie zasadą personalizmu). Dlatego jedno z podstawowych pytań w przedsiębiorczości dotyczy osobowości przedsiębiorcy.

Znaczna część literatury ${ }^{28}$ wskazuje na związki przedsiębiorczości z pewnymi szczególnymi cechami, takimi jak: potrzeba sukcesu, wiara w siebie, optymizm czy skłonność do ryzyka, również umiejętność podejmowania decyzji w warunkach niepewności i stresu, elastyczność, umiejętność kierowania ludźmi i wzbu-

\footnotetext{
${ }^{27}$ Piasecki B., Ekonomika i zarządzanie mała firma, PWN, Warszawa-Łódź 1998, s. 24.

${ }^{28}$ Por. Alvarez S.A., Barney J.B., Discovery and Creation: Alternative Theories of Entrepreneurial Action, "Strategic Entrepreneurship Journal", 2007, vol. 1; Nicolaou N., Shane S., Cherkas L., Spector T.D., The Influence of Sensation Seeking in the Heritability of Entrepreneurship, "Strategic Entrepreneurship Journal", 2008 vol. 2; Alvarez S.A., Introduction to Creativity, Imagination, and Opportunities, "Strategic Entrepreneurship Journal", 2008 vol. 2; Shalley Ch.E., Perry-Smith J.E., The Emergence of Team Creative cognition: the Role of Diverse Outside Ties, Sociocognitive Network Centrality, and Team Evolution, "Strategic Entrepreneurship Journal" 2008, vol. 2; Sudoł S., Przedsiębiorczość - jej pojmowanie, typy i czynniki ja ksztattujące, „Problemy Zarządzania", 2008 nr 2.
} 
dzania w nich entuzjazmu (potrzebna jest charyzma i zdolności przywódcze). Przedsiębiorczości sprzyja ambicja, wysoki poziom aspiracji, potrzeba osiągnięć, pracowitość, wytrwałość, skłonność do podejmowania działań rozsądnie ryzykownych, samodzielność myślenia i kreatywność. Zgodnie ze stanowiskiem M. Romanowskiej ${ }^{29}$ - zwolenniczki tezy o wrodzonych cechach przedsiębiorczych - można wyposażyć człowieka przejawiającego przedstawione cechy w wiedzę niezbędną, aby profesjonalnie wykorzystywał ten dar.

$\mathrm{Z}$ drugiej strony badania nad przedsiębiorczością wykazują, że nie jest to cecha wrodzona $^{30}$, choć w najnowszych badaniach nad przedsiębiorczością pojawił się czynnik genetyczny ${ }^{31}$. Pomimo, że pewnych działań można się nauczyć, to przedsiębiorczość nie ma uniwersalnego wzorca, gdyż ma charakter sytuacyjny $^{32}$ (zależy zarówno od sytuacji rynkowej ${ }^{33}$, stanu wewnątrz przedsiębiorstwa, jak i pewnych cech przedsiębiorcy). Spojrzenie na pojęcie „przedsiębiorczość” wymaga uwzględnienia powiązań, jakie zachodzą pomiędzy pojmowaniem tej kategorii jako cechy (T. Kotarbiński, T. Pszczółkowski) i jako funkcji (J.B. Say, P.F. Drucker, J.A. Schumpeter), co pozwala na określenie pewnego zbioru zachowań, mających na celu tworzenie i realizowanie przedsięwzięć, umożliwiających osiągnięcie określonych celów (zarówno stricte biznesowych, jak i nie-

29 Romanowska M., Ksztattowanie postaw przedsiębiorczych na studiach ekonomicznych, w: Dietl J., Sapijaszka Z. (red.), Studia ekonomiczne - czy tylko wiedza i umiejętności?, Fundacja Edukacji Przedsiębiorczości, Łódź 2008, s. 151.

${ }^{30}$ Koźmiński A.K., Zarządzanie $w$ warunkach niepewności, Wydawnictwo Naukowe PWN, Warszawa 2004, s. 163.

${ }^{31}$ Wynika z nich, że wpływa on na prawdopodobieństwo stania się przedsiębiorcą poprzez pewien szczególny mechanizm - ,poszukiwanie wrażeń”. Zwiększa on prawdopodobieństwo tego, że ludzie angażują się w różnorodne ryzykowne inicjatywy ( $\mathrm{w}$ tym $\mathrm{m}$. in. stają się przedsiębiorcami). Badania trwają i postępują w kierunku poszukiwania genów odpowiedzialnych za dziedziczenie skłonności do poszukiwania wrażeń (naukowcy dochodzą w ten sposób do poziomu reakcji fizykochemicznych, które dokonują się poza świadomością człowieka).

Por. Nicolaou N., Shane S., Cherkas L., Spector T.D., The Influence ... op. cit.; Hofstede G., Hofstede G.J., Kultury i organizacje, PWE, Warszawa 2007, s. 16 i nast.

${ }^{32} \mathrm{~W}$ psychologii przedsiębiorczość jest traktowana jako zbiór cech jednostki, będący wynikiem interakcji jaka zachodzi między wrodzonymi cechami osobowości a stymulacją pochodzącą z otoczenia. Od strony posiadanych właściwości osoby przedsiębiorcze charakteryzują się ponadprzeciętną motywacją osiągnięć, wewnętrznym umiejscowieniem poczucia kontroli, otwartością na doświadczenia oraz silną potrzebą niezależności. Można im również przypisać dużą sprawność w kontaktach społecznych (posiadają umiejętność rozpoznania oczekiwań partnerów interakcji oraz łatwość dostosowywania się do zmieniających się warunków otoczenia - na poziomie deklaratywnym jest to cecha lekarzy dentystów - por. wyniki badania I i III). Ponadto osoby przedsiębiorcze są gotowe ponosić odpowiedzialność za skutki swojego działania. Zarówno sukcesy, jak i porażki przypisują sobie, a nie okolicznościom zewnętrznym; zwiększa to ich satysfakcję w momencie osiągania pozytywnych wyników i mobilizuje do poprawy w sytuacji niepowodzenia.

Por. Zalaśkiewicz T., Przedsiębiorczość ... op. cit., s. 308 i nast.

${ }^{33}$ Wpływa na nią środowisko (kulturowe, społeczne, polityczne, ekonomiczne), sprzyjające rozwojowi cech przedsiębiorczych. 
ekonomicznych). U. Ornarowicz twierdzi, że w naukach o zarządzaniu „być przedsiębiorczym" oznacza ${ }^{34}$ : posiadanie pomysłu, idei, umiejętności rozpoznania możliwości jej realizacji wraz z formułowaniem na tej podstawie celów i zadań, a także umiejętności przewidywania wyników i oceniania szans wykonania zaplanowanych działań. Dominuje zatem prakseologiczne podejście do przedsiębiorcy, jako tego, który stawia cele oraz dba o ich sprawną realizację.

Przyjmując, że działania i postawy przedsiębiorcze stanowią zasób niematerialny przedsiębiorstwa (kapitał społeczny), to można opisać je językiem kompetencji ${ }^{35}$. Synteza definicji kompetencji ${ }^{36}$ przedstawionych przez prekursorów tego pojęcia - D. McClellanda czy R. Boyatzis'a - pozwala na postrzeganie kompetencji, jako wewnętrznej charakterystyki jednostki, która pozostaje w związku przyczynowo-skutkowym z opartymi na określonych kryteriach wyjątkowymi osiągnięciami w danej sytuacji ${ }^{37}$. G. Hamel i C.K. Prahalad argumentują, iż z punktu widzenia efektywności w przyszłości, dla organizacji szczególnie ważne jest skoncentrowanie się na rozwoju tych kompetencji, które prowadzą do wykształcenia nowych usług ${ }^{38}$ oraz wyróżniającej obsługi, nabierającej w podmiotach usługowych szczególnego znaczenia.

Pomimo że kompetencje definiowane są w różny sposób, można przyjąć następujące postulaty $^{39}$ :

- podstawą kompetencji są: wiedza (w przypadku lekarzy - tak stricte zawodowa, jak i związana z - szeroko pojętymi - ekonomicznymi aspektami prowadzenia gabinetu), umiejętności (zarówno medyczne, jak z obszaru komunikacji interpersonalnej, radzenia sobie ze stresem, zarządzania czasem itp.), doświadczenie (tak zawodowe, jak i życiowe) i postawa; należy jednak mieć na uwadze fakt, że same cechy danej osoby nie przynoszą wartoś-

\footnotetext{
${ }^{34}$ Ornarowicz U., Menedżer XXI wieku, Oficyna Wydawnicza SGH, Warszawa 2008, s. 132 i nast.

${ }^{35}$ E.Gummesson twierdzi, że podstawowym komponentem usługi profesjonalnej są zasoby organizacji usługowej (por. Gummesson E., Models of Professional Services Marketing, Stockholm 1979, s. 86). Termin zasoby w literaturze anglojęzycznej często jest zastępowany określeniem: kompetencje (competency). Są one kategorią obejmującą wszystkie czynniki wpływające na zdolność do realizacji określonego świadczenia. Mogą być rozpatrywane na poziomie indywidualnym - osoby profesjonalisty i na poziomie organizacyjnym - opisując kompetencje gabinetu.

${ }^{36} \mathrm{G}$. Filipowicz zwrócił uwagę na fakt, że pojęcie kompetencje zawsze występuje w liczbie mnogiej - niezwykle trudno wyizolować pojedynczą kompetencję i traktować ją jako właściwość całkowicie oderwaną od innych kompetencji, niezależną; dlatego rozpatruje się wiązki, zbiory kompetencji w odniesieniu do określonych zawodów. Por. Filipowicz G., Zarządzanie kompetencjami zawodowymi, PWE, Warszawa 2004, s. 36 i nast.

${ }^{37}$ Por. Spencer L.M., Spencer S.M., Competence at work: models for superior performance, John Wiley\&Sons Inc., Nowy Jork 1993.

${ }^{38}$ Hamel G., Prahalad C.K., Competing for the Future, "Harvard Business Review", 1994 lipiecsierpień, s. 122 i nast.

${ }^{39}$ Kazibudzki P., Kompetencje przedsiębiorcy-menedżera. Ideologia kształtowania, Wydawnictwo My Book, Szczecin 2007, s. 46.
} 
ci dodanej, o ile nie zostaną wykorzystane do sprawnego i przynoszącego wymierne efekty działania;

- identyfikacja kompetencji zależy od przyjętej (istotnej z punktu widzenia specyfiki przedsiębiorstwa - branża, wielkość, forma własności, styl zarządzania itp.) koncepcji struktury obszarów kompetencji (na którą wpływa szeroko rozumiane - otoczenie biznesu i w związku z tym oprócz kompetencji uniwersalnych występują kompetencje specjalistyczne).

W potocznym rozumieniu przedsiębiorczość oznacza pomysłowość, rzutkość, zaradność $^{40}$. Sens tej kompetencji obejmuje takie elementarne składniki jak: aktywność, dynamizm, ekspansywność, wyobraźnia i zdolność przewidywania, intuicja. Przykłady innych zestawów kompetencji, zaproponowane przez różnych autorów, przestawione są w tabeli 13.

Tabela 13. Cechy charakterystyczne dla postaw przedsiębiorczych w świetle wybranych pozycji literatury

\begin{tabular}{|c|c|}
\hline Autor & Grupa cech charakterystycznych dla postawy przedsiębiorczej \\
\hline J.A.Schumpeter ${ }^{\mathrm{a}}$ & $\begin{array}{l}\text { aktywność, pracowitość, zaradność, zorganizowanie, odwaga, inicjatywa, } \\
\text { skłonność do podejmowania ryzyka, kreatywność, innowacyjność, determinacja, } \\
\text { konsekwencja, cierpliwość, przebojowość, łatwość w nawiązywaniu kontaktów, } \\
\text { inspirowanie innych }\end{array}$ \\
\hline P.F. Drucker ${ }^{b}$ & $\begin{array}{l}\text { nastawienie na wynik, potrzeba osiągnięć, elastyczność, spostrzegawczość, } \\
\text { determinacja, konsekwencja, }\end{array}$ \\
\hline B. Piasecki ${ }^{\mathrm{C}}$ & $\begin{array}{l}\text { aktywność, pracowitość, zaradność, zorganizowanie, odwaga, inicjatywa, } \\
\text { skłonność do podejmowania ryzyka, nastawienie na wynik, potrzeba osiągnięć, } \\
\text { elastyczność, spostrzegawczość, kreatywność, innowacyjność, determinacja, } \\
\text { konsekwencja, przebojowość, łatwość w nawiązywaniu kontaktów, }\end{array}$ \\
\hline M. Kets de Vries ${ }^{\mathrm{d}}$ & $\begin{array}{l}\text { odwaga, inicjatywa, skłonność do podejmowania ryzyka, aktywność, } \\
\text { pracowitość, zaradność, zorganizowanie, opanowanie, asertywność, elastyczność, } \\
\text { spostrzegawczość, kreatywność, innowacyjność, przebojowość, łatwość w nawią- } \\
\text { zywaniu kontaktów, inspirowanie innych }\end{array}$ \\
\hline P. McGowan ${ }^{\mathrm{e}}$ & opanowanie, asertywność, determinacja, konsekwencja, cierpliwość \\
\hline W.Dobrołowicz ${ }^{\mathrm{f}}$ & $\begin{array}{l}\text { aktywność, pracowitość, zaradność, zorganizowanie, odwaga, inicjatywa, } \\
\text { skłonność do podejmowania ryzyka, nastawienie na wynik, potrzeba osiągnięć, } \\
\text { determinacja, konsekwencja }\end{array}$ \\
\hline A. Pocztowski ${ }^{\mathrm{g}}$ & $\begin{array}{l}\text { Elementy emocjonalne (uczucia, nastroje), elementy poznawcze (wiedza, } \\
\text { umiejętności, opinie, informacje), behawioralne (predyspozycje do pewnych } \\
\text { zachowań w określonych sytuacjach) }\end{array}$ \\
\hline
\end{tabular}

Źródło: opracowanie własne na podstawie: ${ }^{a}$ Schumpeter J.A., Teoria ... op. cit., s. $104 ;{ }^{b}$ Drucker P.F., Innowacje ... op. cit., s. 36; ${ }^{\mathrm{c}}$ Piasecki B., Ekonomika ... op. cit.; ${ }^{\mathrm{d}}$ Pieluch T., Uwarunkowania rozwoju przedsiębiorczości, w: Przedsiębiorczość i innowacyjność matych średnich przedsiębiorstw - wyzwania

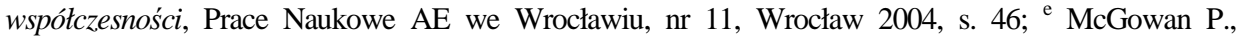
Innowacja i przedsiębiorczość wnętrza, w: Stewart D. (red.), Praktyka kierowania, OWE, Warszawa

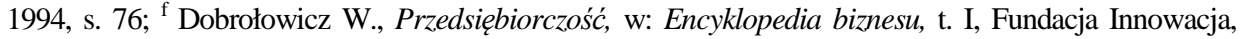
Warszawa 1995; ${ }^{\mathrm{g}}$ Juchnowicz M. (red.), Kapitat ludzki a ksztattowanie przedsiębiorczości, Poltext, Warszawa 2004, s. 232.

${ }^{40}$ Por. Sobol E. (red.), Nowy stownik ... op. cit., s. 769. 
W badaniu II lekarze dentyści zostali poproszeni o wybranie z listy cech (zaczerpniętych z powyższej tabeli) najlepiej ich opisujące i na tej podstawie zostały wyłonione trzy typy postaw, których prorynkowe działania były później analizowane. Wyniki badań są przedstawione w ostatnim rozdziale.

Podsumowując, można wskazać, że w kwestii kompetencji przedsiębiorców istnieją różne nurty koncepcyjne ${ }^{41}$ :

- podejście behawioralne ${ }^{42}$ (reprezentowali je m. in. D. McClelland, C. Woodruffe) nawiązuje do charakterystyki samego przedsiębiorcy; na kompetencje składają się głównie cechy osobowościowe przedsiębiorcy ${ }^{43}$ i różnego rodzaju umiejętności, które uwidaczniają się $\mathrm{w}$ jego zachowaniach;

- podejście funkcyjne (przedstawiane m. in. przez R. Boyatzis'a, G. Chandlera) wywodzi kompetencje z funkcji pełnionych przez przedsiębiorców i menedżerów;

- podejście akademickie (reprezentowane przez np. E. Chella, T. McEvansa) wiąże kompetencje z różnymi obszarami wiedzy i umiejętności;

- podejście zintegrowane (reprezentowane $\mathrm{m}$. in. przez T. Laua, K. Chana, T. Mana) preferuje wszechstronne podejście do kompetencji, do których zalicza podstawowe obszary charakterystyczne (cechy osobowościowe, umiejętności i wiedzę), które są dzielone na mniejsze zbiory, a te na tzw. wiązki kompetencji.

Obok kompetencji - w funkcjonowaniu podmiotów rynkowych - szczególnego znaczenia nabiera intuicja, rozumiana jako wiedza, która powstała w rezultacie wewnętrznej wnikliwości i rozumieniu występujących zjawisk, zachodzących procesów itp. Intuicję rozpatruje się niekiedy jako drugą stronę innowacji ${ }^{44}$, która wewnątrz przedsiębiorstwa jest celową próbą uzyskania korzyści ze zmiany. Tak rozumiana intuicja pojawia się $\mathrm{w}$ działaniach rynkowych dentystów i staje się Schumpeterowską determinantą bycia przedsiębiorcą.

\subsection{INTUICJA W DZIAŁANIACH RYNKOWYCH}

Blisko trzydzieści lat temu o intuicji w pracy lekarza Z. Marek pisał tak: „Sądzę, że jeszcze daleka od zakończenia jest dyskusja nad tym, czy medycyna jest sztuką, sztuką i nauką zarazem, czy też tylko nauką. Nie wydaje się jednak,

\footnotetext{
${ }^{41}$ Kazibudzki P., Wzorzec kompetencji ... op. cit., s. 31 i nast.

${ }^{42}$ I tego rodzaju podejście został przedstawione w niniejszej pracy (por. punkt 3.3. tego rozdziału).

${ }^{43}$ Cechy osobowościowe uwzględnia się szczególnie w badaniach mających na celu ocenę zdolności przedsiębiorczych osób, które założyły lub zamierzają założyć przedsiębiorstwo.

${ }^{44}$ Krzakiewicz K., Kognitywne kompetencje menedżerów w aspekcie zarządzania strategicznego, „Zeszyty Naukowe UE w Poznaniu” nr 189, Poznań 2011, s. 111.
} 
aby rozstrzygnięcie tego cokolwiek wyjaśniło. Wśród osiągnięć lekarza nie można przecież dostatecznie precyzyjnie oddzielić tego, co zależało wyłącznie od jego wiedzy i kwalifikacji zawodowej, a co od intuicji. Czy intuicja jest cechą charakteru i intelektu daną tylko niektórym z lekarzy, czy też sublimacją doświadczenia lekarskiego, wspomaganego sprawnym intelektem i usłużną pamięcią? Pytanie nie wydaje się wymagać jednoznacznej odpowiedzi. Za pewnik wolno przyjąć, że lepsze wyniki osiąga lekarz, który umie nawiązać kontakt ze swoim pacjentem, mobilizując jego aktywne nastawienie do leczenia, aniżeli lekarz dysponujący nawet szerszą wiedzą zawodową, ale pozbawiony tych pożądanych cech intelektu i charakteru. ${ }^{, 45}$ Dziś wobec rosnącej złożoności i turbulentności otoczenia podmiotów rynkowych oraz wywoływanej tym niepewności $\mathrm{w}$ ich funkcjonowaniu należy podkreślić rolę intuicji w kształtowaniu bazowego, kognitywnego stylu współczesnego dentysty (zarówno w jego roli pierwotnej tj. lekarza, jak i - wynikającej ze zmian społeczno-gospodarczych - przedsiębiorcy). Jest to widoczne w podejściu zaproponowanym przez M. Polanyi'ego, który zwrócił uwagę na znaczenie nieuświadomionych predyspozycji i stwierdził: „(...) my wiemy więcej, niż mówimy, że wiemy" "t6 (tym samym wyróżnił wiedzę jawną i ukrytą, którą rozpatruje się w procesie organizacyjnego uczenia się). Intuicja pozwala dentyście poruszać się między różnymi rozwiązaniami problemu w świadomym lub nieświadomym kognitywnym procesie. Połączenie dokładnej i niepewnej informacji pozwala na sformułowanie bardziej racjonalnych i efektywnych decyzji. W praktyce ,dokładna informacja” jest najczęściej związana z aspektem stricte medycznym funkcjonowania gabinetu (to stosunkowo bezpieczny grunt, po którym porusza się lekarz), choć oczywiście nieznane lekarzowi objawy chorobowe pacjenta należą do kategorii ,niepewnej informacji”. Z drugiej strony „niepewna informacja” odnosi się do rynkowych aspektów funkcjonowania gabinetu np. polityka cen, system obsługi, aktywność na portalach społecznościowych (za które odpowiada przedsiębiorca). Stomatolog-przedsiębiorca wykorzystuje intuicję, gdy zetknie się z niedostateczną liczbą faktów i ze złożonymi alternatywami lub kiedy chce uprościć daną sytuację decyzyjną. ${ }^{47}$ Myślenie intuicyjne związane jest ściśle z uczeniem się, gdyż jest umiejętnością dostosowywania się do zmian m. in. dzięki wyciąganiu wniosków z wcześniejszych doświadczeń.

Pomimo, że badacze doszli do zgodności co do znaczenia intuicji w funkcjonowaniu uczestników rynku, to w różny sposób rozpatrują jej rolę w procesie po-

\footnotetext{
${ }^{45}$ Marek Z., Niektóre przyczyny konfliktów między pacjentem a lekarzem, w: Kielanowski T. (red.), Etyka i deontologia ... op. cit., s. 169.

${ }^{46}$ Polanyi M., The Tacit Dimension, Anchor Books, Nowy Jork 1967.

${ }^{47}$ Krzakiewicz K., Kognitywne kompetencje ... op. cit., s. 110.
} 
dejmowania decyzji. ${ }^{48}$ Przykłady zróżnicowanego podejścia do pojęcia „intuicja" przedstawione są w tabeli 14.

Tabela 14. Pojęcie ,intuicja” w świetle wybranych pozycji literatury

\begin{tabular}{|c|c|}
\hline Autor & $\begin{array}{r}\text { Proponowana definicja } \\
\end{array}$ \\
\hline $\begin{array}{l}\text { R.C.Blattberg, } \\
\text { S.J. Hoch }\end{array}$ & $\begin{array}{l}\text { Krytyczne spojrzenie na określoną postać danych i sytuacji, tzn. formułowanie } \\
\text { sądów, kiedy normatywna analiza jest bezsilna. }\end{array}$ \\
\hline $\begin{array}{l}\text { K.S. Bowers, } \\
\text { G. Regher, } \\
\text { C. Balthazard, } \\
\text { K. Parker }\end{array}$ & $\begin{array}{l}\text { Nieuświadomione, o charakterze a priori, postrzeganie relacji (ich układu, } \\
\text { wagi, struktury), co nakierowuje myślenie i proces analizy na przeczucia lub } \\
\text { hipotezę, dotyczącą charakteru tych relacji. }\end{array}$ \\
\hline $\begin{array}{l}\text { J.L. Showers, } \\
\text { L. Chakrin }\end{array}$ & $\begin{array}{l}\text { Zdolność do holistycznej oceny sytuacji i syntezy wszystkich dostępnych } \\
\text { sposobów działań. }\end{array}$ \\
\hline M. Swink ${ }^{\mathrm{d}}$ & $\begin{array}{l}\text { Wrodzona zdolność do rozwiązywania problemów dzięki wyobrażeniom } \\
\text { dotyczącym przyczyn danej sytuacji. }\end{array}$ \\
\hline K.E. Weick ${ }^{\mathrm{e}}$ & $\begin{array}{l}\text { Skoncentrowana profesjonalna umiejętność, która pozwala na znalezienie } \\
\text { odpowiedzi bez dokładnego zrozumienia wszystkich prowadzących do niej } \\
\text { kroków. }\end{array}$ \\
\hline
\end{tabular}

Źródło: opracowanie własne na podstawie: ${ }^{a}$ Blattberg R.C., Hoch S.J., Database Models and Managerial Intuition, „Management Science“, $1990 \mathrm{nr}$ 36(8), s. 887 i nast.; b Bowers K.S., Regher G., Balthazard C., Parker K., Intuition in the Context of Discovery, "Cognitive Psychology", $1990 \mathrm{nr}$ 22, s. 72 i nast.; " Showers J.L., Chakrin L., Reducing Uncollectable Revenue from Residential Telephone Customers, Interfaces, $1991 \mathrm{nr} 11$, s. 21 i nast.; ${ }^{\mathrm{d}}$ Swink M., The Influence of User Charakteristics on Performance in a Logistic DSS Application, "Decision Science", $1995 \mathrm{nr}$ 26(4), s. 503 i nast.; ${ }^{e}$ Weick K.E., Making Sense of the Organization, Black Well, Oxford 2001 s. 88.

Uwzględniając definicje zaproponowane przez M. Swinka i K.E. Weick’a, można sformułować pogląd, że wielu dentystów (dobrze widoczne jest to w badaniu I w badanej podgrupie o stażu krótszym niż 15 lat oraz w badaniu III) cechuje wrodzona zdolność do rozwiązywania rynkowych problemów (dzięki wyobrażeniom dotyczącym przyczyn określonych sytuacji), a także (i to dotyczy całej badanej grupy) umiejętność znajdowania rozwiązań na pojawiające problemy bez dokładnego zrozumienia wszystkich elementów wpływających na kształtowanie danego zjawiska, czy stanu ekonomicznego. $\mathrm{Z}$ tego względu można przyjąć, że dzięki intuicji (pozwalającej na uzyskiwanie korzyści ze zmian w funkcjonowaniu podmiotu np. w zakresie obsługi pacjentów) dentyści są Schumeterowskimi przedsiębiorcami. Warto jednak podkreślić, że rosnące wymagania rynku mogą przyczynić się (i przyczyniają - w wielu klinikach stomatologicznych proces ten już nastąpił) do zmierzchu tylko intuicyjnego zarządzania na rzecz bardziej świadomego stosowania instrumentów konkurowania w funkcjonowaniu gabinetów stomatologicznych (m. in. do wykorzystywania możliwości, jakie daje zarządzanie wraz z planowaniem długookresowym ${ }^{49}$ ).

\footnotetext{
${ }^{48}$ Ibidem s. 110.

${ }^{49}$ Autorzy książki Zarządzanie strategiczne w opiece zdrowotnej uważają, że długookresowe planowanie oparte jest na założeniu, że dany podmiot będzie w przyszłości oferować te same usługi (np. stomatologiczne), jak w momencie planowania. Podczas gdy planowanie strategiczne oparte jest na
} 


\section{BIZNESOWA ROLA DENTYSTY W PRYWATNYM GABINECIE STOMATOLOGICZNYM}

\subsection{ARCHETYPOWE ROLE STOMATOLOGA}

K. Rogoziński wskazuje, że „kierujący małą organizacją usługową [tu: gabinetem stomatologicznym - przypis A. B-P.] musi występować w poczwórnej roli:

- jako przedsiębiorca,

- jako usługodawca-wykonawca,

- jako marketer,

- jako menedżer zarządzający personelem zestrojonym z cyklem obsługi odbiorcy" ${ }^{\prime 5}$.

Powyższe rozróżnienie pozwala - wg K. Rogozińskiego - na pokazanie istoty organizacji usługowej - komplementarności funkcjonalnej. I w dalszej części pracy zostania podjęta próba uchwycenia tej komplementarności, dzięki omówieniu ról (działań i umiejętności z nimi związanymi), jakie lekarz dentysta pełni w gabinecie.

Przedsiębiorca vs menedżer - to odmienne, archetypowe role, jakie prezentują zarządzający. Role, które pełni (może pełnić) również stomatolog, jako właściciel gabinetu, przełożony personelu, dyrektor kliniki stomatologicznej. Problem różnic między tymi pojęciami jest podnoszony w literaturze już od czasu ekonomii klasycznej, ale w latach 70. XX w. nabrał nowego wymiaru ${ }^{51}$. I choć czasami pojęcia te są używane zamiennie dla określenia osoby „stojącej na czele” przedsiębiorstwa, to można wskazać czynniki bardzo wyraźnie je różnicujące (por. tabela 15).

\footnotetext{
założeniu, że kierownictwo musi okresowo ocenić, czy oferta przedsiębiorstwa powinna pozostać w dotychczasowej formie, czy powinna zostać zastąpiona innym rodzajem działalności. Tym samym w gabinetach stomatologicznych realizowane planowanie długookresowe.

Por. Swayne L.E., Duncan W.J., Ginter P.M., Zarzadzanie ... op. cit., s. 8

${ }^{50}$ Rogoziński K., Kompetencje menedżera organizacji ustugowej, w: Rogoziński K., Panasiuk A. (red.), Zarzadzanie organizacjami ustugowymi, Zeszyty Naukowe nr 229, Wydawnictwo UE w Poznaniu, Poznań 2012, s. 21.

${ }^{51}$ Por. m. in. Zaleznik A., Managers and Leaders. Are They Different?, "Harvard Business Review", 2004 nr 1 HBR OnPoint8334 by Harvard Business School Publishing, s. 74 i nast.; Malach-Pines A., Sadeh A., Dvir D., Yafe-Yanai O., Entrepreneurs and Managers: Similar Yet Different, "The International Journal of Organizational Analysis, 2002, nr 2, s. 172 i nast.; Gupta V., MacMillan I., Surie G., Entrepreneurial Leadership: Developing and Measuring a Cross-cultural Construct, "Journal of Business Venturing", 2004, vol. 19, s. 241 i nast.
} 
Tabela 15. Cechy charakterystyczne dla przedsiębiorcy i menedżera

\begin{tabular}{|l|l|lr|}
\hline \multicolumn{2}{|c|}{ Cechy przedsiębiorcy } & \multicolumn{3}{|c|}{ Cechy menedżera } \\
\hline $\begin{array}{l}\text { Intuicyjna umiejętność rozpoznawania możli- } \\
\text { wości rynkowych (czasami weryfikowana bada- } \\
\text { niami rynku) }\end{array}$ & Rozpoznawanie możliwości rynkowych \\
\hline $\begin{array}{l}\text { Zdolność inspirowania poprzez tworzenie wizji. } \\
\text { Zdolność przewodzenia i manipulowania }\end{array}$ & $\begin{array}{l}\text { Zdolność przewodzenia, nadzorowania } \\
\text { i manipulowania }\end{array}$ \\
\hline $\begin{array}{l}\text { Zdolność postrzegania całości (podejście } \\
\text { holistyczne) }\end{array}$ & Uzdolnienia analityczne & marketingowe \\
\hline Entuzjazm, obniżony próg krytycyzmu & $\begin{array}{l}\text { Zrównoważenie emocjonalne, } \\
\text { proporcji }\end{array}$ & poczucie \\
\hline $\begin{array}{l}\text { Zdolność odraczania korzyści na dalszy } \\
\text { horyzont czasowy }\end{array}$ & $\begin{array}{l}\text { Chęć uzyskania pozycji kierowniczej } \\
\text { i korzyści materialnych w stosunkowo } \\
\text { krótkim czasie }\end{array}$ \\
\hline $\begin{array}{l}\text { Rozległa wiedza o wytwarzanym produkcie } \\
\text { (postawa hobbysty) }\end{array}$ & $\begin{array}{l}\text { Ograniczona wiedza o } \\
\text { produkcie }\end{array}$ \\
\hline Niechęć do pracy ,u innych” & $\begin{array}{l}\text { Gotowość podejmowania pracy kierowniczej } \\
\text { w różnych organizacjach }\end{array}$ \\
\hline
\end{tabular}

Źródło: Wilk A., Przedsiębiorczość i przywództwo, „Przegląd Organizacji”, 2006, nr 8, s. 7.

Logika menedżerska zakłada osiągnięcie z góry zdefiniowanego celu za pomocą wyznaczonych do tego środków, jest to procedura zgodna $\mathrm{z}$ istotą planowania - z przeświadczeniem, że przewidywanie przyszłości pozwala ją lepiej kontrolować. Natomiast logika przedsiębiorcza wychodzi od dostępnych zasobów i dostosowuje do nich osiągalne cele.

Przyglądając się cechom zawartym $\mathrm{w}$ tabeli 15 , można $\mathrm{z}$ całą pewnością powiedzieć, że te, które charakteryzują przedsiębiorcę są bliższe sylwetce większości badanych stomatologów (np. lekarze dentyści raczej nie rozpoznają możliwości rynkowych poprzez badania marketingowe, mają szeroką wiedzę o oferowanych usługach, raczej nie są zainteresowani podejmowaniem pracy kierowniczej w różnych organizacjach).

A. Mayo i N. Nohria w swoich badaniach nad zarządzaniem i przywództwem $\mathrm{w}$ amerykańskich firmach $\mathrm{w} \mathrm{XX} w{ }^{52}$ wyodrębnili trzy archetypy ról zarząd-

52 B. Czarniawska-Joerges i R. Wolff zwracają uwagę na cykliczność zainteresowania praktyki i teorii poszczególnymi rolami i tłumaczą ją zmiennymi warunkami gospodarki, które stawiają przed przedsiębiorstwami zmieniające się wyzwania. Uważają oni, że role te odzwierciedlają pragnienia i obawy dzielone przez organizacyjne społeczności i są symbolami, które pomagają przypisywać znaczenie wydarzeniom zachodzącym w organizacji. Pytanie: „Czym różnią się menedżerowie i liderzy?" postawił w latach 70. XX w. - profesor Harvard Business School - A. Zaleznik. Dekadę później spopularyzował się inny tok badań teoretycznych, dotyczący rozróżnienia menedżerów i przedsiębiorców, zarówno w kontekście małych, rosnących przedsiębiorstw, jak i dużych korporacji. Współcześnie - w kontekście trwającego od kilku lat kryzysu - można obserwować debatę nad relacją między rolami przedsiębiorcy i lidera.

Por. Czarniawska-Joerges B., Wolff R., Leaders, Managers, Entrepreneurs on and off the Organizational Stage, "Organization Studies", 1991, nr 4, s. 530; Zaleznik A., Managers and leaders... op. cit.; Malach-Pines A., Sadeh A., Dvir D., Yafe-Yanai O., Entrepreneurs ... op. cit.; 
czych: przedsiębiorcy, lidera i menedżera ${ }^{53}$. Skupili się na istocie zarządzania i przywództwa w kolejnych okresach minionego wieku, identyfikując role główne i stwierdzili, że wszystkie były niezbędne dla utrzymania żywiołowości amerykańskiej gospodarki - przedsiębiorcy zakładali nowe firmy, menedżerowie rozwijali i optymalizowali je, a liderzy transformowali w krytycznych momentach. Przyglądając się temu rozróżnieniu, można powiedzieć z całą pewnością, że dwie pierwsze role na pewno dotyczą większości polskich stomatologów: otwierają prywatne (indywidualne lub grupowe) praktyki lekarskie, które są podmiotami typu profit; zajmują się ich codziennym funkcjonowaniem i w wielu przypadkach doprowadzają do rozwoju. Niektórych stomatologów można określić również mianem liderów - dotyczy to tych dentystów, których gabinety/kliniki przeszły głębokie zmiany ${ }^{54}$ związane np. ze zmianą rynku działania (np. w ujęciu geograficznym lub profilu demograficznym obsługiwanych pacjentów).

Problematyka ekonomicznych ról pełnionych przez lekarzy w podmiotach medycznych nie jest nowa, np. już w latach 80. XX w. T. Brzeziński pisał, że „lekarz współczesny powinien czuć się odpowiedzialny za całokształt działania zespołu, w którym pracuje, za jego stronę organizacyjną [dentysta jako menedżer - przypis A.B-P], czy czynności lecznicze lekarza, za pracę pielęgnacyjną pielęgniarki, za kulturę bycia rejestratorki i sumienność salowej [dentysta jako przełożony - przypis A.B-P] - wszystko to bowiem składa się na środowisko, w którym przebywa chory i wszystko ma bezpośredni wpływ na wyniki postępowania leczniczego" "55; dzisiaj powiedzielibyśmy również na jakość obsługi, jakość relacji pacjent - personel podmiotu medycznego, satysfakcję pacjenta z kontaktu z usługodawcą. T. Brzeziński widział menedżerską rolę lekarza i jako przełożonego, ze zrozumiałych względów w latach 80 . ubiegłego stulecia nie mógł się odnosić do roli lekarza, jako właściciela gabinetu (choć nawet

Utsch A., Rauch A., Rotfhfuss R., Frese M., Who becomes a small scale entrepreneur in a postsocialist environment: On the difference between entrepreneurs and managers in East Germany, "Journal of Small Business Management", 1999 vol. 37, s. 3; Stewart W.H., Watson W.E., Carland J.C., Carland J.W., A Proclivity for entrepreneurship: A comparison of entrepreneurs, small business owners, and corporate managers, "Journal of Business Venturing", 1998 vol. 14; Busenitz L.W., Barney J.B., Differences between entrepreneurs and managers in large organizations: Biases and heuristics in strategic decision-making, "Journal of Business Venturing" 1997, vol. 12; Gupta V., MacMillan I.C., Surie G., Entrepreneurial ... op. cit.; Fernald Jr. L.W., Solomon G.T., Tarabishy A., A new paradigm: Entrepreneurial leadership, "Southern Business Review", Spring 2005, nr 2.

${ }^{53}$ Mayo A., Nohria N., Zeitgeist Leadership, „Harvard Business Review”, 2005 nr 10, s. 48.

${ }^{54}$ Do niedawna stosunkowo stabilna sytuacja na rynku usług stomatologicznych właściwie nie dawał podstaw do działań przypisanych liderom, ale od połowy $2011 \mathrm{r}$. w wielu gabinetach widać zmniejszenie liczby - szczególnie nowych - pacjentów (ze wskazań stomatologów wynika, że od 20 nawet do 50\%), dlatego należy przypuszczać, że i tę rolę w najbliższej przyszłości lekarze zaczną pełnić w szerszym zakresie w gabinetach (chcąc uniknąc skutków zmniejszenia liczby nabywców ich usług).

${ }^{55}$ Brzeziński T., Tradycyjne zasady ... op. cit., s. 44 i nast. 
wówczas funkcjonowały prywatne gabinety - głównie stomatologiczne właśnie). Poniżej zostaną krótko scharakteryzowane role, jakie pełni (może pełnić) dentysta w gabinecie stomatologicznym; rola: przedsiębiorcy, menedżera i przełożonego.

\subsubsection{DENTYSTA JAKO PRZEDSIECBIORCA}

Pamiętając o rozważaniach zawartych w pierwszym rozdziale, można spojrzeć na stomatologa - przedsiębiorcę ${ }^{56}$, jako na osobę, która - obok chęci osiągania korzyści ekonomicznych - dąży do realizacji osobistych celów (płaszczyzna behawioralna obejmuje chęć osiągania sukcesów i satysfakcji z pracy, niezależności, rozwoju zawodowego oraz wyznawany przez dentystę system wartości). Dentysta jako przedsiębiorca ma reagować na zmiany (lub uprzedzać je), co wymaga od niego nie tylko umiejętności dostrzegania ich ${ }^{57}$, ale również umiejętności reagowania na nie - podjęcia działań (np. sferze kontaktów z pacjenttami, czy kierowania personelem), które przyczynią się do utrzymania/poprawy pozycji konkurencyjnej gabinetu na rynku. I jeśli np. będzie odkrywał nowe/ inne sposoby zaspokajania potrzeb pacjentów (dostarczania im wartości), to jego postawę można utożsamiać z innowacyjnością.

Z punktu widzenia zasobowej perspektywy przedsiębiorczości dentysta (kapitał ludzki) jest kluczowym zasobem gabinetu, jako przedsiębiorstwa zarobkującego, ze względu na fakt podejmowania przez niego rozstrzygających decyzji co do funkcjonowania podmiotu na rynku ${ }^{58}$. Jego pomysły $\mathrm{i}$ intencje formułują sposób działania gabinetu i są czynnikiem rozwoju gabinetu, jako przedsięwzięcia biznesowego ${ }^{59}$.

Indywidualna przedsiębiorczość stomatologa (związana z rozpoczęciem działalności gospodarczej w ramach wykonywanego wolnego zawodu) jest związana $\mathrm{z}$ następującymi atrybutami ${ }^{60}$ :

\footnotetext{
${ }^{56}$ Lekarz dentysta jest przedsiębiorcą w świetle art. 43 Kodeksu Cywilnego (Ustawa Kodeks Cywilny z dnia 23 kwietnia 1964 r., Dz. U. nr 16, poz. 93 z późn. zm., a także art. 4, ust. 2 Ustawy o swobodzie działalności gospodarczej z dnia 2 lipca 2004 r. (Dz. U. nr 173, poz. 1807 z późn. zm.). ${ }^{57} \mathrm{np}$. dentyści o Sylwetce B z badania II posiadali ją w niewielkim zakresie, podczas gdy ci o Sylwetce A charakteryzowali się Kirznerowską czujnością.

${ }^{58}$ Ucbasaran D., Wright M., Westhead P., A longitudinal study of habitual entrepreneurs: starter and acquirers, "Entrepreneurship and Regional Development", 2003 vol. 15, s. 207 i nast.

${ }^{59}$ Bird B., Implementing Entrepreneurial Ideas: The Case for Intention, „Academy of Management Review", 1988 vol. 13, nr 3, s. 442.

${ }^{60}$ Por. Karlof B., Strategia biznesu. Koncepcje i modele. Przewodnik, Biblioteka Menedżera i Bankowca, Warszawa 1992, s. 76; Gabryszak R., Kontrowersje wokót przedsiębiorczości, „Ekonomika i Organizacja Przedsiębiorstwa”, 2005 nr 6, s. 103; Kwiatkowski S., Przedsiębiorczość intelektualna, Wydawnictwo Naukowe PWN, Warszawa 2000, s. 8.
} 
- indywidualna własność, z którą wiąże się całkowita identyfikacja stomatologa (właściciela gabinetu) z działaniami i dążeniem do sukcesu gabinetu, jako podmiotu rynkowego;

- lekarz dentysta dąży do celu, podejmując samodzielnie decyzje;

- zarządzanie gabinetem ma charakter kompleksowy (decyzje podejmowane przez stomatologa dotyczą zarówno sfery medycznej, jak i pozamedycznej);

- lekarz ma wysokie oczekiwania wobec siebie (w przypadku, gdy zatrudnia personel pomocniczy również wobec niego);

- lekarz dentysta podejmuje ryzyko na własny rachunek (np. wprowadzając w gabinecie rozwiązania ekonomiczne, których efektów nie jest w stanie do końca przewidzieć), pragnie widzieć rezultaty swych działań (np. w obszarze relacji interpersonalnych na płaszczyźnie: dentysta - pacjent i dentysta personel gabinetu);

- w gabinecie jest mało zbiurokratyzowany system kontroli.

Lekarz dentysta, podejmując się wykonywania zawodu we własnym gabinecie, staje się przedsiębiorcą (założycielem przedsiębiorstwa). I w trakcie prowadzonej działalności nie przestaje nim być, wprost przeciwnie - zaczyna pełnić inne funkcje. Wykorzystując idee różnych szkół myślenia o przedsiębiorczości, można wskazać, że ${ }^{61}$ :

- lekarz ma intuicyjną zdolność do przedsiębiorczych zachowań, co pozwala mu odróżnić się od innych (szkoła ,wielkiej osoby”),

- dentysta ma unikatowy system wartości, który nim kieruje i popycha w kierunku zaspokajania własnych potrzeb (szkoła psychologiczna),

- lekarz zachowuje się w sposób przedsiębiorczy (nawet nie będąc właścicielem gabinetu), tzn. jego działania są innowacyjne (szkoła klasyczna),

- dentysta jest organizatorem i zarządcą zasobów i procesów zachodzących w gabinecie (szkoła menedżerska),

- stomatolog bardziej efektywnie będzie realizował cele, jeśli będzie polegał na innych, a nie działał w pojedynkę (szkoła liderów).

Dentysta zaczyna funkcjonować, jako podmiot rynkowy, który chce pozyskać nabywców swoich usług, dobrych dostawców, podwykonawców, odpowiednich pracowników itp.; jako menedżer, jako przełożony. I wypełnianie tych ról staje się swoistym wyzwaniem dla lekarza.

${ }^{61}$ Bławat F., Przedsiębiorca $w$ teorii przedsiębiorczości i praktyce matych firm, Gdańskie Towarzystwo Naukowe, Gdańsk 2003, s. 27 
Ekonomia czerpie z aksjologii ${ }^{62}$, akcentując, by prowadzenie działalności gospodarczej nie skupiało się tylko na maksymalizacji zysku, ale było działaniem rozumnym i odpowiedzialnym. Zakładała to nie tylko etyczna myśl antycznych filozofów, ale również etyka cnoty w poglądach J. Dietla i W. Gasparskiego: „bycie istotą ludzką wiąże się z życiem w społeczności, rozwojem cnót i nabywaniem umiejętności potrzebnych do ludzkiego bytowania $\mathrm{z}$ innymi, a ludzki umysł określa podstawowe cnoty potrzebne do wspólnego życia." ${ }^{63}$ Wyzwaniem dla dentysty, jako przedsiębiorcy, staje się pogodzenie obszaru biznesowego funkcjonowania gabinetu ze specyfiką medyczną i ograniczeniami z niej wynikającymi (przedmiotem zainteresowania jest zdrowie i życie człowieka). Czy dziś „sama” etyka lekarska wystarczyłaby do dobrego poprowadzenia gabinetu? W sferze stricte medycznej na pewno tak - pacjent czułby się szanowany, otoczony opieką i dobrze leczony. Niemniej jednak wydaje się, że - szczególnie w podmiotach typu profit - działania z zakresu etyki lekarskiej można „wzmocnić” działaniami z zakresu etyki biznesu ${ }^{64}$, która podpowiada, jak dentysta-przedsiębiorca ma godzić myślenie ekonomiczne $\mathrm{z}$ myśleniem o dobru drugiego człowieka oraz jak spełniać swoją powinność „,cłłowieka gos-

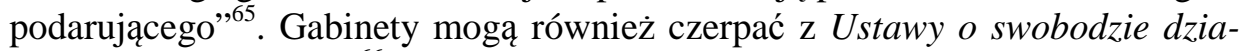
talności gospodarczej ${ }^{66}$, której art.17 mówi, że „,przedsiębiorca wykonuje działalność gospodarczą na zasadach uczciwej konkurencji, poszanowania dobrych obyczajów oraz słusznych interesów konsumentów”, a art. 18 - „przedsiębiorca obowiązany jest spełniać określone przepisami prawa warunki wykonywania działalności gospodarczej w szczególności dotyczące ochrony przed

\footnotetext{
${ }^{62}$ Jej przedstawiciele wskazują, że wartości stanowią bardzo ważny składnik osobowości człowieka - są wyznacznikami sposobu postępowania celowego, czynnikami weryfikacji i ustalania preferencji pojawiających się celów. Por. Brzozowski P., Skala Wartości. Polska adaptacja Value Survey M.Rokeacha, COMPIS, Warszawa 1996, s. 4; Kałuszyński M., Myślenie etyczne, Zakład Narodowy im. Ossolińskich, Wrocław 1980, s. 18.

${ }^{63}$ Dietl J., Gasparski W. (red.), Etyka biznesu, Wydawnictwo Naukowe PWN, Warszawa 1999, s. 93 i nast.

${ }^{64}$ Etyka w biznesie koncentruje się na postępowaniu człowieka, udziela odpowiedzi na pytanie: Jak postępować?; formułując zasady, jakich należy przestrzegać: 1) zasadę moralności opartą na prawdzie (zasady moralne tworzą bazę dla oceny poprawności pozostałych zasad, dobre postępowanie to dobry interes, przedsiębiorstwa winny się troszczyć o stworzenie wizerunku moralnej poprawności); 2) zasadę prawości - prawość w biznesie zaczyna się „,na samej górze”; 3) zasadę uczciwości oznacza to, że ludzie uczą się i tworzą hierarchie wartości obserwując to, co robią inni; 4) zasadę roztropności, rzetelności, niezdolności do oszustw; 5) zasadę szacunku i poszanowania cudzej własności, pracy, wiedzy, umiejętności; 6) zasadę odpowiedzialności i sumienia; 7) zasadę unikania konfliktu interesów oraz korupcji; 8) zasadę pogłębiania odpowiedzialności prawnej i moralnej; 9) zasadę życzliwości; 10) zasadę skuteczności, ale nie za wszelką cenę.

Por. Chryssides G.D., Kaler J.H., Wprowadzenie do etyki biznesu, PWN, Warszawa 1999.

${ }^{65}$ Por. Klimczak B., Lewicka-Strzałecka A. (red.), Etyka i ekonomia, Wyd. PTE, Warszawa 2007.

${ }^{66}$ Ustawa o swobodzie działalności gospodarczej z 2 lipca 2004 r. Dz. U. nr 173, poz. 1807 z późn. $\mathrm{zm}$.
} 
zagrożeniem życia, zdrowia ludzkiego i moralności publicznej, a także ochrony środowiska".

Konkludując, można stwierdzić, że uwarunkowania i intencje współczesnej przedsiębiorczości obejmują przede wszystkim:

- motywacje osiągnięć i samorealizacyjne (zarówno w obszarze stricte medycznym, jak i biznesowym - co pokazują wyniki badania I zawarte w tym i kolejnym rozdziale oraz badania II - w V rozdziale);

- aktywność intelektualną (rozumianą jako skłonność do zgłaszania/realizacji własnych propozycji zmian i usprawnień w funkcjonowaniu podmiotu np. w zakresie obsługi nabywcy);

- koszt psychiczny (rozumiany jako ogół frustracji odczuwanych w miejscu pracy, w skrajnej sytuacji prowadzący nawet do wypalenia zawodowego ${ }^{67}$ );

- metody kierowania (ogół działań przełożonego sprzyjających lub przeciwdziałających wykorzystywaniu kwalifikacji, umiejętności i dobrej woli podwładnych w realizacji zadań podmiotu).

W tabelach 18 i 19 przedstawione są wyniki samooceny lekarzy dentystów, a w tabelach 20 i 21 - studentów kierunku lekarsko-dentystycznego w zakresie ich umiejętności intra- i interpersonalnych powiązanych z postawą przedsiębiorczą.

\subsubsection{DENTYSTA JAKO MENEDŻER}

W literaturze można spotkać różne znaczenia pojęcia „,menedżer”, najczęściej odnoszą się one do jego funkcji w organizacji:

- menedżer to osoba trudniąca się zawodowo zarządzaniem firmą lub jej częścią przy wykorzystaniu wiedzy fachowej, metod i technik zarządzania $^{68}$,

${ }^{67} \mathrm{Z}$ badań wynika, że zespół wypalenia zawodowego jest częstą przypadłością lekarzy dentystów. Jest on pochodną następujących czynników: 1) środowiskowych - przede wszystkim będących efektem: a) kontaktu z pacjentami, b) presji czasu (czyli nadmiernej liczby czynności klinicznych do wykonania w zbyt krótkim czasie), c) dodatkowych obowiązków administracyjnych, d) poświęcania energii na poszukiwanie sposobów pozyskiwania większej liczby pacjentów zamiast leczenia; 2) indywidualnych - będących efektem konfrontacji - młodzieńczych - marzeń i oczekiwań z realiami (różnice mentalne, relacyjne sprawiają, że spot-kanie z rzeczywistością staje się początkiem wielu frustracji). Por. Bladowski M., Depresja w środowisku lekarzy stomatologów, cz. I, „As Stomatologii”, $2010 \mathrm{nr}$ 1, s. 8 i nast., Bladowski M., Depresja w środo-wisku lekarzy stomatologów, cz. II. Skale pomiaru depresji, „As Stomatologii”, $2010 \mathrm{nr}$ 2, s. 128 i nast., Bladowski M., Zacharko-Klafft M., Depresja w środowisku lekarzy stomatologów, cz. III. Metody leczenia depresji, „As Stomatologii”, 2010 nr 3, s. 216 i nast. 
- menedżer to osoba upełnomocniona przez właścicieli przedsiębiorstwa do kierowania na bieżąco jego działalnością ${ }^{69}$,

- menedżer to osoba, która odpowiada za kierowanie działaniami prowadzącymi do osiągania celów organizacji, czyli osoba powołana do świadomego, ustawicznego kształtowania organizacji ${ }^{10}$,

- menedżer to autorytet władzy, jest ,profesjonalistą, który posiada umiejętność adaptacji do zmian, rozwiązuje problemy i jest skuteczny w działaniu, cechuje go praktycyzm, racjonalizm i stanowczość" ${ }^{71}$.

Stomatolog nie jest dyplomowanym specjalistą ds. zarządzania, nie jest profesjonalistą trudniącym się zawodowo zarządzaniem gabinetem. Jednak biorąc pod uwagę fakt, że jako właściciel gabinetu staje się niejako automatycznie upełnomocniony do zarządzania jego działalnością, to można określić go mianem menedżera. Również przyjmując za P.F. Druckerem uproszczone podejście do istoty zarządzania ${ }^{72}$, zgodnie z którym „menedżer działa, podejmując decyzje”; a także: ,zarządzanie jest zawsze procesem podejmowania decyzji" można powiedzieć, że lekarz dentysta jest menedżerem w swoim gabinecie. Poszukuje on rozstrzygnięć na wielu płaszczyznach funkcjonowania gabinetu (dążąc do zaspokojenia potrzeb pacjentów i osiągnięcia osobistej satysfakcji oraz korzyści ekonomicznej), np. orientacja marketingowa wymusza udzielanie odpowiedzi na pytania:

- komu będzie oferowana usługa gabinetu? (np. pacjentom prywatnym vs pacjentom, za których płaci NFZ),

- za jaką cenę będą oferowane usługi?,

- jakie działania umożliwiają pozyskanie nowych nabywców? (np. konkurencyjne ceny, poziom obsługi pacjentów, kwalifikacje personelu).

$\mathrm{Z}$ drugiej strony można wskazać pewne ograniczenia w utożsamianiu dentysty $\mathrm{z}$ menedżerem. W tabeli 16 przedstawione są - zaproponowane przez J. Jończyk - różnice w osobowości menedżera i lekarza. Z tego porównania wy-

${ }^{68}$ Borkowska S., Bohdziewicz P. (red.), Menedżer u progu XXI wieku, wyd. WSHE, Łódź 1998, s. 129.

${ }^{69}$ Penc J., Decyzje w zarządzaniu, Wyd. Profesjonalnej Szkoły Biznesu, Kraków 1995.

${ }^{70}$ Stoner J.A., Frejman R.E., Gilbert G.R., Kierowanie, PWE, Warszawa 1999, s. 65.

${ }^{71}$ Drucker P.F., Praktyka zarządzania, Czytelnik, Warszawa-Kraków 1998, s. 157.

${ }^{72}$ Podobne podejście można znaleźć u J. Adaira, wg którego zarządzanie to „,decydowanie o tym, co jest do zrobienia, i wprowadzanie tego w życie" (por. Adair J., Anatomia biznesu. Podejmowanie decyzji. Podstawowa umiejętność w procesie zarzadzania, wyd. Studio EMKA, Warszawa 2001, s. 16), czy J.S. Hamonda i in., którzy mówią, że ,podejmowanie decyzji to najważniejsze zadanie każdego menedżera" (por. Hamond J.S., Keeney R.L., Raiffa H., Myślowe pułapki, które prowadza do ztych decyzji, "Harvard Business Review. Polska", 2005 nr 1, s. 117).

${ }^{73}$ Drucker P.F., Praktyka ... op. cit., s. 376. 
nika, że mentalność lekarza i menedżera są odmienne, co może prowadzić do konfliktów, które mogą być źródłem frustracji czy nawet efektu wypalenia zawodowego).

Tabela 16. Porównanie mentalności (osobowości) menedżera i lekarza

\begin{tabular}{|l|l|l|}
\hline \multicolumn{1}{|c|}{ Cechy/kryteria } & \multicolumn{1}{c|}{ Osobowość menedżera } & \multicolumn{1}{c|}{ Osobowość lekarza } \\
\hline Podstawowa wierność interesom & Organizacji & Pacjenta \\
\hline Odpowiedzialność & Zbiorowa & Osobista \\
\hline Zależność służbowa & Hierarchiczna (pionowa) & Heterarchiczna (pozioma) \\
\hline Ramy czasowe & $\begin{array}{l}\text { Długookresowe } \\
\text { (przyszłość) }\end{array}$ & $\begin{array}{l}\text { Krótkookresowe } \\
\text { (teraźniejszość) }\end{array}$ \\
\hline Sprzężenia zwrotne & Opóźnione, niejasne & $\begin{array}{l}\text { Natychmiastowe, } \\
\text { konkretne }\end{array}$ \\
\hline Tolerancja dla wieloznaczności & Duża & Mała \\
\hline
\end{tabular}

Źródło: Jończyk J., Zarzadzanie zasobami ludzkimi w zakładach opieki zdrowotnej, Difin, Warszawa 2008, s. 55.

W przypadku lekarza dentysty, który jest właścicielem gabinetu i odpowiada za jego funkcjonowanie dochodzi do konieczności znalezienia kompromisu pomiędzy przedstawionym w tabeli 16 odmiennymi postawami. Tym samym dochodzi do ukształtowania specyficznej sytuacji, w której lekarz dentysta jest:

- zorientowany i na pacjenta i na gabinet,

- osobiście odpowiada za sytuację medyczno-ekonomiczną,

- jest przełożonym personelu (zależność pionowa), z którym stara się tworzyć partnerskie stosunki w obsłudze pacjentów (zależność pozioma);

- jako lekarz zorientowany jest na wskazanie pacjentowi planu kompleksowego leczenia (długi okres) oraz optymalną realizację konkretnego świadczenia (krótki okres); a jako menedżer musi myśleć o jednostkowej cenie zabiegu gwarantującej zysk (krótki okres) oraz zarządzaniu relacjami z pacjentami (długi okres).

Pionierzy nauk o zarządzaniu za czynnik sprawczy efektywności organizacji uważali umiejętności menedżerskie. ${ }^{74} \mathrm{Wg}$ R. de Rovera pierwszą definicję umiejętności menedżerskich w historii nowożytnej opracował około 1442 r. zakonnik - Bernardino ze Sieny ${ }^{75}$. W odniesieniu do etyki w biznesie głosił, że handel i prowadzenie działalności gospodarczej nie muszą być grzeszne, bowiem spełniają one istotne funkcje społeczne, o ile przyczyniają się dla dobra

\footnotetext{
${ }^{74}$ Por. Taylor F., The Principles of Scientific Management, Nowy Jork 1911, s. 782 i nast. za: Dobska M., Rogoziński K. (red.), Podstawy zarzadzania zakładem opieki zdrowotnej, Wydawnictwo Naukowe PWN, Warszawa 2008, s. 323.

${ }^{75}$ Jabłoński M., Klasyczne podejścia w identyfikacji kompetencji kierowniczych, „Organizacja i Kierowanie", $2009 \mathrm{nr} 1$, s. 23.
} 
obywateli. Nawoływał do jawności w prowadzeniu działalności gospodarczej, zalecał biznesmenom przechowywanie rachunków i sprawozdań z przeprowadzanych transakcji, tak aby $\mathrm{w}$ razie potrzeby mogli oni udowodnić swoją uczciwość. Określił cechy menedżera, zwracając także uwagę na ówcześnie panujący niedostatek kierowników o odpowiednich zdolnościach. Do kluczowych cech menedżerów zaliczył ${ }^{76}$ :

- wydajność (skuteczność),

- poczucie odpowiedzialności pełnionej przez siebie roli,

- pracowitość,

- zdolność (chęć) ponoszenia ryzyka,

- znajomość warunków i szans rynkowych,

- przywiązywanie dużej wagi do detali, które w prowadzeniu działalności gospodarczej posiadają wiodącą rangę.

W 1959 r. R.A. Gordon i J.E. Howell zidentyfikowali cztery podstawowe grupy umiejętności, mających szczególne znaczenie dla skuteczności pracy kierowniczej, a mianowicie ${ }^{77}$ :

- rozwiązywanie problemów (podejmowanie decyzji, analiza, ocena),

- umiejętności w zakresie aspektów organizacyjnych (przepływy informacji, podział pracy, planowanie, delegowanie, koordynacja),

- intrapersonalne (silna motywacja osobista),

- komunikacyjne (komunikacja werbalna i niewerbalna, słowna i liczbowa, formułowanie myśli, transmitowanie/utrzymywanie/interpretowanie jakościowych i ilościowych informacji i danych).

Kolejni ekonomiści, zajmujący się omawianą problematyką, rozszerzali i/lub modyfikowali klasyfikacje, zgodnie z którymi przedstawiali umiejętności menedżerskie, np. R.L. Katz wskazał na następujące umiejętności ${ }^{78}$ :

- techniczne - zdolność posługiwania się metodami, technikami i wiedzą w wyspecjalizowanej dziedzinie,

- społeczne - zdolność współpracowania z innymi ludźmi, rozumienia ich i motywowania (zarówno indywidualnie, jak i grupowo),

\footnotetext{
${ }^{76}$ De Rover R., San Bernardino of Siena and Saint'Antonio of Florence: The two great economic thinkers of the middle ages, Harvard Graduate School of Business Administration, Baker Library, Boston 1967, s. 13 za: Jabłoński M., Klasyczne podejścia w identyfikacji kompetencji kierowniczych, „Organizacja i kierowanie”, $2009 \mathrm{nr} 1$.

${ }_{77}$ Gordon R.A., Howell J.E., Higher Education for Business, Garland, Nowy Jork 1959, s. 44 i nast.

${ }^{78}$ Stoner J.A., Frejman R.E., Gilbert D.R., Kierowanie... op. cit., s. 33.
} 
- koncepcyjne - zdolność koordynowania i integrowania wszystkich interesów i działań organizacji; wiążą się z postrzeganiem organizacji jako całości, rozumieniem współzależności zachodzących między poszczególnymi jej częściami i przewidywaniem, w jaki sposób zmiana w którejkolwiek jej części wpłynie na całość.

J. Penc ${ }^{79}$, pisząc o kompetencjach menedżerskich, akcentuje następujące obszary: umiejętność podejmowania trafnych decyzji; umiejętność tworzenia przyszłości organizacji; umiejętność współdziałania z ludźmi; umiejętność doskonalenia kultury, wizerunku i reputacji przedsiębiorstwa; umiejętność samodoskonallenia i kreowania kariery.

Z kolei A. Rakowska podkreśla, że kompetencje menedżerskie stanowią swoisty potencjał, którym dysponuje menedżer i obejmują ${ }^{80}$ :

- umiejętności - na które składają się: kierowanie sobą, planowanie i przewidywanie, zarządzanie zmianami, rozwiązywanie problemów i podejmowanie decyzji, umiejętność negocjacji i rozwiązywania konfliktów, budowanie dobrych relacji z innymi ludźmi i motywowanie pracowników;

- wiedzę - obejmującą najnowsze trendy i rozwiązania z zakresu organizacji i zarządzania, dotyczącą możliwości wykorzystania technologii informatycznej;

- osobowość - na którą się składa: chęć i motywacja do uczenia się, otwartość na nowości i gotowość do podejmowania ryzyka, co najmniej przeciętna pewność siebie i energiczność, duża odporność na stres, otwartość na innych ludzi i głoszone przez nich idee, co najmniej przeciętna niezależność od innych oraz elastyczność w myśleniu.

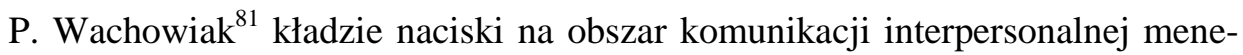
dżera i wskazuje na: umiejętności komunikowania się; umiejętności motywowania pracowników; umiejętności rozwiązywania konfliktów oraz umiejętności negocjacyjne.

Warto podkreślić, że - szeroko pojęte - kompetencje społeczne stanowią istotny zasób osobisty menedżera, zapewniając mu skuteczność w działaniu i umożliw-

\footnotetext{
${ }^{79}$ Penc J., Role i umiejętności menedżerskie. Sekrety sukcesu i kariery, Difin, Warszawa 2005, s. 5 i nast.

80 Por. Rakowska A., Kompetencje kadry kierowniczej we wspótczesnych organizacjach, Wydawnictwo Uniwersytetu Marii Curie-Skłodowskiej, Lublin 2007.

81 Wachowiak P., Profesjonalny menedżer. Umiejętność petnienia ról kierowniczych, Difin, Warszawa 2001, s. 5 i nast.
} 
wiając mu osiąganie założonych celów $\mathrm{w}$ kontaktach $\mathrm{z}$ innymi ludźmi. Do istotnych umiejętności interpersonalnych można zaliczyć m. in. ${ }^{82}$ :

- nawiązywanie i podtrzymywanie kontaktu (z podwładnymi, przełożonymi, odbiorcami usług), które wymagają takiego zachowania jak: ustalenie właściwego dystansu fizycznego (który zapewnia rozmówcom komfort w trakcie rozmowy, a więc nie jest ani zbyt mały, ani zbyt nadmierny), utrzymywanie kontaktu wzrokowego, zwrócenie ciała w kierunku rozmówcy, reagowanie zmianami $\mathrm{W}$ wyrazie twarzy (zmiany mimiki powinny odzwierciedlać rodzaj i intensywność emocji wyrażanych przez rozmówcę);

- właściwe motywowanie - zgodnie z zasadami: motywowania pozytywnego, uwzględniania motywu samorealizacji, różnicowania bodźców, niewielkiej odległości czasowej między zadaniem a wynagrodzeniem, widoczności wpływu pracownika na efekty wykonywanej przez niego pracy (co zapobiega ,rozproszeniu odpowiedzialności”) ${ }^{83}$;

- wywieranie wpływu - dzięki werbalnym ${ }^{84}$ i niewerbalnym ${ }^{85}$ czynnikom; również poddawanie się wpływom innych (działanie to powinno być świadome i zamierzone, aby menedżer nie był postrzegany jako osoba niezdecydowana i pozbawiona pewności siebie ${ }^{86}$ );

- umiejętność tworzenia i prowadzenia zespołu oraz kształtowania atmosfery współpracy, sprzyja temu partnerski styl stosunków interpersonalnych i komunikacji, jasno określone, czytelne zasady funkcjonowania w grupie oraz gotowość menedżera do udzielania podwładnym wsparcia (informacyjnego, instrumentalnego, emocjonalnego) i zachęcanie ich do świadczenia sobie wzajemnej bezinteresownej pomocy w rozwiązywaniu problemów;

\footnotetext{
${ }^{82}$ Matecka M., Głowacka M.D., Jakubek E., Kompetencje spoteczne jako element kompetencji zawodowych menedżerów, w: Lewandowski R., Kautsch M. (red.), Przeksztatcenia strukturalne i społeczne w ochronie zdrowia, seria „Przedsiębiorczość i Zarządzanie”, tom XIII, zeszyt 5, Łódź 2012, s. 242 i nast.

${ }^{83}$ Penc J., Nowoczesne kierowanie ludźmi. Wywieranie wptywu $i$ wspótdziatanie $w$ organizacji, Difin, Warszawa 2007, s. 195 i nast.

${ }^{84}$ Obejmują $\mathrm{m}$. in.: 1) wyrażanie bezpośrednich próśb, pochwał również gróźb (ale w długim okresie okazują się one nieskuteczne); 2) racjonalne przekonywanie (wyrażanie prośby z jednoczesnym odwołaniem się do własnej wiedzy), 3) konsultacje (umożliwienie pracownikowi współudziału w podejmowaniu decyzji). Za: Penc J., Nowoczesne ... op. cit., s. 239 i nast.

${ }^{85}$ Efekt w postaci zmiany zachowania przynoszą także takie strategie, jak: 1) pozytywne i negatywne wzmocnienia (kary i nagrody), 2) modelowanie (służenie własnym przykładem), 3) inspirowanie (wzbudzanie entuzjazmu pracownika w odniesieniu do jakiegoś zadania), 4) wykorzystywanie wsparcia ze strony innych osób (w sytuacjach, gdy menedżer nie ma możliwości bezpośredniego oddziaływania na zachowanie danej osoby). Za: Penc J., Nowoczesne... op. cit., s. 239 i nast.

${ }^{86}$ Borkowski J., Podstawy psychologii społecznej, Dom Wydawniczy ELIPSA, Warszawa 2003, s. 118.
} 
- autoprezentacja rozumiana jako proces kontrolowania własnego wizerunku publicznego $^{87}$, w celu: zyskania sympatii, uchodzenia za osobę kompetentną oraz demonstrowania własnego statusu i władzy ${ }^{88}$.

Umiejętności te zostały włączone do kwestionariuszy ankiet w badaniach I - III.

Z przedstawionych poglądów różnych autorów, zajmujących się problematyką umiejętności kierowniczych, wynika, iż pojęcie „umiejętności” jest pojęciem węższym niż „kompetencje”, a samo nabycie umiejętności nie jest warunkiem wystarczającym do tego, aby menedżer był kompetentny. Dlatego trzeba podkreślić, że o właściwym uruchomieniu potencjału posiadanego przez lekarza dentystę jako menedżera, decydują trzy podstawowe grupy czynników ${ }^{89}$ :

- czynniki wewnętrzne - związane są m.in. z wiekiem podmiotu, kulturą organizacyjną, dostępnością zasobów itp.,

- czynniki zewnętrzne - wiążą się ze środowiskiem, w którym podmiot działa, w szczególności dotyczą różnorodności oferty, stopnia rozwoju i struktury rynku, nasilenia konkurencji, stabilności prawa,

- czynniki osobowe - dotyczą m. in. poziomu aspiracji stomatologów - menedżerów, ich zaangażowania, tolerancji na niepewność itp.

Warto również zauważyć, że choć zarządzanie i przedsiębiorczość rozwijają się niezależnie, to istnieje ścisły związek między nimi. Przedsiębiorczość dotyczy identyfikacji szans i kreowania nowości (w obszarze np. oferty produktowej, sposobu obsługi), które umożliwią poszukiwanie przewagi konkurencyjnej. Natomiast zarządzanie skupia się na podejmowaniu decyzji, umożliwiających zbudowanie przewagi konkurencyjnej w kontekście uwarunkowań otoczenia, w którym podmiot działa. Integracja tych dwóch podejść daje efekt w postaci przedsiębiorczego zarządzania podmiotem rynkowym. Odpowiedzialność za podejmowanie decyzji spoczywa na lekarzu dentyście - to on powinien identyfikować zmiany, inspirować, organizować i wdrażać nowe rozwiązania. I w tym ujęciu widać chyba najlepiej przedsiębiorczo-menedżerską rolę stomatologa w gabinecie.

Zmieniające się uwarunkowania rynku usług stomatologicznych (np. wzrost zainteresowania wyglądem - a nie tylko zdrowiem - zębów u części społeczeństwa, rosnąca liczba lekarzy dentystów, posiadających prawo do wykonywania zawodu) wskazują na potrzebę oparcia zarządzania gabinetem na działaniach zoriantowanych na aktywności wyprzedzającej teraźniejszość. Aby działać sku-

\footnotetext{
${ }^{87}$ Leary M., Wywieranie rażenia na innych. O sztuce autoprezentacji, GWP, Gdańsk 2000, s. 14.

${ }^{88}$ Kenrick D.T., Neuberg S.L., Cialdini R.B., Psychologia społeczna, GWP, Gdańsk 2002, s. 226 i nast.

${ }^{89}$ Finkelstein S., Hambrick D.C., Strategic Leadership; Top Executives and their Effects on Organizations, West Publishing Company, Mineapolis/St. Paul 1996, s. 27.
} 
teczniej dentyści powinni poszukiwać przyszłościowych dla siebie segmentów (np. przez wybór określonej specjalizacji), identyfikować i kreować potrzeby stomatologiczne u swoich pacjentów, wprowadzać nowe sposoby obsługi pacjentów. Wskazuje to na konieczność wprowadzenia zarządzania przedsiębiorczego w gabinetach, aby podmiot był wrażliwy na odkrywanie szerokiej gamy potencjalnych zmian i postrzegał je jako szanse (a nie zagrożenia) oraz właściwie wykorzystywal ${ }^{90}$. Jego inicjatorem i realizatorem powinien być lekarz dentysta, a podstawą zaufanie (na płaszczyźnie lekarz - personel gabinetu, lekarz - pacjenci, personel gabinetu - pacjenci) i sieć więzi społecznych. Wiele gabinetów posiada odpowiedni potencjał do tego, aby zarządzanie przedsiębiorcze stało się w nich rzeczywistością ${ }^{91}$, a w wielu jest już realizowane. Przeprowadzone badania upoważniają do stwierdzenia, że lekarze - głównie w grupie, w której od ukończenia studiów przez dentystę minęło 6-21 lat działają w oparciu o zarządzanie przedsiębiorcze, w odróżnieniu od grupy „więcej niż 21 lat”, w której styl zarządzania jest bliższy administracyjnemu).

Podsumowując rozważania dotyczące roli menedżera, pełnionej przez lekarza dentystę, można przedstawić - prezentowane w literaturze na temat zarządzania w ochronie zdrowia - cechy opisujące dobrego menedżera ${ }^{92}$ :

- cieszy się wśród pracowników powszechnym zaufaniem oraz akceptacją swojego osobistego systemu wartości i wizji rozwoju placówki zdrowotnej,

- potrafi wyprowadzić podmiot z trudnej sytuacji finansowej przez zwiększenie jego produktywności i wprowadzanie innowacji,

- jest wrażliwy na cierpienie chorych,

- identyfikuje szanse i zagrożenia płynące z otoczenia podmiotu oraz formułuje nowe zasady jego działania (uwzględniając jego moce i słabe strony),

- posiada dość szczegółową wiedzę (i stale ją uzupełnia) w zakresie różnych „pozamedycznych” dziedzin związanych z funkcjonowaniem placówki ochrony zdrowia,

- potrafi przeprowadzić ważne dla placówki projekty przez szczeble strategiczne, naukowe, finansowe i polityczne.

\footnotetext{
${ }^{90}$ Bratnicki M., Przedsiębiorczość i dynamika organizacji, „Organizacja i kierowanie”, $2001 \mathrm{nr} 2$, s. 3 i nast.

${ }^{91}$ Przywołując cechy podmiotu, w którym jest realizowane przedsiębiorcze zarządzanie, podane przez H. Bienioka: 1) płaska i elastyczna struktura organizacyjna, 2) nieformalny system kontroli, 3) stopniowy rozwój podmiotu, 4) pracownicy zaangażowani w realizację zadań, 5) planowanie przeplata się z działaniem (tj. plan wyłania się w toku działań); można zauważyć, że tworzą one obraz funkcjonowania wielu gabinetów stomatologicznych. Por. Bieniok H., Zarzadzanie mata firma, Wydawnictwo Akademii Ekonomicznej w Katowicach, Katowice 1996, s. 81 i nast.

${ }_{92}$ Por. Durlik M., Zarzadzanie procesami leczenia w opiece zdrowotnej, w: Trocki M., Nowoczesne zarzadzanie w opiece zdrowotnej, Warszawa 2002.
} 


\subsubsection{DENTYSTA JAKO PRZELOŻONY}

Współczesny przełożony to nie kierownik, którego działania skoncentrowane są głównie na kontrolowaniu podwładnych, to osoba, która poprzez własny przykład, przejawiane zachowania, wywołuje u pracowników emocje, będące podstawą podejmowanych przez nich działan ${ }^{93}$ - to przywódca. Jest „osobą, która wywiera wpływ na zachowania ludzi bez konieczności użycia siły i jest akceptowana w tej roli przez innych" ${ }^{, 4}$. Przykładowe definicje terminu przywództwo, dostępne w literaturze zarządzania, przedstawione są w tabeli 17.

Tabela 17. Pojęcie ,przywództwo" w świetle wybranych pozycji literatury przedmiotu

\begin{tabular}{|l|l|}
\hline \multicolumn{1}{|c|}{ Autor } & \multicolumn{1}{c|}{ Proponowana definicja } \\
\hline $\begin{array}{l}\text { A. Austen-Tynda, } \\
\text { R. Kozłowski, } \\
\text { K. Burda-Świerz }\end{array}$ & $\begin{array}{l}\text { Przywództwo można określić jako pewien atrybut, zestaw cech przypisywanych } \\
\text { jednostkom, które są uznawane za przywódców. }\end{array}$ \\
\hline G.A. Yukl $^{\text {b }}$ & $\begin{array}{l}\text { Przywództwo (leadership) to kierownictwo formalne sprawowane w organizacji, } \\
\text { wynikające z formalnej funkcji (managerial leadership). }\end{array}$ \\
\hline J.C. Maxwell $^{\text {c }}$ & Przywództwo jest zdolnością, która polega na wywieraniu wpływu. \\
\hline A. Wajda ${ }^{\mathrm{d}}$ & $\begin{array}{l}\text { Zawężenie pojęcia ,przywództwo” do procesów grupowych, polegających na } \\
\text { wywieraniu wpływu przez przywódcę na otaczające go zespoły ludzkie, prowadzi } \\
\text { do zdefiniowania go, jako władzy, która na podstawie osobistych cech lidera } \\
\text { prowadzi do dobrowolnego uznania jego zwierzchności. }\end{array}$ \\
\hline R.W. Griffin & $\begin{array}{l}\text { Przywództwo to proces, który polega na użyciu wpływu, bez sięgania po środki } \\
\text { przymusu, z zamiarem kształtowania celów grupy lub organizacji, motywowania } \\
\text { zachowań nastawionych na osiąganie tych celów oraz dopomożenia w } \\
\text { zdefiniowaniu kultury grupy lub organizacji. }\end{array}$ \\
\hline J.P. Kotter & $\begin{array}{l}\text { Przywództwo polega na opracowaniu wizji przyszłości i strategii pozwalających } \\
\text { ją urzeczywistnić oraz jednoczeniu, motywowaniu i inspirowaniu ludzi; a jego } \\
\text { najważniejszym elementem jest umiejętność radzenia sobie w zmiennych } \\
\text { warunkach. }\end{array}$ \\
\hline
\end{tabular}

Źródło: opracowanie własne na podstawie: ${ }^{\text {a }}$ Austen-Tynda A., Kozłowski R., Burda-Świerz K., Istota i znaczenie przywództwa dla kształtowania konkurencyjności jednostki ochrony zdrowia, w: Frączkiewicz-Wronka A., Austen-Tynda A. (red.), Przywództwo w ochronie zdrowia. Idee $i$ instrumenty, Wolters Kluwer Polska sp. z o.o., Warszawa 2009, s. 17. ; ${ }^{\mathrm{b}}$ Yukl G.A., Leadership in Organization, $2^{\text {nd }}$ ed., Nowy Jork 1998.; ${ }^{c}$ Maxwell J.C., Być liderem, Medium, Warszawa 1994, s. 15.; ${ }^{\mathrm{d}}$ Wajda A., Organizacja i zarzadzanie, PWE, Warszawa 2003.; ${ }^{\mathrm{e}}$ Griffin R.W., Podstawy ... op. cit., s. 491 i nast.; ${ }^{\mathrm{f}}$ Kotter J.P., Co ta naprawdę robią przywódcy? Przywództwo, Wydawnictwo Helion, Gliwice 2005.

Lekarz dentysta, jako przywódca, powinien posiadać określone predyspozycje, by tworzyć właściwą atmosferę pracy w gabinecie. W kontekście posiadania

93 Głowacka M.D., Czajka P., Zarzadzanie zasobami ludzkimi w zakładzie opieki zdrowotnej, w: Głowacka M.D., Galicki J., Mojs E. (red.), Zarzadzanie zakładem opieki zdrowotnej, ABC a Wolters Kluwer business, Warszawa 2009, s. 152.

94 Austen-Tynda A., Kozłowski R., Burda-Świerz K., Istota i znaczenie przywództwa dla ksztattowania konkurencyjności jednostki ochrony zdrowia, w: Frączkiewicz-Wronka A., AustenTynda A. (red.), Przywództwo w ochronie zdrowia. Idee i instrumenty, Wolters Kluwer Polska sp. z o.o., Warszawa 2009, s. 17. 
przez niego w dużej mierze tylko wiedzy stricte zawodowej i relatywnie niskiego poziomu umiejętności w zakresie kierowania personelem (respondenci badania I ocenili swoje umiejętności w tym zakresie najniżej spośród badanych postaw i umiejętności), można powiedzieć, że powinien stać się innowatorem, aby w odpowiedni sposób wywierać wpływ na współpracowników i w konsekwencji doprowadzić do kompatybilności interesów osobistych personelu z interesem gabinetu (tak na płaszczyźnie medycznej, jak i biznesowej).

Psychologia zarządzania do najważniejszych uwarunkowań zachowań przywódcy - decydujących o jego efektywności - zalicza ${ }^{95}$ :

- predyspozycje osobowościowe,

- temperament,

- zdolności intelektualne,

- inteligencję emocjonalną,

- umiejętność radzenia sobie ze stresem.

Czynniki te w znacznej mierze determinują potencjał ludzki w jego aspekcie jakościowym, tj. w sferze ${ }^{96}$ :

- kompetencji: predyspozycji intelektualnych, interpersonalnych i emocjonalnych,

- umiejętności: analizowania i wnioskowania, przewodzenia, komunikowania się, współdziałania samooceny i samodyscypliny, podejmowania ryzyka, adaptacji do zmiany,

- motywacji wewnętrznej: wyznaczanych sobie celów, wartości, postaw, norm moralnych, asertywności, realizmu, wytrwałości, entuzjazmu, odporności na stres, inicjatywności, zaangażowania, odpowiedzialności osobistej.

Interesujące w omawianym aspekcie są badania G. Beavera i P. Jenninga ${ }^{97}$, którzy przeprowadzili analizę zależności między umiejętnościami kierowniczymi a przewagą konkurencyjną małych przedsiębiorstw. I stwierdzili, że główną przyczyną niemożności osiągnięcia i utrzymania satysfakcjonującego poziomu wyników jest niski poziom kompetencji kierowniczych. Sformułowali również tezę, że w przypadku małych firm sukces może odnieść przedsiębiorca nie tylko posiadający wysoki poziom kompetencji kierowniczych, co reprezentujący

\footnotetext{
95 Sowińska A., Psychologiczne uwarunkowania skutecznego przywództwa, w: FrączkiewiczWronka A., Austen-Tynda A. (red.), Przywództwo ... op. cit., s. 142.

${ }^{96}$ Ibidem s. 144.

${ }^{97}$ Beaver G., Jennings P., Managerial Competence and Competitive Advantage in the Small Business: An Alternative Perspective, w: Developing Core Competencies in Small Business for the $21^{\text {st }}$ Century, University of Vaasa, 1996, s. 182 i nast.
} 
właściwe wartości i umiejący tworzyć odpowiednią atmosferę. Na podstawie badań własnych autorki uprawnionym staje się sformułowanie podobnych wniosków: lekarze dentyści (prowadząc swoje mikro i małe przedsiębiorstwa) w ograniczonym stopniu wykorzystują możliwości, jakie daje umiejętne kierowanie innymi (np. w zakresie podziału pracy - praca na jednym vs dwóch fotelach, delegowania uprawnień do podejmowania decyzji), co uniemożliwia lepsze wykorzystanie czasu pracy. Uzasadnionym wydaje się rekomendowanie podnoszenia kwalifikacji lekarzy dentystów w tym zakresie, aby warunki pracy były nie tylko optymalne dla pracowników, ale również tworzyły odpowiednie tło do wykonywanych świadczeń medycznych (tym samym przyczyniały się do kreowania pozytywnego wizerunku praktyki w oczach pacjenta). Jest to o tyle istotne, że zdolność budowania jedności zespołu (,utożsamiania się” lub ,poczucia przynależności” do zespołu/gabinetu) staje się poszukiwaną umiejętnością przywódczą ${ }^{98}$.

W badaniach nad przywództwem w sektorze ochrony zdrowia korzysta się często z teorii przywództwa wypracowanych w obszarze innych sektorów. Jednak - jak podkreśla N. Goodwin ${ }^{99}$ - mimo pewnych podobieństw między organizacjami usługowymi, występujące między nimi różnice nie pozwalają na bezkrytyczne przenoszenie teorii i uzyskanych wyników badań, ponieważ przywództwo w placówce ochrony zdrowia jest złożonym zjawiskiem (ze względu na konieczność pogodzenia aspektów stricte medycznych i ekonomicznych). Przywódcy w organizacjach ochrony zdrowia powinni umieć godzić pojawiające się sprzeczności między ideami sprawiedliwości społecznej a dążeniem do maksymalizacji zysku. Oznacza to m. in. umiejętność adaptowania dla praktyki zarządzania w placówkach ochrony zdrowia metod i narzędzi wypracowanych w innych sektorach, wzbogacając je o szczególne komponenty i wartości, nieodzowne w ochronie zdrowia. Na lekarzach kierujących pracą zespołu ciąży moralny obowiązek przekazywania swym współpracownikom wiedzy i doświadczenia, a więc dbanie o ich jak najlepsze wyszkolenie zawodowe, a także o wysoki poziom etyczny. J. Bogusz zauważa, że obowiązek dbania o wysoki poziom etyczny współpracowników może być spełniony tylko wówczas, gdy pamięta się, że przestrzeganie zasad etyki lekarskiej i dbałość o zachowanie godności zawodowej, które obowiązuje każdego lekarza, dotyczy zwłaszcza osób zajmujących kierownicze stanowiska (dlatego ich postępowanie powinno być zawsze wzorem i przykładem godnym naśladowania) ${ }^{100}$.

\footnotetext{
${ }^{98}$ Cardona P., Ray C., Zarzadzanie poprzez misje, Oficyna Wolters Kluwer Business, Kraków 2009, s. 30 i nast.

${ }^{99}$ Goodwin N., Leadership and the UK Health Service, „Health Policy”, 2000 vol. 51, s. 54.

${ }^{100}$ Bogusz J., Zasady deontologiczne zwiazane z posteppami wiedzy ludzkiej, w: Kielanowski T. (red.), Etyka ... op. cit., s. 115.
} 
Problemem przywództwa w ochronie zdrowia szeroko zajmują się A. Frączkiewicz-Wronka i A. Austen ${ }^{101}$, pisząc: ,przywódcy często muszą współpracować z interesariuszami należącymi do różnych sfer instytucjonalnych, a zatem wyznającymi różne poglądy, interesy i wartości. Zadaniem przywódców w tym sektorze jest współpraca $\mathrm{z}$ inreresariuszami nad ukształtowaniem wspólnych wartości, które prowadzą do godzenia różnych, czasami sprzecznych celów i aspiracji interesariuszy w procesie ciąłego budowania strategii, która legitymizuje przywódców przed nimi. W szczególności przywódcy muszą mieć lub nabyć takie cechy, jak: szacunek, etyczność, uczciwość, powiązania interpersonalne, chęć służenia innym, umiejętność wprowadzania zmian, poświęcenie, inteligencja emocjonalna, umiejętność współpracy i dzielenia się, zaufanie, umiejętność rozwiązywania konfliktów, ponadto powinni być zdolni do oceny członków swojego zespołu, innych liderów i samych siebie." 102 Problematyka przywództwa będzie podjęta jeszcze w V rozdziale.

\subsection{DENTYSTA JAKO PARTNER RYNKOWY}

Istotną rolą podmiotów rynkowych jest dostarczanie wartości klientowi ${ }^{103}$. Na propozycję wartości dla klienta nie składa się tylko przedmiot wymiany handlowej rozumiany jako materialny produkt lub usługa. W ofercie mieści się również zaplanowane zaangażowanie emocjonalne klienta - jak twierdzi L.P. Carbone: ,jest to kompletna propozycja wartości emocjonalnych i racjonalnych, stworzona i zarządzana dla całego doświadczenia klienta."104 Trudność zdefiniowania pojęcia „wartości dla klienta” wynika z jego wieloznaczności i różnorodności w sposobie werbalizacji wartości przez konsumentów. Badania V.A. Zeithaml wskazują na cztery sposoby rozumienia wartości ${ }^{105}$ :

- wartość to niska cena,

- wartość jest tym, czego nabywca oczekuje od produktu,

- wartość, to jakość, jaką klient otrzymuje za cenę, którą płaci,

- wartość jest tym, co klient dostaje, w zamian za to, co daje.

\footnotetext{
${ }^{101}$ Por. również Mruk H., Przywództwo w zakładach opieki zdrowotnej, ABC a Wolters Kluwer business, Warszawa 2010.

${ }^{102}$ Frączkiewicz-Wronka A., Austen A., Efektywne przywództwo w ochronie zdrowia - wyniki badań empirycznych, ,Zeszyty Naukowe UE w Poznaniu” nr 187, Poznań 2011, s. 87.

103 Wartość dla klienta jest konstruktem wielowymiarowym. Od jakości odróżnia ją przede wszystkim ujęcie w kategoriach postrzeganych kosztów i korzyści, natomiast jako alternatywna do zadowolenia klienta miara daje lepsze możliwości kształtowania przewagi konkurencyjnej na rynku. ${ }^{104}$ Carbone L.P., Clued In. How to Keep Customers Coming Back Again and Again, FT Prentice Hall, Upper Saddle River, Nowy Jork 2004, s. 28.

${ }^{105}$ Zeithaml V.A., Consumer perceptions of Price, Quality, and Value: a Means-End Model and Synthesis of Evidence, "Journal of Marketing", 1988, nr 3.
} 
Dokonując syntezy swoich obserwacji, V.A. Zeithaml zdefiniowała postrzeganą wartość dla klienta ,jako całościową ocenę użyteczności produktu, dokonaną przez konsumenta na podstawie spostrzeżeń tego, co się otrzymało i tego, co się dało". Takie właśnie podejście, które wywodzi wartość z porównania szeroko pojętych postrzeganych kosztów oraz postrzeganych korzyści, wydaje się dominować w literaturze ${ }^{106}$, choć istnieją i inne konceptualizacje, oparte na wielowymiarowych konstruktach odnoszących się do potrzeb i korzyści dla nabyw$\mathrm{cy}^{107}$. Podobnie można zdefiniować wartość produktu medycznego dla pacjenta - A. Wągrodzka podaje: „wartość produktu medycznego stanowi postrzeganą użyteczność przebytego leczenia, umożliwiającą zaspokojenie odczuwanych potrzeb, pomniejszoną o postrzegane poniesione koszty" ${ }^{\text {108 }}$. Taka interpretacja wartości produktu medycznego dla pacjenta wykazuje zysk (jakość życia) z podjętego działania związanego z zachowaniami dotyczącymi choroby (stan negatywny), a w konsekwencji z odzyskaniem zdrowia (stan pozytywny).

Koncepcja łańcucha wartości w usługach może być usadowiona w trzech nurtach $^{109}$ :

- opracowanie koncepcji towarów/usług - polegającej na sprecyzowaniu rodzaju i szerokości oferty usługowej (w przypadku gabinetów stomatologicznych jest to obszar stricte medyczny, który może być wsparty filozofią marketingową - zarówno w tradycyjnym ujęciu tj. jako marketing-mix, jak

106 Näslund D., Olsson A., Karlsson S., Operationalizing the Concept of Value - an Action Research-Based Model, "The Learning Organization" 2006, nr 3; Kotler Ph., Marketing, Dom Wydawniczy REBIS, Poznań 2005; Stach P., Problemy konceptualizacji i operacjonalizacji wartości dla klienta, „Przegląd Organizacji”, 2009, nr 9, s. 44.

Należy zauważyć, że literaturze przedmiotu istnieje rozbieżność poglądów co do tego, jak nabywca dochodzi do syntetycznej oceny wartości: czy wynika ona z różnicy pomiędzy korzyściami i kosztami (por. Blois K., Analyzing Exchange Through the Use of Value Equations, „The Journal of Business \& Industrial Marketing”, 2004 nr 4-5), czy jest raczej stosunkiem korzyści i kosztów (Ravald A., Grönroos Ch., The Value Concept and Relationship Marketing, "European Journal of Marketing", 1996, nr 2). Z arytmetycznego punktu widzenia iloraz korzyści i kosztów daje wyższy wynik wartości niż różnica pomiędzy korzyściami i kosztami (dlatego w przypadku ilorazu wartości byłaby mniej obciążona kosztami).

${ }^{107}$ Roig J.C.F., Garcia J.S., Tena M.A.M., Monzonis J.L., Customer Perceived Value in Banking Services, "International Journal of Bank Marketing", $2006 \mathrm{nr} 5$.

${ }^{108} \mathrm{Na}$ postrzegane poniesione koszty składają się m. in.: 1) ból i inne dolegliwości fizyczne jako efekty wykonywanych zabiegów, 2) obce wnętrze gabinetu, 3) brak kontroli pacjenta nad tym, co się dzieje wokół niego, 4) dysonans w odczuwaniu bezpieczeństwa, 5) nadmiar urządzeń technicznych niezbędnych do postawienia diagnozy oraz ograniczanie się wykonawców do czynności technicznych (odpersonalizowanie pacjenta), 6) ambiwalentna ocena wiarygodności informacji lekarza: sceptycyzm i nadzieja, 7) niepokój o plany na przyszłość. Por. Wągrodzka A., Analiza wartości produktu dla nabywcy ustugi medycznej szpitala, „Marketing i Rynek”, 2005 nr 1, s. 21.

109 Porter M., Competitive Advantage, Free Press, Nowy Jork 1985, s. 25 i nast.; Treacy M., Wiersman F., Customer Intimacy and other Value Disciplines, "Harvard Business Review", 1993, nr 71, s. 84 i nast. 
i związanym z kształtowaniem długookresowych relacji) oraz metod konkurowania rynku (obok konkurowania jakością usługi - obszar stricte medyczny, gabinety mogą konkurować również jakością obsługi - obszar związany z marketingiem relacji),

- $\quad$ współpracy z klientem - oznaczającej zespół czynności ściśle związanych $\mathrm{z}$ operowaniem na rynku takimi instrumentami, jak marketing (w tym: badanie rynku, segmentacja, poziom oferowanych cen, budowanie relacji ${ }^{110}$ itp.), komunikacja interpersonalna, czy rzetelność zawodowa;

- łańcuchu podaży jako grupy procesów związanych z organizacją przepływu dóbr od źródeł ich pozyskania aż do ostatecznego odbiorcy (z koniecznością uwzględnienia m.in. kosztów i czasu realizacji tych przepływów).

I wszystkie te obszary można odnaleźć w funkcjonowaniu gabinetów stomatologicznych. Lekarz dentysta (o silnej orientacji rynkowej) mógłby podjąć się sformułowania filozofii działania gabinetu $\mathrm{w}$ tych zakresach ${ }^{111}$. Idąc dalej, można byłoby zaproponować - za R. Srivastavem, T. Shervanim i L. Fahey’em - aby stomatolodzy traktowali pacjentów i partnerów rynkowych nie tylko jako podmioty działań marketingowych, lecz jako zasoby, o które należy dbać i które trzeba rozwijać ${ }^{112}$.

Jak widać omawianie biznesowych ról dentysty, wymaga również „wyjścia poza gabinet" i spojrzenia na jego miejsce w przestrzeni społeczno-ekonomicznej. Jest to o tyle istotne, że w funkcjonowaniu współczesnych podmiotów rynkowych szczególnego znaczenia nabiera ich uczestnictwo w sieciach relacji społecznych. Podejście to wpisuje się w teorię kapitału społecznego. Jedna z definicji kapitału społecznego przedsiębiorstwa mówi, iż „stanowi on kategorię wynikającą z uczestnictwa w sieci powiązań i relacji, które - opierając się na podzielanych normach, zasadach i wartościach, a także zaufaniu - umożliwiają stronom dostęp do zasobów, w szczególności do wiedzy i kompetencji. Wszystko to jest ukierunkowane na generowanie określonych korzyści dla przedsiębiorstwa, takich jak: poprawa efektywności działania, zwiększenie możliwości rozwoju, uzyskanie przewagi konkurencyjnej." ${ }^{113}$ Dzięki kapitałowi

\footnotetext{
${ }^{110}$ M. in. R. Norman i F. Ramirez twierdzą, że nabywca jest aktywnym współtwórcą wartości, dlatego istotnym jest by był partnerem w biznesie. Por. Norman R., Ramirez F., Designing interactive strategy from Value - chain to Value Constellation, John Wiley \& Sons, Nowy Jork, 1994, s. 15 i nast.

${ }^{111}$ Inną sprawą pozostaje to, na ile działania te byłyby wynikiem przemyśleń dentysty opartych na ekonomicznych przesłankach, a na ile wynikiem intuicji czy nawet przypadku.

112 Srivastava R., Shervani T., Fahey L., Market - Based Assets and Shareholder Value: A Framework for Analysis, "Journal of Marketing" 1998, vol. 62, s. 2 i nast.

${ }^{113}$ Krause D.R., Handfield R.B., Tyler B.B., The Relationships Between Supplier Development, Commitment, Social Capital Accumulation and Performance Improvement, "Journal of Operations Management", 2007, vol. 25.
} 
społecznemu pojawia się w przedsiębiorstwie kapitał relacyjny (odnoszący się zarówno do nabywców towarów/usług podmiotu - o czym będzie mowa w IV rozdziale, jak i dostawców, czy innych uczestników rynku) i może rozwijać kapitał intelektualny ${ }^{114}$ (będzie o nim mowa w III rozdziale).

Gabinet stomatologiczny, jako uczestnik rynku, jest jednym z ogniw sieci, w ramach której dochodzi $\mathrm{m}$. in. do przeniesienia wartości od producentów materiałów stomatologicznych do ostatecznych nabywców - pacjentów. Gabinet pełni w tym łańcuch wartości rolę pośrednika - jako wykonawca dostarcza użyteczną usługę pacjentowi, a jako detalista w łańcuchu logistycznym - jest odbiorcą materiałów, narzędzi i sprzętu stomatologicznego od ich producentów (lub pośredników rynkowych - zarówno hurtowników, jak i detalistów). Choć trudno mówić w tym przypadku o łańcuchu dostaw, jako integrującej filozofii zarządzania całym przepływem w kanale dystrybucji od dostawcy do ostatecznego klienta ${ }^{115}$, to $\mathrm{z}$ łańcuchem logistycznym mamy niewątpliwie do czynienia. Decyzje dentysty związane $\mathrm{z}$ wyborem materiałów, narzędzi i sprzętu będą wpływały na wartość dostarczoną pacjentowi ${ }^{116}$. Decyzje dotyczące wyboru dostawcy materiałów będą wpływały nie tylko na koszty funkcjonowania gabinetu, ale również na komfort pracy stomatologa (dostawca zaopatrujący dentystę w gabinecie vs konieczność dokonania zakupu w siedzibie dystrybutora, realizacja pojedynczych zakupów vs grupowanie zamówień itp.) i wartość dostarczoną pacjentowi (dostawca protez - wirtuoz w zawodzie vs rzemieślnik w zawodzie technika protetyki). Oba kierunki przepływu od i do gabinetu są oparte na relacjach - odpowiednio z pacjentem i dostawcą, które są uwarunkowane zaufaniem (m. in. co do uczciwości i rzetelności partnera) i zaangażowaniem stron w optymalny przebieg kontaktów między podmiotami rynku.

Lekarz dentysta, zamawiając materiały stomatologiczne, wybiera z oferty rynkowej, kierując się m.in. ich ceną, jakością (np. wytrzymałością), dostępnością, niezawodnością, rekomendacjami osób trzecich itp. te, które uzna za odpowiednie dla swojej praktyki. Jego decyzja zakupowa będzie miała wpływ na ofertę, którą będzie przedstawiał nabywcom swoich usług np. w zakresie ceny. Wybór technika dentystycznego, z którym lekarz będzie współpracował również przekłada się na ofertę dla pacjenta (np. w zakresie czasu obsługi,

\footnotetext{
${ }^{114}$ Nahapiet J., Ghoshal S., Social Capital, Intellectual Capital, and the Organizational Advantage, “Academy of Management Review", 1998, vol. 23, nr 2.

115 Definicja wg M.C. Cooper i L.M. Ellram, por. Cooper M.C., Ellram L.M., Characteristics of Chain Management and the Implications for Purchasing and Logistics Strategy, "International Journal of Logistics Management", 1993 nr 2, s. 1 i nast.

${ }^{116} \mathrm{~W}$ gabinecie, który zajmuje się pacjentami w ramach kontraktu z NFZ - ze względów kosztowych - najczęściej są inne materiały, niż w gabinecie, w którym pacjenci opłacają wizyty z dochodów własnych. Czego efektem może być inna wartość dostarczona pacjentowi, odnosząca się np. do wyglądu (kolor wypełnienia) i wytrzymałości pracy; również czynnika czasu oczekiwania na wizytę, czy jakości komunikacji interpersonalnej itp.
} 
wytrzymałości pracy itp.). Dlatego bez wątpienia decyzje zakupowe (odnoszące się do nabywania dóbr i usług stomatologicznych oraz usług dodatkowych np. związanych ze sterylizacją narzędzi) podejmowane przez lekarza mają wpływ na ofertę gabinetu.

Do działań, realizowanych przez stomatologa (lub oddelegowanego do realizacji zadania członka personelu), jako uczestnika sieci powiązań, wynikających z realizacji koncepcji łańcucha wartości, można zaliczyć m. in.:

- wybór lokalizacji gabinetu przed rozpoczęciem działalności lub w trakcie jej prowadzenia (optymalnej nie tylko ze względu na przepisy dotyczące warunków, jakie musi spełniać lokal przeznaczony na gabinet stomatologiczny, ale również ze względu na fizyczny dostęp - wygodny dla pacjentów czy względy marketingowe),

- określenie zapotrzebowania na odpowiednie grupy materiałów, lekarstw, narzędzi, środków opatrunkowych, odzieży ochronnej itp.,

- a następnie określenie i wybór dostawców, przyjęcie dostawy i ocena dostawcy (umożliwiająca podjęcie decyzji o kontynuowaniu współpracy lub poszukiwaniu nowego dostawcy),

- magazynowanie zakupionych środków (uwzględniające specyficzne wymagania i konieczność dokonywania przeglądu pod kątem terminów przydatności do użycia),

- transport narzędzi do i z miejsca ich sterylizacji (jeśli nie odbywa się w gabinecie),

- transport odzieży do i z miejsca jej prania,

- zgłaszanie reklamacji u dostawców i podwykonawców, jeśli zajdzie taka konieczność,

- gromadzenie i usuwanie odpadów,

- prowadzenie kalendarza przyjęć i obsługę nabywcy na odpowiednim poziomie (z uwzględnieniem ewentualnych reklamacji).

O tym, jak w praktyce wygląda rola gabinetu stomatologicznego, jako ogniwa w łańcuchu logistycznym będzie mowa w kolejnych rozdziałach (jako o odbiorcy materiałów i usług w rozdziale III, jako o dostawcy świadczeń medycznych w rozdziale IV i V). 


\subsection{UMIEJĘTNOŚCI I KOMPETENCJE PRZEDSIĘBIORCZE - WYNIKI BADAŃ}

\subsubsection{SAMOOCENA LEKARZY DENTYSTÓW}

Badania pokazują ${ }^{117}$, że zarówno cechy psychologiczne, jak i demograficzne ${ }^{118}$ mogą mieć wpływ na zaangażowanie się jednostki w działalność przedsiębiorczą. Rozumienie przedsiębiorczości, jako złożonej kategorii, pozwala odnieść się również do osobowościowych determinantów przedsiębiorczości, a mianowicie:

- określonej postawy wobec zadań (ujawnia się poprzez gotowość do podejmowania umiarkowanego ryzyka),

- innowacyjności,

- motywacji do osiągnięć.

O innowacyjności i gotowości do podejmowania ryzyka świadczy otwartość na doświadczenia (będąca również wskaźnikiem motywacji osiągnięć), która przejawia się w niezależności w wydawaniu opinii oraz nastawieniu na zdobywanie wiedzy. Z motywacją osiągnięć wiążą się również sumienność (postrzegana poprzez zdyscyplinowanie, wytrwałość), stabilność emocjonalna (rozumiana jako brak dominacji emocji negatywnych oraz brak skłonności do reagowania napięciem i lękiem w sytuacjach trudnych np. konfliktowych z pacjentem).

W pracy przyjęto założenie, że dentysta jest przedsiębiorcą - zakładając i prowadząc własny gabinet, gdyż przejawia w ten sposób motywację do osiągnięć i podejmowania ryzyka (zaczyna zarządzać nie dysponując profesjonalną wiedzą w tym zakresie) oraz innowacyjność, jeśli rynkowo zaczyna działać inaczej, niż pozostali dentyści na rynku. Ponieważ podejmuje decyzje związane z rynkowym funkcjonowaniem gabinetu (co - zgodnie z przedstawioną wcześniej uproszczoną definicją zarządzania P.F. Druckera - pozwala na nazwanie go menedżerem), to spojrzenie na lekarza dentystę przez pryzmat cech i funkcji przedsiębiorcy w organizacji, skłoniło autorkę do wykorzystania do oceny postawy przedsiębiorczej stomatologa listy kluczowych umiejętności menedżerskich D.A. Whettena i K.S. Camerona ${ }^{119}$ rozszerzonej o elementy, które wg autorki są

\footnotetext{
117 Por. Kristiansen S., Indarti N., Entrepreneurial intention among Indonesian and Norwegian students, "Journal of Enterprising Culture", 2004 nr 1; Kraśnicka T., Koncepcje rozwoju... op. cit.

${ }^{118} \mathrm{~W}$ grupie respondentów badania I oraz badania III dominowały kobiety i - wbrew wcześniejszym intencjom autorki - wobec zbyt małej grupy reprezentowanej przez mężczyzn-dentystów nie udało się zbadać wpływu płci na umiejętności i kompetencje przedsiębiorcze.

${ }^{119}$ Autorzy na podstawie przeglądu klasyfikacji umiejętności menedżerskich oraz na podstawie badań na grupie 400 menedżerów reprezentujących różne szczeble zarządzania i sektory, stworzyli listę umiejętności wpływających na skuteczność kierowania. Powstała ona na podstawie następujących kryteriów: 1) wykorzystanie umiejętności, które są połączeniem zarówno cech osobowych, jak i umiejętności interpersonalnych, 2) koncentracja na charakterystykach (obejmujących tylko zacho-
} 
istotne w pracy lekarza dentysty, jako właściciela gabinetu. Lista D.A. Whettena na i K.S.Camerona obejmuje ${ }^{120}$ :

- umiejętności intrapersonalne:

- doskonalenie samoświadomości (w tym: identyfikacja własnych mocnych i słabych stron, umiejętność określania i formułowania własnych wartości i priorytetów itp.),

- kierowanie stresem, dotyczy umiejętności radzenia sobie ze stresem (identyfikowania czynników stresotwórczych oraz ich eliminowania), umiejętności redukowania napięcia (poprzez m. in. umiejętność: ustalania celów, zarządzania czasem, równoważenia realizowanych aktywności prywatno-zawodowych),

- twórcze rozwiązywanie problemów, dotyczy zmiany nawyków myślowych, umiejętności właściwego łączenia i myślenia racjonalnego i kreatywnego, a także umiejętności kreowania innowacyjnego klimatu;

- umiejętności interpersonalne:

- ustanawianie wspierającej komunikacji (obejmującej skuteczne słuchanie i mówienie), umiejętność doskonalenia innych poprzez kształtowanie odpowiednich zachowań oraz udzielanie porad współpracownikom;

- zdobywanie władzy i wpływu, dotyczy umiejętności wpływania na innych (dzięki: umiejętności identyfikowania źródeł władzy, wykorzystania władzy jako czynnika wpływu na innych, właściwego i nie nadużywającego wykorzystania władzy);

- motywowanie innych, dotyczy usprawniania wydajności organizacyjnej poprzez właściwe wykorzystanie potencjału ludzkiego (umiejętność ustalania standardów dla wykonywanych zadań i umiejętność nagradzania skutecznych działań), zrozumienie procesu motywacyjnego i potrzeb pracowników;

- $\quad$ skuteczne delegowanie, które polega na określeniu, jakie zadania, komu, kiedy i jak delegować, a także określeniu stopnia nadzoru w trakcie realizacji i przydzielania uprawnień do wykonywania zadań;

- kierowanie konfliktami, wymaga umiejętności identyfikowania źródeł konfliktów, radzenia sobie z emocjami w konflikcie; ponadto zachowanie asertywne, umiejętność zachowania dobrych relacji z innymi;

wania, które można nabyć w trakcie szkoleń) menedżerów osiągających wysokie wyniki, 3) oparcie na ogólnych, a nie specyficznych (np. branżowych czy sytuacyjnych) umiejętnościach.

Por. Whetten D.A., Cameron K.S., Developing Management Skills, Glenview, IL, Scott, Foresman 1984, w: Rakowska A., Sitko-Lutek A., Doskonalenie kompetencji menedżerskich, Wydawnictwo Naukowe PWN, Warszawa 2000, s. 22 i nast.

${ }^{120}$ Ibidem s. 22 i nast. 
- grupowe podejmowanie decyzji (to $\mathrm{m}$. in. umiejętność organizowania i prowadzenia zebrań oraz publicznych prezentacji).

Wśród respondentów badania I 57,52\% zadeklarowało, że zależy im na tym, aby być sprawnym menedżerem, a $15,03 \%$ stwierdziło, że nie jest to dla nich ważne (78\% tej grupy stanowili lekarze stomatolodzy będący pracownikami). Aby przyjrzeć się umiejętnościom menedżerskim dentystów, poproszono ich o ustosunkowanie się do szeregu kwestii, odnoszących się do ich zachowań w życiu zawodowym. Wyniki samooceny respondentów zamieszczone są w tabelach $18-19$.

W tabeli 18 przedstawiony jest ranking umiejętności i postaw intrapersonalnych dentystów (związanych z postawą dentysty jako przedsiębiorcy i menedżera). Najwyżej lekarze dentyści ocenili swoje zaangażowanie w pracę (93,9\% respondentów oceniło się dobrze i bardzo dobrze w tym zakresie). Jest to nie tylko jedna z głównych cech przedsiębiorcy ${ }^{121}$, ale również ważna cecha w kontekście nawiązywania relacji z pacjentami, którzy doceniają zaangażowanie stomatologów w wykonywaną pracę i traktują je jako jeden z filarów dobrej obsługi. Przeszło połowa respondentów oceniła u siebie dobrze lub bardzo dobrze wszystkie (poza odpornością na stres) przedstawione do analizy umiejętności. Pozostałe wysokie noty dotyczyły:

- wykorzystywania w praktyce wiedzy zdobytej na szkoleniach $(85,55 \%$ wskazań), co daje podstawę do określenia dentystów mianem pracowników wiedzy (szerzej na ten temat w następnym rozdziale); natomiast relatywnie nisko ocenili swoją umiejętność pozyskiwania wiedzy od przedstawicieli handlowych (1/10 respondentów oceniła swoją umiejętność w tym zakresie bardzo wysoko, a 1/10 zadeklarowała, że nie umie tego robić w ogóle);

- identyfikowania własnych mocnych i słabych stron - 76,4\% badanych potrafi to robić dobrze i bardzo dobrze;

- myślenia alternatywnego $(71,61 \%)$, które wskazuje na możliwość elastycznego działania; tak wysoka samoocena w kategorii myślenia ,jeśli tak ..., to tak ..." pozwala przypuszczać, że lekarze dentyści stosunkowo łatwo znajdują rozwiązania problemów pojawiających się w gabinecie (nie tylko w kwestii stworzenia alternatywnych planów leczenia dla danego pacjenta), inną kwestią pozostaje zdolność wprowadzania ich w życie;

- określania priorytetów w życiu zawodowym $(69,57 \%)^{122}$ i hierarchii w życiu osobistym i zawodowym $(64,2 \%)$ może świadczyć nie tylko o umiejęt-

\footnotetext{
${ }^{121} \mathrm{~W}$ tym kontekście niemal wszyscy badani lekarze dentyści są przedsiębiorcami S.L. Muellera i T.S. Anisya (por. tabela 4).

122 Ale już umiejętność planowania rozwoju zawodowego została oceniona niżej, a umiejętność planowania działań na najbliższy miesiąc jeszcze niżej.
} 
ności stawiania celów zawodowych, ale również o umiejętności zachowywania równowagi w życiu zawodowym i osobistym ${ }^{123}$, choć trzeba zaznaczyć, że dalsze wyniki pokazują niski poziom umiejętności z zakresu radzenia sobie z negatywnymi emocjami.

Tabela 18. Ranking umiejętności intrapersonalnych dentystów - wyniki samooceny

\begin{tabular}{|c|c|c|c|c|c|c|c|c|c|}
\hline \multirow[b]{2}{*}{$\begin{array}{c}\text { Postawy/ } \\
\text { umiejętności w zakresie }\end{array}$} & \multicolumn{5}{|c|}{$\begin{array}{l}\text { Stanowisko respondenta } \\
\text { (procent wskazań) }\end{array}$} & \multirow[b]{2}{*}{$\bar{x}$} & \multirow[b]{2}{*}{ Do } & \multirow[b]{2}{*}{ Me } & \multirow[b]{2}{*}{$\mathbf{S}(\mathbf{x})$} \\
\hline & $\begin{array}{c}\text { brak } \\
\text { (1) }\end{array}$ & $\begin{array}{c}\text { mały } \\
\text { stopień } \\
\text { (2) }\end{array}$ & $\begin{array}{c}\text { średnio } \\
(3)\end{array}$ & $\begin{array}{c}\text { dobrze } \\
\text { (4) }\end{array}$ & \begin{tabular}{|c} 
bardzo \\
dobrze \\
(5)
\end{tabular} & & & & \\
\hline Zaangażowanie w pracę & 0,61 & 0,0 & 5,52 & 38,04 & 55,83 & 4,48 & 5 & 5 & 0,66 \\
\hline $\begin{array}{l}\text { Wykorzystywanie w praktyce } \\
\text { wiedzy ze szkoleń }\end{array}$ & 0,0 & 1,81 & 12,65 & 46,39 & 39,16 & 4,23 & 4 & 4 & 0,74 \\
\hline $\begin{array}{l}\text { Identyfikacji własnych mocnych i } \\
\text { słabych stron }\end{array}$ & 0,61 & 3,12 & 19,88 & 55,28 & 21,12 & 3,93 & 4 & 4 & 0,77 \\
\hline Myślenia alternatywnego & 1,29 & 3,87 & 23,23 & 49,03 & 22,58 & 3,88 & 4 & 4 & 0,85 \\
\hline $\begin{array}{l}\text { Określania priorytetów w życiu } \\
\text { zawodowym }\end{array}$ & 3,11 & 4,35 & 22,98 & 48,45 & 21,12 & 3,80 & 4 & 4 & 0,93 \\
\hline $\begin{array}{l}\text { Ustalania hierarchii działań w ży- } \\
\text { ciu osobistym i zawodowym }\end{array}$ & 3,70 & 6,79 & 25,31 & 39,51 & 24,69 & 3,75 & 4 & 4 & 1,02 \\
\hline Zarządzania czasem w gabinecie & 2,47 & 5,56 & 28,40 & 43,21 & 20,37 & 3,73 & 4 & 4 & 0,93 \\
\hline $\begin{array}{l}\text { Szybkiego wdrażania nowych } \\
\text { materiałów i technik pracy }\end{array}$ & 2,47 & 6,79 & 26,85 & 46,60 & 17,28 & 3,70 & 4 & 4 & 0,92 \\
\hline $\begin{array}{l}\text { Planowania własnego rozwoju } \\
\text { zawodowego }\end{array}$ & 3,03 & 4,85 & 31,52 & 41,21 & 19,39 & 3,69 & 4 & 4 & 0,94 \\
\hline $\begin{array}{l}\text { Wprowadzania zmian w życiu } \\
\text { zawodowym }\end{array}$ & 1,85 & 3,70 & 35,19 & 43,21 & 16,05 & 3,68 & 4 & 4 & 0,85 \\
\hline $\begin{array}{l}\text { Pozyskiwania wiedzy od sprze- } \\
\text { dawców materiałów }\end{array}$ & 1,25 & 8,75 & 24,38 & 53,13 & 12,50 & 3,67 & 4 & 4 & 0,85 \\
\hline $\begin{array}{l}\text { Ustalania realnych celów w gabi- } \\
\text { necie }\end{array}$ & 5,0 & 7,50 & 31,88 & 42,50 & 13,13 & 3,51 & 4 & 4 & 0,98 \\
\hline Zwiększania odporności na stres & 3,09 & 7,41 & 40,12 & 40,12 & 9,26 & 3,45 & 3 & $3 ; 4$ & 0,88 \\
\hline $\begin{array}{l}\text { Planowania działań na najbliższy } \\
\text { miesiąc }\end{array}$ & 9,09 & 9,09 & 25,32 & 45,45 & 11,04 & 3,40 & 4 & 4 & 1,09 \\
\hline
\end{tabular}

Źródło: opracowanie własne na podstawie przeprowadzonych badan.

Stosunkowo wysoka samoocena lekarzy dentystów w zakresie umiejętności i postaw intrapersonalnych pozwala przypuszczać, że realizują się oni w miejscu pracy (motywacja do osiągnięć).

\footnotetext{
${ }^{123}$ Jest to o tyle ważna umiejętność, iż może pomagać w niedopuszczaniu do pojawienia się uczucia porażki w spełnianiu własnych oczekiwań wyczerpania emocjonalnego, depersonalizacji pacjentów, a w konsekwencji do zespołu wypalenia zawodowego (rozumianego jako „stan fizycznego, emocjonalnego wyczerpania w wyniku wykonywanej pracy, objawiający się chronicznym zmęczeniem.") por. Sęk H., Wypalenie zawodowe: przyczyny i zapobieganie, Wydawnictwo Naukowe PWN, Warszawa 2004.
} 
W tabeli 19 przedstawiony jest ranking umiejętności interpersonalnych lekarzy stomatologów. Jako swoje główne atuty wskazali oni: umiejętność utrzymywania dobrych relacji $\mathrm{z}$ pacjentami $\mathrm{w}$ długim okresie (90,85\% wskazań) i nawiązywania dobrego kontaktu $\mathrm{z}$ pacjentem $\mathrm{w}$ trakcie pierwszej wizyty $(89,02 \%)$. Świadczy to o skupianiu się na pacjencie i potwierdza, że powołanie wpływa na funkcjonowanie respondentów w życiu zawodowym, z drugiej strony stanowi solidną podstawę do wdrażania $w$ gabinecie filozofii marketingu relacji. Na dalszych miejscach uplasowały się umiejętności z zakresu komunikacji interpersonalnej, co również należy uznać za ważne z punktu widzenia utrzymywania pozytywnych relacji z pacjentami w długim okresie.

Tabela 19. Ranking umiejętności i postaw interpersonalnych dentystów - wyniki samooceny

\begin{tabular}{|c|c|c|c|c|c|c|c|c|c|}
\hline \multirow[b]{2}{*}{$\begin{array}{c}\text { Postawy/ } \\
\text { umiejętności w zakresie }\end{array}$} & \multicolumn{5}{|c|}{$\begin{array}{c}\text { Stanowisko respondenta } \\
\text { (procent wskazań) }\end{array}$} & \multirow[b]{2}{*}{$\bar{x}$} & \multirow[b]{2}{*}{ Do } & \multirow[b]{2}{*}{ Me } & \multirow[b]{2}{*}{$\mathbf{S}(\mathbf{x})$} \\
\hline & $\begin{array}{l}\text { brak } \\
\text { (1) }\end{array}$ & \begin{tabular}{|c|} 
mały \\
stopień \\
$(2)$ \\
\end{tabular} & średnio & $\begin{array}{c}\text { dobrze } \\
(4)\end{array}$ & $\begin{array}{c}\text { bardzo } \\
\text { dobrze } \\
(5)\end{array}$ & & & & \\
\hline $\begin{array}{l}\text { Utrzymywanie dobrych relacji } \\
\text { z pacjentem w długim okresie }\end{array}$ & 0,61 & 0,61 & 7,93 & 50,0 & 40,85 & 4,30 & 4 & 4 & 0,69 \\
\hline $\begin{array}{l}\text { Nawiązywanie dobrego kontaktu } \\
\text { z pacjentem w trakcie pierwszej } \\
\text { wizyty }\end{array}$ & 0,61 & 2,44 & 7,93 & 50,0 & 39,02 & 4,24 & 4 & 4 & 0,75 \\
\hline Aktywne słuchanie & 0,61 & 1,24 & 14,92 & 44,72 & 38,51 & 4,19 & 4 & 4 & 0,78 \\
\hline Rozwiązywanie problemów & 0,0 & 3,82 & 18,47 & 59,24 & 18,47 & 3,92 & 4 & 4 & 0,72 \\
\hline Jasne, precyzyjne kon & 5,81 & 1,29 & 23,23 & 40,65 & 29,03 & 3,86 & 4 & 4 & 1,04 \\
\hline $\begin{array}{l}\text { Zachowar } \\
\text { współprac }\end{array}$ & 9,03 & 3,47 & 11,81 & 46,53 & 29,17 & 3,83 & 4 & 4 & 1,16 \\
\hline $\begin{array}{l}\text { Radze } \\
\text { składa }\end{array}$ & 0,61 & 5,68 & 21,38 & 56,60 & 15,72 & 3,81 & 4 & 4 & 0,79 \\
\hline Praca z dzieckie & 4,94 & 11,11 & 19,14 & 38,27 & 26,54 & 3,70 & 4 & 4 & 1,13 \\
\hline Chwa & 11,9 & 2,79 & 20,98 & 41,26 & 23,08 & 3,61 & 4 & 4 & 1,22 \\
\hline Medic & 8,28 & 7,64 & 27,39 & 46,50 & 10,19 & 3,43 & 4 & 4 & 1,05 \\
\hline Udziel & 3,21 & 8,33 & 42,95 & 37,18 & 8,33 & 3,39 & 3 & 3 & 0,88 \\
\hline bw w ga- & 10,0 & 8,67 & 24,00 & 48,67 & 8,67 & 3,37 & 4 & 4 & 1,09 \\
\hline Nagradzanie skutecznych działań & 11,97 & 7,75 & 26,76 & 40,85 & 12,68 & 3,35 & 4 & 4 & 1,17 \\
\hline Radzenie sobie z krytyką & 7,84 & 6,54 & 38,56 & 37,91 & 9,15 & 3,34 & 3 & 3 & 1,01 \\
\hline e & 9,09 & 11,04 & 31,17 & 35,06 & 13,64 & 3,33 & 4 & 3 & 1,13 \\
\hline $\begin{array}{l}\text { Wywieranie wpływu na decyzje } \\
\text { rozmówców }\end{array}$ & 5,03 & 10,69 & 36,48 & 43,40 & 4,40 & 3,31 & 4 & 3 & 0,91 \\
\hline $\begin{array}{l}\text { Wykorzystywanie pozamedycz- } \\
\text { nych informacji od pacjentów } \\
\text { do przekonywania ich do wyboru } \\
\text { określonej opcji usługi }\end{array}$ & 6,62 & 14,57 & 29,80 & 41,72 & 7,28 & 3,28 & 4 & 3 & 1,02 \\
\hline $\begin{array}{l}\text { Umiejętność ustalania standardów } \\
\text { dla wykonywanych przez pra- } \\
\text { cowników zadań }\end{array}$ & 10,1 & 8,63 & 35,25 & 38,1 & 7,91 & 3,25 & 4 & 3 & 1,06 \\
\hline
\end{tabular}




\begin{tabular}{|l|c|c|c|c|c|c|c|c|c|}
\hline $\begin{array}{l}\text { Motywowanie pracowników do } \\
\text { podnoszenia kwalifikacji }\end{array}$ & 12,86 & 10,00 & 30,71 & 32,86 & 13,57 & 3,24 & 4 & 3 & 1,20 \\
\hline Udzielanie rad pracownikom & 12,33 & 13,01 & 21,23 & 45,1 & 8,33 & 3,24 & 4 & 4 & 1,16 \\
\hline $\begin{array}{l}\text { Delegowanie zadań na współpra- } \\
\text { cowników }\end{array}$ & 18,37 & 9,52 & 24,49 & 34,69 & 12,93 & 3,14 & 4 & 3 & 1,30 \\
\hline $\begin{array}{l}\text { Budowanie autorytetu osobistego } \\
\text { przełożonego }\end{array}$ & 15,94 & 9,42 & 31,16 & 36,96 & 6,52 & 3,09 & 4 & 3 & 1,17 \\
\hline $\begin{array}{l}\text { Nadzór i ocena zadań realizowa- } \\
\text { yych przez pracowników }\end{array}$ & 16,67 & 18,84 & 26,09 & 31,88 & 6,52 & 2,93 & 4 & 3 & 1,20 \\
\hline Zarządzanie personelem gabinetu & 19,29 & 12,86 & 30,71 & 31,43 & 5,71 & 2,91 & 4 & 3 & 1,20 \\
\hline $\begin{array}{l}\text { Identyfikowanie źródeł konfliktu } \\
\text { w zespole }\end{array}$ & 27,01 & 12,41 & 22,63 & 28,47 & 9,49 & 2,81 & 4 & 3 & 1,36 \\
\hline Publiczne prezentacje & 33,77 & 17,22 & 18,54 & 25,83 & 4,64 & 2,50 & 1 & 2 & 1,32 \\
\hline $\begin{array}{l}\text { Karanie za pracę poniżej } \\
\text { możliwości }\end{array}$ & 33,09 & 22,30 & 29,50 & 10,79 & 4,32 & 2,31 & 1 & 2 & 1,16 \\
\hline
\end{tabular}

Źródło: opracowanie własne na podstawie przeprowadzonych badan.

Lekarze dentyści słabsze noty wystawili sobie w zakresie radzenia sobie z negatywnymi odczuciami, czy postawami w kontaktach z innymi osobami (co może stanowić sygnał podatności lekarzy dentystów na wypalenie zawodowe):

- mediować w konflikcie nie potrafi lub potrafi w małym stopniu 15,92\% respondentów, a 10,19\% radzi sobie w tym zakresie bardzo dobrze;

- udzielać konstruktywnej krytyki nie potrafi lub bardzo słabo daje sobie z tym radę 1 na 10 respondentów, a kolejne 10\% - bardzo dobrze,

- przyjmować krytykę potrafi 9,15\% badanych, a 14,38\% deklaruje, że nie,

- radzenie sobie z emocjami w konflikcie jest problemem dla $20 \%$ respondentów, a dla 13,64\% - nie,

- identyfikowania źródeł konfliktu w zespole nie potrafi $40 \%$ badanych, a $10 \%$ deklaruje, że potrafi.

Najsłabiej badani ocenili swoje umiejętności odnoszące się do kontaktów ze współpracownikami - rola stomatologa przełożonego. Choć 75,7\% deklaruje, że potrafi zachowywać dobre relacje ze współpracownikami, a 9,03\% - że nie, to gdy mowa o zarządzaniu personelem tylko $5,71 \%$ respondentów ocenia się bardzo dobrze w tym zakresie, a 32,15\% - słabo lub deklaruje, że w ogóle nie posiada takiej umiejętności. Znajduje to potwierdzenie w konkretnych zagadnieniach odnoszących się bardziej szczegółowo do aspektu kierowania personelem, i tak:

- chwalenie pracowników to umiejętność, którą na bardzo dobrym poziomie ma niespełna $1 / 4$ badanych, a w ogóle $-1 / 10$, 
- umiejętność nagradzania pracowników bardzo dobrze oceniło u siebie $12,68 \%$ badanych, a blisko $20 \%$ - zadeklarowało bardzo niski poziom lub brak tej umiejętności,

- umiejętność diagnozowania problemów w gabinecie jest na bardzo dobrym poziomie u 8,67\% badanych, a u co dziesiątego - brak takiej umiejętności,

- umiejętność ustalania standardów dla wykonywanych przez pracowników zadań $-7,91 \%$ badanych twierdzi, że ma ją na wysokim poziomie, a $18,7 \%$ - że ma ją na niskim lub nie posiada w ogóle,

- umiejętność nadzoru i oceny zadań realizowanych przez pracowników charakteryzuje 6,52\% badanych na wysokim poziomie, a 16,67\% - w ogóle,

- umiejętność motywowania pracowników do podnoszenia kwalifikacji $13,57 \%$ badanych oceniła u siebie bardzo dobrze, a 22,86\% - słabo lub uznała, że jej nie posiada,

- umiejętność udzielania rad - 8,33\% respondentów zadeklarowało, że posiada rozwiniętą tę umiejętność, a przeszło $1 / 4$ - że nie lub w niewielkim stopniu,

- karać pracowników potrafi 4,32\% badanych, a 55,39\% zadeklarowało, że nie potrafi lub w bardzo niewielkim stopniu.

Respondenci widzą przełożenie własnych braków na umiejętność budowania autorytetu osobistego przełożonego (1/4 zadeklarowała, że nie posiada takiej umiejętności lub posiada ją w niewielkim stopniu, a 6,52\% - oceniło się bardzo dobrze w tym zakresie). Stosunkowo słabe wyniki mogą budzić zdziwienie wobec faktu, że lekarz dentysta do budowy autorytetu może wykorzystywać przede wszystkim swoje umiejętności stricte zawodowe i etykę lekarską, a dopiero w dalszej kolejności umiejętności z zakresu zarządzania personelem. Niemniej jednak należy podkreślić najsłabszy wynik samooceny w zakresie kontaktów z personelem - brak umiejętności w tym zakresie może rzutować na atmosferę pracy, rozwój zawodowy pracowników, samodzielność pracowników $\mathrm{w}$ podejmowaniu decyzji, a w konsekwencji na relacje $\mathrm{z}$ pacjentami (por. rysunek 6). Dbałość o satysfakcję pacjentów, deklarowana przez lekarzy dentystów, powinna stanowić zachętę do tego, aby dentyści, zatrudniający pracowników, zmierzali w kierunku zwiększania swojej wiedzy i umiejętności w zakresie kierowania personelem.

Identyfikacja cech i postaw prezentowanych przez lekarzy dentystów w życiu zawodowym - w oparciu o ich samoocenę - w ujęciu pozytywnym, pozwala na stwierdzenie, że: są oni zaangażowani w pracę, mają rozwinięte umiejętności intrapersonalne, są nastawieni na dobre relacje z pacjentami. Nieco gorzej wypadają w sytuacjach stresu, a ich najsłabszą stroną są umiejętności z zakresu kierowania personelem. Postawy i działania lekarza dentysty w ujęciu normatywnym będą przedstawione w punkcie 3.3 .3 tego rozdziału. 


\subsubsection{SAMOOCENA STUDENTÓW STOMATOLOGII}

$\mathrm{O}$ ocenę własnych umiejętności i postaw związanych $\mathrm{z}$ funkcjonowaniem w środowisku pracy zostali poproszeni również studenci kierunku lekarskodentystycznego łódzkiego UM - wyniki badania III. W tabelach 20 i 21 przedstawiony jest ranking dokonanej samooceny w zakresie czynników intra$\mathrm{i}$ interpersonalnych.

Tabela 20. Ranking intrapersonalnych umiejętności studentów - wyniki samooceny

\begin{tabular}{|c|c|c|c|c|c|c|c|c|c|}
\hline \multirow{2}{*}{$\begin{array}{c}\text { Postawy/ } \\
\text { umiejętności w zakresie }\end{array}$} & \multicolumn{5}{|c|}{$\begin{array}{c}\text { Stanowisko respondenta } \\
\text { (procent wskazań) }\end{array}$} & \multirow[b]{2}{*}{$\bar{x}$} & \multirow[b]{2}{*}{ Do } & \multirow[b]{2}{*}{ Me } & \multirow[b]{2}{*}{$\mathbf{S}(\mathbf{x})$} \\
\hline & $\begin{array}{l}\text { brak } \\
\text { (1) }\end{array}$ & \begin{tabular}{|l} 
mały \\
stopień \\
$(2)$
\end{tabular} & $\begin{array}{c}\text { średnio } \\
\text { (3) }\end{array}$ & $\begin{array}{c}\text { dobrze } \\
(4)\end{array}$ & $\begin{array}{c}\text { bardzo } \\
\text { dobrze } \\
(5)\end{array}$ & & & & \\
\hline Zaangażowanie w pracę & 2,11 & 1,04 & 6,32 & 46,32 & 44,22 & 4,29 & 4 & 4 & 0,81 \\
\hline Myślenie alternatywne & 0,0 & 3,16 & 18,95 & 46,32 & 31,58 & 4,06 & 4 & 4 & 0,80 \\
\hline $\begin{array}{l}\text { Ustalanie hierarchii działań w } \\
\text { życiu osobistym i zawodowym }\end{array}$ & 0,0 & 5,21 & 17,71 & 43,75 & 33,33 & 4,05 & 4 & 4 & 0,85 \\
\hline $\begin{array}{l}\text { Określanie priorytetów w życiu } \\
\text { zawodowym }\end{array}$ & 0,0 & 4,21 & 16,84 & 51,58 & 27,37 & 4,02 & 4 & 4 & 0,79 \\
\hline $\begin{array}{l}\text { Identyfikacja własnych mocnych i } \\
\text { słabych stron }\end{array}$ & 0,0 & 0,0 & 27,37 & 50,53 & 22,11 & 3,95 & 4 & 4 & 0,71 \\
\hline \begin{tabular}{|l|} 
Planowanie własnego rozwoju \\
zawodowego
\end{tabular} & 0,0 & 0,0 & 26,04 & 53,13 & 20,83 & 3,95 & 4 & 4 & 0,69 \\
\hline $\begin{array}{l}\text { Planowanie działań na najbliższy } \\
\text { miesiąc }\end{array}$ & 0,0 & 7,37 & 22,11 & 40,0 & 30,53 & 3,94 & 4 & 4 & 0,91 \\
\hline Zwiększanie odporności na stres & 3,23 & 4,30 & 24,73 & 53,76 & 13,98 & 3,71 & 4 & 4 & 0,88 \\
\hline
\end{tabular}

Źródło: Opracowanie własne na podstawie przeprowadzonego badania.

$\mathrm{Z}$ danych zawartych w tabeli 20 wynika, że studenci - podobnie, jak lekarze najwyżej ocenili swoje zaangażowanie pracę (choć na niższym poziomie, niż praktycy zawodu). Pozostałe kwestie, które były przedmiotem oceny (m. in. umiejętność określania priorytetów, planowania) przeszło $70 \%$ badanych oceniła, jako posiadane na bardzo wysokim lub wysokim poziomie. Najniżej respondenci ocenili umiejętność zwiększania odporności na stres.

W odniesieniu do umiejętności interpersonalnych respondenci badania III wysoko ocenili się w zakresie aktywnego słuchania, jasnego i precyzyjnego komunikowania oraz nawiązywania dobrego kontaktu z pacjentem. Najsłabiej ocenili swoją umiejętność publicznych prezentacji. 
Tabela 21. Ranking interpersonalnych umiejętności i postaw studentów - wyniki samooceny

\begin{tabular}{|c|c|c|c|c|c|c|c|c|c|}
\hline \multirow[b]{2}{*}{$\begin{array}{c}\text { Postawy/ umiejętności w } \\
\text { zakresie }\end{array}$} & \multicolumn{5}{|c|}{$\begin{array}{c}\text { Stanowisko respondenta } \\
\text { (procent wskazań) }\end{array}$} & \multirow[b]{2}{*}{$\bar{x}$} & \multirow[b]{2}{*}{ Do } & \multirow[b]{2}{*}{ Me } & \multirow[b]{2}{*}{$\mathbf{S}(\mathbf{x})$} \\
\hline & $\begin{array}{r}\text { brak } \\
\text { (1) }\end{array}$ & $\begin{array}{c}\text { mały } \\
\text { stopień } \\
\text { (2) }\end{array}$ & $\begin{array}{r}\text { średnio } \\
\text { (3) }\end{array}$ & $\begin{array}{c}\text { dobrze } \\
\text { (4) }\end{array}$ & $\begin{array}{c}\text { bardzo } \\
\text { dobrze } \\
(5)\end{array}$ & & & & \\
\hline $\begin{array}{l}\text { achowanie dobrych relacji z } \\
\text { nymi }\end{array}$ & 0,0 & 0,0 & 12,50 & 44,79 & 42,71 & 4,30 & 4 & 4 & 0,68 \\
\hline Aktywne słuchanie & 0,0 & 2,08 & 12,50 & 53,13 & 32,29 & 4,16 & 4 & 4 & 0,72 \\
\hline Jasne, $p$ & 0,0 & 1,04 & 22,92 & 46,88 & 29,17 & 404 & & & 0,75 \\
\hline $\begin{array}{l}\text { Nawią } \\
\text { pacjent } \\
\text { pierwsz }\end{array}$ & 3,13 & 1,04 & 14,58 & 54,17 & 27,08 & 4,01 & 4 & 4 & 0,86 \\
\hline Rozwis & 0,0 & 0,0 & 16,67 & 69,79 & 13,54 & 3,97 & & 4 & 0,55 \\
\hline $\begin{array}{l}\text { Utrzy1 } \\
\text { pacjen }\end{array}$ & 3,13 & 1,04 & 14,58 & 61,46 & 19,79 & 3,94 & 4 & 4 & 0,82 \\
\hline Udziel & 0,0 & 2,08 & 30,21 & 50,0 & 17,71 & 3,83 & 4 & 4 & 0,74 \\
\hline Media & 2,08 & 2,08 & 29,17 & 46,88 & 19,79 & 3,80 & 4 & 4 & 0,85 \\
\hline Praca z dzieckiem-pacjente & 3,16 & 5,26 & 26,32 & 40,0 & 25,26 & 3,79 & 4 & 4 & 0,99 \\
\hline Radzenie sobie $\mathrm{z}$ & 0,0 & 12,50 & 33,33 & 34,38 & 19,79 & 3,61 & 4 & 4 & 0,94 \\
\hline$\overline{\text { Radze }}$ & 1,04 & 8,33 & 36,46 & 41,67 & 12,50 & 3,56 & & 4 & 0,86 \\
\hline ywwieranie wpływu na d & 1,04 & 3,13 & 45,83 & 39,58 & 10,42 & 3,55 & 3 & 4 & 0,77 \\
\hline ubliczne prezentacje & 5,21 & 11,46 & 42,71 & 27,08 & 13,54 & 3,32 & 3 & 3 & 1,02 \\
\hline
\end{tabular}

Źródło: Opracowanie własne na podstawie przeprowadzonego badania.

Można w tym miejscu przywołać wyniki badań naukowców z Case Estern Reserve University's School of Dental Medicine i z Weatherhead of Management, którzy odkryli, że w praktykach klinicznych studentów liczy się bardziej inteligencja emocjonalna ${ }^{124}$ (EI), niż inteligencja racjonalna (IQ). Czynnikami szczególnie wspomagającymi studentów posiadających wysoki poziom EI są umiejętności do samokontroli, w szczególności: ${ }^{125}$

- optymizm,

- panowanie nad własnymi emocjami (umiejętności te studenci stomatologii w badaniu III ocenili u siebie jako posiadane na relatywnie niskim poziomie - średnia wskazań poniżej 4),

\footnotetext{
124 Inteligencja emocjonalna jest jedną z kwalifikacji wyróżniających. Obejmuje następujące poziomy: świadomość własnych uczuć, kontrolowanie uczuć, samodyscyplina, empatia i umie-

jętności społeczne. Por. Goleman D., Emotional Intelligence: Why Il Can Matter More Than IQ, Bantam, Nowy Jork 1995.

125 Teich S.T., Wan Z., Faddoul F.F., Relationship Between Broken Appointments and Dental Students' Clinical Experience Lewel, "Journal Dental Education”, 2012 nr 76, s. 1167 i nast.
} 
- umiejętność do jasnego określania celów podczas przeprowadzania zabiegu,

- inicjatywa,

- przytomność umysłu i umiejętność adaptacji do nieoczekiwanych zdarzeń (umiejętność myślenia alternatywnego respondenci badania III ocenili powyżej 4).

Podsumowując, samoocena studentów jest na wyższym poziomie niż lekarzy dentystów, co z jednej strony może być wynikiem wiary we własne możliwości i nabywania kompetencji społecznych w trakcie kształcenia w szkole, a z drugiej - braku doświadczenia, wynikającego z ograniczonego dostępu do realiów funkcjonowania gabinetu stomatologicznego. Jej relatywnie wysoki poziom stanowi wartościowy zasób osobisty studenta, który uzupełniając wiedzę i umiejętności stricte medyczne, będzie stanowił jego potencjał przedsiębiorczy przy rozpoczynaniu pracy zawodowej.

\subsubsection{KOMPETENCJE IDEALNEGO DENTYSTY - PERSPEKTYWA PACJENTA, LEKARZA I STUDENTA}

O przedstawienie sylwetki (cech, postaw i zachowań) wzorcowego lekarza dentysty zostali poproszeni respondenci badania I, III i IV.

Pacjenci na pytanie: „Jaki powinien być idealny dentysta?” udzielali odpowiedzi w formie opisowej. Oto wybrane przykłady ${ }^{126}$, zgrupowane w trzech obszarach tematycznych, normatywnego spojrzenia na stomatologa przez pacjenta:

1. odniesienia do postawy stricte medycznej:

- być rzetelny, doktadny i kompetentny,

- leczyć i doradzać, co warto poprawić,

- być z powotania, stużac swoim pacjentom $w$ doprowadzeniu ich do zdrowia,

- zachęcić mnie do regularnego odwiedzania gabinetu,

- być profesjonalista i mieć dobrze wyposażony gabinet,

- brać petna odpowiedzialność za leczenie,

- doktadnie wyleczyć uzębienie i dać porady, jak dbać o zęby;

2. odniesienia do obsługi (w tym komunikacji z pacjentem):

- być uprzejmym i zrozumieć pacjenta,

- być dostepny zawsze,

- postarać się, żebym się nie stresowata,

- przekonać mnie, że nie będzie bolało,

- budzić zaufanie,

- być uprzejmy, z poczuciem humoru,

- szanować pacjenta, jego zęby, kieszeń i zdrowie,

$126 \mathrm{~W}$ przytoczonych wypowiedziach zachowano ich treść, a w niektórych zmodyfikowano pisownię. 
- potrafi odpowiednio podejść do człowieka, wszystko mu wyjaśnić,

- patrzé́ na mnie, jak na człowieka przerażonego,

- być cierpliwy,

- indywidualne podejście do problemów pacjenta,

- podpowiadać rozwiazania adekwatne do możliwości finansowych;

3. odniesienia do obszaru medycznego i pozamedycznego:

- być delikatny i precyzyjny,

- rzetelnie wykonywać swoja pracę, z sympatia dla pacjenta,

- być uśmiechnięty $i$ wykonywać rzetelnie swoja prace,

- być profesjonalnym, podchodzić do każdego z życzliwościa,

- wykonać rzetelnie ustuge za rozsądna cenę,

- jasno wyjaśnić co robi z moim uzębieniem, być profesjonalista,

- wzbudzać zaufanie i być profesjonalny,

- być delikatny i doktadnie informować o przebiegu leczenia oraz wykonywać swoja prace z petnym zaangażowaniem,

- być dobrym specjalista i umieć rozmawiać z pacjentem.

I na koniec: być taki, jak mój obecny.

Jak widać z przytoczonych przykładów, pacjenci zwracają uwagę nie tylko na profesjonalizm stricte medyczny stomatologa, ale również elementy związane $\mathrm{z}$ obsługą (jest to obszar funkcjonowania gabinetu, w którym dobre rezultaty dają rozwiązania z zakresu marketingu relacji).

Natomiast jeśli chodzi o opinie stomatologów i studentów kierunku lekarskodenstystycznego, to lekarza dentystę - w ujęciu normatywnym - powinna charakteryzować głównie ${ }^{127}$ :

- dobra wiedza stricte medyczna (absolutnie konieczny czynnik dla 73,78\% respondentów badania I, a ważny w sumie dla $96,65 \%$ i odpowiednio $61,46 \%$ oraz $92,71 \%$ dla respondentów badania III),

- przyjazne nastawienie wobec pacjentów i personelu (czynnik absolutnie konieczny dla $68,29 \%$ lekarzy dentystów i ważny w sumie dla $98,17 \%$ oraz odpowiednio 58,96\% i 93,7\% dla studentów),

- zdrowa postawa moralna (bardzo ważny czynnik dla $61,73 \%$ respondentów badania I i ważny w sumie dla $96,92 \%$ oraz odpowiednio $54,74 \%$ i $92,63 \%$ dla studentów).

Poza tą triadą - mającą korzenie w etyce lekarskiej - oczekiwania respondentów pokryły się co do wysokiego poziomu inteligencji (zwłaszcza emocjonalnej), który powinien posiadać stomatolog, ale co do innych elementów postawy

${ }^{127}$ Wskazania lekarzy dentystów były bardziej zdecydowane - czynnik uzyskiwał wyższe poparcie - we wszystkich trzech obszarach, niż studentów. 
idealnego dentysty - były już odmienne (choć różnice nie były istotne statystycznie). Wykres 1 przedstawia intrapersonalne predyspozycje wzorcowego lekarza stomatologa, a wykres 2 - interpersonalne wg lekarzy dentystów i studentów kierunku lekarsko-dentystycznego.

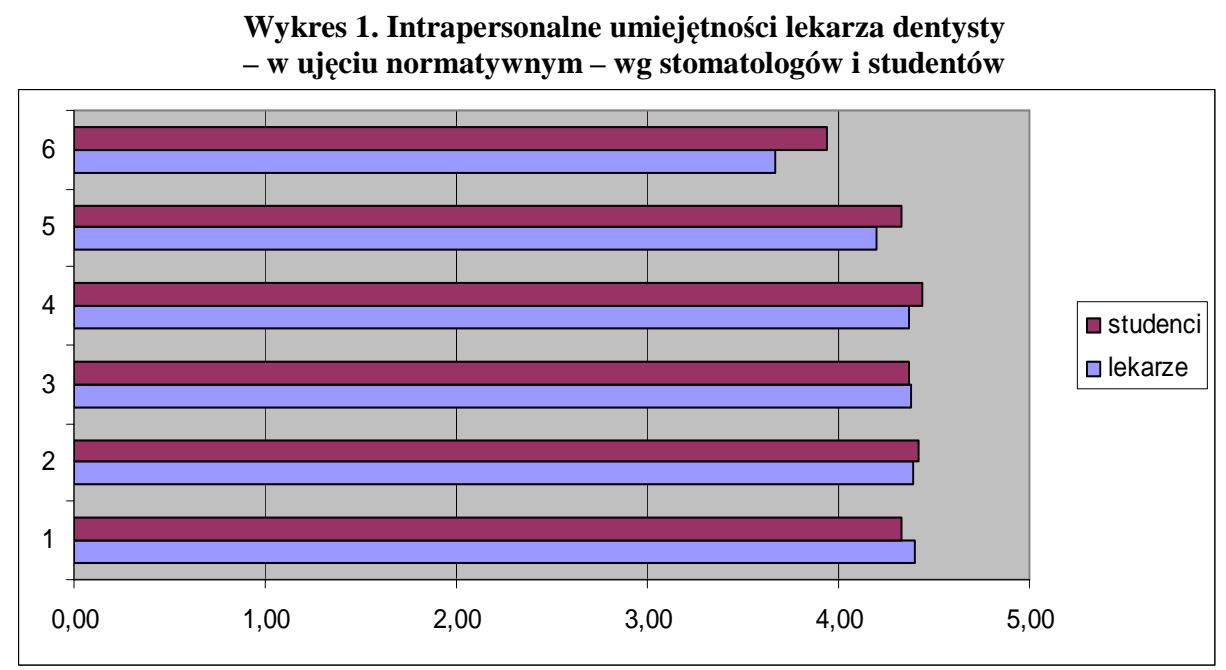

Źródło: opracowanie własne na podstawie przeprowadzonych badan.

Legenda: oznaczenia na osi rzędnych: 1) odwaga do wprowadzania zmian, 2) radzenie sobie ze stresem, 3) wysoki poziom inteligencji, 4) kreatywność, 5) pewność siebie, 6) skłonność do podejmowania ryzyka.

Stomatolodzy uznali, że dentysta powinien mieć odwagę do wprowadzania zmian i niewielką skłonność do podejmowania ryzyka ${ }^{128}$ (można wnioskować, że zmiany, które mieliby wprowadzać, powinny być już sprawdzone w innych gabinetach i jako bezpieczne wprowadzone do własnego gabinetu - pojawia się tu rola dentysty jako przedsiębiorcy imitatora). Odmienne stanowisko zajęli studenci, którzy od idealnego stomatologa oczekują znacznej pewności siebie, kreatywności i skłonności do podejmowania ryzyka (a więc przedsiębiorczości Schumpeterowskiej).

Największą rolę wśród umiejętności i postaw lekarza dentysty w ujęciu normatywnym respondenci badania I przypisali komunikacji interpersonalnej, a badania III - umiejętności organizowania pracy. Jako relatywnie najmniej ważną umiejętność idealnego stomatologa lekarze dentyści uznali umiejętność prowadzenia spotkań z pracownikami, a studenci - dbałość o stan środowiska naturalnego. Zestawienie pozostałych oczekiwań co do postaw, umiejętności

${ }^{128}$ Ich deklaracje pozostają w opozycji do słów R. Lavina, przedstawionych we wstępie pracy. 
i zachowań idealnego lekarza dentysty w ujęciu normatywnym przedstawia wykres 2 .

Wykres 2. Interpersonalne umiejętności lekarza dentysty - w ujęciu normatywnym - wg stomatologów i studentów

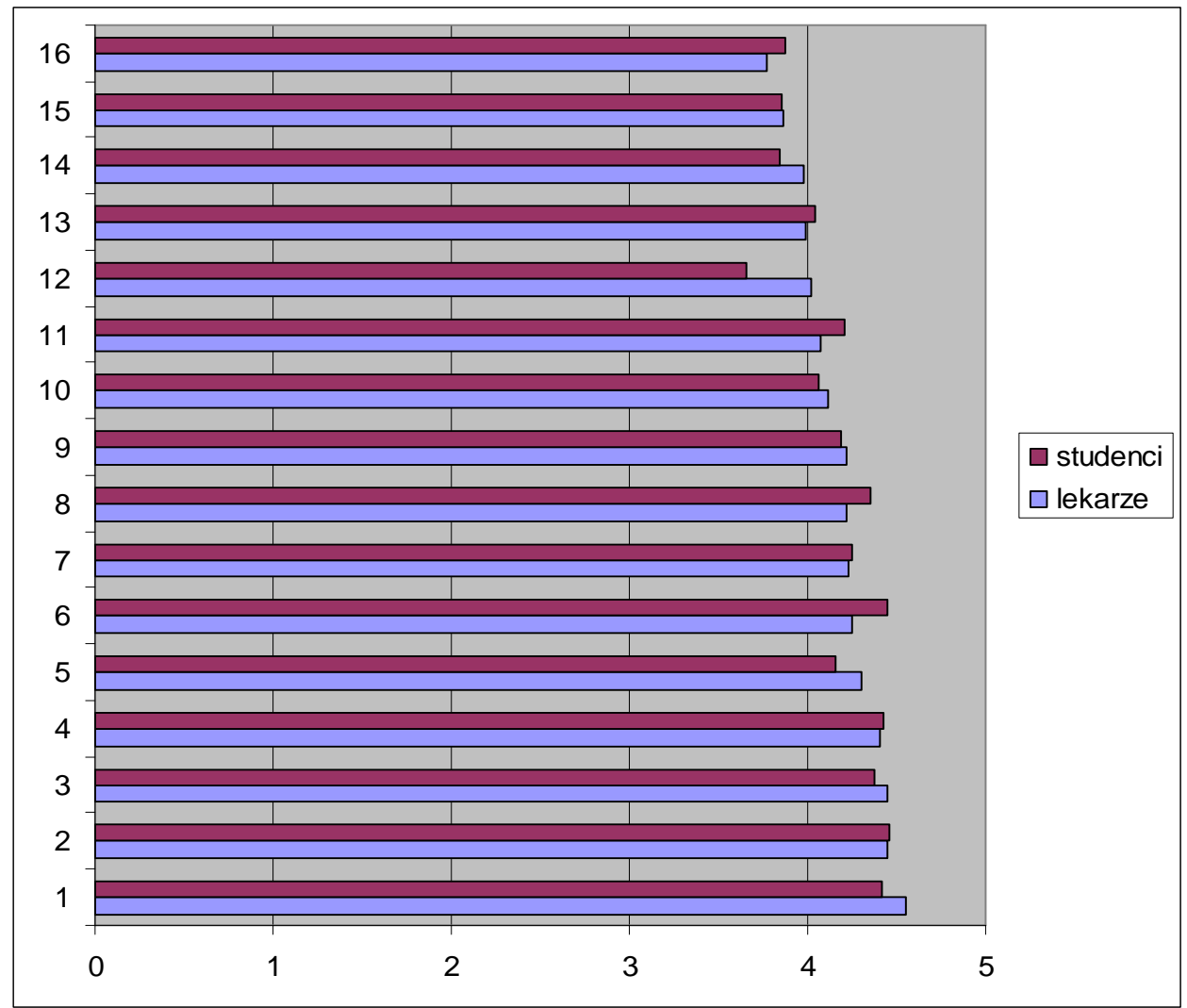

Źródło: opracowanie własne na podstawie przeprowadzonych badań.

Legenda: oznaczenia na osi rzędnych: 1) komunikacja interpersonalna, 2) umiejętność organizowania pracy, 3) dbanie o rozwój zawodowy własny i personelu, 4) kreowanie przyjaznych warunków pracy, 5) umiejętność kierowania konfliktem, 6) optymalne motywowanie personelu, 7) poszukiwanie nowości technicznych i technologicznych, 8) budowanie autorytetu osobistego, 9) zapewnienie sprawnego przepływu informacji w gabinecie, 10) zapewnienie sprawnego przepływu informacji na płaszczyźnie: gabinet - otoczenie, 11) umiejętność adaptowania rozwiązań stosowanych w innych podmiotach dla potrzeb własnego gabinetu, 12) dbałość o stan środowiska naturalnego, 13) dobre stosunki z dostawcami materiałów i usług do gabinetu, 14) doświadczenie w kierowaniu, 15) delegowanie uprawnień na członków personelu, 16) umiejętność prowadzenia spotkań z pracownikami. 
Otrzymany wzorzec lekarza dentysty jest podobny do przedsiębiorcy przyszłości z badania P. Kazibudzkiego ${ }^{129}$. Kompetencje przedsiębiorcy ,jutra" w dużym stopniu odzwierciedlają jakość i skuteczność wykonywanych przez niego działań biznesowych, ich ranking przedstawia się następująco:

- skuteczność,

- uczciwość,

- elastyczność,

- zaradność,

- otwartość na ludzi,

- sprawiedliwość,

- komunikatywność,

- kreatywność.

\section{PRZEDSIĘBIORCZOŚĆ RODZINNA 4.1. ISTOTA PRZEDSIĘBIORSTWA RODZINNEGO}

Jednym z wymiarów przedsiębiorczość jest przedsiębiorczość rodzinna, która może wpływać na intencje przedsiębiorcze poszczególnych osób. Jednym z celów cząstkowych pracy jest określenie uwarunkowań i skali przedsiębiorczości rodzinnej wśród lekarzy dentystów. Aby go zrealizować, najpierw zostanie krótko zarysowany aspekt teoretyczny tego zagadnienia, a następnie - przedstawione wyniki badań.

Przedsiębiorczość rodzinna oznacza prowadzenie rodzinnej firmy, ale w literaturze nie ma jednolitej definicji przedsiębiorczości rodzinnej czy też firmy rodzinnej ${ }^{130}$. Najczęściej przyjmuje się, że wyróżnikiem firmy rodzinnej jest własność rodziny, zarządzanie przez rodzinę oraz pokoleniowa ciągłość właścicieli z danego kręgu rodzinnego, choć w literaturze przedmiotu funkcjonuje wiele definicji przedsiębiorstw rodzinnych, które próbują wyjaśnić jego społeczno-ekonomiczną specyfikę (przykłady kilku różnych podejść prezentuje tabela 22).

\footnotetext{
${ }^{129}$ Kazibudzki P., Wzorzec kompetencji przedsiębiorcy przyszłości i jego empiryczna walidacja, „Ekonomika i Organizacja Przedsiębiorstwa”, 2010 nr 11, s. 34.

${ }^{130}$ Niedbała E., Firmy rodzinne - obiekt badawczy, „Master of Business Administration”, $2002 \mathrm{nr} 5$, s. 44.
} 
Tabela 22. Pojęcie ,przedsiębiorstwo rodzinne”

w świetle wybranych pozycji literatury przedmiotu

\begin{tabular}{|c|c|}
\hline Autor podejścia & Treść definicji ,,przedsiębiorstwo rodzinne” \\
\hline R.G.Donnelley ${ }^{a}$ & $\begin{array}{l}\text { Z biznesem rodzinnym mamy do czynienia, jeśli co najmniej dwie generacje jednej } \\
\text { rodziny miały znaczacy wpływ na cele i polityke firmy. }\end{array}$ \\
\hline P.A. Frishkoff ${ }^{b}$ & $\begin{array}{l}\text { Firma rodzinna posiada dowolną formę prawną, kapitał przedsiębiorstwa znajduje } \\
\text { się w całości lub w decydującej części w rękach rodziny, przynajmniej jeden czło- } \\
\text { nek rodziny wywiera decydujący wpływ na kierownictwo lub sam sprawuje funkcję } \\
\text { zarządczą, z zamiarem trwałego utrzymania przedsięwzięcia w rękach rodziny. }\end{array}$ \\
\hline Ł. Sułkowski & $\begin{array}{l}\text { Przedsiębiorstwo rodzinne jest podmiotem gospodarczym, w którym większość } \\
\text { struktury własności oraz funkcja zarządzania całym podmiotem pozostają w rękach } \\
\text { jednej rodziny. }\end{array}$ \\
\hline $\begin{array}{l}\text { K. Ashley- } \\
\text { Cotleur }\end{array}$ & $\begin{array}{l}\text { Z biznesem rodzinny mamy do czynienia, jeżeli pracuje w nim co najmniej dwóch } \\
\text { członków rodziny, którzy sprawują kontrolę nad zarządzaniem i finansami, a suk- } \\
\text { cesja w firmie miała miejsce lub jest planowana. }\end{array}$ \\
\hline G. Thornton ${ }^{\mathrm{e}}$ & $\begin{array}{l}\text { Wszystkie przedsiębiorstwa, w których władza i udziały skoncentrowane są w rę- } \\
\text { kach niewielkiej grupy osób, są w pewnym sensie przedsiębiorstwami rodzinnymi, } \\
\text { bo prowadzona działalność jest źródłem wynagrodzenia, dochodu i majątku } \\
\text { wszystkich - przyszłych czy obecnych - członków rodziny, nawet tych niepracu- } \\
\text { jących w firmie. }\end{array}$ \\
\hline $\begin{array}{l}\text { Inicjatywa Firm } \\
\text { Rodzinnych w } \\
\text { Polsce }^{f}\end{array}$ & $\begin{array}{l}\text { Przedsiębiorstwo rodzinne to podmiot o dowolnej formie prawnej, którego kapitał } \\
\text { w całości lub w decydującej części znajduje się w posiadaniu rodziny, przynajmniej } \\
\text { jeden jej członek wywiera decydujący wpływ na kierownictwo lub sam sprawuje } \\
\text { funkcję kierowniczą z zamiarem trwałego utrzymania przedsięwzięcia w rękach } \\
\text { rodziny. }\end{array}$ \\
\hline PARP $^{g}$ & $\begin{array}{l}\text { Firma rodzinna to każdy podmiot gospodarczy z sektora mikro, małych lub średnich } \\
\text { przedsiębiorstw, o dowolnej formie prawnej, zarejestrowany i działający w Polsce, } \\
\text { w którym: 1) co najmniej dwóch członków rodziny wspólnie pracuje w tym } \\
\text { przedsiębiorstwie; 2) co najmniej jeden członek rodziny ma istotny wpływ na } \\
\text { zarządzanie; 3) członkowie rodziny posiadają znaczące (większościowe) udziały } \\
\text { w przedsiębiorstwie, 4) nie występują podmioty reprezentujące następujące sekcje } \\
\text { PKD 2004: sekcja A - rolnictwo, łowiectwo, myślistwo, sekcja B - rybactwo, } \\
\text { sekcja L - administracja publiczna, sekcja P - gospodarstwa domowe zatrudniające } \\
\text { pracowników, sekcja Q - organizacje i zespoły eksterytorialne; 5) wykluczono } \\
\text { podmioty funkcjonujące w formie działalności gospodarczej osób fizycznych, } \\
\text { nikogo nie zatrudniające. }\end{array}$ \\
\hline
\end{tabular}

Źródło: opracowanie własne na podstawie: ${ }^{\text {a }}$ Donnelley R.G., The Family Business, w: Aronoff C.E., Astrachan J.H., Ward J.L. (red. ), Family Business Sourcebook, september 2002, s. 4 i nast., za: Kowalewska A., Szut J., Sułkowski Ł, Marjański A., Definicja pojęcia firmy rodzinnej, w: Kowalewska A. (red.), Firmy rodzinne w polskiej gospodarce - szanse $i$ wyzwania, Wyd. Naukowe Technologii Eksploatacji - PIB, Warszawa 2009, s. 29; ${ }^{\text {b }}$ Frishkoff P.A., Understanding Family Business, Austin Family Business Program, 15 April 1995 , za: Kowalewska A. i in. Definicja ... op. cit., s. 29; ${ }^{\text {c }}$ Sułkowski Ł., Organizacja a rodzina, więzi familijne $w$ życiu gospodarczym, TNOiK, Torun 2004, s. 100; ${ }^{\mathrm{d}}$ AshleyCotleur K., Family Business and Relationship Marketing: The Impact of Relationship Marketing in Second Generation Family Business, Frostburg State University, www.usabe.org, za: Kowalewska A. i in.

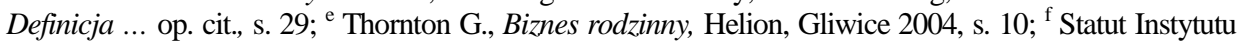
Firm Rodzinnych, www.firmyrodzinne.pl/index.php?option=com_content\&view=article\&id=56:statut \&catid=42:dokumenty\&Itemid=63.; ${ }^{\mathrm{g}}$ Wilmańska A. (red.), Raport $o$ stanie sektora matych $i$ średnich przedsiębiorstw w Polsce w latach 2008-2009, PARP Warszawa 2010, www.parp.gov.pl. 
Choć można mówić o dużej różnorodności definicyjnej pojęcia „przedsiębiorstwo rodzinne"131 (wynikającej m.in. z tego, że jego cechy są rozpatrywane na gruncie wielu nauk, m.in.: zarządzania, ekonomii, socjologii, psychologii), to - co oczywiste - wszystkie lączą dwa elementy: rodzina i przedsiębiorstwo ${ }^{132}$, których - często odmienne (por. tabela 23) - normy, znajdują swój specyficzny wyraz w tego typu podmiotach. Sprzężenie pomiędzy normami rodziny i przedsiębiorstwa wynika $\mathrm{m}$. in. ${ }^{133}$ :

- z odmiennego sposobu funkcjonowania przedsiębiorstw rodzinnych,

- wyznaczonych przez podmiot celów (często nie związanych jedynie $\mathrm{z}$ biznesem),

- misji i wizji przyszłości rodziny i firmy; w przedsiębiorstwach rodzinnych uwzględniając ich jakościowe cechy społeczne - można wyodrębnić różne rodzaje tj. o różnej skali aktywności ${ }^{134}$ :

- przedsiębiorstwa substytucji dochodów lub zastępujące pracę, utworzone przez osoby zagrożone utratą pracy lub przez bezrobotnych; właściciele traktują je głównie jako sposób na przeżycie, pracując dla siebie i rodziny;

- przedsiębiorstwa stylu życia, założone przez osoby, które celowo porzuciły dotychczasową pracę, nie oczekując nawet wyższych dochodów, a jedynie niezależności i satysfakcji z pracy;

- przedsiębiorstwa przedsiębiorcze, które właściciele traktują jako sposób na życie, dążąc do rozwoju firmy;

- planów sukcesyjnych,

- systemu kultywowanych wartości,

- polityki finansowej.

131 Kowalewska A., Szut J., Sułkowski Ł., Marjański A., Definicja pojęcia firmy rodzinnej, w: Kowalewska A. (red.), Firmy rodzinne w polskiej gospodarce - szanse $i$ wyzwania, Wyd. Naukowe Technologii Eksploatacji - PIB, Warszawa 2009, s. 29.

132 Pigla A., Spoteczne i gospodarcze funkcjonowanie przedsiębiorstw rodzinnych, w: Listwan T., Mruk H., Zarzadzanie matymi i średnimi przedsiębiorstwami - problemy wspótczesne, Wyd. Forum Naukowe, Poznań 2009, s. 221.

133 Winnicka-Popczyk A., Popczyk W., Firma rodzinna w rozwiniętej gospodarce rynkowej”, w: Jeżak J., Popczyk W., Winnicka-Popczyk A., Przedsiębiorstwo rodzinne, funkcjonowanie i rozwój, Difin, Warszawa 2004, s. 20.

${ }^{134}$ Piasecki B., Przedsiębiorczość ... op. cit., s. 94 i nast. 
Tabela 23. Porównanie norm rodziny i norm przedsiębiorstwa

\begin{tabular}{|l|l|}
\hline \multicolumn{1}{|c|}{ Normy rodziny } & \multicolumn{1}{|c|}{ Normy przedsiębiorstwa } \\
\hline $\begin{array}{l}\text { Stwarzanie szans realizacji potrzeb osobom } \\
\text { spokrewnionym, zwłaszcza własnym dzieciom }\end{array}$ & $\begin{array}{l}\text { Zatrudnianie tylko osób odpowiednio } \\
\text { Wykwalifikowanych }\end{array}$ \\
\hline $\begin{array}{l}\text { Zapewnienie wsparcia odpowiedniego do } \\
\text { pojawiających się potrzeb }\end{array}$ & $\begin{array}{l}\text { Zapewnienie wynagrodzenia odpowiedniego do } \\
\text { wkładu oraz rynkowych uwarunkowań }\end{array}$ \\
\hline $\begin{array}{l}\text { Postrzeganie każdego członka rodziny jako } \\
\text { unikalnej jednostki, równe traktowanie } \\
\text { rodzeństwa }\end{array}$ & $\begin{array}{l}\text { Brak zindywidualizowanego podejścia do } \\
\text { pracownika; tendencja do identyfikowania } \\
\text { najlepszych }\end{array}$ \\
\hline $\begin{array}{l}\text { Stwarzanie każdemu możliwości nauki } \\
\text { odpowiednio do potrzeb }\end{array}$ & $\begin{array}{l}\text { Stwarzanie możliwości nauki odpowiednio } \\
\text { do potrzeb organizacji }\end{array}$ \\
\hline
\end{tabular}

Źródło: Siefer T., Du kommst später mal in die Firma! Psychosoziale Dynamik von Familienunternehmen”, Heidelberg 1996, s. 63, za: Safin K., Przedsiębiorstwo rodzinne - istota i zachowania strategiczne, AE im. O. Langego we Wrocławiu, Wrocław 2007, s. 2.

Charakterystyka przedsiębiorstwa rodzinnego jest wynikową cech przynajmniej dwóch z trzech subsystemów ${ }^{135}$ :

- rodzinnego - jego elementami są członkowie rodziny, jej kolejne pokolenia (podsystem ten jest wewnętrznie skupiony na członkach rodziny, opierając się na uczuciach, wychowaniu, zapewnieniu bezpieczeństwa itp.);

- gospodarczego (przedsiębiorstwa) - elementami składowymi tego podsystemu są: kierownicy, pracownicy, klienci; jego głównym zadaniem jest osiągniecie wyznaczonych celów przedsiębiorstwa;

- własności - jego elementami są wszyscy właściciele przedsiębiorstwa (tak członkowie rodziny, jak i osoby spoza niego); zawiera zbiór zasad i reguł, które dotyczą funkcjonowania i zarządzania przedsiębiorstwem oraz postaw etyczno-moralnych członków rodziny zaangażowanych w przedsięwzięcie (utrzymanie rodzinnego charakteru firmy, kultywowanie tradycji rodzinnych, przywiązanie członków rodziny do firmy, ich lojalność, jedność, pracowitość oraz przekazanie jej następnemu pokoleniu).

Przedsiębiorstwa rodzinne, jako specyficzny rodzaj przedsiębiorstw, posiadają pewne unikatowe zalety, mające istotny wpływ na uzyskanie przewagi konkurencyjnej nad innymi podmiotami gospodarczymi (por. tabela 24). Z punktu widzenia gabinetów stomatologicznych istotnymi są:

- dbałość o dziedzictwo (przejawiająca się w trosce o jakość, która wpływa na „zachowanie dobrego nazwiska" - markę dentysty);

- personalizacja więzi organizacyjnych i związane z nią zaufanie do współpracowników;

- zorientowanie na przyszłość (związane z dążeniem do stabilnego wzrostu).

${ }^{135}$ Winnicka-Popczyk A., Popczyk W., Firma rodzinna ... op. cit., s. 21-23. 
Tabela 24. Zalety i wady przedsiębiorstw rodzinnych

\begin{tabular}{|c|c|c|}
\hline Kryterium & $\begin{array}{r}\text { Zalety } \\
\end{array}$ & \begin{tabular}{|r} 
Wady \\
\end{tabular} \\
\hline Rodzina & $\begin{array}{l}\text { - głębokie poczucie własności firmy, } \\
\text { - członków rodziny cechuje wzajemny sza- } \\
\text { cunek, dbałość o dziedzictwo i jakość oferty, } \\
\text { - przywiązanie do tradycji, } \\
\text { - swoboda w działaniu jest znacznie wię- } \\
\text { ksza niż w innych przedsiębiorstwach, } \\
\end{array}$ & $\begin{array}{l}\text { - zbyt emocjonalne podejście, problemy } \\
\text { z komunikacją oraz zrozumieniem, } \\
\text { - brak obiektywizmu w podejmowanych } \\
\text { decyzjach przez wzgląd na członków ro- } \\
\text { dziny, będących pracownikami przedsię- } \\
\text { biorstwa, }\end{array}$ \\
\hline $\begin{array}{l}\text { Zarządzanie } \\
\text { zasobami } \\
\text { ludzkimi }\end{array}$ & $\begin{array}{l}\text { - większe zaufanie wobec pracowników z } \\
\text { rodziny, } \\
\text { - niski stopień sformalizowania działalności, } \\
\text { przekładający się na: * bardziej sprawną i } \\
\text { efektywną komunikację w firmie, * perso- } \\
\text { nalizację więzi organizacyjnych (rodzinna } \\
\text { atmosfera), * większą troskę o satysfakcję } \\
\text { zawodową pracowników, * relatywnie wyż- } \\
\text { sze wynagrodzenia, }\end{array}$ & $\begin{array}{l}\text { - opór przed dopuszczeniem zewnętrz- } \\
\text { nych menedżerów do zarządzania, } \\
\text { - nierówne traktowanie pracowników } \\
\text { z rodziny i spoza rodziny, } \\
\text { - zatrudnianie rodziny, niezależnie } \\
\text { od ich kwalifikacji, } \\
\text { - problem ze zwalnianiem członków } \\
\text { rodziny, }\end{array}$ \\
\hline $\begin{array}{l}\text { Dom } \\
\text { a } \\
\text { praca }\end{array}$ & $\begin{array}{l}\text { - wspólna praca, to wspólny sukces, } \\
\text { - identyfikacja rodziny z firmą, } \\
\text { - wspólny cel, jako czynnik spajający } \\
\text { rodzinę, } \\
\text { - troska członków rodziny o siebie nawza- } \\
\text { jem, o współpracowników i klientów, } \\
\text { - lepsza motywacja (właścicieli i pra- } \\
\text { cowników), }\end{array}$ & $\begin{array}{l}\text { - zbyt ścisłe zintegrowanie życia rodziny } \\
\text { z życiem firmy i przenoszenie ewentu- } \\
\text { alnych konfliktów rodzinnych na sferę } \\
\text { biznesu, } \\
\text { - problemy z łączeniem ról zawodowych } \\
\text { i rodzinnych przez zatrudnionych pra- } \\
\text { cowników z rodziny, }\end{array}$ \\
\hline Finanse & $\begin{array}{l}\text { - wykorzystanie wewnętrznych zasobów } \\
\text { finansowych, } \\
\text { - niezależność i stabilność finansowa, }\end{array}$ & $\begin{array}{l}\text { - ograniczony dostęp do zewnętrznego } \\
\text { kapitału, } \\
\text { - ryzyko utraty dorobku rodziny np. } \\
\text { w przypadku kryzysu, } \\
\text { - konserwatyzm i niechęć do korzystania } \\
\text { z zaplecza doradczego i finansowego, } \\
\end{array}$ \\
\hline $\begin{array}{l}\text { Kontrola } \\
\text { kosztów }\end{array}$ & $\begin{array}{l}\text { - ograniczona do minimum biurokracja, } \\
\text { - mniejsze koszty kontroli i monitoringu, }\end{array}$ & $\begin{array}{l}\text { - możliwe trudności z wprowadzeniem } \\
\text { mechanizmów kontroli wydatków } \\
\text { członków rodziny, }\end{array}$ \\
\hline Sukcesja & $\begin{array}{l}\text { - zaplanowanie strategii sukcesji, } \\
\text { - możliwość przygotowania następcy do } \\
\text { objęcia funkcji zarządzającego, }\end{array}$ & $\begin{array}{l}\text { - brak strategii wycofywania się starsze- } \\
\text { go pokolenia z aktywnego zarządzania } \\
\text { firmą rodzinną, } \\
\text { - stawianie zbyt wysokich oczekiwań } \\
\text { następcom, }\end{array}$ \\
\hline $\begin{array}{l}\text { Horyzont } \\
\text { czasowy }\end{array}$ & $\begin{array}{l}\text { - zorientowanie na przyszłość, } \\
\text { - długoterminowe cele firmy, związane } \\
\text { z oczekiwaniem stabilnego wzrostu w per- } \\
\text { spektywie długoterminowej, } \\
\text { - umiejętność dostosowania się do zmien- } \\
\text { nych warunków otoczenia, } \\
\text { - zdolność do szybkiego podejmowania } \\
\text { decyzji. }\end{array}$ & $\begin{array}{l}\text { - trwanie przy złych decyzjach na skutek } \\
\text { uporu rodziny, } \\
\text { - krótkookresowe decyzje zarządcze. }\end{array}$ \\
\hline
\end{tabular}

Zródło: opracowanie własne na podstawie: Kowalewska A. (red.) Badanie firm rodzinnych.

Raport końcowy, s. 100-124, opracowany na zlecenie PARP, Warszawa 2009, www.parp.gov.pl. 
Z rodzinnym charakterem przedsiębiorstwa związane są także słabości i zagrożenia (por. tabela 24), wśród których - jako ważne w gabinetach stomatologicznych - można wymienić przede wszystkim: przenoszenie konfliktów w rodzinie na grunt przedsiębiorstwa (i odwrotnie), nepotyzm i jego skutki w zakresie polityki personalnej.

Podsumowując, warto zauważyć, że przenikanie się więzi rodzinnych i ekonomicznych w przedsiębiorstwach rodzinnych jest zarówno źródłem przewag, jak i ograniczeń rozwoju tych podmiotów. ${ }^{136}$ Podobne uwarunkowania mogą dotyczyć również gabinetów stomatologicznych, w których zatrudnieni są zstępni. Istotną zaletą gabinetu, jako firmy rodzinnej będzie możliwość uczenia się od doświadczonych członków rodziny. Większa otwartość w przekazywaniu wiedzy będzie dotyczyła zarówno warsztatu stricte medycznego, jak i obszaru pozamedycznego funkcjonowania gabinetu.

\subsection{ASPEKT PRZEDSIĘBIORCZOŚCI RODZINNEJ W GABINETACH STOMATOLOGICZNYCH - WYNIKI BADAŃ}

Problematykę związaną z gabinetem, jako firmą rodzinną w badaniu I, zaczęto eksplorować pytaniem: „Czy w gabinecie pracuje ktoś z najbliższej rodziny dentysty?". Przeszło 3/4 respondentów badania I odpowiedziało na to pytanie „nie” (76,69\% wskazań). Spośród pozostałych, którzy odpowiedzieli twierdząco: 57,9\% wskazało, że członek rodziny pracuje jako dentysta; 28,9\% - jako personel pomocniczy; a pozostali, że zajmuje inne stanowisko (np. recepcjonistki, pracownika ds. PR gabinetu).

Przypomnijmy, że większość respondentów - 81,33\% to właściciele gabinetów/ klinik stomatologicznych (przedsiębiorcy Quasneya - por. tabela 4). Spośród tych osób zdecydowaną większość stanowili założyciele (przedsiębiorcy Smitha, von Milesa i Knighta - por. tabela 4). Szczegółowy rozkład odpowiedzi na pytanie w jaki sposób dentysta stał się właścicielem gabinetu przedstawiony jest $\mathrm{w}$ tabeli 25 . Biorąc pod uwagę, że gabinety stomatologiczne również $\mathrm{w}$ minionym systemie polityczno-gospodarczym funkcjonowały, jako podmioty prywatne, autorka badania spodziewała się, że ok. 15-20\% respondentów, to osoby, które dzięki dziedziczeniu są właścicielami gabinetów, dlatego otrzymane wyniki - niespełna 5\% badanych jest właścicielem gabinetu dzięki sukcesji - były dużym zaskoczeniem.

${ }^{136}$ Kowalewska A. (red.) Badanie firm rodzinnych... op. cit., s. 112. 
Tabela 25. Sposób zostania właścicielem gabinetu stomatologicznego przez dentystę - badanie I

\begin{tabular}{|l|l|}
\hline \multicolumn{1}{|c|}{ Źródło własności gabinetu } & Wskazania (\%) \\
\hline założenie & 88,89 \\
\hline $\begin{array}{l}\text { dziedziczenie/otrzymanie w drodze darowizny od poprzedniego właściciela } \\
\text { (członka rodziny) }\end{array}$ & 4,86 \\
\hline kupno działającego gabinetu & 2,78 \\
\hline inne & 3,47 \\
\hline
\end{tabular}

Źródło: opracowanie własne na podstawie przeprowadzonego badania.

Wyniki badania pokazują również, że w Polsce nie ma „rynku gabinetów stomatologicznych"137 - niespełna 3\% badanych zostało właścicielem gabinetu kupując istniejący podmiot. W praktyce lekarz dentysta, kończąc działalność, pozbywa się poszczególnych składników majątku, a pacjenci odchodzą do innej praktyki. Wydaje się, że jesteśmy jeszcze zbyt młodą gospodarką rynkową (brak tradycji w tym zakresie), aby tego typu rozwiązania pojawiły się w najbliższym czasie na większą skalę na rynku. Niemniej jednak obserwowanie kierunków zmian w tym zakresie w przyszłości (i szukanie odpowiedzi na pytanie: „Co się będzie działo z bardzo dobrze wyposażonymi gabinetami/klinikami stomatologicznymi?", a nie poszczególnymi składnikami ich majątku), może być ciekawym doświadczeniem badawczym ${ }^{138}$.

Badając problematykę funkcjonowania firm rodzinnych $w$ gabinetach stomatologicznych, zajęto się również zstępnymi w rodzinie stomatologów. Rozkład odpowiedzi na pytanie: „Czy respondent rozważa zatrudnienie dziecka w gabinecie?" przedstawia tabela 26.

Spośród respondentów, którzy byli właścicielami gabinetów 17,61\% zadeklarowało, że nie ma dzieci, dlatego odpowiedzi pozostałych nie sumują się do $100 \%$. Odpowiedzi dotyczące zstępnych - w aspekcie kontynuowania dzieła rodziców przez dzieci respondentów, są już zgodne z intuicyjnym oczekiwaniem badającego - przeszło 20\% respondentów zadeklarowało, że dzieci będą pracowały w zawodzie lekarza dentysty (choć $4,23 \%$ nie razem z rodzicem).

\footnotetext{
${ }^{137}$ Jak ma to miejsce np. w Niemczech, gdzie stomatolog, który odchodzi na emeryturę, odeprzedaje swoją praktykę - rozumianą jako gabinet $\mathrm{z}$ wyposażeniem i pacjenci w nim się leczący - innemu lekarzowi, który wcześniej np. przez rok już pracował w gabinecie, aby pacjenci zdążyli się do niego przyzwyczaić.

${ }^{138}$ Zjawisko to dotyczy również innych podmiotów medycznych - liczne prywatne szpitale, stacje dializ, czy przychodnie medycyny rodzinnej będą również mogły być przedmiotem sprzedaży. Pierwsze tego typu transakcje (dotyczące np. szpitali) miały już miejsce - pojawia się wówczas problem uwzględnienia ich specyfiki w wycenie majątku - związany z kapitałem intelektualnym. Wycena tej wartości niematerialnej dotyczy nie tylko wiedzy i umiejętności specjalistów medycznych (np. profesor mikrochirurg oka z 20-letnim stażem vs dyplomowana położna z 2-letnim stażem), ale również kapitału klienckiego (np. pacjent $\mathrm{w}$ gabinecie stomatologicznym vs pacjent $w$ stacji dializ) $i$ in.
} 
Tabela 26. Zatrudnienie dziecka stomatologa w gabinecie - badanie I

\begin{tabular}{|l|c|}
\hline \multicolumn{1}{|c|}{$\begin{array}{c}\text { Odpowiedzi na pytanie: } \\
\text { Czy respondent } \text { zatrudni dziecko } \boldsymbol{w} \text { swoim } \text { gabinecie } \text { stomatologicznym? }\end{array}$} & $\begin{array}{c}\text { Wskazania } \\
(\%)\end{array}$ \\
\hline nie, dzieci nie kształcą się w tym kierunku & 36,62 \\
\hline nie, dzieci rozpoczną praktykę stomatologiczną we własnym gabinecie & 4,23 \\
\hline tak, jako stomatologa & 16,90 \\
\hline tak - już praktykuje ze mną & 1,41 \\
\hline tak, na stanowisku innym niż stomatolog & 1,41 \\
\hline $\begin{array}{l}\text { inne - w badaniu pojawiły się odpowiedzi np. } \\
\text { - dzieci sa za małe, żeby coś konkretnego powiedzieć; } \\
\text { - tak, ale to daleka przysztość; } \\
\text { - dziecko ma 6 lat, ale nie chciałbym, aby moje dziecko byto dentystą }\end{array}$ & \\
\hline
\end{tabular}

Źródło: opracowanie własne na podstawie przeprowadzonego badania.

Przedstawione wyniki badań pozwalają stwierdzić, że wśród praktykujących lekarzy dentystów przedsiębiorczość rodzinna miała marginalne znaczenie w uruchomieniu działalności gospodarczej (dotyczyła niespełna 5\% responsdentów badania I), ale już w aspekcie zatrudnienia dziecka w gabinecie przeszło 1/5 badanych zadeklarowała, że ta płaszczyzna przedsiębiorczości rodzinnej $\mathrm{ma} /$ będzie miała miejsce w gabinecie. Co pozwala wskazać na rosnące znaczenie przedsiębiorczości rodzinnej w funkcjonowaniu gabinetów.

Jeśli chodzi o wyniki uzyskane w ramach badania III, to: wśród badanych studentów $28 \%$ pochodziło z rodziny, w której rodzic/opiekun był stomatologiem (i w tej grupie można upatrywać potencjalnych sukcesorów gabinetów stomatologicznych - firm rodzinnych). Na pytanie: „Czy studenci chca podjać prace w gabinecie rodzica?" większość (89\%) odpowiedziała, że tak, choć wskazywała różne powody. Szczegółowy rozkład odpowiedzi na pytanie przedstawiony jest $\mathrm{w}$ tabeli 27 .

Tabela 27. Zatrudnienie w gabinecie rodzica/opiekuna stomatologa

\begin{tabular}{|l|c|}
\hline \multicolumn{1}{|c|}{$\begin{array}{c}\text { Odpowiedzi na pytanie: } \text { Czy student zamierza } \\
\text { po ukończeniu studiów podjąć prace } \mathbf{w} \text { gabinecie rodzica? }\end{array}$} & $\begin{array}{c}\text { Wskazania } \\
(\%)\end{array}$ \\
\hline tak, chcę wejść do gabinetu o ugruntowanej pozycji rynkowej & 24 \\
\hline tak, nie chcę szukać innego gabinetu, ponieważ może to być trudne & 6 \\
\hline tak, chcę kontynuować tradycję rodzinną & 24 \\
\hline tak, liczę na merytoryczne wsparcie rodzica & 35 \\
\hline nie, chcę się usamodzielnić & 11 \\
\hline nie, praca z rodziną rodzi konflikty & 0 \\
\hline
\end{tabular}

Źródło: Opracowanie własne na podstawie przeprowadzonego badania.

W odniesieniu do $11 \%$ studentów pochodzących z rodzin, w których rodzic/ opiekun był stomatologiem, można mówić o intencjach przedsiębiorczych,

${ }^{139}$ Wypowiedź lekarza dentysty z 14 letnim stażem. 
wyrażonych w tzw. ukrytej przedsiębiorczości ${ }^{140}$, podczas gdy wśród pozostałych studentów odsetek ten jest prawie 3 razy większy. Wynik ten pokazuje, że dla większości osób o „stomatologicznych uwarunkowaniach rodzinnych” wybór kierunku studiów był świadomą decyzją - związaną $\mathrm{m}$. in. z zapewnieniem sobie poczucia bezpieczeństwa w rozpoczynaniu życia zawodowego. I czynnik ten przeważył nad „duchem przedsiębiorczości” badanych studentów.

Rozkład odpowiedzi na pytanie o wyborze drogi zawodowej po studiach wśród studentów nie pochodzących z rodzin stomatologicznych był inny (por. tabela 28), niż przedstawiony powyżej. Wśród respondentów przeważała opinia (68\% wskazań), że po ukończeniu studiów woleliby zatrudnić się, jako pracownicy w funkcjonujących gabinetach, niż otwierać własne praktyki i jest to niższy odsetek, niż u osób ,stomatologicznych uwarunkowaniach rodzinnych”. O przedsiębiorczości ukrytej, można mówić w odniesieniu do $29 \%$ badanych nie mających w najbliższej rodzinie lekarza dentysty.

Tabela 28. Planowane miejsce pracy po zakończeniu studiów wśród studentów nie mających $w$ najbliższej rodzinie lekarza dentysty

\begin{tabular}{|l|c|}
\hline \multicolumn{1}{|c|}{$\begin{array}{r}\text { Odpowiedzi na pytanie: } \\
\text { Gdzie student zamierza podjąć prace po zakończeniu studiów? }\end{array}$} & $\begin{array}{c}\text { Wskazania } \\
(\%)\end{array}$ \\
\hline zatrudnienie się w gabinecie, który ma podpisaną umowę z NFZ & 22 \\
\hline zatrudnienie się w gabinecie, który funkcjonuje w oparciu o płatności pacjentów & 31 \\
\hline zatrudnienie się w jakimkolwiek gabinecie & 15 \\
\hline otwarcie własnego gabinetu z pomocą rodzica „niestomatologa” & 20 \\
\hline otwarcie własnego gabinetu w oparciu o własne środki & 9 \\
\hline inne $^{141}$ & 3 \\
\hline
\end{tabular}

Źródło: Opracowanie własne na podstawie przeprowadzonego badania.

Konkludując, odpowiedź na pytanie czy „Czy uwarunkowania rodzinne (rodzic/ opiekun jest z zawodu stomatologiem) wzmacniaja intencje przedsiębiorcze studentów?" jest negatywna, gdyż studenci wolą zatrudnić się w gabinecie u rodzica, niż usamodzielnić; w odróżnieniu od studentów, którzy nie mają w najbliższej rodzinie lekarza dentysty - częściej deklarują chęć rozpoczęcia działalności

${ }^{140}$ Ukryta przedsiębiorczość (latent entrepreneurship) odnosi się do deklarowanej preferencji zostania samozatrudnionym.

Por. Grilo I., Irigoyen J-M., Entrepreneurship in the UE: To Wish and not to be, "Small Business Economics", 2006 t. 26, $\mathrm{nr} 4$.

${ }^{141}$ Jako ,inne” respondenci wskazali następujące rozwiązania: 1) najpierw zatrudnię się w prywatnym gabinecie, który ma podpisana umowe z NFZ, a póżniej otworze prywatny gabinet; 2) najpierw specjalizacja, więc zatrudnię się w prywatnym gabinecie celem zdobycia doświadczenia (ok.2 lat) $i$ otwarcie własnego gabinetu, 3) otwarcie swojego gabinetu lub wyjazd za granice (zarobki z pracy u "kogoś" za granica sa na porównywalnym poziomie z zarobkami w prywatnym gabinecie w kraju). Praca u "kogoś" to określony czas. Niestety w swoim gabinecie pracuje się "na okragto", trzeba myśleć o materiatach, sterylizacji, sprzęcie, itp. wnioski nasuwaja się same.... 
na własny rachunek. Jednak ze względu na zbyt małą próbę badawczą nie można tych wniosków uogólniać.

\section{REASUMPCJA}

Z przeprowadzonych badań wyłania się silna orientacja na pacjenta stomatologów - zarówno badani lekarze (badanie I), jak i studenci stomatologii (badanie III), jako główną determinantę wyboru zawodu wskazali: ,wyleczenie pacjenta”. Praktycy zawodu zadeklarowali korzyść dla pacjenta (satysfakcja i pozyskanie jego zaufania), jako ważniejsze niż własne korzyści (satysfakcja z wykonywanej pracy i dobra atmosfera pracy - odpowiednio 4 i 5 miejsce w rankingu motywów pracy zawodowej). Natomiast przyszli adepci zawodu, jako drugi co do ważności motyw w pracy zawodowej wskazali: „rozwój własnych kwalifikacji medycznych", a dopiero później pozyskanie zaufania pacjenta i jego satysfakcję. Ranking pięciu najważniejszych motywatorów zamykają: „dochody pozwalające na godne życie”. Jest to wyraźny znak, że w funkcjonowaniu podmiotów zajmujących się opieką zdrowotną coraz częściej - w sposób kompleksowy - uwzględniane są reguły rynkowe (m. in. rachunek ekonomiceny, zaspokajanie potrzeb nabywców). Sytuacja wygląda nieco inaczej w podmiotach publicznych i niepublicznych (m. in. ze względu na obowiązujące przepisy; na to, kto zarządza podmiotem i jakie pozamedyczne cele realizuje), ale niewątpliwie „myślenie ekonomiczne”, zajmuje obok „myślenia medycznego", niezwykle ważne miejsce w placówkach zdrowotnych. Dlatego rośnie w nich znaczenie racjonalności podejmowanych decyzji m. in. dzięki podwyższaniu poziomu wiedzy i zwiększaniu kompetencji zawodowych osób zarządzających tymi podmiotami. Współczesny właściciel (w pracy rozumiany jako przedsiębiorca) gabinetu powinien dysponować wiedzą z zakresu ekonomii, finansów, zarządzania i marketingu oraz prawa, gdyż ma do spełnienia w podmiocie szereg różnorodnych zadań ${ }^{142}$ :

- ustala (wybiera właściwe) cele i określa czynniki warunkujące osiągnięcie tych celów, a także przekazuje informacje o nich współpracownikom;

- organizuje pracę i - często również - strukturę podmiotu; dobiera ludzi do zadań, które trzeba wykonać;

- motywuje i informuje pracowników ${ }^{143}$; to do niego należy stworzenie od podstaw (lub modyfikacja dotychczasowego) zespołu; wdrażanie polityki awansów (np. poziomych), określenie i przestrzeganie reguł wynikających z systemu bodźców (nagród i kar) mających ukierunkować pracowników na efektywną pracę;

\footnotetext{
${ }^{142}$ Wajda A., Podstawy nauki o zarzadzaniu organizacjami, Difin, Warszawa 2003, s. 77 i nast.

${ }^{143}$ System porozumiewania się z podwładnymi powinien być oparty na podstawowych regułach komunikacji.
} 
- dokonuje pomiaru tj. na podstawie ustalonych ${ }^{144}$ sposobów oceny pracy analizuje efektywność pracowników, a następnie informuje pracowników o wynikach swoich analiz;

- rozwija ludzi - to od jego kompetencji i postawy zależy, czy pracownicy będą rozwijali się zawodowo, czy znaczenie ich rozwoju będzie marginalizowane; postawa przełożonego wpływa również na postawy społeczne pracowników $\mathrm{w}$ relacjach $\mathrm{z}$ innymi (zarówno współpracownikami, jak i nabywcami usług). Jednak w praktyce jego działania są zdecydowanie bardziej oparte na kompetencjach osobistych, intuicji i zdroworozsądkowym podejściu, niż na zasobach specjalistycznej - menedżerskiej wiedzy. Parafrazując słowa J.B. Say’a, można powiedzieć, że „talent dentysty stanowi część jego majątku, ale ponieważ nie może być przedmiotem wymiany, można go oszacować tylko na podstawie dochodu dożywotniego, jaki z tego talentu otrzymuje." ${ }^{145} \mathrm{Z}$ tego względu lekarz dentysta powinien dbać o ten talent - podnosić poziom posiadanych kwalifikacji, aby sprostać zmieniającym się wymaganiom otoczenia i organizacji; aby zrealizować plany rozwoju osobistego.

Z przeprowadzonego badania I wynika, że lekarze dentyści dobrze oceniają swoje umiejętności intra- i interpersonalne w zakresie kontaktów z pacjentami, natomiast w obszarze kontaktów z pracownikami - słabiej (co może sygnalizować brak pewności siebie w działaniu w tym zakresie i w konsekwencji słabe efekty podejmowanych działań). Natomiast studenci kierunku lekarsko-dentystycznego (badanie III) swoją umiejętność zachowania dobrych relacji z pacjentami i zaangażowania w pracę ocenili dobrze.

Przedstawione wyniki pozwalają na stwierdzenie, że stosunkowo wysoka samoocena lekarzy dentystów (i studentów stomatologii) w zakresie umiejętności intrapersonalnych może świadczyć o znacznej wartości kapitału intelektualnego $\mathrm{w}$ gabinecie stomatologicznym, a więc $-\mathrm{z}$ punktu widzenia zasobowej teorii konkurencyjności - wskazuje na duży potencjał gabinetów stomatologicznych do poprawiania ich pozycji konkurencyjnej.

\footnotetext{
144 Pracownicy powinni znać/mieć dostęp do norm określających pracę na ich stanowisku oraz czynników pomocnych w jej wykonaniu.

${ }^{145}$ Say J.B., Traktat o ekonomii politycznej, PWN, Warszawa 1960, s. 867.
} 


\title{
ROZDZIAL III \\ GABINET STOMATOLOGICZNY JAKO PODMIOT NA RYNKU USŁUG
}

\author{
„Celem zaś przedsiębiorstwa \\ nie jest po prostu wywarzanie zysku \\ ale samo jego istnienie jako wspólnoty ludzi, \\ którzy na różny sposób zdążaja \\ do zaspokojenia swych podstawowych potrzeb \\ i stanowia szczególna grupę \\ stużaca całemu społeczeństwu."
}

Jan Paweł II, Centesimu Annus

\section{GABINET STOMATOLOGICZNY PODMIOTEM USŁUGOWYM}

\subsection{ISTOTA USŁUG}

Znaczne zdywersyfikowanie sektora usług powoduje trudności $\mathrm{w}$ ich definiowaniu. Zasadniczo można wyróżnić dwa podejścia w tym zakresie:

- definiowanie usług przez podkreślenie procesowej natury usługi ${ }^{1}$ - usługę należy postrzegać jako część szerszej koncepcji produktu, jako „to, co można zaoferować w celu zaspokojenia potrzeby bądź pragnienia",;

- definiowanie usług przez podanie charakterystyk usługi ${ }^{3}$ - wówczas usługą są wszystkie produkty niematerialne, różniące się od produktów materialnych zasadniczo pięcioma charakterystykami, które są określane jako „5 x NIE” ${ }^{4}$. Chodzi o: niematerialność ${ }^{5}$, niejednorodność ${ }^{6}$, nieroz-

\footnotetext{
${ }^{1}$ Grönroos Ch., Service Management and Marketing: A customer Relationship Management Approach, Wiley, Nowy Jork 2001, Solomon M.R., Surprenant C., Czepiel J.A., Gutman E.G., A role theory perspective on dyadic interactions: the service encounter, "Journal of Marketing" 1985, nr 1; Lovelock C., Services Marketing, Prentice-Hall, Englewood Cliffs, Nowy Jork, 1991; Zeithaml V.A., Bitner M.J., Services Marketing: Integrating Customer Focus across the Firm, McGraw-Hill, Nowy Jork, 2003, Vargo S.L., Lush R.F., The four service marketing myths-remnants of a good-based, manufacturing model, "Journal of Service Research", $2004 \mathrm{nr} 4$.

${ }^{2}$ Kotler Ph., Marketing: analiza, planowanie, wdrażanie, Wydawnictwo Felberg SJA, Warszawa 1999, s. 16.

${ }^{3}$ Por. Edvardsson B., Gustafsson A., Roos I., Service portraits in service research - a critical review, "International Journal of Service Industry Management", 2005, nr 1; Fitzimmons J.A., Fitzsimmons M.J., Service Management. Operations, Strategy, Information Technology, McGrawHill International Edition, 2008.

${ }^{4}$ Tej negatywnej atrybucji usług autorka przeciwstawiła swoją - pozytywną atrybucję (opartą na założeniu, że usługa „staje się" w momencie, gdy zlecający spotyka się z wykonawcą i przedstawia swoje oczekiwania względem usługi), która stanowi rozwinięcie słowa STANDING (synchronize,
} 
łączność ${ }^{7}$ nietrwałość ${ }^{8}$, niemożność nabycia usługi na własność 9 . Szczegółowe zdefiniowanie tych cech wpływa na kształt funkcjonalnych obszarów zarządzania przedsiębiorstwem usługowym; i tak:

- usługodawcy powinni być w stanie przekształcić niematerialne usługi w konkretne korzyści - może się to odbywać w ramach procesu, do któ-

trust, art, negotiate, diversity, interactive, non-stop, good). Por. Bukowska-Piestrzyńska A., Określanie atrybutów ustug, „Ekonomika i Organizacja Przedsiębiorstwa”, 2009 nr 9, s. 22 i nast.

${ }^{5}$ Niematerialność ma swój wyraz w tym, że usługa: 1) to proces, czynność, aktywność, świadczenie, które może, ale nie musi prowadzić do powstania dobra materialnego, 2) pojawia się wtedy, gdy użyteczności dostarczane klientom nie pochodzą od dobra (rzeczy), ale od niej samej, 3) ma wymiar czasu, co oznacza że zachodzi w określonym czasie (pracy), ma długość mierzoną jednostkami czasu, 4) jest oceniana przez pryzmat doświadczenia lub wręcz niemożliwa do oceny (kolor, smak, wielkość są niemożliwe i trudne do identyfikacji przez rozpoczęciem procesu świadczenia), stąd powinna być oparta na zaufaniu, 5) nie może zaistnieć bez aktywności klienta - złożenie zlecenia wydobywa usługę z fazy statycznej (potencjalnej) i wprowadza ja w fazę dynamiczną tj. świadczenia, stąd szansa na monitorowanie relacji z klientem powinno być podstawą kształtowania i rozwoju koncepcji zarządzania relacjami z klientem. Por. Rogoziński K., Nowy marketing ... op. cit., s. 19; Bateson J.E.G., Managing Services Marketing, The Dryden Press, Orlando 1991, s. 7; Mazur J., Zarzadzanie marketingiem ustug, Difin, Warszawa 2001, s. 20; Bitner M.J., Zeithaml V.A., Service Marketing, McGraw-Hill, Nowy Jork 2003, s. 37; Zeller P., Produkt w ustugach edukacyjnych - sposób definiowania i konsekwencje dla dziatań marketingowych, w: Nowaczyk G., Lisiecki P. (red.), Marketingowe zarzadzanie szkota wyższa, Wydawnictwo WSzB, Poznań 2006, s. 210.

${ }^{6}$ Niepowtarzalność klienta jest dla przedsiębiorstwa wyzwaniem w odniesieniu do umiejętności jej rozpoznania oraz dostosowania wszystkich elementów formujących proces świadczenia (np. w gabinecie stomatologicznym klient może odczuwać ból fizyczny, zmęczenie, niewygodę, stres itp.). Tym samym wpływa na niemożność pełnej standaryzacji procesu świadczenia usługi (zależy on m. in. od: zachowania personelu, zachowania klienta, zachowania innych współusługodawców, miejsca i czasu świadczenia oraz czynników zewnętrznych).

${ }^{7}$ Nierozdzielność jest cechą odnosząca się do: 1) konieczności jednoczesnego świadczenia i konsumpcji usługi, 2) faktu, iż proces świadczenia przyjmuje formę prosumpcji, w ramach której klient przyjmuje rolę współwykonawcy, 3) ograniczenia skali świadczenia usług (by dostosować do popytu), 4) konieczności zaistnienia kontaktu klient - personel w ramach procesu obsługi klienta (obejmuje on wiele elementów o charakterze marketingowym tj. przyjmowanie zlecenia, informowanie, doradztwo, sprzedaż i promocję osobistą, świadczenie, kontrolę). Por. Mazur J., Zarzadzanie ... op. cit., s. 2 i nast.; Rogoziński K., Nowy marketing ... op. cit., s. 20; Toffler A., Trzecia ... op. cit., s. 310 i nast.; Fisk R.P., Grove S.J., John J., Interactive Service Marketing, Houghton Miffilin Company, 2008, s. 7; Gummesson E., Total Relationship Marketing, Rethinking Marketing Management, form 4 Ps to 30 Rs, Butterworth-Heinemann, Oxford 1999, s. 45 i nast.

${ }^{8}$ Nietrwałość może być definiowana jako: brak możliwości magazynowania usług i wytwarzania w celu magazynowania, stąd może dochodzić do nierównowagi w popycie i podaży, co może skutkować utratą części klientów lub niewystarczającym popytem do pokrycia kosztów utrzymywania potencjału usługowego. Por. Mazur J., Zarzqdzanie ... op. cit., s. 25; Rogoziński K., Nowy marketing ... op. cit., s. 20; Mudie P., Cottam A., Ustugi, zarzadzanie i marketing, Wydawnictwo Naukowe PWN, Warszawa 1998, s. 22.

${ }^{9}$ Brak praw przewłaszczenia wynika $\mathrm{z}$ faktu nabycia przez klienta prawa dostępu, używania, skorzystania z określonego świadczenia, korzystania ze środków należących do usługodawcy oraz określonego czasu pracy personelu. Por. Rogoziński K., Nowy marketing ... op. cit., s. 21; Czubała A., Jonas A., Smoleń T., Wiktor J.W., Marketing usług, Wolters Kluwer, Kraków 2006, s. 15. 
rego L.P. Carbone i S.H.Haeckel ${ }^{10}$ proponują zestaw koncepcji pod nazwą inżynierii doznań klienta - firmy muszą najpierw stworzyć przejrzystą wizję tego, jaki efekt chciałyby wywrzeć na docelowych interesariuszach, a następnie opracować spójną listę wskazówek (dotyczących różnych działań i ich kontekstów), dzięki którym udałoby się to osiągnąc (przyglądając się działaniom niektórych gabinetów trudno mówić o inżynierii doznań klienta ${ }^{11}$ );

- klient pojawiając się w przedsiębiorstwie usługowym, ujawnia elementy składowe swojej niepowtarzalności ${ }^{12}$ i niejako wymusza przeniesienie punktu ciężkości funkcjonowania podmiotu w kierunku indywidualizacji świadczenia i doskonalenia obsługi klienta, poprzez np..$^{13}$ inwestowanie w dobre procedury zatrudniania i szkolenia; rekrutację właściwych pracowników (w gabinecie stomatologicznym pracownicy powinni być nie tylko kompetentni i powinno im zależeć na dobru pacjenta, ale powinni również być zdolni do szybkiej reakcji, wykazywać inicjałtywę i umieć rozwiązywać problemy; wprowadzać procesy standaryzacji jakości obsługi, aby zidentyfikować potencjalne błędy proceduralne i nie dopuścić do ich powstawania lub wyeliminować istniejące); monitorowanie poziomu satysfakcji klientów (np. wprowadzenie systemu uwag i zażaleń, przeprowadzanie wywiadów z klientami i szukanie porównań jakości z konkurencją).

- $\quad$ kontakt personel - nabywca usługi ma bezpośredni wpływ na doświadczenia klienta i przebieg całego procesu usługi, stąd konieczność traktowania zarządzania personelem jako priorytetu;

- nietrwałość implikuje konieczność zarządzania potencjałem usługowym (zarządzaniem popytem i podażą usług ${ }^{14}$ ), np. przez modyfikację elementów marketingu-mix, dywersyfikację obsługiwanych grup klientów.

Problematyce usług stosunkowo dużo miejsca poświęca marketing (przegląd wybranych definicji zamieszczony jest $\mathrm{w}$ tabeli $29^{15}$ ), a w szczególności marketing relacji.

\footnotetext{
${ }^{10}$ Carbone L.P., Haeckel S.H., Engineering ... op. cit.

${ }^{11}$ Więcej na ten temat w punkcie 2.1 kolejnego rozdziału.

${ }^{12}$ Rogoziński K., Nowy marketing ... op. cit., s. 21.

${ }^{13}$ Kotler Ph., Shalowitz J., Stevens R.J., Marketing strategiczny ... op. cit., s. 372 i nast.

${ }^{14}$ Bitner M.J., Zeithaml V.A., Service ... op. cit., s. 410 i nast.

15 Zestawienie to było prezentowane w: Bukowska-Piestrzyńska A., Finansowanie marketingu w ochronie zdrowia, CeDeWu.pl, Warszawa 2010, s. 25.
} 
Tabela 29. Definicje usług prezentowane $w$ wybranych pozycjach z zakresu marketingu

\begin{tabular}{|c|c|}
\hline Autor & Treść definicji \\
\hline $\begin{array}{l}\text { Ph. Kotler, } \\
\text { G. Armstrong, } \\
\text { J. Saunders, } \\
\text { V. Wong }\end{array}$ & $\begin{array}{l}\text { Usługa to wszelka działalność lub korzyść, którą jedna ze stron może } \\
\text { zaoferować drugiej, z zasady niematerialna i nie prowadząca do uzyskania } \\
\text { jakiejkolwiek własności. }\end{array}$ \\
\hline Ph. Kotler ${ }^{b}$ & $\begin{array}{l}\text { Usługa jest dowolnym działaniem, jakie jedna strona może zaoferować innej; } \\
\text { jest ono nienamacalne i nie prowadzi do jakiejkolwiek własności. Jego } \\
\text { produkcja może być związana lub nie z produktem fizycznym. }\end{array}$ \\
\hline M. Pluta-Olearnik & $\begin{array}{l}\text { Usługi to korzyści oferowane do sprzedaży w istocie swej niewymierne i su- } \\
\text { biektywnie oceniane przez nabywców. }\end{array}$ \\
\hline $\begin{array}{l}\text { L. Garbarski, } \\
\text { I. Rutkowski, }_{\text {W. Wrzosek }}{ }^{\text {W }}\end{array}$ & $\begin{array}{l}\text { Usługą jest działalność służąca zaspokajaniu potrzeb ludzkich, która nie } \\
\text { znajduje żadnego ucieleśnienia w nowych dobrach materialnych. }\end{array}$ \\
\hline W.J. Stanton ${ }^{\mathrm{e}}$ & $\begin{array}{l}\text { Usługa to występująca odrębnie działalność, nie przynosząca materialnego } \\
\text { efektu, dostarczająca nabywcy określonych korzyści, które nie są koniecznie } \\
\text { związane ze sprzedażą produktów lub innych usług. }\end{array}$ \\
\hline A. Payne ${ }^{f}$ & $\begin{array}{l}\text { Usługa jest to każda czynność zawierająca w sobie element niematerialności, } \\
\text { która polega na oddziaływaniu na klienta lub przedmiot bądź nieruchomości } \\
\text { znajdujące się w jego posiadaniu, a która nie powoduje przeniesienia prawa } \\
\text { własności. Przeniesienie prawa własności może jednak nastąpić, a świadczenie } \\
\text { usługi może być lub też nie być ściśle związane z dobrem materialnym. }\end{array}$ \\
\hline K. Rogoziński ${ }^{\mathrm{g}}$ & $\begin{array}{l}\text { Usługa to podejmowane zlecenie, intencjonalne świadczenie pracy i/lub } \\
\text { korzyści. Służy wzbogaceniu walorów osobistych bądź wolumenu } \\
\text { użyteczności dóbr, jakimi usługobiorca dysponuje. }\end{array}$ \\
\hline
\end{tabular}

Źródło: opracowanie własne na podstawie: ${ }^{a}$ Kotler Ph., Armstrong G., Saunders J., Wong V.,

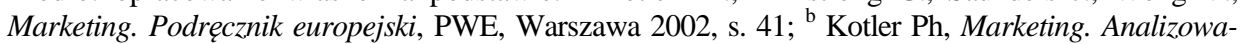
nie, planowanie, wdrażanie i kontrola, Gebethner \& Ska, Warszawa 1994, s. 426; ${ }^{\mathrm{C}}$ Pluta-Olearnik M., Marketing ustug, PWE, Warszawa 1993, s. 21; ${ }^{\mathrm{d}}$ Garbarski L., Rutkowski I., Wrzosek W., Marketing. Punkt zwrotny nowoczesnej firmy, PWE, Warszawa 2000, s. 648; ${ }^{\text {e }}$ Stanton W.J., Fundamentals of Marketing, McGraw Hill, Nowy Jork 1981, s. 441; ${ }^{\mathrm{f}}$ Payne A., Marketing ustug, PWE, Warszawa 1996, s. 20.; ${ }^{\mathrm{g}}$ Rogoziński K., Ustugi ... op. cit., s. 36.

Elementy wspólne „marketingowych” definicji „usługi” obejmują następujące aspekty:

- usługi to działania zaspokajające określone potrzeby ludzkie,

- usługi to czynności o charakterze niematerialnym (nie mające cech fizycznych),

- czynności usługowe tworzą konkretne relacje między dwoma odrębnymi podmiotami: jeden z nich to usługodawca (osoba/podmiot świadczący usługę), drugi to usługobiorca (konsument usługi). Dążenie do spełnienia obietnicy złożonej potencjalnemu klientowi, wymusza na usługodawcy stworzenie odpowiednich warunków do interakcji z usługobiorcą, gdyż tylko w ten sposób możliwe jest budowanie zaufania. Wiarygodność i bezpieczeństwo, umiejętność słuchania i empatia przyczyniają się do tego, że usługodawca może dodatkowo oddziaływać na korzystającego z usługi. 
Usługa realizowana jest na styku relacji organizacji z klientem. Proces usługowy obejmuje proces przygotowania i realizacji usługi oraz jej wykonywania, w który zaangażowany jest klient ${ }^{16}$, a także elementy posprzedażowe (związane np. z warunkami gwarancji czy sposobem obsługi - ewentualnych - reklamacji). Proces przygotowania i realizacji usługi obejmuje czynności związane z:

- badaniem potrzeb usługowych,

- opracowaniem projektu usługi,

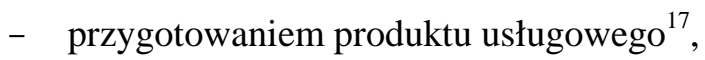

- wykonaniem usługi.

Na wynik procesu usługowego i na ocenę usługi przez klienta zewnętrznego wpływają zasoby, takie jak:

- ludzie, to pracownicy przygotowujący usługę i pracownicy bezpośrednio obsługujący klientów (front-line officers),

- materiały wykorzystywane w usłudze (facilitating goods),

- urządzenia i infrastruktura (supporting facility),

- informacja (information).

Nie wchodząc w szczegółowe prezentacje klasyfikacji usług ${ }^{18}$, z punktu widzenia niniejszej pracy koniecznym wydaje się przedstawienie jednej $\mathrm{z}$ nich - uwzględniającej poziom indywidualizacji świadczenia. Kryterium to pozwala na wyróżnienie: ${ }^{19}$

- usług świadczonych masowo - odnoszących się do dużej liczby klientów, przy małym wpływie indywidualnego klienta na warunki transakcji; mających przy tym charakter przystąpieniowy (np. usługi bankowe),

\footnotetext{
${ }^{16}$ Dobrowolska A., Dobrowolski W., Wptyw technologii informatycznej na jakość procesu usługowego i na klienta, w: Borys T., Rogala P., Orientacja na klienta jako kryterium doskonatości, Prace Naukowe Uniwersytetu Ekonomicznego we Wrocławiu, nr 151, Wyd. UE, Wrocław 2011, s. 105.

${ }^{17}$ Produkt usługowy można zdefiniować jako: 1) sposób osiągnięcia korzyści i zaspokojenia odczuwalnych potrzeb, 2) zbiór korzyści dla nabywcy, 3) wszystko, co można oferować na rynku, 4) jako każdy przedmiot lub proces, który przedstawia wartość dla konsumentów, 5) usługę, która stwarza możliwość wyboru takiej kombinacji tworzących ów produkt elementów, iż powstać może jedyna, swoista wiązka korzyści dla usługobiorcy, 6) DNA procesu świadczenia. Por. Mazur J., Zarzadzanie marketingiem ... op. cit., s. 169; Pluta-Olearnik M., Marketing ustug bankowych, PWE, Warszawa 1999, s. 61; Payne A., Marketing ... op. cit., s. 159; Rogoziński K., Nowy marketing ... op. cit., s. 53; Johnson R., Clark G., Service Operations Management, Prentice Hall, Coventry 2001, s. 28.

${ }^{18}$ Szeroko na ten temat pisze: Daszkowska M., Ustugi. Produkcja, rynek, marketing, Wydawnictwo Naukowe PWN, Warszawa 1998; Rogoziński K., Ustugi ... op. cit.

${ }^{19}$ Chłodnicki M., Ustugi profesjonalne - przez jakość do lojalności klientów, Wyd. AE w Poznaniu, Poznań 2004, s. 11.
} 
- usług świadczonych klientom indywidualnym - w których rozpoznanie potrzeb klientów odgrywa kluczowe znaczenie w dążeniu do optymalnej ich realizacji (np. usługi konsultingowe, architektonicznie).

Istnieją jednak branże, które plasują się niejako pomiędzy wymienionymi powyżej grupami usług, a należą do nich $m$. in. usługi medyczne, w których jest bardzo wysoka indywidualizacja zleceń, a liczba nabywców kwalifikuje je jako masowe. I pogodzenie tej dwoistości usługi medycznej jest wyzwaniem stojącym przed lekarzami - z jednej strony duża liczba pacjentów w poczekalni (na przyjęcie których jest ograniczony czas), z drugiej konieczność - oczekiwanej indywidualizacji podejścia do pacjenta. Problem ten dotyczy zarówno lekarzy w publicznych (tu można potraktować go jako bardzo pilny), jak i niepublicznych podmiotach ochrony zdrowia.

Sektor usługowy jest bardzo zróżnicowany - obejmuje zarówno usługi produkcyjne (np. roboty instalacyjno-montażowe), czy konsumpcyjne (np. kosmetyczne i fryzjerskie), jak i ogólnospołeczne (np. oferowane przez wymiar sprawiedliwości). Z punktu widzenia tematyki niniejszej pracy istotne są tzw. usługi profesjonalne ${ }^{20}$. Choć nie ma jednoznacznego kryterium, pozwalającego precyzyjnie wyodrębnić grupę usług profesjonalnych, to można wyróżnić pewne cechy charakterystyczne dla tej grupy usług. I tak ${ }^{21}$ :

- usługodawca powinien posiadać wysokie (najwyższe z możliwych) kwalifikacje zawodowe, potwierdzone dyplomem akademickim oraz stopniami naukowymi,

- profesjonaliści mają obowiązek zrzeszania się (tzn. profesjonalista musi być członkiem samorządu zawodowego),

\footnotetext{
${ }^{20}$ Określenie profesjonalista w języku potocznym używane jest zamiennie z specjalista, ekspert, czy nawet znawca określonego tematu czy rzemiosła. Dlatego wato podkreślić, że na istotę profesjonalizmu składa się: 1) posiadanie ugruntowanej i specjalistycznej wiedzy, 2) odpowiednia postawa moralna, warunkująca dochodzenie do mistrzostwa. Jednak posiadana wiedza czy doświadczenie (kreujące „,pracownika wiedzy”) stanowią dopiero punkt wyjścia działań profesjonalisty, którego musi cechować ponadto publiczne powołanie do działania na rzecz i dla dobra klienta (tym samym dobro klienta jest celem działań każdego profesjonalisty). Klient oczekuje, że - mając na celu jego dobro - profesjonalista podejmie wszelkie konieczne działania. Kontakt między usługodawcą i usługobiorcą opiera się na zaufaniu, jakim klient obdarza profesjonalistę, oczekując w zamian zaangażowania. Por. Rogoziński K., O profesjonalizmie ksztattującym osobowość oraz jego wptywie na kulturę organizacji ustugowej, w: Rogoziński K. (red.) Marketing ustug profesjonalnych. Kultura organizacji - osobowość profesjonalisty, Wyd. AE w Poznaniu, Poznań 2001, s. 16; Chłodnicki M., Ustugi profesjonalne ... op. cit., s. 10; Thakor M.V., Kumar A., What is a professional service? A conceptual review and bi-national investigation, "Journal of Services Marketing", 2000 nr 1, s. 66. ${ }^{21}$ Dobska M., Rogoziński K., Podstawy zarządzania ... op. cit., s. 214.
} 
- ogromne znaczenie ma zaufanie, jakim klient obdarza usługodawcę (ponieważ świadczenie usługi przez profesjonalistę oznacza najczęściej rozwiązywanie bardzo ważnego dla usługobiorcy problemu).

W związku z powyższym zawód ,usługodawcy profesjonalisty” staje się swego rodzaju powołaniem (co zostało przedstawione w punkcie $1.1 \mathrm{w}$ II rozdziale), czyli wykonywaniem szczególnie wyróżnionej społecznie funkcji, dlatego etos profesjonalisty nie może być zdominowany przez biznes ${ }^{22}$. W przypadku usług medycznych koniecznym staje się poszukiwanie równowagi między etosem lekarza a ekonomicznym wymiarem prowadzenia podmiotu leczniczego czy praktyki lekarskiej. Ważne jest, by w tym poszukiwaniu równowagi nie zapominać o prawach pacjenta i zwykłej ludzkiej uczciwości. Jednym z narzędzi, które lekarz-profesjonalista może zastosować w celu usatysfakcjonowania pacjenta i poprawy wyników ekonomicznych swojej placówki zdrowotnej może być marketing relacji (o którym będzie mowa w kolejnym rozdziale).

\subsection{USŁUGA MEDYCZNA}

Celem systemu opieki zdrowotnej jest realizowanie usług zdrowotnych (wyrażające się w zabezpieczeniu i dostarczeniu obywatelom możliwie pełnego zakresu świadczeń zdrowotnych), obejmujących ${ }^{23}$ :

- świadczenia zdrowotne ${ }^{24}$ - są to działania służące zachowaniu, ratowaniu, przywracaniu i poprawie zdrowia oraz inne działania medyczne wynikające z procesu leczenia lub przepisów odrębnych, regulujących zasady ich wykonywania (w szczególności związane z badaniem i poradą lekarską, leczeniem, rehabilitacją leczniczą, badaniem diagnostycznym oraz pielęgnacją chorych);

- Śsiadczenia zdrowotne rzeczowe - są to związane z procesami leczenia leki, wyroby medyczne (w tym wyroby medyczne będące przedmiotami ortopedycznymi) i środki pomocnicze;

- świadczenie towarzyszące - to zakwaterowanie i wyżywienie w zakładzie opieki zdrowotnej całodobowej lub całodniowej oraz usługi transportu sanitarnego.

\footnotetext{
${ }^{22}$ Uzasadnieniem wysokiego etosu jest odpowiedzialność za sferę publiczną (np. zdrowie społeczeństwa), spełniana i gwarantowana przez korporacyjny nadzór (np. Naczelnej Rady Lekarskiej). ${ }^{23}$ art. 3 Ustawy o zaktadach opieki zdrowotnej z 30 sierpnia 1991 r. (Dz. U. nr 91, poz. 408 z późn. $\mathrm{zm})$.

${ }^{24}$ Można wskazać następujące rodzaje świadczeń: 1) podstawowa opieka zdrowotna, 2) leczenie szpitalne, 3) ambulatoryjne leczenie specjalistyczne, 4) programy zdrowotne, 5) rehabilitacja lecznicza, 6) opieka długoterminowa, 7) leczenie stomatologiczne, 8) leczenie uzdrowiskowe, 9) pomoc doraźna, 10) zaopatrzenie w sprzęt ortopedyczny.
} 
Tak szeroko zdefiniowane pojęcie „świadczenia opieki zdrowotnej” pozwala na oddzielenie działań stricte medycznych od pomocniczych. Może mieć to swoje konsekwencje w przyjęciu optyki marketingowej przez podmiot opieki medycznej, gdyż przy działaniach stricte medycznych lekarz będzie wykorzystawał wiedzę zdobytą na studiach oraz etykę zawodową. Natomiast do działań pomocniczych będzie mógł wykorzystać m. in. instrumentarium marketingu. Choć należy podkreślić, że takie rozgraniczenie jest raczej umowne, gdyż w kontaktach stricte medycznych lekarz - pacjent reguły marketingu relacji z zakresu komunikacji znajdą również swoje zastosowanie.

Usługi medyczne, należące do kategorii usług profesjonalnych, charakteryzują się kilkoma istotnymi elementami ${ }^{25}$ :

- w usługach zdrowotnych dominuje asymetria informacji ${ }^{26}$ - rozumiana jako spotkanie dwóch nierównych partnerów: $\mathrm{z}$ jednej strony pacjent pełen obaw i wątpliwości, nie będący w stanie ocenić jakości technicznej świadczonej usługi (ze względu na brak wiedzy w tym zakresie); z drugiej - personel medyczny posiadający specjalistyczną wiedzę i pewną wolność decyzyjną; konsekwencją tej cechy jest konieczność delegowania uprawnień i istnienie zaufania; istnienie asymetrii informacji ogranicza efektywność mechanizmu rynkowego i generuje pojawienie się negatywnej lub pozytywnej selekcji ${ }^{27}$, pokusy nadużycia (moral hazard) ${ }^{28}$ czy przyczynia się do kreacji popytu ${ }^{29}$;

${ }^{25}$ por. Bojar I., Wdowiak L., Zarzadzanie marketingowe w zaktadach opieki zdrowotnej, „Zdrowie Publiczne", 2001 nr 5-6; Hołub J., Kierunki rozwoju marketingu na rynku ustug medycznych, „Przegląd Organizacji”, $2001 \mathrm{nr}$ 6, Krawczyńska A., Trzmielak D., Jakość ustug medycznych, „Przegląd Organizacji”, $2001 \mathrm{nr}$ 2; Gruca-Wójtowicz P., Jakość usług medycznych w kontekście zróżnicowania oczekiwań stron zainteresowanych, „Problemy Jakości”, 2009 nr 3, s. 23; Dobska M., Rogoziński K. (red.), Podstawy zarzadzania ... op. cit., s. 69.

26 Por. Getzen T.E., Ekonomika zdrowia, Wydawnictwo Naukowe PWN, Warszawa 2000; Jacobs P., The Economics of Health and Medical Care, Aspen Publishers, Gaithersburg in Maryland 1997.

${ }^{27}$ Zjawisko dotyczy sytuacji, gdy towar o gorszej jakości wypiera z rynku towar lepszej jakości np. obniżenie honorariów lekarskich przez publicznych płatników sprawia, że najlepsi lekarze - w poszukiwaniu godnego wynagrodzenia - rezygnują z pracy w systemie publicznym i świadczą usługi zdrowotne w prywatnych podmiotach, a w konsekwencji przeciętna jakość usług świadczonych w ramach publicznego systemu opieki zdrowotnej obniża się.

${ }^{28}$ Pojęcie to odnosi się do zmian w zachowaniu pacjentów pod wpływem uzyskania ochrony ubezpieczeniowej i uwolnienia się od związanego z ubezpieczonym ryzykiem; może przybierać postać: 1) pokusy nadużycia ex ante - transfer ryzyka na instytucję ubezpieczeniową powoduje, że maleje motywacja jednostki do zachowań prozdrowotnych; 2) pokusy nadużycia ex post - posiadanie ubezpieczenia sprzyja rozwijaniu postaw roszczeniowych (np. żądaniu świadczeń przekraczających rzeczywiste potrzeby medyczne). Por. Sowada C., Wspótpłacenie - szanse, zagrożenia $i$ warunki szerszego zastosowania w systemie powszechnego spotecznego ubezpieczenia zdrowotnego, ,Zeszyty Naukowe Ochrony Zdrowia - Zdrowie Publiczne i Zarządzanie”, 2004 t. II, nr 1, s. 11 i nast.

${ }^{29}$ Kreacja sztucznego popytu dotyczy sytuacji, gdy lekarz - podejmując decyzje w imieniu i zastępstwie pacjenta - kieruje się własnymi celami dochodowymi (zwiększenie sprzedaży oferowanych 
- usługa medyczna kategoryzowana jest jako heterogeniczna - istnieje (większa lub mniejsza ${ }^{30}$ ) swoboda w wyborze technologii procesu świadczenia usługi (różne techniki i metody rozpoznawania i leczenia choroby oraz rehabilitacji i profilaktyki); swoboda ta ma znaczenie ekonomiczne, gdyż dokonywany w jej ramach wybór powoduje zróżnicowanie kosztów opieki zdrowotnej;

- usługa medyczna obarczona jest dużą niepewnością - stosowanie tych samych leków u różnych pacjentów, którym postawiono podobną diagnozę nie musi spowodować takich samych efektów; podobnie jak różne mogą być wyniki leczenia zębów różnych pacjentów (efekt będzie zależał np. od „stanu wyjściowego" uzębienia pacjentów);

- usługa medyczna jest zindywidualizowana - każdy „,medyczny przypadek” musi być rozpatrywany indywidualnie, a każdy pacjent powinien być traktowany zgodnie z jego oczekiwaniami;

- suwerenność pacjenta jest ograniczona (szczególnie w stanach nagłych, w których pacjent nie może określić swoich potrzeb i zdany jest całkowicie na decyzje personelu medycznego);

- podczas usługi medycznej pacjentom najczęściej towarzyszy stres;

- usługę medyczną można określić jako złożony pod względem psychologicznym proces zaspokajania potrzeb (dodatkowo wiążący się ze złożonością procedur), który odbywa się „,na oczach klientów”;

- cechują je szczególne wymagania w zakresie kwalifikacji kadr (dopuszczenie do zawodu medycznego, a następnie konieczność podnoszenia kwalifikacji jest szczegółowo regulowane przepisami prawa), dlatego personel powinien ciągle podnosić zawodowe kwalifikacje,

- w usługach medycznych, podobnie do innych usług, personel nie zawsze może w pełni usatysfakcjonować odbiorców swoich usług, choć dążenie do tego powinno stanowić wyzwanie dla wszystkich członków personelu (od recepcjonistki, przez personel techniczny i pomocniczy, średni personel medyczny, na lekarzach kończąc);

- usługa zdrowotna to ten rodzaj opieki, w której maksymalizuje się mierzalne dobro pacjenta, mając na względzie równowagę oczekiwanych korzyści i strat, towarzyszących procesowi opieki na wszystkich jego etapach. Każda

przez siebie świadczeń). Por. Evans R.G., Supplier-induced demand: some empirical evidence and implications, w: Perlman M. (red.), The Economics of Health and Medical Care, Macmillan, Londyn, 1974, s. 162 i nast.; Reinhardt U.E., The Theory of Physician-Induced Demand. Reflections after a Decade, "Journal of Health Economics" 1985, t. 4, s. 187 i nast.

${ }^{30}$ Współcześnie swobodę tę ogranicza rosnąca rola materialnych czynników procesu świadczenia usług opieki zdrowotnej (głównie sprzętu i aparatury oraz leków). 
usługa, świadczona pacjentowi, dostarczana jest (powinna być) zgodnie $\mathrm{z}$ aktualnym stanem wiedzy, winna podnosić prawdopodobieństwo uzyskania pożądanego wyniku opieki oraz redukować prawdopodobieństwo niepożądanych rezultatów.

Ch. Grönroos twierdzi, że celem podejmowanych na rzecz usługobiorcy - pacjenta aktywności jest rozwiązanie jego zdrowotnego problemu; co pozwala na wyróżnienie następujących aspektów usług zdrowotnych: ${ }^{31}$

- funkcjonalnego - usługa zdrowotna jako działanie podejmowane przez usługodawcę (personel gabinetu stomatologicznego) na rzecz pacjenta;

- użytecznego - usługa zdrowotna, jako nośnik określonych wartości (użyteczności) dla pacjenta,

- technicznego - usługa zdrowotna, jako procedura posterowania w procesie diagnozy i terapii,

- relacyjnego - usługa zdrowotna, jako swoisty dialog (spotkanie) usługobiorcy z usługodawcą.

Uwzględnienie wymienionych aspektów przy opracowywaniu planu oferty rynkowej podmiotu opieki zdrowotnej sprawia, że na oferowaną usługę należy spojrzeć szeroko i uwzględnić pięć poziomów produktów: ${ }^{32}$

- rdzeń produktu - to główna korzyść, której naprawdę poszukuje pacjent (np. pacjent przychodzący do gabinetu stomatologicznego oczekuje rozwiązania jego problemu zdrowotnego),

- poziom podstawowy - wymaga przekształcenia głównej korzyści w ofertę w postaci dobrze wyposażonego gabinetu (unit, mikroskop, urządzenie do RTG itp.), posługującego się odpowiednimi materiałami stomatologicznymi,

- produkt oczekiwany - obejmuje zestaw cech i warunków, których kupujący się spodziewają, nabywając świadczenie (np. czystość w gabinecie, działający sprzęt, warunki w trakcie świadczenia usługi),

- produkt poszerzony - przekracza oczekiwania klienta, może dotyczyć np. szczególnej wygody fizycznej w poczekalni i gabinecie, wsparcia emocjonalnego itp.,

\footnotetext{
${ }^{31}$ Grönroos Ch., Service management and marketing. Managing the moments of truth in service competition, Lexington Books, Massachusetts, Toronto 1990, s. 27 za: Rudawska I., Ekonomizacja relacji pacjent - ustugodawca $w$ opiece zdrowotnej, Studia i rozprawy T.602, wyd. Uniwersytetu Szczecińskiego, Szczecin 2006, s. 25.

${ }^{32}$ Kotler Ph., Shalowitz J., Stevens R.J., Marketing strategiczny ... op. cit., s. 365 i nast.
} 
- produkt potencjalny - zawiera wszystkie możliwe ulepszenia i przekształcenia, które usługa może przejść w przyszłości; stanowi sposób na wypracowanie wysokiej oceny u klienta i odróżnienie placówki od ofert konkurencji.

Warto zauważyć, że „,wchodzenie” na coraz wyższy poziom produktu zwiększa koszty funkcjonowania podmiotu, kreując korzyści dla pacjenta. Zwiększone korzyści bardzo szybko stają się korzyściami przewidywalnymi (i traktowanymi przez nabywcę, jako należne), stanowiąc niezbędny element pozycji konkurencyjnej. $\mathrm{Z}$ drugiej strony trzeba mieć na uwadze potencjalne zagrożenie, dotyczące tego, że niektórzy konkurenci mogą zaoferować uboższą wersję za dużo niższą cenę i przejąć niektórych nabywców usług.

Potrzeby pacjentów w zakresie - szeroko pojętej - oferty rynkowej (będące przedmiotem badania IV) oraz zakres oferty dostępnej w gabinecie stomatologicznym (czego dotyczy badanie I) zostaną przedstawione $\mathrm{w}$ punkcie $4 \mathrm{w}$ IV rozdziale.

\subsection{JAKOŚĆ USŁUG}

\subsubsection{CECHY JAKOŚCI USŁUG}

Jakość świadczonych usług jest jednym z kluczowych czynników wpływających na trwałość i głębokość więzi z pacjentami. Determinuje zachowania dotychczasowych świadczeniobiorców, powiększając ich skłonność do podejmowania leczenia w danym podmiocie opieki zdrowotnej ${ }^{33}$. Określana jest jako funkcja dwóch zmiennych: oczekiwań usługobiorców i ich faktycznych doznań podczas procesu świadczenia usługi ${ }^{34}$. Definicję jakości opartą na wymienionych zmiennych proponuje m. in. A. Parasuraman, mówiąc: „Jakość usługi to miara wskazująca, w jakiej mierze realizacja konkretnego świadczenia odpowiada oczekiwaniom klienta. Świadczenie usług wysokiej jakości oznacza stałe spełnianie przez dostawcę oczekiwań swoich klientów." ${ }^{35}$ Inną propozycję przedstawiają V.A. Zeithaml i M.J .Bitner, które pod pojęciem jakości rozumieją świadczenie wartościowej usługi na poziomie spełniającym oczekiwania klientów lub je przekraczającym. Jakość, którą klient zauważa jest wynikiem porównania jego oczekiwań w stosunku do jakości usługi z jakością rzeczywiście świadczonej usługi. ${ }^{36}$ Obszary, które są oceniane przez nabywcę usługi (również pacjenta) przedstawia rysunek 1.

\footnotetext{
${ }^{33}$ Furtak R., Marketing partnerski na rynku ustug, PWE, 2003, s. 130.

${ }^{34}$ Por. Mazur J., Zarzadzanie marketingiem ... op. cit.

${ }^{35}$ Parasuraman A., Measuring and monitoring service quality, w: Glyn W.J., Barnes J.G. (red.), Understanding Services Management, John Wiley \& Sons, Chichester 1995.

${ }^{36}$ Zeithaml V.A., Bitner M.J., Services ... op. cit.
} 


\section{Rysunek 1. Elementy usługi oceniane przez klientów}

*Przebieg procesu

*Etapy procesu

*Elastyczność a standardy

*Technologia a czynnik ludzki

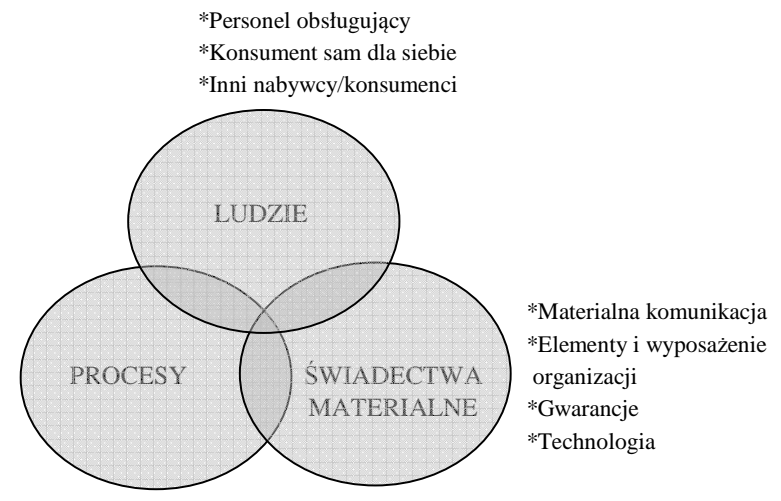

Źródło: Zeithaml V.A., Bitner M.J., Services ... op. cit., s. 115.

W literaturze panuje zgodność co do tego, że zagadnienie jakości w usługach jest nierozerwalnie związane $\mathrm{z}$ udzielaniem świadczenia ${ }^{37}$; np. L.L. Berry, A. Parasuraman, V.A. Zeithaml zaprezentowali szeroką charakterystykę kryteriów stosowanych przez klientów do oceny jakości usług ${ }^{38}$ :

- wiarygodność (credibility), co oznacza zaufanie, uczciwość usługodawcy;

- bezpieczeństwo (security), rozumiane jako pozbawienie usługi elementów ryzyka; bezpieczeństwo osobiste klienta (poufność), jak również bezpieczeństwo jego pieniędzy;

- dostępność (access), dogodna lokalizacja, bezproblemowy dostęp do usługi dla każdego zainteresowanego, odpowiedni czas otwarcia placówek i krótki czas oczekiwania na wykonanie usługi;

- komunikatywność (communication), wsłuchiwanie się w głosy klientów, ale także przekazywanie na bieżąco - sformułowanej prawidłowo i w sposób zrozumiały dla każdego nabywcy - informacji o usługach;

- zrozumienie klienta (understanding the customer), podejmowanie działań skierowanych na poznanie specyficznych potrzeb klienta, indywidualne traktowanie klienta oraz identyfikacja stałych, lojalnych klientów;

- elementy materialne (tangibles), stosowane środki materialne tj. stan podmiotu i jego wyposażenie, wygląd pracowników, broszury i ulotki firmowe, druki firmowe, materiały promocyjne;

\footnotetext{
${ }^{37}$ Prace poświęcane tej problematyce można znaleźć w dorobku naukowym m. in.: Ch. Grönroos, E. Gummessona, L.L. Berry'ego, A. Parasuramana, V.A. Zeithml, K. Rogozińskiego.

${ }^{38}$ Zeithaml V.A., Parasuraman A., Berry L.L., Delivering Quality Service - balancing customer perceptions and expectations, „The Free Press”, Nowy Jork 1990.
} 
- zdolność reagowania (responsiveness), okazywanie chęci pomocy klientom w rozwiązywaniu ich problemów oraz natychmiastowe świadczenie usługi;

- solidność (reliability), zdolność wykonywania świadczonych usług w sposób rzetelny i dokładny;

- fachowość (competence), umiejętności oraz posiadana wiedza pozwalają na dostarczanie usługi wysokiej jakości zarówno przez personel liniowy, jak i pracowników ich wspierających;

- uprzejmość (courtesy), odnoszenie się personelu do klienta grzecznie, z życzliwością, szacunkiem i uśmiechem.

W praktyce zaczęto posługiwać się pięcioma z wymienionych wymiarów jakości usług: solidnością, wymiarem materialnym, reakcją na oczekiwania nabywcy, fachowością oraz empatią. Te wymiary stały się kanwą do przygotowania kwestionariusza do badania IV (w odniesieniu do oczekiwań pacjentów w zakresie jakości usług stomatologicznych i ich ocen kontaktów usługowych).

Istnieje wiele sposobów postrzegania cech jakości usług, wynikających z odmiennego definiowania tego pojęcia. W tabeli 30 przedstawione są wybrane cechy jakości usług. Ich przegląd pozwala na stwierdzenie, że koncentrują uwagę usługodawcy na zaspokojeniu - szeroko pojętych - potrzeb nabywcy. Najczęściej spotykane w literaturze definicje jakości usług można zaliczyć do grupy definicji jakości zorientowanych na klienta, które zakładają, że usługa jest tożsama z procesem usługowym, a jakość jest to zgodność z wypełnieniem oczekiwań klienta i ocenić ją może jedynie klient. Pierwszą definicję jakości usług zgodnie z tym podejściem zaproponowała Ch. Grönroos, stwierdzając, że ,jakość postrzeganej usługi jest wynikiem oceny procesu usługowego, w którym klient porównuje swoje oczekiwania z usługą otrzymaną"39, a całkowita jakość oferty usługowej może być rozpatrywana w trzech wymiarach:

- technicznym - rozumianym jako wynik procesów operacyjnych,

- funkcjonalnym - będącym wynikiem kontaktów między usługodawcą a klientem,

- wyobrażeń klienta o usługodawcy.

Nieco szerzej opisał te wymiary K. Rogoziński, odwołując się do pracy P.L. Townsenda i J.E. Gebhardta ${ }^{40}$; wskazując następujące składowe jakości usługi profesjonalnej:

39 Por. Aldlaigan A.H., Buttle F.A., SYSTRA-SQ: a New measure of bank service quality, "International Journal of Service Industry Management" $2002 \mathrm{nr} 4$.

${ }^{40}$ Townsend P.L., Gebhardt J.E., Quality in Action. 93 Lessons in Leadership, Participation and Measurement, J.Wiley\&Sons Inc. 1992, section 62, vocabulary, s. 154, za: Rogoziński K., Nowy marketing ustug, Wyd. AE w Poznaniu, Poznań 1998, s. 14. 
- jakość w percepcji usługobiorcy ${ }^{41}$ - jest to jakość odczytana, doświadczona i percypowana przez nabywcę $\mathrm{w}$ czasie trwania pełnego cyklu usługi; usługodawca powinien zwracać szczególną uwagę na momenty prawdy, dotrzymywanie warunków umowy i zaspokojenie potrzeb nabywcy (który występuje jako „ekspert od jakości”);

- jakość w faktach i normach - na tej płaszczyźnie znajdują się wszystkie aspekty usługi możliwe do zmierzenia, unormowania i wystandaryzowania, stąd konieczne jest określenie parametrów wykonania świadczenia (warunków brzegowych realizacji); usługa rozpatrywana z tego pułapu możliwa jest do oceny w odniesieniu do wcześniej stworzonego modelu opartego na wskaźnikach i innych mierzalnych parametrach, co więcej jakość może być z łatwością weryfikowana przez innego wykonawcę;

- jakość w relacjach - dotyczy umiejętności współpracy z klientem, jest to szczególnie ważny element budowania jakości usługi, gdyż w kontaktach firma profesjonalna - klient ścierają się odmienne doświadczenia rynkowe i pola percepcji, kompetencje w rozwiązywaniu problemów, charaktery i osobowości ${ }^{42}$. Kontakt (tzw. moment prawdy) jest oceniany przez klienta (np. zostałem potraktowany jak VIP vs traktowali mnie w lekceważący sposób) i wymaga ciągłej troski - również po zakończeniu świadczenia, aby klient był źródłem pozytywnych referencji rynkowych ${ }^{43}$.

Tak szerokie ujęcie zagadnienia wyraźnie pokazuje optykę marketingową ${ }^{44}$ w podejściu do jakości usług, jako realizację spełniającą lub przekraczającą

\footnotetext{
${ }^{41}$ Różnica między usługą oczekiwaną a faktycznie otrzymaną jest sprawą indywidualną i subiektywną dla każdego klienta (również pacjenta). W związku z tym nie może być mierzona obiektywnie. W usługach medycznych takiemu pomiarowi poddana może zostać jedynie jakość techniczna, będąca rezultatem procesu świadczenia usługi z czysto narzędziowego, klinicznego punktu widzenia. Prawidłowa diagnoza, terapia zgodna $\mathrm{z}$ aktualną wiedzą medyczną, bezbłędne wykonanie operacji - wszystkie te elementy determinują jakość techniczną. Indywidualizacja percepcji jakości usługi medycznej, jak i silny subiektywizm oceny świadczenia ze strony pacjenta, sprawiają, że bardziej adekwatne jest posługiwanie się pojęciem ,postrzeganej jakości usługi” - mianem tym określa się wynik komparatywnej oceny dwóch elementów: usługi doświadczonej i oczekiwań wobec niej projektowanych. Por. Parasurman A., Zeithaml V.A., Berry L.L, A conceptual model ... op. cit., s. 41-50.

${ }^{42}$ Korbacz M., Janiszewska K., Zasady wspótpracy z firma świadczaca ustugi profesjonalne, w: Rogoziński K. (red.), Marketing ustug profesjonalnych, Wyd. AE w Poznaniu, Poznań 1999, s. 233.

${ }_{43}$ Jakość usług i obsługi wpływa na to, jak klient postrzega przedsiębiorstwo, a w długim okresie na jego lojalność. Można również wskazać badania, które pokazują, że zadowolony klient niekoniecznie musi być lojalny, np. z badań sprawdzonych przez Fundację Rockefellera wynika, że: 1) $4 \%$ klientów odchodzi z powodu nie załatwionej reklamacji, 2) $9 \%$ rezygnuje z danej firmy ze względu na działania konkurentów, 3) 9\% odchodzi z powodu zmiany miejsca zamieszkania, 4) $68 \%$ dokonuje zmiany bez żadnego specjalnego powodu. Por. Griffin J., Customer Loyalty. How to Earn It, How to Keep It, Jossey-Bass Publishers, San Francisco 1997, s. 186.

${ }^{44}$ Zeithaml V.A., Parasuraman A., Berry L.L, Delivering Quality ... op. cit.
} 
oczekiwania nabywcy (tym samym usługa posiada odpowiednią jakość, jeżeli została wykonana - co najmniej - zgodnie z oczekiwaniami klienta ${ }^{45}$ ).

Tabela 30. Cechy jakości usług w świetle wybranych pozycji literatury

\begin{tabular}{|c|c|}
\hline Autor & Cechy jakości usług \\
\hline Ch. Grönroos ${ }^{\mathrm{a}}$ & $\begin{array}{l}\text { odzyskiwanie (powrót do stanu początkowego), postawy i zachowanie, dostęp- } \\
\text { ność i elastyczność, reputacja i zaufanie, profesjonalizm i wiarygodność, pewność } \\
\text { i zaufanie; }\end{array}$ \\
\hline $\begin{array}{l}\text { A. Parasuraman, } \\
\text { V.A. Zeithaml, } \\
\text { L.L. Berry }\end{array}$ & $\begin{array}{l}\text { pewność, odpowiedzialność, namacalność, niezawodność, empatia, wiarygodność, } \\
\text { dostępność, solidność, komunikacja, zrozumienie klienta, grzeczność, kompeten- } \\
\text { cja, odpowiedzialność, aktywa trwałe (namacalność, techniczna obudowa obsługi), } \\
\text { bezpieczeństwo; }\end{array}$ \\
\hline $\begin{array}{l}\text { J. Haywood- } \\
\text { Farmer }^{\mathrm{c}}\end{array}$ & $\begin{array}{l}\text { 1) aspekty behawioralne, takie jak: terminowość, szybkość usługi, komunikacja } \\
\text { (werbalna i pozawerbalna), grzeczność, przyjacielskość, takt, ciepło, postawa, ton } \\
\text { głosu, ubiór, schludność, uprzejmość, uwaga, zaangażowanie, rozwiązywanie } \\
\text { problemów, reagowanie na skargi; 2) profesjonalizm rozumiany jako umiejętność } \\
\text { postawienia diagnozy, a także pozostałe umiejętności: innowacyjność, szczerość, } \\
\text { poufność, elastyczność, dyskrecja, wiedza; } 3 \text { ) udogodnienia fizyczne i procesów: } \\
\text { lokalizacja, rozmiar, niezawodność urządzeń, przepływ procesu, zdolności } \\
\text { procesu, równowaga, kontrola przepływu, elastyczność procesu, terminowośc, } \\
\text { szybkość, zakres oferowanych usług, komunikacja; }\end{array}$ \\
\hline $\begin{array}{l}\text { T. Mersha, } \\
\text { V. Adlakha }\end{array}$ & $\begin{array}{l}\text { wiedza o usłudze, staranność usługi, chęć poprawy błędów, uzasadnione koszty, } \\
\text { terminowość usług, grzeczność, entuzjazm/pomocność, przyjacielskość, przestrze- } \\
\text { ganie przyjętych godzin pracy, kontynuacja usług, przyjazne środowisko; }\end{array}$ \\
\hline A. Ghobadian ${ }^{\mathrm{e}}$ & $\begin{array}{l}\text { kompetencje, dostępność, odpowiedzialność, zrozumienie klienta, wiarygodność, } \\
\text { grzeczność, komunikacja, materialność, bezpieczeństwo, indywidualizacja działań; }\end{array}$ \\
\hline R. Johnson ${ }^{f}$ & $\begin{array}{l}\text { odpowiedzialność, troska, dostępność, wiarygodność, integracja, przyjacielskość, } \\
\text { grzeczność, komunikacja, kompetencje, funkcjonalność, zaangażowanie, } \\
\text { dostępność, bezpieczeństwo, elastyczność, estetyka, czystość, komfort; }\end{array}$ \\
\hline $\begin{array}{l}\text { G. Philip, } \\
\text { S.A. Hazlett }\end{array}$ & $\begin{array}{l}\text { Model atrybutów P-C-P: 1) atrybuty zasadnicze: odpowiednia informacja; } \\
\text { 2) atrybuty rdzenne: niezawodność, odpowiedzialność, pewność, empatia; } \\
\text { 3) atrybuty peryferyjne: dostępność, materialność. }\end{array}$ \\
\hline $\begin{array}{l}\text { Z. Yang, } \\
\text { X. Fang } \\
\end{array}$ & $\begin{array}{l}\text { odpowiedzialność, solidność, wiarygodność, kompetencje, dostępność, zawartość, } \\
\text { grzeczność, ciągłe doskonalenie, komunikacja, pakiet usług, bezpieczeństwo; }\end{array}$ \\
\hline D.A. Gavin ${ }^{i}$ & $\begin{array}{l}\text { Wymiary jakości: 1) użyteczność (odpowiada charakterystykom wewnętrznym } \\
\text { istoty usługi), 2) niezawodność (bezusterkowość w określonym czasie i warun- } \\
\text { kach), 3) praktyczność (określa akceptowalność rozwiązania, łatwość jego } \\
\text { obsługi), 4) zgodność z wymaganiami (stopień zgodności z uprzednio ustalonymi } \\
\text { standardami), 5) trwałość (zdolność wykorzystania produktu w wyznaczonym } \\
\text { okresie pracy tzw. długość życia produktu), 6) osobliwość (określa cechy } \\
\text { drugorzędne oferty, które są uzupełnieniem cech związanych z użytecznością tzw. } \\
\text { charakter produktu), 7) estetyczność (odzierciedla subiektywne opinie o usłudze, } \\
\text { będące wyrazem przeżyć psychofizycznych tj. wizerunek w świadomości konsu- } \\
\text { menta), 8) postrzegana jakość (związana ściśle z marką i reputacją dostawcy); }\end{array}$ \\
\hline
\end{tabular}

${ }^{45}$ Jeśli jakość oczekiwana jest: 1) równa jakości realizacji, to usługa zyskuje akceptację klienta, można powiedzieć o satysfakcji nabywcy z kontaktu z usługodawcą; 2) większa niż zrealizowana, to powoduje niezadowolenie i rozczarowanie klienta (pojawia się stan określany mianem dyssatysfakcji), 3) na niższym poziomie niż zrealizowana, to realizacja usługi wywołuje pozytywne reakcje, zyskuje uznanie i oceny formułowane w superlatywach. 


\begin{tabular}{|l|l|}
\hline J.A.Fitzsimmons, & $\begin{array}{l}\text { Na jakość wpływają: 1) urządzenia i infrastruktura: lokalizacja, wystrój wnętrza, } \\
\text { M.J.Fitzsimmons }\end{array}$ \\
& $\begin{array}{l}\text { urządzenia wspomagające, projekt architektoniczny, rozmieszczenie urządzeń; } \\
\text { 2) dobra materialne: konsystencja, jakość, różnorodność (wybór); 3) informacja: } \\
\text { dokładność, terminowość, użyteczność; 4) usługi ,jawne”: przeszkolony } \\
\text { personel usługowy, kompletność usługi, spójność, dostępność; 5) usługi } \\
\text {,niejawne”: postawa pracowników (np. taktowność), atmosfera, oczekiwanie na } \\
\text { usługę, status, poczucie zadowolenia, prywatność i bezpieczeństwo, wygoda; }\end{array}$ \\
\hline C. King & $\begin{array}{l}\text { Wymiary jakości: odpowiedzialność, kompetencje, dostęp, uprzejmość, } \\
\text { komunikatywność, wiarygodność, bezpieczeństwo i zrozumienie. }\end{array}$ \\
\hline
\end{tabular}

Źródło: opracowanie własne na podstawie: ${ }^{a}$ Grönroos Ch., Service quality: the six criteria of good perceived service, „Review of Business”, $1988 \mathrm{nr} \mathrm{3;}{ }^{\text {b }}$ Parasuraman A., Zeithaml V.A., Berry L.L., A conceptual model of service quality and its implications for future research, "Journal of Marketing", 1985 vol. 49; Parasuraman A., Zeithaml V.A., Berry L.L., Reasons of expectations as a comparison standard in measuring service quality: implication for further research, "Journal of Marketing" 1994, vol. 58; ' Haywood-Farmer J., A conceptual model of service quality, „International Journal of Operations and Productions Management”, $1988 \mathrm{nr} \mathrm{6;}{ }^{\mathrm{d}}$ Mersha T., Adlakha V., Attributes of service quality: the consumers perspective, „International Journal of Service Industry Management”, $1991 \mathrm{nr} \mathrm{3;}{ }^{\mathrm{e}}$ Ghobadian A., Service quality concepts and models, "International Journal of Quality \& Reliability Management", $1994 \mathrm{nr} 9$; ${ }^{\mathrm{f}}$ Johnson R., The determinants of service quality: satisfiers and dissatisfiers, „International Journal of Service Industry Management", $1995 \mathrm{nr} \mathrm{5;}{ }^{\mathrm{g}}$ Philip G., Hazlett S.A., The measurement of service quality": a New $P-C-P$ attributes model, "International Journal of Quality \& Reliability Management", $1997 \mathrm{nr} 3$; ${ }^{\mathrm{h}}$ Yang Z., Fang X., Online service quality dimensions and the relationships with satisfaction. A content analysis of customer reviews of securities brokerage services, „International Journal of Service Industry Management" , $2004 \mathrm{nr} 3 ;{ }^{\mathrm{i}}$ Sojki B. (red.), Zarzadzanie produktem, PWE, Warszawa 2003, s. 121; ${ }^{j}$ Fitzimmons J.A., Fitzsimmons M.J., Service Management ... op. cit.; ${ }^{\mathrm{k}}$ King C., A framework for a service quality assurance system, "Quality Progress", $1997 \mathrm{nr} 9$.

We współczesnej literaturze z zakresu marketingu panuje zgodność, co do tego, że jakość jest jednym z ważniejszych źródeł, przewagi konkurencyjnej, jak pisze K. Cholewicka-Goździk: „Dla wielu klientów wysoka jakość jest źródłem ich lojalności. Lojalność zapewnia utrzymanie klientów, realizację wartości klienta w pełnym cyklu jego życia poprzez dostarczenie mu przekraczającej oczekiwania klienta, propozycji wartości."46

Propozycję aplikacji myślenia i działania projakościowego do sfery usług przedstawił K. Rogoziński w formule $3 \mathrm{M}^{47}$ :

- management - obejmuje sformułowanie misji, celów strategicznych i wyprowadzenie wizji prowadzenia biznesu; ukształtowanie odpowiedniej kultury i struktury organizacji; zdefiniowanie jakości wewnętrznej; przygotowanie materialnych i organizacyjnych warunków świadczenia usług na zaplanowanym poziomie jakości, wypracowanie adekwatnego do nich stylu zarządzania;

\footnotetext{
${ }^{46}$ Cholewicka-Goździk K., Istota zarządzania jakościa, „Problemy Jakości”, 2008, nr 6, s. 6.

${ }^{47}$ Rogoziński K., Nowy marketing ... op. cit., s. 242.
} 
- mistrzostwo zawodowe - dotyczy opracowania i właściwego doboru oraz perfekcyjnego stosowania procedur postępowania i stworzenia systemu motywacyjnego, który będzie stymulował do wzrostu zaangażowania w pracy na rzecz jakości;

- marketing - utożsamiany z orientacją zewnętrzną, jako otwarcie się na otoczenie, w tym szczególnie na nabywców, którzy mogą być włączani w proces projektowania usługi; dzięki temu mogą stać się współtwórcami jakości oferty (w tym ujęciu właściwą koncepcją wydaje się być marketing relacyjny).

Jej przejrzystość i kompleksowe ujęcie zagadnienia sprawia, że może ona być stosowana nawet $\mathrm{w}$ małych podmiotach usługowych (z zachowaniem specyfiki usług medycznych w gabinetach stomatologicznych również). Wdrożenie jej do funkcjonowania gabinetu stomatologicznego mogłoby się przyczynić do większego zaangażowania pracowników, w konsekwencji do wyższego poziomu jakości obsługi pacjenta (i dostarczania mu większej wartości) i w efekcie zwiększenia zadowolenia pacjenta. Autor omawianego rozwiązania, aby nadać swojej koncepcji dynamicznego charakteru, wskazuje na konieczność uwęględnienia dwóch ruchów ${ }^{48}$ :

- ruchu zstępującego, który polega na dyfuzji wprowadzonych rozwiązań przy wykorzystaniu do tego marketingowej interpretacji jakości (wszystko zostaje podporządkowane zespoleniu jakości z wartością ${ }^{49}$ );

- ruchu wstępującego, który jest ruchem oddolnym, swoistą odpowiedzią udzieloną przez każdego pracownika, a potwierdzoną w zachowaniu - działaniu - pracy - postawie - zaangażowaniu, a następnie powrotem do źródła (kultury organizacji), by w nim potwierdzić trafność powyższych zachowań $^{50}$.

Ponieważ model tworzenia jakości usług medycznych jest dynamiczny, należy prognozować przyszłe potrzeby odbiorców i próbować dostosowywać ofertę do

\footnotetext{
${ }^{48}$ Ibidem s. 242 i nast.

${ }^{49}$ Orientacja na jakość przesądza o sposobie spełniania funkcji wykonawczych, marketingowych i ukierunkowuje na powiększenie wartości wspólnie dodanej.

${ }^{50}$ Pracownicy działający projakościowo - wg. K. Rogozińskiego - czerpią satysfakcję z wykonywanej pracy i osiągania coraz wyższego poziomu działań. Tym samym jakość - rozumiana jako doskonalenie obsługi nabywcy - staje się formą samodoskonalenia pracowników (współtworząc całość, jaką jest ucząca się organizacja). Lekarze dentyści w swojej pracy działają dla dobra nabywców swoich usług; podnoszą swoje kwalifikacje, by robić to coraz lepiej, dlatego wydaje się uzasadnionym określenie gabinetu stomatologicznego mianem organizacji uczącej się (szerzej na ten temat w punkcie 2 tego rozdziału).
} 
oczekiwań nabywców. Wymaga to zapewnienia zgodności ze standardami medycznymi w kilku sferach ${ }^{51}$ :

- sferze opieki medycznej, obejmującej obszar, w którym pacjent zwraca szczególną uwagę na kontakty interpersonalne, na komunikację z lekarzem, pielęgniarką oraz pozostałymi uczestnikami procesu leczenia (występującymi po stronie świadczeniodawcy),

- sferze informacyjnej ${ }^{52}$, zawierającej zasób wiedzy, jaki dostarczany jest pacjenttowi; naturalna asymetria wiedzy między lekarzem (szerzej: personelem placówki zdrowotnej) przyczynia się do powstawania bariery komunikacyjnej (to od postawy pracowników będzie zależało na ile/czy w ogóle uda się ją zniwelować);

- sferze technicznej, która dotyczy wizerunku oraz zachowań okołomedycznych; decydujące są czynniki łatwe w odbiorze przez pacjenta - schludność personelu, wygląd poczekalni, gabinetów czy traktowanie pacjenta zgodnie z zasadami etyki zawodowej lub zwykłej grzeczności;

- sferze zarządzania i ekonomii, dotyczącej z jednej strony gospodarowania zasobami ludzkimi placówki, z drugiej zaś efektywnego wykorzystania środków finansowych (w ramach limitów przyznawanych przez publicznego płatnika usług - NFZ - i w przypadku podmiotów obsługujących tylko prywatnych pacjentów - środków pochodzących z opłat za świadczenia);

- sferze marketingu, która wymaga spojrzenia na szeroko pojęte oczekiwania pacjenta dla zoptymalizowania jakości świadczonych usług.

R.S. Maxwell ${ }^{53}$ uważa, że jakość usług zdrowotnych zależna jest od spełnienia oczekiwań w takich obszarach, jak: dostępność, proporcjonalność usług w stosunku do potrzeb, wydajność (w stosunku do pacjenta), równość, społecz-

\footnotetext{
${ }^{51}$ Opolski K., Dykowska G., Możdżonek M., Zarzadzanie przez jakość w ustugach zdrowotnych. Teoria i praktyka, CeDeWu, Warszawa 2003, s. 28 i nast.

${ }^{52} \mathrm{Z}$ punktu widzenia pacjenta czynnikiem w najwyższym stopniu kreującymi jakość usług jest odpowiednio zaprogramowany proces komunikacji wzbogacony o edukację pacjenta. Por. Bjorkman T., Hansson L., Svensson B., Berglund I., What is important in psychiatric outpatient care? Quality of care the patient's perspective, "International Journal for Quality in Health Care", $1995 \mathrm{nr} 4$.

Program komunikacji ma prowadzić nie tylko do zrozumienia potrzeb, wymagań i zachowań pacjentów, ale również przyczynić się do tego, by pacjent uczył się, jak uczestniczyć w procesie interakcji, aby lepiej zaspokajać potrzeby. Proces ten określa się jako wzajemną naukę relacji. Por. Grönroos Ch., Creating a relationship dialogue: communication, interaction and value, "The Marketing Review", $2000 \mathrm{nr}$ 5, s. 11.

${ }^{53}$ Maxwell R.S., Quality Assurance in Health, "British Medical Journal”, 1984 nr 288.
} 
na akceptacja i ekonomizacja świadczeń. Jakość w opiece zdrowotnej zdeterminowana jest przez szereg wymiarów, które mogą podlegać ocenie ${ }^{54}$ :

- skuteczność - świadczenie usług w oparciu o wiedzę i aktualne doniesienia nauki (evidence based medicine - EBM),

- bezpieczeństwo - unikanie zdarzeń niepożądanych, które mogą wystąpić w trakcie leczenia pacjentów,

- dostępność - świadczenie usług bez zbędnej zwłoki, ograniczenie czasu oczekiwania na podjęcie leczenia stanowiące zagrożenie dla zdrowia lub życia pacjentów,

- adekwatność - dostosowanie oferty świadczeń do realnych potrzeb pacjentów,

- sprawiedliwość - zapewnienie równego dostępu do usług niezależnie od statusu pacjentów (wiek, płeć, miejsce zamieszkania, poziom dochodów),

- efektywność - unikanie marnotrawstwa zasobów przez ocenę ekonomiczną technologii medycznych.

Takie podejście ukazuje wielość i różnorodność czynników determinujących jakość opieki zdrowotnej.

Jak już zostało powiedziane jakość w relacjach personel podmiotu opieki zdrowotnej - pacjent przejawia się w tzw. momentach prawdy. Koncepcją umożliwwiającą identyfikację poszczególnych momentów prawdy w kontaktach stron procesu usługowego jest ,łańcuch jakości" ${ }^{, 55}$. Jest on swego rodzaju scenariuszem procesu doświadczania usługi przez pacjenta (por. rysunek 2). Stopień szczegółowości owego ,scenariusza” zależy od stopnia precyzji przyjętych standardów usługi oraz dalszych praktycznych implikacji wykorzystania „łańcucha jakości” w placówce zdrowotnej.

Analiza elementów, składających się na kompleksową obsługę pacjenta w ramach „łańcucha jakości”, skupia się zarówno na „uzbrojeniu” pracowników obsługi, jak i ich postawach i kompetencjach. Umożliwia zdiagnozowanie ewentualnych zagrożeń - określenie miejsc, które wymagają udoskonalenia czy eliminacji. I. Rudawska zwraca uwagę, że model łańcucha jakości w praktyce wymaga uzupełnienia o analizę następujących zagadnień ${ }^{56}$ :

\footnotetext{
${ }^{54}$ Instytute of Medicine Committee on Quality of Health Care in America, Crossing the Quality Chasm: A new Health System for the $21^{\text {st }}$ Century, DC: National Academies Press, Washington 2001.

${ }^{55}$ Scheaff R., Marketing for Health Services, Heinemann, Londyn 1991, s. 63 i nast.

${ }^{56}$ Rudawska I., Pacjent - klient na rynku ustug zdrowotnych, „Marketing i Rynek”, 2003 nr 1, s. 6.
} 
- motywów, dzięki którym pacjent decyduje się na skorzystanie z usługi (determinanty wyboru usługodawcy przez pacjentów - badanie IV - będą przedstawione w punkcie 4, IV rozdziału),

- społecznego wymiaru zaistniałej sytuacji (jej wpływu na role społeczne pacjenta),

- jednostkowego wymiaru zdarzenia (zaangażowanie członków rodziny i przyjaciół w opiekę nad pacjentem),

- psychologicznego wymiaru sytuacji (obawy i stres towarzyszące pacjentowi),

- przepływu strumienia informacji między pacjentem a usługodawcą,

- przepływu strumienia płatności między klientem, usługodawcą i płatnikiem oraz związanych z tym procedur administracyjnych,

- pozostałych czynników, które w jakikolwiek sposób mogłyby oddziaływać na sposób dostarczania usługi.

\section{Rysunek 2 Fragment „łańcucha jakości” w gabinecie stomatologicznym}

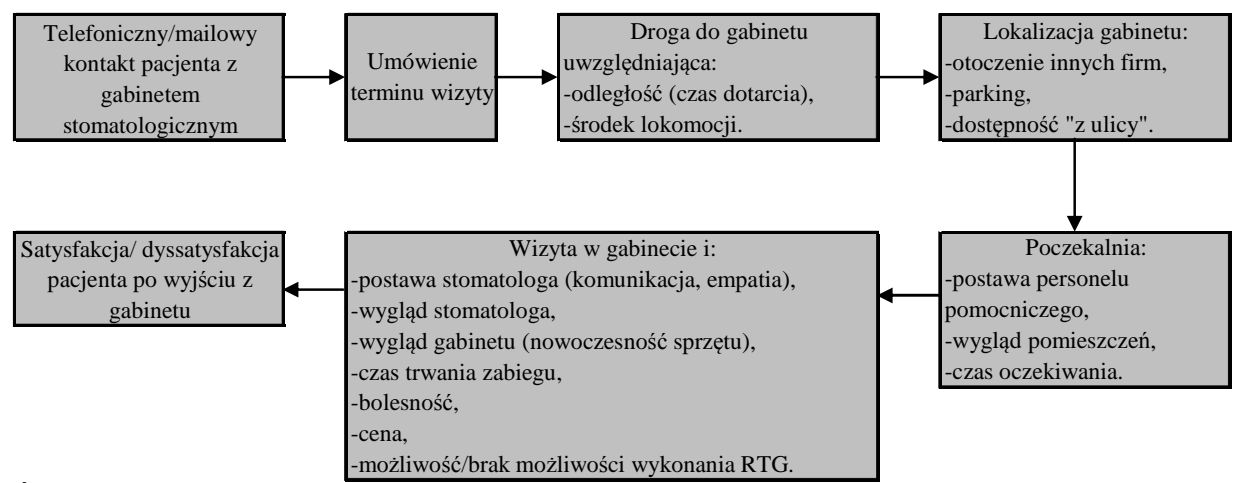

Źródło: opracowanie własne na podstawie Scheaff R., Marketing for Health Services, Heinemann, Londyn 1991, s. 63 i nast.

Podejście zgodne z ideą łańcucha jakości stawia kwestię jakości usługi medycznej w perspektywie ralacyjnej, a więc odnoszącej się nie tylko do umiejętności i zasobów usługodawcy (tak stricte medycznych, jak i pozamedycznych), ale i do odczuć pacjenta powstających na bazie jego oczekiwań oraz doświadczeń. Relacja łącząca pacjenta $z$ lekarzem staje się obiektem oceny i weryfikacji z poprzedzającymi rzeczywistą interakcję oczekiwaniami. ${ }^{57}$ Zależność tę przedstawia rysunek 3 .

\footnotetext{
${ }^{57}$ Por. Newsome P.R., Wright G.H., A review of patient satisfaction, "British Dental Journal", 1999 vol. 186, $\mathrm{nr}$ 4, s. 162 za: Rudawska I., Jakość relacji pacjent-profesjonalista $w$ sektorze ustug medycznych, „Problemy Jakości”, 2005, nr 3, s. 13.
} 


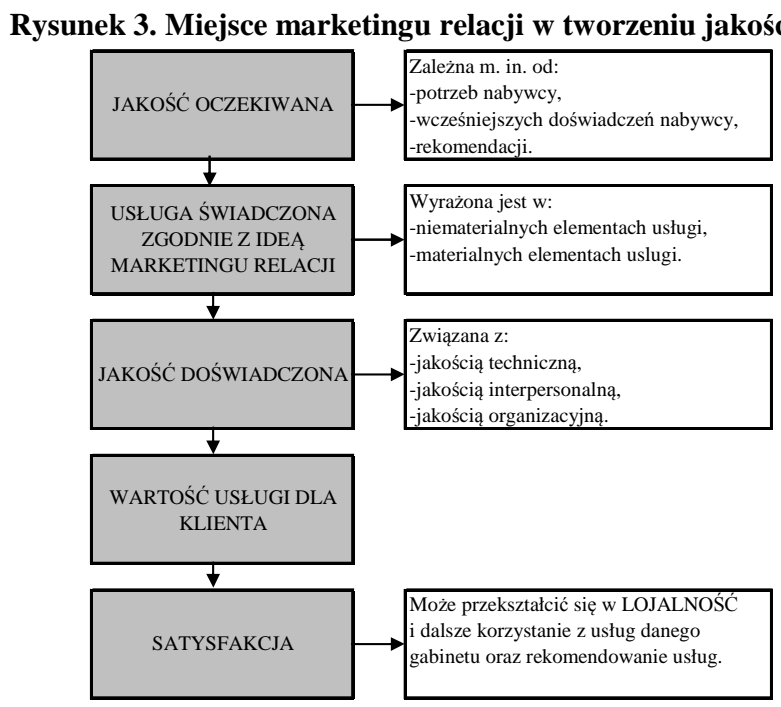

Źródło: opracowanie własne.

W świetle przedstawionych rozważań można wyróżnić trzy wymiary jakości opieki zdrowotnej $^{58}$ :

- techniczny $^{59}$ - efektywność, biegłość, bezpieczeństwo, troska; dotyczy możliwości osiągania najlepszych wyników w opiece zdrowotnej;

- interpersonalny - skoncentrowany na relacjach pacjenta z personelem medycznym (to szacunek dla pacjenta, dochowanie tajemnicy zawodowej, udzielanie informacji adekwatnej do poziomu wiedzy i wymagań pacjenta);

- organizacyjny - odnosi się do miejsca świadczenia usługi; zawiera w sobie m. in. wygląd podmiotu opieki zdrowotnej (w tym czystość pomieszczeń), ciągłość i wydajność opieki medycznej.

\footnotetext{
${ }^{58}$ Szczepska M., Standaryzacja jakości opieki pielęgniarskiej, „Pielęgniarstwo”, 1996 nr 4, s. 30.

${ }^{59}$ Jest ona istotna ze stricte medycznego punktu widzenia. Oznacza, że podmiot opieki zdrowotnej dostarcza usługi odpowiadające stanowi zdrowia pacjenta. Jej główne aspekty to: 1) prawdopodobieństwo przyniesienia korzyści pacjentowi, przewyższa prawdopodobieństwo wyrządzenia mu szkody, 2) poprawne dostarczenie opieki pacjentowi w bezpieczny i kompetentny sposób oraz w odpowiednim czasie. Por. Lawthers A.G., Pomiar jakości a menedżer ochrony zdrowia, „Zdrowie i zarządzanie", $1999 \mathrm{nr} \mathrm{3,} \mathrm{s.} 19$ i nast.

Ten wymiar jakości jest poza obszarem zainteresowania niniejszej pracy. Zostało przyjęte, że jest on oferowany pacjentowi na optymalnym poziomie.
} 
Podsumowując, można stwierdzić, że dążenie do poprawy jakości usług ${ }^{60}$ jest drogą do maksymalizacji korzyści klienta, a w konsekwencji do skłonienia go do ponownego skorzystania $\mathrm{z}$ oferty danego podmiotu. A. Payne ${ }^{61}$ uznaje, że jedynie z poziomu marketingu relacyjnego możliwe jest zapewnienie jakości usługi i obsługi nabywcy, pozwalającej na utrzymanie klientów. Obsługa klienta może być rozpatrywana $\mathrm{w}$ ujęciu wąskim - jako realizacja rdzenia usługi lub szerokim, w którym obejmuje ${ }^{62}$ :

- kształtowanie produktu (tu: świadczenia stomatologicznego) jako elementu większej całości;

- pełną obsługę cyklu aktywności klienta (związaną m.in. z działaniami z zakresu profilaktyki);

- uznanie i stosowanie podstawowych zasad marketingu relacyjnego, czyli:

- wszystkie działania podejmowane przez pracowników gabinetu (tak dentystę, jak i personel pomocniczy) powinny zmierzać - przez staranną realizację - do uzyskania efektu zgodnego z oczekiwaniami pacjenta (zarówno w wymiarze technicznym, jak i organizacyjnym oraz interpersonalnym),

- odchylenia od ustaleń wymagają akceptacji usługobiorcy (wynika to również z faktu, iż lekarz dentysta musi otrzymać zgodę pacjenta na rozpoczęcie leczenia),

- konieczna jest natychmiastowa reakcja na jakiekolwiek uchybienia, czy błędy w realizacji zlecenia,

- kompleksowa obsługa (od umówienia pacjenta na wizytę, przez realizację świadczenia, aż po ewentualną reklamację).

\subsubsection{JAKOŚĆ A SATYSFAKCJA}

Rozważania na temat jakości usług, warto uzupełnić o pojęcie satysfakcji, gdyż jakość i satysfakcja, chociaż pozytywnie skorelowane, nie powinny być utożsamiane. Jakość usług jest kategorią kognitywną, wycenianą lub wartościowaną. Natomiast satysfakcja stanowi wrażenie $\mathrm{z}$ doświadczenia usługi rozpatrywane w kontekście stawianych jej oczekiwań (o czym była już mowa w poprzednim punkcie). Jest swoistą kombinacją komponentów afektywnych, opartych na odczuciach (w konsekwencji najczęściej subiektywnych).

$60 \mathrm{Z}$ drugiej strony podkreślenia wymaga fakt, iż lekarz nie zawsze może w pełni usatysfakcjononować pacjenta, co więcej absolutyzacja satysfakcji mogłaby stanowić nawet zamach na jego profesjonalizm. Por. Rogoziński K., O marketingu - mimo wszystko inaczej, „Marketing i Rynek", 1999 nr 1, s. 8 i nast.

${ }^{61}$ A. Payne, The Essence of Services Marketing, Prentice Hall, Londyn 1993, s. 215; Podobne stanowisko zajmuje K. Rogoziński, I. Rudawska.

${ }^{62}$ K. Rogoziński, Nowy marketing ... op. cit., s. 84 i nast. 
Jak twierdzi M. Chłodnicki „większość studiów na temat satysfakcji bazuje na paradygmacie oczekiwań - niepowodzenia (tzw. teoria niepowodzenia), na który składają się:

- oczekiwania,

- akt świadczenia,

- potwierdzenie (bądź niepotwierdzenie),

- satysfakcja." 63

T. Sztucki definiuje satysfakcję jako subiektywne odczucie zadowolenia ${ }^{64}$ z odniesionych korzyści i spełnionych oczekiwań z nabycia, konsumpcji i użytkowania produktu bądź usługi, wynikające z zaspokojenia potrzeby lub rozwiązania występującego problemu (np. zdrowotnego). ${ }^{65}$ Tak więc satysfakcja jest wynikiem jakości zapewnionej przez usługodawcę.

Podobnie M. Bitner i A. Hubbert ${ }^{66}$ różnicy w pojęciach "jakość" i "satysfakcja" upatrują w fakcie, że jakość jest zjawiskiem poprzedzającym satysfakcję klienta. Satysfakcja pojawia się jako wynik doświadczenia po zakupie. Ponadto rozróżniają satysfakcję całkowitą (overall-satisfaction) oraz satysfakcję z pojedynczego świadczenia (encounter satisfaction), traktując tę pierwszą jako sumę satysfakcji $\mathrm{z}$ wszystkich aktów świadczenia $\mathrm{w}$ danej organizacji usługowej.

R.L. Oliver, twierdzi, że „oczekiwania bazujące na usłudze idealnej mogą być oczekiwaniami jakości usługi. Oczekiwania bazujące na własnych doświadczeniach będą ascendentem satysfakcji." ${ }^{67}$ Ta interpretacja może tłumaczyć powód, dla którego klienci mogą być zadowoleni z usług o niskiej jakości, a niezadowoleni z usługi o jakości wysokiej. Satysfakcja jest zjawiskiem doświadczalnym, podczas gdy klienci mogą mieć wyobrażenie na temat jakości usługi, nie mając z nią żadnych doświadczeń (i tu szczególnego znaczenia nabierają rekomendacje, które tworzą wizerunek podmiotu w oczach potencjalnych klientów). Ponadto jakość jest podejściem długookresowym (tzn. zakłada odniesienie do jakiegoś obiektywnego standardu oraz długoterminową powta-

\footnotetext{
${ }^{63}$ Chłodnicki M., Ustugi profesjonalne ... op. cit., s. 43

${ }^{64}$ Podobne stanowisko zajmuje np. Van Ossel G., Measuring Customer Satisfaction, w: Van Looy B., Van Dierdinck R., Gemmel P. (red.), Service Management. An Integrated Approach, Pitman Publishing, 1998, s. 126.

${ }^{65}$ Sztucki T., Marketig przedsiębiorcy i menedżera, Placet, Warszawa 2000, s. 65.

${ }^{66}$ Bitner M.J., Hubert A.R, Encounter satisfaction versus overall satisfaction versus quality, w: Rust R.T, Oliver R.L (red.), Service Quality: New Directions in Theory and Practice, Sage, Londyn 1983, s. 72-94.

${ }^{67}$ Oliver R.L., A Conceptual Model of Service Quality and Service Satisfaction: Compatible Goals, Different Concepts, “ Advances in Services Marketing and Management”, 1993 vol. 2, s. 65-85.
} 
rzalność poziomu wykonania), natomiast satysfakcja jest przejściową oceną (bazującą na konkretnej transakcji bądź specyficznym wydarzeniu).

Odmienne stanowisko w omawianej kwestii zajęli R.N. Bolton i J.H. Drew ${ }^{68}$, którzy wykorzystując algebraiczne przedstawienie jakości usług, dostarczyli dowodu na istnienie porządku przyczynowo-skutkowego między obydwiema kategoriami (jakością i satysfakcją) - przy czym satysfakcja jest zjawiskiem poprzedzającym jakość.

Wydawałoby się, że przedstawione powyżej podejścia wyczerpują problem tego, który ze stanów „satysfakcja” czy "jakość” występuje pierwszy w procesie usługowym. Ale w literaturze można znaleźć jeszcze inne: postrzegana przez klientów jakość usług jest zjawiskiem, które zarówno poprzedza satysfakcję, jak i jest jej konsekwencją. Badania prowadzone przez D. Iacobucciego, A.L. Ostroma i K.A. Graysona ${ }^{69}$, pozwoliły na sformułowanie wniosków, iż zależności pomiędzy jakością usług a satysfakcją klienta są dwubiegunowe (co oznacza, że empiryczne określenie, które z badanych zjawisk występuje jako pierwsze jest niemożliwe).

Nie ulega wątpliwości, że jakość i satysfakcja są ze sobą ściśle powiązane ${ }^{70}$, choć w literaturze brak jest konsensusu co do specyfikacji relacji między nimi. W pracy przyjęto założenie (por. rysunek 3), że pracownicy gabinetu stomatologicznego powinni świadczyć usługi wysokiej jakości (zarówno w obszarze technicznym, jak i interpersonalnym oraz organizacyjnym), aby usatysfakcjonować nabywców swoich usług (a więc ,jakość” poprzedzająca „satysfakcję”), co przyczyni się do tego, że pacjenci staną się ambasadorami gabinetu i będą przekazywać informacje o wysokiej jakości usług innym - potencjalnym nabywcom. Nowi pacjenci będą przychodzić do gabinetu z relatywnie wysokimi oczekiwaniami co do poziomu oferowanej jakości, które gabinet będzie starał się zaspokoić. Ta swoista spirala rosnących oczekiwań staje się przyczyną, dla której dentysta (również inne osoby z personelu gabinetu) powinien nauczyć się rozpoznawać pozamedyczne oczekiwania pacjentów. Tym samym zmieniające się oczekiwania pacjentów, co do jakości świadczenia i obsługi, przyczyniają się do tego, że gabinet, który chce zachowywać lub umacniać swoją rynkową pozycję staje się organizacją uczącą.

\footnotetext{
${ }^{68}$ Bolton R.N., Drew. J.H., A longitudinal analysis of the impact of service changes on consumer attitudes, "Journal of Consumer Research" 1991 vol. 17, s. 375 i nast.

${ }^{69}$ Iacobucci D., Ostrom A.L., Grayson K.A., Distinguishing service quality and customer satisfaction: the voice of the consumer, ,Journal of Consumer Psychology”, 1995 vol. 3, s. 277 i nast.

${ }^{70}$ Brady M.K., Robertson C.J., Searching for a Consensus on the Antecedents Role of Service Quality and Satisfaction: An Exploratory Cross National Study, „Journal of Business Research”, 2001 vol. 51, s. 53 i nast.; Peltier J.W., Boyt T., Obstetrical care and patient loyalty, "Marketing Health Services", 1999 t. 19, s. 3.
} 


\section{GABINET JAKO ORGANIZACJA UCZĄCA SIE}

\subsection{INNOWACJA JAKO INSTRUMENT PRZEDSIĘBIORCZOŚCI}

Przypomnijmy, że I.M. Kirzner uznaje przedsiębiorcę nie za źródło innowacyjnych pomysłów kreatywnych ex nihilo, ale za kategorię czujną na warunki, które już istnieją, choć nie zostały jeszcze dostrzeżone. Gdy zyskowne metody produkcji są technologicznie dostępne, gdy przepływ oszczędności wystarcza do stworzenia kapitału, to przedsiębiorczość zapewnia, że innowacje zostaną wprowadzone $^{71}$. Bez przedsiębiorczości, bez Kirznerowskiej czujności na nowe okoliczności, długoterminowe korzyści mogą zostać niewykorzystane. Z tego względu pojęcie ,innowacyjność” należy rozumieć szeroko jako każdą zmianę, która zastąpi dotychczasową rzeczywistość lepszym rozwiązaniem ${ }^{72}$. Tak szeroko rozumiana innowacja wymaga zaangażowania pracowników wszystkich szczebli w poszukiwanie i wdrażanie nowych rozwiązań funkcjonowania przedsiębiorstwa ( $\mathrm{w}$ poszukiwanie wiedzy na ten temat i uczenie się nowych sposobów działania).

Wiek XXI nazywany jest wiekiem wiedzy, kapitału intelektualnego, czy nowej ekonomii. Przedsiębiorstwa, prowadzące działalność w warunkach zmienności i konkurencji, powinna cechować innowacyjność, szybkość działania, umiejętność podejmowania ryzyka, chęć ustawicznego uczenia się. Istotna jest również umiejętność sprawnego wdrażania i utrwalania przedsięwzięć wpływających na poprawę ich działania. Ważne dla współczesnych przedsiębiorstw i dla przyszłości mogą być stwierdzenia P.F. Druckera, że supergwiazdą przedsiębiorczości jest innowacja oparta na wiedzy. Zgodnie $\mathrm{z}$ tą ideą przedsiębiorstwa powinny dążyć do wypracowania nowego zestawu postaw i modeli zachowań, który będzie stanowił receptę dla pracowników, jak mają się zachowywać w nowych i zmieniających się okolicznościach. Drucker mówi także o praktykowaniu systematycznej innowacji ${ }^{73}$, polegającej na ,celowym i zorganizowanym

\footnotetext{
${ }^{71}$ Por. Rothbard M.N., Man, Economy and State, Princeton, tom 2, s. 493 i nast. za: Kirzner I.M., Konkurencja ... op. cit., s. 76.

${ }^{72}$ Drucker P.F., Innowacja ... op. cit., s. 160.

${ }^{73}$ Nie należy mylić innowacji operacyjnych z bieżącymi usprawnieniami operacji czy doskonałością operacyjną - określenia te odnoszą się do osiągania wysokiej efektywności w obecnie stosowanym trybie prowadzenia działań operacyjnych (tj. do ograniczania liczby błędów, obniżania kosztów i zapobiegania opóźnieniom, jednakże bez wprowadzania zasadniczych zmian w sposobach wykonywania pracy). „Innowacje operacyjne oznaczają nowe sposoby realizowania zamówień, opracowywania nowych produktów, obsługi klientów albo wykonywania przez firmę każdej z tych czynności." Innowacja operacyjna to głęboka zmiana wpływająca na samą istotę funkcjonowania firmy: na to, jak wykonuje się w niej pracę. Jej skutki oddziałują na wszystkie aspekty działalności przedsiębiorstwa. Za: Hammer M., Transformacja firmy poprzez innowację operacyjna, „Harvard Business Review”, $2004 \mathrm{nr}$ 5; Stańczak-Strumiłło K., Strumiłło J., Innowacje operacyjne w jednostkach ochrony zdrowia, w: Lewandowski R., Walkowiak R., Kautsch M., Wspótczesne wyzwania menedżerskie w ochronie zdrowia, OWSzliZ im. prof. T. Kotarbińskiego, Olsztyn 2009, s. 27.
} 
poszukiwaniu zmian oraz na systematycznej analizie możliwości, jakie te zmiany mogą oferować dla innowacji ekonomicznej, bądź społecznej." ${ }^{, 74}$ Jego zdaniem systematyczna innowacja oznacza stałe monitorowanie siedmiu źródeł możliwości innowacyjnych, podzielonych na dwie grupy ${ }^{75}$ :

- źródła znajdujące się w przedsiębiorstwie i/lub wewnątrz sektora usług:

- to, co niespodziewane (niespodziewany sukces, niespodziewana porażka, niespodziewane wydarzenie zewnętrzne),

- niezgodność (pomiędzy rzeczywistością istniejącą faktycznie a rzeczywistością, jaką zakłada się, że ,jest” albo ,powinna być”),

- potrzeba procesu (wyraża się w doskonaleniu procesu, wymianie słabego ogniwa, zmianie procedur),

- zmiany w strukturze rynku albo strukturze branży;

- źródła innowacji, obejmujące zmiany, dokonujące się poza przedsiębiorstwem i branżą:

- demografia,

- zmiany w postrzeganiu i znaczeniu pewnych zjawisk społecznych,

- nowa wiedza.

Oprócz czynników zewnętrznych, można wskazać również wewnętrzne uwarunkowania procesów innowacyjnych ${ }^{76}$ : np. własna motywacja i aktywność twórcza osób, które uczestniczą w procesie innowacyjnym (ich ambicje i chęć zdobycia awansu zawodowego); nagromadzone przez przedsiębiorstwo zasoby rzeczowe, zasoby kapitałowe, zasoby ludzkie; system zarządzania i rozwiązania motywacyjne. Te czynniki stanowią potencjał innowacyjny, czyli zdolność podmiotu do efektywnego wprowadzania innowacji, a w konsekwencji poprawiania jego pozycji konkurencyjnej.

W ujęciu P.F. Druckera innowacja jest pojęciem społecznym (naruszającym dotychczasowe wzorce produkcyjne i konsumpcyjne ${ }^{77}$ ) i ekonomicznym (a nie

Podstawą uzyskania efektów dzięki wprowadzeniu innowacji operacyjnych jest stworzenie odpowiedniej atmosfery dla tych innowacji. U podstaw wprowadzania innowacji operacyjnych leżą następujące pytania: 1) How can we do what we do faster? 2) How can we do what we do better? 3) How can we do what we do at the lower cost? 4) Why do we do it the way we do? 5) Why do we do what we do at all? Por. Hammer M., Champy J., Reengineering w przedsiębiorstwie, Neuman Management Institute, Warszawa 1996.

${ }^{74}$ Drucker P.F., Natchnienie i fart, czyli innowacja i przedsiębiorczość, Wydawnictwo Studio EMKA, Warszawa 2004.

${ }^{75}$ Ibidem.

76 Zienkowski L., Co sprzyja rozwojowi gospodarczemu, Wydawnictwo Naukowe Scholar, Warszawa 2005, s. 79.

${ }^{77} \mathrm{~W}$ gabinecie stomatologicznym może przyjąć postać zmiany sposobu leczenia pacjenta - z pozycji siedzącej na leżącą; z pracy wykonywanej w całości tylko przez stomatologa (tzw. praca na dwie ręce) na pracę $\mathrm{z}$ asystą (tzw. praca na cztery ręce); z pracy lekarza dentysty przy jednym fotelu na 
tylko technicznym). Jest „specyficznym narzędziem przedsiębiorczości - działaniem, które nadaje zasobom nowe możliwości tworzenia bogactwa" ${ }^{\text {78 }}$. Definicja ta różni się od Schumpeterowskiej ${ }^{79}$ interpretacji innowacji tym, że pojawia się tutaj nowe pojęcie: zasób - innowacja tworzy zasoby. Nie ma w gospodarce większego zasobu od tego, jakim jest siła nabywcza, a ta tworzona jest przez przedsiębiorcę, który wprowadza innowacje. $\mathrm{Z}$ tego powodu wszystkie zmiany w gabinecie stomatologicznym, będące np. wynikiem implementacji do gabinetu marketingu relacji, prowadzące do zwiększenia zadowolenia pacjenta (zgodnie z sugestią C. Fornella: „lojalni klienci nie zawsze są zadowoleni, ale zadowoleni klienci mają tendencję, aby być lojalnymi" 80 ), a w konsekwencji również zwiększenia skłonności do korzystania z usług danego usługodawcy (np. dzięki edukowaniu pacjentów w obszarze znaczenia profilaktyki w ochronie zdrowia jamy ustnej) i zmniejszenia prawdopodobieństwa rezygnacji z jego usług ${ }^{81}$; można uznać za innowacje Druckera.

Zwolennikiem szerszego ujmowania omawianego pojęcia był także M.E. Porter, który twierdził, że innowacje to nowe produkty, nowe procesy wytwarzania, nowoczesny marketing, innowacyjna dystrybucja oraz nowoczesne kierowanie ludźmi ${ }^{82}$. Dlatego prorynkowe działania podejmowane w gabinecie stomatologicznym (np. w zakresie zmian w sposobie obsługi pacjentów; dostosowanie gabinetu do obsługi wybranych grup pacjentów - dzieci, niepełnosprawnych; organizacja usług z zakresu tzw. turystyki medycznej) można uznać za innowacyjne w sensie Porterowskim.

Jak wynika z przedstawionych spojrzeń na innowacje w usługach, wiążą się one w znacznym stopniu z pomysłami na sposób działania podmiotu (są to tzw.

pracę przy dwóch fotelach. Przykładem zmiany postaw konsumpcyjnych może być rosnące zainteresowanie poprawą wyglądu zębów np. wybielaniem, korekcją zgryzu (efektem jest noszenie stałych aparatów przez osoby w różnym wieku - od nastolatków po czterdziestokilkulatków).

${ }^{78}$ Kasperkiewicz W., Procesy innowacyjne $w$ gospodarce rynkowej. Teoria i praktyka, Naukowe Wydawnictwo Piotrkowskie, Piotrków Trybunalski 2008, s. 16.

${ }^{79}$ J.A. Schumpeter definicję ,innowacji” odniósł do pięciu przypadków: 1) wytworzenie i wprowadzenie nowego produktu, czy towaru na rynek, 2) wprowadzenie nowej metody produkcji, 3) otwarcie nowych rynków zbytu, 4) pozyskanie nowego źródła surowców, 5) przeprowadzenie nowej organizacji jakiegoś przemysłu, np. utworzenie lub zlikwidowanie monopolu. Por. Kasperkiewicz W., Procesy ... op. cit., s. 14.

${ }^{80}$ Fornell C., A National Customer Satisfaction Barometr: The Swedish Experience, "Journal of Marketing", 1992 vol. 56, nr 1, s. 6 i nast.

${ }^{81}$ Ulaga W., Eggert A., Relationship Value and Relationship Quality. Broadening the Nomological Network of Business-to-Business Relationships, "European Journal of Marketing", 2006 vol. 40, nr 3-4, s. 321; Gaurav K., Impact of Relationship Marketing Strategy on Customer Loyalty, "The Icfaian. Journal of Marketing Research”, 2008 nr 11, s. 7 i nast.

${ }^{82}$ Kasperkiewicz W., Procesy ... op. cit., s. 17. 
innowacje miękkie, odnoszące się do organizacji i zarządzania) i mogą przejawiać się $\mathrm{w}^{83}$ :

- nowej koncepcji usługi - usługa staje się wartością dla klienta poprzez dia$\log \mathrm{z}$ nim, tworzenie środowiska współpracy personelu $\mathrm{z}$ klientem oraz przejrzystość w działaniu podmiotu; usługa budowana jest na podstawie zasobów wiedzy podmiotu ( $\mathrm{tj}$. wiedzy usługodawcy i personelu pomocniczego oraz nabywców usług);

- nowej płaszczyźnie współpracy z klientem - dotyczy to nowego sposobu budowania relacji między podmiotem a nabywcą usługi, a także oferowania produktu (np. komunikowanie klientowi wizji i misji placówki, pozyskiwanie i wykorzystywanie wiedzy klienta - o potrzebach, o stopniu ich zaspokojenia - w świadczeniu usług);

- nowym systemie dostarczania usług - odnosi się do wewnętrznych warunków organizacyjnych, które muszą stwarzać pracownikom świadczącym usługi odpowiednie środowisko wykonywania zadań, rozwijania i oferowania usług (chodzi o wyposażenie pracowników w odpowiednie narzędzia, umiejętności oraz uprawnienia pozwalające im na szukanie innowacyjnych rozwiązań konkretnych problemów pojawiających się w czasie pracy);

- zastosowaniu nowych technologii ${ }^{84}$, które uzupełniają środowisko społeczne innowacji i dotyczą głównie innowacji organizacyjnych i menedżerskich (takich jak: wdrażanie zaawansowanych technik zarządzania np. TQM; wprowadzenie istotnie zmienionych struktur organizacyjnych) oraz innowacji marketingowych (i $\mathrm{w}$ tym znaczeniu gabinety stomatologiczne mogą stawać się i stają się innowacyjne).

Wprowadzanie nowych rozwiązań w funkcjonowaniu podmiotu wymaga otwartości i zaangażowania zarówno decydentów, jak i pracowników wykonawczych. Wymaga ciągłej Kirznerowskiej czujności, by Porterowska innowacyjność mogła zaistnieć. Z tego względu podmioty, które dzięki przedsiębiorczości są innowacyjne, stają się organizacjami uczącymi ${ }^{85}$, ciągle nastawionymi na zdobywanie i efektywne wykorzystywanie wiedzy.

\footnotetext{
${ }^{83}$ den Hertog P., Co-producers of innovation: on the role of knowledge-intensive business services in innovation, w: Gadrey J., Gallouj F., Elgar E.(red.), Productivity, innovation and knowledge in services, New Economic and Socio-Economic Approaches, Cheltenham-Northampton 2002, s. 226 i nast.

${ }^{84}$ Definicja OECD określa „innowacje technologiczne”, jako wszelką działalność innowacyjną przedsiębiorstw, która nie jest związana z opracowywaniem i wprowadzaniem na rynek nowych lub istotnie zmienionych wyrobów i usług lub wdrażaniem nowych lub istotnie zmienionych procesów. Por. Raport: Dziatalność innowacyjna przedsiębiorstw z sektora ustug 2001-2003, GUS, Warszawa 2005, s. 133.

${ }^{85} \mathrm{~K}$. Watkins i V. Marsick uważają, że współczesne podmioty rynkowe nie są jedynie zbiorem jednostek, które się uczą, ale przejawiają zdolność do zmiany - wyprzedzają zmiany czy kształtują je (np. redefiniują kulturę organizacji, dzielą się z pracownikami i klientami informacją i angażują ich
} 


\subsection{WIEDZA W GABINECIE STOMATOLOGICZNYM}

\subsubsection{ZARZĄDZANIE WIEDZĄ W GABINECIE}

Już w latach 80. XX w. ekonomiści za główny kapitał przedsiębiorstwa zaczęli uznawać kapitał ludzki, twierdząc, że możliwości gospodarki w długim okresie w generowaniu postępu technicznego oraz efektywnego wykorzystania istniejącego zasobu majątku trwałego są w istotny sposób od niego zależne ${ }^{86}$. P.F. Drucker zauważył, że rozwijająca się Nowa Gospodarka (por. punkt 1.1 w pierwszym rozdziale) przesuwa punkt ciężkości z tradycyjnych, klasycznych czynników wzrostu gospodarczego (praca, ziemia kapitał) na wiedzę ${ }^{87}$. J.H. Dunning do najważniejszych przejawów globalizacji na przełomie XX i XXI w. zaliczył m. in. wzrost znaczenia nauki, doświadczenia, wiedzy oraz kapitału ludzkiego w rozwoju przedsiębiorstw ${ }^{88}$.

Jeśli przyjmie się, że wiedza to umiejętność poruszania się w zastanej rzeczywistości ${ }^{89}$, to człowiek musi wykorzystywać dotychczasowe doświadczenia (swoje i innych), aby aktywnie dostosowywać się do zmieniającej się rzeczywistości. I.M. Kirzner mówi, że „wiedza na temat niepewnych możliwości, wymaga oddzielnego, dodatkowego poziomu przedsiębiorczości, potrzebnego do wykorzystania tej nabytej wiedzy - taka niepewna i niepełna wiedza jest wtedy 'zatrudnionym' elementem produkcji, a przedsiębiorczą rolę spełnia ktoś, mający pewność, że ta wiedza faktycznie zapewnia możliwość zysku." ${ }^{, 90}$ Dla pokazania roli wiedzy w zakładaniu i rozwijaniu przedsiębiorstwa, można wyróżnić jej kilka rodzajów: ${ }^{91}$

- wiedza wspólna gałęziowa - jest to rodzaj wiedzy, który trzeba mieć, aby na danym rynku prowadzić działalność (np. wiedza z zakresu stomatologii); można ją uzyskać przez zakup specjalistycznego wyposażenia i narzędzi (w których jest ona ucieleśniona); edukację i studiowanie fachowej literatury; zatrudnianie pracowników ze stażem w innych podmiotach, zajmujących się podobną działalnością; korzystanie z usług firm konsultingowych oraz przez benchmarking; część gabinetów stomatologicznych organizuje

w proces podejmowania decyzji. Por. Cahill D.J., The Managerial Implications of the Learning Organization: A New Tool for Internal Marketing, "Journal of Services Marketing", 1995 vol. 9, nr 4, s. 43 za: Kozielski R. (red.), Wskaźniki marketingowe, Oficyna a Wolters Kluwer business, Warszawa 2011, wyd. IV zmienione, s. 27.

${ }^{86}$ Lucas R.E., On the Mechanics of Economic Development, "Journal of Monetary Economics", $1988 \mathrm{nr} 1$.

${ }^{87}$ Drucker P.F., Post - Capitalist Society, Harper Collins, Nowy Jork, 1993.

${ }^{88}$ Dunning J.H., Towards a New Paradigm of Development: Implications for Determinants of International Business, "Transnational Corporations", $2006 \mathrm{nr} 1$.

${ }^{19}$ Kasperkiewicz W., Procesy ... op. cit., s. 23.

${ }^{90}$ Kirzner I.M., Konkurencja ... op. cit., s. 70.

${ }^{91}$ Noga A., Teorie ... op. cit., s. 94 i nast. 
swoją działalność przy wykorzystaniu modeli współpracy (z lekarzami dentystami innych specjalności czy technikami dentystycznymi), pozwalając na to, aby wiedza „rozlewała się” (knowledge spillover);

- wiedza kierownicza (Marshallowski czynnik wytwórczy zarządzania) - profesjonalne zarządzanie istotnie rozwija wiedzę przedsiębiorczą, dzięki której powstało i funkcjonuje przedsiębiorstwo;

- wiedza skodyfikowana - może być sposobem na zwiększanie wiedzy w przedsiębiorstwie przez np. nowoczesne systemy informatyczne (umożliwiające gromadzenie i przechowywanie opisu przeprowadzonych zabiegów u pacjentów, zdjęć RTG, wirtualnych modeli ortodontycznych itp.);

- wiedza szczegółowa ${ }^{92}$, którą zdobywa się poza kodyfikacją w wyniku doświadczenia, ciągłego napotykania w biznesie i rozwiązywania wielu nietypowych problemów (np. przy podpisywaniu kontraktu z NFZ); dotyczy bardzo specyficznych, praktycznych problemów danego podmiotu (np. postępowanie z pacjentem roszczeniowym); kształtuje wiedzę indywidualną ludzi zatrudnionych w podmiocie;

- wiedza zespołowa obejmuje synergicznie zintegrowaną wiedzę członków zespołu, a system wiedzy zespołowej tworzy wiedzę ukrytą podmiotu; jak twierdzi A. Pałacki: „Można mieć pracowników w firmie o dużej wiedzy indywidualnej i mały efekt synergii w postaci addytywnej wiedzy zespołowej, można mieć zespół o mniejszej wiedzy indywidualnej pracowników i duży efekt synergii $w$ postaci multiplikacyjnej. To duża sztuka organizacyjno-menedżerska tworzenia zespołów ludzkich, w których zachodziłby silny efekt synergiczny połączenia wiedzy indywidualnej w wiedzę zorganizowaną (teamową).",93

Zdaniem I.M. Kirzner ,przedsiębiorcza wiedza może być określona, jako 'najwyższy poziom wiedzy', wiedza ostateczna, potrzebna do wykorzystania informacji już posiadanej (albo możliwej do odkrycia). ${ }^{, 4} \mathrm{Z}$ tego względu podmioty, które chcą funkcjonować na rynku powinny skupić się na jej pozyskiwaniu i rozwijaniu, gdyż stała się ona zasobem organizacyjnym ${ }^{95}$, decydującym

\footnotetext{
${ }^{92}$ Jensen M., Meckling W., Theory of the Firm: Managerial Behavior, Agency Costs, and Capital Structure, "Journal of Financial Economics", $1976 \mathrm{nr} 3$.

${ }_{93}$ Pałącki A., Zespotowe centra motywacji i kompetencji jako sposób kreowania $i$ alokowania wiedzy $w$ przedsiębiorstwie, praca doktorska niepublikowana, AF, Warszawa 2004 za: Noga A., Teorie ... op. cit.

${ }^{94}$ Kirzner I.M., Konkurencja ... op. cit., s. 71.

${ }^{95}$ Za budowę architektury wiedzy organizacyjnej - wg S.Tama - odpowiadają następujące typy wiedzy: 1) ,wiedzieć - kiedy” (know - when), prawidłowa ocena odpowiedniego czasu realizacji zamierzeń np. kiedy najlepiej sprzedawać, wprowadzać zmiany, 2) „wiedzieć - który(e)” (know - which), znajomość własnych mocnych i słabych stron i wiedza na które funkcje organizacji zwrócić szczególną uwagę, 3) ,znać relacje” (know - between), to wiedzieć jakie są zależności pomiędzy poszcze-
} 
o przetrwaniu organizacji tak jak ziemia, kapitał finansowy czy praca ludzka. Powinny stać się organizacjami uczącymi się (w rozumieniu definicji zaproponowanej przez D. Urlicha i S. Nason: „organizacje uczące się posiadają umiejętność dynamicznej adaptacji do zmian zachodzących w otoczeniu, potrafią kreować i w odpowiedni sposób dopasowywać do systemu zarządzania organizacją nowe narzędzia i mechanizmy" ${ }^{96}$ ). Dlatego warunkiem funkcjonowania gabinetu, jako organizacji uczącej się, jest umiejętność pozyskiwania wartościowych informacji od pacjentów (np. o ich pozamedycznych oczekiwaniach dotyczących jakości usługi), właściwego ich analizowania i interpretowania oraz optymalnego wykorzystywania dla poprawy funkcjonowania gabinetu (i w konsek- wencji poprawy jego pozycji konkurencyjnej). Warto w tym miejscu zauważyć, iż niektórzy badacze ${ }^{97}$ twierdzą, że istotę działalności marketingowej lepiej wyraża idea „organizacji uczącej się”, niż klasyczne teorie i definicje marketingu ${ }^{98}$. I biorąc pod uwagę fakt, że oczekiwania nabywców ewoluują, zmienia się liczba innych gabinetów w pobliżu, to oczywiste jest, że prorynkowe działania gabinetu powinny podążać za tymi zmianami lub nawet je wyprzedzać (wówczas dentysta, jako prekursor rynkowy, stawałby się Schumpeterowskim przedsiębiorca). Uczenie się organizacji - wg D. Pitta i F. Franza$\mathrm{ka}$ - może obejmować dwa typy zachowań organizacyjnych ${ }^{99}$ :

- uczenie adaptacyjne - to zachowania defensywne, polegające na dostosowywaniu się organizacji w celu pozyskania klientów i obrony swojej pozycji przed konkurentami;

- uczenie kreatywne - to zachowania ofensywne (proaktywne), związane z sytuacją, gdy organizacja wykracza poza zdefiniowane założenia co do rynku, czy konkurencji i podejmuje próbę kwestionowania dotychczaso-

gólnymi funkcjami organizacji czy rynkami, na których ona działa, 4), ,wiedzieć - gdzie” (know where), to znać potencjalne rynki zbytu, źródła pozyskiwania czynników wytwórczych.

Ponadto w literaturze wymienia się kategorie: 5) „,wiedzieć - czy” (know - whether), np. czy kontynuować badania nad technologiami o potencjalnie niebezpiecznych skutkach ubocznych, 6) „,wiedzieć - czy i jeśli” (know - if), np. czy zwalniać badaczy w przypadku zaprzestania badań, a jeśli zwalniać, to na jakich warunkach.

Por. Dziuba D.T., Sektor informacyjny w badaniach ekonomicznych, Difin, Warszawa 2010, s. 56.

${ }^{96}$ Urlich D., Nason S., Learning Capability, Oxford Press, Nowy Jork 1998.

${ }^{97}$ Cunnington B., The Marketing Learning Identity, "Journal of Customer Marketing”, 1996, nr 5.

98 Autorka dostrzega konieczność uczenia się przez wszystkich członków gabinetu, jako procesu wpływającego na możliwość lepszego zaspokajania potrzeb nabywców (zarówno w obszarze stricte medycznym, jak i związanym z pozamedycznymi czynnikami realizacji świadczeń zdrowotnych), stąd wynika zasygnalizowanie tego zjawiska w pracy. $\mathrm{W}$ dalszej części opracowania zostanie przedstawiony aspekt marketingu relacji z uwzględnieniem jego elastycznego charakteru, a więc w perspektywie nieodzowności identyfikowania zmian rynkowych i odpowiadania na nie (gabinet podejmuje i modyfikuje działania pozwalające na budowanie i utrzymywanie relacji z pacjentami).

${ }^{99}$ Pitta D., Franzak F., Boundary Spinning Product Development in Consumer Markets - Learning Organization Insight, "Journal of Consumer Marketing", 1996 nr 5. 
wych zasad czy fundamentów swojego funkcjonowania. Wychodzenie poza przyjęte standardy, normy czy procesy, sprawia, że możliwe staje się odkrywanie nowych możliwości rynkowych, co przyczynia się do konieczności zarządzania wiedzą w organizacji.

W latach 90. XX w. powstało nowe spojrzenie na zarządzanie wiedzą $\mathrm{w}$ przedsiębiorstwie ( $\mathrm{w}$ tabeli 31 przedstawione są wybrane definicje pojęcia „zarządzanie wiedzą "100), wskazano jej strategiczny potencjał - wg I. Nonaki: „Jedynym pewnym źródłem przewag konkurencyjnych jest wiedza. Kiedy zmieniają się rynki, eksplodują nowe technologie, mnożą się konkurenci, a produkty starzeją się prawie w ciągu nocy; przedsiębiorstwami, mającymi sukcesy, są te, które konsekwentnie tworzą nową wiedzę, rozpowszechniają ją szeroko w całej organizacji i szybko przekształcają w nowe technologie i produkty. Takie działania określa się jako 'przedsiębiorstwo kreowane przez wiedzę', którego jedynym biznesem są systematyczne innowacje". ${ }^{101}$ Źródłem innowacji, pochodzącej bezpośrednio od pracowników jest ich fachowa wiedza, specjalistyczne umiejętności, które wykorzystywane w praktyce organizacyjnej, przekładają się na rozwój podmiotu. Obok wiedzy stricte zawodowej, istotna jest też ta związana z prowadzeniem gabinetu, jako podmiotu zarobkującego, a także umiejętności interpersonalne (np. związane $\mathrm{z}$ rozwiązywaniem problemów), umiejętność reagowania na zmiany, czy efektywnego działania zawodowego w kontakcie ze światem społecznym. Szerokie przygotowanie pracowników może przyczynić się do tworzenia warunków sprzyjających kreatywności i przedsiębiorczości, stając się tym samym ważnym składnikiem konkurencyjności przedsiębiorstwa.

\footnotetext{
${ }^{100} \mathrm{~W}$ literaturze przedmiotu można znaleźć również głosy mówiące o tym, iż trudno (czy raczej nie można) pogodzić ze sobą science i management. Science nie poddaje się żadnym obróbkom administracyjnym, prawnym, technicznym, przecież - co oczywiste - trudno mówić o zarządzaniu kwantową teorią grawitacji. Dlatego - wg M. Morawskiego - pojęcie „zarządzanie wiedzą” jest raczej tworem językowym, czy może skrótem myślowym (mającym pokazać rangę świadomego zaplanowanego, kontrolowanego - wykorzystywania wiedzy w przedsiębiorstwie), niż określeniem konkretnego procesu zachodzącego w przedsiębiorstwie. I właśnie, jako pewien skrót myślowy, oddaje ideę modelu przedsiębiorstwa zorientowanego na wiedzę. Idea ta wyraża się w całościowym spojrzeniu na istotę przedsiębiorstwa nowego typu, które musi mieć wbudowane mechanizmy funkcjonowania w turbulentnym otoczeniu (gdzie występuje presja konkurencyjna i związana z nią nietrwałość przewagi strategicznej). por. Czerny J., Paradygmaty wspótczesnej filozofii nauki, Intermedia, Katowice 2005; Kobyłko G., Morawski M. (red.), Przedsiębiorstwo zorientowane na wiedze, Difin, Warszawa 2006; Morawski M., Zarzadzanie profesjonalistami, PWE, Warszawa 2009, s. 30.

${ }^{101}$ Kukliński A., Pawłowski K., Woźniak J., Kreatywna i innowacyjna Europa wobec wyzwań XXI wieku, Urząd Marszałkowski Województwa Małopolskiego Departament Polityki Regionalnej, s.81.
} 
Tabela 31. Pojęcie ,zarządzanie wiedzą" w świetle wybranych pozycji literatury przedmiotu

\begin{tabular}{|l|l|}
\hline \multicolumn{1}{|c|}{ Autor } & \multicolumn{1}{|c|}{ Proponowana definicja } \\
\hline T. Stewart $^{\mathrm{a}}$ & $\begin{array}{l}\text { Zarządzanie wiedzą to posiadanie wiedzy, zdobywanie i organizowanie jej oraz } \\
\text { wykorzystywanie w sposób przynoszący określone korzyści. }\end{array}$ \\
\hline Definicja IBM $^{\mathrm{b}}$ & $\begin{array}{l}\text { Zarządzanie wiedzą to ,sposoby i środki za pomocą jakich firma używa zasobów } \\
\text { wiedzy dla generowania wartości ekonomicznej”.' }\end{array}$ \\
\hline A.J. Fazlagić & $\begin{array}{l}\text { Zarządzanie wiedzą to ,celowy proces, w którym wiedza, umiejętności, fachowe } \\
\text { doświadczenie oraz komunikacja zostają poddane systematycznemu } \\
\text { administrowaniu. Celem zarządzania wiedzą jest mądre podejmowanie decyzji } \\
\text { i ich realizacja - ważna jest etyka pracy i wspólnie wyznaczony zestaw wartości.” }\end{array}$ \\
\hline $\begin{array}{l}\text { H. Davenport, } \\
\text { L. Prusak }\end{array}$ & $\begin{array}{l}\text { Zarządzanie wiedzą to ogół procesów: tworzenie wiedzy, kodyfikacja wiedzy } \\
\text { (nadanie wiedzy odpowiedniej formy) i transfer wiedzy (w tym: transmisja } \\
\text { i absorpcja wiedzy) umożliwiających osiaggnięcie celów organizacji. }\end{array}$ \\
\hline E. Skrzypek & $\begin{array}{l}\text { Zarządzanie wiedzą odpowiedzialne jest za modyfikację wiedzy, w tym za } \\
\text { kompetencje pracowników, które obejmują ogół wiedzy, umiejętności, } \\
\text { doświadczenia, postaw, a więc także gotowość do działania i zdolność do } \\
\text { przystosowania się do zmieniających się warunków. }\end{array}$ \\
\hline
\end{tabular}

Źródło: opracowanie własne na podstawie: ${ }^{a}$ Stewart T., The Wealth of Knowledge, Intellectual Capital and the Twenty-First Century Organization, Nicholas Brealey Publishing, Londyn 2001, s. 112; ${ }^{b}$ Definicja IBM, Are you to speed on knowledge management, HR Focus, 2000, vol. 77 s. 5; ${ }^{c}$ Fazlagić A.J., Zarzadzanie wiedza, Wyd. Millenium, Gniezno 2006, s. 56; ' ${ }^{\mathrm{d}}$ Malewska K., Zastosowanie koncepcji podejścia zasobowego w praktyce zarzq̨dzania strategicznego, w: Kruk H., Skrzeszewska K. (red.), Europejskie wymiary przedsiębiorczości, Akademia Morska, Gdynia 2008, s. 84 i nast.; ${ }^{\mathrm{e}}$ Skrzypek E., Jakość i efektywność, Wyd. UMCS, Lublin 2002.

Definicje w tabeli 31 (obejmujące nieco odmienne szczegółowe obszary zainteresowania) ukazują, że trudno jest stworzyć jedną i ścisłą definicję zarządzania wiedzą. Niemniej jednak można przyjąć, że zarządzanie wiedzą to proces, w którym działania są ukierunkowane na: pozyskiwanie wiedzy z otoczenia, korzystanie $\mathrm{z}$ wiedzy w organizacji, rozwój i utrzymanie dotychczas zdobytych aktywów wiedzy i w końcu jej sprzedaż w formie nowych produktów i usług oraz nowego sposobu obsługi klienta.

W organizacjach uczących się zwraca się uwagę na to, że skuteczne zarządzanie wiedzą ma miejsce tylko wtedy, gdy przedsiębiorstwo potrafi wydobyć wiedzę od swoich pracowników (można to uzyskać np. poprzez zapewnienie im należytych warunków pracy). Pracownicy bowiem są najcenniejszym zasobem w firmie, dzięki ich fachowej wiedzy można osiągnąć przewagę konkurencyjną oraz szybszy wzrost wartości przedsiębiorstwa. Decydenci w przedsiębiorstwach zaczynają to dostrzegać i zastanawiają się, jak udostępniać zdobytą wiedzę pracownikom, a także w jaki sposób zatrzymać wiedzę w przypadku, gdy pracownik przestaje pracować w danym podmiocie (wiedza „odchodzi” często do konkurencyjnego podmiotu).

W koncepcji zarządzania wiedzą ścierają się dwie szkoły myślenia:

- jedną $\mathrm{z}$ nich reprezentuje G. Kelly (The Psychology of Personal Constructs), który mówi, że "Dyrektorem szpitala powinien być medyk. 
Dowódcą armii powinien być wojskowy. Przełożonym księży powinien być duchowny. Szefem przedsiębiorstwa powinien być ekonom."1

- drugą - L. Porter (A study of personal satisfaction), który stwierdza, że „Liderem dowolnej firmy może być każda osoba, mająca kompetencje menedżerskie, i nie ma to związku z profesją, branżą, itp.",103

Ze względu na fakt, że znaczna część prywatnych gabinetów, to podmioty o niewielkiej liczbie zatrudnionych (lub wręcz tylko formy samozatrudnienia dentystów) w praktyce dominuje pierwsze podejście - decydentem w gabinecie stomatologicznym jest dentysta. Jednak należy mieć na uwadze również istnienie dużych klinik, czy sieci gabinetów, w których decydentami są już najczęściej osoby nie będące stomatologami (tak więc zarządzanie w gabinetach może być koordynowane nie tylko przez lekarzy). W omawianej sytuacji widać zjawisko tzw. podwójnej blokady, która polega na tym, że gabinetem zarządza lekarz dentysta bez odpowiedniej wiedzy menedżerskiej, albo „kontraktowy” menedżer bez odpowiedniej wiedzy stomatologicznej. Pokazuje ono znaczenie kompleksowej wiedzy (obejmującej zarówno obszar medyczny, jak i biznesowy) dla lepszego funkcjonowania gabinetu. I staje się jednym z powodów rosnącego zainteresowania lekarzy szkoleniami, studiami podyplomowymi z zakresu - szeroko pojętego - ekonomicznego funkcjonowania podmiotów opieki zdrowotnej.

W warunkach coraz szybszych zmian techniczno-technologicznych zdolność przystosowania się każdej organizacji jest funkcją posiadanej wiedzy o klientach, konkurentach, dostawcach, partnerach biznesowych. Umiejętne pozyskanie, przetworzenie, transferowanie i wykorzystywanie zasobów wiedzy nie może być pozostawione przypadkowym, nieskoordynowanym i jednostkowym inicjatywom różnych pracowników. Lekarz dentysta staje się odpowiedzialny za kompleksowe podejście do wiedzy (obejmującej medyczne i ekonomiczne aspekty funkcjonowania gabinetu), aby stała się ona Kirznerowską wiedzą przedsiębiorczą.

\subsubsection{DENTYSTA JAKO PRACOWNIK WIEDZY}

Twórcą koncepcji pracownika nowego typu (knowledge worker) jest P.F. Drucker, który stworzył terminy: „wykwalifikowanej pracy” (pracy z wiedzą) i ,wykwalifikowanego pracownika” (pracownika wiedzy; wykształconego fachowca świadczącego usługi, najczęściej profesjonalne, na własny rachunek $)^{104}$. Twierdził również, że wykwalifikowani pracownicy, to wy-

\footnotetext{
${ }^{102}$ Kelly H.R., Knowledge and practice in firms, Dawidson, Dallas 2000, s. 93.

${ }^{103}$ Porter L., Leadership in economy and firms, Social-Library, Nowy Jork 2002, s. 99.

104 Drucker P.F., Społeczeństwo prokapitalistyczne, Wydawnictwo Naukowe PWN, Warszawa 1999, s. 13.
} 
kształceni praktycy, potrafiący wykorzystać wiedzę do celów prowadzonej działalności (stosujący wiedzę do pracy), którzy pracują ,i rękami”, i korzystają $\mathrm{z}$ wiedzy teoretycznej (wymaga się od nich zarówno konkretnych umiejętności, jak i merytorycznego przygotowania). „W przeciwieństwie do siły roboczej z 'czasów kapitalizmu' wykwalifikowani pracownicy posiadają zarówno środki produkcji, jak i narzędzia produkcji. Te pierwsze poprzez przynależność do funduszy emerytalnych, te drugie jako wykwalifikowani pracownicy, ponieważ są właścicielami swej wiedzy i mogą ją zabrać ze sobą, gdzie chcą."

Pracownicy wykorzystują swój umysł do tworzenia nowej wartości poprzez nowe idee i projekty, dokonują interpretacji i wykorzystują informacje, by tworzyć i dostarczać nową wartość tak dla organizacji, jak i dla klienta. E. Skrzypek zwraca uwagę, iż poziom motywacji do pracy pracowników zależy od tego, jak ich wiedza jest wykorzystywana, a sukcesy nagradzane. Ponadto pracownicy wiedzy mają unikatowe doświadczenie, są przedsiębiorczy, kreatywni i posiadają dużą zdolność dostosowywania się do zmian, preferują pracę $\mathrm{w}$ zaspo$\mathfrak{ł a c h}^{106}$. M. Morawski twierdzi, że pracownik wiedzy:

- „wie, to znaczy ma kwalifikacje intelektualne w sensie ogólnym i odpowiednie przygotowanie teoretyczne w swoimi przedmiocie działania; oprócz przygotowania $\mathrm{w}$ zakresie profesjonalnej wiedzy dziedzinowej, posiada również ugruntowaną wiedzę z dziedzin pokrewnych (...);

- umie, czyli ma wieloletnie doświadczenie w praktycznym zastosowaniu swojej wiedzy; potrafi zastosować właściwe metody i techniki we właściwych sytuacjach, znając potencjalne korzyści i zagrożenia ich zastosowania, rodzaje ewentualnych barier, procedury implementacji, sposoby weryfikacji efektów działania; jego umiejętności $\mathrm{z}$ latami stają się nawykami dobrej pracy, a wybór odpowiedniej metody ma charakter tyle intuicyjny, ile racjonalny;

- umie być, czyli ma umiejętności interpersonalne, przede wszystkim związane $\mathrm{z}$ pracą twórczą $\mathrm{w}$ zespole specjalistów; potrafi w zespole pełnić rolę wykonawcy i lidera, nawiązując bezpośrednią komunikację, elastycznie reagując na zmiany czy asertywnie negocjując sporne kwestie; ma wysoki poziom inteligencji emocjonalnej;

- chce, to znaczy jest twórczo umotywowany, reaguje pozytywnie na bodźce rozwijające jego potencjał, musi mieć świadomość wagi realizowanej misji; jest zorientowany na sukces w różnych jego postaciach;

\footnotetext{
${ }^{105}$ Ibidem s. 14.

${ }^{106}$ Skrzypek E., Kreatywność pracowników wiedzy i ich wptyw na innowacyjność przedsiębiorstw, w: Okoń-Horodyńska E., Wisła R. (red.) Kapitat intelektualny i jego ochrona, Instytut Wiedzy i Innowacji, Warszawa 2009, s. 207 i nast.
} 
- może, w dużej części sam organizuje swoje miejsce pracy, tworząc niezbędne warunki techniczne, materialne czy przestrzenne.” 107

Przyglądając się powyższym cechom pracownika wiedzy, nietrudno odnaleźć w tym opisie sylwetkę lekarza dentysty, który:

- wie - dysponuje wiedzą dziedzinową (potwierdzoną zdanym egzaminem państwowym),

- umie - potrafi zastosować odpowiednią procedurę leczniczą do potrzeb konkretnego pacjenta,

- umie być - posiada umiejętności interpersonalne (z przeprowadzonych badań wynika, że lekarze dentyści oceniają zdecydowanie wyżej swoje umiejętności w tym zakresie na płaszczyźnie lekarz - pacjent, niż lekarz - personel pomocniczy),

- chce - ma wewnętrzną motywację do rozwoju zawodowego oraz podnoszenia kwalifikacji niemedycznych (por. tabele 8, 10, 32, 85),

- może - większość polskich stomatologów (wykonujących zawód) samodzielnie - poprzez rozpoczęcie działalności we własnym gabinecie - organizuje swoje miejsca pracy.

Warto podkreślić, że część z wymienionych czynników nie jest związana z wiedzą stricte medyczną, z tego względu dentysta prowadzący gabinet na własny rachunek powinien być otwarty na pozyskiwanie wiedzy $\mathrm{z}$ obszaru biznesowego funkcjonowania gabinetu (np. z zakresu marketingu relacji).

Zarysowana powyżej koncepcja pracownika wiedzy wpisuje się w szerszą problematykę - kapitału intelektualnego (intellectual capital), stanowiącego stosunkowo nową kategorię w teorii ekonomii oraz teorii zarządzania ${ }^{108}$. W ostatnich dekadach kapitał intelektualny (mający źródło w wiedzy i zasobach niematerialnych podmiotu) zaczyna odgrywać coraz większą rolę w procesach tworzenia i wzrostu wartości rynkowej przedsiębiorstw; stając się głównym źródłem kreowania przewagi konkurencyjnej ${ }^{109}$.

\footnotetext{
${ }^{107}$ Morawski M., Zarzadzanie profesjonalistami, PWE, Warszawa 2009, s. 45 i nast.

${ }^{108}$ Problematyka ta została spopularyzowana w literaturze ekonomicznej i zarządczej w latach 90. XX w. Genezy pojęcia należy upatrywać w rachunkowości zarządczej w obszarze wyceny zasobów niematerialnych (których udział w całkowitej wartości przedsiębiorstwa znacząco wzrósł w warunkach współczesnej gospodarki).

${ }^{109}$ Brooking A., Intellectual Capital, Core Basset for the Third Millenium Enterprise, International Thomson Business Press, Londyn 1988, s. 12; Stewart T., The Wealth ... op. cit., s. 12 i nast.
} 
Kapitał intelektualny - wg L. Edvinssona i M.S. Malone'a - można podzielić na ${ }^{110}$ :

- kapitał ludzki ${ }^{111}$, obejmujący wiedzę, umiejętności, doświadczenia i zdolności pracowników; kapitał ten obniża się wraz z odejściem zatrudnionych z przedsiębiorstwa, co może powodować negatywne zmiany w zajmowanej przez przedsiębiorstwo pozycji konkurencyjnej ${ }^{112}$ (w klinice zatrudniającej kilku dentystów może to być dobrze widoczne - dentysta, który odchodzi z pracy ,zabierając” ze sobą znaczną część „,swoich” pacjentów, sprawia, że liczba nabywców świadczeń zdrowotnych w klinice maleje); pozyskanie nowego tego typu kapitału wiedzy wymaga kolejnych nakładów, co również nie sprzyja kreowaniu wartości podmiotu gospodarczego, tym bardziej, że w przypadku, gdy nowo pozyskany dentysta nie praktykuje jeszcze zbyt długo lub gdy jest to jego pierwsza praca, to praktycznie pozyskiwanie nowych pacjentów rozpoczyna „od zera” (co będzie czasochłonnym zajęciem) i powrót „do wartości przychodów” sprzed odejścia poprzedniego dentysty może się znacznie przesunąć w czasie;

- kapitał strukturalny, obejmujący:

- kapitał kliencki ${ }^{113}$ (relacyjny), który wymaga dbałości o jakość usług, utrzymywania standardów, dobrych relacji z usługobiorcami i pracownikami i właściwej z nimi komunikacji (co pozwala uwiarygodnić ofertę, minimalizować niepewność klienta i budować jego satysfakcję); buduje wartość dla klienta, a tym samym wpływa na wartość podmiotu; obejmuje wiedzę przedsiębiorstwa pozyskaną z powiązań z podmiotami zewnętrznymi (klientami, dostawcami, partnerami handlowymi itp.); składa się z tych części kapitału ludzkiego i strukturalnego, które są powiązane $\mathrm{z}$ grupami interesu (stakeholders); przykłady to: marka, wizerunek firmy, lojalność klientów, satysfakcja klientów, powiązania $\mathrm{z}$ dostawcami, siła handlowa, zdolności negocjacyjne, działania na rzecz środowiska; im więcej relacji nawiąże podmiot i je utrzyma, tym większa będzie jego wartość rynkowa ${ }^{114}$;

${ }^{110}$ Edvinsson L., Malone M.S., Kapitat intelektualny, Wydawnictwo Naukowe PWN, Warszawa 2001, s. 45.

${ }^{111}$ Trudno jednoznacznie rozdzielić kapitał ludzki od kapitału relacyjnego - jakość obu składników kapitału intelektualnego wpływa na kształtowania wartości dla usługobiorcy. W podnoszeniu jakości obu członów kapitału intelektualnego ważny jest zestaw umiejętności i kompetencji pracowników, związanych z identyfikacją potrzeb klienta, elastycznym dostosowywaniem się do poziomu intelektualnego i preferencji partnera, profesjonalnym podejściem do obsługi, empatią oraz przestrzeganiem etycznych standardów.

${ }^{112}$ Urbanek G., Wycena aktywów niematerialnych przedsiębiorstwa, PWE, Warszawa 2008, s. 40 i nast.

113 W literaturze można znaleźć odniesienia do pośredniego wpływu połączonych kapitałów relacyjnego i społecznego (wynikającego z uczestnictwa w sieciach powiązań i relacji), na wyniki finansowe przedsiębiorstw por. Krause D.R., Handfield R.B., Tyler B.B., The Relationships ... op. cit. ${ }^{114}$ Urbanek G., Wycena ... op. cit., s. 40 i nast. 
- kapitał organizacyjny - jest złożony z - omówionego na początku rozdziału - kapitału innowacyjnego oraz kapitału procesów wzmacniających efektywność wytwarzania lub dostawy usług.

Nie ulega wątpliwości, że stomatolog kształtuje kapitał intelektualny gabinetu: dokształca się, dba o podnoszenie kompetencji pracowników (por. tabela 32), wdraża nowe rozwiązania, kształtuje relacje z otoczeniem (por. wyniki badań w tym i następnym rozdziale) i nawet jeśli robi to wyłącznie intuicyjnie, to wpływa w ten sposób na sukces rynkowy swojego przedsięwzięcia biznesowego - zwiększając satysfakcję klientów i poprawiając pozycję konkurencyjną swojego gabinetu.

\subsection{WIEDZA W GABINECIE - W ŚWIETLE BADAŃ}

Jedno z kluczowych założeń organizacji uczącej się odnosi się do samopoznania pracowników (por. punkt 1.2.2 w II rozdziale). W przeszłości kierunek kariery pracowników wyznaczała i określała organizacja (w niektórych przedsiębiorstwach nadal tak się dzieje), a dziś i w przyszłości pracownik sam będzie ponosił odpowiedzialność za własny rozwój. P.F. Drucker twierdzi, że należy nauczyć się rozwijać samego siebie, określając w jakiej sferze można wnieść największe korzyści do organizacji, w której się pracuje. Uważa, że niewielu menedżerów ma świadomość, w jaki sposób mogą wykorzystywać przewagę, wynikającą z własnych silnych stron; dlatego też zaleca, aby koncentrowali się na doskonaleniu posiadanych umiejętności i angażowali się $\mathrm{w}$ realizację tych zadań, które najbardziej odpowiadają ich indywidualnym metodom pracy. Kiedy menedżer uświadomi sobie swoją unikatową przewagę i podstawowe wartości, wówczas będzie zdolny do identyfikacji szans, pojawiających się w otoczeniu ${ }^{115}$.

Podobny mechanizm można zauważyć w gabinecie stomatologicznym - lekarze podnoszą swoje kwalifikacje medyczne, dążąc do coraz lepszej technicznej jakości oferowanych usług. Jako osoby zarządzające gabinetem stomatologicznym, powinni również dążyć do zwiększania kwalifikacji w niemedycznych obszarach funkcjonowania gabinetu (jako zarobkującego podmiotu rynkowego). Zidentyfikowane w pracy (por. punkt 3.3. w II rozdziale) mocne i słabe strony dentystów oraz studentów kierunku lekarsko-dentystycznego w obszarze umiejętności interpersonalnych i intrapersonalnych mogą stanowić wskazówkę co do kierunku doskonalenia posiadanych umiejętności (zarówno w celu ich wzmocnienia np. utrzymania dobrych relacji z pacjentami, jak i pozyskania np. radzenia sobie w sytuacjach kryzysowych), aby zwiększyć również poziom jakości usług w wymiarze personalnym i organizacyjnym.

\footnotetext{
${ }^{115}$ Drucker P.F., Managing Oneself, „Harvard Business School Publishing”, 1999.
} 
Z badania I wynika, że w gabinetach ze szkoleń korzystają przede wszystkim lekarze (por tabela 32). Podnoszą oni swoje kwalifikacje w obszarze stricte zawodowym $^{116}$.

Biorąc pod uwagę aspekt zdobywania wiedzy o szerokim zakresie dzięki szkoleniom, na uwagę zasługuje fakt, że blisko 1/4 lekarzy podnosi swoje kwalifikacje również w zakresie pozamedycznych obszarów funkcjonowania gabinetu. Ze szkoleń ,niemedycznych” personel pomocniczy korzysta w mniejszym zakresie niż lekarze - 14,11\%. Zdecydowanie większa dysproporcja w podnoszeniu kwalifikacji między lekarzami a personelem pomocniczym dotyczy szkoleń stricte medycznych - tylko $27,61 \%$ personelu podnosi swoje kwalifikacje. Respondenci usprawiedliwiali ten stan najczęściej faktem, że sami uczą personel potrzebnych rzeczy, bądź - nieco rzadziej - stosunkowo niedawno ukończoną szkołą przez asystentkę stomatologiczną. Szkolenia są formą inwestycji w pracowników, swoistym ,,papierkiem lakmusowym” myślenia o rozwoju kapitału intelektualnego gabinetu - jego wskazania w odniesieniu do lekarzy dentystów są budujące, ale w stosunku do personelu pomocniczego widać wyraźny deficyt w tym zakresie ${ }^{117}$.

Tabela 32. Udział w szkoleniach personelu w badanych gabinetach stomatologicznych

\begin{tabular}{|l|c|}
\hline \multicolumn{1}{|c|}{ Szkoleniami w gabinecie objęci są } & Wskazania (\%)* \\
\hline dentysta - szkolenia z zakresu stricte medycznego & 98,16 \\
\hline dentysta - z szkolenia z zakresu biznesu & 23,93 \\
\hline personel - ze stricte medycznego & 27,61 \\
\hline personel - z zakresu umiejętności interpersonalnych & 14,11 \\
\hline Inne & 0,61 \\
\hline
\end{tabular}

Źródło: opracowanie własne na podstawie przeprowadzonego badania.

* odpowiedzi nie sumują się do $100 \%$, ponieważ respondenci mogli zaznaczyć wszystkie odpowiedzi, które ich dotyczyły.

Wśród respondentów badania I 67,07\% zadeklarowało, że nawet gdyby nie musieli zdobywać punktów edukacyjnych, to nadal uczestniczyliby w szkoleniach, aby podnosić swoje zawodowe kwalifikacje; kolejnych 13,41\% zmniejszyłoby liczbę odbywanych szkoleń o $1 / 4$, natomiast $8,54 \%$ minimum o połowę.

\footnotetext{
${ }^{116}$ Co z jednej strony jest wyrazem dążenia do rozwoju zawodowego, a z drugiej - wynika z faktu, że lekarz w ciągu 4 lat musiał zdobyć 200 punktów edukacyjnych.

${ }^{117}$ Zbliżone wyniki uzyskano w ramach badań przeprowadzonych w 2006 r. : ponad $93 \%$ lekarzy planowało udział w kursach i szkoleniach, a $92,1 \%$ w ciągu ostatnich 24 miesięcy podejmowało działania „na własną rękę”, by podnosić kwalifikacje. Wśród pozostałego personelu medycznego $40 \%$ chciało się dokształcać, a $60 \%$ respondentów przyznało, że w ostatnich 24 miesiącach nie podejmowało żadnej inicjatywy w kierunku podnoszenia własnych kwalifikacji.

por. raport Biaty personel. Badania kwalifikacji i umiejętności pracowników w zakładach ochrony zdrowia w województwie łódzkim, WUP Łódź 2006, s. 62.
} 
Niewielka część respondentów - 2,44\% zrezygnowałaby ze szkoleń w ogóle ${ }^{118}$. Natomiast $8,54 \%$ respondentów nie potrafiło zająć stanowiska w tej sprawie. Ciekawe spojrzenie na sytuację braku konieczności zbierania punktów edukacyjnych daje podział badanej z uwzględnieniem pozycji zawodowej dentysty właściciel gabinetu vs pracownik (por. tabela 33). Blisko $70 \%$ właścicieli gabinetów nadal korzystałoby z tej samej liczby szkoleń (wśród pracowników odsetek ten wyniósł 55\%). Na zmniejszenie liczby odbywanych szkoleń minimum o połowę zdecydowałaby się $1 / 5$ badanych dentystów pracowników wobec $6 \%$ dentystów - właścicieli gabinetów.

Tabela 33. Postawy respondentów a brak formalnej konieczności podnoszenia kwalifikacji

\begin{tabular}{|l|c|c|c|}
\hline $\begin{array}{c}\text { Konsekwencje braku konieczności } \\
\text {,gromadzenia" punktów edukacyjnych }\end{array}$ & ogółem (\%) & $\begin{array}{c}\text { właściciele } \\
\text { gabinetów (\%) }\end{array}$ & $\begin{array}{c}\text { pracownicy } \\
(\mathbf{\%})\end{array}$ \\
\hline rezygnacja ze szkoleń w ogóle & 2,44 & 2,29 & 3,23 \\
\hline dalsze korzystanie z tych samych szkoleń & 67,07 & 69,47 & 54,84 \\
\hline zmniejszenie liczby odbywanych szkoleń o 1/4 & 13,41 & 14,50 & 9,68 \\
\hline $\begin{array}{l}\text { zmniejszenie liczby odbywanych szkoleń } \\
\text { minimum o 1/2 }\end{array}$ & 8,54 & 6,11 & 19,35 \\
\hline nie mam zdania & 8,54 & 7,63 & 12,90 \\
\hline
\end{tabular}

Źródło: opracowanie własne na podstawie przeprowadzonych badań.

Zdobywanie wiedzy, nowych umiejętności czy kompetencji implikuje powstanie nowego typu pracownika. Zgodnie $\mathrm{z}$ Taylorowskim homo economicus, przeważał pogląd, iż aktywność zawodowa pracownika jest determinowana przez jego chęć do maksymalizowania swoich zarobków; a dziś w literaturze z zakresu zarządzania pojawia się pojęcie homo competens, czyli jednostki, której zachowanie motywowane jest postrzeganiem własnej listy kompetencji (obejmującej np. konieczność rozwoju stricte medycznego, umiejętność radzenia sobie ze stresem, kierowanie personelem i in.), co potwierdzają również wyniki badania I i III (por. punkt 1.2.2. w II rozdziale), pokazujące, że podnoszenie kwalifikacji i rozwój zawodowy stanowią główne motywy działań stomatologów i studentów.

\subsection{WIEDZA AKADEMICKA A PROWADZENIE GABINETU}

Kształcenie studentów i lekarzy od lat zdąża w dwóch zasadniczych kierunkach ${ }^{119}$ :

- wykształcenia fachowego, zawodowego - studentom i młodym lekarzom przekazywane jest optimum wiadomości, pozwalające na rozpoczęcie pracy w zawodzie ${ }^{120}$;

\footnotetext{
${ }^{118}$ Osoby te nie uzasadniły swojego stanowiska, ale biorąc od uwagę ich długoletni staż - wszystkie pracują w zawodzie więcej niż 21 lat - może wynikać $\mathrm{z}$ wiary we własną wiedzę.

${ }^{119}$ Bogusz J., Zasady deontologiczne ... op. cit., s. 109.
} 
- wpojenia zasad etyczno-moralnych i wykształcenia poczucia odpowiedzialności (chodzi tu przede wszystkim o poczucie odpowiedzialności wobec własnego sumienia).

I choć od kilku lat w uczelniach medycznych zaczynają funkcjonować jednostki organizacyjne (katedry, zakłady) zajmujące się problematyką ekonomicznoprawnych uwarunkowań funkcjonowania podmiotów leczniczych, to ich wpływ na kształcenie przyszłych lekarzy pozostaje niewielki. Wydaje się, że z punktu widzenia osób, które będą wykonywały zawód w warunkach gospodarki wolnorynkowej, a w szczególności chciałyby wykonywać zawód w ramach prywatnych form prowadzenia działalności (indywidualnych/zbiorowych praktyk lekarskich czy spółek) jest to wiedza istotna. I hipotezę o zapotrzebowaniu na ten rodzaj wiedzy w ramach kształcenia akademickiego autorka przyjęła - w ramach przeprowadzonych badań postanowiono sprawdzić, czy w odczuciu lekarzy dentystów (obecnych i przyszłych) trzeci - biznesowy filar kształcenia jest potrzebny, czy też nie.

Respondenci w badaniu I - praktykujący lekarze dentyści, w większości prowadzący działalność na własny rachunek - zostali poproszeni o ocenę, czy studia w akademii/uniwersytecie medycznym powinny być wzbogacone o elementy biznesowe (np. zarządzanie personelem, marketing usług, efektywna komunikacja z pacjentem itp.) i ok. $80 \%$ zadeklarowało, że taka wiedza powinna być przekazywana studentom, jako element przygotowania do pracy (por. tabela 34). Tylko jedna osoba uznała, że kwestie biznesowe zdecydowanie nie powinny być przedmiotem zainteresowania na studiach stomatologicznych.

Tabela 34. Zagadnienia biznesowe a uczelnia medyczna - perspektywa lekarzy dentystów (badanie I)

\begin{tabular}{|l|c|}
\hline \multicolumn{1}{|c|}{$\begin{array}{c}\text { Odpowiedzi na pytanie: Czy zagadnienia biznesowe powinny być } \\
\text { elementem studiów stomatologicznych? }\end{array}$} & Wskazania (\%) \\
\hline tak, jest to niezbędna wiedza do funkcjonowania gabinetu na rynku & 59,81 \\
\hline tak, ale w niewielkim zakresie, bo tego można nauczyć się ,,samemu” & 20,89 \\
\hline właściwie nie, bo można się tego nauczyć, prowadząc własny gabinet & 4,67 \\
\hline $\begin{array}{l}\text { właściwie nie, taką wiedzę można pozyskać we własnym zakresie (np. } \\
\text { czytając 1-2 książki na ten temat), żeby dać sobie radę na rynku }\end{array}$ & 0,0 \\
\hline zdecydowanie nie & 0,61 \\
\hline nie mam zdania na ten temat & 14,02 \\
\hline
\end{tabular}

Źródło: opracowanie własne na podstawie przeprowadzonych badań.

Opinie studentów (wyniki badania III) co do tego, czy studia na uczelni medycznej przygotowują do prowadzenia własnego gabinetu stomatologicznego

\footnotetext{
${ }^{120}$ Wobec ogromnego zasięgu wiedzy lekarskiej i ciągłego jej przyrostu nie jest możliwe - co zrozumiałe - przekazanie maksimum wiedzy, ale - jak już zostało powiedziane - dziś wiedza to umiejętność odnajdywania źródeł potrzebnych informacji.
} 
są bardzo podzielone - ok. $40 \%$ respondentów twierdziło, że tak, a drugie tyle, że nie. Szczegółowy rozkład odpowiedzi na to pytanie przedstawia tabela 35.

Tabela 35. Zagadnienia biznesowe a uczelnia medyczna - pespektywa studentów kierunku lekarsko-dentystycznego (badanie III)

\begin{tabular}{|l|c|}
\hline $\begin{array}{c}\text { Odpowiedzi na pytanie: Czy uczelnia medyczna przygotowuje do } \\
\text { prowadzenia prywatnego gabinetu stomatologicznego? }\end{array}$ & Wskazania (\%) \\
\hline na pewno tak & 6,25 \\
\hline raczej tak & 35,42 \\
\hline raczej nie & 30,21 \\
\hline na pewno nie & 9,38 \\
\hline nie mam zdania & 16,67 \\
\hline inne & 1,04 \\
\hline
\end{tabular}

Źródło: Opracowanie własne na podstawie przeprowadzonego badania.

Wśród powodów, dla których uczelnie medyczne nie powinny kształcić w zakresie niemedycznych obszarów funkcjonowania gabinetu, respondenci wskazywali najczęściej trzy:

- można się tego nauczyć poza uczelnia - na pewno sa kursy, na których można się wszystkiego dowiedzieć ${ }^{121}$;

- sa to zwykte sprawy, więc nie ma takiej potrzeby ${ }^{122}$;

- $w$ uczelni jest przekazywane dużo specjalistycznej wiedzy, więc nie potrzebne jest ,doktadanie” dodatkowych informacji ${ }^{123}$.

Wśród badanych praktykujących lekarzy dentystów przeważa stanowisko co do zasadności wprowadzania - szeroko pojętej - wiedzy biznesowej w mury uczelni medycznych, co pozwalałoby na pozytywną weryfikację hipotezy postawionej we wstępie pracy, mówiącej o tym, iż wśród dentystów (lekarzy i studentów) istnieje duże (powyżej 50\% badanych) zapotrzebowanie na wiedzę z zakresu biznesowego funkcjonowania gabinetów. Jednak ze względu na stanowisko studentów, wśród których tylko $40 \%$ wyraziło taką opinię, nie jest to możliwe. Biorąc pod uwagę fakt, że - uwzględniając dotychczasowe statystyki i deklaracje zgłaszane w trakcie badania III większość absolwentów kierunków lekarsko-dentystycznych będzie podejmowała (próbowała podjąć) pracę na własny rachunek, to taka zachowawcza postawa studentów może wywoływać

\footnotetext{
${ }^{121} \mathrm{~W}$ trakcie prowadzonych wywiadów żaden z ok. 30 respondentów nie potrafił wskazać przykładu kursu, na którym mógłby zdobyć - szeroko pojętą - wiedzę ekonomiczną.

${ }^{122}$ Respondenci wyjaśniali takie stanowisko przede wszystkim tym, że: 1) mieli elementarną wiedzę z zakresu przedsiębiorczości przekazywaną w szkole średniej, 2) obserwują innych i są przekonani, że nie napotkają na problemy w prowadzeniu gabinetu, 3) nie planują własnej praktyki, więc taka wiedza nie będzie im potrzebna.

${ }^{123}$ Studenci przekonywali, że mają dużo nauki stricte medycznej, na której muszą się skupić, a „prowadzenia biznesu nauczą się później.” Po zapoznaniu się z wynikami badania I, w którym praktykujący lekarze stomatolodzy zajęli stanowisko, że taka wiedza powinna być przekazywana, wszyscy studenci, z którymi były prowadzone wywiady wyrazili zdziwienie takim stanowiskiem.
} 
zdziwienie. Tym bardziej, że - jak wynika z badań F. Wilson, J. Kickul, D. Marlino ${ }^{124}$ - programy ukierunkowane na rozwój przedsiębiorczości ${ }^{125}$ mają większe pozytywne oddziaływanie na kobiety, niż na mężczyzn (co oznacza, że stymulują i rozwijają przedsiębiorczość, pewność i wiarę w siebie oraz przekonanie o przedsiębiorczych umiejętnościach w większym stopniu u kobiet niż u mężczyzn). Ponieważ większość studentów kierunków lekarsko-dentystycznych to kobiety, to gdyby na uczelniach medycznych pojawiły się programy stymulujące przedsiębiorczość, to - z przytoczonych wyników badań F. Wilson i in. - wynika, że byłyby to dobrze ukierunkowane działania. Studentki mogłyby poznać mechanizmy funkcjonowania podmiotu rynkowego, jakim jest gabinet stomatologiczny, w warunkach gospodarki wolnorynkowej i z szerszą wiedzą wkroczyć w życie zawodowe w prywatnym gabinecie stomatologicznym.

\section{FUNKCJONOWANIE GABINETÓW NA RYNKU - WYNIKI BADAŃ}

\subsection{RYNEK DZIALANIA BADANYCH GABINETÓW STOMATOLOGICZNYCH}

W tej części pracy zostaną przedstawione - oparte na wynikach przeprowadzonych badań I, III i IV - działania podejmowane przez lekarzy dentystów na rynku. Charakterystyka respondentów badania I z punktu widzenia miejsca wykonywanej działalności przedstawiona jest w tabeli 36.

Tabela 36. Wielkość miejscowości w której funkcjonuje gabinet

\begin{tabular}{|l|c|}
\hline \multicolumn{1}{|c|}{ Miejscowość o liczbie mieszkańców } & Wskazania (\%) \\
\hline większej niż 500tys. osób & 22,43 \\
\hline 200-500tys. osób & 19,05 \\
\hline 50-200 tys. osób & 22,02 \\
\hline 10-50tys. osób & 26,19 \\
\hline mniejszej niż 10tys. osób & 10,31 \\
\hline
\end{tabular}

Źródło: opracowanie własne na podstawie przeprowadzonego badania.

Przeszło połowę respondentów stanowili lekarze $\mathrm{z}$ miejscowości małych i średnich, co nie dawało im jednak uprzywilejowanej (tj. monopolistycznej)

\footnotetext{
${ }^{124}$ Wilson F., Kickul J., Marlino D., Gender, Entrepreneurial Self-Efficacy, and Entrepreneurial Career Intentions: Implications for Entrepreneurship Education, "Entrepreneurship: Theory \& Practice", 2007 t. 31, nr 3.

${ }^{125}$ F. Ferrante podkreśla, że wydatki państwa na - szeroko pojętą - edukację biznesową powinny nie tylko stymulować przedsiębiorczość, ale także podwyższać kulturę przedsiębiorczości w społeczeństwie (tj. aprobatę społeczeństwa dla działań przedsiębiorczych, zrozumienie wpływu przedsiębiorców na tworzenie dobrobytu narodowego i postępu gospodarczego, społeczną akceptację dla możliwości ponoszenia porażek i niepowodzeń). Por. Ferrante F., Revealing Entrepreneurial Talent, "Small Business Economics", 2005 t. 25, nr 2.
} 
pozycji rynkowej. Zdecydowana większość gabinetów - 97,04\% funkcjonuje w warunkach działania na rynku innych gabinetów, więc działania podejmowane przez stomatologów powinny uwzględniać istnienie konkurencji i fakt, że pacjenci - nabywcy usług mają wybór przy podejmowaniu decyzji o tym, w którym gabinecie będą się leczyć. Szczegółowo sytuację rynkową respondentów pod względem liczby podmiotów działających w pobliżu danego gabinetu stomatologicznego przedstawia tabela 37.

Tabela 37. Liczba gabinetów w pobliżu (w promieniu 5km) gabinetu respondenta

\begin{tabular}{|l|c|}
\hline \multicolumn{1}{|c|}{ Orientacyjna liczba gabinetów } & Wskazania (\%) \\
\hline Brak & 1,18 \\
\hline 1-2 gabinety & 13,02 \\
\hline 3-5 gabinetów & 18,93 \\
\hline więcej niż 5 gabinetów & 65,09 \\
\hline nie wiem & 1,78 \\
\hline
\end{tabular}

Źródło: opracowanie własne na podstawie przeprowadzonego badania.

Respondenci mają świadomość istnienia konkurencyjnych gabinetów, jednak w większości nie czują zagrożenia związanego z przechodzeniem pacjentów do konkurencyjnych gabinetów (por. tabela 38). Jedna piąta respondentów obawia się przechodzenia pacjentów do konkurencji. Rozpatrywanie tego zagadnienia z punktu widzenia płci respondentów daje ciekawe obserwacje - mężczyźnidentyści czują się pewniej na rynku (12,9\% mężczyzn wskazało, że czuje zagrożenie związane $\mathrm{z}$ istnieniem konkurencji wobec $22,73 \%$ kobiet). Ponadto nie czują oni zagrożenia związanego z odpływem pacjentów w 67,74\% przypadków (wobec 63,64\% wskazań kobiet).

Tabela 38. Obawy respondentów związane z odejściem pacjenta do konkurencyjnego gabinetu

\begin{tabular}{|l|c|}
\hline $\begin{array}{c}\text { Poczucie zagrożenia związane z przechodzeniem pacjentów do } \\
\text { konkurencyjnych gabinetów }\end{array}$ & Wskazania (\%) \\
\hline nie ma & 64,67 \\
\hline jest & 22,16 \\
\hline nie wiem/trudno powiedzieć & 14,37 \\
\hline
\end{tabular}

Źródło: opracowanie własne na podstawie przeprowadzonego badania.

Oceniając stopień zagrożenia odejścia pacjentów do konkurencyjnego gabinetu, posłużono się również czynnikiem czasu, od jakiego dentysta funkcjonuje na rynku (por. wykres 3). Najpewniej w tym względzie czują się osoby, które przynajmniej od 11 lat wykonują zawód (co jest zrozumiałe ze względu na fakt, że mają już grupę stałych i - często - lojalnych pacjentów). Natomiast osoby, które ukończyły studia w okresie krótszym niż 10 lat przed badaniem mają obawy związane z lojalnością pacjentów lub nie potrafią zająć jednoznacznego stanowiska (co również może świadczyć o braku pewności rynkowej w tym zakresie). 
Wykres 3. Poczucie zagrożenia odejściem pacjenta do innego gabinetu a czas jaki upłynął od ukończenia studiów przez respondenta

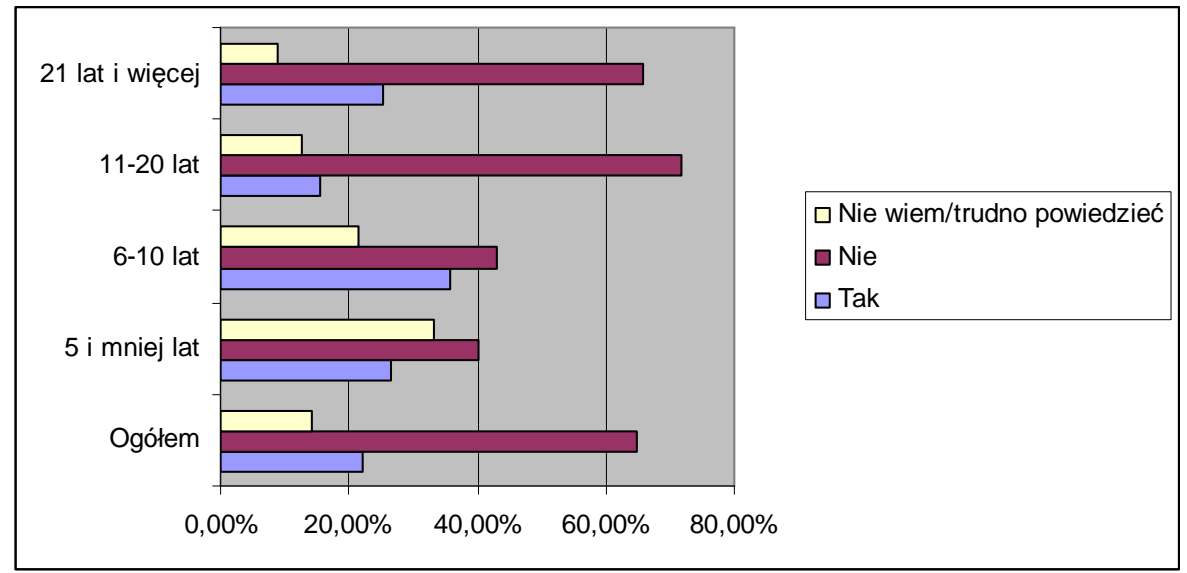

Źródło: opracowanie własne na podstawie przeprowadzonych badań.

Niepewność rynkowa jest związana $\mathrm{m}$. in. z brakiem wiedzy i umiejętności w zakresie prorynkowego funkcjonowania. Często barierą jest również brak prze-konania co do możliwości pogodzenia niektórych rynkowych inicjatyw $\mathrm{z}$ etyką lekarską - wynika on najczęściej z tego, że stomatolog nie wie, czy można je pogodzić, a nie z tego, że na pewno jest przekonany o kolidowaniu tych dwóch obszarów. Spowodowane jest to przede wszystkim brakiem wiedzy o możliwościach rynkowego oddziaływania - 32,48\% respondentów badania I zadeklarowało, że nie dysponuje wiedzą na temat możliwości wykorzystania marketingu w gabinecie, a 21,66\% - że w małym stopniu. Tylko 3,18\% badanych oceniło swoją wiedzę bardzo dobrze, a kolejnych 16,56\% - dobrze. Jeszcze słabiej wypadła samoocena z zakresu umiejętności zbierania informacji o rynku (przede wszystkim o działaniach innych gabinetów): 44,87\% respondentów nie dysponuje taką umiejętnością, kolejne $22,44 \%$ w małym stopniu, a 7,05\% badanych oceniło się na dobrze i bardzo dobrze w tym zakresie.

Większość respondentów ma pacjentów, którzy są nabywcami usług medycznych w gabinecie dłużej niż 5 lat (por. tabela 39), co z punktu widzenia marketingu należy uznać za sukces. Z drugiej strony - niemal - co piąty badany nie potrafił określić, jaki typ pacjentów dominuje w jego gabinecie, co może świadczyć o słabej znajomości pacjentów (a w konsekwencji słabej orientacji rynkowej respondenta ${ }^{126}$; trudno w takiej sytuacji rekomendować efektywne wdrażanie marketing-

\footnotetext{
${ }^{126}$ Sytuacja taka jest możliwa np. w tzw. mcdentach - gabinetach sieciowych, w których zatrudnieni dentyści obsługują pacjentów skierowanych przez recepcjonistkę właśnie do nich. Rotacja personelu z jednej strony, tzw. pacjenci bólowi z drugiej mogą się przyczynić do zaistnienia sytuacji, że dentysta „nie ma swoich pacjentów”.
} 
gu relacji). Biorąc pod uwagę fakt, że pacjenci nie lubią chodzić do dentysty ${ }^{127}$, zaskakuje niski odsetek gabinetów, w których pacjent pojawił się jedynie jednorazowo.

Tabela 39. Czas trwania relacji dentysta - pacjent

\begin{tabular}{|l|c|}
\hline Pacjenci obsługiwani w gabinecie & Wskazania (\%) \\
\hline są klientami gabinetu dłużej niż 5 lat & 57,49 \\
\hline są klientami gabinetu 3-5 lat & 13,17 \\
\hline są klientami gabinetu 1-3lata & 16,17 \\
\hline $\begin{array}{l}\text { są nabywcami świadczeń w gabinecie krócej niż rok, ale byli w gabinecie } \\
\text { chociaż 2 razy }\end{array}$ & 3,59 \\
\hline przychodzą na pojedynczą wizytę i więcej się nie pojawiają & 1,20 \\
\hline trudno powiedzieć, który typ pacjentów dominuje & 18,56 \\
\hline
\end{tabular}

Źródło: opracowanie własne na podstawie przeprowadzonego badania.

Uwzględniając rodzaj prowadzonej działalności (por. tabela 40), należy zauważyć, że badane gabinety miały zdywersyfikowaną ofertę stricte stomatologiczną. W przypadku ortodontów można mówić o wąskiej specjalizacji zajmują się tylko tym obszarem stomatologii. Swego rodzaju wyróżnik rynkowy gabinetu stanowi implantologia, gdyż stosunkowo niewielu lekarzy dentystów ją wykonuje (z racji relatywnie niedawnego pojawienia się tej metody na rynku i w konsekwencji braku umiejętności stomatologów w tym zakresie). Natomiast sprzedaż akcesoriów i medykamentów do higieny jamy ustnej stanowiła poszerzenie oferty w niewielu gabinetach.

Tabela 40. Rodzaj prowadzonej działalności w badanych gabinetach

\begin{tabular}{|l|c|}
\hline \multicolumn{1}{|c|}{ Rodzaj prowadzonej działalności } & Wskazania(\%)* \\
\hline Stomatologia estetyczna & 88,17 \\
\hline Protetyka & 96,45 \\
\hline Chirurgia stomatologiczna & 84,62 \\
\hline Stomatologia zachowawcza & 96,45 \\
\hline Endodoncja & 92,90 \\
\hline Pedodoncja & 78,11 \\
\hline Periodontologia & 50,30 \\
\hline Ortodoncja & 17,75 \\
\hline Implantologia & 26,63 \\
\hline Sprzedaży akcesoriów do higieny jamy ustnej & 10,65 \\
\hline Sprzedaży medykamentów do pielęgnacji jamy ustnej & 4,73 \\
\hline
\end{tabular}

Źródło: opracowanie własne na podstawie przeprowadzonego badania.

* Odpowiedzi nie sumują się do $100 \%$, ponieważ respondenci mogli zaznaczyć wszystkie obszary, które ich dotyczyły.

${ }^{127}$ Ponad 50\% pacjentów deklaruje, że nie lubi wizyt u stomatologa. Za: Gathel R.J., The prevalence of dental fear and avoidance expanded adult and recent adolescent surveys, "Journal American Dental Association", 1989, nr 118. Z badań własnych autorki wynika, że 25,3\% pacjentów odczuwa strach przed wizytą u stomatologa. 


\section{2. ŹRÓDŁA FINANSOWANIA DZIAŁALNOŚCI}

Od kilku lat Polacy z dochodów własnych finansują ok. 80\% wartości świadczeń stomatologicznych. Biorąc pod uwagę, że w 2013r. rynek usług stomatologicznych ma być wart ok. 13 mld zł ${ }^{128}$, daje to kwotę przeszło $10 \mathrm{mld}$ zł. Wydatki NFZ na opiekę stomatologiczną w latach 2003-2013 przedstawione są w tabeli 41. Charakterystyczne jest to, że od lat udział wydatków na świadczenia stomatologiczne w kosztach świadczeń zdrowotnych ogółem u publicznego płatnika maleje. Polak, który chce korzystać z dobrych materiałów stomatologicznych przestaje mieć jakikolwiek wybór - musi opłacać wizytę w gabinecie $\mathrm{z}$ dochodów własnych. Trudno wobec takich faktów nie nazywać funkcjonowania opieki zdrowotnej w zakresie stomatologii rynkiem. Usługa, będąca przedmiotem zawieranych transakcji ma szczególny charakter (dotycząc zdrowia i życia człowieka), ale mechanizmy związane z jej dostarczaniem mają cechy rynkowe.

Tabela 41. Udział wydatków na stomatologię w wydatkach NFZ w latach 2003-2013

\begin{tabular}{|l|l|l|l|}
\hline \multirow{2}{*}{ Rok } & \multicolumn{3}{|c|}{ Koszty świadczeń opieki zdrowotnej (w tys. zł) } \\
\cline { 2 - 4 } & Ogółem & stomatologia & \% \\
\hline 2003 & 21015737 & 722693 & 3,44 \\
\hline 2004 & 29172340 & 948078 & 3,25 \\
\hline 2005 & 32117350 & 967967 & 3,01 \\
\hline 2006 & 34436796 & 1017026 & 2,95 \\
\hline 2007 & 41140654 & 1313178 & 3,19 \\
\hline 2008 & 52359434 & 1889474 & 3,60 \\
\hline 2009 & 55523114 & 1901844 & 3,43 \\
\hline 2010 & 57161002 & 1716877 & 3,00 \\
\hline 2011 & 56663995 & 1753223 & 3,09 \\
\hline 2012 & 63993613 & 1801224 & 2,82 \\
\hline 2013 & 63230834 & 1824112 & 2,85 \\
\hline
\end{tabular}

Źródło: Plan finansowy NFZ na lata 2003 - 2013. www.nfz.gov.pl.

Biorąc pod uwagę źródło finansowania prowadzonej działalności respondentów badania I, to - zgodnie z sytuacją na tym znacznie skomercjalizowanym rynku usług zdrowotnych - przeważają gabinety, w których pacjenci opłacają wizyty ze środków własnych (por. tabela 42). Na oparcie swojej działalności tylko na kontrakcie z NFZ zdecydowało się 4,1\% respondentów. Większość gabinetów funkcjonowała na rynku usług stomatologicznych stricte komercyjnych - w oparciu o środki pochodzące $\mathrm{z}$ prywatnych źródeł finansowania (tj. z prywatnych środków pacjentów, z opłat pracodawców itp.).

${ }^{128}$ Szacunki firmy analitycznej PMR z Krakowa. 
Tabela 42. Pochodzenie środków finansowych za usługi stomatologiczne w gabinetach respondentów badania I

\begin{tabular}{|l|c|}
\hline \multicolumn{1}{|c|}{ Źródło finansowania funkcjonowania gabinetu } & Wskazania (\%) \\
\hline wyłącznie środki pochodzące „, prywatnych kieszeni pacjentów” & 58,00 \\
\hline wyłącznie w oparciu o kontrakt NFZ & 4,10 \\
\hline w oparciu o prywatne środki pacjentów i kontrakt z NFZ & 33,10 \\
\hline $\begin{array}{l}\text { w oparciu o środki pochodzące „, prywatnych kieszeni pacjentów” } \\
\text { i abonamenty wykupione przez pracodawców }\end{array}$ & 3,60 \\
\hline $\begin{array}{l}\text { w oparciu o środki pochodzące „, prywatnych kieszeni pacjentów” } \\
\text { i dodatkowe prywatne ubezpieczenia }\end{array}$ & 4,70 \\
\hline $\begin{array}{l}\text { inne } \\
\text { np. umowy z firmami obsługującymi polskie i zagraniczne statki w porcie } \\
\text { morskim; środki unijne; fundusz socjalno-medyczny dla pracowników firm } \\
\text { korporacyjnych. }\end{array}$ & 1,80 \\
\hline
\end{tabular}

Źródło: opracowanie własne na podstawie przeprowadzonego badania.

Warto w tym miejscu nadmienić, że respondenci badania I stosunkowo dobrze ocenili swoją umiejętność zarządzania finansami gabinetu - 57,1\% badanych uznała, że radzi sobie w tym względzie dobrze lub bardzo dobrze, tylko 7,38\% stwierdziło, że nie ma w tym obszarze umiejętności.

Przedstawione $\mathrm{w}$ tabeli 42 wyniki znajdują potwierdzenie w badaniach strony popytowej transakcji na komercyjnym rynku usług stomatologicznych. Sposób finansowania usług stomatologicznych przez pacjentów - wyniki badania IV - przedstawiony jest w tabeli 43.

Tabela 43. Sposób finansowania świadczenia stomatologicznego przez pacjentów

\begin{tabular}{|l|c|}
\hline \multicolumn{1}{|c|}{ Sposób płatności } & Wskazania (\%) \\
\hline leczenie wyłącznie prywatnie (pacjent opłaca wizytę) & 54,4 \\
\hline $\begin{array}{l}\text { świadczenie finansowane wyłącznie przez NFZ, ale za materiały o lepszej } \\
\text { jakości pacjent dopłaca w kasie gabinetu, }\end{array}$ & 22,0 \\
\hline leczenie finansowane wyłącznie z NFZ i pacjent nie dopłaca za wizytę & 10,8 \\
\hline $\begin{array}{l}\text { świadczenie finansowane jest przez NFZ w jednym gabinecie, a w innym } \\
\text { pacjent leczy się prywatnie (opłaca wizyte) }\end{array}$ & 9,7 \\
\hline $\begin{array}{l}\text { leczenie finansowane wyłącznie przez NFZ, ale za lepszej jakości materiały } \\
\text { pacjent dopłaca w gabinecie - nieoficjalnie }\end{array}$ & 2,4 \\
\hline leczenie wyłącznie prywatne - pracodawca opłaca wizyty pacjenta & 0,7 \\
\hline
\end{tabular}

Źródło: opracowanie własne na podstawie przeprowadzonego badania.

W czasie, gdy było przeprowadzane badanie pacjenci leczący się w gabinetach, które miały podpisaną umowę z NFZ, mogli dopłacać w gabinecie za leczenie z wykorzystaniem wyższej jakości materiałów, stąd tyle wariantów odpowiedzi. Dominującą formą finansowania były środki własne pacjentów. Jeden na dziesięciu pacjentów korzystał wyłącznie z opieki finansowanej ze środków ubezpieczenia zdrowotnego.

Wobec przedstawionych danych o źródłach finansowania świadczeń stomatologicznych, można byłoby postawić pytanie: na ile opieka zdrowotna w zakresie 
usług stomatologicznych jest jeszcze zadaniem publicznym? Pytanie ważne z punktu widzenia polityki społecznej państwa, niemniej jednak w pracy nie będzie podjęta próba odpowiedzi na nie.

\subsection{MOCNE STRONY GABINETU}

Respondenci badania I zostali poproszeni o określenie mocnych stron gabinetów, w których pracują. Ich odpowiedzi przedstawione są w tabeli 44. Do najważniejszych czynników zaliczyli: kwalifikacje medyczne stomatologa i nowoczesny sprzęt (a więc czynniki głównie medyczne), dużą grupę lojalnych klientów i dużą różnorodność usług (którą można potraktować zarówno jako czynnik medyczny, jak i marketingowy). Kwalifikacje menedżerskie stomatologa, jako atut gabinetu wskazał co dziesiąty badany - z jednej strony może to świadczyć o niskim znaczeniu tego czynnika w oczach stomatologów, a z drugiej - o ich niskim poziomie i dlatego mało znaczącym udziale wśród mocnych stron gabinetu.

Tabela 44. Ranking atutów gabinetów stomatologicznych - w oczach lekarzy dentystów

\begin{tabular}{|l|c|}
\hline \multicolumn{1}{|c|}{ Ranking czynników } & Wskazania (\%)* \\
\hline kwalifikacje medyczne dentysty & 89,29 \\
\hline nowoczesny sprzęt & 65,48 \\
\hline duża grupa lojalnych pacjentów & 61,31 \\
\hline duża różnorodność usług & 51,79 \\
\hline renoma gabinetu & 39,88 \\
\hline lokalizacja podmiotu & 38,10 \\
\hline stosowane materiały & 36,90 \\
\hline doświadczony personel & 31,55 \\
\hline niskie ceny & 26,79 \\
\hline kwalifikacje medyczne personelu pomocniczego & 16,67 \\
\hline kwalifikacje interpersonalne pracowników gabinetu & 13,10 \\
\hline kwalifikacje menedżerskie stomatologa & 10,71 \\
\hline młody personel & 7,14 \\
\hline wąska specjalizacja & 5,36 \\
\hline aktywność w Internecie (np. na portalach społecznościowych) & 2,98 \\
\hline Inne & 1,79 \\
\hline
\end{tabular}

Źródło: opracowanie własne na podstawie przeprowadzonych badań.

*Wskazania nie sumują się do $100 \%$, gdyż możliwe było zaznaczenie 5 odpowiedzi.

Ciekawe spojrzenie na ranking atutów współczesnych gabinetów stomatologicznych $\mathrm{w}$ oczach pracujących $\mathrm{w}$ nich dentystów daje uwzględnienie płci respondentów (por. Wykres 4). 
Wykres 4. Atuty gabinetu stomatologicznego a płeć respondenta w badaniu I

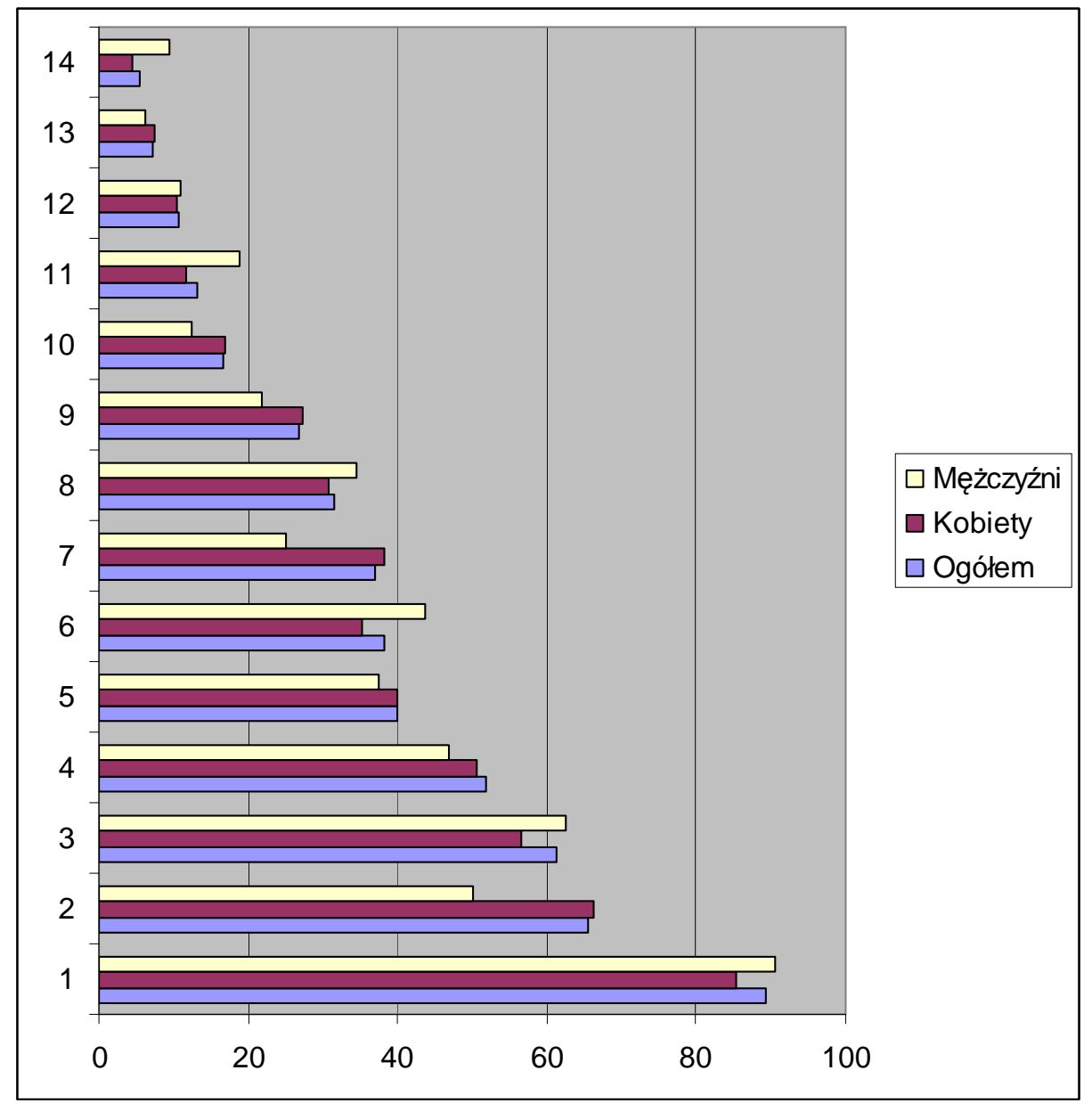

Źródło: opracowanie własne.

Atuty gabinetu: 1) kwalifikacje medyczne dentysty, 2) nowoczesny sprzęt, 3) duża grupa lojalnych pacjentów, 4) duża różnorodność usług, 5) renoma gabinetu, 6) lokalizacja podmiotu, 7) stosowane materiały, 8) doświadczony personel, 9) niskie ceny, 10) kwalifikacje medyczne personelu pomocniczego, 11) kwalifikacje interpersonalne pracowników gabinetu, 12) kwalifikacje menedżerskie stomatologa, 13) młody personel, 14) wąska specjalizacja.

Lekarze-mężczyźni większe znaczenie, niż średnia wskazań, przypisują kwalifikacjom medycznym dentysty, dużej grupie lojalnych klientów, lokalizacji podmiotu, doświadczonemu personelowi, kwalifikacjom interpersonalnym pracowników gabinetu, kwalifikacjom menedżerskim stomatologa oraz wąskiej specjalizacji. Przyglądając się tym czynnikom można stwierdzić, że dentyści stawiają na te elementy funkcjonowania gabinetu, które wpływają na ,zbliżenie gabinetu do pacjenta", są bliższe idei marketingu relacji. Natomiast lekarze-ko- 
biety wśród atutów gabinetu o randze przewyższającej średnią wskazały: nowoczesność sprzętu i stosowane materiały stomatologiczne, dużą różnorodność usług, niskie ceny, młody personel, a więc czynniki o charakterze atrybucji zewnętrznej, bliższe tradycyjnemu marketingowi (zgodnemu z formułą marketing-mix). Należy jednak zauważyć, że większość tych różnic (dla empirycznego poziomu istotności $\mathrm{p}<0,05$ ) nie była istotna statystycznie (wyjątek stanowili mężczyźni pod względem czynnika: 2, 6, 11 i 14).

Również w badaniu III respondenci zostali poproszeni o odniesienie się do kilkunastu kwestii, jako potencjalnych obszarów mocnych stron w funkcjonowaniu współczesnego gabinetu stomatologicznego. Ich ranking jest przedstawiony w tabeli 45 .

Tabela 45. Ranking atutów współczesnego gabinetu stomatologicznego - w oczach studentów

\begin{tabular}{|l|c|}
\hline \multicolumn{1}{|c|}{ Ranking czynników } & Wskazania (\%)* \\
\hline kwalifikacje medyczne dentysty & 75,00 \\
\hline nowoczesny sprzęt & 66,67 \\
\hline stosowane materiały stomatologiczne & 47,87 \\
\hline renoma gabinetu & 44,21 \\
\hline duża grupa lojalnych pacjentów & 40,0 \\
\hline kwalifikacje medyczne personelu pomocniczego & 37,5 \\
\hline lokalizacja podmiotu & 31,18 \\
\hline kwalifikacje interpersonalne pracowników gabinetu & 25,0 \\
\hline kwalifikacje menedżerskie stomatologa & 18,75 \\
\hline niska cena & 14,89 \\
\hline młody personel & 14,74 \\
\hline wąska specjalizacja & 8,42 \\
\hline aktywność w Internecie (np. na portalach społecznościowych) & 8,42 \\
\hline duża różnorodność usług & 4,26 \\
\hline doświadczony personel & 4,26 \\
\hline wysoka cena & 3,33 \\
\hline Ż́odlo: Oprawanie wasne na porsawe przerowadzonego badan & \\
\hline
\end{tabular}

Źródło: Opracowanie własne na podstawie przeprowadzonego badania.

* Wskazania nie sumują się do 100, gdyż respondenci mogli zaznaczyć do 5 odpowiedzi.

Pierwsze dwa atuty współczesnego gabinetu stomatologicznego studenci wskazali takie, jak dentyści. Podobieństwo w postrzeganiu mocnych stron gabinetu widać również w odniesieniu do specjalizacji i aktywności w Internecie; pozostałe czynniki zostały ocenione inaczej. Różnice przedstawione są na wykresie 5 (są one istotne statystycznie dla poziomu istotności p < 0,05; oprócz pozycji 2 i 6).

Należy podkreślić fakt, że studenci w większości nie postrzegają lojalności pacjentów, jako czynnika wpływającego na wzmocnienie pozycji gabinetu. Może to świadczyć o braku zrozumienia roli rynkowej stomatologa, jako usługodawcy i może stać się źródłem późniejszych frustracji - z przywoływanych już badań M. Bladowskiego i in. wynika, że konieczność aktywnego pozyskiwania pacjent- 
tów jest wskazywana, jako jedno ze źródeł wypalenia zawodowego dentystów ${ }^{129}$ ) i może być argumentem przemawiającym za włączeniem - szeroko pojętych rynkowych mechanizmów funkcjonowania gabinetu do treści kształcenia uczelni medycznych.

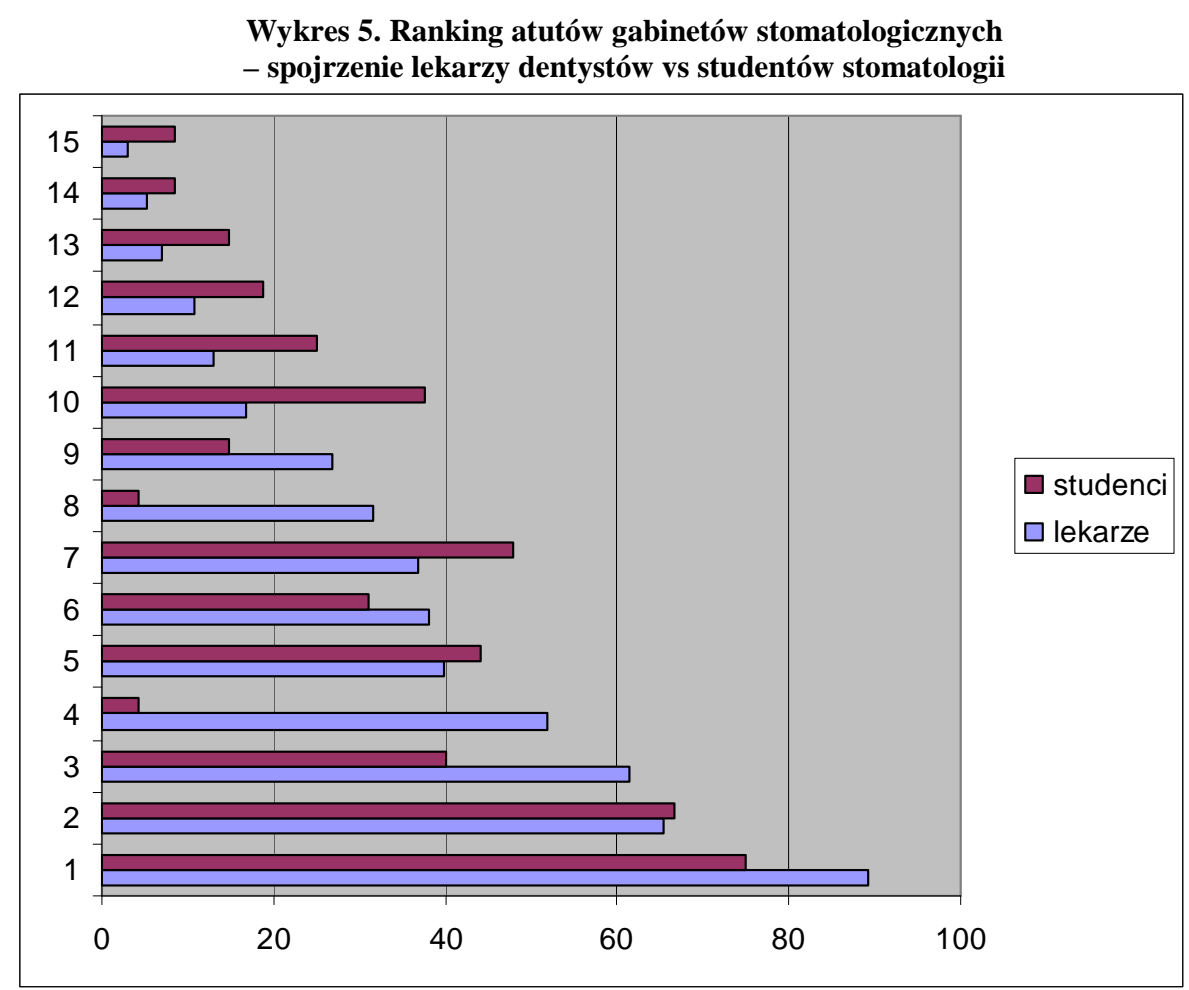

Źródło: opracowanie własne.

Atuty gabinetu: 1) kwalifikacje medyczne dentysty, 2) nowoczesny sprzęt, 3) duża grupa lojalnych pacjentów, 4) duża różnorodność usług, 5) renoma gabinetu, 6) lokalizacja podmiotu, 7) stosowane materiały, 8) doświadczony personel, 9) niskie ceny, 10) kwalifikacje medyczne personelu pomocniczego, 11) kwalifikacje interpersonalne pracowników gabinetu, 12) kwalifikacje menedżerskie stomatologa, 13) młody personel, 14) wąska specjalizacja, 15) aktywność w Internecie.

${ }^{129}$ B.Sapilak, A.Steciwko, M.Melon twierdzą, że: „obecnie 30\% polskich pracowników ochrony zdrowia prezentuje pełnoobjawowy zespół wypalenia, co wymaga zarówno podjęcia szybkich działań zaradczych, jak i przemyślanych zmian systemowych.” por. Sapilak B., Steciwko A., Melon M., Zespót wypalenia zawodowego - czy stoimy na przegranej pozycji?, „Lekarz”, $2006 \mathrm{nr}$ 9, s. 14 i nast.

Z drugiej strony - wg. T.Grygiela, L.Wdowiak., B.Frączak - ,niepokojącym zjawiskiem jest fakt, iż środowisko stomatologów wydaje się lekceważyć zespół wypalenia zawodowego i nie próbuje mu przeciwdziałać." por. Grygiel T., Wdowiak L., Frączak B., The increase of burnout symptoms among dentists In Poland between 2001 and 2010 - a survey, "eDentico", $2010 \mathrm{nr}$ 3, s. 42 
W tym miejscu można przedstawić również odpowiedzi studentów na pytanie: „Jaki powinien być idealny gabinet przyszłości?” (przykładowe odpowiedzi przedstawione są w tabeli 46). Ponieważ pytanie miało charakter otwarty, to dla oddania specyfiki odpowiedzi, zostały one zagregowane w czterech grupach:

- orientacja na gabinet sensu stricte - dotyczyło jej 53\% odpowiedzi,

- orientacja na pacjenta - $20 \%$ odpowiedzi miało taki charakter,

- orientacja na stomatologa - $15 \%$ odpowiedzi było ukierunkowanych na osobę lekarza dentysty,

- podejście kompleksowe - zostało zawarte w 11\% odpowiedzi.

Przedstawione w tabeli 46 wypowiedzi studentów uprawniają do stwierdzenia, że dla studentów w ich przyszłej pracy zawodowej - oprócz wyleczenia pacjenta - powinno być ważne: odpowiednie wyposażenie gabinetu; atmosfera pracy (w tym jakość relacji ze współpracownikami); dbanie o pacjenta w pozamedycznych obszarach usługi (np. punktualność, próba likwidacji stresu); zadowolenie - z pracy u lekarza, z usługi - u pacjenta.

Tabela 46. Gabinet stomatologiczny w oczach studentów - ujęcie normatywne

\begin{tabular}{|c|c|}
\hline Orientacja na: & Przykładowe charakterystyki* \\
\hline - gabinet & $\begin{array}{l}\text { - Będzie RTG, sieć z danymi pacjentów, kilka stanowisk, pomieszczenie socjalne, } \\
\text { pomieszczenia z autoklawem, fajna atmosfera, pracownicy w podobnym wieku; } \\
\text { - Pracownicy doskonale wspótpracują i można wykonać gamę zabiegów } \\
\text { stomatologicznych; } \\
\text { - Sprzęt najnowszej generacji i panuje przyjazna atmosfera; } \\
\text { - Musi być sprzęt najwyższej klasy i odpowiednio wykwalifikowani ludzie; } \\
\text { - Będzie doskonaty sprzęt, najlepsze materiaty, wykwalifikowany personel; } \\
\text { - Pracownicy muszą być odpowiednio wykwalifikowani i mieć dobry kontakt } \\
\text { z pacjentem; } \\
\text {-Powinno być petno kwiatów oraz powinno być czysto; } \\
\text { - Mam nowoczesny sprzęt stomatologiczny i bogata ofertę ustug; } \\
\text { - Jest specjalistyczny sprzet wysokiej klasy, umożliwiajacy efektywna prace; }\end{array}$ \\
\hline - stomatologa & $\begin{array}{l}\text { - Chciałabym mieć dobre relacje interpersonalne; } \\
\text { - Mam szansę rozwijać się; } \\
\text { - Sam dla siebie jestem kierownikiem; }\end{array}$ \\
\hline - pacjenta & $\begin{array}{l}\text { - Pacjenci będa przychodzili z przyjemnością, bez stresów; } \\
\text { - Obok gabinetu znajduje się pokój do zabaw dla dzieci; } \\
\text { - Jest dużo zadowolonych pacjentów; } \\
\text { - Pacjenci są zadowoleni z wykonywanych ustug, jestem w stanie pomóc każdemu; } \\
\text { - Jest atmosfera choćby w niewielkim stopniu likwidująca stres pacjenta; } \\
\text { - Pacjent będzie na pierwszym miejscu; }\end{array}$ \\
\hline $\begin{array}{l}\text { - kompleksowe } \\
\text { podejście }\end{array}$ & $\begin{array}{l}\text { - Będzie pracowała wykwalifikowana kadra medyczna, przyjaźnie nastawiona do } \\
\text { pacjenta, wykonujaca swoją pracę rzetelnie. Będziemy dziatać tak, aby pacjent } \\
\text { byt w petni zadowolony i zawsze do nas wracat orazpolecat nasz gabinet innym } \\
\text { osobom. Trzeba pamiętać, iż w ustugach medycznych „poczta pantoflowa” } \\
\text { odgrywa znaczaca rolę. To nie promocja czy zniżka, jak w przypadku innych } \\
\text { ustug proponowanych na różnych portalach społecznościowych zachęci do }\end{array}$ \\
\hline
\end{tabular}




\begin{tabular}{|l|}
\hline przybycia na wizytę - pamiętajmy. \\
- Nowoczesny sprzęt oraz przyjaźnie nastawieni pracownicy względem siebie \\
i pacjentów; \\
- Zależy mi na punktualności i odczuciu, że na każdego pacjenta jest tyle czasu, ile \\
wymaga, dogodne ceny i estetyczny wyglad personelu oraz gabinetu, dodatkowo \\
możliwość niekompletnego leżenia podczas leczenia; \\
- Panuje tad i porzadek, pacjenci są zadowoleni, a praca jest dla mnie \\
przyjemnościa; \\
- Obie strony sa zadowolone.
\end{tabular}

Zródło: wyniki badań własnych

*W zaprezentowanych przykładach zachowano sens wypowiedzi respondentów, natomiast nie zachowano oryginalnej pisowni.

\subsection{KONTAKTY Z DOSTAWCAMI MATERIAŁÓW}

Jak już zostało powiedziane w II rozdziale, gabinet stomatologiczny jest jednym z uczestników w sieci powiązań między podmiotami rynku, który nie tylko oferuje swoje usługi ostatecznym nabywcom - pacjentom, ale przejawia również aktywność rynkową w zakresie zakupów zaopatrzeniowych (materiałów i usług umożliwiających funkcjonowanie gabinetu). Dokonując zakupów materiałów do realizacji usług, stomatolodzy uwzględniają przede wszystkim ich jakość (przeszło 90\% wskazań), kierują się również wiedzą wyniesioną ze szkoleń. Szczegółowy rozkład odpowiedzi w zakresie głównych czynników decyzyjnych przy wyborze materiałów stomatologicznych przedstawiony jest $\mathrm{w}$ tabeli 47 . Pierwsze cztery pozycje zawarte $\mathrm{w}$ tabeli 47 pozwalają na stwierdzenie, że dentyści dbają o jakość usługi już w fazie przygotowawczej procesu usługowego, co stawia ich w pozytywnym świetle z punktu widzenia etyki (tak lekarskiej, jak i biznesu).

Tabela 47. Determinanty wyboru materiałów stomatologicznych - w badaniu I

\begin{tabular}{|l|c|}
\hline Determinanta zakupu & Wskazania (\%)* \\
\hline Jakość & 91,12 \\
\hline własna wiedza ze szkoleń & 61,54 \\
\hline opinia zaufanych koleżanek/kolegów & 49,70 \\
\hline marka produktu & 44,97 \\
\hline niska cena & 12,43 \\
\hline Intuicja & 9,47 \\
\hline reklama w czasopismach branżowych & 7,10 \\
\hline $\begin{array}{l}\text { opiniami dentystów-Internautów (np. pozyskanymi na specjalistycznych } \\
\text { forach dyskusyjnych, portalach społecznościowych itp.) }\end{array}$ & 5,33 \\
\hline wysoka cena & 2,37 \\
\hline inne (np. własne doświadczenie) & 2,96 \\
\hline
\end{tabular}

Źródło: opracowanie własne na podstawie przeprowadzonego badania.

* Odpowiedzi nie sumują się do $100 \%$, ponieważ respondenci mogli zaznaczyć 3 odpowiedzi.

Choć cena nie była dla respondentów podstawowym kryterium wyboru stosowanych materiałów stomatologicznych, to możliwość jej zmiany stanowiła główny powód zmiany dostawców materiałów stomatologicznych (w ten spo- 
sób stomatolodzy przejawiają swój racjonalizm i jawią się, jako osoby gospodarujące). Inne - mniej znaczące - powody zmiany dostawcy są związane z czynnikami pozacenowymi i dotyczą obszaru obsługi sprzedażowej (komunikacja interpersonalna, solidność dostawy). Rozkład odpowiedzi na pytanie o powód zmiany dostawcy materiałów ${ }^{130}$ w ciągu ostatniego roku przedstawia tabela 48 .

Tabela 48. Ranking czynników wpływających na zmianę dostawcy materiałów (badanie I)

\begin{tabular}{|l|c|}
\hline Powody zmiany dostawcy materiałów stomatologicznych $\mathbf{( N = 1 0 4 )}$ & Wskazania (\%)*** \\
\hline Znalezienie dostawcy, który te same materiały oferuje w niższych cenach & 50,89 \\
\hline inne (np. problemy z uczciwościa dostawcy; niezgodność cennika zfaktura) & 32,54 \\
\hline podniesienie cen przez poprzedniego dostawcę & 13,61 \\
\hline problemy z kompletnością dostaw & 10,06 \\
\hline $\begin{array}{l}\text { problemy natury komunikacyjnej z dostawcą (był nieuprzejmy; nie słuchał } \\
\text { tego, co się do niego mówi itp.) }\end{array}$ & 9,47 \\
\hline problemy z terminowością dostaw & 8,28 \\
\hline ,zniknięcie” z rynku poprzedniego dostawcy & 8,28 \\
\hline $\begin{array}{l}\text { zmiana rodzaju materiałów, które są wykorzystywane w gabinecie } \\
\text { (a w konsekwencji ich dystrybutora) }\end{array}$ & 2,37 \\
\hline
\end{tabular}

Źródło: opracowanie własne na podstawie przeprowadzonego badania.

* Na to pytanie odpowiadali tylko ci respondenci, których omawiany problem dotyczył.

** Odpowiedzi nie sumują się do 100\%, ponieważ respondenci mogli wskazać dwie odpowiedzi.

\subsection{OUTSOURCING FUNKCJI POMOCNICZYCH}

Obok zakupu materiałów, kontakt z dostawcami zewnętrznymi w gabinecie stomatologicznym może dotyczyć również zakupu usług - co jest związane z wykorzystaniem outsourcingu w gabinecie. Stomatolodzy na pytanie: „Czy stosuja outsourcing w swoich gabinetach?” odpowiadali w większości (90\%), że nie, a pozostali - że nie wiedzą. Jednak odpowiedzi na pytania szczegółowe wyłoniły zupełnie inny obraz. I tak: najczęściej przedmiotem outsourcingu w gabinecie były prace związane z księgowością - u większości badanych dentystów kwestie podatkowe zlecone były zewnętrznej firmie (por. tabela 49), a tylko niespełna 1/4 respondentów prace te realizowała wewnątrz prowadzonej działalności (samodzielnie lub zajmował się tym pracownik gabinetu).

Tabela 49. Zakres outsourcingu działań związanych z księgowością gabinetu - w badaniu I

\begin{tabular}{|l|c|}
\hline \multicolumn{1}{|c|}{ Prace związane z księgowością } & Wskazania (\%) \\
\hline zlecone są zewnętrznej firmie rachunkowej & 72,78 \\
\hline stomatolog prowadzi samodzielnie & 15,98 \\
\hline są w zakresie obowiązków wykwalifikowanego pracownika podmiotu & 8,28 \\
\hline inne (głównie: prowadzi je nieodptatnie ktoś z najbliższej rodziny dentysty) & 3,55 \\
\hline
\end{tabular}

Źródło: opracowanie własne na podstawie przeprowadzonego badania.

\footnotetext{
${ }^{130}$ Koordynacja zasobów ekonomicznych gabinetu w celu poprawy efektu działania jest przejawem przedsiębiorczości w rozumieniu m. in. L. Walrasa, R. Cantillona, J.M. Keynesa, L. von Milesa (por. tabela 4).
} 
Kolejna czynność pomocnicza - pranie odzieży służbowej - w dużej mierze została wyłączona z zakresu zadań stomatologa (por. tabela 50). Najpopularniejszym sposobem stało się delegowanie tej czynności na pracowników. Ale nawet w sytuacji, gdy za czystość odzieży odpowiada stomatolog (blisko 40\% respondentów), to nie zajmuje się tym osobiście, tylko zleca wykonanie na zewnątrz lub zaopatruje personel w odzież jednorazową.

Tabela 50. Osoby odpowiedzialne za pranie odzieży służbowej - w badaniu I

\begin{tabular}{|l|c|}
\hline \multicolumn{1}{|c|}{ Pranie odzieży służbowej } & Wskazania (\%) \\
\hline każdy pracownik wykonuje indywidualnie & 62,87 \\
\hline $\begin{array}{l}\text { jest w gestii właściciela gabinetu, który zawozi (sam lub deleguje do tego } \\
\text { pracownika) odzież do pralni }\end{array}$ & 22,16 \\
\hline Inne (np. używana jest odzież jednorazowa) & 8,38 \\
\hline $\begin{array}{l}\text { jest w gestii właściciela gabinetu, a odzież odbiera z gabinetu pracownik } \\
\text { pralni }\end{array}$ & 6,59 \\
\hline
\end{tabular}

Źródło: opracowanie własne na podstawie przeprowadzonego badania.

Inne funkcje pomocnicze prowadzonej działalności już w mniejszym zakresie są przekazywane na zewnątrz gabinetu. I tak np. sprzątanie w większości gabinetów jest wykonywane przez personel pomocniczy, a u ok. 39\% respondentów jest wykonywane przez osobę spoza gabinetu (por. tabela 51). Przeszło $1 / 5$ respondentów pracuje w gabinecie, w którym nie zatrudnia personelu i1/2 z nich sama sprząta w gabinecie (wskazując czynnik finansowy, jako główny powód nie korzystania z zewnętrznej pomocy w tym zakresie). Niewykorzystywanie korzyści wynikających ze zlecania prac na zewnątrz może wpływać na wydłużenie czasu pracy dentysty, przemęczenie, a w końcu zniechęcenie czy wręcz wypalenie zawodowe.

Tabela 51. Zakres outsourcingu działań związanych ze sprzątaniem w gabinecie - w badaniu I

\begin{tabular}{|l|c|}
\hline \multicolumn{1}{|c|}{ Prace związane ze sprzątaniem w gabinecie } & Wskazania (\%) \\
\hline Leżą w gestii personelu pomocniczego & 55,69 \\
\hline są wykonywane przez osobę ,przychodzącą” na zakończenie na dnia pracy & 32,93 \\
\hline dentysta sam sprząta gabinet & 10,18 \\
\hline przeprowadza pracownik wynajętej firmy sprzątającej & 5,99 \\
\hline
\end{tabular}

Zródło: opracowanie własne na podstawie przeprowadzonego badania.

W najmniejszym zakresie outsourcing jest wykorzystywany w gabinetach w odniesieniu do sterylizacji narzędzi $-5,95 \%$ badanych dentystów w pełni zleca tę usługę na zewnątrz (por. tabela 52). Zdecydowana większość respondentów przeprowadza ją we własnym zakresie (wskazując czynnik czasu - związany z obsługą tej procedury na zewnątrz - jako główną determinantę przeprowadzania sterylizacji $\mathrm{w}$ gabinecie). 
Tabela 52. Miejsce przeprowadzania sterylizacji narzędzi - w badaniu I

\begin{tabular}{|c|c|}
\hline Sterylizacja narzędzi & Wskazania (\%) \\
\hline jest przeprowadzana w gabinecie & 91,67 \\
\hline jest wykonywana przez podmiot zewnętrzny & 5,95 \\
\hline jest wykonywana częściowo w gabinecie, częściowo na zewnątrz & 2,38 \\
\hline
\end{tabular}

Należy podkreślić szerokie spektrum powodów podejmowania lub nie podejmowania decyzji o outsourcingu funkcji pomocniczych w gabinecie - od kosztowych (np. sprzątanie), po te związane $\mathrm{z}$ wiedzą (np. księgowość), czynnikiem czasu (np. księgowość, sterylizacja), czy uciążliwością określonych działań (np. sprzątanie, pranie odzieży służbowej).

\subsection{ZATRUDNIENIE W GABINECIE}

Większość dentystów, którzy wzięli udział w badaniu I, prowadziła gabinety $\mathrm{w}$ formie indywidualnej praktyki - 79,88\% wskazań. Te, które były prowadzone $\mathrm{w}$ formie grupowej praktyki, to najczęściej spółki jawne (57\%), spółki z o.o. (14,3\%) i spółki partnerskie $(10,7 \%)$. W gabinetach stomatologicznych w Polsce pracuje ok. 150 tys. osób ${ }^{131}$, z czego ok. 36 tys. to lekarze dentyści i zbliżoną proporcję zatrudnienia można zaobserwować w badaniu $\mathrm{I}^{132}$. W badanej grupie 21,9\% gabinetów nie zatrudniało pracowników. Analizując poziom zatrudnienia $\mathrm{w}$ gabinetach, należy podkreślić ich rozwój. Zmiany w czasie w tym zakresie przedstawione są w tabeli 53.

Tabela 53. Zmiany poziomu zatrudnienia $w$ badanych gabinetach stomatologicznych - od początku działalności do dnia badania

\begin{tabular}{|l|c|c|c|c|}
\hline \multirow{2}{*}{ Stan na: } & \multicolumn{4}{c|}{ Liczba osób zatrudnionych w gabinecie } \\
\cline { 2 - 5 } & $\bar{x}$ & $\mathbf{S}(\mathbf{x})$ & max. & min. \\
\hline początku działalności & 1,80 & 1,81 & 9 & 0 \\
\hline dwa lata przed badaniem & 3,04 & 4,49 & 15 & 0 \\
\hline w trakcie badania & 3,37 & 4,43 & 18 & 0 \\
\hline
\end{tabular}

Źródło: opracowanie własne na podstawie przeprowadzonego badania.

Biorąc pod uwagę gabinety zatrudniające pracowników, to w $57,24 \%$ z nich personel podlega ocenie. Jako powody nie oceniania personelu były wskazywane następujące:

\footnotetext{
${ }^{131} \mathrm{~W}$ gabinetach/klinikach stomatologicznych oprócz asystentek stomatologicznych, higienistek czy rejestratorek znajdują zatrudnienie specjaliści ds. public relations czy reklamy (którzy dbają o relacje z otoczeniem); opiekunowie klienta (którzy mogą porozmawiać z pacjentem cierpiącym na dentofobię, czy zając się dzieckiem); specjaliści ds. turystyki (którzy zajmują się turystyką stomatologiczną pacjentów zagranicznych) itp.

${ }_{132}$ Pomimo braku losowości w doborze próby do badania, otrzymana próba odzwierciedla strukturę populacji generalnej.
} 
- wzajemne zaufanie,

- wysokie kwalifikacje pracownika gwarantuja dobra prace,

- każdy pilnuje własnego zakresu obowiązów,

- mam za mato czasu na wszystko,

- pracownik zbyt krótko pracuje,

- nie mam w tym zakresie umiejętności, nie wiem jak to zrobić.

- stale sa podnoszone kwalifikacje personelu, za wcześnie na oceny,

- personel pracuje dobrze.

Rozkład odpowiedzi na pytanie: „Jak często personel jest oceniany?” przedstawiony jest w tabeli 54. Trudno mówić o jakiejś wyraźnej tendencji w zakresie częstotliwości oceniania personelu. Tym bardziej, że jednorazowa ocena, czy ocena dokonywana rzadziej niż raz na rok - nie może być uznana za odpowiednią. Tak więc tylko $\mathrm{w}$ odniesieniu do $1 / 3$ badanych można powiedzieć, że lekarz dentysta prezentuje aktywną postawę, jako przełożony oceniając swoich współpracowników ${ }^{133}$.

Tabela 54. Częstotliwość oceny personelu - w badaniu I

\begin{tabular}{|l|c|}
\hline \multicolumn{1}{|c|}{ Częstotliwość oceny personelu } & Wskazania (\%) \\
\hline rzadziej niż raz na rok & 8,45 \\
\hline raz na rok & 16,90 \\
\hline co kwartał & 10,56 \\
\hline co miesiąc & 12,68 \\
\hline był oceniany dopiero raz & 7,75 \\
\hline nie jest oceniany & 42,76 \\
\hline
\end{tabular}

Źródło: opracowanie własne na podstawie przeprowadzonego badania.

Przedmiotem oceny personelu są najczęściej umiejętności zawodowe i zachowanie względem pacjentów, które determinują jakość wykonywanej pracy i wpływają na relacje z pacjentami. Ranking czynników, które są przedmiotem oceny w pracy personelu przedstawia tabela 55 .

Tabela 55. Czynniki oceniane w pracy personelu - w badaniu I

\begin{tabular}{|l|c|}
\hline \multicolumn{1}{|c|}{ Obszary oceny personelu } & Wskazania (\%)* \\
\hline umiejętności stricte zawodowe & 78,05 \\
\hline zachowanie względem pacjentów & 74,39 \\
\hline zachowanie względem współpracowników & 54,88 \\
\hline wiedza & 50,00 \\
\hline wyniki pracy & 48,78 \\
\hline terminowość wykonywanej pracy & 24,39 \\
\hline $\begin{array}{l}\text { liczba godzin przepracowanych w danej jednostce czasu } \\
\text { (np. w ciągu miesiąca) }\end{array}$ & 18,29 \\
\hline
\end{tabular}

${ }^{133}$ Warto przypomnieć, że respondenci wśród swoich umiejętności interpersonalnych najsłabiej ocenili właśnie umiejętności z zakresu kierowania personelem - por. punkt 3.3.1. w II rozdziale. 


\begin{tabular}{|l|c|}
\hline $\begin{array}{l}\text { liczba przyjętych pacjentów w danej jednostce czasu } \\
\text { (np. w ciągu miesiąca) }\end{array}$ & 10,98 \\
\hline $\begin{array}{l}\text { inne (np. liczba wykonanych punktów z kontraktu z NFZ, } \\
\text { zaangażowanie w pracę i własny rozwój) }\end{array}$ & 2,44 \\
\hline
\end{tabular}

Źródło: opracowanie własne na podstawie przeprowadzonego badania.

* Odpowiedzi nie sumują się do $100 \%$, ponieważ respondenci mogli zaznaczyć wszystkie odpowiedzi, które ich dotyczyły.

Przedmiotem oceny dokonywanej $\mathrm{w}$ gabinecie stomatologicznym są głównie: umiejętności zawodowe personelu i sposób traktowania pacjentów, a w dalszej kolejności zachowanie względem pozostałych członków personelu gabinetu i posiadana wiedza.

\subsection{MIEJSCE INTERNETU W GABINECIE STOMATOLOGICZNYM}

Posiadanie adekwatnej informacji jest nieodzownym elementem, umożliwiającym dokonanie wyboru usługi zdrowotnej, dlatego poszukiwanie informacji przez pacjentów stanowi bardzo ważny etap w procesie podejmowania decyzji co do wyboru lekarza. Poszukiwania te dotyczą alternatywnych rozwiązań problemu zdrowotnego, uzależnionego m. in. od ${ }^{134}$ :

- ilości niezbędnego czasu i środków finansowych, potrzebnych do zebrania informacji,

- informacji już posiadanych,

- stopnia postrzegania ryzyka w przypadku dokonania niewłaściwego wyboru usługi zdrowotnej.

$\mathrm{Z}$ badania przeprowadzonego na reprezentatywnej próbie Polaków w $2007 \mathrm{r}^{135}$ wynika, iż co czwarty respondent uważał, że zasoby sieci Internet są ważnym źródłem informacji o zdrowiu, chorobach i problemach zdrowotnych. Najczęstszym sposobem korzystania z Internetu było szukanie informacji, które pomogłyby $w$ podjęciu decyzji o potrzebie konsultacji z fachowym pracownikiem medycznym. Można zadać sobie pytanie na ile lekarze dentyści wykorzystują Internet, aby dotrzeć do tej (ciągle rosnącej) grupy Polaków, która korzysta $\mathrm{z}$ Internetu ${ }^{136}$.

134 Bober B., Rola informacji $w$ procesie świadczenia ustugi szpitalnej - redukcja ryzyka decyzyjnego, w: Lewandowski R., Walkowiak R. (red.), Wspótczesne wyzwania strukturalne i menedżerskie $w$ ochronie zdrowia. Problemy zarzadzania, OWSzliZ im. prof. T. Kotarbińskiego, Olsztyn 2010.

${ }^{135}$ Staniszewski A., Bujnowska-Fedak M.M., Korzystanie z Internetu medycznego i ustug z zakresu e-zdrowia w opinii publicznej Polaków w 2007r, 2009. www.img.custompublish.com/getfile.php/ 670534.357.pyabxupqta/korzystanie1_results_Poland_2.pdf?-return

${ }^{136}$ Można powiedzieć, że misją Internetu w odniesieniu do usług medycznych jest: 1) udzielenie pacjentowi pełnej informacji na temat wszelkich możliwych zaakceptowanych przez medycynę 
Obowiązkiem lekarza jest dostarczenie pacjentowi niezbędnych informacji, wspieranie go na każdym etapie procesu podejmowania decyzji, a taką rolę może pełnić również odpowiednio przygotowana strona www gabinetu/kliniki stomatologicznej. Poprzez zastosowanie różnych funkcji strona taka może kształtować doświadczenia pacjentów, wpływać na ich zadowolenie oraz stopień satysfakcji zdrowotnej. Zmniejsza koszt pozyskania, gromadzenia oraz przetwarzania danych. Ponadto, poprzez całkowitą dostępność oraz interaktywność podnosi poziom jakości dostarczanych do pacjentów informacji (różnorodny typ prezentacji danych, szybki i kompleksowy sposób uaktualniania informacji). Proces poszukiwania informacji daje pacjentowi z jednej strony możliwość bardziej efektywnego znalezienia niezbędnych informacji oraz skutecznego dokonywania oceny istniejących alternatyw, a z drugiej zmniejsza asymetrię informacyjną na linii lekarz - pacjent ${ }^{137}$.

Kolejną możliwością, jaką daje Internet, jest aktywność na portalach społecznościowych. Dziś, aby stworzyć więź z klientami, nie wystarczy podać na stronie internetowej adresu e-mail i numeru telefonu do gabinetu. Ludzie (zwłaszcza młodzi) chcą wchodzić w interakcje przez różne środki komunikacji (Twister, Facebook, fora dyskusyjne itp.), dlatego zamiast oczekiwać, że pacjent - klient skontaktuje się z gabinetem przez „podsunięty” mu kanał komunikacji, można pozwolić (stworzyć warunki), aby sam dokonał wyboru najwygodniejszej dla siebie drogi do podmiotu leczniczego ${ }^{138}$.

Podjęcie społecznościowego wyzwania oznacza całkowitą zmianę - $\mathrm{z}$ jednostronnej komunikacji, jaką dotychczas prowadzi większość gabinetów istniejących w sieci, na faktyczne i aktywne uczestnictwo w życiu pacjentów. Podstawową formą obecności na Facebooku jest strona autorska (fanpage), określająca profil autora - zawiera informacje o podmiocie i jego usługach. Tematy, które porusza się na stronie, powinny być nie tylko profesjonalne, ale - przede wszystkim - atrakcyjnie podane, aby zachęcać innych użytkowników do dołączenia do grupy przyjaciół właściciela strony (co umożliwi tworzenie małych społeczności). Przed umieszczeniem materiałów na swojej stronie na Facebooku, stomatolog powinien przyjrzeć się statystykom dotyczącym

metodach diagnostyki i leczenia; 2) informowanie, wspieranie, udzielanie odpowiedzi, co ma pomóc pacjentowi $\mathrm{W}$ podjęciu decyzji wspólnie $\mathrm{z}$ lekarzem leczącym w późniejszym etapie. Por. Kasztelowicz P., Profesjonalna informacja medyczna w Internecie. Sieci indywidualne - czy moga być lekarstwem na zagrożenia wspótczesnego Internetu? www.am.torun.pl.

${ }^{137}$ Bober B., Rola informacji w ... op. cit., s. 9.

138 Jeśli - być może - brzmi to nieprawdopodobnie, to warto zauważyć, że jeszcze pięć lat temu eRecepta też była traktowana, jako nie przystająca do polskiej rzeczywistości, a dziś staje się coraz powszechniejsza. 
charakterystyki odwiedzających stronę osób (płeć, wiek, rejon zamieszkania), aby dostosować treść przekazu do ich oczekiwann ${ }^{139}$.

Niemal połowa respondentów badania I zadeklarowała, że Internet nie jest wykorzystywany w pracy gabinetu (por. tabela 56). Pasywne możliwości strony internetowej gabinetu (a więc wykorzystanie witryny tylko do informowania pacjentów o danych teleadresowych gabinetu, czy godzinach pracy) wykorzystuje 35,15\% respondentów. W 12,73\% badanych gabinetów istniała interaktywna strona (tj. umożliwiająca informowanie pacjentów o gabinecie i zapewniająca pacjentom kontakt $z$ gabinetem np. poprzez możliwość umówienia się na wizytę bądź zadawanie pytań), kolejne 6,06\% gabinetów było aktywnych na profilach społecznościowych, a 3,03\% wysyłało maila z przypomnieniem o terminie wizyty. Biorąc pod uwagę te wyniki, wydaje się, że gabinety nie wykorzystują możliwości Internetu do komunikacji z pacjentami $\mathrm{i}$ potencjalnymi pacjentami. $\mathrm{Z}$ drugiej strony, jak wynika $\mathrm{Z}$ badania IV zapotrzebowanie ze strony pacjentów na znaczną aktywność stomatologów w sieci jest jeszcze stosunkowo niewielkie (por. tabela 58).

Tabela 56. Wykorzystywanie Internetu w gabinecie stomatologicznym wg lekarzy dentystów

\begin{tabular}{|l|c|}
\hline \multicolumn{1}{|c|}{ Miejsce Internetu w gabinecie stomatologicznym } & Wskazania (\%) \\
\hline internet nie jest wykorzystywany pacjentów o & 49,09 \\
\hline $\begin{array}{l}\text { strona internetowa gabinetu umożliwia poinformowanie } \\
\text { lokalizacji, godzinach pracy podmiotu itp. }\end{array}$ & 35,15 \\
\hline $\begin{array}{l}\text { strona internetowa gabinetu umożliwia informowanie pacjentów o gabinecie i } \\
\text { kontakt z pacjentami np. poprzez możliwość umówienia się na wizytę bądź } \\
\text { zadawanie pytań }\end{array}$ & 12,73 \\
\hline Inne & 7,27 \\
\hline Aktywność na profilach społecznościowych & 6,06 \\
\hline Wysyłanie ofert na skrzynki mailowe potencjalnych pacjentów & 5,45 \\
\hline przypominanie mailem pacjentom o terminie wizyty & 3,03 \\
\hline $\begin{array}{l}\text { pozyskiwanie nowych pacjentów dzięki możliwościom jakie daje kupowanie } \\
\text { usług w ramach tzw. zakupów grupowych }\end{array}$ & 1,21 \\
\hline
\end{tabular}

Źródło: opracowanie własne na podstawie przeprowadzonego badania.

Dość ostrożne podejście do wykorzystania możliwości, jakie daje Internet w komunikowaniu się $\mathrm{z}$ pacjentami może wynikać $\mathrm{z}$ faktu, że jeden na dziesięciu respondentów badania I ocenił, że umiejętności w zakresie obsługi

\footnotetext{
${ }^{139}$ Lek. dent. D.Borczyk (założycielka i członkini Polskiej Akademii Stomatologii Estetycznej), która aktywnie działa w sieci, twierdzi, że: „Dzięki portalowi społecznościowemu przekazuje internautom wiedze na temat nowoczesnych metod leczenia m.in. bezbolesnego uśmierzania bólu; ttumacze, na czym polega stomatologia odmładzająca i dlaczego ścierajace się zęby powoduja zmarszczki. Facebookowe tematy, poruszajace kwestie zdrowia, musza nie tylko być podane w pigutce, ale także w przystępnej formie - wtedy zainteresuja wielu. Być może wśród nich znajda się również moi przyszli klienci.” Por. D.Borczyk, Rozmawiamy nie tylko o pracy, „Medical Tribune. Stomatologia", 2010, nr 12, s. 4.
} 
komputera ma na bardzo niskim poziomie lub nie posiada ich w ogóle (były to lekarki, które ukończyły studia więcej niż 20 lat przed przystąpieniem do badania). Jako bardzo dobre oceniło swoje umiejętności 27,56\% badanych, a dobre $-39,10 \%$.

Respondenci badania III - studenci ocenili swoje umiejętności w omawianym zakresie zdecydowanie wyżej (co zrozumiałe ze względu na ich wiek i fakt, że przez całe swoje życie mają dostęp do komputera i Internetu). Połowa badanych oceniła swoje umiejętności jako bardzo dobre, 36,67\% - jako dobre, a pozostali jako średnie. Przełożyło się to na zdecydowanie inne, niż u lekarzy dentystów, spojrzenie na miejsce Internetu $\mathrm{w}$ gabinecie stomatologicznym. Ranking zastosowań Internetu - w ocenie studentów - w funkcjonowaniu gabinetu przedstawia tabela 57. Znamienna jest liczba wskazań przy odpowiedzi: „Internet nie jest/nie powinien być wykorzystywany w gabinecie”, którą wskazało 49,09\% dentystów i 4,3\% studentów. Kolejna różnica dotyczy możliwości aktywnego komunikowania się z pacjentami np. przypominanie mailem o wizycie 3,03\% badanych stomatologów uznało za dobre rozwiązanie i 51,6\% studentów.

Tabela 57. Internet w gabinecie stomatologicznym wg studentów - badanie III

\begin{tabular}{|l|c|}
\hline \multicolumn{1}{|c|}{ Zastosowanie Internetu w gabinecie } & Wskazania* (\%) \\
\hline $\begin{array}{l}\text { informowanie pacjentów o lokalizacji, godzinach pracy podmiotu itp. } \\
\text { informowanie pacjentów o gabinecie i kontaktu z pacjentami np. poprzez } \\
\text { możliwość umówienia się na wizytę bądź zadawanie pytań }\end{array}$ & 69,9 \\
\hline przypominanie mailem pacjentom o terminie wizyty & 51,5 \\
\hline $\begin{array}{l}\text { pozyskiwanie nowych pacjentów dzięki możliwościom jakie daje } \\
\text { kupowanie usług w ramach zakupów grupowych }\end{array}$ & 38,7 \\
\hline wysyłanie ofert na skrzynki mailowe potencjalnych pacjentów & 31,2 \\
\hline aktywność na profilach społecznościowych & 28,0 \\
\hline nie powinien być stosowany & 4,3 \\
\hline Inne & 3,2 \\
\hline
\end{tabular}

Źródło: Opracowanie własne na podstawie przeprowadzonego badania.

* Odpowiedzi nie sumują się do 100, ponieważ respondenci mogli zaznaczyć wszystkie istotne wg siebie odpowiedzi.

Wydaje się, że osobnego komentarza wymaga zróżnicowanie odpowiedzi dotyczących możliwości pozyskiwania nowych pacjentów dzięki tzw. zakupom grupowym (np. za pośrednictwem portalu Groupon, czy Gruper). Wśród praktykujących stomatologów rozwiązanie to cieszy się małym zainteresowaniem - zaznaczyło je 1,21\% badanych, a wśród studentów - 38,7\%. Wyniki badań pokazują nie tylko odmienne nastawienie obu grup respondentów (dentystów i studentów) do poszukiwania nowych pacjentów z wykorzystaniem sieci, ale pokazują również wyraźnie inne nastawienie do aktywnego poszukiwania pacjentów. Pojawia się tutaj również aspekt etyczny - reklamowanie się w sieci i przyciąganie pacjentów niskimi cenami jest niezgodne z Ko- 
deksem etyki lekarskiej ${ }^{140}$, a tak duży odsetek studentów widzi zasadność stosowania tego rozwiązania. Lekarze dentyści z większą powściągliwością podchodzą do tego rozwiązania, wskazując właśnie zakaz reklamowania, jako podstawowy czynnik hamujący ich aktywność w tym zakresie. Co nie oznacza, że stomatolodzy w ogóle nie podejmują takich działań (choć ze względu na etykę zawodową nie powinni - takie stanowisko zajęła Naczelna Rada Lekarska). Autorka dokonała analizy ofert na portalu zakupów grupowych - Groupon w okresie 28.03.2011-6.08.2012 z zakresu świadczeń stomatologicznych. W ramach badania ilościowego odczytano ogólną liczbę tego typu ofert - w Łodzi były wystawione 52 oferty. Oferentami było 19 podmiotów - zarówno gabinet- tów stomatologicznych, jak i firm kosmetycznych, które świadczą usługi w zakresie wybielania zębów. W tym samym okresie w Warszawie pojawiły się 94 oferty tego typu. W dalszej kolejności - w ramach analizy jakościowej - otwierano wyszukane w ten sposób oferty i analizowano ich treść. Dominowały oferty związane z wybielaniem zębów (52\% ofert), w dalszej kolejności: korygowanie zgryzu i uzupełnianie ubytków z wykorzystaniem implantów, a więc świadczenia mieszczące się w zakresie stomatologii estertycznej (związanej z poprawą wyglądu uzębienia pacjentów). Oferty te są chętnie wykorzystywane przez pacjentów np. 10 maja 2011 r. w Warszawie z oferty: ,skaling, polerowanie, wybielanie nakładkowe za 150 PLN (rabat w wysokości 60\%) skorzystały 503 osoby. Z badania IV wynika, że zakup usługi stomatologicznej w ramach zakupów grupowych jest atrakcyjnym czynnikiem wyboru gabinetu dla 4,4\% respondentów (por. tabela 58).

Tabela 58. Aktywność gabinetu stomatologicznego w sieci jako determinanta wyboru gabinetu przez pacjenta - wyniki badania IV

\begin{tabular}{|l|c|c|}
\hline \multicolumn{1}{|c|}{ Czynnik wyboru } & $\begin{array}{c}\text { czynnik } \\
\text { ważny (\%) }\end{array}$ & $\begin{array}{c}\text { czynnik na pewno } \\
\text { nie ważny (\%) }\end{array}$ \\
\hline możliwość umówienia się na wizytę mailem & 11,7 & 47,7 \\
\hline $\begin{array}{l}\text { opinie internautów na temat stomatologa na portalach } \\
\text { społecznościowych (Fb, nk i in.) }\end{array}$ & 9,6 & 52,1 \\
\hline oferta na w ramach zakupów grupowych & 4,4 & 59,9 \\
\hline aktywność stomatologa na portalach społecznościowych & 0,4 & 92,3 \\
\hline
\end{tabular}

Źródło: opracowanie własne.

Jak już zostało wspomniane najmniejszą rolę Internetowi w gabinecie przypisują pacjenci - wyniki badania IV. W tabeli 58 przedstawione są odpowiedzi na pytanie: „Jakie znaczenie przy wyborze gabinetu miało funkcjonowanie gabinetu w sieci?". I tylko możliwość umówienia się na wizytę mailem oraz

\footnotetext{
${ }^{140}$ Zakres dopuszczalnej informacji rynkowej o gabinecie określiła NRL w uchwale z 16 grudnia 2011 r. Natomiast wg ustawy o działalności leczniczej NZOZ może podać do wiadomości publicznej informacje o zakresie i rodzajach udzielanych świadczeń zdrowotnych, ale nie w formie reklamy.
} 
opinie innych pacjentów na temat dentysty w sieci zyskały uznanie ok. 10\% badanych.

$\mathrm{Na}$ zakończenie warto podkreślić, że rozwój komunikacji w Internecie pomiędzy podmiotami opieki zdrowotnej bądź pomiędzy placówkami ochrony zdrowia a pacjentami postępuje szybko ${ }^{141}$ i lekarze dentyści nie powinni lekceważyć tego kanału komunikacji z pacjentami.

\section{REASUMPCJA}

Gabinet stomatologiczny, jako podmiot działający na rynku, występuje w licznych rolach np. usługodawcy, nabywcy materiałów stomatologicznych, organizacji uczącej się, pracodawcy i wszystkie one powinny być realizowane w optymalny sposób dla dobra funkcjonowania gabinetu, jako podmiotu zarobkującego. Dlatego - w warunkach zmieniającego się rynku usług stomatologicznych - przed lekarzem dentystą staje wyzwanie, by pogodzić etos pracy lekarza z biznesowymi funkcjami. A on sam, jako podstawowy zasób organizacji, ma sprostać wymaganiom rynku - w tym kontekście coraz większego znaczenia nabiera wiedza. G. Ross i J. Ross ${ }^{142}$ twierdzą, że kapitał ludzki jest źródłem powstawania wiedzy w organizacji - dostarcza know-how i instytucjonalną wiedzę, która ma wartość dla firmy. Nie bez powodu zatem powszechną staje się myśl, że prawdziwa wartość organizacji zawiera się przede wszystkim w „sile” umysłów jej pracowników, która zapewnia przedsiębiorstwu funkcjonowanie w warunkach zmian, a także wykorzystanie zmienności jako szansy dla własnego rozwoju ${ }^{143}$. Zgodnie z propozycją M.E. Portera wszelkie prorynkowe działania ${ }^{144}$ lekarza dentysty ( $\mathrm{w}$ miejsce jedynie stricte medycznych) można uznać za przedsiębiorcze. Bardziej wymagające stanowisko zajmuje P.F. Drucker, twierdząc, że przedsiębiorca-innowator w sposób celowy poszukuje zmian, systematycznie analizuje możliwości (zewnętrzne i wewnętrzne), jakie zmiany mogą dać w funkcjonowaniu gabinetu, ale i to podejście znajduje swoją praktyczną realizację w wybranych gabinetach stomatologicznych.

I.M. Kirzner jako konieczny w funkcjonowaniu podmiotu na rynku uznaje element przedsiębiorczości zawarty w ludzkim działaniu w kategoriach czujności

\footnotetext{
${ }^{141}$ Sitting D.F., Results of a content analysis of electronic messages (email) sent between patients and their physicians, "BMC Medical Informatics and Decision Making", 2003 nr 3, s. 11 i nast.

${ }^{142}$ Ross G., Roos J., Measuring Your Company's Intellectual Performance, "Long Range Planning" 1997, t. 30, nr 6, s. 416.

${ }^{143}$ Skuza B., Zarzadzanie kapitatem intelektualnym na przykładzie Grupy Skania, w: Wawrzyniak B. (red.) Zarzadzanie wiedza w przedsiębiorstwie, Wyd. WSzPiZ im. L. Koźmińskiego, Warszawa 2003, s. 197.

${ }^{144}$ Biorąc pod uwagę fakt, iż działania w gabinetach stomatologicznych są najczęściej podejmowane w sposób stopniowy, to można mówić o przedsiębiorczości ewolucyjnej.
} 
na informację, a nie samo jej posiadanie: „Przedsiębiorca jest osobą, która najmuje usługi czynników produkcji. Wśród nich mogą być osoby o pełniejszej wiedzy na temat rynkowej informacji, ale fakt, że ci zatrudnieni posiadacze informacji sami jej nie wykorzystali, pokazuje, iż wiedza ta, być może w najbardziej prawdziwym znaczeniu, posiadana jest nie przez nich, ale przez tego, kto ich wynajmuje. To właśnie on 'wie', kogo zatrudnić, 'wie', gdzie znaleźć ludzi posiadających informacje rynkowe potrzebne do zlokalizowania możliwości zysku. Mimo że sam nie posiada danych, znanych tym, których wynajmuje, zatrudniający przedsiębiorca mimo to 'zna' te dane, w takim sensie, że jego czujność - jego wiedza, gdzie szukać informacji zdominowała bieg wydarzeń." ${ }^{145}$ Lekarze dentyści i studenci wiedzę w obszarze stricte medycznym traktują jako główny atut gabinetu, a kwalifikacje menedżerskie lekarza, jako ważny atrybut współczesnego gabinetu uznało 10,71\% praktyków zawodu i $18,75 \%$ - studentów.

Dualny charakter większości gabinetów stomatologicznych - wymagający myślenia i działania w kategoriach etyki lekarskiej i zgodnie z rachunkiem ekonomicznym, sprawia, że szczególnego znaczenia w funkcjonowaniu gabinetów nabierają wartości, które są spoiwem, łączącym uniwersalne ludzkie potrzeby i aspiracje, altruistyczne postawy wobec pacjentów z celami organizacji ${ }^{146}$. Zgodność celów wynikająca z podobieństwa uznawanych wartości jest również warunkiem kooperacji - człowiek, jako istota złożona uruchomia swoją energię i uzdolnienia, tylko w określonych warunkach (teoria McGregora). Tylko w korzystnym klimacie psychologicznym możliwe staje się wyzwolenie pomysłowości i twórczej inicjatywy jednostek. To kolejna przesłanka wskazująca na łączność ekonomii i aksjologii w gabinecie stomatologicznym - motywacja wewnętrzna, wynikająca ze spójności wartości i celów, jest silniejsza niż motywacja zewnętrzna ${ }^{147}$. Tak więc spójne wewnętrznie wartości stomatologa, stanowią nowy, ważny element budowania przewagi konkurencyjnej.

Ciągłe dążenie do osiągnięcia stanu równowagi lekarsko-ekonomicznej jest wyzwaniem, stającym przed współczesnymi dentystami. Aby ocenić, jak stomatolodzy oceniają swoje osiągnięcia $\mathrm{w}$ tym zakresie, zadano im pytanie: „Czy lekarz dentysta osiagnąt sukces zawodowy?”. Sukces został zdefiniowany, jako utrzymywanie równowagi pomiędzy wewnętrzną (związaną z rozwojem osobistym, pomaganiem innym) i zewnętrzną (związaną z docenianiem przez innych, statusem i wynikiem finansowym podejmowanych działań) motywacją

\footnotetext{
${ }^{145}$ Kirzner I.M., Konkurencja ... op. cit., s. 70.

${ }^{146}$ Stachowicz-Stanuch A., Potęga wartości. Jak zbudować nieśmiertelna firmę, Wydawnictwo Helion, Gliwice 2007, s. 84 i nast.

${ }^{147}$ George B., Sims P., McLean A., Mayer D., Przywództwo oparte na autentyczności, "Harvard Business Review”, 2007 nr 12 (58), s. 118.
} 
oraz osiąganymi efektami wykonywanego zawodu. Rozkład odpowiedzi - z uwęględnieniem płci respondentów - przedstawiony jest w tabeli 59.

Tabela 59. Sukces zawodowy lekarza dentysty a jego płeć

\begin{tabular}{|l|c|c|c|}
\hline $\begin{array}{c}\text { Czy dentysta osiągnął sukces } \\
\text { zawodowy? }\end{array}$ & $\begin{array}{c}\text { Ogółem } \\
\mathbf{N = 1 6 7}\end{array}$ & $\begin{array}{c}\text { Kobiety } \\
\mathbf{N = 1 3 7}\end{array}$ & $\begin{array}{c}\text { Mężczyźni } \\
\mathbf{N = 3 0}\end{array}$ \\
\hline Tak & $53,29 \%$ & $51,8 \%$ & $58,62 \%$ \\
\hline Nie & $1,80 \%$ & $2,26 \%$ & $0 \%$ \\
\hline jeszcze nie & $23,35 \%$ & $24,06 \%$ & $20,69 \%$ \\
\hline nie wiem & $21,56 \%$ & $21,80 \%$ & $20,69 \%$ \\
\hline
\end{tabular}

Źródło: opracowanie własne na podstawie przeprowadzonych badań.

Nieco więcej niż połowa respondentów odpowiedziała, że tak; przy czym mężczyźni byli bardziej zdecydowani w tej kwestii, niż kobiety. Jeden na czterech badanych uznał, że nie osiągnął sukcesu (przeważały optymistyczne odpowiedzi: ,jeszcze nie"), a jeden na pięciu nie potrafił odpowiedzieć na to pytanie. Te ambiwalentne uczucia mogą być wyrazem $\mathrm{m}$. in. trudności w pogodzeniu dwóch ról: lekarza dentysty i przedsiębiorcy. Co znalazło odzierciedlenie, gdy odpowiedzi zostały przefiltrowane przez kategorię ,poczucia zagrożenia związanego z przechodzeniem pacjentów do innego gabinetu":

- wśród najliczniejszej grupy respondentów badania I - lekarzy, którzy deklarowali, że nie czują takiego zagrożenia $61,9 \%$ odpowiedziało, że osiągnęło sukces zawodowy, 21,9\% - że jeszcze nie, a 16,2\% - że ,nie wie" (znamienne jest, że w tej grupie nikt nie wskazał odpowiedzi ,nie”);

- wśród dentystów, którzy czują zagrożenie związane z odpływem pacjentów - tylko 35,9\% stwierdziło, że osiągnęło sukces (i jest to najniższy odsetek spośród wyróżnionych do analizy podgrup) i - odpowiednio najwięcej wskazało - odpowiedź ,nie” 35,9\%, odpowiedź ,nie wiem” wskazało $28,2 \%$ badanych w tej podgrupie.

Ciekawy rezultat dało spojrzenie na odpowiedzi na to pytanie przez pryzmat pozycji zawodowej respondentów: 56,3\% lekarzy dentystów będących właścicielami gabinetu stwierdziło, że osiągnęli sukces, wobec 38,7\% lekarzy wykonujących zawód w charakterze pracownika; odpowiedzi ,jeszcze nie" udzieliło 20\% właścicieli gabinetów i 38,7\% pracowników. Grupa lekarzy dentystów będących pracownikami jest zbyt mała, by uogólniać wnioski, niemniej jednak wydaje się, że praca „na swoim” jest dodatkowym źródłem poczucia spełnienia w wykonywanym zawodzie. 


\title{
ROZDZIAŁ IV \\ BUDOWANIE RELACJI Z KLIENTAMI
}

\author{
„Sukces firmy zależy od \\ osiagnięcia strategicznej przewagi \\ i dostarczenia konsumentom \\ więcej wartości i satysfakcji, \\ niż czynia to konkurenci."
}

H. Szulce ${ }^{1}$

\section{ORIENTACJA NA KLIENTA}

$\mathrm{Na}$ gruncie literatury z zakresu marketingu prowadzona jest dyskusja na temat potrzeby wyraźnego odróżniania marketingowej oraz rynkowej orientacji podmiotów (i jednoczesnego postrzegania tej drugiej jako „rozwinięcia”, czy też „,doskonalszej, bardziej adekwatnej do aktualnych warunków działania” wersji orientacji marketingowej ${ }^{2}$ ). I. Escher wskazuje następujące argumenty zwolenników wyodrębniania tych dwóch terminów ${ }^{3}$ : w organizacji zorientowanej marketingowo główna odpowiedzialność za realizację procesu wdrażania filozofii marketingu spoczywa na pracownikach jednostek marketingowych (specjalnie powołanych i często lokowanych - dla podkreślenia dominującej ich roli w kształtowaniu polityki rynkowej organizacji - na wyższych szczeblach w hierarchii organizacyjnej), tymczasem w organizacji zorientowanej rynkowo ta odpowiedzialność spoczywa na wszystkich pracownikach organizacji. W świetle zaproponowanego rozróżnienia, można stwierdzić, że powodzenie procesu wdrażania reguł koncepcji marketingowej w podmiocie zorientowanym rynkowo (a takim powinien być komercyjny gabinet stomatologiczny) należy upatrywać w postawach (i w wynikających $\mathrm{z}$ nich zachowaniach) wszystkich jego członków ${ }^{4}$.

W przedstawionym kontekście można mówić o koniecznej rynkowej orientacji gabinetów stomatologicznych (por. punkt 1.3. w I rozdziale), gdyż od pracowników gabinetu - mających kontakt z pacjentem (a nie tylko od lekarza dentysty, czy osób odpowiedzialnych w klinice stomatologicznej „za marketing”), zależy praktyczna realizacja marketingu relacji. Swoimi umiejętnościami, zachowaniem, sposobem komunikowania z pacjentami, dążeniem do wprowa-

\footnotetext{
${ }^{1}$ Szulce H., Otoczenie firmy i jego wptyw na zarzadzanie marketingowe przedsiębiorstwem”, w: Mruk H., Pilarczyk B., Szulce H., Marketing. Uwarunkowania i instrumenty, Wyd. AE w Poznaniu, Poznań 2007, s. 28.

${ }^{2}$ Escher I., Możliwe sposoby kształtowania oraz utrwalania pozytywnego kierunku marketingowej postawy pracowników, „Marketing i Rynek” 2010, nr 2, s. 9.

${ }^{3}$ Ibidem s. 9.

${ }^{4}$ Ibidem s. 10.
} 
dzenia swoistej równowagi medyczno-marketingowej w gabinecie, budują (lub nie) zaufanie pacjenta do usługodawcy, a w konsekwencji jego długookresowe zaangażowanie $w$ relację ${ }^{5}$. $Z$ tego względu na lekarzu dentyście (przedsiębiorcy, któremu zależy na utrzymaniu swojego przedsiębiorstwa zarobkowego na rynku w długim okresie), spoczywa obowiązek doskonalenia własnych działań i wpływania na działania personelu $\mathrm{w}$ wyniku doskonałości operacyjnej, którą M. Treacy i F. Weirsem definiują, jako ,jedną z dróg tworzenia wartości dla klienta, która w wyniku procesu planowania, przygotowania, wytworzenia pozwala na dostarczenia wyrobów/usług najbardziej ekonomicznych, przydatnych i najbardziej satysfakcjonujących"״ dla pacjenta. Można przyjąć, że doskonałość operacyjna to umiejętność tworzenia najwyższej wartości dla klientów, przejawiająca się $\mathrm{w}$ dostarczeniu usług przy możliwie niskim koszcie wytwarzania $\mathrm{z}$ najmniejszymi niedogodnościami $\mathrm{i}$ we właściwym czasie. Przyjęcie rynkowej orientacji w gabinecie wymaga ciągłego doskonalenia prowadzonego gabinetu, jako biznesu, pod kątem oczekiwań pacjentów. Wymaga podejmowania takich działań, jak m. in.?:

- stałe podnoszenie jakości usług (o czym była mowa w punkcie 1.3 drugiego rozdziału) z uwzględnieniem możliwości obniżania kosztów, jakie ponosi nabywca (np. czasu, niewygody),

- rozszerzanie zakresu pomocy udzielanej pacjentowi (np. w zakresie edukowania prozdrowotnego czy nawet z zakresu właściwych nawyków żywieniowych) i podnoszenie kompetencji pracowników w kierunku zwiększania ich zdolności do rozwiązywania specjalnych problemów pacjentów (np. postępowanie $\mathrm{z}$ pacjentem niepełnosprawnym, czy tzw. trudnym pacjentem),

- stosowanie innowacyjnych rozwiązań w odniesieniu do oferty usługowej, modyfikowanie pozostałych płaszczyzn usługi (poza jej rdzeniem) pod kątem indywidualizacji wymagań, jakich będzie oczekiwał pacjent.

\footnotetext{
${ }^{5}$ O konieczność łączenia troski o zaspokojenie potrzeb pacjentów w kategoriach behawioralnych z ekonomicznym podejściem pisze I. Rudawska w: Rudawska I., Szanse, granice i konsekwencje stosowania marketingu $w$ opiece zdrowotnej, w: Rudawska I., Urbańczyk E., Ekonomicznoorganizacyjne problemy zarzadzania jednostkami stużby zdrowia, „Studia i materiały Polskiego Stowarzyszenia Zarządzania Wiedzą", Bydgoszcz 2010, s. 241 i nast.

${ }^{6}$ Treacy M., Weirsem F., The Discipline of Market Leaders, Perseus Books, Nowy Jork, 1995.

${ }^{7}$ Penc J., Zarzadzanie w warunkach globalizacji, Difin, Warszawa 2003, s. 204.
} 
Orientacja na klienta, jako przedmiot badań, ma wybitnie interdyscyplinarny charakter - osadzona jest $\mathrm{w}$ wielu dyscyplinach naukowych, a w szczególności :

- ekonomii (w ramach której szczególnie ważnych inspiracji dla rozwoju orientacji na klienta dostarcza teoria użyteczności);

- naukach o zarządzaniu; ewolucja tych nauk eksponuje orientację na klienta, jako jeden ze swych kluczowych nurtów; widoczne jest to zarówno w ciągle wzbogacanej koncepcji TQM oraz $\mathrm{w}$ kierunkach nowelizacji normalizowanych systemów zarządzania (zwłaszcza zarządzania jakością i zarządzania środowiskowego), jak i ewolucji marketingu od tradycyjnego w kierunku marketingu partnerskiego,

- a także w zyskujących coraz większe zainteresowanie modelach doskonałości i w ewolucji logistyki (zwłaszcza w kategorii łańcuchów wartości i dostaw);

- towaroznawstwie jako nauce o jakości towarów, dyscyplinie nauk ekonomicznych i jednocześnie interdyscyplinarnym łączniku tej dziedziny z naukami przyrodniczymi, technicznymi, chemicznymi oraz z zakresu fizyki;

- naukach psychologicznych, a zwłaszcza w - mającej coraz bardziej ugruntowane fundamenty teoretyczne - psychologii konsumenta/klienta, kreującej coraz więcej modeli potrzeb i modeli psychologicznych zachowań klienta oraz podstawy psychologiczne dla zarządzania relacjami z klientem.

Ta różnorodność dyscyplin zajmujących się problematyką orientacji na klienta daje w efekcie możliwość szerokiego traktowania tego pojęcia i wykorzystywania różnych podejść i narzędzi w praktycznej jej realizacji.

Zmiany zachodzące w funkcjonowaniu podmiotów opieki zdrowotnej (m. in. postępujący proces prywatyzacji i rosnąca konkurencja) sprawiają, że pacjent jest postrzegany nie tylko przez pryzmat jego problemów zdrowotnych, ale również przez pryzmat jego możliwości ekonomicznych - jako nabywca usługi, który bezpośrednio lub pośrednio ${ }^{9}$ (ze środków z NFZ) przyczynia się do wpływu środków finansowych do kasy gabinetu lekarskiego. Dlatego orientacja

\footnotetext{
${ }^{8}$ Por. Nieżurawski L., Pawłowska B., Witkowska J., Satysfakcja klienta: strategia - pomiar zarzqdzanie, Wydawnictwo Naukowe Uniwersytetu im. M. Kopernika, Toruń 2010, s. 34 i nast.; Borys T., Klient jako „poczatek” $i$ „koniec” prowadzonej działalności, w: Borys T., Rogala P., Orientacja na klienta jako kryterium doskonatości, Prace Naukowe UE we Wrocławiu, nr 151, Wyd. UE, Wrocław 2011, s. 44.

${ }^{9}$ Z raportu „Diagnoza społeczna 2011” wynika, że w 2011 r. 91,5\% gospodarstw domowych korzystało z opieki zdrowotnej finansowanej ze środków publicznych, a 49,1\% wykorzystywało również środki prywatne (podczas gdy np. w roku 2003 odsetek ten wynosił 35,6\%, a w 2007 44\%). W 2011 r. abonament stanowił źródło finansowania opieki zdrowotnej dla 6,3\% gospodarstw domowych (wobec 4,9\% w 2000r). Por. www.diagnoza.com
} 
na indywidualnego nabywcę usług zdrowotnych pojawia się w wielu podmiotach opieki zdrowotnej. Istotna różnica między „zwykłym” klientem a pacjentem - konsumentem świadczenia zdrowotnego sprowadza się do tego, że klient może zrezygnować z zakupu (nie stanie się właścicielem kolejnej książki, nie kupi butów, nie skorzysta $\mathrm{z}$ usług pralni chemicznej itp.), a pacjent nie zrezygnuje z porady lekarza, gdyż przedmiotem konsultacji (istotą realizowanego świadczenia) jest jego zdrowie lub życie ${ }^{10}$. I tu pojawia się miejsce dla teorii agencji wraz $\mathrm{z}$ zagadnieniami kosztów transakcyjnych, która jest obszarem zainteresowania ekonomii instytucjonalnej (o czym była mowa w I rozdziale).

Jak już zostało wcześniej powiedziane stosunek lekarz - pacjent z zasady ma charakter asymetryczny ${ }^{11}$, dlatego lekarze powinni działać dla dobra pacjenta i traktować wszystkich pacjentów w sposób profesjonalny, wykorzystując swoje kompetencje, umiejętności i wiedzę oraz nie powinni angażować się emocjonalnie w sprawy pacjentów ${ }^{12}$. Jednak w praktyce można wskazać różnice interesów w relacji lekarz - pacjent, wynikające z odmiennych oczekiwań, różnic w poziomie wiedzy, a często i sprzecznych celów pomiędzy laikiem a profesjonalistą (tzw. ,zderzenie perspektyw”). Źródła tego potencjalnego konfliktu tkwią $\mathrm{m}$. in. $\mathrm{w}$ rozbieżności pomiędzy oczekiwaniami i wyobrażeniami na temat pacjenta na styku „,dwóch kultur” - „kultury lekarza” i „kultury pacjenta”. Lekarz jest najczęściej stroną dominującą w hierarchicznym układzie organizacji

\footnotetext{
${ }^{10} \mathrm{Z}$ raportu „Diagnoza społeczna 2011” wynika, że w praktyce Polacy jednak rezygnują z tej usługi. Podstawowy powód to względy finansowe: Polacy rezygnują z zakupu leków - 18,1\%, leczenia zębów - 17,3\% (choć należy pamiętać, że osoby rezygnujące $\mathrm{z}$ wizyty odpłatnej mogą się leczyć w publicznej placówce zdrowia), wykonania protez - 6,6\%. Najrzadziej z wszelkich rodzajów usług zdrowotnych rezygnują gospodarstwa osób pracujących na własny rachunek, a najczęściej gospodarstwa rencistów i utrzymujących się ze źródeł niezarobkowych. Więcej przeciętnie jest rezygnacji na wsi niż w miastach. Por. www.diagnoza.com

${ }^{11}$ Asymetria informacyjna pogłębia się jeśli pryncypał nie jest $\mathrm{w}$ stanie monitorować umiejętności (hidden characteristics), zamiarów (hidden intention), wiedzy (hidden knowledge) i działań agenta (hidden action), jak to ma miejsce m. in. w usługach zdrowotnych. Informacji tych pryncypał potrzebuje do określenia sposobu i wysokości zapłaty za wysiłek włożony przez agenta w wykonanie zlecenia. T.E. Getzen przyznając, że pacjent - udający się do lekarza - nie posiada wiedzy, czego tak naprawdę potrzebuje, ani ile to powinno kosztować; podkreśla, że choć informacje, którymi dysponuje lekarz również nie są doskonałe, to i tak są o wiele lepsze od tych, które może zdobyć pacjent. Teoretycznie można przyjąć, że dochodzi do sytuacji, w której agent wybiera łatwiejsze działania do wykonania, a twierdzi, że wykonał trudniejsze, czego pryncypał nie jest w stanie stwierdzić (rodzaj pokusy nadużycia ${ }^{11}$ ) i opłaca droższą procedurę. W tym kontekście widać, jak ważna jest etyka lekarska i etyka biznesu oraz rola zaufania w zapobieganiu nieprawidłowościom na płaszczyźnie lekarz - pacjent (a także powstającym w systemie ochrony zdrowia w sytuacji pojawienia się trzeciej strony - płatnika np. NFZ).

Por. Saam N.J., Asymmetry in information versus asymmetry in Power: Implicite assumptions of agency theory?, "The Journal of Socio-Economics", 2007, nr 36, s. 825 i nast.; Getzen T.E., Ekonomika ... op. cit., s. 122.

${ }^{12}$ Gidens A., Socjologia, PWN, Warszawa 2004, s. 182.
} 
opieki zdrowotnej - jest ekspertem w dziedzinie medycyny (jego zawód posiada prestiż społeczny, a jego rola ma charakter stały). Natomiast pacjent jest zależny od lekarza, musi uznać swój brak kompetencji w dziedzinie medycyny i podporządkować się jego decyzjom. Jego rola ma charakter zmienny - dziś jest osobą chorą; a jutro - jako osoba zdrowa - będzie towarzyszył komuś z rodziny, jako pacjentowi. Zderzeniem perspektyw jest również fakt, że pacjent postrzega siebie i swoją chorobę, jako jedność, skupia się na sobie; a lekarz często zajmuje się „chorobą”, a nie człowiekiem ${ }^{13}$, ponadto musi brać pod uwagę wszystkich pacjentów. M. Sokołowska ${ }^{14}$ mówi jeszcze o tym, że pacjent - z reguły - chce, aby wizyta trwała jak najdłużej (choć w przypadku np. osób młodych, czy wizyt $\mathrm{w}$ gabinecie stomatologicznym reguła ta nie działa), natomiast lekarz musi przyjąć wielu innych oczekujących, czyli jego rolą jest pogodzenie interesu jednostki $\mathrm{z}$ interesem ogólnospołecznym.

Orientację na klienta można odnieść także do społecznej odpowiedzialności biznesu $^{15}$, w myśl której przedsiębiorstwo, funkcjonując jako system otwarty, wspólistnieje z otoczeniem, wpływa na nie i jest od niego zależne, dlatego aby skuteczna stała się działalność społecznie odpowiedzialna oraz nadzór nad prawidłowym funkcjonowaniem, przedsiębiorstwo musi wiedzieć wobec kogo jest odpowiedzialne. $\mathrm{Z}$ pomocą tej kwestii przychodzi teoria interesariuszy (stakeholders theory), której istota sprowadza się do konstatacji, że celem przedsiębiorstwa jest osiąganie równowagi między sprzecznymi celami do

\footnotetext{
${ }^{13}$ Asymetryczność roli lekarza w porównaniu z rolą pacjenta nie stoi jednak w sprzeczności z postulowaną zgodnością ich relacji. T. Parsons zakłada, że pacjent akceptuje swoją rolę i okazuje lekarzowi zaufanie, lekarz zaś wzajemnie rozumie potrzeby pacjenta i działa w jego interesie. Por. Parsons T., The sick ... op. cit., s. 257 i nast.

${ }^{14}$ Sokołowska M., Powstanie $i$ rozwój socjologii medycyny w Polsce, w: Sokołowska M., Hołówka J., Ostrowska A. (red.), Socjologia a zdrowie, PWN, Warszawa 1976, s. 94 i nast.

${ }^{15}$ Granice tego, co można przyjąć za społeczną odpowiedzialność biznesu są płynne, choć można wskazać podstawowe kategorie zobowiązań, a mianowicie: 1) zobowiązania ekonomiczne (ocenomic responsibilities) - związane są z charakterem przedsiębiorstwa, jako organizacji powołanej do realizacji celu/celów gospodarczych; wytwarzanie dóbr i usług zaspokajających potrzeby klientów, generowanie dodatniego wyniku finansowego, tworzenie miejsc pracy itp.; 2) zobowiązania prawne (legal responsibilities) - wynikają ze społecznego oczekiwania, że przedsiębiorstwo realizując cele gospodarcze, będzie działało w ramach obowiązujących przepisów; 3) zobowiązania etyczne (ethical responsibilities) - dotyczą oczekiwań wykraczających poza jedynie przestrzeganie prawa; oczekuje się, że przedsiębiorstwa będą podzielały normy i wartości obowiązujące w danym społeczeństwie i ich przestrzegały nawet wtedy, gdy nie są one usankcjonowane przepisami; 4) zobowiązania dyskrecjonalne (discrectionary responsabilities) - związane są z dodatkowymi działaniami przedsiębiorstw na rzecz społeczeństwa; działania te są dobrowolne i wykraczają poza to, co wynika z przestrzegania obowiązujących norm i wartości i stanowią wkład przedsiębiorstwa w rozwiązywanie problemów społecznych oraz poprawę warunków życia.

Por. Carroll A.B., A three dimensional conceptual model of corporate social performance, “Academy of Management Review”, 1979, vol. 4, nr 4.
} 
jakich dążą grupy interesariuszy, związane z działalnością przedsiębiorstwa ${ }^{16}$. W jej kontekście można wskazać na dualny podział działań, poprzez który organizacje realizują społeczną odpowiedzialność ${ }^{17}$ :

- działania zewnętrzne, podejmowane są przez organizację w stosunku do zewnętrznych interesariuszy, obejmują $\mathrm{m}$. in. ochronę środowiska naturalnego, wysoką jakość świadczeń, uwzględnianie lokalnego interesu społecznego, zaspokajanie potrzeb pacjentów ${ }^{18}$;

- działania wewnętrzne, które podejmowane są wewnątrz organizacji w stosunku do wewnętrznych interesariuszy, obejmują m. in.: humanizację warunków pracy, godziwe wynagradzanie pracowników, zapewnienie odpowiednich świadczeń socjalnych i satysfakcji z pracy. Interesariusze wewnętrzni przedsiębiorstw - dzięki swej pracy, wiedzy i kompetencjom - mogą w istotny sposób wpływać na wartość przedsiębiorstwa ${ }^{19}$. Dlatego w podmiotach opieki zdrowotnej - w ramach realizowanej strategii - pracownicy powinni być traktowani w sposób podmiotowy tj. z uwzględnieniem ich potrzeb i oczekiwań oraz optymalnym wykorzystaniem ich pracy zgodnie z celami placówki ${ }^{20}$.

\footnotetext{
${ }^{16}$ Sokołowska A., Społeczna odpowiedzialność małego przedsiębiorstwa - w kierunku uczciwego traktowania klienta, w: Borys T., Rogala P., Orientacja na ... op. cit., s. 567; Borys T., Klient jako ... op. cit., s. 52 i nast.

${ }^{17}$ Por. Filek J., Spoteczna Odpowiedzialność Biznesu. Tylko moda czy nowy model prowadzenia działalności gospodarczej? Urząd Ochrony Konkurencji i Konsumentów, Kraków 2006, s. 4; Kopycińska D., Koncepcja społecznej odpowiedzialności firmy - poezja teorii $i$ prozy życia, w: Gacparski W., Dietl J. (red.), Etyka biznesu w dziataniu. Doświadczenia i perspektywy, Wydawnictwo Naukowe PWN, Warszawa 2001, s. 186 i nast.

18 Odpowiedzialne społecznie działania mikro i małego przedsiębiorstwa wobec klientów mogą przejawiać się w: 1) traktowaniu klientów uczciwie i z szacunkiem, 2) działalności zgodnej z poszanowaniem praw konsumenta, 3) ochronie danych i prywatności klienta, 4) edukowaniu klientów, 5) oferowaniu klientom produktów (towarów i usług) o najwyższej jakości, 6) terminowości i rzetelności w realizacji zamówień, 7) dbałości o zdrowie i bezpieczeństwo klientów, 8) profesjonalnej obsłudze i wspieraniu klientów, 9) rozbudowanym systemie obsługi posprzedażnej (w tym gwarancyjnej), 10) poszanowaniu godności człowieka w działaniach marketingowych, 11) jasnej, czytelnej i dostępnej informacji o ofercie, 12) personifikacji relacji z klientem. I w tym sensie gabinet stomatologiczny można nazwać przedsiębiorstwem społecznie odpowiedzialnym. Por. Sokołowska A., Spoteczna odpowiedzialność ... op. cit., s. 574.

${ }^{19}$ W kontekście placówek zdrowotnych pisali na ten temat: Frączkiewicz-Wronka A., Wronka M., Kotowski P., Koncentracja na zewnętrznym otoczeniu jednostki ochrony zdrowia - wyznaczanie kierunków działania przez przywódcę, w: Frączkiewicz-Wronka A., Austen-Tynda A. (red.), Przywództwo $w$ ochronie zdrowia. Idee $i$ instrumenty, Wolters Kluwer, Polska 2009, s. 77; Agyeman-Budu E.A., Wevaert F., Investing in health care management: a way to Explorer the future value Outlook of the health care sector, "Corporate governance" 2006, $\mathrm{nr}$ 4, s. 437.

${ }^{20}$ Bartkowiak G., Geneza i teoretyczna podstawa zarzadzania zasobami ludzkimi, w: Dobska M., Rogoziński K. (red.), Podstawy zarzadzania ... op. cit., s. 316 i nast.
} 
Podsumowując, można zauważyć, że na współczesnym rynku coraz trudniej uzyskać i utrzymać przewagę konkurencyjną jedynie poprzez jakość oferowanych produktów/usług. Coraz częściej nabywca bierze pod uwagę cały zestaw korzyści oferowanych przez sprzedawcę - wiązkę korzyści, na którą oprócz podstawowego produktu czy usługi składa się szereg innych elementów; źródłem tych wartości staje się orientacja na klienta, wyrażona m. in. w odpowiedniej obsłudze klienta. Obsługę klienta często rozpatruje się na trzech płaszczyznach $^{21}$ :

- jako określone działania - są to szczególne zadania, które podmiot musi wykonać, aby zaspokoić potrzeby klienta (np. obsługa reklamacji),

- jako pomiar wykonania działań - bierze się pod uwagę określone mierniki realizacji wyników działań (np. odsetek zamówień zrealizowanych terminowo),

- jako filozofię - istotna jest ranga zobowiązania (za które odpowiedzialny jest cały podmiot), polegającego na zapewnieniu klientowi satysfakcji dzięki możliwie najlepszej obsłudze.

Powyższe spojrzenie na obsługę klienta, pozwala na zdefiniowanie marketingowego punktu widzenia orientacji na klienta - J.J. Lamin robi to w następujący sposób: orientacja na klienta oznacza „dążenie do zrozumienia potrzeb klienta, zaangażowanie się $w$ tworzenie wartości na jego rzecz i antycypowanie problemów nowych klientów"22. To syntetyczne podejście pozwala na wskazanie osiąganych przez przedsiębiorstwo określonych korzyści, wśród których można wymienić: efektywne zaspokajanie potrzeb klientów (aspekt ekonomiczno-finansowy), wykorzystywanie zadowolenia klientów w perspektywie długookresowej (aspekt rynkowo-strategiczny), a w przypadku podmiotów opieki zdrowotnej dodatkowo: holistyczne traktowanie pacjenta (i jako chorego i jako nabywcę świadczenia).

${ }^{21}$ Coyle J., Bardi E., Langley C.J., Zarzadzanie logistyczne, PWE, Warszawa 2002, s. 155.
${ }^{22}$ Lamin J.J., Strategiczne zarzadzanie marketingowe, PWN, Warszawa 2001, s. 87. 


\section{ISTOTA MARKETINGU RELACJI}

\subsection{EWOLUCJA MARKETINGU - ZARYS ZAGADNIENIA}

Zmiany ${ }^{23}$ zachodzące $w$ myśleniu (i pisaniu) o marketingu i w jego rynkowej roli $\mathrm{w}$ ostatnich latach ${ }^{24}$ dobrze oddaje ewolucja definicji marketingu przedstawianej przez Amerykańskie Stowarzyszenie Marketingu (American Marketing Associattion). W 1985 r. marketing został określony, jako ,proces planowania i realizacji pomysłu, ceny, promocji i dystrybucji idei, produktów i usług w celu doprowadzenia do wymiany zaspokajającej cele i jednostek i organizacji”, a w 2007 r. - jako „działalność, zbiór instytucji i procesów tworzenia, komunikowania, dostarczania oraz wymiany ofert posiadających wartość dla klientów, odbiorców, partnerów oraz społeczeństwa jako całości” ${ }^{25}$. W definicji tej odchodzi się od traktowania marketingu jako funkcji organizacji oraz wiązania marketingu $\mathrm{z}$ podziałem na jednostki organizacyjne i lokowania go tylko w jednym dziale. Przyjęcie zwrotu „marketing jest działalnością” oznacza, iż nie jest on już traktowany jako funkcja organizacji, lecz jako działalność, w którą angażują się organizacje ${ }^{26}$, co oznacza „,upodmiotowienie” marketingu. Definicja nie precyzuje kto ma prowadzić „marketing”, dlatego można przyjąć, że każdy pracownik może być odpowiedzialny za jego realizację. Oczywiście do przełożonych/menedżerów/właścicieli będzie należało określenie strategii i kierunku działań, które będą realizowane, ale codzienne wdrażanie marketingu należy już do wszystkich pracowników. Ponadto w tym podejściu wyraźnie jest

\footnotetext{
${ }^{23}$ Zmiany zachodzące w filozofii marketingu G. Langley przedstawił w trzech etapach: 1) marketing masowy - charakteryzował się koncentracją na całym rynku w celu odpowiedzi na pytanie co do wielkości rynku na określony produkt; miał na celu wypromowanie produktu i marki oraz skłonienie potencjalnych konsumentów do zakupu; 2) marketing celowy - jego intencją było „,celowanie” do mniejszych segmentów klientów, którzy ewentualnie są zainteresowani zakupem, w porównaniu do obecnych nabywców na rynku, ich dochodów, zawodu, statusu rodzinnego itp.; 3) marketing relacji - wskazuje, że przedsiębiorstwa konkurujące powinny dążyć do pełnego zrozumienia i współpracy z nabywcami, odkrycia ich indywidualnych gustów, preferencji, potrzeb; przedsiębiorstwo musi spoglądać wewnątrz segmentów, aby zobaczyć, co każdy z klientów robi, jaka jest jego wartość i jak kształtują się koszty jego obsługi - firmy rozwijają się poprzez tworzenie długich relacji z tymi klientami, którzy mogą przynosić największe zyski. Por. Langley G., BIIA Relationship Marketing Conference - Information quality and Customer Marketing, $1997 \mathrm{nr} \mathrm{5,} \mathrm{s.} 424$.

${ }^{24}$ Przegląd paradygmatów i teorii $\mathrm{w}$ marketingu $\mathrm{w}$ ujęciu historycznym jest przedstawiony m. in. w: Sagan A., Paradygmaty w marketingu - próba syntezy, „Marketing i Rynek”, 2012, nr 11, s. 2 i nast.

${ }^{25}$ Por. Kamiński J., Nowa definicja marketingu AMA, „Marketing i Rynek”, 2009 nr 5, s. 7 i nast.

${ }^{26}$ Już w latach 90 . XX w. pojawiły się w literaturze przedmiotu tezy, że cele marketingu muszą być realizowane nie tylko w ramach funkcjonalnej komórki marketingowej, ale także na wszystkich poziomach firmy dzięki koordynacji interfunkcjonalnej. Uznano ją za jeden z trzech - obok orientacji na klienta i konkurencję - komponentów orientacji rynkowej przedsiębiorstwa. Por. Lamin J.J., Strategiczne ... op. cit., s. 29 i nast.; Deshpande R., „Forseeing” marketing, ,Journal of Marketing”, 1999, vol. 63; Narver J.C., Slater S.F., The effect of a market orientation on business profitability, "Journal of Marketing", 1999, vol. 54.
} 
podkreślone znaczenie „elementu oferty” oraz jej wartości dla - szeroko pojętej grupy - klientów, co koresponduje - z rozwiniętym już w literaturze - podejściem kreowania i dostarczania wartości dla klientó $w^{27}$. Umieszczenie w nowej definicji sformułowania „wymiany ofert” spowodowało, że marketing stał się bardziej ,interakcyjny”. Podkreślona została tym samym rola dwóch stron wymiany w kształtowaniu ostatecznego efektu działań marketingowych (włączenie nabywcy w działania marketingowe podmiotu jest zgodne m. in. z wykorzystywaniem jego roli jako prosumenta). J. Kamiński wyraźnie stwierdza, że nowa definicja, poprzez odejście od postrzegania marketingu przez pryzmat organizacji dążącej do osiągnięcia korzyści, oddali marketing od nauk o zarządzaniu oraz powinna wpłynąć na odnowienie jego ściślejszych związków z ekonomią ${ }^{28}$. Czy tak się stanie? Trudno jednoznacznie rozstrzygać, ale można zgodzić się z tą wypowiedzią, że zwrócenie uwagi na „wymianę ofert" zbliża spojrzenie na marketing do teorii racjonalnego (nawet jeśli jest to ograniczona racjonalność) wyboru. Każda ze stron może zdecydować kto będzie dla niej partnerem. Dotyczy to również usług stomatologicznych, bo o ile lekarz dentysta musi przyjąć pacjenta z zagrożeniem życia, o tyle w innych sytuacjach może - w pewien ograniczony sposób - wpływać na to kogo będzie leczył (np. nie podpisanie kontraktu z NFZ, to ukierunkowanie gabinetu tylko na pacjentów prywatnych). Wybór ma również pacjent - czeka w kolejce do stomatologa w gabinecie, który ma podpisany kontrakt z NFZ i „odbiera” należne świadczenia (ich charakterystyka może dotyczyć np. rodzaju materiału stosowanego do leczenia), albo korzysta z usługi prywatnie (wówczas m. in. zasobność jego portfela wpływa na wybór metody leczenia) ${ }^{29}$.

Ewolucję marketingu widać również w zmianie filozofii - guru współczesnego marketingu - Ph. Kotlera, który w latach 90 . XX w. twierdził, że „utrzymanie klienta $^{30}$ jest ważniejsze niż jego przyciągnięcie. Sprawą kluczową jest tutaj zadowolenie klienta" ${ }^{, 31}$, a dziesięć lat później położył nacisk na tworzenia war-

\footnotetext{
${ }^{27}$ Por. Doyle P., Marketing ... op. cit.; Baker S., New Consumer Marketing: Managing a Living Demand System, West Sussex, England, John Wiley \&Sons, 2003; Kotler Ph., Marketing, Rebis, Warszawa 2005; Szymura-Tyc M., Marketing we wspótczesnych procesach tworzenia wartości dla klienta i przedsiębiorstwa, Wyd. AE w Katowicach, Katowice 2005.

${ }^{28}$ Kamiński J., Nowa definicja ... op. cit., s. 12.

${ }^{29} \mathrm{~W}$ rozdziale III w punkcie 3.2 pokazano, że biorąc pod uwage rozmiar finansowania usług stomatologicznych przez NFZ, wybór ten jest pozorny dla większości Polaków (którzy z prywatnych środków finansują 80\% świadczeń).

${ }^{30}$ Odpowiednia obsługa klienta (customer service), jako jeden z elementów marketingu-mix, pozwala „poza” produktem zasadniczym na utrzymanie klienta. Ph. Kotler rozwinął to podejście, wprowadzając nowy paradygmat 4C: 1) wartość dla klienta lub rozwiązanie dla klienta (customer value or customer solution), 2) koszt klienta (customer cost), 3) wygoda nabycia (convenience), 4) komunikacja, czyli dialog z klientem (communication). Por. Kotler Ph., Marketing, Dom ... op. cit., s. 16 i nast.

${ }^{31}$ Kotler Ph., Marketing, Gebethner\&S-ka, Warszawa 1994, s. 18.
} 
tości dla klienta: „celem marketingu nie jest maksymalizacja satysfakcji klienta(...) jest tworzenie wartości dla klienta w zamian za zysk" ${ }^{\prime 32}$. Tym samym klient jest dla przedsiębiorstwa źródłem biznesu z jednej strony i zasobem $\mathrm{z}$ drugiej $^{33}$. Podobne stanowisko zajął P. Doyle, mówiąc, że ,marketing jest procesem zarządczym ukierunkowanym na maksymalizację zwrotów dla udziałowców poprzez utrwalenie relacji z cenionymi klientami i tworzenie przewagi konkurencyjnej" ${ }^{34}$.

XXI w. przyniósł kolejne nowe spojrzenia na rolę marketingu w funkcjonowaniu podmiotów rynkowych, jednym z nich jest dostarczanie doświadczeń klientowi. Zadaniem marketingu doświadczen ${ }^{35}$ jest dostarczenie przemyślanej mieszanki dóbr materialnych, usług oraz zapamiętywanych doświadczeń angażujących emocje, wiążących klientów z podmiotem ${ }^{36}$. To, że produkt jest dobry, to często zbyt mało, aby przyciągnąć uwagę konsumentów (stanowi warunek konieczny, ale niewystarczający, aby wyróżnić się na rynku ${ }^{37}$ ). W ofercie mieści

${ }^{32}$ Armstrong G., Kotler Ph., Saunders J., Wong V., Marketing. Podręcznik europejski, PWE, Warszawa 2002, s. 53.

${ }^{33}$ Takie postrzeganie klienta można odnieść również do usług stomatologicznych, w których indywidualny nabywca świadczenia przynosi dochód gabinetowi, wpływając jednocześnie na działania podejmowane przez lekarza dentystę (np. w zakresie wyboru rodzaju szkoleń doskonalących umiejętności).

${ }^{34}$ Doyle P., Marketing ... op. cit., s. 35.

${ }^{35} \mathrm{Z}$ badań, przeprowadzonych przez C. Shawa i J. Ivensa, wynika, że $85 \%$ zarządzających wyższego szczebla zgodziło się ze stwierdzeniem, że wyróżnienie się na rynku jedynie poprzez tradycyjne elementy nie jest wystarczającą strategią biznesową; a 95\% badanych stwierdziło, że to doświadczenie klienta stanie się nowym polem walki i źródłem trwałego wyróżniania. Por. Shaw C, Ivens J., Building Great Customer Experiences, Palgrave MacMillan, Basingstoke 2005, s. 2 i nast.

${ }^{36}$ Cortes R., Create emotional connections with consumers, "Caribbean Business", 30 September 2004, s. 41.

${ }^{37}$ Jednym z pierwszych ekonomistów, który zwrócił uwagę na to, że jakość produktu/usługi jest niewystarczającym elementem wpływającym na decyzje zakupowe klienta był J.M. Juran, który twierdził, że dla klienta nie jest przeznaczany produkt jako rzecz o określonych właściwościach, ale taki, który ma przydatność użytkową. Tym samym postawił w centrum uwagi przedsiębiorstwa klienta (a nie tylko dobrej jakości produkt/usługę) i jego oczekiwania. Kolejnym krokiem w postrzeganiu oferty dla klienta była teoria M.E. Portera, wg której każdy podmiot ma niepowtarzalny zbiór procesów, a w ich ramach działań, które przenikając się wzajemnie, tworzą specyficzny łańcuch, zdolny wytworzyć (bądź nie) taką, a nie inną wartość dla klienta (i taką wartością mogą być dostarczane emocje). W każdym z działań może być tworzona wartość cząstkowa (wartość dodana), która w połączeniu z innymi daje wartość dla klienta. Ph. Kotler zaproponował model kreowania wartości dla klienta. Postawienie klienta w centrum uwagi zmusza przedsiębiorstwo, do sprawdzenia, jakiej wartości klient oczekuje (jaką zaakceptuje, za jaką jest skłonny zapłacić) i dostarczenia mu jej. Ph. Kotler rozpatruje wartość jako użyteczność produktu i rozumie przez to pojęcie: 1) korzyści, jakie może przynieść produkt klientowi (oprócz samej wartości produktu, mogą to być: wartość usług związanych z produktem, wartość wkładu pracy pracowników, wartość wizerunku organizacji), 2) koszty, jakie musi ponieść klient w procesie nabywania produktu (m. in. koszty wydatkowania czasu, koszty wydatkowania energii czy koszty zaangażowania psychicznego). 
się również zaplanowane zaangażowanie emocjonalne klienta ${ }^{38}$ : ,,jest to kompletna propozycja wartości emocjonalnych i racjonalnych, stworzona i zarządzana dla całego doświadczenia klienta" "39 . Można zatem uznać, że marketing doświadczeń wiąże się z kreowaniem interakcji podmiotu rynkowego z klientem, które będą go angażować emocjonalnie ${ }^{40}$. W gabinecie stomatologicznym emocje często towarzyszą nabywcy świadczenia od początku kontaktu z podmiotem (np. stres, strach), dlatego ważnym staje się, aby nie były to jedynie emocje negatywne; aby przekształcać emocje (które pacjent doświadczył wcześniej i ,przynosi” ze sobą do gabinetu) o zabarwieniu negatywnym w pozytywne lub chociaż neutralne; a pacjenta, który przychodzi z neutralnym nastawieniem zachwycić. Dlatego aby właściwie zidentyfikować wszystkie punkty kontaktu pacjenta z gabinetem i poznać towarzyszące im emocje, pracownicy gabinetu powinni skupić się na ,rozłożeniu" na czynniki pierwsze procesu świadczenia usług medycznych i ,nadać doświadczeniom odpowiednią rangę, dokładnie taką, jaką nadaje im klient" (w praktyce chodzi o znalezienie odpowiedzi na pytanie: „Co tak naprawdę kupuje pacjent w danym gabinecie?” czy tylko produkt - licówki, czy też pozytywną wartość dla siebie w postaci lepszego samopoczucia z poprawy wyglądu $)^{41}$.

Dotychczas emocje stanowiły niedocenianą przez biznes sferę oddziaływania, który koncentrował się przede wszystkim na racjonalnej stronie człowieka. Jednak, jak wynika z badań G. Zaltmana, aż w 89\% wpływ na decyzje konsumenckie ma podświadomość ${ }^{42}$. Wywiera ona zatem wpływ dalece większy, niż można by przypuszczać, zważywszy na dominujące na rynkach praktyki marke-

Por. Juran J.M., Gryna F.M., Jakość - projektowanie, analiza, Wydawnictwo Naukowo-Techniczne, Warszawa 1974, s. 23 i nast.; Porter M.E., Competitive ... op. cit.; Kotler Ph., Marketing - analiza ... op. cit., s. 85; Kotler Ph., Marketing Management, Prentice Hall, Inc., New Jersey 1994, s. 290.

38 Badania R.A. Westerbrook wskazują, że znaczące emocjonalnie doświadczenia, zwiększają skłonność klientów do rekomendacji produktów. Por. Westerbrook R.A., Produkt/consumptionbased affective responses and postpurchase processes, "Journal of Marketing Research", August 1987, vol. 24, s. 267.

Natomiast B.J. Pine i J.H. Gilmore podkreślają, że doświadczenie, jako propozycja wartości dla klienta różni się tak znacząco od oferty usługowej, jak usługi od produktów materialnych. Zakup usług wiąże się z nabyciem niematerialnego produktu, pewnego zbioru działań na rzecz klienta. Kupując doświadczenia, konsument płaci za „spędzenie czasu, ciesząc się serią zapadających w pamięć wydarzeń, które wystawia - jak w sztuce teatralnej - przedsiębiorstwo, angażując go w osobisty sposób". Por. Pine B.J., Gilmore J.H., The Experience Economy: Work is Theatre and Every Business a Stage, "Harvard Business School Press", Boston, 1999, s. 2.

${ }^{39}$ Carbone L.P., Clued In: How to Keep Customers Coming Back Again and Again, FT Prentice Hall, Upper Saddle River, Nowy Jork 2004, s. 28.

${ }^{40}$ Marconi J., Creating the Marketing Experience. New Strategies for Building Relationships with Your Target Market, Thomson, Mason, 2005, s. 51.

${ }^{41}$ Bernacik M., CEM - nowy wymiar orientacji na klienta, „Modern Marketing”, 2004 nr 1, s. 41.

${ }^{42}$ Zaltman G., How Customer Think: Essentials Insights into the Mind of the Market, "Harvard Business School Press", Boston 2003, s. 9. 
tingowe. G. Zaltman twierdzi, że ,materialne atrybuty produktów i usług mają znacząco mniejszy wpływ na preferencje konsumentów, niż podświadome zmysłowe i emocjonalne elementy wynikające z całkowitego doświadczenia" "43. Można przyjąć założenie - zgodnie z behawioralną teorią perspektywy - że w usługach stomatologicznych wpływ ten może być większy ze względu na świadomy strach odczuwany przez pacjentów. W badaniu IV 25,3\% pacjentów zadeklarowało, że boi się chodzić do dentysty (w grupie mężczyzn 30 lat i więcej ten odsetek wyniósł 35,6\%), a 13,7\% nie potrafiło określić, czy boi się chodzić do stomatologa, więc można się spodziewać, że negatywne emocje lub problem z ich sprecyzowaniem może wpływać na decyzje nabywców. Z badania IV wynika, że odsetek osób, które się boją wizyt u stomatologa i wskazały odpowiedź, że w ciągu ostatnich pięciu lat nie były u stomatologa ani razu lub były raz był wyższy, niż osób, które nie boją się chodzić do dentysty. Jednak ze względu na zbyt małą liczebność tej grupy nie można uogólnić wniosków. Wynik ten może stanowić kierunek dalszych badań w zakresie wywierania wpływu na decyzje nabywców przez usługodawców (z wykorzystaniem narzędzi marketingu).

Podsumowując, można przywołać słowa R. Kozielskiego, który twierdzi, że na współczesny marketing można spojrzeć z trzech perspektyw ${ }^{44}$ :

- kulturowej - skoncentrowanej na filozofii prowadzenia biznesu (budowaniu kultury organizacyjnej opartej na innowacyjności, skłonności do dzielenia się wiedzą, uczenia się rynku i uwzględniania roli nabywcy w działaniach organizacji);

- $\quad$ strategicznej - skupionej na posiadanych zasobach i ich potencjale rozwojowym, określeniu rynku działania, przyszłych źródłach przewagi konkurencyjnej itp.;

- operacyjnej - odnoszącej się do budowania, komunikowania i dostarczania wartości dla interesariuszy organizacji; umiejętności realizacji codziennych działań w efektywny sposób.

Wszystkie wymienione płaszczyzny umożliwiają tworzenie przewagi konkurencyjnej podmiotu, dlatego stały się przedmiotem zainteresowania w przeprowadzonych badaniach.

\footnotetext{
${ }^{43}$ Smith S., Wheeler J., Managing the Customer Experience, FT Prentice Hall, Pearson Education, Londyn 2002, s. 56.

${ }^{44}$ Kozielski R. (red.), Wskaźniki marketingowe, Oficyna a Wolters Kluwer business, Warszawa 2011, wyd. IV zmienione, s. 23 i nast.
} 


\subsection{MARKETING RELACJI}

Do początku lat 90 . XX w. marketing traktowany był przez firmy świadczące usługi profesjonalne, jako temat tabu. Wszelkie działania pochodzące z koszyka narzędzi marketingu uważane były za nieetyczne, a wiele narzędzi „,klasycznego" marketingu-mix było i jest prawem zabronione do dziś (np. zakaz reklamy obowiązujący lekarzy czy prawników).

Trudności w prostej transpozycji narzędzi marketingu-mix na potrzeby usług doprowadziły do opracowania alternatywnych metod i narzędzi zastosowania filozofii marketingu. Alternatywny w stosunku do adaptacyjnego marketing relacyjny ${ }^{45}$ (w polskiej literaturze przedmiotu pojawiają się określenia: marketing relacji, marketing partnerski) został wprowadzony do literatury przedmiotu w latach $80 . \mathrm{XX}$ w. - wywodzi się z tzw. nordyckiej szkoły marketingu i ma swoje źródło w - opracowanym $\mathrm{w}$ tej szkole - marketingu interakcyjnym ${ }^{46}$. „Tradycyjny” marketing bierze „za cel” wybrane segmenty rynku, a marketing relacji $^{47}$ skupia się na procesach kreowania skutecznych, zadowalających i etycznych relacji między stronami procesu usługowego (dzięki koordynacji wszystkich aktywności przedsiębiorstwa), których efektem jest wspólne two-

${ }^{45} \mathrm{~W}$ nowym podejściu klasyczny marketing mix - 4P został zastąpiony paradygmatem 11c: 1) customer - rodzaj relacji, cele i strategia współpracy zależy od wymagań kooperujących stron; 2) categories - określenie kategorii produktów i usług dostarczanych klientowi; 3) capabilities wielkość i jakość zasobów niezbędnych do wytworzenia i dostarczenia klientowi oczekiwanej wartości; 4) cost, profitability and value - zwiększenie opłacalności klienta dla firmy (dzięki obniżeniu kosztów związanych z obsługiwaniem danego klienta lub stworzeniu nowych źródeł przychodów); 5) control of the contact to cash processes - nadzór i zarządzanie procesami związanymi z wymianą informacji oraz rozliczeniem i dostawą; 6) collaboration and integration wielowymiarowość kontaktów pomiędzy pracownikami firmy powinna być zintegrowana (w celu integracji działań klienta i dostawcy); 7) customization - tworzenie nowej wartości dla klienta wymaga zindywidualizowania produktów i usług oraz metod ich wytwarzania i dystrybucji; 8) communications, interaction and positioning - odbiorca jest jednocześnie klientem, partnerem i czynną stroną handlową, dlatego podmiot powinien plasować się w umyśle klienta oraz śledzić działa konkurencji z usług której mógłby skorzystać klient; 9) customer measurements - proces monitorowania opinii klientów na temat poziomu świadczonych usług oraz postępu w zacieśnianiu więzi z klientem jest niezbędny; 10) customer care - dbałość o klienta obejmuje tworzenie procesów dostarczania informacji i zarządzania nimi w czasie rzeczywistym, szkolenia, korygowanie błędów na podstawie informacji zwrotnych oraz usługi podnoszące wartość oferty dostarczanej klientowi; 11) chain of relationship - dzięki współpracy między ogniwami łańcucha (obejmujących powiązania wewnętrzne - pomiędzy pracownikami podmiotu oraz powiązania zewnętrzne $\mathrm{z}$ dostawcami i pośrednikami w kanałach dystrybucji) tworzona jest lepsza wartość dla ostatecznego klienta.

${ }^{46}$ Gummesson E., Letinen U., Grönroos Ch., Nordic Perspectives on Relationship Marketing, „European Journal of Marketing”, 1997, vol. 31 za: Chłodnicki M., Ustugi ... op. cit., s. 23.

47 Bardzo szczegółową analizę marketingowej koncepcji tworzenia relacji z klientami można znaleźć w: Rudawska E., Znaczenie relacji ... op. cit. 
rzenie wartości ${ }^{48}$. Próbą operacjonalizacji marketingu relacji w usługach profesjonalnych jest uwzględnienie wszystkich stosunków rynkowych (wewnętrznych i zewnętrznych) w jakie podmiot jest zaangażowany. Model relacji rynkowych A. Payne'a (tzw. model sześciu rynków) zawiera sześć obszarów budowania relacji ${ }^{49}$ :

- rynek wewnętrzny - tj. personel placówki;

- rynek dostawców materiałów i sprzętu;

- rynek pośredników - tj. NFZ, przedsiębiorców wykupujących abonamenty dla swoich pracowników;

- rynek instytucji wspierających np. banki, samorząd;

- rynek konkurentów,

- rynek pacjentów; na którym koncentruje się uwaga pracy.

W tabeli 60 zostały przedstawione przykłady definicji omawianego pojęcia.

Tabela 60. Pojęcie marketing relacji w świetle wybranych pozycji literatury przedmiotu

\begin{tabular}{|l|l|}
\hline \multicolumn{1}{|c|}{ Autor definicji } & \multicolumn{1}{|c|}{ Treść definicji } \\
\hline L.L. Berry & $\begin{array}{l}\text { Marketing relacji to tworzenie, utrzymywanie i wzbogacanie relacji z klientem. } \\
\text { Pozyskiwanie nowego klienta stanowi jedynie pierwszy krok w procesie } \\
\text { marketingu. }\end{array}$ \\
\hline Ch. Grönroos & $\begin{array}{l}\text { Marketing relacji to tworzenie, utrzymywanie i wzbogacanie więzi z klientami } \\
\text { i ich partnerami w taki sposób, aby cele obu stron zostały osiągnięte poprzez } \\
\text { obustronną wymianę i realizację poczynionych obietnic. Jego celem jest nie } \\
\text { tylko identyfikowanie i ustanawianie, utrzymywanie i wzmacnianie relacji } \\
\text { z udziałowcami podmiotu, ale również - kiedy to konieczne - kończenie relacji } \\
\text { z zyskiem, który zadowala wszystkie strony zaangażowane w relację. }\end{array}$ \\
\hline $\begin{array}{l}\text { V.A. Zeithaml, } \\
\text { M.J. Bitner }\end{array}$ & $\begin{array}{l}\text { Marketing relacyjny to filozofia prowadzenia biznesu, która skupia swoje } \\
\text { działania na zatrzymaniu i ulepszaniu relacji z dotychczasowymi klientami. }\end{array}$ \\
\hline $\begin{array}{l}\text { M. Christopher, } \\
\text { A. Payne, } \\
\text { D. Ballantyne }\end{array}$ & $\begin{array}{l}\text { Autorzy opisują marketing relacyjny, odwołując się do trzech kategorii pojęć: } \\
\text { jakości usługowego produktu, obsługi nabywcy i marketingu tradycyjnego. } \\
\text { Stwierdzili, że jego zadaniem jest budowanie więzi i zatrzymanie klientów. }\end{array}$ \\
\hline $\begin{array}{l}\text { J. Copulsky, } \\
\text { M. Wolf }{ }^{\mathrm{c}}\end{array}$ & $\begin{array}{l}\text { Marketing relacji to proces polegający na stworzeniu bazy danych o już } \\
\text { posiadanych oraz potencjalnych klientach i zbliżeniu się do nich za pomocą } \\
\text { zróżnicowanych, charakterystycznych dla każdego z nabywców informacji. } \\
\text { Wymaga prowadzenia analizy kosztów zdobycia i utrzymania każdego klienta } \\
\text { oraz długoterminowej oceny zbudowanych relacji. }\end{array}$ \\
\hline T. Cram ${ }^{\text {f }}$ & $\begin{array}{l}\text { Marketing relacji to konsekwentne stosowanie uaktualnionej wiedzy } \\
\text { o indywidualnych klientach dla zaprojektowania produktu/usługi, które jest } \\
\text { skomunikowane interaktywnie, celem rozwinięcia i kontynuowania wzajemnie } \\
\text { korzystnych więzi. }\end{array}$ \\
\hline $\begin{array}{l}\text { R.M. Morgan, } \\
\text { S.D. Hunt }\end{array}$ & $\begin{array}{l}\text { Marketing relacji dotyczy wszelkiej aktywności marketingowej, której celem } \\
\text { jest nawiązywanie, utrzymywanie i pogłębianie korzystnej wymiany wzajemnej. }\end{array}$ \\
\hline
\end{tabular}

${ }^{48}$ Gummesson E., Making relationship marketing operational, "International Journal of Service Industry Management”, 1994, t. 5, nr 5.

${ }^{49}$ Por. Payne A., Marketing ... op. cit., s. 55. 


\begin{tabular}{|c|c|}
\hline $\begin{array}{l}\text { N. Tzokas, } \\
\text { M. Saren }\end{array}$ & $\begin{array}{l}\text { Marketing relacji jest procesem planowania, rozwoju i pielęgnowania klimatu } \\
\text { więzi promującego dialog między firmą i jej klientami. Jego następstwem będzie } \\
\text { wpojenie wzajemnego zrozumienia i zaufania oraz respektowanie możliwości } \\
\text { każdej ze stron w zgodzie z ich rolami ustalonymi na rynku i w społeczeństwie. }\end{array}$ \\
\hline Ph. Kotler ${ }^{i}$ & $\begin{array}{l}\text { Marketing relacji buduje silne ekonomiczne, techniczne i społeczne więzi } \\
\text { między stronami, co obniża koszty zawierania transakcji i oszczędza czas. } \\
\text { Przeważnie zawieranie transakcji przestaje być wtedy negocjowane za każdym } \\
\text { razem i staje się przedmiotem rutynowego działania. }\end{array}$ \\
\hline $\begin{array}{l}\text { M. Rydel, } \\
\text { C. Ronkowski }\end{array}$ & $\begin{array}{l}\text { Marketing relacji oznacza koncepcję zarządzania i działania na rynku, wg której } \\
\text { skuteczność rynkowa firm zależna jest od nawiązywania partnerskich } \\
\text { stosunków z uczestnikami rynku. Koncepcja ta zakłada budowę związków } \\
\text { lojalnościowych z klientami i aliansów strategicznych z partnerami w biznesie. }\end{array}$ \\
\hline I.H. Gordon ${ }^{\mathrm{k}}$ & $\begin{array}{l}\text { Marketing relacyjny to proces identyfikacji i kreacji nowej wartości z każdym } \\
\text { klientem, a następnie dzielenie się korzyściami w ramach układu partnerskiego, } \\
\text { obejmującego cały okres aktywności nabywczej klienta. Jego podstawą jest } \\
\text { zrozumienie znaczenia trwałej współpracy między dostawcami a wybraną grupą } \\
\text { klientów oraz kierowanie nią w celu tworzenia wspólnej wartości po to, aby } \\
\text { następnie się nią podzielić. Mechanizmem umożliwiającym efektywną } \\
\text { współpracę są wzajemne powiązania i dostosowanie struktur organizacyjnych } \\
\text { partnerów. }\end{array}$ \\
\hline K. Fonfara ${ }^{I}$ & $\begin{array}{l}\text { Koncepcja marketingu kładzie nacisk na proces zarządzania, tzn. tworzenia, } \\
\text { rozwoju i utrzymywania powiązań firmy z innymi podmiotami. Eksponuje } \\
\text { bezpośredni, interakcyjny, dwu- i wielostronny charakter kontaktów między } \\
\text { sprzedającym a nabywcą oraz innymi podmiotami w procesie tworzenia oraz } \\
\text { dostawy produktów i usług. Dodatkowo podkreśla ona trwały charakter } \\
\text { powiązań między partnerami wymiany. Stworzenie i utrzymanie tych powiązań } \\
\text { wymaga czasu, wysiłku i pieniędzy. }\end{array}$ \\
\hline K. Rogoziński ${ }^{\mathrm{f}}$ & $\begin{array}{l}\text { Marketing relacji oznacza mobilizację personelu, mającą na celu uczynić } \\
\text { z nabywcy nie tylko współtwórcę wartości - produktu, ale związać go na stałe } \\
\text { z firmą. }\end{array}$ \\
\hline R. Furtak ${ }^{\mathrm{m}}$ & $\begin{array}{l}\text { Marketing relacji oznacza koncepcję zarządzania i działania na rynku, według } \\
\text { której powodzenie rynkowe firmy zależy od nawiązywania partnerskich } \\
\text { i długookresowych stosunków z uczestnikami rynku. }\end{array}$ \\
\hline
\end{tabular}

Źródło: opracowanie własne na podstawie: ${ }^{a}$ Berry L.L., Relationship Marketing, w: Berry L.L., Shostack G.L., Upah G.D., Emerging Perspectives on Services Marketing, American Marketing Association, Chicago 1983, s. 26; ${ }^{\mathbf{b}}$ Grönroos Ch., Service Management and Marketing. Managing the Moments of Truth in Service Competition's, Free Press, Lexington 1990, s. 138; Grönroos Ch., From Marketing-mix to Relationship Marketing: Towards a Paradigm Shift In Marketing, „Management Decisions” 1994, nr 3; c Zeithaml V.A., Bitner M.J., Service Marketing, The McGraw-Hill Companies Inc., Nowy Jork, 1996, s. 171; ${ }^{\text {d }}$ Rogoziński K., Nowy marketing ... op. cit., s. 24, ${ }^{\mathrm{e}}$ Copulsky J.R., Wolf M.J., Relationship Marketing. Positioning for the Future, "Journal of Business Strategy", 1990, nr 7-8, vol. 11, s. 17; ${ }^{\mathrm{f}}$ Cram T., The Power of Relationship Marketing, Pitman Publishing, Londyn 1994, s. 19; ${ }^{\mathbf{g}}$ Morgan R.M., Hunt S.D., The Commitment-Trust Theory of Relationship Marketing, "Journal of Marketing", 1994, vol. 58, ' ${ }^{\text {h }}$ Tzokas N., Saren M., Relationship Marketing In Consumer Markets from the Private to the Communal, Seminar on

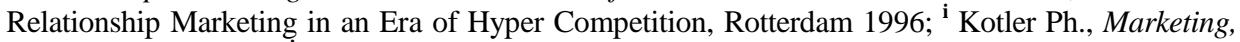
Dom ... op. cit., s. 13; ${ }^{j}$ Rydel M., Ronkowski C., Marketing partnerski, „Marketing i Rynek”, 1995 $\mathrm{nr}$ 9; ${ }^{\mathbf{k}}$ Gordon I.H., Relationship Marketing. New Strategies, Techniques and Technologies to Win the Customers You Want and Keep Them Forever, John Wiley \& Sons, Toronto 1998, s. 9; ${ }^{1}$ Fonfara K., Marketing partnerski na rynku przedsiębiorstw, PWE, Warszawa 1999, s. 59; ${ }^{\text {I }}$ Rogoziński K., Nowy marketing ... op. cit., s. 40.; ${ }^{\mathbf{m}}$ Furtak R., Marketing ... op. cit., s. 44. 
Przedstawione w tabeli 60 definicje w dużej mierze akcentują rolę człowieka, jako uczestnika aktu świadczenia usługi, poprzez następujące charakterystyki ${ }^{50}$ :

- dowartościowanie klientów z równoczesnym uznaniem ich za współtwórców usług (w konsekwencji traktowanie klienta w kategoriach kapitału firmy), powoduje, że cel działań marketingowych przesuwa się z pozykiwania ciągle nowych klientów na stworzenie i utrzymanie więzi z określonym klientem (co pozwoli na transformację klientów w adwokatów firmy usługowej $)^{51}$; podmiot koncentruje swoje wysiłki na przygotowaniu i oferowaniu świadczenia przynoszącego klientom wartość (w przypadku usług stomatologicznych relacje pacjenta $\mathrm{z}$ dentystą mogą stanowić wartość samoistną, która w procesie świadczenia usługi stanowić będzie o satysfakcji pacjenta);

- ponadprzeciętne zadania stawiane personelowi zatrudnionemu w usługach, który musi wykazywać szersze spektrum umiejętności ${ }^{52}$ niż „czyste” świadczenie usługi; personel powinien posiadać - obok umiejętności stricte zawodowych - rozwinięte umiejętności interpersonalne, które będą wpływały na jakość relacji z klientem (za kreowanie których pracownicy są odpowiedzialni ${ }^{53}$ ). Jak twierdzi I.H. Gordon w przedsiębiorstwie usługowym, wykorzystującym reguły marketingu relacji, większość pracowników powinna być przede wszystkim współtwórcami procesów służących poszczególnym kategoriom partnerów - ich zadaniem jest bowiem współpracować z partnerami zarówno spoza firmy, jak i z firmy w celu stworzenia takiej wartości, jakież życzy sobie klient ${ }^{54}$. Pionier marketingu usług profesjonalnych A. Willson wskazuje, że naczelnym zadaniem profesjonalisty jest uczynienie nieznanej klientowi sytuacji bardziej przystępną i pewną ${ }^{55}$. I ta idea jest również główną przesłanką zastosowania marketingu w usługach medycznych ${ }^{56}$.

\footnotetext{
${ }^{50}$ Mazur J., Zarzqdzanie ... op. cit., s. 57.

${ }^{51}$ Chłodnicki M., Ustugi profesjonalne ... op. cit., s. 23.

${ }^{52}$ Personel „pierwszej linii” jest w stanie zrozumieć sytuację klienta, problemy, jaki napotyka, poznać jego oczekiwania i indywidualne upodobania oraz zidentyfikować nastrój klienta w chwili obsługiwania.

${ }^{53}$ Chłodnicki M., Ustugi profesjonalne ... op. cit., s. 24.

${ }_{54}^{5}$ Gordon I.H., Relacje z klientem. Marketing partnerski, PWE, Warszawa 2001, s. 57.

${ }^{55}$ Wilson A., The marketing of professional services, McGraw-Hill, Book Company Ltd., Londyn 1972, s. 65.

${ }^{56}$ Stanowisko takie jest zgodne m. in. ze stanowiskiem K. Rogozińskiego, który zauważył, że już u zarania wyłaniania się zawodu lekarza, jawił się on jako archetyp profesjonalisty, we współczesnym rozumieniu tego słowa. I przyjmując tę optykę marketing usług profesjonalnych należy potraktować, jako podstawę marketingu usług medycznych. Por. Dobska M., Rogoziński K. (red.), Podstawy zarządzania ... op. cit., s. 211.
} 
W pracy przyjęto, że marketing relacji w gabinecie stomatologicznym dotyczy wszelkich aktywności ukierunkowanych na pacjenta, podejmowanych przez personel gabinetu na zewnątrz podmiotu i wewnątrz (w trakcie pobytu pacjenta w gabinecie), zmierzających do ciągłego uaktualniania wiedzy o jego potrzebach $^{57}$ dla stworzenia optymalnej usługi (w wymiarze medycznym i pozamedycznym) w celu nawiązania partnerskich stosunków o trwałym charakterze, które będą wynikiem wzajemnego zrozumienia i zaufania. Obejmuje marketingową postawę personelu ${ }^{58}$, wyrażającą się w zdolności inicjowania i utrzymywania dobrych bezpośrednich kontaktó $\mathrm{w}^{59} \mathrm{z}$ pacjentami.

Relacja, nawiązywana podczas świadczenia usługi, oparta jest na zaangażowaniu, zaufaniu i akceptacji współzależności między usługodawcą i usługobior$\mathrm{cą}^{60}$. Rozwija się ona stopniowo - od świadomej identyfikacji relacji przez jej badanie i zgłębianie, narastające zaangażowanie i oddanie, aż do jej rozwiązania i rozpadu.

Na relacje z klientami - wg R. Kozielskiego - można spojrzeć z pięciu
poziomów ${ }^{61}$ :

${ }^{57}$ Jest to zgodne z przyjętą w III rozdziale koncepcją, że marketing relacji - jako proces - jest przejawem uczenia się organizacji.

${ }_{58}$ I. Escher podkreśla, że pojęcie „,marketingowa postawa pracowników” w literaturze jest różnorodnie i niejednoznacznie określone. W efekcie nie ma jednej standardowej listy zmiennych, które mogłyby stanowić dla wszystkich badaczy empirycznie mierzalne wyróżniki wymiarów owej postawy, dlatego również nie ma opracowań oferujących kompleksowe narzędzia pomiaru tych wymiarów. Postawa jest w rzeczywistości zmienną nieobserwowalną, a zatem, gdy mowa o „pomiarze postawy", nie mierzy się postawy jako takiej, lecz mierzy się jej konkretne wymiary. Dalej ten sam autor zauważa, że marketingowa postawa pracownika jest względnie trwałą strukturą (lub dyspozycją do pojawienia się takiej struktury) procesów poznawczych, emocjonalnych tendencji do zachowań, w której wyraża się pozytywny bądź negatywny stosunek pracownika wobec faktu uzależnienia sprawności działania organizacji oraz własnej ścieżki zawodowej od wprowadzania w organizacji zmian ukierunkowanych na utrzymanie korzystnych relacji z zewnętrznymi i wewnętrznymi klientami organizacji ( $w$ tym zmian w sferze dotychczasowych zadań, kwalifikacji, zachowań samego pracownika itp.). Takie rozumienie wskazuje na możliwość mówienia o marketingowej postawie pracownika niezależnie od tego, jaką funkcję pełni on $\mathrm{w}$ organizacji. $\mathrm{Z}$ tego względu uczynienie z personelu podmiotu opieki zdrowotnej i jego stosunku do pacjenta kwestii nadrzędnej w marketingu relacji, sprawia, że należy przyjąć, iż nie uda się zadowolić klienta placówki, jeśli nie ułoży się należycie współpracy między pracownikami. Por. Escher I., Możliwe ... op. cit., s. 10.

${ }_{59}$ Bezpośrednie relacje stanowią pomost pomiędzy gabinetem i pacjentem, który podczas wizyty w gabinecie (zarówno pierwszej, jak i kolejnych) weryfikuje obraz profesjonalnej praktyki i złożone mu przez nią obietnice. Interakcje te mają decydujący wpływ na ewoluowanie oceny jakości świadczenia przez pacjenta w tzw. momentach prawdy (moments of truth).

Por. Grönroos Ch., Services Management and Marketing ... op. cit., s. 42.

${ }^{60}$ Paluchowski W.J., Czy marketingowi potrzebna jest psychologia?, w: Rogoziński K. (red.), Marketing ustug profesjonalnych. Wpisanie marketingu w strukturę organizacji ustugowej, materiał z IV konferencji 20-21 maja 2002, s. 35.

${ }^{61}$ Kozielski R. (red.), Wskaźniki marketingowe, Oficyna a Wolters Kluwer business, Kraków 2008, s. 160. 
- ponownych zakupów (wskaźnik retencji),

- udziału wydatków na daną markę w całości wydatków klienta na daną kategorię produktów (wskaźnik share of wallet),

- skłonności klienta do rekomendacji (NPS ${ }^{62}$ ),

- skłonność do zmiany firmy (wskaźnik utraty klientów),

- wartości życiowej klienta (wskaźnik CLV).

W dalszej części rozdziału zostaną przedstawione wyniki badań pacjentów (badanie IV) dotyczące wskaźnika retencji, skłonności do rekomendacji i skłonności do zmiany świadczeniodawcy.

Jak już zostało wcześniej powiedziane, jakość w rozumieniu marketingu relacji to realizacja - świadczenie usługi, które spełnia lub przekracza oczekiwania nabywcy. Usługa ma więc odpowiednią jakość, jeśli została wykonana - przynajmniej zgodnie z oczekiwaniami klienta ${ }^{63}$. Dbałość o jakość jest koniecznością dla podmiotu, który chce funkcjonować na rynku w długim okresie, gdyż stwarza możliwość pozyskiwania nowych pacjentów dzięki marketingowi szeptanemu ${ }^{64}$. Ponadto poziom jakości zgodny z oczekiwaniami nabywcy usługi

\footnotetext{
${ }^{62}$ Net promotor score (NPS) jest miarą lojalności klientów i jakości budowanych z nimi relacji; ma postać: NPS = odsetek 'promotorów” marki - odsetek ,destruktorów” marki. Może przyjmować wartości od $-100 \%$ (wszyscy nabywcy to destruktorzy marki) do $+100 \%$ (wszyscy klienci są promotorami marki). Jest jedną z metod oceny satysfakcji klientów, przywiązania i skłonności do polecania usług czy produktów firmy. Dzięki obserwacji zmian wartości NPS w długim okresie można określić jakość prowadzonych działań firmy nakierowanych na budowanie satysfakcji klientów, a także możliwości przyszłego wzrostu. W interpretacji wskaźnika R. Kozielski pisze: „Im wyższa wartość wskaźnika, tym większa jest liczba tych, którzy są na tyle usatysfakcjonowani ofertą firmy, że skłonni są polecić tę ofertę znajomym i rodzinie (można przyjąć, że dzięki temu pozostaną oni klientami firmy na dłużej i stworzą okazję generowania przyszłych zysków). Wysoki wskaźnik oznacza, że wśród klientów dominują ci, którzy są pozytywnie (czy nawet entuzjastycznie) nastawieni do podmiotu i jego oferty. Taką firmę można nazwać lokomotywą wzrostu, gdyż ma solidny fundament rozwoju w postaci usatysfakcjonowanych klientów, którzy wykazują dużą skłonność do rekomendowania firmy innym."

Por. Kozielski R. (red.), Wskaźniki ... op. cit., s. 159 i nast.

${ }^{63}$ Zelthaml V.A., Parasurman A., Berry L.L., Delivering quality Service, za: Rogoziński K., Nowy marketing ... op. cit., s. 56.

${ }^{64}$ Mówiąc o marketingu szeptanym, trzeba mieć na uwadze jego szczególną rolę w odniesieniu do usług (ze względu na ich - przedstawione wcześniej - cechy charakterystyczne). Rekomendacja (rozumiana jako pozytywna opinia lub polecenie) rodziny lub przyjaciół jest uznawana za jedno z najbardziej wiarygodnych źródeł komunikacji. Niezależnie od motywów podejmowania decyzji o zakupie oraz od podejścia do samego procesu zakupu, rekomendacja może mieć istotny wpływ na decyzje nabywcy na prawie każdym jego etapie. Wpływ jaki wywiera źródło na odbiorcę komunikatu jest wyjaśniany przy użyciu klasycznych modeli wpływu społecznego. W ramach tych modeli często kategoryzuje się oddziaływanie źródła na wpływ informacyjny oraz normatywny. W komunikacji nieformalnej pojawiają się oba wpływy: 1) informacyjny - wówczas gdy informacja jest akceptowana, jako fakt dowodzący stanu rzeczywistego; 2) normatywny - jako spełnienie przez
} 
(lub je przekraczający) jest pierwszym krokiem do pojawienia się satysfakcji klienta, która może przekształcić się w lojalność pacjenta wobec gabinetu (por. rysunek 3), tak więc jakość wpływa na siłę i długotrwałość relacji, a w konsekwencji na rentowność relacji (jak wynika z badań przeprowadzonych przez F.F. Reichhelda i W.E. Sassera ${ }^{65}$, wraz z upływem czasu, przez jaki klient pozostaje lojalny jednej firmie, zwiększa się jego jednostkowa rentowność) i pozycję konkurencyjną podmiotu. Wpływ jakości usług i innych czynników na rentowność relacji z klientem przedstawia rysunek 4.

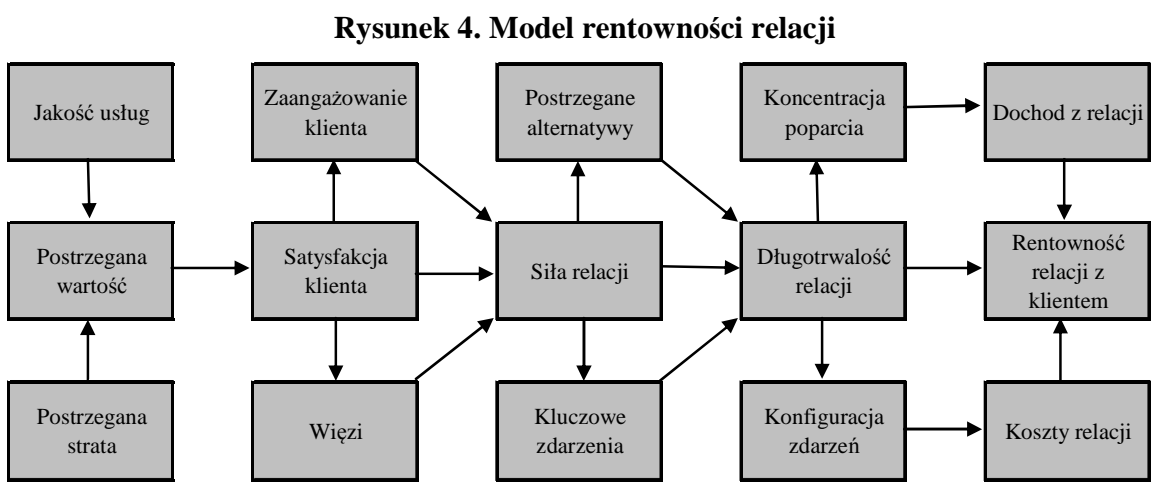

Objaśnienie terminów zastosowanych na rysunku:

- postrzegana jakość usługi - ocena usługi dokonywana przez nabywcę (bazująca na jego własnym doświadczeniu, skonfrontowanym $\mathrm{z}$ formalnymi i nieformalnymi standardami oceny);

- postrzegana strata - strata w oczach klienta, wynikająca ze wszystkich jego doświadczeń, porównywanych z formalnymi i nieformalnymi standardami ocen;

- postrzegana wartość ${ }^{66}$ - jakość usługi porównywana z postrzeganą stratą (dla pacjenta wartość produktu medycznego stanowi postrzeganą użyteczność przebytego leczenia, umożliwiającą zaspokojenie odczuwanych potrzeb, pomniejszoną o postrzegane koszty);

odbiorcę zwerbalizowanych oczekiwań źródła. Siła wpływu rekomendacji jest zależna od wielu czynników, m. in. od poziomu oddziaływania wpływu informacyjnego i normatywnego. Wyniki badań prowadzonych w ramach socjologii społecznej oraz marketingu sugerują, że jednym z ważniejszych determinantów wpływu informacyjnego i normatywnego jest charakterystyka źródła oraz postrzegany rodzaj zakupu (produkt częstego, okresowego lub epizodycznego zakupu). Por. Bansal H.S., Foyer P.A., World of mouth processes within a services purchase decision context, "Journal of Service Research", 2000, nr 2; Deutsch M., Gerrard H.B., A study of normative and informational social influences upon individual judgement, "Journal of Abnormal Social Psychology”, 1955, vol. 51; Gilly M.C., Graham J.L., Wolfinbarger M.F., Yale L.J., A Dyadic Study of Interpersonal Information Search, "Academy of Marketing Science", 1998 vol. 26, nr 2, s. 83 i nast.

${ }^{65}$ Reichheld F.F., W.E.Sasser Jr., Zero Defections: Quality Comes To Services, Harvard Business Review, 1990.

${ }^{66}$ Można w tym miejscu zwrócić uwagę na to, iż specyfika budowania wartości dla klienta w usługach jest wyzwaniem dla kapitału intelektualnego. Jakość usług, utrzymywanie standardów, dobre 
- satysfakcja klienta - wrażenie z doświadczenia usługi przez nabywcę (zdobyte w ramach relacji z usługodawcą), rozpatrywane w kontekście stawianych jej oczekiwań;

- zaangażowanie - wola stron do działania i ich stanowisko wobec współpracy z innymi;

- siła relacji - jest mierzona zarówno zachowaniami nabywczymi, jak i komunikacyjnymi klienta (przejawiającymi się zarówno skłonnością do rekomendacji, jak i składania reklamacji); lojalność (rozumiana jako powtórne zakupy), która bazuje na pozytywnym zaangażowaniu, sugeruje silną relację; jest ona stymulowana poprzez więzi między klientem a usługodawcą;

- więzi - można je interpretować, jako bariery wyjścia wiążące usługobiorcę z usługodawcą i utrzymujące wzajemne relacje; wyróżnić można wiele typów więzi, jak: ekonomiczne, technologiczne, geograficzne, socjalne, kulturowe, ideologiczne, psychologiczne itd.;

- kluczowe zdarzenia - zdarzenia o przełomowym znaczeniu dla trwania relacji; o takim ich charakterze mogą decydować $\mathrm{m}$. in.: wzajemne otrzymywanie wartości w trakcie danego zdarzenia porównywane z zasobami stron i ich dotychczasowymi doświadczeniami;

- koncentracja poparcia - jest wyrażana udziałem wydatków przeznaczonych przez nabywcę na zakupy u usługodawcy;

- długotrwałość relacji - czas trwania relacji;

- konfiguracja zdarzeń - rodzaje i liczba zdarzeń, które zachodzą w okresie trwania relacji między usługodawcą i usługobiorcą;

- dochód z relacji - całkowity dochód z relacji uzyskany w danym okresie rozrachunkowym;

- koszt relacji - całkowity koszt obsługi relacji w danym okresie rozrachunkowym;

- zyskowność relacji - dochód z relacji pomniejszony o poniesione koszty.

Źródło: Storbacka K., Strandvik T., Grönroos Ch., Managing customer relationship for profit, „International Journal of Service Industry Management”, 1994, nr 5, s. 26 i nast.

Analiza czynników, wpływających na rentowność relacji z nabywcą usługi w kontekście specyficznych rozwiązań stosowanych w danym gabinecie stomatologicznym, umożliwiłaby podjęcie decyzji co do kierunków zmian, jakie należałoby wprowadzić, aby jego rentowność wzrosła.

Konkludując, warto podkreślić, że budowanie długotrwałych relacji z klientami (tworzenie, utrzymywanie i wzmacnianie więzi) wymaga od członków personelu (a dentysty w szczególności) pewnych kompetencji, a mianowicie umiejętności z zakresu ${ }^{67}$ :

- budowania zaufania - wymaga to uczciwości, lojalności i wzajemnego szacunku (szerzej na ten temat w punkcie 3.2. tego rozdziału);

- komunikowania się - rozumianego jako zdolność do porozumiewania się, zapewniania zgodności pomiędzy intencją nadawcy i odbiorcy komunikatu

relacje z usługobiorcami (w tym: właściwa z nimi komunikacja) pozwalają uwiarygodnić ofertę, minimalizować niepewność klienta i budować jego satysfakcję.

${ }^{67}$ Niewiadomski P., Menedżer sprzedaży - model kluczowych kompetencji a efektywność działań, „Marketing i Rynek”, 2009 nr 9, s. 16. 
- wzajemnego zrozumienia (szerzej na ten temat $\mathrm{w}$ punkcie 3.4. tego rozdziału);

- budowania zespołu - umiejętność ta wyraża się w realizacji działań, które prowadzą do ukształtowania w zespole pozytywnych cech (na tę kategorię składają się: umiejętność wywierania wpływu, umiejętność motywowania, umiejętność wydobywania zdolności podwładnych, umiejętność rozwiązywania konfliktów itp.),

- efektywności interpersonalnej - wyrażającej się w umiejętności sprawnego $\mathrm{i}$ efektywnego funkcjonowania $\mathrm{w}$ relacjach $\mathrm{z}$ innymi osobami; kontrolowania dynamiki kontaktów interpersonalnych, mającego na celu ich usprawnienie i osiągnięcie określonych celów (por. punkt 3.3. w II rozdziale).

Wymienione argumenty pozwalają na stwierdzenie, że w podmiocie zorientowanym rynkowo członkowie personelu powinni zadbać o podnoszenie poziomu pozamedycznych kompetencji. Jest to tym bardziej istotne, że nie tylko wpłynie na jakość kontaktów między pracownikami i polepszenie jakości kontaktów pracownik - nabywca usługi, ale wpłynie również na rynkowy wizerunek podmiotu, a w konsekwencji jego pozycję konkurencyjną.

\subsection{MARKETING W USEUGACH ZDROWOTNYCH}

Ojczyzną pojęcia healthcare marketing i głównych kierunków jego rozwoju są Stany Zjednoczone. W Polsce planowanie i realizacja działań marketingowych ${ }^{68}$ w placówkach zdrowotnych jest stosunkowo młodym zagadnieniem, choć z roku na rok nabiera szczególnego wymiaru i znaczenia ${ }^{69}$.

W latach 70. XX w. prace Ph. Kotlera i S. Levy'ego ${ }^{70}$, a także G. Zaltmana i I. Vertinsky'ego ${ }^{71}$, dotyczące objęcia teorią i praktyką marketingu pozagospodarczych dziedzin życia (w tym w sektorze usług zdrowotnych), wywoływały wiele kontrowersji, a w literaturze z zakresu marketingu pojawiały się głosy

\footnotetext{
${ }^{68}$ Należy wyraźnie zaznaczyć, że nadrzędnym celem placówek zdrowotnych jest działanie na rzecz pacjenta. Orientacja marketingowa może być pomocna w realizacji tego celu, ponieważ oznacza nastawienie na potrzeby pacjentów (ze szczególnym uwzględnieniem jakości obsługi) i zwrócenie uwagi na relacje typu personel medyczny - pacjent. Jednak wspieranie sprzedaży usług medycznych jest odmienne od powszechnie postrzeganych i dotyczących firm nastawionych na osiąganie zysku ze względu na specyfikę oferowanej usługi i konieczność przestrzegania przez lekarzy Kodeksu etyki lekarskiej.

${ }^{69}$ Zajmują się tą tematyką m. in. A. Bukowska-Piestrzyńska, B. Iwankiewicz-Rak, H. Mruk, K. Rogoziński, I. Rudawska.

${ }^{70}$ Kotler Ph., Levy S., Broadening the concept of marketing, ,Journal of Marketing”, 1969, vol. 33, nr 1 , s. 10 i nast.

${ }^{71}$ Zaltman G., Vertinsky I., Health service marketing: a suggested model, "Journal of Marketing", 1971, vol. 35, s. 19 i nast.
} 
krytyczne wobec układu pacjent - usługodawca ${ }^{72}$. Niejasności związane z aplikacją marketingu $\mathrm{w}$ tę relację wiążą się z faktem, iż marketing - w tradycyjnym ujęciu - był rozumiany jako sposób oddziaływania na ludzi - potencjalnych nabywców dóbr/usług w celu zwiększania sprzedaży produktów (a tego podmiotom opieki zdrowotnej robić nie wolno) i w konsekwencji osiągnięcia zysków przez przedsiębiorstwo. Ekonomizacja relacji pacjent - lekarz prowadzi do zmiany paradygmatu $\mathrm{w}$ postrzeganiu kontaktu lekarz - pacjent ze stricte medycznego na oparty na filozofii marketingu relacji. Marketing zarówno $\mathrm{w}$ tradycyjnym ujęciu ( $\mathrm{z}$ analizą rynku, segmentacją rynku, zastosowaniem koncepcji marketingu-mix i kontrolą działań marketingowych), jak i marketing relacji (z budowaniem zaufania, efektywną komunikacją, zaangażowaniem stron $\mathrm{w}$ proces usługowy), pojawił się i w literaturze i w praktyce podmiotów opieki zdrowotnej (częściej w komercyjnych niż publicznych).

I medycyna i marketing relacji $\mathrm{w}$ centrum uwagi stawiają dobro pacjenta - nabywcy usługi: zaspokojenie jego potrzeb (w szczególności: rozwiązanie problemów zdrowotnych pacjenta). Medycyna skupia uwagę na aspekcie stricte zdrowotnym, a marketing zwraca uwage na pozamedyczne uwarunkowania realizacji świadczeń medycznych. To dualne podejście do pacjenta to propozycja przejścia od tradycyjnego podejścia - leczenia pacjenta - do nowoczesnego tj. dostarczania rozwiązań umożliwiających harmonizowanie systemu bioenergetycznego człowieka na poziomach: fizycznym, psychicznym i duchowym ${ }^{73}$.

Podmioty opieki zdrowotnej - jak już zostało zasygnalizowane w II rozdziale - funkcjonują w sieci powiązań społecznych, w związku z tym ukształtowanie prawidłowych relacji z interesariuszami pozwala zagwarantować ich przychylność przy realizacji celów podmiotu. Wynika stąd konieczność podejmowania działań, zmierzających do identyfikacji oczekiwań interesariuszy (zwłaszcza pacjentów) oraz uwzględnienia tych oczekiwań w działaniach organizacji ${ }^{74}$. $\mathrm{Z}$ przeprowadzonych badań wynika, że gabinety stomatologiczne raczej nie badają rynku (argument: „przecież mam pacjentów”). Nie chodzi o przeprowadzenie kompleksowej analizy - obejmującej wszystkie obszary funkcjonowania gabinetu - zakrojonej na szeroką skalę i czaso- i kosztochłonnej. Często dentyści nie próbują nawet przyjrzeć się gustom, potrzebom i zapatrywaniom obecnych pacjentów, bo to oni są specjalistami i „wiedzą lepiej” (por. wyniki

\footnotetext{
${ }^{72}$ Por. O'Conner Ch., Why marketing isn't working in the health care arena, "Journal of Health Care Marketing", 1982, vol. 2, nr 1, s. 31 i nast.

${ }^{73}$ Perechuda K., Coaching wiedzy medycznej jako instrument przewagi konkurencyjnej na rynku ustug medycznych, w: Perechuda K., Kowalewski M., Zarzadzanie komercyjna firma medyczna, Wolters Kluwer business, Warszawa 2008, s. 162.

${ }^{74}$ Adamczyk J., Społeczna odpowiedzialność przedsiębiorstw. Teoria i praktyka, PWE, Warszawa 2009, s. 42 i nast.
} 
badania II - tabela 87: 1/5 respondentów zajęła takie stanowisko). Postawa taka wynika również $\mathrm{z}$ faktu, że stomatolodzy często obawiają się, iż sobie nie poradzą z profesjonalnym badaniem pozamedycznych potrzeb pacjentów, gdyż najczęściej nie znają metod badań opinii; obawiają się zbyt wielu formalności i kosztów z nimi związanych (nie wiedząc nawet ile takie badanie mogłoby kosztować). Choć z drugiej strony należy podkreślić, że w wielu gabinetach podejmowane są planowe działania o orientacji rynkowej.

Zadaniem marketingu relacji w usługach zdrowotnych jest $\mathrm{m}$. in. wpływanie na komfort obsługi pacjenta w placówce medycznej, np. poprzez: wpływanie na emocje nabywcy (m. in. dzięki zmniejszaniu poziomu strachu u pacjentów), poprawianie kontaktu pracowników gabinetu z pacjentem (m. in. dzięki komunikacji dostosowanej do oczekiwań pacjenta), czy w końcu może być stosowany do wywierania wpływu na pozanabywcze zachowania ludzi w obszarze zdrowia (np. dzięki edukacji w zakresie profilaktyki). Dla gabinetu stomatologicznego umiejętność zachowań rynkowych członków zespołu ma jeszcze inny wymiar: podstawowym narzędziem marketingowym jest właściwa komunikacja z rynkiem i uzyskiwane w jej rezultacie rekomendacje. Pamiętając, że usługę realizują ludzie - najważniejszy staje się poziom indywidualnej pracy z pacjentem. Lepszy kontakt na płaszczyźnie lekarz - pacjent oznacza lepsze rozpoznanie i zaspokojenie - również pozamedycznych - potrzeb pacjentów i w efekcie uzyskanie rekomendacji i pozyskanie w ten sposób nowych nabywców. $\mathrm{Z}$ tego względu stomatolog działający prorynkowo, powinien robić coś więcej, niż ,dobrze opiekować się zębami swoich pacjentów”, np. powinien mieć z nimi dobry kontakt interpersonalny, by móc czynić - dobrze przyjmowane przez pacjenta - pomocne sugestie dotyczące dbałości o higienę jamy ustnej. W ciągu całego okresu istnienia związku nabywcy usługi z jej wykonawcą następuje - szeroko rozumiana - wymiana na płaszczyźnie uczuć ${ }^{75}$, wiedzy i czynności ${ }^{76}$ (w tym kontekście poniżej zostaną przedstawione: zaufanie, zaangażowanie, komunikacja i edukowanie pacjentów). Kiedy program marketingu relacji jest stosowany właściwie, organizacja zaczyna skupiać się w tym samym stopniu na kształtowaniu relacji z nabywcami, co na ofercie stricte medycznej; co jest związane $\mathrm{z}$ faktem, iż marketing relacji powstał na styku marketingu, jakości i obsługi nabywcy usługi (por. rysunek 5).

\footnotetext{
${ }^{75}$ Usługi zdrowotne niejako z definicji związane są z emocjami (np. lękiem, strachem przed bólem, chorobą). Rolą personelu staje się kreowanie pozytywnych emocji u pacjentów (np. poprzez podejmowanie dialogu, indywidualizację podejścia do pacjentów). Im silniejsze uczucia, które klient i świadczeniodawca żywią wobec siebie, tym związek jest trwalszy.

Por. Sokołowska M., Socjologia medycyny, PZWL, Warszawa 1986.

${ }^{76}$ Storbacka K., Lehtinen J.R., Sztuka budowania trwatych związków z klientami, Dom Wydawniczy ABC, Kraków 2001, s. 35.
} 
Rysunek 5. Powiązania pomiędzy jakością, obsługą klienta i marketingiem

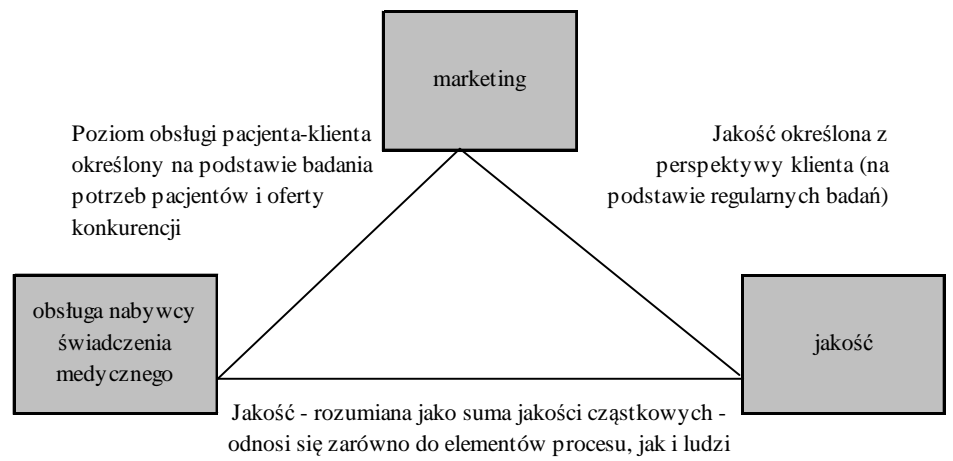

Źródło: opracowanie własne na podstawie: Payne A., Marketing ... op. cit.

Podsumowując, można powtórzyć za I. Rudawską, że współzależność między stronami kontaktu usługowego w komercyjnym podmiocie opieki zdrowotnej jest realizowana na kilku płaszczyznach:

- ,ekonomicznej - kondycja ekonomiczna usługodawcy uzależniona zostaje od liczby świadczonych usług, będących konsekwencjami wyborów pacjentów i postrzeganej przez nich jakości usług,

- psychologicznej - reputacja usługodawcy kształtowana jest przez pozytywne opinie wygłaszane przez pacjentów, zobowiązuje zarazem do dotrzymywania obietnic danych nabywcom usług,

- etycznej - obie strony wyrażają zgodność, co do sposobu postępowania i moralnych uzasadnień podejmowanych wyborów"

\section{WYBRANE DETERMINANTY RELACJI}

\subsection{ZAANGAŻOWANIE}

Podstawowym narzędziem kształtowania relacji w organizacji jest kultura usługowa, rozumiana przez $\mathrm{Ch}$. Grönroos jako kultura organizacyjna, w ramach której istnieje zrozumienie dla znaczenia wysokiej jakości usług świadczonych zarówno klientom wewnętrznym, jak i zewnętrznym, stanowiąca „,naturalny sposób życia" i najważniejszą normę dla wszystkich ${ }^{78}$.

J. Mazur podkreśla, że pracownicy organizacji usługowej starają się sprostać wymaganiom klientów tym lepiej, im bardziej sami są usatysfakcjonowani ze

\footnotetext{
${ }^{77}$ Rudawska I., Koncepcja marketingu relacji $w$ sektorze ustug zdrowotnych, „Ruch prawniczy, ekonomiczny i socjologiczny", 2004, zeszyt 4, s. 166 i nast.

${ }^{78}$ Grönroos Ch., Service Management and Marketing ... op. cit., s. 244.
} 
swojej pracy i utożsamiają się z celami firmy (por. rysunek $7 \mathrm{w}$ V rozdziale). Są oni uczestnikami specyficznej wymiany (dokonywanej między personelem i zatrudniającą ich firmą), której przedmiotem jest $\mathrm{z}$ jednej strony praca, a $\mathrm{Z}$ drugiej - wynagrodzenie, prestiż, możliwość kontynuowania kariery, atmosfera w pracy, poczucie własnej wartości, przynależność do zespołu, wdzięczność klientów itd. ${ }^{79}$ I dalej ta sama autorka pisze: „Tylko pracownik traktujący tę wymianę za korzystną dla siebie, jest w stanie dokładać wszelkich starań, by świadczyć usługi na najwyższym poziomie. Pracownicy zdegustowani i niedoceniani nie są gotowi wkładać wiele wysiłku w obsługę nabywców. Przenosząc swoje niezadowolenie na relacje z klientami, stają się źródłem niepochlebnych opinii o przedsiębiorstwie" ${ }^{, 0}$.

$\mathrm{Z}$ powyższych względów fundamentem relacji powinno być zaangażowanie ${ }^{81}$, które - wg M. Juchnowicz - jest wielowymiarowym konstruktem, określającym podstawę identyfikacji jednostki $\mathrm{z}$ organizacją, uwzględniającym poczucie przywiązania do firmy i lojalność, poziom satysfakcji wynikający z tej przynależności, a także stopień aktywności na rzecz realizacji celów biznesowych podmiotu $^{82}$. Zaangażowanie w relację można zdefiniować również jako ,wiarę partnera wymiany, że trwająca relacja z innym jest na tyle ważna, że uzasadnia podejmowanie maksimum wysiłków, ukierunkowanych na jej utrzymanie (zaangażowane strony wierzą, że warto jest nad tą relacją pracować, aby zapew-

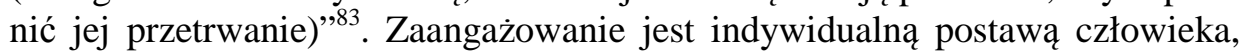
która - opierając się na zaufaniu - powoduje większą staranność w kontaktach z innymi. Wpływa na poprawę komunikacji interpersonalnej, gdyż obie strony dążą do wzajemnego zrozumienia w celu niedopuszczenia do błędnego rozpoinania intencji rozmówcy (i w konsekwencji do podjęcia niewłaściwych działań). Przyczynia się do dbałości o sposób wykonywania codziennych zadań i ich efekt (tak dla osoby, na rzecz której są wykonywane - np. zadowolenie z profesjonalnej obsługi; jak i wykonawcy - satysfakcja z dobrze wykonywanej pracy i zadowolenia odbiorcy).

\footnotetext{
${ }^{79}$ Mazur J., Zarzadzanie ... op. cit., s. 58.

${ }^{80}$ Ibidem s. 175.

${ }^{81}$ Poglądy takie głoszą m. in. L.L. Berry, A. Parasuraman, którzy obopólne zaangażowanie uczestników traktują jako wyznacznik relacji usługowych; czy R.M. Morgan, S.D. Hunt, którzy definiują zaangażowanie jako wzajemne przekonanie stron, że wartość upatrywana w długotrwałej relacji jest dla nich na tyle znacząca, iż stanowi swoiste zabezpieczenie (gwarancję) dołożenia wszelkich staran, by ja utrzymać. za: Rudawska I., Ksztattowanie zaangażowania $w$ relacjach ustugowych (na przyktadzie rynku ustug zdrowotnych), „Marketing i Rynek”, $2004 \mathrm{nr} 3$, s. 15.

82 Juchnowicz M., Zarzadzanie kapitatem ludzkim a poziom zaangażowania pracowników, „Zarządzanie Zasobami Ludzkimi”, 2010 nr 3-4, s. 58.

${ }_{83}$ Morgan R.M., Hunt S.D., The Commitment-trust Theory of Relationship Marketing, "Journal of Marketing", $1994 \mathrm{nr} 3$.
} 
Koncepcja zaangażowania, obecna od lat w piśmiennictwie z zakresu teorii wymiany społecznej, stanowiła jej wyróżnik w stosunku do teorii wymiany ekonomicznej. Przyjęcie paradygmatu marketingu relacji, który traktuje zaangażowanie zarówno jako kategorię społeczną, jak i ekonomiczną, sytuację tę zmieniło. Zwraca na to uwagę I. Rudawska, twierdząc, że relacje usługodawca - usługobiorca (personel placówki zdrowia - pacjent) są rozpatrywane przez socjologów i psychologów medycyny na gruncie stosunków społecznych, a przez ekonomistów, jako sposób na zatrzymanie pacjenta, jako nabywcy usług w długim okresie. Dlatego w gabinecie stomatologicznym podejście stricte medyczne (wynikające $\mathrm{z}$ etyki altruizmu, mające rodowód społeczny) nie pozostaje $\mathrm{w}$ sprzeczności $\mathrm{z}$ podejściem marketingowym (wynikającym z imperatywu doskonałej obsługi klienta), a wręcz - dzięki stawianiu pacjenta w centrum uwagi - mogą (i powinny) nawzajem się uzupełniać i stać się kluczowym elementem w kreacji wartościowej relacji na płaszczyźnie: personel placówki zdrowotnej - pacjent oraz lekarz dentysta - personel pomocniczy ${ }^{84}$. Można powiedzieć, że zaangażowanie, rozumiane dualnie - jako kategoria ekonomiczna i społeczna jest zjawiskiem sprzyjającym, a niekiedy $i$ warunkującym istnienie korzystnych efektów w relacji usługodawca - usługobiorca.

Mówienie o zaangażowaniu, wymaga - wg D. Kukiełki-Pucher i M. Dobkowskiej - uwzględnienia psychologicznego stanu charakteryzującego związek klienta (wewnętrznego - członka personelu gabinetu ${ }^{85}$, zewnętrznego - pacjenta) z gabinetem, wiążącego się bezpośrednio z decyzjami o pozostaniu w nim lub odejściu. Autorki wyróżniają trzy typy zaangażowania ${ }^{86}$ :

- afektywne - wyraża się w emocjonalnym przywiązaniu do organizacji; wpływa na stopień $\mathrm{w}$ jakim członek personelu gabinetu lub pacjent zamierza wytrwać i kultywować relacje $\mathrm{z}$ usługodawcą ${ }^{87}$; jest związane z następującymi czynnikami:

\footnotetext{
${ }^{84}$ Rudawska I., Kształtowanie zaangażowania $w$ relacjach ustugowych (na przykładzie rynku ustug zdrowotnych), „Marketing i Rynek”, 2004 nr 3, s. 16.

${ }^{85}$ Wyniki badania przeprowadzonego w tym zakresie są przedstawione w: Bukowska-Piestrzyńska A., Emocje pracowników w gabinecie stomatologicznym, ,e-Dentico”, $2012 \mathrm{nr}$ 5, s. 122 i nast.

${ }^{86}$ Kukiełka-Pucher D., Dobkowska M., Pracownik emocjonalnie zaangażowany, „Manager”, 2004 nr 5, s. 16.

${ }^{87} \mathrm{~W}$ tym ujęciu usługodawcą jest sam stomatolog - przełożony pozostałych członków personelu (również innych lekarzy dentystów). Stomatologa - przedsiębiorcę również dotyczy kwestia zaangażowania, ale w sytuacji, gdy jest właścicielem gabinetu, to niejako automatycznie pojawia się zaangażowanie - zależy mu na utrzymaniu na rynku własnego gabinetu, jako podmiotu, w którym może pomagać pacjentom - motyw altruistyczny i przedsiębiorstwa zarobkującego - motyw ekonomiczny. Wyniki badania I i III potwierdzają wysoki stopień zaangażowania lekarzy i studenttów w wykonywaną pracę - przypomnijmy, że dokonując samooceny swoich postaw i umiejętności intrapersonalnych dentyści najwyżej ocenili właśnie swoje zaangażowanie w pracę - 93,87\% respondentów badania I oceniło się w tym zakresie dobrze lub bardzo dobrze (por. tabela 18), a w badaniu III - 90,54\% badanych (por. tabela 20 ).
} 
- stabilnością - odnoszącą się do silnej wiary i akceptacji celów i wartości usługodawcy, który za nadrzędny cel - zgodnie z Kodeksem etyki lekarskiej - uznaje dobro pacjenta;

- poświęceniem - oznaczającym gotowość do podjęcia określonych wysiłków (często wykraczających poza rutynowe aktywności) dla dobra organizacji i realizacji - zakładanych przez nią - celów;

- lojalnością - interpretowaną jako gotowość i intencja podtrzymania własnego członkowstwa w organizacji jako klienta (tak pacjenta, jak i pracownika);

- wykalkulowane - związane $\mathrm{z}$ postrzeganymi kosztami rezygnacji z członkowstwa w organizacji; powstaje, gdy klient uświadamia sobie, że opuszczając organizację mógłby stracić to, co do tej pory $w$ nią zainwestował (np. czas) lub gdy zdaje sobie sprawę z ograniczonej liczby dostępnych miejsc pracy - dotyczy pracownika, czy braku gabinetów stomatologicznych w najbliższej okolicy - dotyczy pacjenta;

- moralne (normatywne) - wiąże się z poczuciem obowiązku pozostania w podmiocie; jest efektem doświadczeń podkreślających zalety bycia lojalnym np. w wyniku otrzymywania od organizacji określonych korzyści: lojalność wobec pracodawcy może wynikać z korzyści takich jak opłaty za szkolenia zawodowe (tworzą u pracownika poczucie zobowiązania i potrzebę odwzajemnienia); lojalność wobec usługodawcy może wynikać z faktu, że stomatolog zawsze znajduje czas dla pacjenta w dniu w którym on zadzwoni (lub najpóźniej następnym), aby umówić się na wizytę.

Brak zaangażowania ze strony personelu mógłby przyczynić się do braku zaangażowania ze strony pacjentów (co mogłoby się przejawiać np. notorycznym niedotrzymywaniem terminów wizyt), a w konsekwencji wpłynąć na efektywność gabinetu. Jak już zostało powiedziane badania wskazująa ${ }^{88}$, że podniesienie efektywności pracowników wynika głównie z zaangażowania afektywnego (stomatolog - jako właściciel gabinetu przejawia ten rodzaj zaangażowania). Natomiast zaangażowanie wykalkulowane wpływa na zmniejszenie efektywności, ponieważ pracownicy pragnący odejść $\mathrm{z}$ organizacji, których powstrzymują jedynie przewidywane konsekwencje, starają się tylko utrzymać obecną posadę, wkładając w pracę minimum wymaganego wysiłku. Przypuszcza się, że motywacja wewnętrzna (poczucie osiągnięć i samorealizacji) związana jest $\mathrm{z}$ zaangażowaniem emocjonalnym, natomiast motywacja zewnętrzna (np. płaca) wiąże się raczej z zaangażowaniem wykalkulowanym. Tylko zaangażowaniu afektywnemu przypisuje się wpływ na pozostanie pacjenta i pracownika w relacji z usługodawcą.

${ }^{88}$ Kukiełka-Pucher D., Dobkowska M., Pracownik ... op. cit., s. 16. 
I. Rudawska - opierając się na teorii zaangażowania R. Morgana i S. Hunta oraz na teorii współzależności - wyprowadziła model kreacji zaangażowania w relację usługodawca-pacjent, bazujący na zaufaniu (jako sposobie przeciwdziałania niepewności przebiegu i rezultatu wymiany w usługach zdrowotnych). Model kreacji zaangażowania $\mathrm{w}$ relację lekarz dentysta - pacjent można przedstawić tak, jak na rysunku 6.

Rysunek 6. Model kreacji zaangażowania pacjenta w relację z usługodawcą
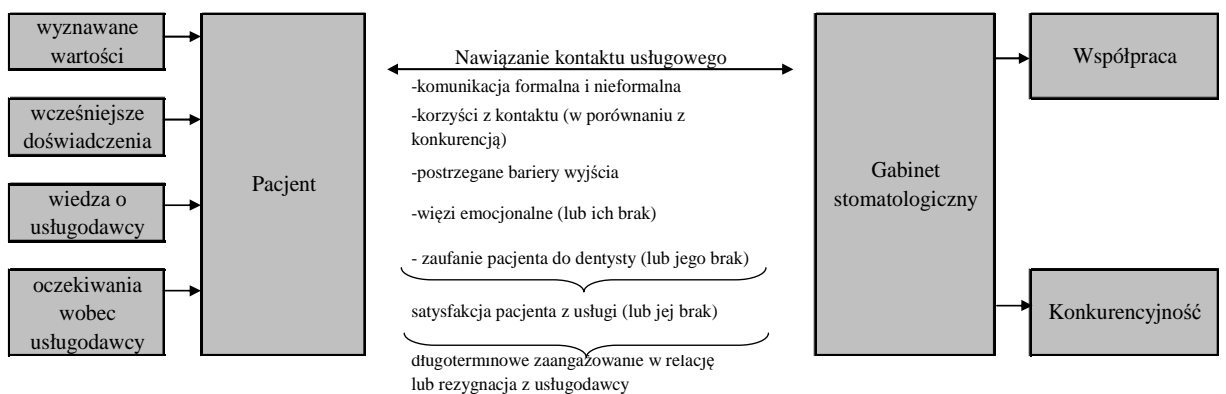

Źródło: opracowane na podstawie: Morgan R.M., Hunt S.D., The Commitment-trust ... op. cit.; Hocutt M.A., Relationship Dissolution Model: Antecedents of Relationship Commitment and the Likelihood of Dissolving a Relationship, "International Journal of Service Industry Management”, 1998, nr 2.

Czynnikami satysfakcji w największej mierze przyczyniającymi się do powstania zaangażowania będą elementy ekspresyjne (np. empatia usługodawcy, poświęcenie czasu i uwagi leczonemu ${ }^{89}$ ), a nie instrumentalne procesu usługowego (np. sprzęt, wygląd gabinetu/poczekalni), co potwierdzają wyniki badania IV, przedstawione $\mathrm{w}$ dalszej części rozdziału. $\mathrm{Z}$ tego powodu dentyści powinni być szczególnie uwrażliwieni na konieczność pojawienia się zaufania na płaszczyźnie pacjent - lekarz dentysta (szerzej na ten temat w następnym podpunktcie), jeśli współpraca ma być kontynuowana. Istotne jest również, aby to, co zostało pacjentowi obiecane (np. na stronie internetowe gabinetu, czy w trakcie prezentacji planu leczenia), zostało zrealizowane (zarówno na płaszczyźnie stricte medycznej, jak i w obszarze pozamedycznym).

Jako konkluzja przedstawionych rozważań zostanie zaprezentowana opinia dwóch niezależnych zespołów: F.R. Dwyera, P.H. Schurra i S. Ocha (model Buyer-Seller Relationship Life Cycle $)^{90}$ oraz A. Payne'a, M. Christophera,

\footnotetext{
${ }^{89}$ Wnioski z badania: Aldana J.M., Piechulek H., AlSatir A., Client Satisfaction and Quality of Health Care, "Bulletin of the World Health Organization", $2001 \mathrm{nr} 6$.

${ }^{90}$ Dwyer F.R., Schurr P.H., Och S., Developing Buyer-Seller Relationships, "Journal of Marketing", 1987, nr 51, s. 11 i nast.
} 
D. Ballantyne'a (model The Commitment Ladder) ${ }^{91}$, które stoją na stanowisku, że w związku kupującego ze sprzedającym albo zwiększa się zażyłość, albo zostaje on rozwiązany. Stawiając kolejne tezy, autorzy twierdzą, że metodą na ustanowienie silnych i długotrwałych więzi z klientami jest spełnianie i przekraczanie ich oczekiwań wobec jakości usług ${ }^{92}$. Świadczenie usług na takim poziomie skutkuje automatycznie przesuwaniem klientów w górę drabiny lojalności. Podobny mechanizm można zaobserwować na płaszczyźnie dentysta - pacjent. Im częściej pacjent korzysta z usług stomatologicznych (por. tabela 74), tym przejawia większą chęć na pozostanie nabywcą świadczeń danego gabinetu.

\subsection{ZAUFANIE}

Teoretycy marketingu (np. V. Liljander, I. Roos, P. Doyle ${ }^{93}$ ) traktują zaufanie jako najważniejszy instrument marketingowego oddziaływania, który pomaga uwiarygodnić rynkową pozycję podmiotu w oczach interesariuszy. Wybrane definicje tego pojęcia przedstawione są w tabeli 61 .

Tabela 61. Pojęcie,,zaufanie” w świetle wybranych pozycji literatury przedmiotu

\begin{tabular}{|l|l|}
\hline \multicolumn{1}{|c|}{ Autor definicji } & \multicolumn{1}{c|}{ Treść definicji } \\
\hline $\begin{array}{l}\text { R.M. Morgan } \\
\text { S.D. Hunt }{ }^{\mathrm{a}}\end{array}$ & $\begin{array}{l}\text { Zaufanie to chęć do inwestowania zasobów w relacje z innym podmiotem. Jest } \\
\text { to przekonanie, że żadna ze stron nie będzie nigdy działać na szkodę partnera, } \\
\text { wykorzystując jego słabe strony. Zaufanie i zaangażowanie są esencjonalnym } \\
\text { elementem tworzenia relacji. }\end{array}$ \\
\hline P. Sztompkab & $\begin{array}{l}\text { Zaufanie to: ,emocje okazywane ludziom, przedmiotom czy instytucjom, } \\
\text { takim jak firma, rząd czy społeczeństwo. Zaufanie jest wiarą w określone } \\
\text { działania czy własności obiektu obdarzonego zaufaniem. Często oznacza } \\
\text { nawet przekonanie jednej ze stron o tym, że motywacją drugiej strony wobec } \\
\text { niej jest bycie uczciwym i chcącym dobrze działać. Zaufanie jest zakładem } \\
\text { podejmowanym na temat niepewnych, przyszłych działań innych ludzi czy } \\
\text { instytucji.” Jego rola rośnie w sytuacji coraz szerszego spektrum potencjalnych } \\
\text { wyborów dostępnych człowiekowi. Aby wybrać spośród możliwych dróg } \\
\text { postępowania (np. dokonać wyboru lekarza) często należy odwoływać się do } \\
\text { zaufania, które zapewnia komunikację oraz umożliwia współpracę pomiędzy } \\
\text { ludźmi w realizacji wspólnych celów. }\end{array}$ \\
\hline $\begin{array}{l}\text { J. Brockner, } \\
\text { P.A.Siegel, J.P.Daly, } \\
\text { T. Tyler, Ch. Martin }\end{array}$ & $\begin{array}{l}\text { Zaufanie wynika z pozytywnych wyobrażeń, będących konsekwencją } \\
\text { dotychczasowych wzajemnych interakcji. }\end{array}$ \\
\hline L. Gilson ${ }^{\text {d }}$ & $\begin{array}{l}\text { Zaufanie oznacza oczekiwanie i wiarę, że partner będzie działał we wspólnym } \\
\text { interesie. Z drugiej strony - wiąże się z niepewnością dotyczącą motywów, } \\
\text { intencji i działań partnera. }\end{array}$ \\
\hline
\end{tabular}

${ }^{91}$ Christopher M., Payne A., Ballantyne D., Relationship Marketing, Butterworth-Heinemann Ltd., Oxford 1991, s. 22.

92 White S.S., Schneider B., Climbing the Commitment Ladder. The Role of Expectations Disconfirmation on Customers' Behavioral Intentions, "Journal of Service Research", $2000 \mathrm{nr}$ 3, vol. 2, s. 241.

${ }^{93}$ Liljander V., Roos I., Customer-relationship levels - from spurious to true relationship, "Journal of Services Marketing” 2002, nr 7, s. 595; Doyle P., Marketing ... op. cit., s. 102. 


\begin{tabular}{|c|c|}
\hline $\begin{array}{l}\text { Ch.Hampden- } \\
\text {-Turner, } \\
\text { A.Trompenaars }\end{array}$ & $\begin{array}{l}\text { Zaufanie ma zdolność hamowania zachowań oportunistycznych. Przed } \\
\text { zachowaniami nieetycznymi silniej chronią bliskie więzi międzyludzkie, niż } \\
\text { uregulowania prawne i inne sztywne zasady. }\end{array}$ \\
\hline $\begin{array}{l}\text { W. Urban, } \\
\text { D. Siemieniako }\end{array}$ & $\begin{array}{l}\text { Zaufanie wiąże się z oczekiwaniem, że partner wymiany będzie się troszczył } \\
\text { w pierwszej kolejności o dobro klienta, a nie o własny interes. Warunkiem ko- } \\
\text { niecznym zaufania klienta jest wystąpienie wiary w dobre intencje dostawcy } \\
\text { usług. }\end{array}$ \\
\hline $\begin{array}{l}\text { C. Moorman, } \\
\text { R. Deshpande, } \\
\text { G. Zaltman }\end{array}$ & $\begin{array}{l}\text { Zaufanie, to „gotowość polegania na partnerze wymiany, co do którego } \\
\text { jesteśmy przekonani.” Definiowane w kategoriach behawioralnych oznacza } \\
\text { gotowość polegania na obiekcie (osobie, organizacji) w warunkach opisywa- } \\
\text { nych przez niepewność i brak całkowitej lub częściowej kontroli nad sytuacją. }\end{array}$ \\
\hline $\begin{array}{l}\text { P.M. Doney, } \\
\text { J.P. Canzon }\end{array}$ & $\begin{array}{l}\text { Zaufanie wobec danej osoby/podmiotu jest definiowane najczęściej (zarówno } \\
\text { przez dyscyplinę marketingu, jak i psychologii społecznej), jako postrzegana } \\
\text { wiarygodność i życzliwość obiektu wobec partnera (osoby, organizacji). }\end{array}$ \\
\hline M.A. Hocutt ${ }^{1}$ & $\begin{array}{l}\text { Zaufanie jest podstawowym warunkiem zaangażowania uczestników } \\
\text { wymiany. Wpływa na jakość relacji, a więc i jakość samego usługowego } \\
\text { produktu, przez kształtowanie postaw i zachowań obu jej uczestników. }\end{array}$ \\
\hline $\begin{array}{l}\text { A. Zaheer, } \\
\text { B. McEvil, } \\
\text { W. Peerone }\end{array}$ & $\begin{array}{l}\text { Zaufanie to oczekiwanie, że na partnerze można polegać, iż dotrzyma swoich } \\
\text { zobowiązań w sposób przewidywalny oraz, że będzie działał uczciwie w obli- } \\
\text { czu różnych możliwości. }\end{array}$ \\
\hline
\end{tabular}

Źródło: opracowanie własne na podstawie: ${ }^{a}$ Morgan R.M., Hunt S.D., The Commitment ... op. cit.,

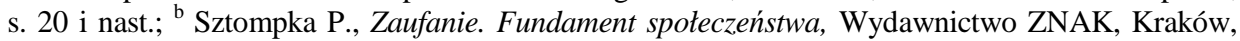
2007, s. 47; ${ }^{c}$ Brockner J., Siegel P.A., Daly J.P., Tyler T., Martin Ch., When Trust Matters: The Moderating Effect of Outcome Favorability, “Administrative Science Quarterly”, 1997 nr 42, s. 558 i nast.; ${ }^{\mathrm{d}}$ Gilson L., Trust and the development of Health care as a social institution, "Social Science \& Medicine" 2003, nr 56, s. 1453 i nast.; ${ }^{e}$ Hampden-Turner Ch., Trompenaars A., Siedem kultur kapitalizmu, Oficyna Ekonomiczna, Kraków 2000, s. 56; ${ }^{\mathrm{f}}$ Urban W., Siemieniako D., Lojalność klientów. Modele, motywacja i pomiar, Wydawnictwo Naukowe PWN, Warszawa 2008, s. 85; ${ }^{\mathrm{g}}$ Moorman C., Deshpande R., Zaltman G., Relationships Between Providers and Users of Market Research: The Role of Personal Trust, "Working Paper", nr 93, "Marketing Science Institute", Cambridge 1993, za: Furtak R., Marketing ... op. cit.; Moorman C., Deshpande R., Zaltman G., Factors affecting trust in market research relationship, "Journal of Marketing", 1993 vol. 57, s. 82; ${ }^{\mathrm{h}}$ Doney P.M., Canzon J.P., An examination of the nature of trust in buyer-seller relationship, "Journal of Marketing", 1997 vol. 61, s. 36; ${ }^{i}$ Hocutt M.A., Relationship ... op. cit., s. 190; ${ }^{\mathrm{j}}$ Zaheer A., McEvil B., Peerone W., Does Trust Matter? Exploring the effects of interorganizational and interpersonal trust on performance, "Organization Science", 1998 vol. 9, $\mathrm{nr}$ 2, s. 141 i nast.

Jak wynika z definicji przedstawionych $\mathrm{w}$ tabeli 61 zaufanie to wiara, że partner działa dla dobra drugiej strony kontaktu; wiara, która wpływa na zaangażowanie w relację między nimi. Takie podejście jest widoczne w gabinecie stomatologicznym, w którym pacjent oczekuje, że lekarz dentysta będzie się troszczył w pierwszej kolejności o jego dobro (por. wykres 5 i punkt 1.2.2 w rozdziale II). Pacjent szuka w lekarzu człowieka, który udzieli mu pomocy, chociaż konkretne oczekiwania pacjenta, jak powinna wyglądać ta pomoc, mogą być różne (w zależności np. od jego wieku; rodzaju choroby; wcześniejszych doświadczeń 
z podmiotami systemu opieki zdrowotnej ${ }^{94}$; czy nawet rodzaju podmiotu, w którym pacjent się leczy - prywatny vs publiczny). Istotne jest również to, że zaufanie jest efektem wszystkich dotychczasowych interakcji pomiędzy pacjentem a pracownikami gabinetu. Powyższe argumenty pozwalają na sformułowanie wniosku, że personelu do każdego kontaktu z pacjentem (bezpośredniego i pośredniego) powinien podchodzić z należytą starannością (mając na uwadze, że wpływa w ten sposób na odczucia pacjenta). Postawa personelu względem pacjentów ma znaczenie również z tego względu, że bliski, szczery kontakt może wpływać niejako ochronnie przed - ewentualnymi - zachowaniami nieetycznymi. Trwała więź pomiędzy lekarzem a pacjentem, oparta na zaufaniu i umożliwiająca transfer wiedzy, będzie zniechęcała obie strony do pokusy nadużycia; tym bardziej, że potrzeba zaufania rośnie w sytuacji konieczności zawierzenia intencjom i decyzjom lekarza ${ }^{95}$, a posiadane zaufanie niweluje potrzebę stałego monitorowania i kontrolowania zachowań drugiej strony ${ }^{96}$. Zaufanie do lekarza zwiększa również skłonność pacjenta do brania odpowiedzialności za własne zdrowie i umacnia chęć uczestnictwa w procesie podejmowania decyzji o sposobie leczenia ${ }^{97}$. D. Walczak-Duraj analizując wzorce przedsiębiorczości eksponuje rolę zaufania i kapitału społecznego w procesie wykształcania się przedsiębiorczości etycznej ${ }^{98}$. W tym rozumieniu etyka i etyczność postępowania jest jednym z istotnych parametrów przedsiębiorczego zarządzania.

K. Stefaniak zwraca uwagę na korzyści emocjonalne pacjenta z kontaktu z lekarzem - pacjent płacąc za wizytę lekarską, „nie kupuje automatycznie zdrowia”, kupuje nadzieję (na poprawę stanu zdrowia, na całkowite wyzdrowienie) związaną z efektami podjętego leczenia. Interakcja z lekarzem dostarcza pacjentowi emocjonalnego wsparcia, choćby przez to, że jest ktoś, kto chce z nim utrzymywać kontakt, okazuje zainteresowanie, także dzięki słowom akceptacji. Dlatego pacjent „ocenia” lekarza w trakcie rozmowy nie tylko pod kątem jego umiejętności technicznych, ale również pod kątem jego umiejętności interpersonalnych $^{99}$. Wynika $\mathrm{z}$ tego, że dentyści powinni się skupiać $\mathrm{w}$ takim samym stopniu na właściwych relacjach z klientami, co na utrzymywaniu (również poszerzaniu) oferty produktowej gabinetu na odpowiednim poziomie (w zakresie aktual-

\footnotetext{
${ }^{94}$ Leonard L., Carbone B.L.P., Heeckel S.H., Managing the total customer, experience, "Sloan Management Review", 2002, nr 3, s. 85 i nast.

${ }_{95}$ Mohseni M., Lindstrom M., Social capital, trust in the health-care system and self-rated Health: The role of Access to Health care in a population-based study, "Social Science \& Medicine", 2007 nr 64, s. 1373 i nast.

${ }^{96}$ Taylor-Gooby P., Trust, risk and health care reform, „Health, Risk \& Society”, 2006 nr 8, s. 97 i nast.

${ }^{97}$ Mechanic D., The functions and limitations of trust in the provision of medical Care, "Journal of Health Politics, Policy and Law”, 1998 nr 4, s. 661 i nast.

${ }^{98}$ Walczak-Duraj D., Ład etyczny w gospodarce rynkowej. Doświadczenia polskiej transformacji, Wyd. UŁ, Łódź 2002, s. 218 i nast.

${ }^{99}$ Stefaniak K., Wtadza ... op. cit., s. 133.
} 
ności stosowanych rozwiązań; jakości stosowanych materiałów; podnoszenia poziomu kwalifikacji zawodowych itp.). W opiece zdrowotnej ofertą usługową jest deklaracja (identyfikowana $\mathrm{z}$ osobą konkretną wykonawcy) gotowości i chęci do redukcji poczucia niepewności pacjenta w obszarze jego zdrowia ${ }^{100}$, dlatego znaczenie zaufania jest nie do przecenienia.

Pacjent, wchodząc do gabinetu, obdarza lekarza (i w pewnym zakresie również personel gabinetu) zaufaniem ${ }^{101}$, które może mieć wpływ na:

- rezultaty leczenia uzyskiwane przez pacjenta ${ }^{102}$, dzięki m. in.:

- zwiększeniu motywacji do poszukiwania pomocy i korzystania z profilaktyki,

- poprawie komunikacji między lekarzem i pacjentem (co może przyczynić się do większej otwartości i szczerości pacjenta, a w konsekwencji bardziej dokładnego rozpoznania w trakcie wywiadu lekarskiego),

- poprawie postrzegania skuteczności leczenia i oceny własnego zdrowia oraz poprawie samopoczucia i jakości życia (w tym jakości życia związanej ze zdrowiem jamy ustnej);

- wyniki ekonomiczne lekarza - świadczeniodawcy.

Powyższe względy upoważniają do stwierdzenia, że dla dentysty, który zamierza realizować ideę marketingu relacji $\mathrm{w}$ gabinecie, pierwszym krokiem powinno być podjęcie działan, mających na celu budowę i umacnianie zaufania pacjenta. Warunkiem sine qua non pojawienia się zaufania są właściwe relacje interpersonalne ${ }^{103}$ między uczestnikami procesu usługowego. Usługodawcy (tu: personel gabinetu stomatologicznego) zdobywają zaufanie pacjenta poprzez

100 Por. Styś A., Olearnik J., Ustugi w rozwoju spoteczno-gospodarczym, PWE, Warszawa 1989, s. 131.

${ }^{101}$ Z badań przeprowadzonych przez CBOS (na reprezentatywnej próbie dorosłych Polaków) wynika, że zdecydowana większość respondentów (70\%) deklaruje, że ufa lekarzom, których porady zasięga lub u których się leczy, choć jedynie 13\% ma do nich bardzo duże zaufanie. $\mathrm{Z}$ drugiej strony $1 / 4$ ankietowanych określa swoje zaufanie do lekarzy, jako małe. Prezentowane wyniki wskazują również, że w porównaniu do 2001 r. zaufanie do lekarzy w 2010 r. zmniejszyło się o 10 p.p. Por. Wądołowska K., Opinie o opiece zdrowotnej, CBOS, 2010, s. 7.

${ }_{102}$ Hall M.A., Law, medicine and trust, "Stanford Law Review", 2002, vol. 55, nr 2, s. 463 i nast.; Thom D.H., Hall M.A., Pawlson L.G., Measuring patient's trust in physicians when assessing quality of care, "Health Affairs" Milwood, 2004 vol. 23, nr 4, s. 124 i nast.

${ }^{103}$ Jeżeli w organizacji nie zostały wykształcone prawidłowe relacje interpersonalne między pracownikami, to jej członkowie powoli tracą poczucie więzi ze sobą, co może przyczynić się do braku zadowolenia z pracy. W takiej sytuacji dobrzy pracownicy mogą odejść, a ci, którzy pozostaną są niezadowoleni. Efektem będzie spadek sprawności funkcjonowania podmiotu. Por. Hallowell E.M., The Human Moment At Work, „Harvard Business Review”, 1999 January-February, s. 60.

Nieprawidłowe relacje interpersonalne skutkują również niewłaściwą obsługą klientów, a to z kolei przyczynia się do niezadowolenia klientów, a w konsekwencji - prawdopodobnie - rezygnacji $\mathrm{z}$ oferty podmiotu, a efektem będzie spadek dochodów podmiotu. 
swoje postępowanie, którego filarami powinny być zasady Kodeksu etyki lekarskiej oraz:

- prawość w realizacji świadczenia, w sposobach przekonywania pacjenta co do wyboru określonego postępowania leczniczego;

- szczerość, która umożliwia przekazanie informacji o dobrych intencjach gabinetu, woli współpracy i szacunku do pacjenta ${ }^{104}$;

- profesjonalne zachowanie, bazujące na wiedzy medycznej oraz na skrupulatności, uprzejmości i emocjonalnej stabilności, pokazujące obraz rzetelnego przedsiębiorstwa;

- przestrzeganie reguł gry rynkowej bez oszukiwania, uchylania się od obowiązków, działania na niekorzyść pacjenta, pracownika czy dostawcy, bądź innych form nieczystego postępowania ${ }^{105}$;

- lojalność personelu w stosunku do pacjenta (przejawiająca się w - przywoływanym już - dotrzymywaniu obietnic), która może dać w efekcie lojalność pacjenta w stosunku do gabinetu (w myśl zasady wzajemności).

Wśród działań, które personel gabinetu może podjąć w celu budowania i utrzymywania zaufania, za A.B. Eisingerichem i L. Mingiem, można wymienić ${ }^{106}$ :

- komunikację wewnętrzną i zewnętrzną,

- edukację klientów,

- rozszerzenie oferty usług o nowe atrybuty (np. większy zakres usług, większą dostępność itp.),

- dokonywanie usprawniających zmian strukturalnych (np. w przebiegu procesów) i - jeśli to konieczne - zmian personalnych,

- zmiany w infrastrukturze (mające podnieść komfort pobytu pacjenta w gabinecie i/lub komfort pracy personelu),

- personalizację usług,

- oferowanie usług wysokiej jakości (wyrażające się np. posługiwaniem się certyfikatami jakości),

- artykułowanie zaufania do klientów.

${ }^{104}$ Hope E., Odpowiedzialność w dziataniach public relations - zasady etyczne, w: Olędzki J., Tworzydło D. (red.), Public relations. Znaczenie społeczne i kierunki rozwoju, Wyższa Szkoła Informatyki i Zarządzania w Rzeszowie, Wydawnictwo Naukowe PWN, Warszawa 2006, s. 148.

105 Firma=etyka; pracownicy, dostawcy, spoteczeństwo, Zeszyt 1, Forum Odpowiedzialnego Biznesu, Warszawa 2009, s. 13.

${ }^{106}$ Eisingerich A.B., Ming L., Perceived service quality and customer trust in a professional service setting: What difference does customer education make? AMA Winter Educators' Conference Proceedings, $2007 \mathrm{nr}$ 18, s. 170 i nast. 
Na zakończenie rozważań o roli zaufania w kreowaniu relacji na płaszczyźnie usługodawca - usługobiorca można przytoczyć argumenty W.M. Grudzewskiego, I.K. Hejduk, A. Sankowskiej, M. Wańtuchowicz, przemawiające za tym, że podmiotach usługowych (w gabinetach lekarskich w szczególności) zaufanie jest strategicznym zasobem organizacji; dzięki niemu bowiem:

- „każda organizacja może odpowiadać na dynamiczne zmiany w turbulentnym otoczeniu ${ }^{107}$ (test cenności),

- wysoki poziom zaufania jest aktywem niematerialnym nielicznych organizacji (test rzadkości),

- zaufanie interpersonalne stanowi specyficznie pojmowany akcjonariat pracowniczy, ponieważ może występować u wszystkich pracowników (test własności),

- zaufanie wykazuje duży opór na naśladowanie bądź automatyczne kopiowanie, więc jest trudne do imitacji ${ }^{108}$ (test naśladownictwa),

- przy kreowaniu zaufania z biegiem czasu ma ono tendencję do wzrastania ${ }^{109}$ (test trwałości),

- zaufania nie można zastąpić innymi użytecznymi wartościami, ponieważ to ono jest stymulatorem innych norm kulturowych (test substytucyjności),

- zaufanie może być podstawą konkurencyjnej strategii działania (test konkurencyjności),

- zaufania nie można ukształtować przez administracyjne rozporządzenia i skodyfikowane przepisy organizacyjne (test formalizacji),

- zaufanie obejmuje praktycznie wszystkie aspekty funkcjonowania przedsiębiorstwa lub innej organizacji ${ }^{110}$ (test organizacji)" ${ }^{111}$.

Konkludując, warto podkreślić istotne i w usługach ciągle rosnące znaczenie zaufania i zaangażowania $\mathrm{w}$ relację, jako podstawy w dążeniu do kreowania

\footnotetext{
${ }^{107}$ Co jest przejawem proaktywnej postawy lekarzy dentystów i sposobem na poprawę pozycji konkurencyjnej gabinetu.

${ }^{108} \mathrm{Z}$ tego powodu ten zasób niematerialny staje się ważnym instrumentem w kreowaniu i umacnianiu pozycji konkurencyjnej gabinetu.

${ }^{109}$ Z punktu widzenia marketingu relacji jest to szczególnie ważne, gdyż zacieśnianie więzi między stomatologiem-usługodawcą a pacjentem-usługobiorcą przyczynia się - zgodnie z wynikami badania IV - do wzrostu poziomu lojalności pacjentów.

${ }^{110}$ Co potwierdza wcześniejsze spostrzeżenia, iż wrażenia pacjenta związane z pobytem w gabinecie dotyczą zarówno medycznych, jak i pozamedycznych obszarów jego działania.

111 Grudzewski W.M., Hejduk I.K., Sankowska A., Wańtuchowicz M., Zarządzanie zaufaniem w organizacjach wirtualnych, Difin, Warszawa 2007, s. 32.
} 
i wzmacniania długookresowych, zrównoważonych więzi między lekarzemusługodawcą i pacjentem-usługobiorcą $^{112}$.

\subsection{EDUKOWANIE PACJENTÓW}

Jednym z istotnych składników usług medycznych, pomagającym w budowaniu zaufania do lekarza, a w konsekwencji kształtowaniu długo- okresowych relacji na płaszczyźnie pacjent - gabinet, jest edukacja prozdrowotna, czyli odejście od modelu medycyny typu ex post (leczenie skutków) i przejście do modelu ex ante (niwelowanie przyczyn choroby) ${ }^{113}$.

Edukowanie pacjenta można rozumieć, jako proces zmieniania jego wiedzy, postaw i umiejętności oraz oddziaływania na zachowanie w celu utrzymania lub poprawy zdrowia ${ }^{114}$. Jego podstawowym celem jest zachęcenie pacjenta do wdrożenia poprawnych nawyków higienicznych, aktywnego uczestnictwa w leczeniu (rozumianego $\mathrm{m}$. in. jako dotrzymywanie terminów okresowych przeglądów stanu jamy ustnej), a także - jeśli to konieczne - zmiany nawyków żywieniowych. Wymaga to traktowania pacjenta jako partnera, uszanowania jego woli, możliwości i doświadczeń. Edukacja pacjenta przynosi wymierne korzyści zarówno w sferze klinicznej, jak i społecznej, pomaga pacjentom w radzeniu sobie z własnymi problemami zdrowotnymi, wpływa dodatnio na jego samopoczucie i satysfakcję (np. z lepszego wyglądu zębów) ${ }^{115}$, przyczynia się do wzmacniania więzi między pacjentem i lekarzem. Co pozwala na traktowanie jej, jako integralnej części dobrej jakościowo opieki zdrowotnej gabinetu stomatologicznego. Z punktu widzenia pacjenta, najważniejszą osobą, która powinna uczyć o zdrowiu i chorobie jest lekarz ${ }^{116}$. Z badania IV wynika, że edukowanie pacjenta jest ważne lub bardzo ważne dla $83,3 \%$ badanych (por. tabela 2.2 w załączniku 2 i wykres 5), z tego względu można rekomendować traktowanie edukacji przez lekarzy dentystów, jako ważny instrument marketingowego oddziaływania na pacjentów. Jest to o tyle istotne, że w praktyce z punktu widzenia lekarzy (nawet pozytywnie ustosunkowanych do kwestii edukacji pacjenta, profilaktyki i promocji zdrowia), działania te często mają niską rangę

\footnotetext{
${ }^{112}$ W literaturze takie stanowisko można znaleźć m. in. u: Morgan R.M., Hunt S.H., The Commitment ... op. cit., s. 20 i nast.; Cowles D., The Role of Trust in Consumer Relationships: Asking the Right Questions, "Management Decisions", 1997 vol. 35, nr 4, s. 273; Ulaga W., Eggert A., Relationship Value ... op. cit., s. 315 i nast.

${ }_{113}^{113}$ Perechuda K., Coaching wiedzy ... op. cit., s. 163.

${ }^{114}$ Vahabi M, Ferris L.E., Improving written patient education materials: a review of the evidence, "Health Education Journal", 1995 nr 1, s. 99 i nast.

${ }^{115}$ Por. Evason E, Whittington D., Patient satisfaction studies: problems and implications explored in a pilot a pilot study in Northern Ireland, "Health Education Journal", $1991 \mathrm{nr}$ 2, s. 73 i nast.

116 Por. Huges M., Patient attitude to health education in general practice, "Health Education Journal”, $1988 \mathrm{nr}$ 4, s. 130 i nast.
} 
i postrzegane są jako problematyczne w znaczeniu uzyskiwanych efektów ${ }^{117}$. $\mathrm{Z}$ badania I (por. tabela 69) wynika, że regularne rozmowy z pacjentem o profilaktyce zawsze lub często prowadzi 73\% lekarzy. Argumenty wskazywane przez lekarzy dentystów, którzy odbywają takie rozmowy bardzo rzadko (4,9\% wskazań), jako swoiste usprawiedliwienie niezbyt szerokiego edukowania pacjentów, były dwa podstawowe:

- „,nie mam na to czasu” - powód braku czasu był wskazywany najczęściej,

- ,juz to zrobiłam/tem” tj. raz została przekazana informacja pacjentowi (i w domyśle: to powinno wystarczyć) - wydaje się, że taka postawa może wynikać z braku zrozumienia dla roli edukacji, jako procesu, a nie jednorazowego działania.

K. Perechuda proponuje, aby w ramach budowania zaufania pacjenta do podmiotu leczniczego i kształtowania relacji z nim, lekarz dentysta (dotyczy to również higienistek stomatologicznych) stosował edukację pacjenta w następujących obszarach ${ }^{118}$ :

- przyczyn powstawania chorób zębów i przyzębia,

- metod zapobiegania chorobom,

- opanowywania procesów i instrumentów prawidłowej profilaktyki,

- dyfuzji najnowszej wiedzy medycznej do pacjenta-klienta.

Z perspektywy obsługi posprzedażowej dentysta powinien „dyskretnie czuwać” nad zdrowiem swojego pacjenta-klienta (np. proponując porady on-line na stronie internetowej swojego gabinetu). To „dyskretne czuwanie” powinno mieć zróżnicowany charakter (tzw. strategia selektywnego oddziaływania), i - wg K. Perechudy - mogłoby obejmowac ${ }^{119}$ :

- identyfikację klientów zorientowanych na usługi o wysokim stopniu innowacyjności,

- wprowadzenie coachingowego podejścia w stosunku do wybranej - najbardziej rentownej grupy pacjentów,

- tworzenie społeczności klientów łaknących wiedzy medycznej, jako instrumentu rozwiązywania ich problemów zdrowotnych i pozazdrowotnych,

- budowanie marketingu relacji z nowym segmentem klientów, opartej na dyfuzji wiedzy medycznej.

\footnotetext{
${ }^{117}$ Dixon-Woods M., Dissemination of printed information for patients: a qualitative study of general practices, "Health Education Journal", 1998 nr 1, s. 16 i nast.

${ }^{118}$ Perechuda K., Coaching wiedzy ... op. cit., s. 163.

${ }^{119}$ Ibidem s. 175.
} 
Podsumowując, z perspektywy marketingu relacji edukacja pacjenta stanowi nie tylko część składową świadczonej usługi medycznej (co oznacza m. in. konieczność uwzględniania jej w kosztach leczenia), ale również - ważny instrument pozytywnego oddziaływania na pacjenta, przyczyniający się do umacniania zaufania pacjenta do stomatologa. Jest więc nie tylko sposobem oddziaływania stricte medycznego na pacjenta, ale również elementem kształtowania relacji (wpisuje się tym samym $w$ dualne tj. medycznomarketingowe postrzeganie gabinetu).

\subsection{KOMUNIKACJA Z PACJENTEM}

\subsubsection{KOMUNIKACJA Z PACJENTEM - RYS TEORETYCZNY}

Zainteresowanie rolą czynników socjologicznych i psychologicznych w procesie leczenia pojawiło się wraz ze zmianą paradygmatu w naukach medycznych pod koniec lat 60. XX w., kiedy to rozpoczęło się odchodzenie od czysto medycznego (obejmującego tylko zmienne medyczne i koncentrującego się wyłącznie na chorobie, a nie na osobie chorego), mechanicznego podejścia ${ }^{120}$ do pacjenta na rzecz podejścia holistycznego. I od kiedy w latach 60. i 70. XX w. ${ }^{121}$ wykazano, że - obok badania pacjenta i stosowania procedur medycznych - krytyczne znaczenie w stawianiu diagnozy i procesie leczenia ma rozmowa $\mathrm{z}$ pacjentem, to coraz więcej uwagi poświęca się zagadnieniom z zakresu komunikacji $^{122}$. W badaniach nad istotą komunikacji lekarz - pacjent ${ }^{123}$ podej-

\footnotetext{
${ }^{120}$ Krytyka tego modelu pojawiła się ze strony: 1) psychologii medycyny, która skupiając się na osobach uczestników komunikacji (z których każdy wnosi do niej swoje indywidualne właściwości, modyfikujące przebieg czynności o charakterze leczniczym, a także odpowiadające za obecność w konsultacji działań zmierzających do innych celów niż medyczne); podkreśla, że kontakt lekarza z pacjentem ma charakter międzyludzki, stanowi układ interpersonalny, w którym zaangażowane są zmienne psychologiczne (np. świadomość lekarza co do znaczenia poszczególnych czynności, motywy skłaniające pacjenta do szukania pomocy lekarskiej i wykonywania poleceń lekarza). por. Heszen-Niejodek I., Lekarz i pacjent ..., op. cit., Heszen-Klemens I., Psychologia medyczna. Gtówne kierunki badań, Wyd. Uniwersytetu Śląskiego, Katowice 1983; 2) socjologii medycyny, która wychodząc z założenia, że kontakt lekarza z pacjentem nie zachodzi w próżni, ale jest zjawiskiem społecznym (stanowi część systemu społecznego i odbywa się w szerszym kontekście stosunków i norm społecznych); bada relacje lekarz - pacjent jako wzajemnie wyznaczający się układ działań dwóch lub więcej jednostek przebiegający wg pewnych stałych wzorów oraz analizuje wpływ ogólnego systemu społecznego na specyfikę kontaktu lekarz - pacjent.

por. Tobiasz-Adamczyk B., Relacje lekarz-pacjent w perspektywie socjologii medycyny, Wyd. UJ, Kraków, 2002.

${ }^{121}$ Por. Korsch B.M., Gozzi E.K., Francis V., Gaps in doctor-patient communication, "Pediatrics", $1968 \mathrm{nr}$ 42, s. 855 i nast.; Ley P., Communication in the clinical setting, "British Journal of Orthodontics", $1973 \mathrm{nr} 1$, s. 173 i nast.

122 Najogólniej ujmując komunikacja jest procesem porozumiewania, którego zadaniem jest przekazywanie informacji pomiędzy ludźmi. W procesie tym biorą udział: 1) nadawca i odbiorca informacji, 2) kod (język) wspólny dla nadawcy i odbiorcy, 3) kanał (środek komunikacji),
} 
mowana jest próba znalezienia odpowiedzi na pytanie: „Jaki wptyw na satysfakcje pacjenta $z$ wizyty, stosowanie się do zaleceń lekarza, zrozumienie zagadnień medycznych, a tym samym na wyniki leczenia ma przebieg rozmowy lekarza z pacjentem?". Badania te mają charakter ${ }^{124}$ :

- normatywno-preskryptywny - identyfikacja pojawiających się problemów opiera się na założeniach, jak powinna wyglądać idealna komunikacja lekarz - pacjent; normy te często stanowią niepotwierdzone empiryczne hipotezy, bazujące na doświadczeniu praktykujących lekarzy, czy nawet wiedzy zdroworozsądkowej lub aktualnych teoriach popularnonaukowych ${ }^{125}$,

- statystyczny, polegają na identyfikacji, kategoryzacji i liczeniu zachowań komunikacyjnych w interakcji lekarz - pacjent $^{126}$.

Wyniki tych badań mają znaczenie również z punktu widzenia realizacji rynkowej orientacji gabinetu. Zrozumienie znaczenia właściwej komunikacji w nawiązywaniu i utrzymywaniu trwałych relacji z pacjentami stanowi jeden $\mathrm{z}$ fundamentów marketingu w placówkach opieki zdrowotnej. Ranga efektywnej komunikacji z różnymi (np. ze względu na wiek czy wykształcenie) pacjentami wynika również z asymetrii (o której była już wcześniej mowa).

K. Stefaniak zwraca uwagę na fakt, że trudności w komunikacji między lekarzem a pacjentem wynikają $m$. in. $z$ innego podejścia do ciała pacjenta prezentowanego przez pacjenta i lekarza. Dla pacjenta jego ciało jest integralną częścią jego tożsamości - ciało i tożsamość tworzą jedną całość, która w chwili kontaktu z instytucją medyczną ulega swoistemu „rozerwaniu” "127. Aby ingerencja w ciało nie była jednocześnie naruszeniem „ucieleśnionej tożsamości” pacjenta (do czego zobowiązują zasady: zachowania obiektywności i neutral-

\footnotetext{
4) komunikat - zespół sygnałów przedstawiających określoną wiadomość (ważne jest, aby sygnały współtworzące dany komunikat uzupełniały się treściowo i były wzajemnie zgodne). Brak któregokolwiek z wymienionych elementów może spowodować zakłócenia w komunikacji.

${ }^{123}$ por. Ainsworth-Vaughn N., The discourse of medical encounters, w: Schiffrin D., Tannen D., Hamilton H. (red.), The Handbook of Discourse Analysis, Blackwell, Oxford 2001, s. 453 i nast.; Fleischman S., Language and medicine, w: Schiffrin D., Tannen D., Hamilton H. (red.), The Handbook of Discourse Analysis, Blackwell, Oxford 2001, s. 471 i nast.

${ }^{124}$ Stefaniak K., Wtadza ... op. cit., s. 124.

${ }^{125}$ Lalouschek J., Ärztliche Gesprächsausbildung. Eine diskursanalytische Studie zu Formen des ärztlichen Gesprächs, Radolfzell: Verlag für Gesprächsforschung, 2002, s. 14 i nast. za: Stefaniak K., Władza ... op. cit., s. 124.

${ }^{126} \mathrm{~Np}$. instrumentalne zachowania komunikacyjne lekarza, tj. uzyskiwanie i udzielanie informacji, stanowią $60 \%$ interakcji z pacjentem, z czego $23 \%$ to zadawanie pytań pacjentowi. Może to prowadzić do konstatacji, że lekarze zbyt mało czasu poświęcają na informowanie chorego i do postulatu o konieczności zmiany tych proporcji. Za: Tobiasz-Adamczyk B., Relacje ... op. cit.

${ }^{127}$ Por. Stefaniak K., Wtadza ... op. cit.
} 
ności), medycyna „oddziela ciało od człowieka”" ${ }^{\prime 28}$. W trakcie wizyty dochodzi do swoistej transformacji - przejścia ze świata społecznego (człowiek w poczekalni) do świata medycyny (pacjent na fotelu), powitanie należy jeszcze do świata społecznego, ale - rozpoczynając wywiad - lekarz przestaje traktować swojego rozmówcę, jako osobę, a zaczyna postrzegać go jako pacjenta (i skupia się na uwarunkowaniach stricte medycznych wizyty). Skupienie się na problemie zdrowotnym (a nie na człowieku) może wynikać również z tego, że dentysta w trakcie toku studiów stosunkowo późno „spotyka się z pacjentem” i jego wiedza i umiejętności stricte medyczne zajmują w tym kontekście więcej miejsca, niż zainteresowanie człowiekiem. Z punktu widzenia kształtowania relacji stomatolog - pacjent, ważne jest, by profesjonalizm stricte zawodowy nie przesłaniał człowieka, który jest stroną procesu usługowego. Dlatego wywiad z pacjentem powinien umożliwić poznanie jego oczekiwań nie tylko w obszarze stricte zdrowotnym, jeśli stomatolog chce nawiązać z nim długookresowe relacje.

Wracając do problematyki trudności w komunikacji pacjent - dentysta (czy nawet szerzej: personel gabinetu stomatologicznego), można powtórzyć za T.E. Quill ${ }^{129}$, że barierą w komunikacji jest wszystko to, co ogranicza efektywność komunikacji, a w konsekwencji zmniejsza satysfakcję pacjenta z leczenia lub powoduje jego niestosowanie się do zaleceń. Można mówić o barierach ${ }^{130}$ :

- widocznych, które powstają, gdy pacjent otwarcie oskarża lekarza o np. rasizm lub seksizm (pojawiają się rzadko w kontaktach personel - pacjent);

- ukrytych, które najczęściej są trudne do zauważenia, gdyż „na powierzchni interakcji” pozornie wszystko przebiega prawidłowo; do sygnałów świadczących o występowaniu tego typu barier można zaliczyć:

- niezgodność werbalno-niewerbalną - dotyczy sytuacji, kiedy słowa i zachowanie pacjenta są ze sobą sprzeczne (np. na pytanie o samopoczucie lub sytuację rodzinną pacjent odpowiada, że wszystko jest w porządku, ale jednocześnie milknie, smutnieje); bariera ta dotyczy również personelu gabinetu (np. można wyobrazić sobie recepcjonistkę, która mówi do pacjenta: „O, cieszę się, że już pan jest. Doktor zaraz pana przyjmie.", nie odrywając w tym czasie wzroku od monitora komputera czy dokumentów rozłożonych na biurku);

- dysonans kognitywny - powstaje kiedy informacje udzielane przez pacjenta nie tworzą spójnej całości w chwili, gdy dentysta próbuje je powiązać (np. pacjent opowiada, że ma trudności w pracy, niedawno

\footnotetext{
${ }^{128}$ Young K., Narrative embodiments: Enclaves of the self In the realm of medicine, w: Schotter J., Gergen K.J. (red.), Texts of Identity, Sage, Londyn 1989.

${ }^{129}$ Quill T.E., Recognizing ... op. cit.

${ }^{130}$ Ibidem.
} 
umarł mu ojciec, ale na pytanie, czy jest zestresowany, odpowiada, że nie); bariera ta może oczywiście pojawić się również po stronie personelu gabinetu (np. dentysta przedstawia zalety implantów, a na pytanie pacjenta, czy w jego przypadku nie można zastosować tańszego leczenia odpowiada, że implanty są najlepsze);

- nieoczekiwany opór pacjenta - dotyczy sytuacji, gdy pacjent gniewem lub złością reaguje na uwagi (nawet rutynowe) stomatologa;

- dyskomfort lekarza - dotyczy sytuacji, gdy dentysta - również podświadomie - reaguje na pewnych pacjentów i/lub ich problemy negatywnymi emocjami, a w konsekwencji może zdarzyć się, że i zachowaniem;

- niestosowanie się pacjenta do zaleceń, a w konsekwencji często brak rezultatów leczenia - może to świadczyć o trudnościach na płaszczyźnie komunikacji werbalnej i w zakresie wymiany informacji.

Kolejnym źródłem barier w komunikacji lekarz - pacjent jest tzw. zorientowanie na lekarza, podczas gdy w centrum zainteresowania powinien stać pacjent. J. Lalouschek ${ }^{131}$ zauważa, że sygnałem wskazującym na fakt, iż komunikacja zorientowana jest na lekarza, jest:

- kontrolowanie przez medyka przebiegu interakcji: rozpoczyna on i kończy rozmowę, inicjuje nowe wątki, stawia pytania; podczas gdy pacjent jest bierny, odpowiada na pytania i akceptuje decyzje lekarza dentysty;

- to, że wypowiedzi stomatologa zajmują ilościowo większą część interakcji werbalnej, często dlatego, że lekarze przerywają pacjentom i hamują ich inicjatywy; ponadto typowe pytania zadawane przez lekarzy, to pytania zamknięte ${ }^{132}$, które nie dają pacjentom szansy na przedstawienie problemu własnymi słowami; także sami lekarze nie wykazują inicjatywy w informowaniu pacjentów i udzielaniu dodatkowych wyjaśnień.

Można wyróżnić kilka rozwiązań między podejściem skrajnie zorientowanym na lekarza dentystę ${ }^{133}$ (gdy podejmuje on samodzielnie decyzje dotyczące

\footnotetext{
${ }^{131}$ Lalouschek J., Ärztliche ... op. cit.

${ }^{132}$ Badania przeprowadzone przez Y. Ibrahima wykazały, że 97,21\% pytań lekarzy było pytaniami zamkniętymi lub pytaniami o charakterze administracyjnym, wymagającymi krótkich, konkretnych odpowiedzi. Pytania psychologiczne, ukierunkowane na emocje pacjenta, stanowiły $0,48 \%$ wszystkich pytań; pytania o czystym charakterze konwersacyjnym, mające na cel podtrzymanie rozmowy, zaledwie $1,58 \%$; stosunkowo niewielki był też odsetek pytań sprawdzających zrozumienie $-30,42 \%$. Por. Ibrahim Y., Doctor ... op. cit.

${ }^{133}$ Nie powinno się jednoznacznie kojarzyć zorientowania na lekarza ze złym czy nieprawidłowym sposobem prowadzenia rozmowy z pacjentem (chyba że będzie ono wyrażać brak szacunku dla pacjenta jako człowieka), gdyż zależy ono m.in. od sytuacji zdrowotnej pacjenta; jego oczekiwań względem lekarza; tego czy pacjent opłaca wizytę z własnej kieszeni, czy płaci za niego ubezpieczyciel; czy nawet od częstotliwości wizyt w gabinecie lekarskim.
} 
leczenia pacjenta, a następnie go poucza) i skrajnie zorientowanym na pacjenta (gdy stomatolog pozwala pacjentowi na podejmowanie własnych decyzji) ${ }^{134}$ :

- lekarz ,sprzedaje” swoją decyzję pacjentowi,

- lekarz przedstawia swoją decyzję jako propozycję, którą pacjent może odrzucić,

- lekarz przedstawia problem i sugeruje jego rozwiązania lub - po przedstawieniu możliwości i ograniczeń danej metody leczenia - prosi pacjenta o podjęcie decyzji.

Zamykając tę część rozważań, można zauważyć, że do sposobów poprawy kontaktów lekarz - pacjent (najczęściej wymienianych przez pracowników służby zdrowia) można zaliczyć ${ }^{135}$ :

- ustawienie w centrum zainteresowania pacjenta, a nie lekarza,

- skupianie się na osobie, a nie na problemie,

- zaangażowanie się lekarza wobec pacjenta,

- zachowanie się lekarza jako humanistycznego profesjonalisty, a nie żołnierza technologii,

- lepsze podejście do chorego personelu placówki zdrowotnej, przejawiające się m. in. w większej empatii wobec pacjentów, szacunku wobec pacjentów, przyjęciu postawy cierpliwego nauczyciela;

- nie tylko leczenie, ale również opiekowanie się chorym (rozumiane np. jako edukowanie pacjenta w zakresie dbałości o higienę jamy ustnej).

Konkludując, można powtórzyć za I. Rudawską: „Profesjonalista na gruncie usług medycznych to ten, kto potrafi swój profesjonalizm merytoryczny przełożyć na styl komunikacji z klientem tak, aby owocował on dodatnimi następstwami w procesie rozwiązywania problemu zdrowotnego (tzn. postawa i osobowość profesjonalisty powinny przyczyniać się do zwiększania skuteczności postępowania medycznego)" ${ }^{, 136}$, a także wpłynął na zaufanie pacjenta do pracownika gabinetu i przyczynił się do wzmocnienia relacji między nimi.

\footnotetext{
${ }^{134}$ Ibrahim Y., Doctor ... op. cit.

${ }^{135}$ Payne A., Marketing ... op. cit. Potwierdzają to również wyniki badań własnych (badanie IV).

${ }^{136}$ Rudawska I., Jakość relacji pacjent - profesjonalista w sektorze ustug medycznych, „Problemy Jakości”, $2005 \mathrm{nr}$ 3, s. 15.
} 


\subsubsection{KOMUNIKACJA W GABINECIE STOMATOLOGICZNYM - ASPEKT EMPIRYCZNY ${ }^{137}$}

Z badania IV wynika, że najważniejszą potrzebą pacjenta w kontakcie ze stomatologiem jest - co wynika nie tylko z samej istoty zaspokojenia potrzeby zdrowotnej, ale również praw pacjenta ${ }^{138}$ - profesjonalne wykonanie świadczenia i solidność wykonania usługi w zakresie stricte medycznym - 98,9\% respondentów uznało za ważny lub bardzo ważny element wizyty. $\mathrm{W}$ tabeli 2.2. w Załączniku 2 przedstawiony jest ranking oczekiwań pacjentów względem lekarza dentysty i pozostałych pracowników gabinetu (zawierający m. in. zagadnienia z zakresu komunikacji). I nie ulega wątpliwości, że komunikacja interpersonalna na płaszczyźnie pacjent - dentysta jest ważna lub bardzo ważna dla przeszło $80 \%$ ankietowanych, co więcej dla większości obszarów dominanta wskazań wynosiła 5 (a więc czynnik był na pewno ważny w kontaktach pacjent - personel gabinetu). Odpowiadając na pytanie: Czego oczekuja pacjenci od personelu gabinetu stomatologicznego $w$ obszarze komunikacji?, można wskazać następujący ranking:

- uprzejmość (czynnik ważny i bardzo ważny dla 94,6\% respondentów);

- przekazywanie wyczerpującej informacji na temat leczenia (92,8\% wskazań);

- zrozumienie obaw pacjenta (istotne dla 86,8\% respondentów) i poznanie jego oczekiwań (85,6\% respondentów), aby tym łatwiej rozmawiać o problemach zdrowotnych pacjenta i możliwych do podjęcia działaniach z zakresu profilaktyki $(83,3 \%)$;

- dentysta powinien używać języka zrozumiałego dla pacjenta (85,9\% wskazań);

- dentysta nie powinien zbyt mocno naciskać na wybór droższego sposobu leczenia (77,8\% respondentów było takiego zdania);

- kwestia sposobu zwracania się do pacjentów (personalnie vs bezosobowo) podzieliła respondentów dość mocno: 1/3 nie miała zdania, 23,1\% zadeklarowało, że jest im wszystko jedno, a 43,7\% uważa, że dentysta powinien zwracać się do pacjenta personalnie;

\footnotetext{
${ }^{137}$ Wyniki badań przedstawionych w tej części pracy były prezentowane w: Bukowska-Piestrzyńska A., Communication with patients from the perspective of patients, dental surgeons and dentistry students - research results, ,e-Dentico”, $2013 \mathrm{nr} 1$, s. 38 i nast.

${ }^{138}$ Zgodnie z art. 8 Ustawy o prawach pacjenta i Rzeczniku Praw Pacjenta z 6 listopada 2008 r. (Dz.U. nr 52, poz. 417 z 2009r.) pacjent ma prawo do świadczeń zdrowotnych udzielanych z należytą starannością przez podmioty udzielające świadczeń zdrowotnych $\mathrm{w}$ warunkach odpowiadających określonym w odrębnych przepisach wymaganiom fachowym i sanitarnym. Przy udzielaniu świadczeń zdrowotnych lekarz dentysta kieruje się zasadami etyki zawodowej (zgodnymi z Kodeksem etyki lekarskiej).
} 
- najmniejszym zainteresowaniem respondentów cieszyło się wykorzystanie SMSów do komunikacji gabinetu z pacjentem - ok. $45 \%$ badanych stwierdziło, że nie jest to dla nich ważny element w kontaktach z gabinetem (przeciwnego zdania była ok. 1/3 badanych).

Kolejnym zagadnieniem, które było przedmiotem badania IV był wykorzystywany w lingwistyce ${ }^{139}$ model komunikacji lekarz - pacjent (nawiązujący do modelu zgodności T. Parsonsa ${ }^{140}$ i modelu kierowanie - współpraca T. Szasza i M.H. Hollendra ${ }^{141}$ ), który pozwala wyróżnić:

- model paternalizmu ${ }^{142}$, gdy lekarz określa cele i zadania konsultacji oraz podejmuje decyzje, zarówno w kwestii informowania pacjenta, jak i wyboru metody leczenia w oparciu o wiedzę naukową i przy pomocy technologii medycznych, a wszystko dla dobra pacjenta;

- model współpracy (odpowiadający relacji obopólnego uczestnictwa), w którym cele, zadania i decyzje podejmowane w konsultacji są wynikiem

\footnotetext{
${ }^{139}$ Stefaniak K., Władza ... op. cit., s. 250

${ }^{140}$ T. Parsons podkreśla asymetryczny charakter relacji lekarz - pacjent. Lekarz jest stroną dominującą w hierarchicznym układzie organizacji opieki zdrowotnej, jest ekspertem w dziedzinie medycyny, jego zawód posiada prestiż społeczny, jego rola ma charakter stały. Pacjent natomiast jest zależny od lekarza, musi uznać swój brak kompetencji w dziedzinie medycyny i podporządkować się lekarzowi. Asymetryczność roli lekarza w porównaniu z rolą pacjenta nie stoi jednak w sprzeczności z postulowaną zgodnością ich relacji. T. Parsons zakłada, że pacjent akceptuje swoją rolę i okazuje lekarzowi zaufanie, lekarz zaś wzajemnie rozumie potrzeby pacjenta i działa w jego interesie. Por. Parsons T., The sick ... op. cit.

${ }^{141}$ Wykorzystując definicję roli lekarza i pacjenta T. Szasz i M.H. Holleneder zaproponowali trzy modele relacji pacjent - lekarz, różniące się stopniem aktywności pacjenta: 1) model aktywność bierność (dotyczy sytuacji, gdy pacjent jest nieprzytomny lub pod narkozą, a działania lekarza odbywają się niezależnie od niego); 2) model kierowanie-współpraca (dotyczy sytuacji, kiedy lekarz wydaje polecenia, a pacjent je wykonuje); 3) model obopólnego uczestnictwa (dotyczy sytuacji, w której stosunki lekarza z pacjentem są oparte na partnerstwie i współodpowiedzialności; chory „sam prowadzi leczenie”, okresowo konsultując się z lekarzem).

Należy podkreślić, że żadnego z wymienionych modeli nie można określić, jako lepszy czy gorszy od innych, gdyż wszystkie mają zastosowanie w określonych sytuacjach terapeutycznych (np. model kierowanie-współpraca może mieć zastosowanie przy ostrym bólu zęba, a model obopólnego uczestnictwa w sytuacji, gdy pacjent ma założony aparat korygujący zgryz). W procesie leczenia jednego pacjenta przez tego samego lekarza relacje ulegają zmianie (mogą wystąpić wszystkie trzy w różnych przedziałach czasu), gdyż są dopasowywane do okoliczności.

Por. Szasz T., Hollender M.H., A contribution to the philosophy of medicine: The Basic models of the doctor-patient relationship, "Archives of Internal Medicine", $1956 \mathrm{nr} 97$.

142 Pod względem językowym charakteryzuje się wymianą informacji głównie o charakterze biomedycznym tj. związanych bezpośrednio z objawami i historią choroby, a unikaniem rozmów na tematy emocjonalne lub neutralne; dużą liczbą pytań zadawanych przez lekarza, a niewielką przez pacjenta i ogólnie niewielkim udziałem pacjenta w rozmowie z lekarzem; a także brakiem lub niewielką liczbą zachowań budujących pozytywną atmosferę terapii.

Por. Roter D.L., The enduring and evolving nature of the patient-physician relationship, "Patient Education and Counseling", 2000 nr 39.
} 
negocjacji między lekarzem a pacjentem (potrzeby pacjenta są otwarcie wyrażane, a lekarz odgrywa rolę doradcy). Wymiana informacji obejmuje zarówno informacje o charakterze medycznym, jak i emocjonalnym i społecznym, a pacjent jest zachęcany do zadawania pytań i przedstawiania swojego zdania ${ }^{143}$.

W badaniu to dwubiegunowe podejście zostało zmodyfikowane, aby rozszerzyć spektrum możliwych form uzgadniania stanowisk między dentystą a pacjentem w trakcie wizyty (kwestią poruszaną w trakcie wizyty miał być sposób wyboru dalszego leczenia). Dodatkowo odpowiedzi respondentów zostały przefiltrowane przez czynnik częstotliwości korzystania z usług stomatologicznych (por. tabela 62). Oczekiwania respondentów w stosunku do zachowania dentysty w zakresie wyboru metody leczenia były dość zróżnicowane, i tak:

- największa grupa tj. 50,2\% chciałaby, aby lekarz przedstawił możliwości leczenia i krótko je scharakteryzował, a następnie wskazał odpowiednią dla pacjenta $^{144}$;

- niespełna 1/3 respondentów (28\%) chciałaby, aby lekarz przedstawił możliwości leczenia i krótko je scharakteryzował, a następnie pozwolił, aby pacjent sam zdecydował, które będzie stosowane;

- dla 15,3\% badanych ważne byłoby, aby lekarz powiedział, ile określony sposób leczenia może kosztować (maksymalnie i minimalnie), a pacjent sam wybierze opcję leczenia;

- 4,7\% respondentów chciałoby, aby lekarz sam zdecydował o sposobie leczenia bez - zabierającego czas - opisywania sposobu leczenia;

- $\quad 1,8 \%$ pacjentów oczekuje, że lekarz zrobi tylko to, o co pacjent go poprosi.

Jak wynika $\mathrm{z}$ danych zamieszczonych $\mathrm{w}$ tabeli 62 oczekiwanie paternalizmu w zakresie decydowania o kierunku leczenia jest silniejsze u pacjentów rzadziej korzystających z usług dentysty, niż u tych korzystających z usług stomatologicznych regularnie. Model kooperacji w komunikacji w trakcie wizyty jest nieco silniej zaznaczony w grupie pacjentów regularnie odwiedzających gabinet stomatologiczny - zarówno w odniesieniu do wyboru metody leczenia, jak i jego kosztów. Postawę typowego klienta można dostrzec w grupie osób, które relatywnie najrzadziej korzystają z usług stomatologicznych - oczekują tylko wykonania konkretnego świadczenia.

Współczesny pacjent coraz częściej postrzega siebie jako klienta - aktywnie działa na rynku usług medycznych, zdobywa wiedzę, porównuje oferty gabi-

\footnotetext{
${ }^{143}$ Roter D.L., The enduring ... op. cit.

${ }^{144}$ Należy podkreślić, że zgodnie z wyrokiem SN (sygnatura akt III CSK 227/11) do pacjenta należy wybór sposobu leczenia, choćby w ocenie lekarza był on niekorzystny,
} 
netów itp. Jest sceptyczny (nie dowierza bezkrytycznie wszystkiemu, co słyszy i co mu się proponuje), racjonalny, aktywny i niezależny ${ }^{145}$. Dlatego obok tradycyjnego modelu paternalizmu i - przedstawianego jako jego alternatywa - modelu współpracy, obserwuje się obecnie powstawanie trzeciej formy relacji lekarz - pacjent: modelu konsumenckiego, w którym pacjent ustala cele konsultacji i ponosi odpowiedzialność za podejmowane decyzje, zadaje pytania, niemal żąda od lekarza udzielania odpowiedzi i wykonywania usług, sam określa swoje potrzeby, a rola lekarza ograniczona jest do roli konsultanta. Charakterystyczna dla tego modelu jest duża ilość informacji o biomedycznym charakterze udzielanych przez lekarza na żądanie pacjenta, natomiast brak jest informacji o charakterze psychospołecznym i emocjonalnym. Konsultacja staje się transakcją rynkową, pacjent - kupującym, lekarz - dostawcą usługi ${ }^{146}$. W polskich warunkach taka sytuacja może dotyczyć nie tylko pacjentów wyposażonych w wiedzę o świadczeniach stomatologicznych, ale również (a może przede wszystkim?) pacjentów, którzy rzadko korzystają z usług stomatologicznych (por. tabela 62) i/lub leczą się nie opłacając wizyty z własnej kieszeni (koszt wizyty pokrywa NFZ) i prezentują postawę „bo mi się” należy.

Tabela 62. Wpływ częstotliwości korzystania z usług stomatologicznych na oczekiwania wobec dentysty

\begin{tabular}{|l|c|c|c|}
\hline \multicolumn{1}{|c|}{ Oczekiwanie } & $\begin{array}{c}\text { Pacjent w ciągu } \\
\text { ostatnich 5 lat byt } \\
\text { 1-3razy u } \\
\text { dentysty (N=87) }\end{array}$ & $\begin{array}{c}\text { Pacjent jest w } \\
\text { gabinecie 1-3 } \\
\text { razy w roku } \\
\text { (N=150) }\end{array}$ & $\begin{array}{c}\text { Pacjent jest w } \\
\text { gabinecie co } \\
\text { miesiąc-dwa } \\
\text { (N=42) }\end{array}$ \\
\hline $\begin{array}{l}\text { lekarz sam zdecyduje o sposobie leczenia } \\
\text { bez - zabierającego czas - opisywania } \\
\text { sposobu leczenia }\end{array}$ & $3,66 \%$ & $4,68 \%$ & $8,33 \%$ \\
\hline $\begin{array}{l}\text { lekarz przedstawi możliwości leczenia i krót- } \\
\text { ko je scharakteryzuje, a następnie wskaże } \\
\text { odpowiednią dla pacjenta }\end{array}$ & $51,22 \%$ & $49,71 \%$ & $41,67 \%$ \\
\hline $\begin{array}{l}\text { lekarz przedstawi możliwości leczenia i krót- } \\
\text { ko je scharakteryzuje, a następnie pozwoli } \\
\text { aby pacjent sam zdecydował, które będzie } \\
\text { stosowane }\end{array}$ & $24,40 \%$ & $29,24 \%$ & $30,56 \%$ \\
\hline lekarz zrobi tylko to, o co pacjent go poprosi & $3,66 \%$ & $0,58 \%$ & $0,0 \%$ \\
\hline $\begin{array}{l}\text { lekarz powie ile leczenie może kosztować } \\
\text { maksymalnie i minimalnie, a pacjent sam } \\
\text { wybierze opcję leczenia }\end{array}$ & $17,04 \%$ & $15,10 \%$ & $19,44 \%$ \\
\hline
\end{tabular}

Źródło: opracowanie własne na podstawie przeprowadzonego badania.

Do scharakteryzowania umiejętności lekarzy dentystów (badanie I) z zakresu komunikacji zostaną wykorzystane oceny - zaznaczone na szaro - zawarte w tabeli 19.

\footnotetext{
${ }^{145}$ Stefaniak K., Władza ... op. cit., s. 131.

${ }^{146}$ Roter D.L., The enduring ... op. cit., s. 7 i nast.
} 
Lekarze dentyści relatywnie wysoko ocenili - kategorię ogólną - jaką jest umiejętność nawiązywania dobrego kontaktu z pacjentem w trakcie pierwszej wizyty: $89,02 \%$ badanych uznało, że ma dobre lub bardzo dobre umiejętności w tym zakresie. Natomiast już umiejętności szczegółowe z zakresu komunikacji ocenili (oprócz aktywnego słuchania) średnio poniżej czterech (choć w wielu kwestiach dominanta wynosiła 4). I tak:

- umiejętność aktywnego słuchania 83,2\% badanych oceniło, jako dobrą lub bardzo dobrą,

- umiejętność jasnego i precyzyjnego komunikowania się 69,7\% responsdentów uznało, że ma na dobrym lub bardzo dobrym poziomie,

- w zakresie właściwego postępowania w sytuacji, gdy pacjent składa reklamację 72,3\% respondentów stwierdziło, że potrafi dobrze lub bardzo dobrze poprowadzić rozmowę.

Relatywnie słabo dentyści ocenili się w obszarze umiejętności związanych z postępowaniem w sytuacjach konfliktowych oraz udzielaniem i przyjmowaniem krytyki - 15-20\% respondentów uznało, że nie posiada umiejętności w tym zakresie lub posiada je na niskim poziomie.

Zastanawiająca może być samoocena w zakresie wywierania wpływu na decyzje rozmówców - 47,8\% oceniło się pozytywnie w tym zakresie (ale tylko $4,4 \%$ bardo dobrze), kolejnych 36,48\% respondentów uznało, że umiejętności ma na średnim poziomie, a pozostali - 15,72\% w małym stopniu lub w ogóle. Nasuwa się pytanie: jak połowa badanych przekonuje współpracowników czy pacjentów do swoich racji? jakimi metodami forsuje swoje rozwiązania? czy realizuje swoje propozycje, czy też ulega presji rozmówców? Biorąc pod uwagę relatywnie niski wynik samooceny lekarzy dentystów z zakresu umiejętności związanych z mediacjami w konflikcie czy radzenia sobie z krytyką, rysują się pewne możliwe problemy $\mathrm{z}$ optymalną komunikacją $\mathrm{w}$ gabinetach - zarówno $\mathrm{w}$ postępowaniu z tzw. roszczeniowym pacjentem, jak i członkami personelu gabinetu.

Warto podkreślić, że skuteczna komunikacja z pacjentem jest istotnym elementtem kontaktu usługowego, gdyż wpływa nie tylko na aspekt stricte medyczny (związany z zebraniem wywiadu ogólnego i lekarskiego), ale również na pozytywne postrzeganie przez pacjentów lekarza dentysty jako usługodawcy. Tym samym jest ważnym krokiem w nawiązywaniu długotrwałych relacji na płaszczyźnie: pacjent - lekarz dentysta. Ponadto przychylnie nastawiony pacjent dobrze mówi o gabinecie innym - potencjalnym pacjentom, stając się nie tylko wiarygodnym, ale i bezpłatnym źródłem rekomendacji. Przedstawione wyniki upoważniają do konkluzji, iż podniesienie poziomu umiejętności z zakresu komunikacji z pacjentem powinno stać się przedmiotem zainteresowania 
lekarza dentysty (również pozostałych członków gabinetu), gdyż właściwa komunikacja z pacjentem pomaga $w$ nawiązywaniu i utrzymywaniu pozytywnych relacji z pacjentami, w budowaniu wizerunku przyjaznego gabinetu, w długim okresie również wzmacnianiu pozycji konkurencyjnej.

Stosunkowo słabą stroną stomatologów jest umiejętność chwalenia pracowników (23,08\% respondentów oceniło swoje umiejętności wysoko w tym zakresie, a co dziesiąty badany uznał, że w ogóle ich nie posiada); a także udzielanie wskazówek pracownikom (8,3\% respondentów oceniło swoje umiejętności, jako bardzo dobre, a 25,3\% jako słabe lub nie występujące).

Badani studenci (respondenci badania III) dobrze - tyle wynosiła dominanta w większości badanych kwestii - ocenili swoje umiejętności w zakresie komunikacji (por. szare pola w tabeli 21), w niektórych obszarach ocenili się lepiej, niż rynkowi praktycy (np. w zakresie jasnego i precyzyjnego komunikowania się, udzielania konstruktywnej krytyki, czy publicznych prezentacji). Wyniki samooceny studentów można przedstawić następująco:

- umiejętność aktywnego słuchania przez 85,4\% respondentów została oceniona dobrze lub bardzo dobrze i nikt nie zadeklarował, że nie posiada takiej umiejętności,

- umiejętność jasnego i precyzyjnego komunikowania się jako posiadaną na dobrym lub bardzo dobrym poziomie wskazało $76 \%$ badanych,

- umiejętność nawiązywania dobrego kontaktu z pacjentem na ćwiczeniach w trakcie pierwszej wizyty przeszło połowa badanych oceniła jako dobrą, a $27 \%$ jako bardzo dobrą.

Podobnie jak lekarze, studenci słabiej ocenili swoje umiejętności w zakresie udzielania i przyjmowania krytyki oraz postępowania w przypadku sytuacji konfliktowej. Umiejętność wywierania wpływu na decyzje rozmówcy 12,5\% respondentów oceniło na bardzo dobrze, a blisko połowa uznała, że posiada ją na średnim poziomie.

Studenci stomatologii (wyniki badania III) zostali poproszeni o określenie ważności różnych obszarów komunikacji $\mathrm{w}$ gabinecie $\mathrm{z}$ perspektywy nabywcy usługi (por. tabela 63). Pierwsza trójka odpowiedzi pokrywa się z tymi wskazanymi przez pacjentów, choć studenci przypisali czynnikom niższą wagę, niż zrobili to pacjenci. Przed rozpoczęciem badania autorka postawiła taką tezę, że odpowiedzi w tych dwóch grupach badawczych będą niemal identyczne ze względu na fakt, iż studenci mają niewielkie doświadczenie w kontaktach z pacjentami, jako świadczeniodawcy (na I czy II roku niemal żadne) i bliższa jest im perspektywa pacjenta (sami - jak na razie - częściej występują w tej roli). Jednak badanie nie potwierdziło tego założenia, choć różnice $\mathrm{w}$ wartości średniej w odpowiedziach są niewielkie. 
Tabela 63. Oczekiwania pacjentów względem pracowników gabinetu w oczach studentów

\begin{tabular}{|c|c|c|c|c|c|c|c|c|c|}
\hline \multirow[b]{2}{*}{ Oczekiwania } & \multicolumn{5}{|c|}{$\begin{array}{l}\text { Wskazania respondentów } \\
\text { (procent wskazań) }\end{array}$} & \multirow[b]{2}{*}{$\bar{x}$} & \multirow[b]{2}{*}{ Do } & \multirow[b]{2}{*}{$\mathbf{S}(\mathbf{x})$} & \multirow[b]{2}{*}{ Me } \\
\hline & $\begin{array}{c}\text { na } \\
\text { pewno } \\
\text { nie } \\
(1)\end{array}$ & $\begin{array}{c}\text { raczej } \\
\text { nie } \\
(2)\end{array}$ & $\begin{array}{c}\text { trudno } \\
\text { powie- } \\
\text { dzieć } \\
(3)\end{array}$ & $\begin{array}{c}\text { raczej } \\
\text { tak } \\
(4) \\
\end{array}$ & $\begin{array}{c}\text { na } \\
\text { pewno } \\
\text { tak } \\
(5)\end{array}$ & & & & \\
\hline $\begin{array}{l}\text { Dentysta powinien wykonać usłu- } \\
\text { gę w sposób rzetelny i dokładny }\end{array}$ & 0,0 & 0,0 & 3,13 & 21,88 & 75,0 & 4,72 & 5 & 0,52 & 5 \\
\hline $\begin{array}{l}\text { Pracownicy gabinetu powinni być } \\
\text { uprzejmi wobec pacjenta }\end{array}$ & 0,0 & 0,0 & 6,25 & 32,29 & 61,46 & 4,55 & 5 & 0,61 & 5 \\
\hline $\begin{array}{l}\text { Informacja w trakcie leczenia } \\
\text { powinna być wyczerpująca }\end{array}$ & 0,0 & 0,0 & 7,29 & 37,50 & 55,21 & 4,48 & 5 & 0,63 & 5 \\
\hline $\begin{array}{l}\text { Dentysta powinien starać się } \\
\text { rozpoznać potrzeby pacjenta }\end{array}$ & 0,0 & 2,08 & 7,29 & 40,63 & 50,0 & 4,39 & 5 & 0,72 & 5 \\
\hline $\begin{array}{l}\text { Personel powinien rozumieć oba- } \\
\text { wy pacjenta związane } \mathrm{z} \text { wizytą }\end{array}$ & 0,0 & 0,0 & 9,38 & 45,83 & 44,79 & 4,35 & 4 & 0,65 & 4 \\
\hline $\begin{array}{l}\text { Dentysta powinien rozmawiać z } \\
\text { pacjentem językiem prostym i } \\
\text { zrozumiałym }\end{array}$ & 0,0 & 1,04 & 5,21 & 51,04 & 42,71 & 4,35 & 4 & 0,63 & 4 \\
\hline $\begin{array}{l}\text { Dentysta powinien regularnie roz- } \\
\text { mawiać z pacjentem o jego proble- } \\
\text { mach zdrowotnych i profilaktyce }\end{array}$ & 0,0 & 2,08 & 15,63 & 51,04 & 31,25 & 4,11 & 4 & 0,74 & 4 \\
\hline $\begin{array}{l}\text { Dentysta nie powinien „,naciskać” } \\
\text { na pacjenta, aby zdecydował się na } \\
\text { droższą usługę }\end{array}$ & 3,13 & 3,13 & 17,71 & 36,46 & 39,58 & 4,06 & 5 & 0,99 & 4 \\
\hline $\begin{array}{l}\text { Dentysta powinien zwracać się do } \\
\text { pacjenta personalnie, a nie } \\
\text { bezosobowo }\end{array}$ & 4,17 & 10,42 & 27,08 & 32,29 & 26,04 & 3,66 & 4 & 1,10 & 4 \\
\hline Przypominanie o wizycie SMSem & 7,29 & 10,42 & 28,13 & 32,29 & 21,88 & 3,51 & 4 & 1,16 & 4 \\
\hline
\end{tabular}

Źródło: Opracowanie własne na podstawie przeprowadzonego badania.

Jak wynika $\mathrm{z}$ danych przedstawionych $\mathrm{w}$ tabeli 63 , studenci stomatologii uważają, że pacjenci w zakresie obsługi - ze szczególnym zwróceniem uwagi na aspekt komunikacji, oczekują od lekarzy dentystów:

- uprzejmości (93,75\% wskazań wyrażających opinię, że raczej tak lub na pewno tak),

- zrozumiałego języka (93,75\% wskazań, że na pewno tak lub raczej tak),

- wyczerpującej informacji (92,71\%),

- zrozumienia potrzeb pacjenta $(90,63 \%)$ i jego obaw związanych z wizytą w gabinecie $(90,62 \%)$,

- regularnych rozmów o zmianach w zakresie zdrowia i higieny jamy ustnej $(82,29 \%)$,

- nie ,zmuszania” do wyboru droższej metody leczenia $(76,04 \%)$, 
- personalnych a nie bezosobowych komunikatów $(58,33 \%)$,

- przypominania o wizycie SMSem $(54,17 \%)$.

Podsumowując rozważania dotyczące komunikacji, warto wskazać, że z przeprowadzonych badań (wyniki badania I, III i IV) wynika, iż połowa pacjentów nadal oczekuje, że w komunikacji dentysta - pacjent będzie realizowany w gabinecie model paternalizmu.

Umiejętności z zakresu komunikacji należy określić jako ważne w nawiązywaniu i utrzymywaniu relacji z pacjentami. Pacjenci oczekują od pracowników gabinetu przede wszystkim: uprzejmości, wyczerpującej informacji i zrozumienia ich obaw związanych $\mathrm{z}$ wizytą $\mathrm{w}$ gabinecie. Lekarze dentyści i studenci stomatologii formułują identyczne dwa pierwsze priorytety, patrząc na wizytę z perspektywy pacjenta, co może przyczyniać się do zaspokojenia oczekiwań pacjentów w tym zakresie. Warto podkreślić, że poznanie rzeczywistych oczekiwań pacjentów jest o tyle ważne, iż dentysta (i pozostali członkowie personelu gabinetu) mogą dostosować parametry komunikacji do potrzeb swoich pacjentów - nie zaniedbywać obszarów ważnych dla pacjentów i nie skupiać się na tych, które są dla pacjentów mniej istotne, co w konsekwencji może pozwolić na długofalową poprawę efektywności komunikacji ${ }^{147}$ na płaszczyźnie: gabinet - pacjent.

Biorąc pod uwagę samoocenę umiejętności z zakresu komunikacji wśród obecnych i przyszłych lekarzy dentystów, to jest ona wyższa wśród studentów, niż wśród praktykujących stomatologów. Dentyści najwyżej ocenili swoją umiejętność nawiązywania dobrego kontaktu z pacjentem w trakcie pierwszej wizyty, a studenci - aktywnego słuchania; a obie badane grupy najsłabiej oceniły swoje umiejętności w zakresie wywierania wpływu na decyzje rozmówców i publicznych prezentacji.

\footnotetext{
${ }^{147}$ Determinanty efektywności komunikacji są przedstawione m. in. w: Bukowska-Piestrzyńska A., Obstuga klienta gabinetu stomatologicznego, Wyd. Czelej, Warszawa 2011.
} 


\section{MARKETING RELACJI W GABINETACH - WYNIK BADAŃ 4.1. POZAMEDYCZNE OCZEKIWANIA PACJENTÓW}

\subsubsection{CHARAKTERYSTYKA BADANEJ GRUPY}

Zanim zostaną przedstawione działania proklientowskie podejmowane $\mathrm{w}$ gabinetach stomatologicznych, warto przyjrzeć się oczekiwaniom pacjentów w tym zakresie, gdyż zrozumienie i próba sprostania oczekiwaniom pacjentów jest nieodłącznym elementem pracy lekarza i może prowadzić do wzrostu satysfakcji pacjenta $\mathrm{z}$ opieki ${ }^{148}$. Tym samym staje się podstawą do budowania długookresowej relacji z pacjentem. R.L. Kravitz z zespołem ${ }^{149}$ pokazuje, że lekarze często nie doceniają znaczenia oczekiwań pacjentów w przebiegu kontaktu usługowego i nie rozpoznają ich (szczególnie w warstwie pozamedycznej usługi), a w związku z tym często pozostają one nie spełnione. Podczas gdy rozpoznanie i zaspokojenie potrzeb (a przez to zwiększenie satysfakcji pacjenttów) ma istotny walor ekonomiczny, gdyż poprawia relację „koszt-korzyść” dla pacjenta, poprzez zwiększenie korzyści uzyskiwanych przez usługobiorcę i może przyczynić się do tego, że pacjent będzie chciał leczyć się u tego konkretnego lekarza (a więc stanie się fundamentem relacji).

Badanie, mające na celu rozpoznanie pozamedycznych oczekiwań pacjentów względem lekarzy dentystów i ich gabinetów, zostało przeprowadzone w okresie październik-listopad 2011 r. Przeprowadzono je za pomocą standaryzowanego kwestionariusza (liczył on 31 pytań - z opcją pojedynczego lub wielokroćnego wyboru, a także pytania zamknięte skategoryzowane i otwarte). Próbę dobrano na podstawie nielosowego schematu doboru, jako próbę okolicznościową, skierowaną do respondentów (z województwa łódzkiego i mazowieckiego), którzy zostali wyłonieni z zachowaniem struktury płci i wieku dorosłych Polaków w 2010 r. $^{150}$ Rozdano 400 kwestionariuszy ankiety; zwrot otrzymano od 356 osób (najmniejsza stopa zwrotu dotyczyła respondentów z grupy 50+); 279 ankiet było kompletnych i poprawnie wypełnionych i to one stały się przedmiotem dalszej analizy ${ }^{151}$.

\footnotetext{
${ }^{148}$ Kravitz R.L., Cope D.W., Bhrany V., Leake B., Internal medicine patients' expectations for care during office visits, "Journal of General Internal Medicine", 1994 vol. 9, s. 75 i nast.

149 Kravitz R.L. Callahan E.J., Paterniti D., Antonius D., Dunhan M., Lewis C.E., Prevalence and Sources of Patients' Unmet Expectations for care, "Annals of Internal Medicine", $1996 \mathrm{nr}$ 125, s. 730 i nast.

${ }^{150}$ Punktem wyjścia przy określeniu warstw i odpowiadających im kwot stały się dane na temat populacji mieszkańców Polski dostępne w „Roczniku Statystycznym” 2010 r.

${ }^{151}$ Dlatego w badanej grupie nie zostały zachowane - skategoryzowane przy wyborze respondentów - kwoty o profilu demograficznym (uwzględniające wiek i płeć pacjentów). Mimo zastrzeżeń co do statystycznej reprezentatywności zebranych odpowiedzi, zgromadzony materiał pozwolił na sformułowanie ciekawych poznawczo wniosków i pozwolił na odniesienie się do nich przy analizowaniu wyników badania I i III.
} 
Grupę objętą badaniem IV można scharakteryzować w następujący sposób: liczyła ona 279 respondentów (z czego 53,8\% stanowiły kobiety, a 46,2\% - mężczyźni). Strukturę wieku badanych przedstawia tabela 64.

Tabela 64. Struktura wieku badanych pacjentów

\begin{tabular}{|l|c|}
\hline \multicolumn{1}{|c|}{ Wiek badanych } & Wskazania \\
\hline$<30$ & $27,24 \%$ \\
\hline $30-39$ & $22,58 \%$ \\
\hline $40-49$ & $20,79 \%$ \\
\hline $50-60$ & $22,58 \%$ \\
\hline $60<$ & $6,81 \%$ \\
\hline
\end{tabular}

Źródło: opracowanie własne na podstawie przeprowadzonego badania

Biorąc pod uwagę możliwości wyboru gabinetu w pobliżu miejsca zamieszkania respondenta, to dla 8,6\% respondentów gabinet, w którym się leczą był jedynym w najbliższej okolicy (tj. w promieniu $5-7 \mathrm{~km}$ nie było innych tego typu podmiotów). Kolejnych $15,8 \%$ pacjentów zadeklarowało, że w okolicy znajdują się jeszcze 1-2 inne gabinety; 21,6\% badanych - że 3-5 gabinetów; a $32 \%$ - że więcej niż 5 gabinetów. Przeszło jedna piąta badanych $(21,9 \%)$ nie potrafiła odpowiedzieć na pytanie, jaka jest orientacyjna liczba gabinetów w pobliżu gabinetu z usług, którego korzystają (w tej grupie znalazły się osoby, które nie chodzą do dentysty, albo w ciągu ostatnich pięciu lat były 1-2razy, a także osoby z miast liczących 50-200 tyś. mieszkańców). Uwzględniając tę perspektywę, można powiedzieć, że większość respondentów miała swobodny dostęp i możliwość wyboru usługodawcy. Można więc przyjąć, że gabinet, w którym się leczą - przynajmniej w części - spełnia ich oczekiwania.

Przeszło połowa badanych przynajmniej raz $\mathrm{w}$ roku była $\mathrm{w}$ gabinecie na okresowej kontroli stanu jamy ustnej, $\mathrm{z}$ drugiej strony $-10 \%$ badanych w ciągu ostatnich pięciu lat nie było u stomatologa w ogóle lub było raz. Kompleksowe spojrzenie na częstotliwość korzystania z usług stomatologicznych przez respondentów przedstawia tabela 65 (to kryterium stało się czynnikiem różnicującym badaną grupę w trakcie analizy poziomów relacji pacjent - dentysta).

Tabela 65. Częstotliwość korzystania z usług stomatologicznych przez pacjentów

\begin{tabular}{|l|c|}
\hline $\begin{array}{c}\text { Częstotliwość korzystania z usług stomatologicznych w ciągu ostatnich } \\
\text { pięciu lat }\end{array}$ & Wskazania (\%) \\
\hline ani razu & 6,5 \\
\hline Raz & 4,2 \\
\hline 2-3 razy & 24,0 \\
\hline co roku - okresowy przegląd stanu zdrowia jamy ustnej & 23,3 \\
\hline 2-3 razy w roku (w tym coroczna wizyta kontrolna) & 30,5 \\
\hline ostatnio regularnie - co miesiąc ze względu na kompleksowe leczenie zębów & 10,4 \\
\hline ostatnio regularnie - ze względu na założony aparat korygujący zgryz & 1,1 \\
\hline Źódło: opracowanie własne na podstawie przeprowadzonego badania.
\end{tabular}


Większość badanych - 78,5\% korzysta $\mathrm{z}$ usług jednego stomatologa; dodatkowo w tej grupie 1/4 (tj. 20,9\% ogółu badanych) zadeklarowała, że w sytuacji, gdy dentysta nie potrafi wykonać jakiegoś zabiegu (np. resekcja zęba), to korzysta z usług innego dentysty (często z polecenia „własnego" lekarza). Z usług różnych dentystów korzysta 21,5\% badanych.

Respondenci najczęściej korzystają ze świadczeń u określonego lekarza w długim okresie - przeszło połowa leczy się u aktualnego stomatologa dłużej niż 4 lata. Może tp stanowić dowód na to, iż jeśli lekarz dentysta spełnia (w całości lub chociaż w istotnej części) oczekiwania pacjenta, sprawia, że pacjent staje się lojalnym nabywcą usług. Rozkład odpowiedzi na pytanie: „Jak dtugo pacjent korzysta z ustug obecnego dentysty?" przedstawiony jest w tabeli 66.

Tabela 66. Czas trwania kontaktów na płaszczyźnie: pacjent - dentysta

\begin{tabular}{|l|c|}
\hline \multicolumn{1}{|c|}{ Długość okresu kontaktów: pacjent-lekarz dentysta } & Wskazania (\%) \\
\hline pacjent był raz u lekarza dentysty & 10,3 \\
\hline pacjent od roku korzysta ze świadczeń konkretnego stomatologa & 13,5 \\
\hline dwa - trzy lata & 21,1 \\
\hline cztery - sześć lat & 23,8 \\
\hline siedem lat i więcej & 31,3 \\
\hline
\end{tabular}

Źródło: opracowanie własne na podstawie przeprowadzonego badania.

Tylko co dziesiąty badany leczył się cały czas u tego samego dentysty. Dla $19,9 \%$ respondentów obecny dentysta jest drugim stomatologiem, dla 29,6\% - trzecim, dla 13\% - czwartym, a więcej niż piątym - dla 26,1\%. Przyglądając się tym wynikom z perspektywy relacji dentysta - pacjent, można zauważyć, że usługi stomatologiczne charakteryzują się relatywnie wysokim wskaźnikiem retencji. Zdecydowana większość pacjentów $(89,7 \%)$ nie tylko ponowiła zakup świadczenia w gabinecie (por. tabela 66), ale powtarza je regularnie (por. tabela 65). Niemniej tylko $1 / 3$ badanych pacjentów jest w pełni przekonana o słuszności powtarzania zakupów w gabinecie (dostrzega wartość, którą oferuje ten konkretny lekarz dentysta, w tym konkretnym gabinecie), a kolejna trzecia część badanych ma w tym zakresie wątpliwości (11,9\% pacjentów jest przekonanych, że nie straciłoby dużo, przechodząc do innego gabinetu). W tabeli 67 przedstawione są odpowiedzi pacjentów na pytanie o przesłanki pozostawania w danym gabinecie i nie przechodzenia do innego.

Przedstawione opinie pokazują, że trudno mówić w odniesieniu do pacjentów o zdecydowanej gotowości i intencjach podtrzymywania własnej współpracy z gabinetem, a więc trudno mówić o lojalności w rozumieniu R.G. Javalgi i Ch.R. Moberga ${ }^{152}$. Widać tutaj możliwe zagrożenia dla stomatologów - jeśli pacjent otrzyma wyraźny pozytywny sygnał z rynku (tj. od innych pacjentów,

152 Javalgi R.G., Moberg Ch.R., Service loyalty: implications for service providers, "Journal of Services Marketing", 1997 nr 3, s. 167. 
z innego gabinetu), który będzie odpowiadał jego oczekiwaniom, może być skłonny do zrezygnowania z usług dotychczasowego stomatologa, np.:

- licząc, że w innym gabinecie otrzyma tę samą usługę w niższej cenie (28,7\% respondentów wyraziło takie przekonanie, tak więc przynajmniej część z nich mogłaby zrezygnować z usług z tego powodu),

- poszukując wyższej jakości usług - 16,2\% badanych uznało, że prawdopodobnie w innym gabinecie mogłoby uzyskać bardziej profesjonalną pomoc, niż „w swoim” gabinecie przy zbliżonej cenie (i znów: część z nich mogłaby zacząć szukać wyższej jakości w sytuacji nawet jednorazowego braku zadowolenia z usługi w swoim gabinecie).

Tabela 67. Powody nie rezygnowania $\mathrm{z}$ usług gabinetu w perspektywie możliwości korzystania z usług innego gabinetu (badanie IV)

\begin{tabular}{|c|c|c|c|c|c|c|c|c|c|}
\hline \multirow[b]{2}{*}{ Powód } & \multicolumn{5}{|c|}{$\begin{array}{l}\text { Wskazania respondentów } \\
\text { (procent wskazań) }\end{array}$} & \multirow[b]{2}{*}{$\bar{x}$} & \multirow[b]{2}{*}{ Do } & \multirow[b]{2}{*}{$\mathbf{S}(\mathbf{x})$} & \multirow[b]{2}{*}{ Me } \\
\hline & $\begin{array}{c}\text { na } \\
\text { pewno } \\
\text { nie } \\
(1) \\
\end{array}$ & $\begin{array}{c}\text { raczej } \\
\text { nie } \\
(2)\end{array}$ & \begin{tabular}{|c|} 
trudno \\
powie- \\
dzieć \\
$(3)$
\end{tabular} & $\begin{array}{l}\text { raczej } \\
\text { tak } \\
(4) \\
\end{array}$ & \begin{tabular}{|c|} 
na \\
pewno \\
tak \\
$(5)$ \\
\end{tabular} & & & & \\
\hline $\begin{array}{l}\text { Przestając korzystać z usług } \\
\text { danego gabinetu i przechodząc } \\
\text { do innego można dużo stracić }\end{array}$ & 6,7 & 25,6 & 35,6 & 20,4 & 11,9 & 3,05 & 3 & 1,10 & 3 \\
\hline $\begin{array}{l}\text { Prawdopodobnie w innym ga- } \\
\text { binecie można uzyskać tę samą } \\
\text { usługę w niższej cenie }\end{array}$ & 7,0 & 20,2 & 44,1 & 21,7 & 7,0 & 3,01 & 3 & 0,99 & 3 \\
\hline $\begin{array}{l}\text { Prawdopodobnie w innym } \\
\text { gabinecie można uzyskać } \\
\text { bardziej profesjonalną pomoc } \\
\text { przy zbliżonej cenie }\end{array}$ & 9,5 & 30,0 & 44,3 & 11,4 & 4,8 & 2,72 & 3 & 0,96 & 3 \\
\hline $\begin{array}{l}\text { Korzystanie } \mathrm{z} \text { usług gabinetu } \mathrm{z} \\
\text { przyzwyczajenia }\end{array}$ & 19,5 & 39,3 & 14,0 & 20,6 & 6,6 & 2,56 & 2 & 1,2 & 3 \\
\hline
\end{tabular}

Źródło: opracowanie własne na podstawie przeprowadzonego badania.

Często trudno jest odróżnić konsumenta lojalnego od konsumenta nabywającego z nawyku (np. J.M.M. Bloemer i H.D. Kasper dzielą lojalność na prawdziwą i pozorną ${ }^{153}$ ). W odniesieniu do $58,8 \%$ pacjentów można mówić o lojalności w rozumieniu klasycznej literatury marketingu ${ }^{154}$, natomiast $27,7 \%$ badanych przejawia raczej lojalność pozorną (tzw. lojalność z inercji).

${ }^{153}$ Bloemer J.M.M., Kasper H.D., The complex relationship between consumer satisfaction and Brand loyalty, "Journal of Economic Psychology", $1995 \mathrm{nr} 16$.

${ }^{154}$ Por. np. Garbarski L., Rutkowski L., Wrzosek W., Marketing ... op. cit., s. 138: „Lojalność, to dokonywanie zakupów produktów tej samej marki, zakupów w tym samym miejscu sprzedaży lub od tego samego sprzedawcy." 
Przedstawione wyniki są wyraźnym sygnałem, że wysoki wskaźnik retencji nie musi gwarantować utrzymania pacjenta w długim okresie, jako lojalnego nabywcy usługi. Pozostałe poziomy relacji (skłonność do rekomendacji i skłonność do zmiany usługodawcy) będą poddane analizie w punkcie 4.3. tego rozdziału.

\subsubsection{OCZEKIWANIA PACJENTÓW}

Przedmiotem analizy w tym punkcie będą wybrane wyniki badania IV, w zakresie:

- czynników wyboru gabinetu stomatologicznego przez pacjenta,

- oczekiwań respondentów W stosunku do dentysty i pozostałych pracowników gabinetu,

- czynników wpływających na decyzję pacjenta o ponownym skorzystaniu $\mathrm{z}$ oferty gabinetu.

W badaniu IV pacjenci zostali poproszeni o ocenę ważności różnych czynników ${ }^{155}$, mogących mieć wpływ na wybór gabinetu (żaden z respondentów nie wykorzystał możliwości, aby dopisać własny czynnik decyzyjny). Szczegółowy ranking wskazań zawarty jest w tabeli 2.1. w załączniku 2 .

Jako najważniejszą determinantę wyboru gabinetu respondenci wskazali doświadczenie personelu (czynnik ważny lub bardzo ważny dla 89\% badanych). Kolejnym czynnikiem były rekomendacje rodziny i przyjaciół (ważne lub bardzo ważne dla $85,2 \%$ badanych) oraz dogodne terminy wizyt (ważne lub bardzo ważne dla 82,2\% badanych). Również czynnik określony, jako „renoma gabinetu" został oceniony, jako ważny lub bardzo ważny przez przeszło połowę badanych $(72,4 \%)$. Tak więc to, co pacjent wie wcześniej o gabinecie ma największy wpływ na jego decyzję o skorzystaniu, czy nie skorzystaniu z oferty usługodawcy ${ }^{156}$. Pokazuje to znaczenie jakości obsługi aktualnych pacjentów w kontekście budowania pozytywnego wizerunku gabinetu w oczach potencjalnych pacjentów (i może stanowić praktyczną wskazówkę dla lekarzy dentystów co do kierunków oddziaływania na pacjentów).

Respondenci krytycznie odnieśli się do wykorzystywania opinii z Internetu przy wyborze gabinetu $-52,1 \%$ zadeklarowało, że na pewno nie jest to dla nich czynnik decyzyjny, a kolejne $23,2 \%$ o - że raczej nie, a 2,7\% - uznało, że zde-

\footnotetext{
${ }^{155}$ Ponieważ wartość średniej arytmetycznej, mediany i dominanty dla większości analizowanych czynników jest zbliżona, może to stanowić argument za tym, żeby wnioskować, iż badane cechy mają rozkład normalny.

${ }^{156}$ Uwaga ta nie dotyczy w żadnej mierze informacji o gabinecie umieszczonej w prasie lokalnej, bo z tej formy dowiadywania się o działalności gabinetu byłoby skłonnych skorzystać 3,9\% respondentów, wobec $51,2 \%$, którzy na pewno z niej nie skorzystają.
} 
cydowanie tak. Uogólniając, pacjenci nie traktowali możliwości, jakie stwarza Internet, jako czynnika decyzyjnego przy wyborze gabinetu, gdyż:

- $47,7 \%$ nie jest zainteresowanych umawianiem wizyty mailem, wobec $11,7 \%$, którzy braliby ten czynnik pod uwagę przy wyborze gabinetu ${ }^{157}$;

- 59,9\% deklaruje, że nigdy możliwość zakupu tańszej usługi w ramach zakupów grupowych nie wpłynęłaby na ich decyzję o skorzystaniu z oferty gabinetu, wobec 4,4\%, którzy mogliby w ten sposób trafić do gabinetu;

- aktywność stomatologa na portalu społecznościowym - jako determinanta wyboru gabinetu - jest nie ważna lub raczej nie ważna dla 72,3\% badanych.

Natomiast - szeroko pojęty - czynnik dostępności do gabinetu należy uznać, jako ważny przy wyborze konkretnego podmiotu. I tak:

- dogodne godziny pracy gabinetu są ważne lub bardzo ważne dla 83,4\% respondentów,

- łatwość umówienia się na wizytę - 77,8\% wskazań,

- lokalizacja gabinetu - 64,9\% wskazań,

- łatwość dojazdu - 58,9\% wskazań, ale zabezpieczenie miejsc parkingowych przed gabinetem dla pacjentów było ważne/raczej ważne dla 1/4 badanych.

Może to być informacja istotna dla dentysty-przedsiębiorcy w kontekście tradycyjnego marketingu tj. lokalizowania gabinetu $\mathrm{i}$ organizowania jego pracy w zakresie obsługi recepcyjnej.

Kolejny czynnik - niska cena jest ważnym lub raczej ważnym czynnikiem wyboru gabinetu dla $54,9 \%$ badanych (wobec $25 \%$ badanych, dla których jest to raczej lub na pewno nieistotny element). Co ciekawe relatywnie niskim - deklarowanym - zainteresowaniem cieszą się proponowane przez gabinet obniżki cen świadczeń, i tak:

- $\quad 56,4 \%$ badanych uznało, że nie kierowaliby się czynnikiem ,niższych cen usług stomatologicznych w godzinach południowych", wobec 19,5\%, którzy uwzględniliby to przy wyborze gabinetu;

- dla 57,1\% respondentów nie byłaby ważna „karta stałego pacjenta”"158 (umożliwiająca np. 5\% zniżkę na świadczenia) wobec 22,2\%, dla których byłaby istotna.

\footnotetext{
${ }^{157}$ Należy jednak podkreślić, że dla grupy pacjentów do 30 roku życia proporcje te nie są już tak ostre i wynoszą odpowiednio: $32,4 \%$ - nie i $27,7 \%$ - tak.

158 Można zauważyć, że celowe zachęcanie pacjentów atrakcyjną ceną (lub w inny sposób) do skorzystania z usług gabinetu jest niezgodne z Kodeksem etyki lekarskiej i stanowiskiem Naczelnej Rady Lekarskiej. Jednak w praktyce funkcjonowania niektórych gabinetów (dotyczy to np. sieci
} 
Przedstawione wyniki są wyraźnym sygnałem, że jedynie cenowe oddziaływanie na pacjentów przez gabinet będzie trafiało do wąskiej grupy potencjalnych pacjentów. Lekarz stomatolog może sobie zadać pytanie, czy do tej grupy pacjentów adresuje usługi? Czy gabinet, który może pojawić się w pobliżu z niższymi cenami nie stanie się bardziej atrakcyjny dla jego - przyciągniętych do gabinetu w dużej mierze ceną - pacjentów? Można postawić tezę, że opieranie działań komercyjnego gabinetu stomatologicznego na strategii niskich cen może być działaniem nie poprawiającym pozycji konkurencyjnej podmiotu w długim okresie. Tym samym skupianie uwagi tylko na tym instrumencie marketingu-mix okazuje się działaniem krótkotrwałym i mało skutecznym.

Kolejnym badanym zagadnieniem były oczekiwania pacjentów w stosunku do dentysty i pozostałych pracowników gabinetu. Do badania wykorzystano taki zestaw umiejętności i postaw stomatologów, który w świetle literatury przedmiotu ma szczególne znaczenie z punktu widzenia kreowania kapitału relacyjnego (a tym samym może wpływać na jakość kontaktów z pacjentami). Szczegółowy ranking odpowiedzi pacjentów przedstawiony jest $\mathrm{w}$ tabeli 2.2. w Załączniku 2.

Podstawowe oczekiwania pacjentów odnoszą się do dentysty, jako specjalisty i dotyczą: wykonywania usługi w sposób rzetelny i dokładny (98,9\% wskazań) i dysponowania profesjonalną wiedzą i kwalifikacjami $(98,1 \%)$. O ile należy je uznać za w pełni zrozumiałe (lekarz będzie zajmował się zdrowiem pacjenta), o tyle należy pamiętać o asymetrii występującej między lekarzem i pacjentem (oczekuje fachowości, ale jako laik nie potrafi jej ocenić w warstwie stricte medycznej). Dlatego szczególnego znaczenia nabiera:

- zaufanie - jak już zostało powiedziane w punkcie 3.2 tego rozdziału jest to jeden $\mathrm{z}$ elementów budowy relacji; i to żeby dentysta wzbudzał zaufanie było ważne lub bardzo ważne dla $97,1 \%$ badanych,

- poczucie bezpieczeństwa, jakie personel powinien dawać pacjentowi w gabinecie (czynnik ważny lub bardzo ważny dla 95,4\% badanych),

- szacunek dla pacjenta - ważny lub bardzo ważny dla 94,6\% badanych.

I w końcu analiza odpowiedzi na pytanie: „Co skłania pacjentów do powrotu do gabinetu?". Szczegółowe zestawienie ocen różnych czynników decyzyjnych przedstawia tabela 2.3. w załączniku 2. Najkrócej mówiąc: zdolność dentysty i personelu do spełnienia oczekiwań pacjenta, gdyż pierwsze trzy czynniki są takie, jak przy oczekiwaniach wobec gabinetu, choć przekonanie co do ich znaczenia osłabło (niższa wartość średniej arytmetycznej z odpowiedzi). Ponadto

placówek) takie rozwiązania są stosowane (przyjmują formę kart rabatowych czy rodzinnych itp.), dlatego to rozwiązanie zostało uwzględnione w badaniu. 
pacjenci zwracają uwagę na doświadczenie personelu (czynnik ważny/bardzo ważny dla 94,1\% badanych) i nowoczesność sprzętu (91,0\% wskazań).

Porównanie znaczenia czynników decyzyjnych w przypadku wyboru gabinetu i pozostania pacjentem gabinetu przedstawia wykres 6 .

Wykres 6. Determinanty wyboru gabinetu i dalszego korzystania z jego usług w opinii pacjentów (średnia arytmetyczna ze wskazań) - wyniki badania IV

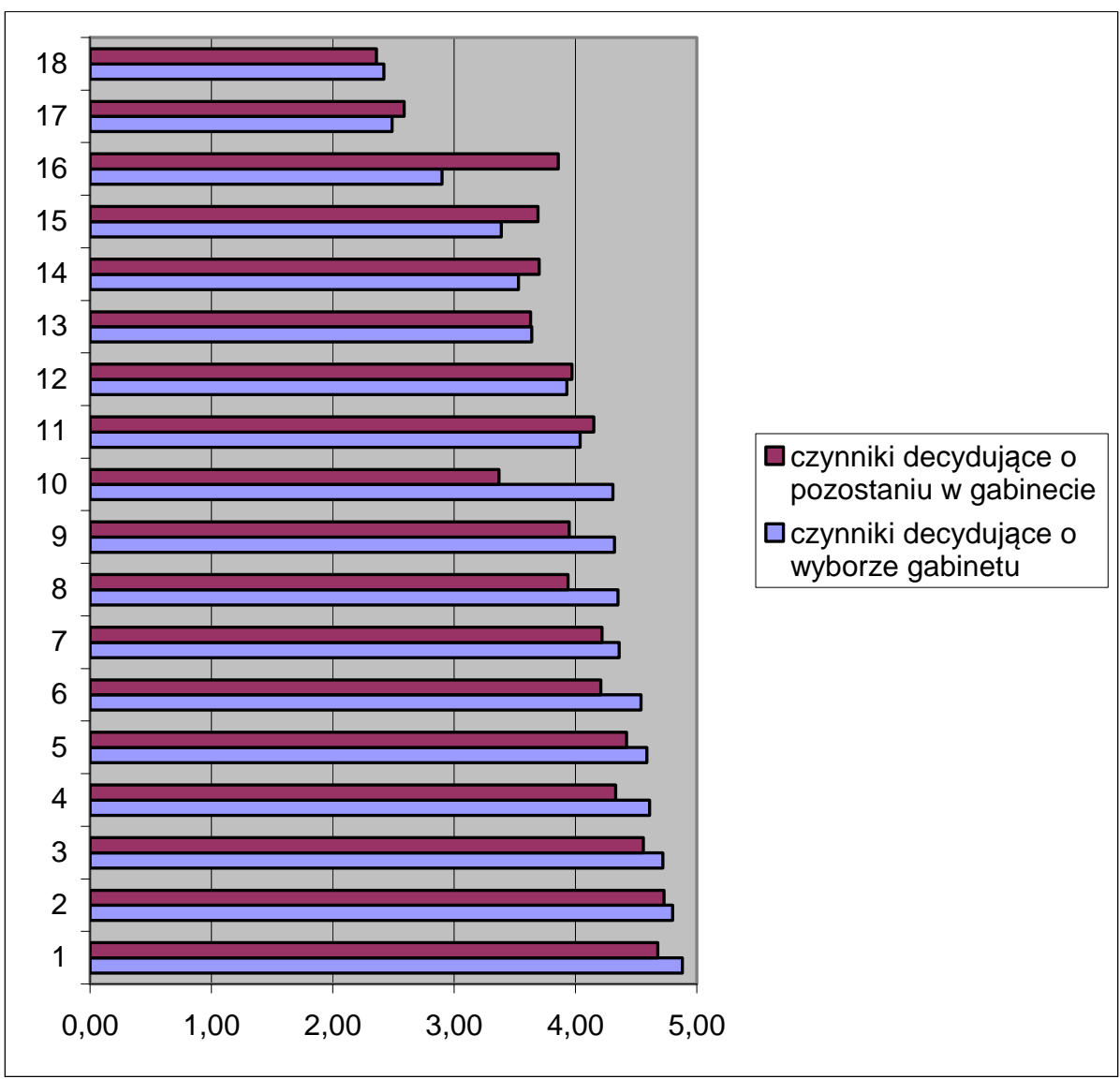

Źródło: opracowanie własne na podstawie przeprowadzonych badań.

Czynniki decyzyjne: 1) Wykonywanie przez dentystę usługi w sposób rzetelny i dokładny, 2) Profesjonalna wiedza i kwalifikacje pracowników, 3) Zaufanie, jakie wzbudza dentysta swoim postępowaniem, 4) Poczucie bezpieczeństwa, jakie daje personel pacjentowi, 5) Uprzejmość pracowników gabinetu wobec pacjenta, 6) Wyczerpująca informacja w trakcie leczenia, 7) Szybka reakcja personelu na potrzeby pacjenta, 8) Punktualne rozpoczynanie wizyt, 9) Starania dentysty ukierunkowane na rozpoznanie potrzeb pacjenta, 10) Rozmowy dentysty z pacjentem o jego problemach zdrowotnych i profilaktyce, 11) Łatwość w umówieniu się na wizytę np. telefonicznie, 12) Renoma gabinetu, 13) Lokalizacja gabinetu, 14) Niskie ceny usług w gabinecie, 15) Duża różnorodność usług, 16) Wygląd gabinetu, 17) Zabezpieczenie miejsc parkingowych dla pacjentów przed gabinetem, 18) Oferowana przez gabinet „karta stałego pacjenta” (umożliwiająca np. 5\% zniżkę na ceny świadczeń). 
Warto zwrócić uwagę na fakt, że oczekiwania pacjentów co do uwarunkowań interpersonalnych kontaktu usługowego były na wyższym poziomie, niż te same czynniki oceniane, jako determinanty powrotu do gabinetu (wpływ na zaistniałą sytuację miał kontakt pacjenta z personelem gabinetu i możliwość porównania oczekiwań z rzeczywistością ${ }^{159}$ ). Natomiast czynniki (z zakresu instrumentarium marketingowego), które w rankingu oczekiwań uplasowały się na dalszych miejscach zyskały zdecydowanie większe znaczenie, jako determinanty zatrzymania pacjenta, jako nabywcy usług w danym gabinecie.

\subsubsection{OCZEKIWANIA PACJENTÓW Z PERSPEKTYWY STOMATOLOGÓW}

Istotnym elementem badania I było określenie stopnia znajomości oczekiwań nabywców usług stomatologicznych przez osoby je oferujące. Ranking czynników decyzyjnych, które wpływają na drugą i kolejną wizytę pacjenta w gabinecie wg lekarzy stomatologów przedstawiony jest w tabeli 68. Do głównych powodów powrotu pacjenta do gabinetu (poza koniecznością dokończenia leczenia) dentyści zaliczyli swoje umiejętności i postawę wobec pacjenta:

- zdolność wykonywania pracy dokładnie (jest to ważny lub bardzo ważny czynnik w oczach $98,8 \%$ badanych dentystów),

- wiedzę i kwalifikacje stomatologa uznało za ważne lub bardzo ważne 95,74\% respondentów,

- zaufanie, jakie wzbudza lekarz wskazało 95,77\% badanych,

- poczucie bezpieczeństwa $\mathrm{w}$ gabinecie - 93,97\% wskazań,

- uprzejmość personelu gabinetu wobec pacjenta - 95,65\% respondentów,

- wyczerpującą informację w trakcie leczenia - wskazało 93,94\% badanych.

Lekarze bardzo zdecydowanie wskazali na wymienione elementy - dominanta wskazań we wszystkich aspektach wynosiła 5, a odsetek osób, które „patrząc na usługi stomatologiczne oczami pacjenta" nie wzięłyby pod uwagę wymienionych czynników był znikomy.

Za najmniej istotne elementy - wpływające powrót pacjenta do gabinetu i pozostanie nabywcą usług w dłuższym okresie - lekarze dentyści uznali ceny usług, wygląd gabinetu, łatwość umówienia się na wizytę i dostępne terminy wizyt.

159 Szczegółowe wyniki ocen pracy personelu gabinetów dokonane przez pacjentów są przedstawione w tabeli $2.4 \mathrm{w}$ Załączniku 2. 
Tabela 68. Determinanty powrotu pacjenta do gabinetu w oczach dentystów - wyniki badania I

\begin{tabular}{|c|c|c|c|c|c|c|c|c|c|}
\hline \multirow[b]{2}{*}{ Czynnik decyzyjny: } & \multicolumn{5}{|c|}{$\begin{array}{l}\text { Stanowisko respondenta } \\
\text { (procent wskazań) }\end{array}$} & \multirow[b]{2}{*}{$\bar{x}$} & \multirow[b]{2}{*}{ Do } & \multirow[b]{2}{*}{$\mathbf{S}(\mathbf{x})$} & \multirow[b]{2}{*}{$\mathbf{M e}$} \\
\hline & $\begin{array}{c}\text { na } \\
\text { pewno } \\
\text { nie } \\
(1)\end{array}$ & $\begin{array}{c}\text { raczej } \\
\text { nie } \\
\\
(2)\end{array}$ & \begin{tabular}{|c} 
nie \\
mam \\
zdania \\
$(3)$
\end{tabular} & $\begin{array}{c}\text { raczej } \\
\text { tak } \\
(4)\end{array}$ & \begin{tabular}{|c|} 
na \\
pewno \\
tak \\
$(5)$
\end{tabular} & & & & \\
\hline $\begin{array}{l}\text { Zdolność wykonywania świadczenia } \\
\text { w rzetelny sposób }\end{array}$ & 0,0 & 0,61 & 0,61 & 32,53 & 66,29 & 4,64 & 5 & 0,53 & 5 \\
\hline $\begin{array}{l}\text { Uprzejmość personelu wobec } \\
\text { pacjentów }\end{array}$ & 0,0 & 0,0 & 4,35 & 28,57 & 67,08 & 4,63 & 5 & 0,57 & 5 \\
\hline Wiedza i kwalifikacje dentysty & 1,22 & 0,0 & 3,05 & 34,15 & 61,59 & 4,55 & 5 & 0,68 & 5 \\
\hline Zaufanie, jakie wzbudza dentysta & 0,0 & 0,61 & 3,62 & 36,73 & 59,04 & 4,54 & 5 & 0,6 & 5 \\
\hline $\begin{array}{l}\text { Wyczerpująca informacja w trakcie } \\
\text { leczenia }\end{array}$ & 0,0 & 1,22 & 4,84 & 41,21 & 52,73 & 4,45 & 5 & 0,65 & 5 \\
\hline $\begin{array}{l}\text { Poczucie bezpieczeństwa, jakie pac- } \\
\text { jent ma w gabinecie }\end{array}$ & 0,0 & 1,20 & 4,82 & 43,37 & 50,60 & 4,43 & 5 & 0,65 & 5 \\
\hline $\begin{array}{l}\text { Podejmowanie wysiłków przez den- } \\
\text { tystę w celu poznania potrzeb } \\
\text { pacjenta }\end{array}$ & 0,61 & 0,61 & 10,98 & 48,78 & 39,02 & 4,25 & 4 & 0,72 & 4 \\
\hline $\begin{array}{l}\text { Szybkość reakcji personelu na potrze- } \\
\text { by pacjentów }\end{array}$ & 0,0 & 1,22 & 15,75 & 45,28 & 37,74 & 4,19 & 4 & 0,74 & 4 \\
\hline Empatyczna postawa dentysty & 1,91 & 3,18 & 15,29 & 35,03 & 44,59 & 4,17 & 5 & 0,93 & 4 \\
\hline Nowoczesny sprzęt & 0,61 & 4,91 & 19,02 & 46,01 & 29,45 & 3,99 & 4 & 0,86 & 4 \\
\hline Przystępne ceny usług & 1,22 & 8,48 & 16,36 & 40,62 & 33,33 & 3,96 & 4 & 0,97 & 4 \\
\hline Dogodne terminy wizyt & 1,22 & 9,15 & 20,73 & 34,76 & 33,54 & 3,88 & 4 & 1,02 & 4 \\
\hline $\begin{array}{l}\text { Wygląd zewnętrzny i wewnętrzny } \\
\text { podmiotu }\end{array}$ & 0,61 & 6,22 & 22,36 & 46,58 & 24,22 & 3,88 & 4 & 0,87 & 4 \\
\hline $\begin{array}{l}\text { Eatwość w umówieniu się na wizytę } \\
\text { (np. telefonicznie, mailowo) }\end{array}$ & 3,03 & 8,48 & 18,18 & 39,39 & 30,91 & 3,87 & 4 & 1,04 & 4 \\
\hline
\end{tabular}

Źródło: opracowanie własne na podstawie przeprowadzonych badań.

W celu porównania odpowiedzi wskazanych przez pacjentów i lekarzy dentystów w odniesieniu do czynników determinujących pozostanie pacjenta w gabinecie (jako nabywcy kolejnych świadczeń) dokonano zestawienia odpowiedzi obu grup badawczych - wyniki przedstawia wykres 7.

Większości analizowanych czynników pozostania pacjenta w gabinecie, jako nabywcy usług stomatologicznych, lekarze dentyści przypisali mniejsze znaczenie, niż pacjenci (choć należy podkreślić, że w wielu przypadkach nie są to różnice istotne statystycznie dla poziomu istotności p<0,05). Można założyć, że jeśli lekarz dentysta przyjął określony poziom ważności danego czynnika, to na zbliżonym poziomie stara się go zaspokoić - z jednej strony może dochodzić do nie oferowania takich wartości, jakich pacjent oczekuje (np. w zakresie nowoczesności sprzętu, dogodnych terminów wizyt, czy łatwości w umówieniu się na wizytę - wszystkie różnice istotne statystycznie dla empirycznego poziomu istotności $\mathrm{p}<0,05)$, a $\mathrm{z}$ drugiej do przeceniania znaczenia pewnych obszarów 
działania gabinetu i poświęcania im zbyt dużej uwagi kosztem innych. $\mathrm{Z}$ wykresu 6 wynika, że lekarze przeszacowują poziom oczekiwań pacjentów w zakresie wyglądu gabinetu i kontaktów interpersonalnych z pacjentami (np. uprzejmość, poczucie bezpieczeństwa, wyczerpująca informacja w trakcie leczenia), ale ponieważ mają one znaczenie z punktu widzenia kreowania relacji, to jeśli są one zapewniane pacjentom na odpowiednim poziomie, powinny korzystnie oddziałływać na długookresową współpracę między dentystą a pacjentem (i budowanie kapitału relacji). Z drugiej strony należy podkreślić, że lekarze nie mogą bezgranicznie poddać się przekonaniu, że ich rolą jest jedynie zaspokajanie oczekiwań pacjenta i że nie mogą wysuwać żądań wobec osoby, której potrzeby mają zaspokoić. Takie służebne podejście mogłoby doprowadzić do niepowodzenia w leczeniu, dlatego otwarty komunikat, o tym czego lekarz oczekuje od pacjenta (np. w zakresie higieny jamy ustnej) jest niezbędny do zapewnienia sukcesu przebiegu leczenia.

Wykres 7. Determinanty powrotu pacjenta do gabinetu w oczach pacjentów (badanie IV) i lekarzy dentystów (badanie I) - średnia arytmetyczna ze wskazań respondentów

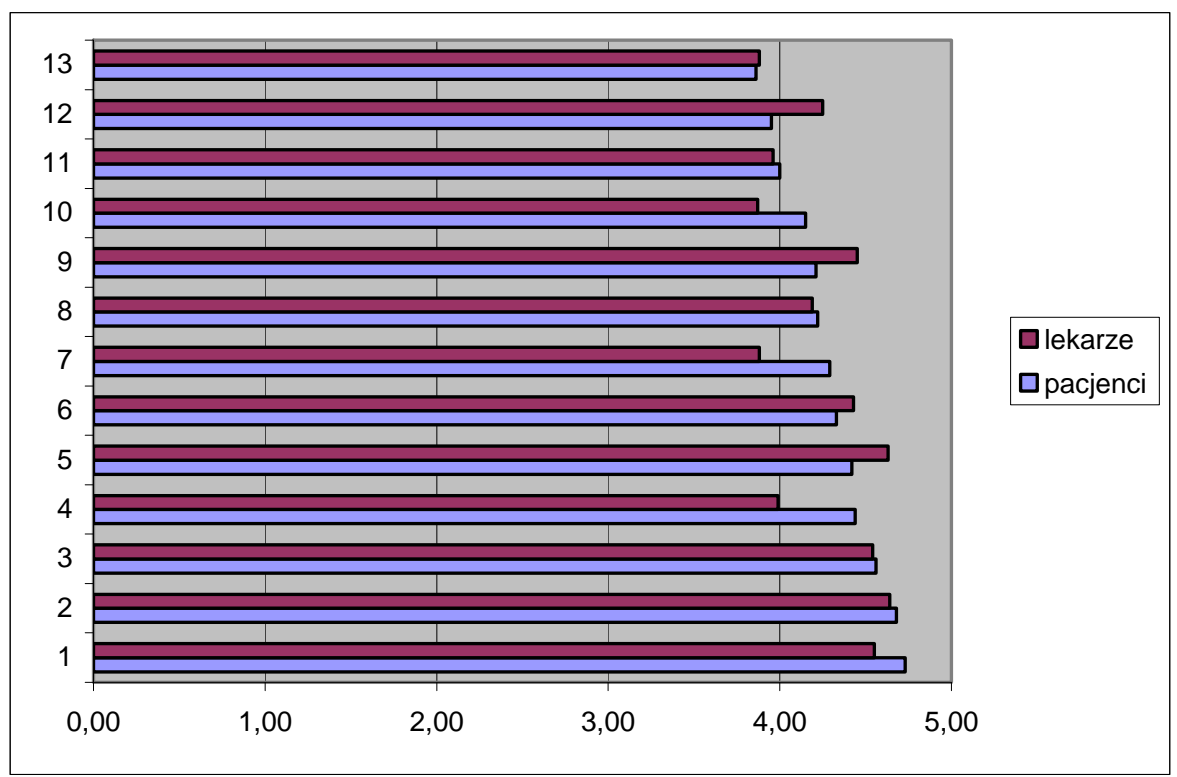

Źródło: opracowanie własne na podstawie przeprowadzonych badań.

Czynniki decyzyjne: 1) Wiedza i kwalifikacje lekarza dentysty, 2) Zdolność do wykonania świadczenia w sposób rzetelny i dokładny, 3) Zaufanie, jakie wzbudza dentysta, 4) Nowoczesny sprzęt, 5) Uprzejmość pracowników wobec pacjenta, 6) Poczucie bezpieczeństwa, jakie pacjent ma w gabinecie, 7) Dogodne terminy wizyt, 8) Szybkość reakcji personelu na potrzeby pacjenta, 9) Wyczerpująca informacja w trakcie leczenia, 10) Łatwość w umówieniu się na wizytę np. telefonicznie, 11) Przystępne ceny, 12) Podejmowanie wysiłków przez dentystę w celu poznania potrzeb pacjentów, 13) Wygląd zewnętrzny i wewnętrzny podmiotu. 
Nieco odmienna perspektywa porównawcza została wykorzystana do oceny wyników badania III - studenci zostali poproszeni o ocenę ważności oczekiwań pacjentów względem pracowników gabinetu (por. tabela 69). Zdecydowana większość analizowanych czynników uzyskała wartość dominanty na poziomie 5. Do najważniejszych oczekiwań pacjentów studenci zaliczyli:

- wykonanie usługi w sposób rzetelny i dokładny - czynnik wskazany jako ważny lub bardzo ważny przez 96, 88\% studentów;

- zdolność dentysty do wzbudzania zaufania w pacjencie - 96,87\% wskazań,

- profesjonalną wiedzę i kwalifikacje pracowników - 93,75\% wskazań.

Tabela 69. Oczekiwania pacjentów względem pracowników gabinetu w oczach studentów

\begin{tabular}{|c|c|c|c|c|c|c|c|c|c|}
\hline \multirow[b]{2}{*}{ Oczekiwania } & \multicolumn{5}{|c|}{$\begin{array}{l}\text { Wskazania respondentów } \\
\text { (procent wskazań) }\end{array}$} & \multirow[b]{2}{*}{$\bar{x}$} & \multirow[b]{2}{*}{ Do } & \multirow[b]{2}{*}{$\mathbf{S}(\mathbf{x})$} & \multirow[b]{2}{*}{ Me } \\
\hline & $\begin{array}{c}\mathrm{Na} \\
\text { pewno } \\
\text { nie } \\
(1)\end{array}$ & $\begin{array}{c}\text { raczej } \\
\text { nie } \\
(2)\end{array}$ & \begin{tabular}{|c|} 
trudno \\
powie- \\
dzieć \\
$(3)$
\end{tabular} & $\begin{array}{c}\text { raczej } \\
\text { tak } \\
(4)\end{array}$ & \begin{tabular}{|c|} 
na \\
pewno \\
tak \\
$(5)$
\end{tabular} & & & & \\
\hline $\begin{array}{l}\text { Dentysta wykonuje usługę w } \\
\text { sposób rzetelny i dokładny }\end{array}$ & 0,0 & 0,0 & 3,13 & 21,88 & 75,0 & 4,72 & 5 & 0,52 & 5 \\
\hline Dentysta wzbudza zaufanie & 0,0 & 0,0 & 3,13 & 27,08 & \begin{tabular}{|l|}
69,79 \\
\end{tabular} & 4,67 & 5 & 0,54 & 5 \\
\hline $\begin{array}{l}\text { Pracownicy dysponują profesjonal- } \\
\text { ną wiedzą i kwalifikacjami }\end{array}$ & 0,0 & 0,0 & 6,25 & 27,08 & 66,67 & 4,60 & 5 & 0,61 & 5 \\
\hline Pracownicy są schludnie ubrani & 0,0 & 0,0 & 7,29 & 30,21 & 62,50 & 4,55 & 5 & 0,63 & 5 \\
\hline Uprzejmość pracowników & 0,0 & 0,0 & 6,25 & 32,29 & 61,46 & 4,55 & 5 & 0,61 & 5 \\
\hline $\begin{array}{l}\text { Informacja w trakcie leczenia } \\
\text { powinna być wyczerpująca }\end{array}$ & 0,0 & 0,0 & 7,29 & 37,50 & 55,21 & 4,48 & 5 & 0,63 & 5 \\
\hline \begin{tabular}{|l|} 
Dentysta powinien starać się \\
rozpoznać potrzeby pacjenta
\end{tabular} & 0,0 & 2,08 & 7,29 & 40,63 & 50,0 & 4,39 & 5 & 0,72 & 5 \\
\hline Wizyta rozpoczyna się punktualnie & 0,0 & 1,04 & 8,33 & 44,79 & 45,83 & 4,35 & 5 & 0,68 & 4 \\
\hline \begin{tabular}{|l|} 
Personel rozumie obawy pacjenta \\
związane $\mathrm{z}$ wizytą w gabinecie
\end{tabular} & 0,0 & 0,0 & 9,38 & 45,83 & 44,79 & 4,35 & 4 & 0,65 & 4 \\
\hline $\begin{array}{l}\text { Dentysta rozmawia z pacjentem } \\
\text { zrozumiałym językiem } \\
\end{array}$ & 0,0 & 1,04 & 5,21 & 51,04 & 42,71 & 4,35 & 4 & 0,63 & 4 \\
\hline $\begin{array}{l}\text { Personel daje pacjentowi poczucie } \\
\text { bezpieczeństwa }\end{array}$ & 0,0 & 1,04 & 10,42 & 43,75 & 44,79 & 4,32 & 5 & 0,70 & 4 \\
\hline $\begin{array}{l}\text { Personel powinien szybko reago- } \\
\text { wać na potrzeby pacjenta }\end{array}$ & 0,0 & 1,04 & 8,33 & 56,25 & 34,38 & 4,24 & 4 & 0,64 & 4 \\
\hline \begin{tabular}{|l|} 
Dentysta regularnie rozmawia z \\
pacjentem o jego problemach \\
zdrowotnych i profilaktyce
\end{tabular} & 0,0 & 2,08 & 15,63 & 51,04 & 31,25 & 4,11 & 4 & 0,74 & 4 \\
\hline $\begin{array}{l}\text { Dentysta nie „naciska” na pacjenta, } \\
\text { aby zdecydował się na droższą } \\
\text { usługę }\end{array}$ & 3,13 & 3,13 & 17,71 & 36,46 & 39,58 & 4,06 & 5 & 0,99 & 4 \\
\hline $\begin{array}{l}\text { Dentysta zwraca się do pacjenta } \\
\text { personalnie, a nie bezosobowo }\end{array}$ & 4,17 & 10,42 & 27,08 & 32,29 & 26,04 & 3,66 & 4 & 1,10 & 4 \\
\hline Przypominanie o wizycie SMSem & 7,29 & 10,42 & 28,13 & 32,29 & 21,88 & 3,51 & 4 & 1,16 & 4 \\
\hline
\end{tabular}

Źródło: Opracowanie własne na podstawie przeprowadzonego badania. 
Zderzenie perspektyw: pacjentów i studentów w zakresie oczekiwań pacjentów wobec pracowników gabinetu przedstawia wykres 8 .

Wykres 8. Oczekiwania pacjentów wobec personelu gabinetu

w oczach pacjentów (badanie IV) i studentów kierunku lekarsko-dentystycznego

(badanie III) - średnia arytmetyczna ze wskazań respondentów

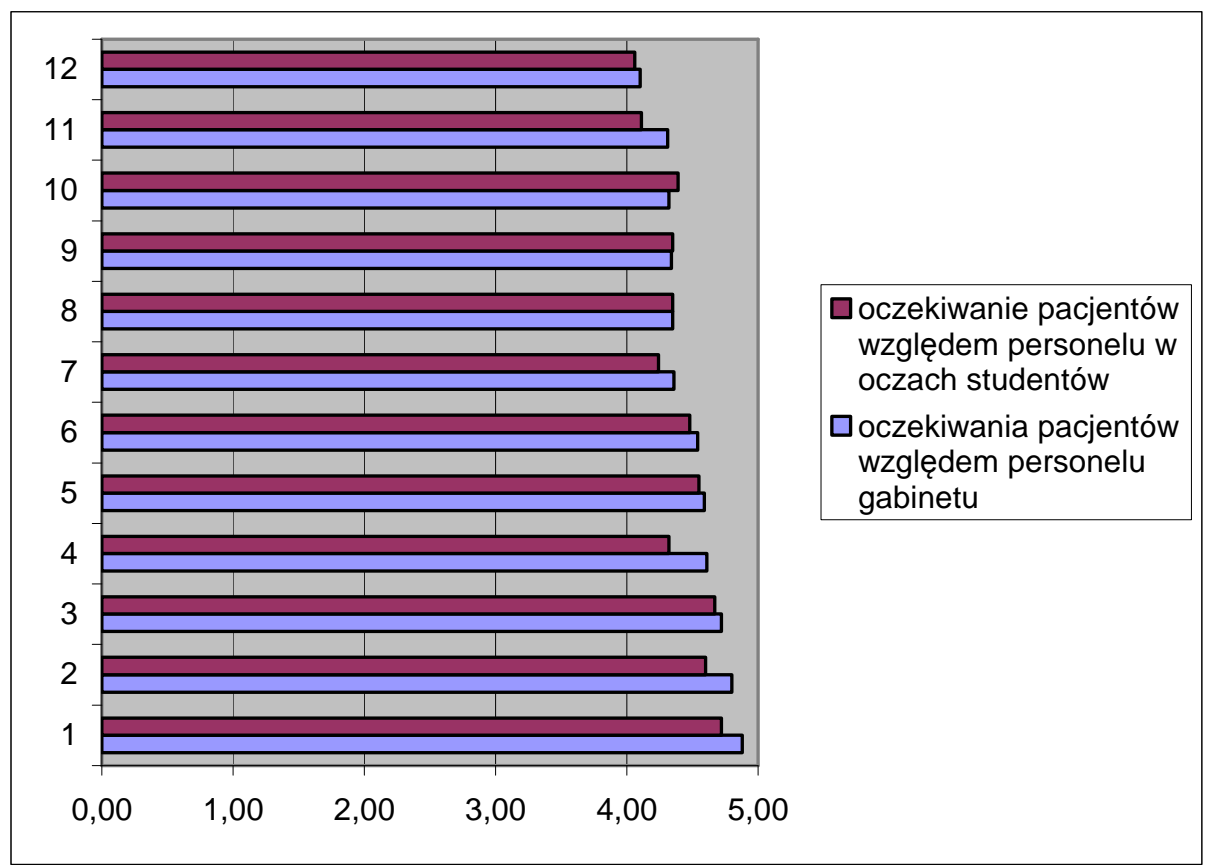

Źródło: opracowanie własne na podstawie przeprowadzonych badań.

Czynnik decyzyjny: 1) Zdolność lekarza do wykonania świadczenia w sposób rzetelny i dokładny, 2) Profesjonalna wiedza i kwalifikacje pracowników gabinetu, 3) Zaufanie, jakie wzbudza swoim postępowaniem dentysta, 4) Poczucie bezpieczeństwa, jakie daje pacjentowi personel, 5) Uprzejmość pracowników wobec pacjenta, 6) Wyczerpująca informacja w trakcie leczenia, 7) Szybkość reakcji personelu na potrzeby pacjenta, 8) Punktualność rozpoczynania wizyt, 9) Rozumienie obaw pacjenta związanych z jego wizytą w gabinecie przez personel, 10) Podejmowanie wysiłków przez dentystę w celu poznania potrzeb pacjentów, 11) Rozmowy dentysty z pacjentem o jego problemach zdrowotnych i profilaktyce, 12) Nie ,naciskanie” na pacjenta, aby zdecydował się na droższe leczenie.

Jak wynika z zaprezentowanych danych to nie praktycy rynkowi, tylko przyszli adepci sztuki lekarskiej lepiej zdefiniowali oczekiwania pacjentów - ranking ich wskazań jest zbieżny z rankingiem oczekiwań pacjentów (tylko w obszarze rozpoznania potrzeb i rozumienia obaw pacjentów przez lekarza studenci uznali ten czynnik za ważniejszy, niż uczynili to pacjenci). Różnice we wskazaniach nie są istotne statystycznie, co można próbować wytłumaczyć dwojako: studenci w swoim życiu częściej występowali w gabinecie stomatologicznym (jak dotąd) w roli pacjentów, więc bliska jest im perspektywa usługobiorcy i z dru- 
giej strony - ten ich brak doświadczenia w roli świadczeniodawcy sprawia, że nie wpadają w pewne rutynowe schematy myślenia praktyków zawodu ${ }^{160}$.

Konkluzje z powyższych rozważań, można przedstawić następujące:

- spośród pozamedycznych oczekiwań pacjentów najważniejsze są te dotyczące „miękkich” aspektów obsługi (postawa personelu wobec pacjenta ${ }^{161}$ - uprzejmość i życzliwość, sposób komunikacji, atmosfera w gabinecie), a więc związane $\mathrm{z}$ marketingiem relacji, z tego względu można wnioskować, iż powinien on stać się świadomym narzędziem prorynkowego oddziaływania współczesnego dentysty;

- lekarz dentysta powinien dążyć do rozpoznania pozamedycznych oczekiwań pacjenta, ponieważ pacjenci oczekują indywidualizacji obsługi,

- lekarz dentysta powinien informować pacjentów o przewidywanych efektach planowanego leczenia (i zagrożeniach związanych $\mathrm{z}$ niepodjęciem leczenia) w sposób dostosowany do ich możliwości percepcyjnych,

- braki w poziomie obsługi na jednej płaszczyźnie można w pewnym stopniu rekompensować podwyższonym poziomem obsługi na innej (ważnej dla pacjenta $^{162}$ ), niemniej jednak konieczne jest traktowanie usługi w dualny sposób (tj. związany z medycznym i niemedycznym jej obszarem) i dążenie do zachowania swoistej równowagi między tymi obszarami (a nie zastępowania jednego obszaru drugim).

\subsection{DZIAŁANIA MARKETINGOWE GABINETÓW STOMATOLOGICZNYCH}

Przed przystąpieniem do prezentacji proklientowskich działań podejmowanych w gabinetach stomatologicznych warto zauważyć, że chociaż kontakty z pracownikami opieki zdrowotnej inicjowane są zazwyczaj przez pacjentów, to zrozumienie ich zachowań nie wyczerpuje tematu budowy relacji na płaszczyźnie gabinet - pacjent. Ważne jest również to, w jakim zakresie lekarze są w stanie rozpoznać determinanty decyzji podejmowanych przez pacjentów (tak w zakresie inicjowania kontaktów, jak i ponownych zakupów) oraz reagować na nie, czy wręcz pobudzać pacjentów do skorzystania z usług gabinetu (np. budując swoją pozycję rynkową, dzięki zadowoleniu dotychczasowych pacjentów). Dziś proaktywne postawy lekarzy stomatologów (jako

\footnotetext{
${ }^{160}$ Przykładem takiego schematu może być sformułowanie: dziś większość pacjentów idzie do tego gabinetu, gdzie jest taniej (co, jak pokazano w wynikach badania IV nie jest prawdą - por. tabela 2.1 i 2.3 w załączniku 2).

${ }^{161}$ Można rekomendować konieczność podnoszenia kwalifikacji personelu gabinetu w tym zakresie.

${ }^{162}$ Podnoszenie poziomu obsługi na płaszczyźnie, która jest nieważna lub mało ważna dla pacjenta nie wpłynie na poprawę odczuć pacjenta.
} 
strony podażowej na rynku usług stomatologicznych) również wpływają na sytuację na rynku, dlatego warto przyjrzeć się działaniom podejmowanym przez gabinety (zwłaszcza z perspektywy kreowania relacji z pacjentami).

Analiza działań marketingowych podejmowanych w gabinetach będzie dotyczyła oceny zakresu ich stosowania oraz możliwości ich doskonalenia. W badaniu I na pytanie dotyczące tego, czy w gabinetach podejmowane są działania marketingowe $41,8 \%$ badanych lekarzy zadeklarowało, że w gabinetach, w których pracują, są podejmowane takie działania. Ale już tylko 3,6\% responsdentów ogółem ( $8,8 \%$ wśród tych, którzy prowadzą działania marketingowe) stwierdziło, że w gabinecie istnieje plan działań marketingowych w wersji sformalizowanej (tj. zapisanej), a u 2,4\% (5,9\% wśród prowadzących działania marketingowe) respondentów zakończyła się realizacja planu marketingowego, a kolejny nie został opracowany. Pozostali respondenci stwierdzili, że nigdy w gabinecie nie było planu marketingowego, jako formalnego dokumentu. W 87,91\% badanych gabinetów nie ma odrębnego stanowiska dla osoby zajmującej się sprawami marketingowymi, w pozostałych jest.

Wśród respondentów 58,2\% stwierdziło, że gabinety nie podejmują działań $\mathrm{z}$ zakresu marketingu. Jednak biorąc pod uwagę odpowiedzi na inne pytania (nie odnoszące się wprost do pojęcia „marketing”, tylko skupione raczej na konkretnych działaniach $\mathrm{z}$ tego obszaru) obraz ten wydaje się nieco inny - $\mathrm{w}$ gabinetach są podejmowane działania $\mathrm{z}$ obszaru marketingu, $\mathrm{z}$ tym, że lekarze mogą ich w taki sposób nie postrzegać (traktując, jako „Zwykłe” działania).

$\mathrm{W}$ tabeli $70^{163}$ przedstawiony jest ranking działań podejmowanych $\mathrm{w}$ gabinetach, w których pracują respondenci. Czynniki związane z tworzeniem odpowiedniej atmosfery ${ }^{164}$ przed rozpoczęciem procesu leczenia (realizacją rdzenia usługi stomatologicznej) zostały sklasyfikowane odpowiednio na 3 (punktualność rozpoczynania wizyt), 8 (dbałość o obsługę przed przyjęciem pacjenta) i 9 miejscu (stosunkowo długi czas poświęcony na wstępną rozmowę z pacjentem), a więc relatywnie wysoko wśród 31 ocenianych aspektów. Od 70 do $86 \%$ respondentów zadeklarowało, że działania te są realizowane zawsze lub często w gabinecie. Choć rozmowa (nie wywiad lekarski) była priorytetem dla 1/4 respondentów, a 1/10 badanych nie przywiązuje uwagi do obsługi przedsprzedażowej w gabinecie.

\footnotetext{
${ }^{163}$ Jej objętość jest związana z tym, że autorce zależało na przyjrzeniu się wielu różnym aspektom funkcjonowania gabinetu (które jako miejsca prawdy, mogą być przedmiotem oceny przez pacjentów) i stworzeniu kompleksowego zestawienia pokazującego hierarchię ich ważności.

${ }^{164}$ Szerzej na ten temat w: Bukowska-Piestrzyńska A., Obstuga klienta gabinetu stomatologicznego, Wyd. Czelej, Warszawa 2011.
} 
Tabela 70. Ranking działań podejmowanych w gabinetach (badanie I)

\begin{tabular}{|c|c|c|c|c|c|c|c|c|c|}
\hline \multirow[b]{2}{*}{ Działanie } & \multicolumn{5}{|c|}{$\begin{array}{l}\text { Wskazania respondentów } \\
\text { (procent wskazań) }\end{array}$} & \multirow[b]{2}{*}{$\bar{x}$} & \multirow[b]{2}{*}{ Do } & \multirow[b]{2}{*}{$\mathbf{S}(\mathbf{x})$} & \multirow[b]{2}{*}{ Me } \\
\hline & $\begin{array}{c}\text { nigdy } \\
(1) \\
\end{array}$ & \begin{tabular}{|c|}
$\begin{array}{c}\text { bardzo } \\
\text { rzadko } \\
(2)\end{array}$ \\
\end{tabular} & $\begin{array}{c}\text { czasami } \\
\text { (3) }\end{array}$ & \begin{tabular}{|c|} 
dość \\
często \\
$(4)$ \\
\end{tabular} & \begin{tabular}{|c|} 
zawsze \\
$(5)$ \\
\end{tabular} & & & & \\
\hline $\begin{array}{l}\text { Poinformowanie pacjenta przed za- } \\
\text { biegiem o jego cenie }\end{array}$ & 3,70 & 0,62 & 6,17 & 20,99 & 68,52 & 4,50 & 5 & 0,93 & 5 \\
\hline $\begin{array}{l}\text { Stosowanie materiałów nowej } \\
\text { generacji }\end{array}$ & 0,0 & 0,61 & 11,04 & 41,72 & 46,63 & 4,34 & 5 & 0,70 & 4 \\
\hline Punktualność rozpoczynania wizyt & 0,0 & 1,26 & 11,95 & 41,51 & 45,28 & 4,31 & 5 & 0,73 & 4 \\
\hline $\begin{array}{l}\text { Konsultacje dotyczące możliwych } \\
\text { metod leczenia i kosztach z nimi } \\
\text { związanych }\end{array}$ & 0,61 & 3,08 & 15,43 & 38,89 & 41,98 & 4,19 & 5 & 0,85 & 4 \\
\hline $\begin{array}{l}\text { Stosowanie nowoczesnych urzą- } \\
\text { dzeń medycznych i metod leczenia }\end{array}$ & 0,0 & 1,86 & 19,25 & 45,96 & 32,92 & 4,10 & 4 & 0,77 & 4 \\
\hline $\begin{array}{l}\text { Regularne rozmowy z pacjentem o } \\
\text { jego problemach zdrowotnych i } \\
\text { profilaktyce }\end{array}$ & 0,0 & 4,91 & 22,09 & 46,01 & 26,99 & 3,95 & 4 & 0,83 & 4 \\
\hline $\begin{array}{l}\text { Dbałość o obsługę przed przyjęciem } \\
\text { pacjenta do gabinetu }\end{array}$ & 10,13 & 6,33 & 12,03 & 25,95 & 45,57 & 3,91 & 5 & 1,32 & 4 \\
\hline $\begin{array}{l}\text { Stosunkowo długi czas poświęcony } \\
\text { na wstępną rozmowę z pacjentem }\end{array}$ & 0,61 & 4,94 & 23,46 & 44,44 & 26,55 & 3,91 & 4 & 0,87 & 4 \\
\hline Elastyczny czas pracy gabinetu & 1,22 & 10,37 & 19,51 & 35,98 & 32,93 & 3,89 & 4 & 1,02 & 4 \\
\hline $\begin{array}{l}\text { Zapewnienie pacjentowi nieskrę- } \\
\text { powanego dostępu do cennika }\end{array}$ & 12,74 & 10,83 & 10,19 & 15,92 & 50,32 & 3,80 & 5 & 1,50 & 5 \\
\hline $\begin{array}{l}\text { Przekazanie pacjentowi rachunku } \\
\text { wraz z wyszczególnieniem } \\
\text { stosowanych zabiegów }\end{array}$ & 12,74 & 15,29 & 30,57 & 24,84 & 16,56 & 3,17 & 3 & 1,25 & 3 \\
\hline $\begin{array}{l}\text { Zabezpieczenie miejsc parkingo- } \\
\text { wych dla pacjentów przed gabinetem }\end{array}$ & 28,75 & 8,75 & 15,0 & 19,38 & 28,13 & 3,09 & 1 & 1,60 & 3 \\
\hline $\begin{array}{l}\text { Zdobywanie przez dentystę kolej- } \\
\text { nych stopni awansu zawodowego } \\
\text { (specjalizacja, stopnie naukowe) }\end{array}$ & 25,16 & 11,61 & 19,35 & 22,58 & 21,29 & 3,03 & 1 & 1,49 & 3 \\
\hline $\begin{array}{l}\text { Ocena jakości świadczonych usług } \\
\text { dokonywana przez pacjentów }\end{array}$ & 30,97 & 10,97 & 25,81 & 21,94 & 10,32 & 2,70 & 1 & 1,38 & 3 \\
\hline $\begin{array}{l}\text { Informowanie pacjentów o wyjątko- } \\
\text { wości usług poprzez podkreślanie } \\
\text { kompetencji i doświadczenia } \\
\text { personelu }\end{array}$ & 30,13 & 12,82 & 25,0 & 21,15 & 10,90 & 2,70 & 1 & 1,38 & 2 \\
\hline $\begin{array}{l}\text { Badanie stopnia zaspokojenia } \\
\text { potrzeb pacjentów }\end{array}$ & 33,33 & 16,67 & 17,95 & 22,44 & 9,62 & 2,58 & 1 & 1,40 & 3 \\
\hline $\begin{array}{l}\text { Wyeksponowanie posiadanych dy- } \\
\text { plomów, świadectw ukończenia } \\
\text { kursów }\end{array}$ & 49,06 & 7,55 & 7,55 & 13,21 & 22,64 & 2,53 & 1 & 1,69 & 3 \\
\hline $\begin{array}{l}\text { Informowanie pacjentów o wyjątko- } \\
\text { wości usług poprzez podkreślanie } \\
\text { nowoczesności urządzeń }\end{array}$ & 37,42 & 14,84 & 20,65 & 18,06 & 9,03 & 2,46 & 1 & 1,38 & 3 \\
\hline $\begin{array}{l}\text { Informowanie pacjenta o ofercie, } \\
\text { godzinach przyjęć gabinetu np. za } \\
\text { pomocą ulotek }\end{array}$ & 41,14 & 18,35 & 16,46 & 15,19 & 8,86 & 2,32 & 1 & 1,37 & 2 \\
\hline
\end{tabular}




\begin{tabular}{|l|c|c|c|c|c|c|c|c|c|}
\hline Przypominanie o wizycie SMSem & 52,87 & 12,10 & 11,46 & 4,46 & 19,11 & 2,25 & 1 & 1,58 & 1 \\
\hline Czasowa obniżka ceny usług & 43,13 & 11,88 & 31,88 & 9,38 & 3,75 & 2,19 & 1 & 1,20 & 2 \\
\hline $\begin{array}{l}\text { Wnoszenie opłat za usługi persone- } \\
\text { lowi pomocniczemu }\end{array}$ & 53,85 & 12,59 & 11,19 & 10,49 & 11,89 & 2,14 & 1 & 1,46 & 1 \\
\hline $\begin{array}{l}\text { Badanie pozamedycznych potrzeb } \\
\text { pacjentów }\end{array}$ & 52,56 & 14,10 & 23,72 & 7,69 & 1,92 & 1,92 & 1 & 1,12 & 1 \\
\hline Ogłoszenia w prasie & 55,35 & 16,98 & 11,95 & 13,21 & 2,52 & 1,91 & 1 & 1,19 & 1 \\
\hline $\begin{array}{l}\text { Organizowanie ,pozamedycznych” } \\
\text { szkoleń }\end{array}$ & 55,48 & 15,48 & 18,10 & 10,32 & 0,61 & 1,85 & 1 & 1,09 & 1 \\
\hline $\begin{array}{l}\text { Składanie pacjentom życzeń } \\
\text { świątecznych (np. tradycyjną pocztą, } \\
\text { mailem) }\end{array}$ & 63,98 & 9,94 & 14,29 & 8,70 & 3,11 & 1,77 & 1 & 1,17 & 1 \\
\hline $\begin{array}{l}\text { Oferowanie pacjentom ,karty } \\
\text { stałego pacjenta” dającej np. 5\% } \\
\text { zniżkę na wszystkie zabiegi }\end{array}$ & 73,13 & 8,13 & 6,25 & 6,88 & 5,63 & 1,64 & 1 & 1,21 & 1 \\
\hline $\begin{array}{l}\text { Publikacje firmowe np. okresowe } \\
\text { wydawnictwo o gabinecie, sprawach } \\
\text { dotyczacych problemów zdrowotnych } \\
\text { pacjentów }\end{array}$ & 74,19 & 10,97 & 6,45 & 3,87 & 4,52 & 1,54 & 1 & 1,08 & 1 \\
\hline $\begin{array}{l}\text { Wywiady dla pasy lokalnej } \\
\text { Dni otwarte }\end{array}$ & 71,97 & 14,01 & 8,28 & 4,46 & 1,27 & 1,49 & 1 & 0,91 & 1 \\
\hline
\end{tabular}

Źródło: opracowanie własne na podstawie przeprowadzonych badań.

Wśród aspektów z zakresu komunikacji na pierwsze miejsce wysuwają się tematy związane $\mathrm{z}$ ceną:

- poinformowanie pacjenta przed zabiegiem o jego cenie (1 miejsce w rankingu) często lub zawsze ma miejsce u $89,5 \%$ respondentów,

- proponowanie pacjentowi tańszego i droższego zabiegu (7) ma miejsce często lub zawsze w $74,2 \%$ badanych gabinetów.

Badani raczej nie wykorzystują potencjału komunikacji interpersonalnej, jako świadomego narzędzia budowania swojego profesjonalnego wizerunku w oczach pacjentów np. poprzez informowanie pacjentów o wyjątkowości usług poprzez podkreślanie kompetencji i doświadczenia personelu (nigdy nie robi tego 30,13\% badanych), czy poprzez podkreślanie nowoczesności urządzeń (nigdy tego nie robi 37,42\% badanych). Z jednej strony przeszło $40 \%$ badanych pokonuje kolejne stopnie awansu zawodowego, ale certyfikaty je potwierdzające eksponuje 22,64\% badanych, podczas gdy 49,06\% nie robi tego nigdy (nie wykorzystując tym samym możliwości, jakie stwarza instrumentarium komunikacji marketingowej).

Inne możliwości z zakresu komunikowania się z pacjentem (np. informowanie pacjenta o godzinach przyjęć np. na ulotkach, przypominanie o terminie wizyty SMSem, zamieszczanie ogłoszeń w prasie, czy udzielanie wywiadów w prasie lokalnej) nie znajdują się w obszarze zainteresowania $60-85 \%$ badanych, podczas gdy maksymalnie jeden na dziesięciu badanych sięga po nie. 
Biorąc pod uwagę, że dla pacjentów sfera komunikacji jest ważna, to lekarzom dentystom należałoby zarekomendować przywiązywanie większej uwagi do tego aspektu kontaktu usługowego, co pozwoliłoby im na umacnianie relacji z nabywcami usług i budowanie pozytywnego wizerunku gabinetu w ich oczach.

Kolejne działania, które mogą sprzyjać wzmacnianiu więzi z pacjentami, to organizacja pracy gabinetu, która może przejawiać się:

- elastycznym czasem pracy gabinetu, dostosowanym do potrzeb pacjenta - jest stosowany w 68,91\% gabinetów,

- w zapewnieniu pacjentowi swobodnego dostępu do cennika usług - rozwiązanie to jest zawsze stosowane u przeszło połowy respondentów, a rzadko lub nigdy u $23,57 \%$,

- we wprowadzeniu procedury oceniania jakości świadczonych usług przez pacjentów - jednak regularnie jest to robione u co dziesiątego dentysty, a u blisko co trzeciego - nigdy.

Również w tym obszarze widać obszary wdrażania zmian w gabinetach, które mogłyby w stosunkowo krótkim czasie wpłynąć na poprawę postrzegania gabinetu przez pacjenta.

Jednym z zadań marketingu usług jest urealnianie usługi. I tego typu działania są stosowane w gabinetach poprzez:

- stosowanie nowoczesnych materiałów stomatologicznych - jest to domena zdecydowanej większości badanych gabinetów $(88,85 \%$ lekarzy zadeklarowało, że stosuje je zawsze lub często);

- stosowanie nowoczesnych urządzeń medycznych i metod leczenia - charakterystyczne dla 78,88\% badanych,

- zabezpieczenie miejsc parkingowych dla pacjentów - 28,13\% wskazań - zawsze i tyle samo - nigdy.

Wśród innych aktywności, podejmowanych w badanych gabinetach, mających na celu wzmacnianie więzi społecznych z pacjentami, można wskazać:

- stosowanie nagród dla najmłodszych pacjentów - przeszło 50\% respondentów stosuje je zawsze,

- badanie stopnia zaspokojenia potrzeb pacjentów - często lub bardzo często wykonuje to $32,06 \%$ badanych (a nigdy nie robiła tego $1 / 3$ respondentów),

- badanie pozamedycznych potrzeb pacjentów - jest realizowane przez 9,61\% lekarzy (nigdy nie było stosowane przez 52,56\%), 
- składanie życzeń pacjentom jest realizowane przez $11,81 \%$ badanych (ale tylko $3,11 \%$ robi to zawsze), natomiast nigdy nie robiło tego $63,98 \%$ respondentów,

- oferowanie karty stałego pacjenta - ma miejsce w $12,51 \%$ badanych gabinetów (nigdy nie robiło tego $73,13 \%$ badanych $^{165}$ ).

Nie można powiedzieć, że pozamedyczne działania zmierzające do zbudowania relacji z pacjentem, nie są podejmowane $\mathrm{w}$ gabinetach, bo w wielu obszarach są. Niemniej jednak nie są one realizowane na szeroką skalę, nawet w tych obszarach, które są ważne dla pacjentów. Z tego względu trudno uznać, że działania marketingowe ${ }^{166}$ są szeroko wykorzystywanym instrumentem konkurencyjności we współczesnych gabinetach stomatologicznych. Z drugiej strony - ci dentyści, którzy stosują je systematycznie, budują w ten sposób pozycję konkurencyjną swojego gabinetu, tym samym wykorzystują pozamedyczny potencjał gabinetu w kreowaniu przewagi konkurencyjnej. Obserwacja rynku usług stomatologicznych pozwala na konkluzję, że oddziaływanie na pacjentów ewoluuje od stricte medycznego (opartego na autorytecie lekarza dentysty jako specjalisty) do medyczno-rynkowego (wykorzystującego instrumenty marketingowe) i to nowe podejście przybiera coraz bardziej świadomą (a nie tylko intuicyjną) formę. Wydaje się, że czas intuicyjnego działania $w$ gabinetach już mija. Profesjonalne (w sensie biznesowym) praktyki stomatologiczne (kliniki czy sieci gabinetów) podejmują aktywne działania na rynku (najczęściej zatrudniając w tym celu wykwalifikowanych menedżerów) i tworzą nowe standardy funkcjonowania, co niejako zmusza inne podmioty z branży do podążania ich śladami. Dentyści stają coraz częściej przed wyzwaniami rynkowymi (a nie medycznymi) i muszą nauczyć się, jak im sprostać, jeśli chcą prowadzić swoje przedsiębiorstwa zarobkowe z sukcesem.

Pytanie: „Jakie powinny być stosowane dziatania we wspótczesnym gabinecie stomatologicznym?" zostało postawione również studentom kierunku lekarskodentystycznego (badanie III), którzy dorastając w warunkach gospodarki rynkowej, mogli jej mechanizmów uczyć się w praktyce (w innych tj. niemedycznych obszarach). Ranking działań, które wskazali studenci przestawiony jest w tabeli $71^{167}$. I właściwie tylko pierwsza pozycja - poinformowanie pacjenta

\footnotetext{
165 Jest to zgodne z oczekiwaniami pacjentów - por. tabele 2.1 i 2.3 w Załączniku 2).

${ }^{166} \mathrm{Na}$ podkreślenie zasługuje fakt, że lekarze ciągle małą wagę nadają badaniu pozamedycznych oczekiwań pacjentów (można zapytać: skąd mogą wiedzieć, jakie są - szczególnie pozamedyczne oczekiwania pacjentów? skąd mogą wiedzieć, co mogliby zmodyfikować w funkcjonowaniu gabinetu?) i badaniu stopnia zaspokojenia tych potrzeb (tu pojawia się pytanie: skąd mogą wiedzieć, co pacjentom odpowiada w funkcjonowaniu gabinetu, a co nie?).

${ }^{167}$ Podobnie, jak w przypadku tabeli 69 autorce zależało na kompleksowym spojrzeniu na różne aspekty funkcjonowania gabinetu, które mogą przyczyniać się do tworzenia i wzmacniania więzi $\mathrm{z}$ pacjentem.
} 
przed zabiegiem o cenie leczenia - jest taka, jak u praktyków zawodu, kolejność pozostałych - inna.

Tabela 71. Działania jakie powinny być podejmowane w gabinecie stomatologicznym (badanie III)

\begin{tabular}{|c|c|c|c|c|c|c|c|c|c|}
\hline \multirow[b]{2}{*}{ Działanie } & \multicolumn{5}{|c|}{$\begin{array}{c}\text { Stanowisko respondenta } \\
\text { (procent wskazań) }\end{array}$} & \multirow[b]{2}{*}{$\bar{x}$} & \multirow[b]{2}{*}{ Do } & \multirow[b]{2}{*}{$\mathbf{S}(\mathbf{x})$} & \multirow[b]{2}{*}{ Me } \\
\hline & $\begin{array}{l}\text { nigdy } \\
\text { (1) }\end{array}$ & $\begin{array}{l}\text { bardzo } \\
\text { rzadko } \\
(2)\end{array}$ & $\begin{array}{c}\text { zzasami } \\
\text { (3) }\end{array}$ & \begin{tabular}{|c|} 
często \\
(4)
\end{tabular} & $\begin{array}{c}\text { zawsze } \\
(5)\end{array}$ & & & & \\
\hline $\begin{array}{l}\text { Poinformowanie pacjenta przed } \\
\text { zabiegiem o cenie }\end{array}$ & 0,0 & 1,04 & 6,32 & 28,42 & 64,22 & 4,56 & 5 & 0,66 & 5 \\
\hline $\begin{array}{l}\text { Dbałość o obsługę przed przy- } \\
\text { jęciem pacjenta do gabinetu }\end{array}$ & 0,0 & 0,0 & 6,32 & 40,00 & 53,68 & 4,47 & 5 & 0,62 & 5 \\
\hline $\begin{array}{l}\text { Zapewnienie pacjentowi swo- } \\
\text { bodnego dostępu do cennika }\end{array}$ & 0,0 & 0,0 & 8,51 & 37,23 & 54,26 & 4,46 & 5 & 0,65 & 5 \\
\hline $\begin{array}{l}\text { Zdobywanie przez dentystę } \\
\text { kolejnych stopni awansu } \\
\text { zawodowego }\end{array}$ & 1,04 & 0,0 & 11,46 & 35,42 & 52,08 & 4,38 & 5 & 0,77 & 5 \\
\hline Punktualne rozpoczynanie wizyt & 1,04 & 2,08 & 7,29 & 39,58 & 50,00 & 4,35 & 5 & 0,79 & 5 \\
\hline $\begin{array}{l}\text { Stosowanie nowoczesnych } \\
\text { metod leczenia }\end{array}$ & 0,0 & 0,0 & 7,29 & 55,21 & 37,50 & 4,30 & 4 & 0,60 & 4 \\
\hline $\begin{array}{l}\text { Stosowanie nagród dla } \\
\text { najmłodszych pacjentów }\end{array}$ & 1,04 & 2,08 & 12,50 & 37,50 & 46,88 & 4,27 & 5 & 0,84 & 4 \\
\hline $\begin{array}{l}\text { Stosowanie nowoczesnych } \\
\text { urządzeń }\end{array}$ & 0,0 & 0,0 & 8,33 & 56,25 & 35,42 & 4,27 & 4 & 0,61 & 4 \\
\hline $\begin{array}{l}\begin{array}{l}\text { Stosowanie materiałów nowej } \\
\text { generacji }\end{array} \\
\end{array}$ & 0,0 & 1,04 & 6,32 & 57,90 & 34,74 & 4,26 & 4 & 0,62 & 4 \\
\hline $\begin{array}{l}\text { Przekazanie pacjentowi } \\
\text { rachunku z wyszczególnieniem } \\
\text { przeprowadzonych zabiegów }\end{array}$ & 3,19 & 4,26 & 9,57 & 40,43 & 42,55 & 4,15 & 5 & 0,77 & 4 \\
\hline $\begin{array}{l}\text { Proponowanie przez dentystę } \\
\text { zabiegów w różnych wariantach } \\
\text { cenowych }\end{array}$ & 0,0 & 3,19 & 14,89 & 45,74 & 36,17 & 4,15 & 4 & 0,79 & 4 \\
\hline Elastyczny czas pracy gabinetu & 1,04 & 1,04 & 21,88 & 44,79 & 31,25 & 4,04 & 4 & 0,82 & 4 \\
\hline $\begin{array}{l}\text { Wyeksponowanie posiadanych } \\
\text { dyplomów, świadectw } \\
\text { ukończenia kursów }\end{array}$ & 3,16 & 4,21 & 20,0 & 38,95 & 33,68 & 3,96 & 4 & 0,99 & 4 \\
\hline $\begin{array}{l}\text { Informowanie pacjentów o wy- } \\
\text { jątkowości usług poprzez pod- } \\
\text { kreśllanie nowoczesności } \\
\text { urządzeń }\end{array}$ & 3,16 & 7,37 & 18,95 & 43,16 & 27,37 & 3,84 & 4 & 1,01 & 4 \\
\hline $\begin{array}{l}\text { Stosunkowo długi czas } \\
\text { poświęcony na wstępną } \\
\text { rozmowę z pacjentem }\end{array}$ & 0,0 & 2,08 & 33,33 & 43,75 & 20,83 & 3,83 & 4 & 0,78 & 4 \\
\hline $\begin{array}{l}\text { Regularne rozmowy z pacjentem } \\
\text { o jego problemach zdrowotnych } \\
\text { i profilaktyce }\end{array}$ & 0,0 & 1,04 & 38,54 & 36,46 & 23,96 & 3,83 & 3 & 0,80 & 4 \\
\hline $\begin{array}{l}\text { Informowanie pacjentów o wy- } \\
\text { jątkowości usług poprzez pod- }\end{array}$ & 2,11 & 8,42 & 22,11 & 41,05 & 26,32 & 3,81 & 4 & 0,99 & 4 \\
\hline
\end{tabular}




\begin{tabular}{|c|c|c|c|c|c|c|c|c|c|}
\hline $\begin{array}{l}\text { kreślanie kompetencji i } \\
\text { doświadczenia personelu }\end{array}$ & & & & & & & & & \\
\hline $\begin{array}{l}\text { Oferowanie pacjentom „,karty } \\
\text { stałego pacjenta” dającej np. } 5 \% \\
\text { zniżkę na zabiegi }\end{array}$ & 1,04 & 10,42 & 30,21 & 35,42 & 22,92 & 3,69 & 4 & 0,98 & 4 \\
\hline $\begin{array}{l}\text { Wnoszenie opłat personelowi } \\
\text { pomocniczemu }\end{array}$ & 5,32 & 9,57 & 19,15 & 43,62 & 22,34 & 3,68 & 4 & 1,09 & 4 \\
\hline $\begin{array}{l}\text { Badanie stopnia zaspokojenia } \\
\text { potrzeb pacjentów }\end{array}$ & 1,04 & 11,58 & 33,68 & 37,88 & 15,79 & 3,56 & 4 & 0,93 & 4 \\
\hline $\begin{array}{l}\text { Informowanie pacjenta o ofercie, } \\
\text { godzinach przyjęć np. za pomocą } \\
\text { ulotek }\end{array}$ & 5,26 & 12,63 & 27,37 & 31,58 & 23,16 & 3,55 & 4 & 1,14 & 4 \\
\hline Przypominanie o wizycie SMSem & 12,63 & 8,42 & 23,16 & 25,26 & 30,53 & 3,53 & 5 & 1,34 & 4 \\
\hline $\begin{array}{l}\text { Ocena jakości świadczonych } \\
\text { usług dokonywana przez } \\
\text { pacjentów }\end{array}$ & 2,11 & 10,53 & 37,89 & 35,79 & 13,68 & 3,48 & 3 & 0,93 & 3 \\
\hline $\begin{array}{l}\text { Zabezpieczenie miejsc parking- } \\
\text { owych dla pacjentów }\end{array}$ & 9,38 & 13,54 & 29,17 & 28,13 & 19,79 & 3,35 & 3 & 1,21 & 3 \\
\hline $\begin{array}{l}\text { Wykorzystywanie gadżetów } \\
\text { reklamowych }\end{array}$ & 6,25 & 13,54 & 34,38 & 31,25 & 14,58 & 3,34 & 4 & 1,08 & 3 \\
\hline $\begin{array}{l}\text { Organizowanie „pozamedycz- } \\
\text { nych” szkoleń }\end{array}$ & 3,13 & 17,71 & 37,50 & 27,08 & 14,58 & 3,32 & 3 & 1,03 & 3 \\
\hline $\begin{array}{l}\text { Zamieszczanie informacji o pro- } \\
\text { wadzonym gabinecie na por- } \\
\text { talach społecznościowych }\end{array}$ & 10,42 & 12,50 & 26,04 & 36,46 & 14,58 & 3,32 & 4 & 1,18 & 4 \\
\hline $\begin{array}{l}\text { Zamieszczanie ogłoszeń o pro- } \\
\text { wadzonej działalności w prasie }\end{array}$ & 8,33 & 11,46 & 38,54 & 33,33 & 8,33 & 3,22 & 4 & 1,03 & 3 \\
\hline Czasowa obniżka ceny usług & 5,26 & 17,89 & 37,89 & 30,53 & 8,42 & 3,19 & 3 & 1,00 & 3 \\
\hline $\begin{array}{l}\text { Publikacje firmowe np. okresowa } \\
\text { publikacja o gabinecie, sprawach } \\
\text { dotyczących problemów } \\
\text { zdrowotnych }\end{array}$ & 7,37 & 15,79 & 46,32 & 24,21 & 6,32 & 3,06 & 3 & 0,98 & 3 \\
\hline $\begin{array}{l}\text { Składanie pacjentom życzeń } \\
\text { świątecznych (np. tradycyjną } \\
\text { pocztą, mailem) }\end{array}$ & 12,50 & 14,58 & 42,71 & 21,88 & 8,33 & 2,99 & 3 & 1,10 & 3 \\
\hline $\begin{array}{l}\text { Badanie pozamedycznych } \\
\text { potrzeb pacjentów }\end{array}$ & 4,21 & 33,68 & 31,58 & 24,21 & 6,32 & 2,95 & 2 & 1,00 & 3 \\
\hline $\begin{array}{l}\text { Wywiady dla prasy lokalnej, } \\
\text { mające zwiększyć rozpoznawalność } \\
\text { gabinetu wśród lokalnej społeczności }\end{array}$ & 13,54 & 16,67 & 40,63 & 21,88 & 7,29 & 2,93 & 3 & 1,11 & 3 \\
\hline Dni otwarte w gabinecie & 9,47 & 26,32 & 33,68 & 24,21 & 6,32 & 2,92 & 3 & 1,07 & 3 \\
\hline
\end{tabular}

Źródło: Opracowanie własne na podstawie przeprowadzonego badania.

Za najważniejsze elementy w funkcjonowaniu współczesnego gabinetu studenci uznali aspekty związane $\mathrm{z}$ organizacją pracy gabinetu (dbałość o obsługę przed rozpoczęciem leczenia - ważna dla $93,68 \%$ badanych; zapewnienie pacjentowi swobodnego dostępu do cennika - istotne dla 91,49\% badanych) i rozwojem zawodowym stomatologa (87,5\% wskazań), dominanta dla tych aspektów wynosiła 5. Dominanta o wartości 4 dotyczyła dbałości o zmaterializowanie usługi (stosowanie nowoczesnych metod, urządzeń i materiałów do leczenia, 
czy elastyczny czas pracy) i komunikacji. Ale wszystkie wskazania dotyczące komunikacji miały średnią ze wskazań niższą niż cztery, tak więc grupę czynników związanych z komunikacją interpersonalną (np. stosunkowo długi czas poświęcony na rozmowę wstępną, edukacja z zakresu profilaktyki, podkreślanie wyjątkowości oferty $\mathrm{w}$ rozmowach $\mathrm{z}$ pacjentami), czy marketingową (np. eksponowanie certyfikatów potwierdzających kwalifikacje dentysty, przypominanie pacjentowi SMSem o terminie wizyty), studenci uznali za mniej ważną w funkcjonowaniu gabinetu. Jak bez przykładania istotnej wagi do komunikacji budować więzi społeczne? Odpowiedź na to pytanie przyniesie prawdopodobnie studentom dopiero kilkugodzinna codzienna praca przy fotelu, a nie ćwiczenia czy laboratoria akademickie odbywające się przez kilka godzin w tygodniu. Dla dodatkowego podkreślenia rangi aspektów komunikacji, można przywołać (zawarte w tabeli $2.4 \mathrm{w}$ załączniku 2) wyniki badania IV, w którym pacjenci uznali m. in., że:

- zawsze są traktowani z szacunkiem przez pracowników gabinetu (dominanta wskazań - 5),

- pracownicy gabinetu rzetelnie przedstawiają korzyści, których może dostarczyć pacjentowi określona usługa (4),

- $\quad$ stomatolog zawsze stara się znaleźć taki wariant ofert, który jest optymalny dla pacjenta (4),

- pracownicy potrafią w jasny sposób przekazać wiedzę dotyczącą specyfiki usługi (4),

- pracownicy gabinetu zachęcają pacjenta do pełnego opisania potrzeb związanych z usługą (4).

$\mathrm{Z}$ punktu widzenia idei marketingu relacji brak umiejętności z zakresu komunikacji lub posługiwanie się nią w ograniczonym zakresie, stwarza zagrożenie dla budowy zaufania na płaszczyźnie pacjent - lekarz. Tym samym budowanie relacji i jej utrzymywanie może być utrudnione (jeśli nie niemożliwe). Po raz drugi pojawia się wniosek o zasadności włączenia - szeroko pojętych - treści ekonomicznych do kształcenia przyszłych lekarzy dentystów (tym razem w odniesieniu do marketingu relacji), co mogłoby być uzasadnione ideą Uniwersytetu Trzeciej Generacji, który postuluje możliwość rynkowego zdyskontowania zdobytej w murach uczelni wiedzy ${ }^{168}$, choć $\mathrm{z}$ drugiej strony nie można odmówić studentom intuicyjnego ,rozumienia rynku usług” o czym poniżej.

Wykres 9 pozwala przyjrzeć się różnicom w postrzeganiu rangi wybranych działań gabinetów stomatologicznych w oczach dentystów i studentów.

${ }^{168}$ Wissena J.G., Uniwersytet Trzeciej Generacji. Uczelnia XXI w., ZANTE, Warszawa 2009, s. 43. 


\section{Wykres 9. Proklientowskie działania gabinetu stomatologicznego - perspektywa stomatologa (badanie I) i studenta kierunku lekarsko-dentystycznego (badanie III) - średnia arytmetyczna ze wskazań respondentów}

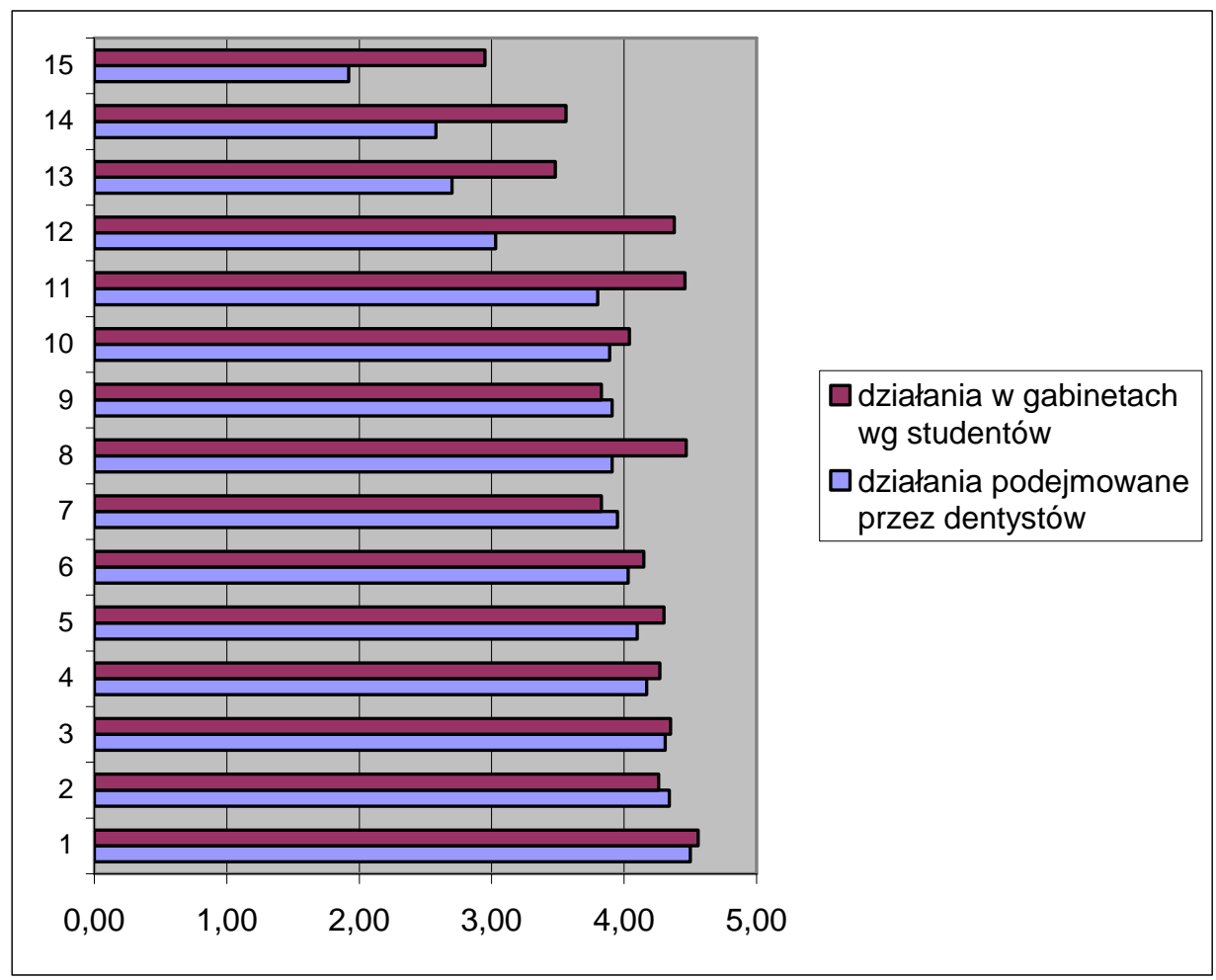

Źródło: opracowanie własne na podstawie przeprowadzonych badań.

Działania: 1) poinformowanie pacjenta przed zabiegiem o jego cenie, 2) stosowanie materiałów nowej generacji, 3) punktualność rozpoczynania wizyty, 4) stosowanie nagród dla najmłodszych pacjentów, 5) stosowanie nowoczesnych urządzeń medycznych i metod leczenia, 6) proponowanie przez dentystę zabiegu tańszego i droższego, 7) regularne rozmowy z pacjentem o jego problemach zdrowotnych i profilaktyce, 8) dbałość o obsługę pacjenta przed rozpoczęciem leczenia, 9) stosunkowo długi czas poświęcony na wstępną rozmowę z pacjentem, 10) możliwość wyboru dogodnego dla pacjenta czasu wizyty, 11) zapewnienie pacjentowi swobodnego dostępu do cennika świadczeń, 12) zdobywanie przez dentystę kolejnych szczebli awansu zawodowego, 13) regularna ocena jakości świadczonych usług dokonywana przez pacjenta, 14) badanie stopnia zaspokojenia potrzeb pacjentów, 15) badanie pozamedycznych potrzeb pacjentów.

Do istotnych różnic - z punktu widzenia niniejszej pracy - pomiędzy praktykami i przyszłymi adeptami zawodu należą:

- badanie pozamedycznych potrzeb pacjentów: dentyści - średnia ze wskazań 1,92 (przy dominancie 1) i studenci - 2,95 (dominanta - 2),

- badanie stopnia zaspokojenia potrzeb pacjentów: lekarze - średnia 2,58 (dominanta 1) i studenci - 3,56 (dominanta 4), 
- okresowa ocena jakości świadczonych usług dokonywana przez pacjentów: dentyści - 2,70 (dominanta 1), studenci - 3,48 (dominanta 3),

- dbałość o obsługę: lekarze dentyści - średnia ze wskazań 3,91 (dominanta 5), a studenci - 4,47 (dominanta 5).

Zrozumienie roli pacjenta, jako współuczestnika (czy wręcz współtwórcy) usługi, jest zdecydowanie większe wśród studentów, niż wśród lekarzy. Jeśli badani zachowają to spojrzenie, rozpoczynając pracę w zawodzie, to implementacja marketingu relacji do gabinetów będzie miała otwartą drogę.

\subsection{POZIOMY RELACJI PACJENT - LEKARZ DENSTYTA}

Marketing relacji akcentuje nowy sposób postrzegania konsumenta na rynku, zakładając, iż postawy i zachowania konsumentów wobec oferty podmiotu są silniej uwarunkowane przebiegiem dotychczasowych interakcji z firmą i opinią na temat firmy wśród krewnych i znajomych, niż bodźcami przekazywanymi $\mathrm{w}$ akcjach promocyjno-reklamowych ${ }^{169}$ (co potwierdziły przedstawione wcześniej wyniki badania IV). Tym samym pacjent z jednej strony jest otwarty na opinie innych nabywców (którzy osobiście sprawdzili jakość obsługi) i jeśli są oni wiarygodni w oczach pacjenta, to korzysta $\mathrm{z}$ ich wskazówek (w badaniu IV - 85,2\% respondentów wskazało taką determinantę wyboru gabinetu - por. tabela $2.1 \mathrm{w}$ załączniku 2). Z drugiej strony - pacjent, jako usługobiorca staje się źródłem rekomendacji dla innych osób. Potencjalny nabywca - poszukujący najlepszej, dostępnej na rynku oferty - jest zainteresowany opinią innych konsumentów i ich doświadczeniami. Prawie 37\% Polaków przyznaje, że raczej chętnie lub bardzo chętnie korzysta $\mathrm{z}$ opinii innych osób przy zakupie produkttów ${ }^{170}$. Szczególnego znaczenia nabierają rekomendacje rodziny/znajomych w przypadku korzystania z usług, szczególnie w przypadku usług profesjonalnych.

W literaturze wskazuje się na prawie siedmiokrotnie większą skuteczność opinii klientów przy przekazywaniu informacji na temat nowej usługi od tradycyjnych źródeł informacji (np. reklamy) ${ }^{171}$. Z badań własnych (badanie IV) wynika, że rekomendacje są ważne lub bardzo ważne dla $85,2 \%$ respondentów przy wyborze gabinetu stomatologicznego z usług, którego zamierzają korzystać, a reklama jest raczej ważna dla 3,9\% respondentów. Dlatego rola pozytywnych opinii wygła-

\footnotetext{
${ }^{169}$ Mitręga M., Marketing relacji. Teoria i praktyka, CeDeWu, Warszawa 2005, s. 28.

${ }^{170} \mathrm{SMG} / \mathrm{KRC}$, Wyniki badań dla Streetcom, prezentowane podczas konferencji „Word of Mouth The Power of Consumers", 8.03.2007, za: Tkaczyk J., Wiarygodność źródet informacji a proces podejmowania decyzji przez konsumenta, w: Rudawska I., Soboń M. (red. nauk.), Przedsiębiorstwo $i$ klient w gospodarce opartej na ustugach, Difin, Warszawa 2009, s. 269.

${ }^{171}$ Ennew Ch., Banerjee A., Li D., Managing Word of mouth communication: empirical evidence, "International Journal of Bank Marketing", 2000, nr 18/2, s. 75 i nast.
} 
szanych przez aktualnych pacjentów i ich celowe rekomendacje są nie do przecenienia $\mathrm{z}$ punktu widzenia gabinetu, jako podmiotu zarobkującego ${ }^{172}$.

Przypomnijmy, że w odniesieniu do 58,8\% pacjentów można mówić o lojalności prawdziwej, a do 27,7\% - o lojalności pozornej (por. tabela 67). Te deklaracje pacjentów nie znajdują, aż tak ostrego potwierdzania w odniesieniu do pozostałych poziomów relacji.

O znaczeniu siły rekomendacji na decyzje pacjentów mogą świadczyć wyniki badania IV, pokazujące, że spośród osób, które leczą się aktualnie u jakiegoś dentysty $80,3 \%$ poleciłoby swojego dentystę komuś z rodziny/przyjaciół; kolejne $16,8 \%$ również, ale tylko w sytuacji, gdyby nie było innego rozwiązania. Natomiast $1,8 \%$ respondentów raczej nie poleciłoby swojego lekarza innym, a 1,1\% zdecydowanie nie. Wskaźnik skłonności do rekomendacji (NPS) dla całej grupy badanej wynosi 79,2\%, co oznacza, że taki odsetek badanych jest na tyle usatysfakcjonowany z kontaktu z dotychczasowym usługodawcą, że pozostanie klientem gabinetu w dłuższym okresie.

Ciekawe spojrzenie na NPS daje przefiltrowanie badanej grupy przez pryzmat częstotliwości korzystania przez pacjentów z usług stomatologicznych (por. tabela 72), okazuje się, że im większa częstotliwość spotkań pacjenta z lekarzem, tym większa skłonność do rekomendowania gabinetu. Może to wynikać z tego, iż pacjent - częściej korzystający ze świadczeń medycznych - ma okazję upewnić się co do jakości usług i rośnie jego przekonanie o słuszności dokonanego wyboru oraz skłonność do rekomendacji (w grupie respondentów regularnie korzystających z usług stomatologicznych wartość NPS była o blisko 20 p.p. wyższa, niż w grupie rzadko korzystających z tego typu usług).

Tabela 72. Częstotliwość korzystania z usług stomatologicznych a chęć rekomendowania gabinetu innym (badanie IV)

\begin{tabular}{|l|c|c|c|}
\hline $\begin{array}{c}\text { Chęć rekomendowania dentysty innym } \\
\text { pacjentom }\end{array}$ & $\begin{array}{c}\text { Pacjent w ciągu } \\
\text { ostatnich 5 lat } \\
\text { był 1-3razy u } \\
\text { dentysty (N*=87) }\end{array}$ & $\begin{array}{c}\text { Pacjent jest w } \\
\text { gabinecie 1-3 } \\
\text { razy w roku } \\
(\mathbf{N = 1 5 0 )}\end{array}$ & $\begin{array}{c}\text { Pacjent jest w } \\
\text { gabinecie co } \\
\text { miesiąc-dwa } \\
(\mathbf{N}=32)\end{array}$ \\
\hline tak, z czystym sumieniem & $75,34 \%$ & $85,35 \%$ & $87,5 \%$ \\
\hline $\begin{array}{l}\text { tak, ale tylko w sytuacji gdyby nie było } \\
\text { innego rozwiązania }\end{array}$ & $17,8 \%$ & $14,0 \%$ & $12,5 \%$ \\
\hline raczej nie & $4,10 \%$ & $0,67 \%$ & $0,0 \%$ \\
\hline zdecydowanie nie & $2,74 \%$ & $0,0 \%$ & $0,0 \%$ \\
\hline NPS & $68,5 \%$ & $84,2 \%$ & $87,5 \%$ \\
\hline
\end{tabular}

Źródło: opracowanie własne na podstawie przeprowadzonego badania.

* W tabeli $\mathrm{N}$ nie sumuje się do 279 , bo 10 respondentów w pytaniu, którego dotyczy tabela zaznaczyło odpowiedź: ,inne”, która nie została uwzględniona w powyższej analizie.

${ }^{172} \mathrm{Z}$ drugiej strony istniejąca wśród dentystów świadomość, że pacjenci przychodzą z polecenia jest argumentem dla nie podejmowania jakichkolwiek działań prorynkowych, gdyż „dobra usłu-ga sama się obroni na rynku." Stwarza to wyraźną barierę we wprowadzaniu zmian w funkcjonowaniu gabinetów. 
Mniej optymistyczny obraz relacji pacjent - lekarz pojawił się, gdy pacjenci zostali zapytani o to: „Czy rozważała Pani/Pan rezygnację z ustug obecnego dentysty?", gdyż 64,9\% nigdy zastanawiało się nad wyborem innego dentysty, a pozostali - tak (wyniki przedstawione są w tabeli 73). Jak wynika z przedstawionych odpowiedzi nawet w sytuacji, gdy pacjent bez zastrzeżeń poleca „swojego lekarza dentystę" innym, nie oznacza to, że jest skłonny kontynuować relację. Wyniki pokazują również, że to, iż pacjent szuka innego stomatologa nie oznacza, że na pewno zrezygnuje z usług dotychczasowego. Otrzymane wyniki wpisują się w rozważania E.M. Gemme ${ }^{173}$ dotyczące tego, że doznanie satysfakcji nie musi oznaczać gotowości do ponownych kontaktów i zachowań nabywczych, a z drugiej strony - brak satysfakcji nie jest wystarczającym przyczynkiem do zakończenia relacji.

Tabela 73. Wskaźniki skłonności do zmiany usługodawcy (badanie IV)

\begin{tabular}{|l|c|}
\hline \multicolumn{1}{|c|}{$\begin{array}{c}\text { Rozważanie rezygnacji z usług obecnego dentysty - stanowisko } \\
\text { pacjenta }\end{array}$} & Wskazania (\%) \\
\hline nie, nigdy & 64,9 \\
\hline tak, ale nie podjął żadnych działań w tym kierunku & 22,5 \\
\hline tak i szukał w Internecie innego gabinetu & 1,4 \\
\hline tak i przeglądał ogłoszenia w prasie w tej sprawie & 0,7 \\
\hline tak i rozmawiał w tej sprawie ze znajomymi, czy mogą kogoś polecić & 8,0 \\
\hline Inne & 2,5 \\
\hline
\end{tabular}

Źródło: opracowanie własne na podstawie przeprowadzonego badania.

Omawiane zjawisko wygląda nieco inaczej, jeśli spojrzy się na badaną grupę z perspektywy częstotliwości korzystania z usług stomatologicznych (por. tabela 74). Jak widać również wskaźnik skłonności do zmiany usługodawcy jest związany z częstotliwością korzystania przez pacjenta z oferty gabinetu - im wyższa częstotliwość, tym mniejsza skłonność do rezygnacji z usługi (związana $\mathrm{z}$ brakiem podejmowania jakichkolwiek działań $\mathrm{w}$ tym zakresie). W grupie pacjentów regularnie korzystających z usług stomatologicznych skłonność do zmiany usługodawcy jest niższa o blisko 20 p.p., niż u pacjentów rzadko korzystających z usług stomatologicznych.

Czym mogłaby być spowodowana chęć rezygnacji z usług lekarza dentysty? Jak już zostało wcześniej powiedziane $\mathrm{m}$. in. tym, że $\mathrm{w}$ innym gabinecie taki sam poziom usługi pacjent spodziewa się otrzymać za niższą cenę lub że w tej samej cenie inny gabinet zaoferuje mu zdecydowanie więcej wartości, niż dotychczasowy. Innym powodem, zdecydowanie bardziej „konkretnym”, niż oczekiwania (o niepewnym efekcie rzeczywistym) jest niewłaściwy - w oczach pacjenta - poziom usługi. Niezadowolony pacjent może zrezygnować z usług dentysty, ale może również wrócić i złożyć reklamację i to, jak zostanie ona

${ }^{173}$ Gemme E.M., Retainig customers in a manager care market, "Marketing Health Services", 1997 t. 17, z. 3 , s. 14 . 
rozpatrzona wpłynie na jego postawę względem usługodawcy - albo upewni pacjenta $\mathrm{w}$ podjętej decyzji o rezygnacji $\mathrm{z}$ usług, albo sprawi, że pacjent - doceniając rzetelność rozpatrzonej reklamacji - stanie się bardziej lojalny.

Tabela 74. Częstotliwość korzystania z usług stomatologicznych a chęć rezygnacji z usług dotychczasowego dentysty (badanie IV)

\begin{tabular}{|c|c|c|c|}
\hline $\begin{array}{l}\text { Rozważanie rezygnacji } \mathrm{z} \text { usług obecnego } \\
\text { dentysty }\end{array}$ & $\mid \begin{array}{c}\text { Pacjent w ciągu } \\
\text { ostatnich } 5 \text { lat był } \\
\text { 1-3razy u dentysty } \\
(\mathrm{N}=87)\end{array}$ & $\begin{array}{c}\text { Pacjent jest w } \\
\text { gabinecie 1-3 } \\
\text { razy w roku } \\
(\mathrm{N}=150)\end{array}$ & $\begin{array}{c}\text { Pacjent jest } \mathbf{w} \\
\text { gabinecie co } \\
\text { miesiąc-dwa } \\
\text { (np. ze względu na } \\
\text { noszony aparat) } \\
(\mathbf{N}=\mathbf{3 2})\end{array}$ \\
\hline nie, nigdy pacjent nie brał tego pod uwagę & $56,16 \%$ & $68,71 \%$ & $75,0 \%$ \\
\hline $\begin{array}{l}\text { pacjent rozważał rezygnację z usług dentys- } \\
\text { ty, ale nie podjął żadnych działań w tym } \\
\text { kierunku }\end{array}$ & $23,29 \%$ & $21,77 \%$ & $18,75 \%$ \\
\hline $\begin{array}{l}\text { pacjent rozważał rezygnację z usług dentysty } \\
\text { i szukał w Internecie innego gabinetu }\end{array}$ & $4,11 \%$ & $0,68 \%$ & $0,0 \%$ \\
\hline $\begin{array}{l}\text { pacjent rozważał rezygnację z usług dentysty } \\
\text { i szukał w prasie ogłoszeń stomatologów }\end{array}$ & $1,37 \%$ & $0,68 \%$ & $0,0 \%$ \\
\hline $\begin{array}{l}\text { pacjent rozważał rezygnację z usług dentysty } \\
\text { i pytał znajomych, czy mogą mu kogoś } \\
\text { polecić }\end{array}$ & $10,16 \%$ & $6,80 \%$ & $3,13 \%$ \\
\hline Inne & $4,11 \%$ & $1,36 \%$ & $3,13 \%$ \\
\hline
\end{tabular}

Źródło: opracowanie własne na podstawie przeprowadzonego badania.

Znaczenie interakcji klientów z pracownikami w sytuacji błędu było przedmiotem badania K.J. Bitner, B.H. Booms, M.S. Tetreault ${ }^{174}$, dotyczącego przyczyn składających się na postrzeganie przez klientów spotkań usługowych jako wysoce satysfakcjonujących, bądź bardzo niezadowalających. Incydenty wywołujące takie emocje zakwalifikowano do trzech grup, z których pierwsza dotyczyła odpowiedzi pracowników na błędy w systemie świadczenia usług (w drugiej grupie mieściły się odpowiedzi personelu na potrzeby i żądania klientów, w trzeciej znalazły się nieoczekiwane przez klientów działania personelu niezwiązane z bazową usługą). I 23\% zapamiętanych przez respondentów satysfakcjonujących kontaktów z usługodawcą związanych było ze sposobem reakcji pracowników $\mathrm{w}$ sytuacji błędu $\mathrm{w}$ usłudze. $\mathrm{Z}$ drugiej strony $-42,9 \%$ niezadowalających wydarzeń miało miejsce $\mathrm{w}$ związku $\mathrm{z}$ brakiem właściwego zachowania pracowników w omawianych sytuacjach, przy czym wypowiedzi niezadowolonych klientów wskazywały na fakt, że główną przyczyną braku satysfakcji był nie tyle sam błąd, co późniejsza odpowiedź personelu. Tak więc nawet wówczas, gdy wystąpi błąd w usłudze, właściwe reakcje personelu: ser-

${ }^{174}$ Bitner M.J., Booms B.H., Tetreault M.S., The Service Ecounter: Diagnosing Favorable and Unfavorable Incidents, "Journal of Marketing", 1990, nr 1 za: Bohuszewicz-Kreft M., Reakcja przedsiębiorstwa na bład w ustudze jako element marketingu partnerskiego, „Marketing i Rynek”, 2004 nr 6, s. 20. 
deczne przeprosiny, wytłumaczenie sytuacji i działanie mające na celu zrekompensowanie błędu mogą spowodować, że usługa będzie postrzegana przez klienta jako wysoce zadowalająca.

Problem składania reklamacji nie dotyczył przeszło połowy badanych pacjentów, choć powody były różne:

- 53,6\% respondentów nie składało reklamacji, gdyż nie było takiej potrzeby,

- $\quad 15,1 \%$ również nie składało reklamacji, choć miało ku temu powody; a ze źle wykonaną - w swoim odczuciu - pracą - pacjenci poszli do innego gabinetu, aby inny dentysta poprawił pracę (pokazuje to, że fakt, iż pacjenci się nie skarżą, nie jest jednoznaczny z ich zadowoleniem z usługi wykonywanej przez stomatologa).

Raz reklamację złożyło $11,9 \%$ badanych, a kilka razy - 6,8\%. Pozostali respondenci (głównie ci nie chodzący do dentysty) nie mogli sobie przypomnieć, czy składali reklamację.

Wśród osób, które składały reklamację (18,7\% ogółu badanych pacjentów) w większości przypadków (blisko 60\% wskazań w tej grupie) stomatolog ze spokojem poprawił nieodpłatnie pracę. I ci respondenci byli zadowoleni ze sposobu rozwiązania ich problemu przez usługodawcę ${ }^{175}$. Pozostała grupa składających reklamację, uznała jej przebieg i/lub efekt za niesatysfakcjonujący:

- $\quad 8,75 \%$ respondentów, zadeklarowało, że dentysta poprawił pracę niedopłatnie, ale przebieg wizyty był daleki od atmosfery spokoju;

- $\quad 6,94 \%$ respondentów stwierdziło, że choć lekarz poprawił pracę, to nie oceniają sposobu rozpatrzenia reklamacji dobrze, gdyż lekarz pobrał opłatę za powtórnie wykonaną pracę, twierdząc, że usterka jest winą pacjenta, który nie stosował się do jego zaleceń;

- dla 14,94\% reklamujących świadczenie pacjentów reklamacja nie zakończyła się poprawą pracy - stomatolog zbył pacjenta (np. mówiąc, że to niemożliwe, wszystko jest w porządku itp.).

I są to pacjenci, których skłonność do rezygnacji z usług dentysty potwierdziły ich wcześniejsze odpowiedzi.

\footnotetext{
${ }^{175}$ Szybkie i sprawne załatwianie reklamacji jest pozytywnie i silnie skorelowane z zaufaniem i zaangażowaniem klientów w relacje. Por. Tax S., Brown S., Chandreshekaran M., Customer Evaluations of Service Complaint Experiences: Implications for Relationship Marketing, „Journal of Marketing", 1998 vol. 62, s. 61.
} 


\section{REASUMPCJA}

Dotychczas najczęściej lekarz był aktywną stroną kontaktu, a pacjent - bierną: lekarz dokonywał wyboru, działał $w$ imieniu $i$ dla dobra pacjenta ${ }^{176}$. Na płaszczyźnie poglądów społecznych zapoczątkowany został proces przewartościowań, który oddala społeczeństwo od akceptacji dominacji profesjonalisty i zmierza do zachowania równowagi w relacjach. Wydaje się, że można mówić o kształtowaniu się pewnego syndromu „wyzwalania pacjenta" ${ }^{\text {"177 }}$, w którym występują tendencje do zastępowania kategorii potrzeby przez kategorię popytu, a systemowego planowania - przez alokację opartą na indywidualnych wyborach ${ }^{178}$. Potwierdzeniem tożsamości indywidualnej, będzie więc zaprzestanie traktowania pacjenta jako jednostki chorobowej, a jako podmiotu relacji usługowej z własną unikatową tożsamością i określonymi potrzebami. I tu pojawia się miejsce dla idei marketingu relacji, który - w połączeniu z medycyną - pozwala na holistyczne spojrzenie na pacjenta; tym bardziej, że lekarze dentyści (badanie I) wysoko ocenili swoje umiejętności w zakresie nawiązywania dobrego kontaktu $\mathrm{z}$ pacjentem $\mathrm{w}$ trakcie pierwszej wizyty ${ }^{179}$. W pracy przyjęto, że marketing relacji w gabinetach stomatologicznych dotyczy wszelkich aktywności ukierunkowanych na pacjenta, podejmowanych przez personel gabinetu, zmierzających do ciągłego uaktualniania wiedzy o jego potrzebach dla stworzenia optymalnej usługi ( $\mathrm{w}$ wymiarze medycznym i pozamedycznym) w celu nawiązania partnerskich stosunków o trwałym charakterze ${ }^{180}$, które będą wynikiem wzajemnego zrozumienia i zaufania. Ponieważ tworzenie i utrzymywanie relacji z pacjentami jest kluczowe dla utrzymania się komercyjnego gabinetu stomatologicznego na rynku, to jego właściciel - najczęściej lekarz dentysta po-

\footnotetext{
176 Sytuacja daleko idącego podporządkowania pacjenta lekarzowi, ze względu na dobro tego pierwszego, jest określana przez socjologów jako relacja paternalistyczna, a przez ekonomistów jako relacja ustanowionego pełnomocnika.

177 Potwierdzeniem mogą być wyniki badania IV, z których wynika, że model paternalizmu w kontaktach z lekarzem jest oczekiwany przez ok. 55\% respondentów, a pozostali oczekują kooperacji w komunikacji (postawa taka jest bliższa pacjentom regularnie korzystającym z usług stomatologicznych).

178 Włodarczyk W.C., Reforma opieki zdrowotnej w Polsce, Studium polityki zdrowotnej, UWM Vesalius, Kraków 1998, s. 26.

${ }^{179}$ Nieco słabiej ocenili swoje umiejętności z zakresu komunikacji z pacjentami, natomiast najsłabiej - komunikacji ze współpracownikami. Przyszli lekarze dentyści ocenili swoje umiejętności z zakresu komunikacji dobrze (często wyżej niż praktycy zawodu).

${ }^{180}$ Relacje z klientami są przedmiotem zainteresowania nie tylko marketingu (por. np. WilmańskaSosnowska S., Lojalność klientów jako wyzwanie wspótczesnego marketingu, w: Gregor B. (red.), Marketing - handel - konsument w globalnym spoteczeństwie informacyjnym, Acta Universitatis Lodziensis nr 179, Folia Oeconomica, Łódź 2004), ale również rachunkowości (np. Jończak E., Problemy wyceny niebilansowego składnika aktywów niematerialnych - klientów, w: „Problemy wyceny w rachunkowości”, Prace Naukowe AE im. O.Langego we Wrocławiu, Wrocław 2001, nr 911), czy zarządzania (por. Blattberg R.C., Getz G., Thomas J.S., Customer Equity. Building and Managing Relationships as Valuable Assets, "Harvard Business School Press", Harvard 2001).
} 
winien dbać nie tylko o jakość usług, ale także o jakość obsługi, która - dzięki dostarczaniu pacjentowi dodatkowej wartości - będzie stawała się istotną determinantą pozycji konkurencyjnej podmiotu. Jeśli oferta gabinetu (tak w obszarze stricte medycznym, jak i pozamedycznym) ma być postrzegana, jako usługa wysokiej jakości, to powinna spełniać oczekiwania pacjentów. Z tego względu działania lekarza dentysty - zmierzające do zdobycia zaufania pacjentów (warunkującego nawiązanie trwałych relacji), powinny być ukierunkowane na spełnianie oczekiwań pacjentów w zakresie $\mathrm{m}$. in. przedstawionych

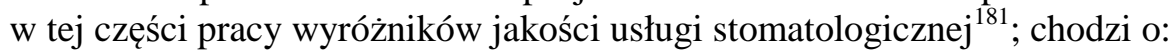

- rzetelność i dokładność usługodawcy,

- wiedzę i kwalifikacje personelu,

- zaufanie jakie wzbudza lekarz dentysta i poczucie bezpieczeństwa, jakie daje pacjentowi,

- uprzejmość personelu i jego szybkie reagowanie na potrzeby pacjenta,

- wyczerpującą informację o leczeniu.

Z przeprowadzonych badań wynika, że wskazania studentów kierunku lekarsko-dentystycznego co do oczekiwań pacjentów były bardziej do nich dopasowane, niż lekarzy dentystów, którzy najczęściej nadawali im mniejsze znaczenie.

Literatura z zakresu marketingu relacji eksponuje interdyscyplinarny charakter podejścia do działań rynkowych przedsiębiorstwa. Powoli zacierają się ostre i jednoznaczne granice między marketingiem, socjologią, psychologią i zarządzaniem kadrami (co w pewnym zakresie udało się pokazać w tym rozdziale). Również z punktu widzenia przedsiębiorstwa mniej istotne są podziały na różne

${ }^{181}$ Podobną listę w odniesieniu do usług zdrowotnych sformułował J.Frąś, który wskazał następujące wyróżniki jakości: 1) niezawodność (pacjenci oczekują usług, które będą charakteryzować się dokładnością, niezawodnością oraz zgodnością z ofertą placówki zdrowotnej, a personel będzie wykonywać swoje usługi rzetelnie i zgodnie z etyką), 2) wrażliwość (pacjenci chcą, aby pracownicy medyczni byli mili, przepełni empatią i gotowi do pomocy), 3) wygląd (pacjenci spodziewają się, że gabinet będzie wyglądać profesjonalnie, a wygląd pracowników będzie taki, że wzbudzi zaufanie), 4) dostępność (pacjenci chcą, aby usługi i personel placówki podmiotu opieki zdrowotnej były dostępne dla nich w czasie i miejscu, w których ich potrzebują), 5) kompetencja (pacjent wymaga profesjonalizmu, chce, aby pracownicy medyczni obsługujący go, posiadali fachową wiedzę), 6) uprzejmość (pacjenci oczekują, że personel będzie w stosunku do nich przyjazny i będzie traktować ich z szacunkiem), 7) przejrzystość (oczekiwanie jasnej i zwięzłej komunikacji pomiędzy pacjentem a personelem medycznym), 8) komunikatywność (pacjent oczekuje od personelu umiejętności skutecznego komunikowania się), 9) odpowiedzialność (związana z przestrzeganiem terminów przez personel medyczny), 10) bezpieczeństwo (zarówno fizyczne, jak i psychiczne).

Por. Frąś J., Zarzqdzanie jakościq ustug w opiece zdrowotnej, w: Rudawska I., Urbańczyk E., Ekonomiczno-organizacyjne ... op. cit., s. 91 i nast. 
dyscypliny, a bardziej - kompleksowe rozwiązanie danego problemu ${ }^{182}$. $\mathrm{Z}$ tego względu można oczekiwać, że w najbliższej przyszłości lekarze dentyści - chcący rozwiązywać - rynkowe problemy swoich gabinetów, zaczną częściej, niż dotychczas, sięgać po - szeroko pojęte - rozwiązania ekonomiczne (w tym marketingowe ${ }^{183}$ ). Zgodnie $\mathrm{z}$ tezą sformułowaną przez K. Rogozińskiego to „spotkanie” medycyny z marketingiem może być bardzo owocne „z powodu bilateralnych korzyści, które pozwalają uchronić medycynę przed zupełnym odhumanizowaniem, a więc szansą zachowania takiego jej statusu, który zgodnie z tradycją określało się jako ars medica. Korzyść drugiego rodzaju wynika stąd, że współczesna praktyka medyczna jest w pewnym sensie skazana na stosowanie marketingu, i to nie tylko dlatego, że w gospodarce rynkowej może on zapewnić 'zasilenie' gabinetu pacjentami (a więc to, że w ogóle jest komu świadczyć usługi). Ważniejsze wydaje się to, że wykonywanie samych usług medycznych, nawet $\mathrm{w}$ największej zgodzie $\mathrm{z}$ tradycją wypracowaną przez zawody medyczne, dziś już nie wystarcza. Marketingowi usług zawdzięczamy co najmniej to, że wypracował sposób przekształcania tradycyjnie rozumianej i wykonywanej usługi w 'produkt', otwierając tym samym nową perspektywę interpretacyjną dla wyjaśnienia, czym naprawdę jest ta działalność usługowa i jaką rolę do odegrania ma w niej pacjent." ${ }^{184}$ Uzasadnienie takiego stanowiska (szczególnie w odniesieniu do komercyjnych gabinetów stomatologicznych) można znaleźć również w podejściu proponowanym przez business economics. Jeden z przedstawicieli tego nurtu - P.F. Drucker stwierdził: „Jeżeli chcemy wiedzieć czym jest biznes, musimy zacząć od sprawy jego celu. Cel zaś musi leżeć poza obrębem samego biznesu. Musi on leżeć w samym społeczeństwie, skoro przedsiębiorstwo jest organem społeczeństwa. Jedyna poprawna definicja celu biznesu brzmi: tworzenie klienteli. (...) to klient decyduje, czym jest biznes. Bo to klient i tylko on, będąc gotów zapłacić odpowiednią cenę za towar czy usługę, przekształca zasoby ekonomiczne w bogactwo, rzeczy w towary. Nie to jest najważniejsze, co myśli o swojej produkcji biznesmen, a szczególnie nie ma znaczenia dla jego przyszłości i sukcesu. Decyduje to, co myśli o swoim zakupie klient." ${ }^{185} \mathrm{Z}$ powyższych względów uzasadnionym staje się rekomendowanie, by lekarz dentysta, który będzie dążył do osiągania dobrych wyników swojego gabinetu (i nie chodzi tu o maksymalizację zysku, tylko o „wymóg skutecznego przetrwania"), postrzegał możliwości jakie daje marketing relacji w kategorii użytecznego rozwiązania.

\footnotetext{
${ }^{182}$ Fonfara K., Przedmowa do ... op. cit., s. 23 i nast.

${ }^{183}$ Patrząc na wyniki badania III, można stwierdzić, że studenci kierunku lekarsko-dentystycznego z jednej strony wymagają wsparcia $\mathrm{z}$ zakresu wiedzy o istocie marketingu, by rozpoznawać oczekiwania pacjentów (por. wykres 7), a z drugiej są otwarci na wprowadzanie marketingowych rozwiązań (por. tabela 71).

${ }^{184}$ Dobska M., Rogoziński K. (red.), Podstawy zarzadzania ... op. cit., s. 212.

${ }^{185}$ Drucker P.F., Praktyka zarzadzania ..., op. cit.
} 


\title{
ROZDZIAŁ V \\ POSTAWA DENTYSTY A DZIAŁANIA Z ZAKRESU MARKETINGU RELACJI W ŚWIETLE BADAŃ
}

\author{
„Działalności ustugowej nie znamionuje \\ ani intensywne wykorzystanie kapitatu, \\ ani nawet intensywne wykorzystanie personelu, \\ lecz zaangażowanie osobowości pracowników \\ zatrudnionych $w$ świadczeniu ustug." \\ R. Normann ${ }^{1}$
}

\section{OPIS BADANIA}

Badanie II zostało przeprowadzone w okresie listopad 2011 - luty 2012 r. Zostało podjęte, aby możliwa była weryfikacja hipotezy mówiącej o tym, iż lekarze dentyści o sylwetce przywódcy transformacyjnego działają bardziej rynkowo $^{2}$, niż ci - o sylwetce przywódcy transakcyjnego, czy mieszanym (tj. transakcyjno-transformacyjnym) lub leseferystycznym stylu przywództwa. Tak przyjęta hipoteza badawcza (niezgodna $\mathrm{z}$ opinią panującą w literaturze, że najlepszymi przywódcami są ci, którzy prezentują zarówno transformacyjne, jak i transakcyjne przywództwo ${ }^{3}$ ) była wynikiem dwudziestu kilku wywiadów przeprowadzonych przez autorkę ${ }^{4}$.

Podstawowym celem badania było określenie postaw przedsiębiorczych stomatologów w kontekście zróżnicowania respondentów ze względu na prezentowany przez nich styl przywództwa. Cele szczegółowe obejmowały znalezienie odpowiedzi na pytania:

- jakie były motywy wyboru zawodu przez respondentów?,

- jakie działania podejmowałby dentysta wobec konkurencji rynkowej?,

- jakie są priorytety w pracy dentysty?,

- jak dentyści oceniają swoje umiejętności interpersonalne i intrapersonalne?,

- jakie czynniki konkurencyjności dostrzegają respondenci we współczesnym gabinecie i gabinecie jutra?,

\footnotetext{
${ }^{1}$ Normann R., Service Management, Strategy and Leadership In Service Business, J.Wiley\&Sons, 1991, s. 17.

${ }^{2}$ Orientacja rynkowa występuje tutaj jako filozofia działania lekarza dentysty w gabinecie, jako podmiocie zarobkowym, ułatwiająca wprowadzenie reguł marketingu relacji.

${ }^{3}$ Bass B.M., Leadership and Performance Beyond Expectations, Free Press, Nowy Jork 1985.

${ }^{4}$ Miały one miejsce w dniach 14-16 kwietnia 2011 r. podczas Zjazdu Szkoleniowego „Nowości Stomatologii Praktycznej” Dentexpo w Warszawie.
} 
- jakie wyzwania stoją przed współczesnym gabinetem stomatologicznym?,

- jak respondenci oceniają swoją postawę w zarządzaniu gabinetem?,

- jak respondenci oceniają swoją postawę w kierowaniu personelem?,

- jak respondenci oceniają swoją postawę w kontaktach z pacjentami?,

- jakie są oczekiwania respondentów w stosunku do uczelni medycznych w zakresie przekazywania wiedzy na temat funkcjonowania prywatnych gabinetów stomatologicznych na rynku?.

Szerokie spektrum pytań szczegółowych miało na celu dokładne zbadanie analizowanego zjawiska. I stworzenie $\mathrm{w}$ miarę kompleksowego wizerunku stomatologa - przedsiębiorcy otwartego na pozamedyczne obszary funkcjonowania gabinetu i podejmującego proklientowskie działania.

$\mathrm{W}$ badaniu $-\mathrm{z}$ wykorzystaniem autorskiej ankiety umieszczonej na portalu e-ankiety.pl - wzięło udział 210 dentystów z całej Polski. Wybór próby był celowy: zaproszenie do wypełnienia ankiety było skierowane do lekarzy dentystów współpracujących $\mathrm{w}$ gabinecie $\mathrm{z}$ innymi osobami; zdeterminowany dostępnością bazy mailingowej podmiotu przeprowadzającego badanie.

Do stworzenia profili sylwetek lekarzy dentystów - osób odpowiedzialnych za funkcjonowanie gabinetu, jako podmiotu zarobkującego, wykorzystano teorię przywództwa ${ }^{5}$ transformacyjno-transakcyjnego, zapoczątkowaną w latach 70 . XX w. przez J.M. Burnsa ${ }^{6}$. Z perspektywy teorii zarządzania istotne wydaje się spojrzenie na tę teorię B.M. Bassa, który podważył założenie, iż transakcyjność (Sylwetka B w pracy) i transformacyjność (Sylwetka A w pracy) są skrajnymi

\footnotetext{
${ }^{5}$ Inne teorie przywództwa , które mogą znaleźć zastosowanie w opiece zdrowotnej przedstawione są m.in. w: Frączkiewicz-Wronka A., Austen-Tynda A., Przywództwo ... op. cit., s. 17 i nast.; Mruk H., Przywództwo w zaktadach opieki zdrowotnej, ABC a Wolters Kluwer business, Warszawa 2010, s. 37 i nast.

${ }^{6}$ Do wyjaśnienia istoty teorii konieczne jest scharakteryzowanie dwóch - skrajnych zdaniem J.M. Burnsa - form przywództwa: 1) transakcyjnego, które można potraktować jako psychologiczną podstawę efektywnego wypełniania roli menedżera (administratora). Przywództwo transakcyjne koncentruje się na relacjach wymiany pomiędzy liderami a ich zwolennikami lub podwładnymi. Poprzez ten proces liderzy odwołują się do indywidualnych oczekiwań ich podwładnych w celu motywowania ich do wypełniania podstawowych zadań. 2) transformacyjnego, będącego partycypacyjnym procesem, poprzez który liderzy i ich zwolennicy koordynują wspólne wysiłki w celu osiągnięcia wyższego poziomu celów prowadzących do gruntownej zmiany. Lider transformacyjny odwołuje się do idei i moralności swych zwolenników, aby zainspirować ich do najwyższego stopnia zaangażowania i przyjęcia celów grupy jako swoich własnych. W tym sensie transformacyjny profil działania pobudza raczej wewnętrzne niż zewnętrzne motywy działań ludzi. Podstawowe oddziaływania lidera transformacyjnego opierają się na zapewnieniu wizji i inspiracji oraz kwestionowaniu status quo. Por. Burns J.M., Leadership ... op. cit.
} 
wartościami pojedynczego continuum ${ }^{7}$. Przyjął, że obie te formy stanowią odrębne koncepcje i mogą w praktyce zachowań menedżerskich współistnieć ${ }^{8}$. Takie czynniki jak: charyzma, rozwaga, intelektualna stymulacja pojawiły się jako główne składniki zachowania transformacyjnego. Podczas gdy nagrody warunkowe i zarządzanie przez wyjątki były głównymi składnikami przywództwa transakcyjnego 9 . Ponadto wprowadził wymiar przywództwa leseferystycznego ${ }^{10}$ na opisanie sytuacji, gdy przełożony zrzeka się odpowiedzialności za podejmowane decyzje (W. Ratyński ujmuje to tak: przełożony jest ,niezdolny do sprawowania konkretnej władzy i kontroli nad swoimi podwładnymi ani do koordynowania ich działań" ${ }^{11}$ ). Ważnym zagadnieniem rozwijającym zaproponowane przez B.M. Bassa podejście jest tzw. efekt augmentacji (augmentation effect), zgodnie z którym efekty uzyskiwane z przywództwa transakcyjnego będą się zwiększały w przypadku wystąpienia również przywództwa transformacyjnego. Efekt ten uzasadniał twierdzenie, że najlepszymi liderami są ci, którzy prezentują zarówno transformacyjne, jak i transakcyjne przywództwo (Sylwetka C w pracy).

W pierwszym kroku badania respondenci wybierali spośród zestawu różnych cech i postaw charakterystyki najlepiej ich opisujące, co pozwoliło na późniejsze przypisanie ich do jednego z czterech typów przywództwa: transakcyjnego, transformacyjnego, stylu będącego połączeniem obu wymienionych (przywództwa transformacyjno-transakcyjnego) oraz przywództwa leseferystycznego (por. tabela 75). Ponieważ wskazania dwóch osób pozwoliły na zakwalifikowanie ich jako Sylwetki D (charakterystycznej dla przywództwa leseferystycznego), to ten rodzaj sylwetki nie stał się przedmiotem badania (do analizy wykorzystano 208 ankiet $^{12}$ ). Określone $\mathrm{w}$ toku postępowania przygotowawczego typy sylwetek, stały się kryterium różnicującym w analizie wyników otrzymanych z dalszej części ankiety.

\footnotetext{
${ }^{7}$ Obie powyższe formy przywództwa mają swoje odpowiednik na gruncie teorii zarządzania, gdzie przywództwo transakcyjne można utożsamiać z archetypem menedżerskim, a przywództwo transformacyjne $\mathrm{z}$ archetypem lidera. Por. Belz G., Triumwirat ról wobec pytań o ewolucję modeli przywództwa, ,Zeszyty Naukowe UE w Poznaniu” nr 187, Poznań 2011, s. 10.

W pracy przyjęto, że różne formy przywództwa można przypisać do odmiennych sylwetek przedsiębiorcy prezentowanych w literaturze przedmiotu.

${ }^{8}$ Por. Bass B.M., Leadership ... op. cit., s. 21; Judge T., Piccolo R., Transformational and Transactional Leadership: A Meta-Analytic Test of Their Relative Validity, "Journal of Applied Psychology", 2004 nr 5, s. 755 za: Belz G., Triumwirat ... op. cit., s. 10.

${ }^{9}$ Bass B.M., Leadership ... op. cit., s. 128 i nast.

${ }^{10}$ Por. Northouse P.G., Leadership. Theory and Practice, Thousand Oaks, Londyn 2004.

${ }^{11}$ Ratyński W., Menedżerskie i organizatorskie metody zarzadzania, KODEKS sp. z o.o., Warszawa 2002

${ }^{12}$ Wśród respondentów dominowały kobiety $-78,2 \%$.
} 
Tabela 75. Typologia sylwetek związana ze stylem przywództwa respondentów badania II

\begin{tabular}{|l|c|}
\hline \multicolumn{1}{|c|}{ Typ sylwetki } & Wskazania (\%) \\
\hline $\begin{array}{l}\text { Osoba o transformacyjnym stylu przywództwa - w pracy określana mianem } \\
\text { „Sylwetka A” }\end{array}$ & 19,05 \\
\hline $\begin{array}{l}\text { Osoba o transakcyjnym stylu przywództwa - w pracy określana mianem } \\
\text { „Sylwetka B” }\end{array}$ & 28,57 \\
\hline $\begin{array}{l}\text { Osoba o mieszanym (transformacyjno-transakcyjnym) stylu przywództwa - } \\
\text { w pracy określana mianem ,Sylwetka C” }\end{array}$ & 51,43 \\
\hline Osoba o leseferystycznym stylu przywództwa - ,Sylwetka D” & 0,95 \\
\hline
\end{tabular}

Zródło: opracowanie własne na podstawie przeprowadzonego badania.

W rozdziale II pokazano, że lekarz dentysta może pełnić w gabinecie role biznesowe o różnym charakterze i w odmienny sposób (np. zachowując się w sposób mniej lub bardziej administracyjny, podejmując działania innowacyjne lub imitując zachowania innych, dając podwładnym przykład własnym zachowaniem lub nakazując określone działania itp.). Można również podjąć próbę przypisania odpowiedników stylów ze zmodyfikowanej teorii przywództwa transakcyjno-transformacyjnego wybranym postawom przedsiębiorczym prezentowanym na gruncie nauk o przedsiębiorczości ${ }^{13}$. I tak:

- styl transformacyjny - można odnieść do przedsiębiorcy inspiratora i inicjatora zmian (człowiek czujny Kirznera, czy innowator Schumpetera) - Sylwetka A,

- styl transakcyjny - można odnaleźć w przedsiębiorcy, jako osobie podejmującej decyzje (koordynator Walrasa i decydent Druckera) - Sylwetka B,

- styl mieszany - charakteryzuje przedsiębiorcę, jako osobę organizującą zasoby (organizator Say'a i człowiek podejmujący umiarkowane ryzyko McClellanda) - Sylwetka C.

Przyjęta typologia sylwetek respondentów badania II, pozwoli na prezentację otrzymanych wyników i wskazanie różnic w podejmowanych przez lekarzy dentystów działaniach rynkowych.

\footnotetext{
${ }^{13}$ Autorka dostrzega analogie w określonych działaniach przedsiębiorczych i stylach przywództwa, stąd wykorzystanie w pracy teorii zapoczątkowanej przez J.M. Burnusa. Jednak biorąc pod uwagę niewielki poziom zatrudnienia $\mathrm{w}$ gabinetach stomatologicznych (większość podmiotów to mikroprzedsiębiorstwa, z bardzo często występującym samozatrudnieniem bez zatrudniania personelu), ma świadomość konieczności zachowania ostrożności przy formułowaniu wniosków w odniesieniu do teorii przywództwa, choć w literaturze przedmiotu teoria przywództwa jest prezentowana na gruncie podmiotów ochrony zdrowia (por. A. Frączkiewicz-Wronka, A. Austen, H. Mruk). Z drugiej strony ze względu na zmiany w strukturze zatrudnienia (np. rosnąca liczba osób na stanowiskach niemedycznych w gabinetach stomatologicznych) w sektorze, nie można wykluczyć, że w ciągu kilku lat mówienie o przywództwie w usługach stomatologicznych będzie, jak najbardziej uzasadnione i uprawomocnione sytuacją rynkową.
} 


\section{CHARAKTERYSTYKA GRUPY BADAWCZEJ}

Biorąc pod uwagę sposób wykonywania zawodu - samozatrudnienie czy wykonywanie zawodu jako pracownik, to wśród badanych dominowały osoby pracujące na własny rachunek, a 1 na 10 badanych był zatrudniony przez kogoś ${ }^{14}$. Uwzględniając przyjętą typologię sylwetek dokonano klasyfikacji badanych z punktu widzenia sposobu wykonywania zawodu (por. tabela 76). Największy odsetek stomatologów o Sylwetce A był w grupie osób zatrudnionych, o Sylwetce B - wśród właścicieli gabinetów, a o Sylwetce C w grupie osób, które wynajmują od kogoś gabinet do prowadzenia działalności (jednak była to najmniej liczna grupa z punktu widzenia statusu zawodowego). Nie można potwierdzić, by różnice te były istotne statystycznie.

Tabela 76. Typ sylwetki a pozycja zawodowa respondenta (badanie II)

\begin{tabular}{|c|c|c|c|c|}
\hline \multirow{2}{*}{ Pozycja zawodowa respondenta } & \multirow{2}{*}{$\begin{array}{c}\text { Struktura } \\
\text { badanej grupy }\end{array}$} & \multicolumn{3}{|c|}{$\begin{array}{c}\text { Odsetek osób prezentujących określony } \\
\text { styl przywództwa }\end{array}$} \\
\hline & & Sylwetka A & Sylwetka B & Sylwetka C \\
\hline właściciel gabinetu & 67,9 & 19,0 & 32,0 & 49,0 \\
\hline współwłaściciel gabinetu & 16,7 & 20,0 & 25,7 & 54,3 \\
\hline pracownik gabinetu & 10,5 & 22,7 & 22,7 & 54,6 \\
\hline $\begin{array}{l}\text { podnajmuje od kogoś gabinet i } \\
\text { prowadzi działalność na własny } \\
\text { rachunek }\end{array}$ & 4,9 & 20,0 & 10,0 & 70,0 \\
\hline
\end{tabular}

Zródło: opracowanie własne na podstawie przeprowadzonego badania.

Biorąc pod uwagę czas, jaki upłynął od ukończenia przez respondentów studiów (por. tabela 77), to w badaniu dominowali dentyści, którzy ukończyli studia więcej niż 16 lat temu, a więc tacy, którzy dysponują już relatywnie długim czasem funkcjonowania na rynku (i - prawdopodobnie - znajomością reguł nim rządzących). Czas, jaki upłynął od ukończenia studiów nie miał wpływu na prezentowany przez respondentów typ przywództwa.

Tabela 77. Czas ukończenia studiów a typ sylwetki dentysty (badanie II)

\begin{tabular}{|l|c|c|c|c|}
\hline \multirow{2}{*}{$\begin{array}{c}\text { Respondenci ukończyli } \\
\text { studia }\end{array}$} & \multirow{2}{*}{$\begin{array}{c}\text { Struktura } \\
\text { badanej } \\
\end{array}$} & \multicolumn{3}{|c|}{ Odsetek osób prezentujących określony styl } \\
& grupy & Sylwetka A & Sylwetka B & Sylwetka C \\
\cline { 3 - 5 } & 8,2 & 20,0 & 26,7 & 53,3 \\
\hline mniej niż 5 lat temu & 38,9 & 21,0 & 30,9 & 48,1 \\
\hline 5-15 lat temu & 52,9 & 18,2 & 28,2 & 53,6 \\
\hline więcej niż 16 lat temu & &
\end{tabular}

Źródło: opracowanie własne na podstawie przeprowadzonego badania.

\footnotetext{
${ }^{14}$ Ponieważ ta grupa jest zbyt mała (22 osoby), aby mogła stanowić osobną kategorię analityczną (podobnie, jak grupa osób podnajmujących gabinet i pracujących na własny rachunek - 10 osób), to analiza wyników badania II nie będzie prowadzona z punktu widzenia własności gabinetu. Jedynym kryterium różnicującym będzie przyjęta typologia sylwetek.
} 
Kolejną kwestią, będącą przedmiotem badania, był aspekt wpływu uwarunkowań rodzinnych na wybór zawodu. Wśród badanych $-23,81 \%{ }^{15}$ wskazało, że ktoś $\mathrm{w}$ rodzinie był $\mathrm{z}$ wykształcenia stomatologiem, natomiast pozostałe $76,19 \%$ wskazało, że w ich rodzinach nie ma osób związanych ze stomatologią (por. tabela 78).

Tabela 78. Zawód lekarza dentysty w rodzinie respondenta a analizowane typy sylwetek

\begin{tabular}{|l|c|c|c|c|}
\hline \multirow{2}{*}{ Rodzic/ce (opiekunowie) respondentów } & \multirow{2}{*}{$\begin{array}{c}\text { Struktura } \\
\text { badanej } \\
\text { grupy }\end{array}$} & \multicolumn{3}{|c|}{$\begin{array}{c}\text { Odsetek osób prezentujących określony } \\
\text { styl przywództwa }\end{array}$} \\
\cline { 3 - 5 } & Sylwetka A & Sylwetka B & Sylwetka C \\
\hline jest/są stomatologami i pracuja//pracowali & 13,6 & 3,6 & 25,0 & 71,4 \\
w zawodzie & & & 6,0 & 33,3 \\
\hline $\begin{array}{l}\text { jest/są stomatologami, ale nie pracują w } \\
\text { zawodzie (zajmują się zawodowo czym } \\
\text { innym) }\end{array}$ & 1,5 & & & 25,0 \\
\hline $\begin{array}{l}\text { nie są stomatologami, ale to było marze- } \\
\text { niem matki/ojca }\end{array}$ & 7,8 & 25,0 & 50,0 \\
\hline $\begin{array}{l}\text { nie są stomatologami i nie pracują w } \\
\text {,branży” medycznej }\end{array}$ & 66,9 & 21,0 & 28,3 & 50,7 \\
\hline $\begin{array}{l}\text { rodzice nie, ale w najbliższej rodzinie } \\
\text { mam osoby pracujące jako dentyści }\end{array}$ & 10,2 & 28,6 & 38,1 & 33,3 \\
\hline
\end{tabular}

Źródło: opracowanie własne na podstawie przeprowadzonego badania.

Powód - „tradycja rodzinna” był najrzadziej wskazywany, jako motyw wyboru zawodu przez respondentów - 11,05\% wskazań (por. tabela 79).

Tabela 79. Motywy wyboru zawodu (badanie II)

\begin{tabular}{|c|c|c|c|c|c|c|c|c|}
\hline \multirow[b]{2}{*}{ Jestem stomatologiem, ponieważ ... } & \multicolumn{5}{|c|}{$\begin{array}{c}\text { Wskazania respondentów } \\
\text { (procent wskazań) }\end{array}$} & \multirow[b]{2}{*}{$\bar{x}$} & \multirow[b]{2}{*}{ Do } & \multirow[b]{2}{*}{ Me } \\
\hline & \begin{tabular}{|c} 
na \\
pewno \\
nie \\
$(1)$
\end{tabular} & $\begin{array}{c}\text { raczej } \\
\text { nie } \\
(2) \\
\end{array}$ & $\begin{array}{c}\text { trudno } \\
\text { powie } \\
\text {-dzieć } \\
(3)\end{array}$ & $\begin{array}{c}\text { raczej } \\
\text { tak } \\
(4) \\
\end{array}$ & $\begin{array}{c}\text { na } \\
\text { pewno } \\
\text { tak } \\
(5) \\
\end{array}$ & & & \\
\hline chciałem pomagać ludziom & 12,02 & 7,69 & 23,56 & 34,62 & 22,12 & 3,47 & 4 & 4 \\
\hline było to moim marzeniem & 13,88 & 7,66 & 24,88 & 27,75 & 25,84 & 3,44 & 4 & 4 \\
\hline $\begin{array}{l}\text { w tym zawodzie widziałam/em } \\
\text { szansę na godne zarobki w prywat- } \\
\text { nym gabinecie }\end{array}$ & 21,74 & 21,74 & 20,77 & 24,64 & 11,11 & 2,82 & 4 & 3 \\
\hline $\begin{array}{l}\text { "tak wyszło" (np. respondent nie } \\
\text { został przyjęty na kierunek lekarski) }\end{array}$ & 58,65 & 10,10 & 8,17 & 12,98 & 10,10 & 2,06 & 1 & 1 \\
\hline to rodzinna tradycja & 80,77 & 4,81 & 3,37 & 2,88 & 8,17 & 1,53 & 1 & 1 \\
\hline
\end{tabular}

Źródło: opracowanie własne na podstawie przeprowadzonego badania.

Podstawowym motywem wyboru zawodu przez respondentów była chęć pomagania innym - 56,74\% wskazań (na pewno tak lub raczej tak) lub

\footnotetext{
${ }^{15}$ Jest to odsetek nieco niższy niż uzyskany w badaniu III - $28 \%$.
} 
realizacja marzeń - 53,59\% wskazań pozytywnych. Względy ekonomiczne spolaryzowały grupę badawczą - $35,7 \%$ badanych zadeklarowało, że był to ważny lub bardzo ważny powód wyboru zawodu, a 43,48\% stwierdziło, że nie kierowało się (lub raczej nie) takimi pobudkami. Przeszło $1 / 5$ badanych wykonuje zawód niejako przez przypadek (dominują Sylwetki B i C). Zróżnicowanie $\mathrm{w}$ motywacji wyboru zawodu różnych typów sylwetek przedstawia wykres 10. Respondenci o Sylwetce B mieli w rodzinie największy odsetek osób pracujących, jako stomatolodzy i ta grupa wskazała, że podstawowym motywem zostania stomatologiem była chęć pomagania ludziom (por. wykres 9), a powód ,zawód dentysty, to szansa na zarobienie dobrych pieniędzy w prywatnym gabinecie" był dla nich najmniej ważny w porównaniu z Sylwetką A i C.

Wykres 10. Średnia wskazań motywu wyboru zawodu a typ sylwetki respondenta (badanie II)

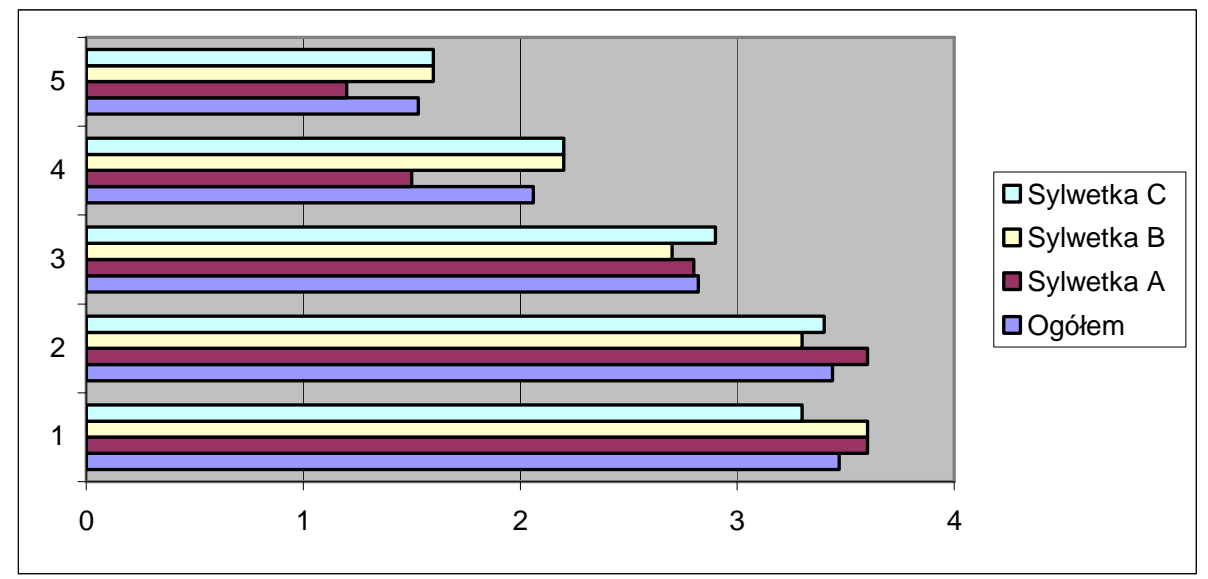

Źródło: opracowanie własne na podstawie przeprowadzonego badania.

Motyw wyboru zawodu: 1) chęć pomocy innym, 2) realizacja marzeń, 3) oczekiwanie godziwych zarobków w prywatnym gabinecie, 4) przypadek, 5) tradycja rodzinna.

Osoby o Sylwetce A zostały stomatologami, aby pomagać innym, ponadto był to wyraz realizacji ich marzeń (co potwierdzają wskazania, że najrzadziej w porównaniu z Sylwetką B i C zostawały lekarzami dentystami ,z przypadku” i z powodu „tradycji rodzinnych"). Z tego względu można postawić tezę o możliwym największym zaangażowania tej grupy w wykonywanie zawodu.

Najmniejszy odsetek osób o sylwetce $\mathrm{C}$ wskazywał motyw pomocy innym, jako powód wykonywania zawodu. $\mathrm{Z}$ drugiej strony osoby te najmocniej (w porównaniu z Sylwetką A i B) zaakcentowały względy ekonomiczne i w tej grupie doszło do największego zbliżenia odsetka osób deklarujących względy humanistyczne i ekonomiczne wyboru zawodu. 
Dla respondentów priorytetem w wykonywanej pracy jest wyleczenie pacjenta (por. tabela 80), choć dla respondentów o Sylwetce C nieco ważniejszy okazał się rozwój własnych kwalifikacji medycznych. Uwzględniając przyjęte profile sylwetek respondentów, należy zauważyć, że ranking pierwszych 5 priorytetów dla Sylwetki A (satysfakcja pacjentów i dobra atmosfera pracy okazały się ważniejsze, niż rozwój własnych kwalifikacji medycznych oraz utrzymanie grupy lojalnych pacjentów ważniejsze niż kwestia uzyskiwanych dochodów ${ }^{16}$ ) i dla Sylwetki B (budowa wizerunku gabinetu w otoczeniu ważniejsza niż dobra atmosfera pracy) jest odmienny, niż ranking dla całej badanej próby.

Tabela 80. Ranking priorytetów w pracy dentysty a sylwetka respondenta

\begin{tabular}{|l|c|c|c|c|}
\hline \multirow{2}{*}{ Ranking priorytetów dentysty w pracy } & \multicolumn{5}{|c|}{$\begin{array}{c}\text { Wsazania respondentów } \\
\text { (procent }\end{array}$} \\
\cline { 2 - 5 } & Ogsḱłem & Sylwetka A & Sylwetka B & Sylwetka C \\
\hline wyleczenie pacjenta & 52,86 & 52,5 & 53,3 & 52,8 \\
\hline rozwój własnych kwalifikacji medycznych & 50,00 & 37,50 & 50,00 & 53,8 \\
\hline satysfakcja pacjenta & 46,67 & 47,50 & 45,0 & 48,1 \\
\hline dobra atmosfera pracy & 30,00 & 42,50 & 16,7 & 32,1 \\
\hline dochody pozwajające na godne życie & 26,67 & 15,0 & 38,3 & 25,5 \\
\hline budowa/poprawa wizerunku gabinetu & 23,33 & 25,00 & 25,0 & 21,7 \\
\hline $\begin{array}{l}\text { utrzymywanie określonej grupy lojalnych } \\
\text { pacjentów }\end{array}$ & 19,52 & 32,50 & 20,0 & 14,2 \\
\hline pozyskiwanie nowych pacjentów & 17,62 & 15,00 & 20,0 & 17,0 \\
\hline wzrost rentowności gabinetu & 14,29 & 15,00 & 10,0 & 16,0 \\
\hline wprowadzanie nowych usług & 10,95 & 12,50 & 10,0 & 11,3 \\
\hline inne ${ }^{17}$ & 0,95 & 0,0 & 0,0 & 0,9 \\
\hline
\end{tabular}

Zródło: opracowanie własne na podstawie przeprowadzonego badania.

* Odpowiedzi nie sumują się do $100 \%$, ponieważ respondenci mogli zaznaczyć do 3 odpowiedzi.

Konkludując, dentysta o Sylwetce A jest zorientowany na pacjenta (jego wyleczenie i satysfakcję) oraz dobrą atmosferę pracy. Dentysta o Sylwetce B i C jest zoriantowany na pacjenta (jego wyleczenie oraz satysfakcję) oraz rozwój własnych kwalifikacji medycznych.

Otrzymane wyniki pokazują, że cele podejmowanej działalności zależą od indywidualnych preferencji i zachowań ludzi, którzy są decydentami (tu: lekarze dentyści) w przedsiębiorstwie (tu: gabinecie stomatologicznym). Pozwala to na podważenie teorii neoklasycznej funkcjonowania przedsiębiorstw - w myśl której interesy ludzi zatrudnionych w przedsiębiorstwie, stosunki międzyludzkie

\footnotetext{
${ }^{16}$ Co w długiej perspektywie - przy odpowiedniej polityce cenowej - nie wyklucza realizacji celu: osiągnięcie dochodów pozwalających na godne życie.

${ }^{17}$ Dwie osoby wskazały odpowiedź: inne, jako jej rozwinięcie napisały, że chodzi im o otrzymywanie gabinetu na najwyższym możliwym poziomie i stały rozwój, a także objęcie planową opieką pacjentów korzystających z usług stomatologa.
} 
i interesy grupowe nie mają wpływu na zachowanie i sposób określania oraz realizację celów - w kontekście funkcjonowania gabinetu. I daje asumpt do podkreślenia, że spojrzenie na funkcjonowanie podmiotów świadczących usługi stomatologiczne wymaga nie tylko wielopłaszczyznowego, ale również interdyscyplinarnego podejścia (co zostało zaznaczone we wstępie pracy).

\section{ZACHOWANIA RYNKOWE RESPONDENTÓW}

Przedmiotem analizy wyników badania II była znajomość najbliższego otoczenia rynkowego gabinetu przez lekarzy dentystów. Na pytanie: „Czy w sąsiedztwie gabinetu, w którym respondent pracuje znajduje się jakiś inny gabinet?" tylko 2,83\% badanych odpowiedziało, że nie ma innych gabinetów (tak więc niewielki odsetek badanych ma uprzywilejowaną - niemal monopolistyczną pozycję rynkową). Żadna z badanych osób nie odpowiedziała na to pytanie „,nie wiem", co może świadczyć o tym, że lekarze dentyści zwracają uwagę na otoczenie, w którym działają. Można postawić pytanie: czy reagują na zmiany, jakie w otoczeniu zachodzą? (o tym w dalszej części). Kolejne 7,14\% badanych stwierdziło, że w pobliżu ich gabinetu jest jeden gabinet, a ok. $90 \%$ - że kilka. Tak więc badani znają najbliższe otoczenie rynkowe gabinetu na tyle, by dostrzec istnienie innych podmiotów, które mogą stanowić dla nich konkurencję.

Aby sprawdzić, jakie działania w swoim gabinecie podejmowałby respondent w różnych sytuacjach rynkowych, badanym zostały postawione dwa pytania:

- „Jakie działania $w$ swoim gabinecie podjałby dentysta, otwierajac nowy gabinet w poblizu już istniejącego gabinetu?",

- „Co zrobi stomatolog, gdy w pobliżu gabinetu, w którym pracuje, wtaśnie otwiera się nowy gabinet?".

Odpowiedzi na te pytania - z uwzględnieniem zróżnicowania ze względu na przyjętą typologię sylwetek - przedstawione są w tabelach 81 i 82.

Tabela 81. Ranking działań podejmowanych przez respondentów badania II a otwieranie gabinetu obok już istniejącego

\begin{tabular}{|l|c|c|c|c|}
\hline \multirow{2}{*}{$\begin{array}{l}\text { Działania podejmowane w sytuacji, gdy w } \\
\text { pobliżu działa gabinet stomatologiczny }\end{array}$} & \multicolumn{4}{|c|}{$\begin{array}{c}\text { Wskazania respondentów* } \\
\text { (procent wskazań) }\end{array}$} \\
\cline { 2 - 5 } & Ogółem & Sylwetka A & Sylwetka B & Sylwetka C \\
\hline wprowadzenie szerszego wachlarza usług & 57,62 & 65,0 & 56,7 & 55,7 \\
\hline $\begin{array}{l}\text { świadczenie tych samych usług, co } \\
\text { konkurencja }\end{array}$ & 38,10 & 30,0 & 41,7 & 39,6 \\
\hline podjęcie decyzji o specjalizacji oferty & 34,76 & 45,0 & 25,0 & 37,7 \\
\hline $\begin{array}{l}\text { prowadzenie intensywnej promocji na } \\
\text { danym terenie }\end{array}$ & 31,43 & 35,0 & 25,0 & 33,0 \\
\hline $\begin{array}{l}\text { decyzja o obsłudze ,innych pacjentów”, niż } \\
\text { w istniejącym gabinecie (np. gabinet dla dzieci) }\end{array}$ & 29,52 & 27,5 & 31,7 & 30,2 \\
\hline
\end{tabular}




\begin{tabular}{|l|c|c|c|c|}
\hline $\begin{array}{l}\text { gabinet pracowałby w innych godzinach, } \\
\text { niż konkurencyjny gabinet }\end{array}$ & 20,95 & 17,5 & 20,0 & 21,7 \\
\hline $\begin{array}{l}\text { zastosowanie dokładnie takich sam cen, jak } \\
\text { w sąsiednim gabinecie }\end{array}$ & 17,62 & 5,0 & 18,3 & 21,7 \\
\hline $\begin{array}{l}\text { zastosowanie niższych cen, niż w gabinecie } \\
\text { obok }\end{array}$ & 10,95 & 12,5 & 10,0 & 11,3 \\
\hline $\begin{array}{l}\text { zastosowanie wyższych cen, niż w } \\
\text { gabinecie obok }\end{array}$ & 9,52 & 20,0 & 3,3 & 8,5 \\
\hline
\end{tabular}

Źródło: opracowanie własne na podstawie przeprowadzonego badania.

* Odpowiedzi nie sumują się do $100 \%$ - respondenci mogli zaznaczyć maksymalnie trzy rozwiązania.

Przedstawiony w tabeli 81 ranking działań, które podejmowaliby lekarze dentyści, otwierając gabinet w pobliżu już istniejącego gabinetu stomatologicznego, pokazuje, że głównym działaniem rynkowym byłoby zaproponowanie szerszego wachlarza usług ${ }^{18}$ (niż w gabinecie konkurencyjnym). Na dalszych miejscach znalazły się: oferowanie takich samych usług, jak konkurencja i specjalizacja usług. Może to dowodzić, iż stomatolodzy dostrzegają możliwość budowania pozycji konkurencyjnej tylko w obszarze stricte medycznym, co wobec relatywnie wąskiego pola działa w tym zakresie nie stwarza dużych możliwości do wyróżnienia się na tle innych gabinetów. Pozamedyczne czynniki oddziaływania na nabywców usług cieszyły się zdecydowanie mniejszym zainteresowaniem respondentów, co może świadczyć o braku zrozumienia lub zaufania do możliwości ich rynkowego oddziaływania. Potwierdzeniem tej tezy może być fakt, że żaden $\mathrm{z}$ respondentów nie zaproponował innych działań, które mogłyby być podjęte w gabinecie w celu wyróżnienia się na tle działających na danym obszarze gabinetów stomatologicznych.

Ponadto można zauważyć, że respondenci o Sylwetce A reagowaliby najmniej przeciętnie na zaistniałą sytuację rynkową tzn. większy odsetek respondentów o Sylwetce A (niż wynosi średnia dla badanej grupy) rozważałby:

- dążenie do wyróżnienia ofertą (przez wprowadzenie szerszego wachlarza usług lub specjalizację działalności),

- podjęcie odmiennych, niż sąsiedni gabinet, decyzji co do ceny usługi (wprowadzenie wyższych lub niższych cen usług).

Osoby z tej grupy najczęściej rozważałyby podjęcie działań z zakresu promocji. Zdecydowałyby się również na pracę gabinetu w innych godzinach, niż konkurencyjny gabinet.

Respondenci o Sylwetce B częściej, niż przeciętnie decydowaliby się na robienie tego samego, co konkurencja (co może świadczyć o małej wierze we własne

\footnotetext{
${ }^{18}$ Można postawić pytanie: Na ile aktualnie posiadana wiedza i umiejętności stricte medyczne pozwoliłyby stomatologowi w krótkim czasie rozszerzyć ofertę?.
} 
umiejętności stricte medyczne i/lub braku wiedzy na temat możliwych pozamedycznych zachowań rynkowych) oraz rozważaliby obsługę innego segmentu pacjentów.

Zachowania osób o Sylwetce C są najbardziej zbliżone do przedstawionego rankingu (co zrozumiałe zważywszy na liczebność grupy). Różnice dotyczą przede wszystkim: większego odsetka odpowiedzi na korzyść decyzji o specjalizacji oferty, czy stosowanie takich samych cen, jak w sąsiednim gabinecie.

Reasumując, w świetle przedstawionego problemu: możliwych działań dentysty w sytuacji, gdy otwiera on gabinet obok już istniejącego, należy stwierdzić, że respondenci o Sylwetce A podejmowaliby najbardziej zróżnicowane działania - miałyby one bardziej rynkowe nastawienie (np. działania z zakresu promocji) i związane byłyby z większym ryzykiem (np. zastosowanie wyższych cen niż konkurencja), niż u dentystów o sylwetce B i C.

Ranking działań, które podejmowaliby lekarze dentyści, gdyby w pobliżu ich gabinetu powstał nowy gabinet stomatologiczny (por. tabela 82) pokazuje, że przeszło połowa respondentów zwracałaby uwagę na to, co robi nowy konkurent, lecz mniej niż 1/4 zareagowałyby na jego działania stosowną zmianą w swoim gabinecie.

Podobnie, jak w poprzedniej sytuacji rynkowej, również na drugie pytanie zdecydowanie inaczej, niż pozostali, odpowiadali respondenci o Sylwetce A - 70\% z nich zwraca uwagę na działania konkurencji (podczas, gdy wśród responsdentów o Sylwetce B odsetek ten wyniósł niespełna 40\%) i niemal 1/3 deklaruje, że odpowiada na działania konkurencji zmianami w swoim gabinecie (a więc odpowiedź na zmiany na rynku pochodzi z wnętrza organizacji - od dentysty). W tej samej grupie odsetek wskazań „nie wiem”, co się dzieje w pobliżu gabinetu był najniższy. Wśród respondentów o Sylwetce B - 1/5 nie wie, że w pobliżu otwiera się nowy gabinet, co może świadczyć o dużej orientacji ,do wewnątrz" gabinetu i nie traktowaniu innych gabinetów, jako konkurentów, którzy mogą wpłynąć na funkcjonowanie własnego gabinetu. Potwierdza to również najniższy odsetek wskazań $\mathrm{w}$ tej grupie $\mathrm{w}$ odniesieniu do opcji: „dentysta zwraca uwagę na działania konkurencji”. Z drugiej strony w tej grupie odsetek wskazań o natychmiastowym podjęciu działań w gabinecie był największy.

Respondenci o Sylwetce C zwracają uwagę na pojawienie się konkurencji (przeszło $50 \%$ wskazań) i $22 \%$ reaguje na zmianę rynkową. Blisko $1 / 3$ badanych z tej grupy nie przejmuje się pojawiającą się konkurencją, licząc na lojalność pacjentów i zasób potencjalnych pacjentów w pobliżu gabinetu (oba czynniki mogące wpłynąć na zmianę są pochodzenia zewnętrznego, co można interpretować, jako oddanie rzeczywistego sprawstwa siłom rynku, a nie własnej inwencji). 
Tabela 82. Ranking działań podejmowanych przez respondentów - obok powstaje nowy gabinet

\begin{tabular}{|l|c|c|c|c|}
\hline \multicolumn{1}{|c|}{$\begin{array}{c}\text { Reakcje dentysty w sytuacji, gdy w } \\
\text { pobliżu powstaje nowy gabinet } \\
\text { stomatologiczny }\end{array}$} & \multicolumn{3}{|c|}{$\begin{array}{c}\text { Wskazania respondentów* } \\
\text { (procent wskazań) }\end{array}$} \\
\cline { 2 - 5 } & Ogółem & Sylwetka A & Sylwetka B & Sylwetka C \\
\hline $\begin{array}{l}\text { Zwraca uwagę na działania podejmowane } \\
\text { przez konkurenta ,z ciekawości” }\end{array}$ & 27,18 & 37,50 & 20,0 & 27,4 \\
\hline $\begin{array}{l}\text { Zwraca uwagę na działania podejmowane } \\
\text { przez konkurenta, żeby zareagować } \\
\text { odpowiednia zmianą w swoim gabinecie } \\
\text { (np. godziny pracy gabinetu) }\end{array}$ & 23,79 & 32,50 & 18,3 & 22,6 \\
\hline $\begin{array}{l}\text { nie przejmuje się tym, bo ma lojalnych } \\
\text { pacjentów }\end{array}$ & 18,93 & 15,0 & 18,3 & 20,8 \\
\hline $\begin{array}{l}\text { nie wie, co się dzieje w pobliżu i nawet nie } \\
\text { zauważa, że otwiera się nowy gabinet }\end{array}$ & 11,65 & 2,5 & 21,7 & 9,4 \\
\hline $\begin{array}{l}\text { nie przejmuje się tym, bo w pobliżu jest } \\
\text { duże osiedle, więc dwa gabinety ,się } \\
\text { utrzymają” (lub podobny powód) }\end{array}$ & 8,74 & 5,0 & 8,3 & 10,4 \\
\hline $\begin{array}{l}\text { natychmiast podejmuje działania } \\
\text { (np. bezpłatny przegląd i plan leczenia dla } \\
\text { nowych pacjentów) }\end{array}$ & 7,77 & 2,50 & 13,3 & 6,6 \\
\hline Inne ${ }^{19}$ & 1,94 & 5,0 & 0,0 & 2,8 \\
\hline
\end{tabular}

Źródło: opracowanie własne na podstawie przeprowadzonego badania.

*Respondenci mogli zaznaczyć tylko jedną odpowiedź.

Wnioski z przedstawionego badania można przedstawić następujące: dentyści o Sylwetce A są zorientowani na zmiany zachodzące w otoczeniu gabinetu bardziej, niż o Sylwetce C i B. Reakcja związana z pojawieniem się nowego gabinetu na rynku jest związana głównie z ich aktywnością, a w mniejszym zakresie poleganiem na przychylności otoczenia (tj. lojalności pacjentów i szerokości rynku), jak ma to miejsce w przypadku Sylwetki C i B. Tym samym można powiedzieć, że respondenci o Sylwetce A dzięki swojej czujności mają przewagę nad innymi gabinetami - gdy inni dopiero dostrzegają zmiany, oni już je spostrzegli i poddali analizie, a następnie ocenili możliwy wpływ tych zmian na swój gabinet i przygotowali się do wprowadzania zmian (lub nawet zaczęli je wdrażać). Gdy będą sprawni w szybkim wdrażaniu i utrwalaniu nowych rozwiązań, to maja szansę na utrzymanie pozycji konkurencyjnej w długim okresie. Dentyści o Sylwetce B w najmniejszym zakresie są zorientowani na zewnątrz organizacji.

\footnotetext{
19 Osoby, które wskazały odpowiedź: „inne” i uzasadniały ją, to jako uzasadnienie podały następujące wyjaśnienia: 1) mam lojalnych pacjentów, nasze ustugi sa na poziomie ponadstandardowym, co pacjenci doceniaja, dzięki temu nowe gabinety nie zagrażaja nam, 2) mam bardzo dobrze wyposażony gabinet, duże grono lojalnych pacjentów i bardzo odległe terminy wizyt, 3) nie przejmuje się tym, ponieważ znam swoja wartość oraz wiem na jakim poziomie sa nasze ustugi, 4) pracuję dalej i obserwuję sytuację na rynku.
} 
Podsumowując powyższe rozważania, można zauważyć, że lekarz dentysta aby szybko reagować na zmiany w otoczeniu (w konsekwencji utrzymywać/ poprawiać swoją pozycję konkurencyjną) powinien dysponować Kirznerowską czujnością. Umiejętność czujnego obserwowania otoczenia i szybkiego angażowania w konieczne działania (niekiedy w oparciu o bardzo słabe, niezauważalne dla innych sygnały) posiadanych zasobów oraz zdobycia dostępu do tych, którymi gabinet aktualnie nie dysponuje. Jak twierdzi J.B. Barney bystrość, zdolność do szybkich zmian i czujność na zmiany rynkowe - są to cechy o wysokich kosztach imitacji, dlatego mogą być źródłem trwałej przewagi konkurencyjnej. Ta przewaga będzie trwać, dopóki cechy te będą ekonomicznie wartościowe (innymi słowy: dopóki otoczenie gabinetu będzie podlegać szybkim zmianom $)^{20}$.

\section{CZYNNIKI KONKURENCYJNOŚCI GABINETU STOMATOLOGICZNEGO}

Kolejną kwestią poddaną analizie - związaną z rynkowym funkcjonowaniem gabinetów stomatologicznych - są czynniki konkurencyjności. Respondenci zostali poproszeni o wskazanie najważniejszych wg nich działań/stanów/ sytuacji, które wpływają na pozycję rynkową współczesnego gabinetu ${ }^{21}$ i będą ważne w przyszłości. Ich ranking w kontekście zróżnicowania ze względu na typologię przyjętych sylwetek respondentów przedstawiony jest w tabeli 83 .

Do najważniejszych czynników konkurencyjności współczesnego gabinetu stomatologicznego respondenci zaliczyli: kwalifikacje medyczne dentysty, nowoczesny sprzęt, renomę gabinetu, dużą różnorodność usług, posiadanie dużej grupy lojalnych klientów, lokalizację gabinetu i doświadczony personel. I choć uznali, że w przyszłości te czynniki też będą ważne, to ich ranga zmniejszy się, a istotna rola dużej grupy lojalnych klientów, lokalizacji podmiotu, doświadczenia personelu, jako czynników konkurencyjnych zostanie zastąpiona takimi czynnikami, jak: ceny, kwalifikacje menedżerskie dentysty czy ciągły dopływ nowych pacjentów ${ }^{22}$.

\footnotetext{
${ }^{20}$ Barney J.B., Resorce - based 'theorie' of competitive advantage: A ten-year retrospective on the resource-based wiev, "Journal of Managemenet", 2001 nr 27, s. 643 i nast.

21 Przypomnijmy, że w badaniu I na kwalifikacje medyczne dentysty, jako czynnik konkurencyjności wskazało 89,29\% lekarzy dentystów, nowoczesność sprzętu - 65,48\%, dużą różnorodność usług $-51,79 \%$ badanych, a duża grupa lojalnych nabywców została wskazana przez $61,31 \%$ lekarzy dentystów.

${ }^{22}$ Można się zastanowić: skąd się ma wziąć zwiększony strumień nowych pacjentów?, skoro jednym z głównych czynników wpływających na decyzje pacjentów są rekomendacje dotychczasowych pacjentów.
} 
Tabela 83. Czynniki konkurencyjności gabinetu stomatologicznego a typ sylwetki respondenta

\begin{tabular}{|c|c|c|c|c|c|c|c|c|}
\hline \multirow{3}{*}{ Czynnik konkurencyjny } & \multicolumn{8}{|c|}{$\begin{array}{l}\text { Wskazania respondentów* } \\
\text { (procent wskazań) }\end{array}$} \\
\hline & \multicolumn{2}{|c|}{ Ogółem } & \multicolumn{2}{|c|}{ Sylwetka A } & \multicolumn{2}{|c|}{ Sylwetka B } & \multicolumn{2}{|c|}{ Sylwetka C } \\
\hline & dziś & $\begin{array}{l}\text { w przy- } \\
\text { szłości }\end{array}$ & dziś & $\begin{array}{l}\text { w przy- } \\
\text { szłości }\end{array}$ & dziś & $\begin{array}{l}\text { w przy- } \\
\text { szłości }\end{array}$ & dziś & $\begin{array}{l}\text { w przy- } \\
\text { szłości }\end{array}$ \\
\hline $\begin{array}{l}\text { kwalifikacje medyczne } \\
\text { dentysty }\end{array}$ & 78,10 & 58,10 & 72,5 & 52,5 & 78,3 & 65,0 & 80,2 & 58,5 \\
\hline nowoczesny sprzęt & 72,38 & 67,14 & 65,0 & 60,0 & 76,7 & 65,0 & 72,6 & 72,6 \\
\hline renoma gabinetu & 55,71 & 48,10 & 60,0 & 45,0 & 60,0 & 48,3 & 52,8 & 50,9 \\
\hline duża różnorodność usług & 48,10 & 44,29 & 52,5 & 55,0 & 48,3 & 43,3 & 47,2 & 42,5 \\
\hline $\begin{array}{l}\text { duża grupa lojalnych } \\
\text { klientów }\end{array}$ & 41,90 & 35,71 & 45,0 & 32,5 & 46,7 & 35,0 & 37,7 & 38,7 \\
\hline lokalizacja podmiotu & 41,43 & 30,00 & 40,0 & 25,0 & 40,0 & 30,0 & 43,4 & 33,0 \\
\hline doświadczony personel & 40,00 & 28,57 & 50,0 & 30,0 & 43,3 & 40,0 & 34,0 & 22,6 \\
\hline ceny & 37,62 & 40,48 & 25,0 & 40,0 & 41,7 & 35,0 & 41,5 & 45,3 \\
\hline $\begin{array}{l}\text { ciągły dopływ nowych } \\
\text { pacjentów }\end{array}$ & 32,38 & 33,81 & 30,0 & 35,0 & 31,7 & 38,3 & 34,0 & 30,2 \\
\hline $\begin{array}{l}\text { kwalifikacje menedżer- } \\
\text { skie dentysty }\end{array}$ & 24,76 & 36,19 & 37,5 & 42,5 & 23,3 & 25,0 & 21,7 & 38,7 \\
\hline stosowane materiały & 23,81 & 16,67 & 27,5 & 15,0 & 16,7 & 18,3 & 26,4 & 17,0 \\
\hline $\begin{array}{l}\text { kwalifikacje interperso- } \\
\text { nalne pracowników }\end{array}$ & 21,90 & 18,10 & 32,5 & 35,0 & 18,3 & 18,30 & 17,0 & 11,3 \\
\hline $\begin{array}{l}\text { kwalifikacje medyczne } \\
\text { personelu pomocniczego }\end{array}$ & 20,00 & 18,57 & 27,5 & 17,5 & 13,3 & 21,7 & 20,8 & 17,9 \\
\hline $\begin{array}{l}\text { bardzo dobra znajomość } \\
\text { rynku i działań konkurent- } \\
\text { tów }\end{array}$ & 17,62 & 24,29 & 27,5 & 30,0 & 13,3 & 25,0 & 16,0 & 22,6 \\
\hline podpisany kontrakt z NFZ & 15,71 & 10,00 & 10,0 & 10,00 & 18,3 & 8,3 & 17,0 & 11,3 \\
\hline $\begin{array}{l}\text { aktywność w Internecie } \\
\text { (na portalach społecznoś.) }\end{array}$ & 14,76 & 32,86 & 17,5 & 40,0 & 8,3 & 20,0 & 17,0 & 36,8 \\
\hline $\begin{array}{l}\text { działania promocyjne (np. } \\
\text { możliwość skorzystania z ofer- } \\
\text { ty gabinetu dzięki zakupom } \\
\text { przez Gruppon) }\end{array}$ & 8,10 & 16,19 & 10,0 & 22,5 & 5,0 & 15,0 & 8,5 & 14,2 \\
\hline wąska specjalizacja & 5,24 & 10,95 & 10,0 & 15,0 & 3,3 & 5,0 & 4,7 & 12,3 \\
\hline młody personel & 2,86 & 5,24 & 0,0 & 2,5 & 0,0 & 1,7 & 5,7 & 7,5 \\
\hline
\end{tabular}

Źródło: opracowanie własne na podstawie przeprowadzonego badania.

*Odpowiedzi nie sumują się do $100 \%$, ponieważ respondenci mogli odnieść się do 7 kwestii.

Biorąc pod uwagę kwalifikacje stomatologa, jako czynnik konkurencyjności gabinetu, można wskazać na ciekawe spostrzeżenia respondentów: uznali, że znaczenie kwalifikacji medycznych stomatologów będzie się w przyszłości zmniejszać (o 20 p.p. mniej wskazań), a rosnąć znaczenie kwalifikacji menedżerskich - wzrost o 11,43 p.p. (wśród respondentów o Sylwetce C - największy - wzrost o 17 p.p.). Zastanawiające jest, że respondenci uznali, iż w przyszłości nowo- 
czesny sprzęt będzie głównym czynnikiem konkurencyjności gabinetu ${ }^{23}$ $67,14 \%$ wskazań, podczas gdy kwalifikacje medyczne dentysty w przyszłości „otrzymały” o 9,04 p.p. mniej wskazań, a stosowane materiały stomatologiczne o 7,14 p.p. (to oznacza, że wg dentystów wyposażenie gabinetu będzie „,budowało renomę” podmiotu w oczach pacjentów, wobec malejącego znaczenia kwalifikacji personelu (co stoi w sprzeczności z wynikami badania IV i jest sygnałem niskiego stopnia znajomości poza- medycznych czynników generujących popyt w usługach stomatologicznych po stronie lekarza dentysty). We współczesnych gabinetach ważne są kwalifikacje interpersonalne - 21,9\% wskazań i kwalifikacje medyczne - 20\%, ale w gabinecie przyszłości znaczenie tych czynników ma być - wg respondentów - mniejsze: 18,1\% wskazań kwalifikacje interpersonalne, 18,57\% - kwalifikacje medyczne.

Wyniki zamieszczone w tabeli 83 pozwalają zauważyć, że kwalifikacje medyczne dentystów są dziś najważniejsze w funkcjonowaniu gabinetu dla dentystów o Sylwetce C, a w przyszłości będą najważniejsze dla Sylwetki B. Sylwetkę A od pozostałych odróżnia m. in. to, że:

- przeszło 1/2 respondentów z tej grupy dużą różnorodność usług postrzega, jako ważny i o rosnącym znaczeniu czynnik konkurencyjności gabinetu stomatologicznego;

- lekarze dostrzegają rosnące znaczenie kwalifikacji interpersonalnych pracowników gabinetu.

Sylwetka B od pozostałych respondentów różni się przede wszystkim tym, że zmiany w konkurencyjności gabinetów dostrzega w:

- rosnącym znaczeniu stosowanych materiałów stomatologicznych,

- rosnącym znaczeniu kwalifikacji medycznych personelu pomocniczego.

Natomiast respondenci o Sylwetce C uważają (inaczej, niż średnia wskazań), że w przyszłości będzie rosło znaczenie posiadania lojalnych pacjentów przez gabinety, jako czynnika konkurencyjności, a ciągłego dopływu nowych pacjentów - malało (co pozostaje w zgodzie z ideą marketingu relacji).

Reasumując, stomatolodzy o Sylwetce A wskazując czynniki konkurencyjności gabinetu (dziś i w przyszłości), większą wagę, niż dentyści o pozostałych typach sylwetek, przywiązują do czynników o orientacji rynkowej:

23 Dla autorki badania zaskakujący był wynik dotyczący malejącego znaczenia kwalifikacji personelu, jako czynnika konkurencyjności gabinetów stomatologicznych. Wg respondentów w przyszłości (w usługach opartych na wiedzy i umiejętnościach człowieka) głównym czynnikiem konkurencyjności ma być sprzęt. W kontekście cywilizacji tercjarnej wydaje się to stanowić pewną barierę w postrzeganiu instrumentów konkurowania prezentowanych przedsiębiorców. 
- zmian w ofercie (zarówno w kierunku dywersyfikacji, jak i specjalizacji);

- kwalifikacji menedżerskich dentysty,

- bardzo dobrej znajomości rynku i działań konkurentów,

- aktywności w Internecie,

- działań promocyjnych.

Stomatolodzy o Sylwetce B wśród czynników konkurencyjności gabinetów stomatologicznych $\mathrm{w}$ przyszłości największego znaczenia upatrują $\mathrm{w}$ stricte medycznych obszarach działania:

- kwalifikacjach medycznych dentysty i personelu medycznego (oraz jego doświadczeniu),

- stosowanych materiałach stomatologicznych.

Lekarze dentyści o Sylwetce $\mathrm{C}$ w gabinecie przyszłości dostrzegają zarówno wagę czynników rynkowych (takich, jak: renoma gabinetu, duża grupa lojalnych klientów ${ }^{24}$, lokalizacja gabinetu), jak i medycznych - nowoczesny sprzęt i stosowane materiały medyczne. W tej grupie respondentów był również największy odsetek wskazań $(11,3 \%)$ na podpisany kontrakt z NFZ, jako czynnik konkurencyjności.

Na dzisiejszym rynku przed podmiotami na nim funkcjonującymi, staje szereg wyzwań. W tabeli 84 przedstawiony jest rozkład odpowiedzi na pytanie: „Co jest wyzwaniem stojącym przed wspótczesnym gabinetem?" Jako najważniejsze zostały wskazane:

- działania zgodnie z Kodeksem etyki lekarskiej (96,19\% wskazań - ważne i bardzo ważne),

- stworzenie i utrzymywanie trwałych relacji z obsługiwanymi pacjentami $(96,67 \%)$,

- pozyskanie nowych pacjentów (94,28\%).

\footnotetext{
${ }^{24}$ Jako jedyni lekarze o Sylwetce C wskazali wzrost znaczenia tego czynnika w przyszłości.
} 
Tabela 84. Ranking wyzwań stojących przed gabinetami stomatologicznymi - wyniki badania $\mathbf{I I}^{25}$

\begin{tabular}{|c|c|c|c|c|c|c|c|c|}
\hline \multirow[b]{2}{*}{ Wyzwanie stojące przed gabinetem } & \multicolumn{5}{|c|}{$\begin{array}{l}\text { Wskazania respondentów } \\
\text { (procent wskazań) }\end{array}$} & \multirow[b]{2}{*}{$\bar{x}$} & \multirow[b]{2}{*}{ Do } & \multirow[b]{2}{*}{ Me } \\
\hline & $\begin{array}{c}\text { w ogóle } \\
\text { nie } \\
\text { ważne } \\
(1)\end{array}$ & $\begin{array}{c}\text { raczej } \\
\text { nie } \\
\text { ważne } \\
(2)\end{array}$ & $\begin{array}{c}\text { trudno } \\
\text { powie- } \\
\text { dzieć } \\
(3)\end{array}$ & $\begin{array}{c}\text { ważne } \\
\text { (4) }\end{array}$ & $\begin{array}{c}\text { bardzo } \\
\text { ważne } \\
(5)\end{array}$ & & & \\
\hline $\begin{array}{l}\text { Działanie zgodnie z Kodeksem etyki } \\
\text { lekarskiej }\end{array}$ & 0,48 & 0,00 & 3,33 & 23,81 & 72,38 & 4,68 & 5 & 5 \\
\hline $\begin{array}{l}\text { Stworzenie i utrzymywanie trwałych } \\
\text { relacji z obsługiwanymi pacjentami }\end{array}$ & 0,00 & 0,95 & 2,38 & 29,05 & 67,62 & 4,63 & 5 & 5 \\
\hline Pozyskanie nowych pacjentów & 0,00 & 0,00 & 5,71 & 48,57 & 45,71 & 4,40 & 4 & 4 \\
\hline $\begin{array}{l}\text { Pozyskanie wykwalifikowanych pra- } \\
\text { cowników i/lub podniesienie kwalifi- } \\
\text { kacji obecnych pracowników }\end{array}$ & 0,48 & 2,38 & 8,10 & 50,95 & 38,10 & 4,24 & 4 & 4 \\
\hline $\begin{array}{l}\text { Poprawa komunikacji między pracow- } \\
\text { nikami a pacjentami }\end{array}$ & 1,43 & 3,33 & 12,38 & 43,33 & 39,52 & 4,16 & 4 & 4 \\
\hline Zwiększenie rentowności działania & 0,00 & 1,43 & 12,86 & 55,24 & 30,48 & 4,15 & 4 & 4 \\
\hline Trwały wzrost przychodów & 0,00 & 3,35 & 13,88 & 58,37 & 24,40 & 4,04 & 4 & 4 \\
\hline Poszerzenie oferty usług & 0,48 & 3,86 & 13,53 & 60,87 & 21,26 & 3,99 & 4 & 4 \\
\hline $\begin{array}{l}\text { Poprawa komunikacji pomiędzy pra- } \\
\text { cownikami }\end{array}$ & 1,44 & 6,25 & 19,23 & 50,00 & 23,08 & 3,87 & 4 & 4 \\
\hline $\begin{array}{l}\text { Opracowanie kompleksowego planu } \\
\text { marketingowowego }\end{array}$ & 3,35 & 11,96 & 34,45 & 33,49 & 16,75 & 3,48 & 3 & 4 \\
\hline $\begin{array}{l}\text { Przygotowanie planu rozwoju na } \\
\text { najbliższe } 3 \text { lata }\end{array}$ & 3,81 & 8,57 & 33,81 & 45,24 & 8,57 & 3,46 & 4 & 3 \\
\hline
\end{tabular}

Źródło: opracowanie własne na podstawie przeprowadzonego badania.

Drogę do stworzenia i utrzymywania długookresowych, trwałych więzi z pacjentami respondenci widzą w podnoszeniu kwalifikacji personelu, poprawie komunikacji między pracownikami a pacjentami oraz samymi pracownikami (co wpisuje się w ideę marketingu relacji). W świetle wcześniejszego wskazania o rosnącym znaczeniu kwalifikacji menedżerskich stomatologów (por. tabela 83) dla 36,19\% respondentów, budujący wydaje się fakt, że przeszło połowa badanych wskazała, że opracowanie kompleksowego planu jest ważne lub bardzo ważne ${ }^{26}$ dla przyszłego funkcjonowania gabinetu. Można również wskazać, że 53,81\% respondentów widzi konieczność przygotowania planu rozwoju gabinetu na najbliższe 3 lata, a tylko co dziesiąty uważa, że nie powinno to być realizowane w gabinecie. Kwestia planowania (zarówno szeroko pojętego rozwoju, jak i działań marketingowych) wywołuje ambiwalentne odczucia u 1/3

\footnotetext{
${ }^{25}$ Wartość wskazań średniej arytmetycznej, dominanty i mediany dla badanych kryteriów w badaniu II była zbliżona (lub identyczna), co pozwala wnioskować, że miał on rozkład normalny.

${ }^{26}$ Inną sprawą jest to, czy takie plany w rzeczywistości powstaną, czy ich tworzenie jako ważne pozostanie w sferze deklaracji.
} 
badanych, co koresponduje z wynikami badania o relatywnie niskim poziomie umiejętności stomatologów w tym zakresie (por. tabela 85).

Wykres 11 przedstawia zróżnicowanie średnich wskazań respondentów co do omawianych zagadnień w kontekście prezentowanych przez respondentów sylwetek.

Wykres 11. Wyzwania stojące przed współczesnymi gabinetami stomatologicznymi a sylwetki respondentów

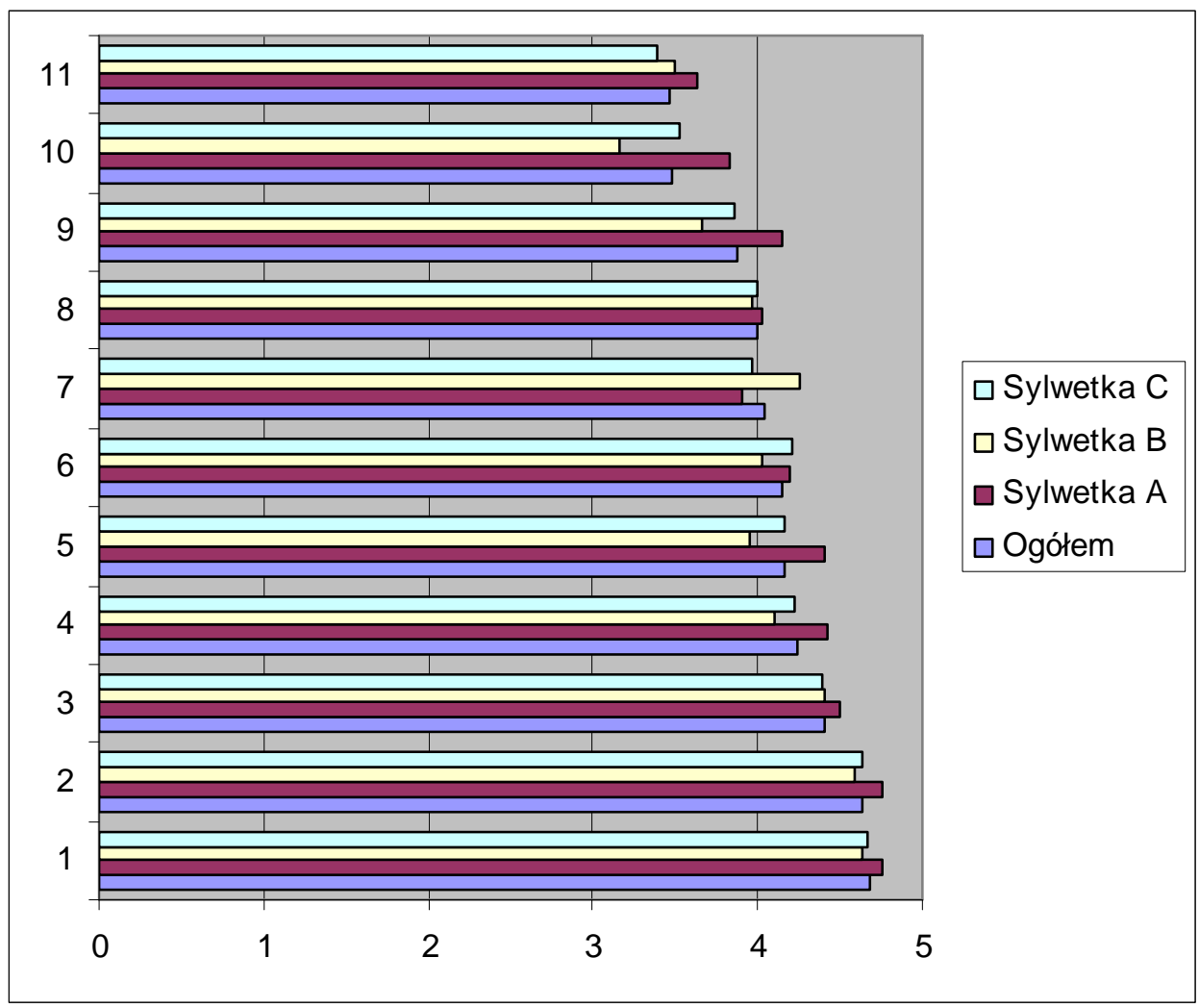

Źródło: opracowanie własne na podstawie przeprowadzonego badania.

Wyzwania stojące przed gabinetami: 1) Działanie zgodnie z Kodeksem etyki lekarskiej, 2) Stworzenie i utrzymywanie trwałych relacji z obsługiwanymi pacjentami, 3) Pozyskanie nowych pacjentów, 4) Pozyskanie wykwalifikowanych pracowników i/lub podniesienie kwalifikacji obecnych pracowników, 5) Poprawa komunikacji między pracownikami a pacjentami, 6) Zwiększenie rentowności gabinetu, 7) Trwały wzrost przychodów, 8) Poszerzenie oferty usług, 9) Poprawa komunikacji pomiędzy pracownikami, 10) Opracowanie kompleksowego planu marketingowego, 11) Przygotowanie planu rozwoju na najbliższe 3 lata.

Osoby o Sylwetce A odpowiedzi o średniej wskazań wyższej, niż pozostali respondenci mają we wszystkich płaszczyznach (oprócz: trwałego wzrostu przy- 
chodów) określonych, jako wyzwania stojące przed współczesnymi gabinetami, co może świadczyć o dostrzeganiu i docenianiu ich znaczenia w funkcjonowaniu gabinetu. Natomiast dentyści o Sylwetce B trwały wzrost dochodów potraktowali, jako zdecydowanie ważniejsze wyzwanie, niż zrobiły to pozostałe grupy, ale w odniesieniu do 7 na 11 analizowanych wyzwań stojących przed współczesnymi gabinetami ich przekonania były zdecydowanie słabsze.

\section{SAMOOCENA UMIEJECTNOŚCI I POSTAW PRZEDSIĘBIORCZYCH BADANYCH LEKARZY DENTYSTÓW 5.1. SAMOOCENA W ZAKRESIE UMIEJECTNOŚCI
INTRAPERSONALNYCH I INTERPERSONALNYCH}

Ocena umiejętności intrapersonalnych dentystów została dokonana w oparciu o samoocenę przeprowadzoną przez respondentów w obszarze kilkunastu czynników (por. tabela 85). Najwyżej badani ocenili swoje zaangażowanie w pracę $92,82 \%$ badanych uważa, że jest zaangażowanych mocno lub bardzo mocno w wykonywanie swojego zawodu. Inne atrybuty, które zyskały wysoką ocenę respondentów, to:

- poziom wiedzy i umiejętności stricte zawodowych - 91,86\% badanych oceniło je dobrze i bardzo dobrze,

- umiejętność wykorzystywania w praktyce wiedzy zdobytej na szkoleniach - 80\% badanych uznało, że potrafi aplikować poznane rozwiązania do swojej praktyki.

Najniżej swoje umiejętności respondenci ocenili w zakresie: radzenia sobie $\mathrm{z}$ emocjami w konflikcie oraz radzenia sobie z krytyką - 1/5 badanych uznała, że nie posiada takich umiejętności, a $2 / 5$ - że posiada. Otrzymane wyniki są bardzo zbliżone do wyników badania I (por. punkt 3.2.1. w II rozdziale pracy).

Tabela 85. Samoocena umiejętności intrapersonalnych dentystów

\begin{tabular}{|c|c|c|c|c|c|c|c|c|}
\hline \multirow[b]{2}{*}{ Umiejętności i postawy dentystów } & \multicolumn{5}{|c|}{$\begin{array}{l}\text { Wskazania respondentów } \\
\text { (procent wskazań) }\end{array}$} & \multirow[b]{2}{*}{$\bar{x}$} & \multirow[b]{2}{*}{ Do } & \multirow[b]{2}{*}{ Me } \\
\hline & brak & \begin{tabular}{|c|}
$\mathrm{w}$ \\
małym \\
stopniu \\
$(2)$
\end{tabular} & $\begin{array}{c}\text { średnio } \\
(3)\end{array}$ & dobrze & $\begin{array}{c}\text { bardzo } \\
\text { dobrze } \\
(5)\end{array}$ & & & \\
\hline Zaangażowanie w pracę & 0,96 & 0,00 & 6,22 & 40,67 & 52,15 & 4,43 & 5 & 5 \\
\hline Wiedza i umiejętności stricte zawodowe & 0,00 & 0,00 & 8,13 & 58,37 & 33,49 & 4,25 & 4 & 4 \\
\hline $\begin{array}{l}\text { Wykorzystywanie w praktyce wiedzy } \\
\text { zdobytej na szkoleniach }\end{array}$ & 0,00 & 3,81 & 16,19 & 47,62 & 32,38 & 4,09 & 4 & 4 \\
\hline $\begin{array}{l}\text { Identyfikacji własnych mocnych i } \\
\text { słabych stron }\end{array}$ & 0,00 & 2,38 & 19,05 & 57,14 & 21,43 & 3,98 & 4 & 4 \\
\hline Obsługa komputera & 1,91 & 5,26 & 20,57 & 39,71 & 32,54 & 3,96 & 4 & 4 \\
\hline $\begin{array}{l}\text { Określanie priorytetów w życiu } \\
\text { zawodowym }\end{array}$ & 0,00 & 1,90 & 21,90 & 57,14 & 19,05 & 3,93 & 4 & 4 \\
\hline
\end{tabular}




\begin{tabular}{|l|c|c|c|c|c|c|c|c|}
\hline Myślenie alternatywne & 1,44 & 5,26 & 21,05 & 46,89 & 25,36 & 3,89 & 4 & 4 \\
\hline $\begin{array}{l}\text { Generowanie nowych rozwiązań w } \\
\text { funkcjonowaniu gabinetu }\end{array}$ & 0,00 & 0,35 & 31,10 & 48,80 & 16,75 & 3,79 & 4 & 4 \\
\hline $\begin{array}{l}\text { Szybkie wdrażanie nowych materiałów i } \\
\text { technik pracy w gabinecie }\end{array}$ & 0,96 & 5,77 & 27,40 & 46,63 & 19,23 & 3,77 & 4 & 4 \\
\hline $\begin{array}{l}\text { Planowanie własnego rozwoju zawodo- } \\
\text { wego }\end{array}$ & 1,43 & 2,86 & 33,33 & 44,76 & 17,62 & 3,74 & 4 & 4 \\
\hline $\begin{array}{l}\text { Ustalanie hierarchii działań w życiu } \\
\text { osobistym i zawodowym }\end{array}$ & 1,90 & 6,67 & 33,33 & 38,57 & 19,52 & 3,67 & 4 & 4 \\
\hline Wprowadzanie zmian w życiu zawodowym & 0,48 & 5,71 & 35,71 & 45,71 & 12,38 & 3,64 & 4 & 4 \\
\hline $\begin{array}{l}\text { Identyfikowanie słabych i mocnych } \\
\text { stron jako przełożonego }\end{array}$ & 0,48 & 7,18 & 32,06 & 50,72 & 9,57 & 3,62 & 4 & 4 \\
\hline Zwiększanie odporności na stres & 3,38 & 12,08 & 33,33 & 34,78 & 16,43 & 3,49 & 4 & 4 \\
\hline Planowanie działań na najbliższy miesiąc & 2,42 & 9,66 & 36,71 & 40,58 & 10,63 & 3,47 & 4 & 4 \\
\hline Radzenie sobie z emocjami w konflikcie & 6,22 & 12,92 & 37,80 & 33,01 & 10,05 & 3,28 & 3 & 3 \\
\hline Radzenie sobie z krytyką & 6,22 & 16,00 & 34,30 & 32,37 & 11,11 & 3,26 & 3 & 3 \\
\hline
\end{tabular}

Źródło: opracowanie własne na podstawie przeprowadzonego badania.

Samoocenę umiejętności intrapersonalnych respondentów z uwzględnieniem prezentowanego przez nich typu sylwetki przedstawia wykres 12 .

W zakresie umiejętności intrapersonalnych dentyści o Sylwetce A ocenili się relatywnie najwyżej w niemal wszystkich badanych obszarach:

- zaangażowania $w$ pracę (przypomnijmy, że ta grupa respondentów z największym wewnętrznym przekonaniem - por. wykres 10 - wybrała wykonywany zawód, co pozwala na stwierdzenie, że wykonują zawód z pasją),

- wykorzystywania w praktyce wiedzy zdobytej na szkoleniach oraz szybkiego wdrażania nowych materiałów i technik pracy w gabinecie,

- obsługi komputera,

- myślenia alternatywnego,

- generowania nowych rozwiązań w funkcjonowaniu gabinetu,

- planowania działań gabinetu i własnego rozwoju zawodowego oraz wprowadzania zmian w życiu zawodowym. 
Wykres 12. Umiejętności intrapersonalne a sylwetka respondenta

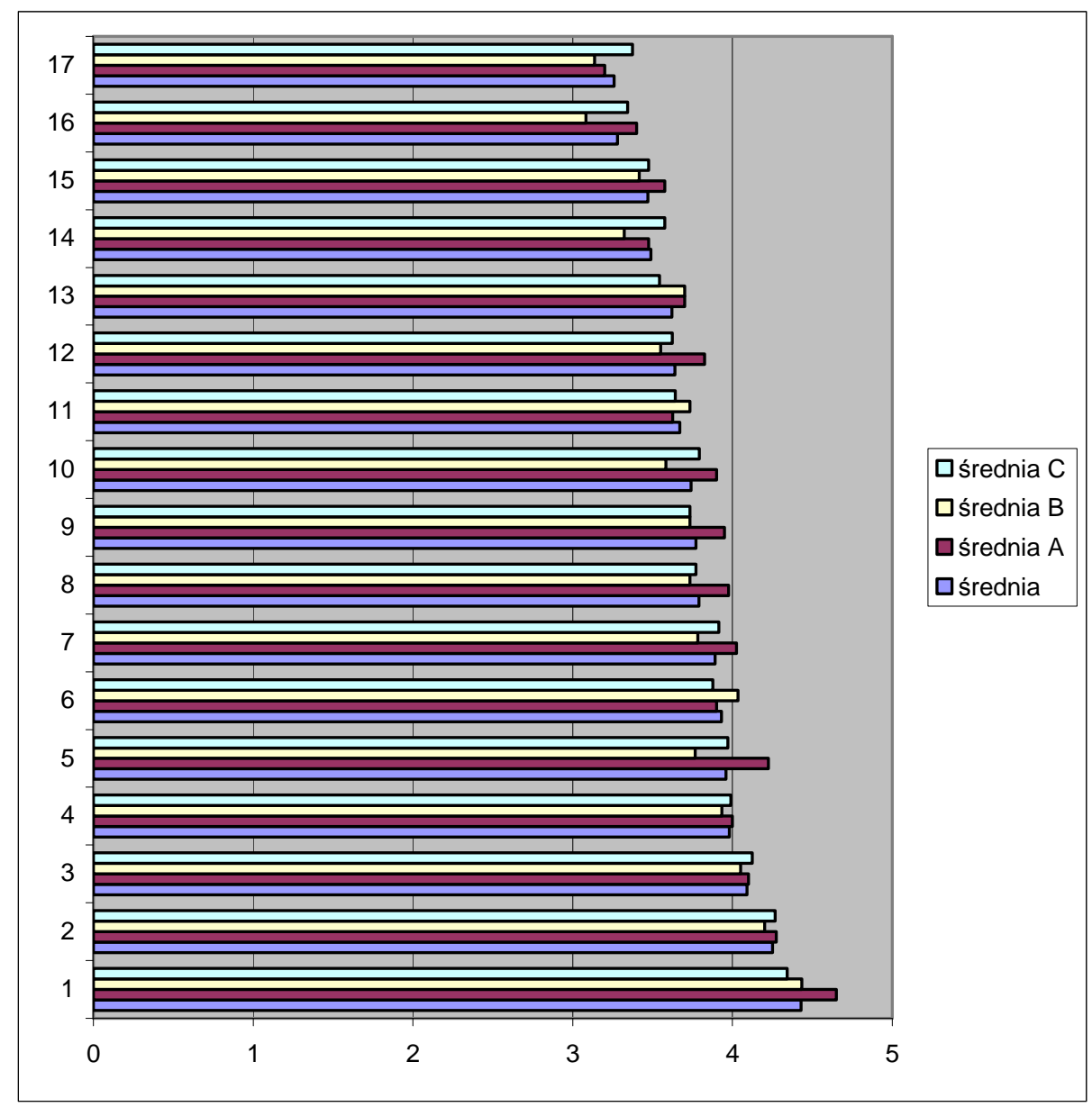

Źródło: opracowanie własne na podstawie przeprowadzonego badania.

Umiejętności i postawy: 1) Zaangażowanie w pracę, 2) Wiedza i umiejętności stricte zawodowe, 3) Wykorzystywanie w praktyce wiedzy zdobytej na szkoleniach, 4) Identyfikacja własnych mocnych i słabych stron, 5) Obsługa komputera, 6) Określanie priorytetów w życiu zawodowym, 7) Myślenie alternatywne, 8) Generowanie nowych rozwiązań w funkcjonowaniu gabinetu, 9) Szybkie wdrażanie nowych materiałów i technik pracy w gabinecie, 10) Planowanie własnego rozwoju zawodowego, 11) Ustalanie hierarchii działań w życiu osobistym i zawodowym, 12) Wprowadzanie zmian w życiu zawodowym, 13) Wskazanie własnych słabych i mocnych stron jako przełożonego, 14) Zwiększanie odporności na stres, 15) Planowanie działań na najbliższy miesiąc, 16) Radzenie sobie z emocjami w konflikcie, 17) Radzenie sobie z krytyką.

Dentyści o Sylwetce B tylko w zakresie określania priorytetów w życiu zawodowym oraz ustalania hierarchii działań w życiu osobistym i zawodowym ocenili się powyżej średniej dla całej grupy badanej. 
Natomiast dentyści o Sylwetce C wysoko ocenili:

- posiadaną wiedzę i umiejętności stricte zawodowe,

- umiejętność planowania rozwoju zawodowego,

- zwiększoną odporność na stres i radzenia sobie z krytyką (w obu tych obszarach autoocena zdecydowanie wyższa, niż u pozostałych badanych).

Kolejnym badanym obszarem były umiejętności interpersonalne dentystów, do oceny których wykorzystano 32 czynniki związane ze sposobem działania respondentów w środowisku pracy (zarówno w odniesieniu do personelu, jak i pacjentów). Uzyskane wyniki przedstawione są w tabeli 86.

Najwyższą ocenę stomatolodzy wystawili sobie za etyczne postępowanie (np. nie wykonywanie zbędnych świadczeń, nie zawyżanie rachunku itp.), 96,65\% respondentów uznało, że ich postawa w zakresie uczciwości wobec pacjentów jest na wysokim bądź bardzo wysokim poziomie.

Badani uznali, że umiejętności z zakresu odpowiedniego podejścia do pacjenta mają na wysokim poziomie i najwyżej ocenili:

- umiejętności z zakresu komunikacji, w tym m. in.:

- umiejętność dostosowania swojego sposobu mówienia do możliwości pacjenta (np. z punktu widzenia jego wieku czy wykształcenia) 91,39\% respondentów oceniło wysoko i bardzo wysoko,

- aktywnego słuchania - $76 \%$ respondentów oceniło się dobrze lub bardzo dobrze w tym zakresie;

- umiejętności społeczne, w tym m. in.:

- umiejętność utrzymywania dobrych relacji z pacjentem w długim okresie $-92,83 \%$ pozytywnych ocen,

- umiejętność nawiązywania dobrego kontaktu z pacjentem w trakcie pierwszej wizyty - 88,04\% dobrych i bardzo dobrych ocen,

- swoją empatię - 87,56\% pozytywnych wskazań,

- dobre relacje ze współpracownikami - 78,46\% wskazań,

- zdolność do przyznania się do błędu - 79,91\% wskazań.

Otrzymane wyniki są zbliżone do wyników badania I (por. punkt 3.3.1. w II rozdziale).

Respondenci stosunkowo nisko ocenili poziom swojej wiedzy i podejmowane działania z zakresu marketingu gabinetu - niespełna $30 \%$ uznało, że może sobie postawić notę dobrą lub bardzo dobrą w tym zakresie, a 30,29\%, że nie posiada lub posiada $\mathrm{w}$ niewielkim stopniu umiejętności w tym zakresie. Jeszcze niższe oceny dotyczyły umiejętności zbierania danych o konkurentach - niemal 50\% badanych uznało, że nie dysponuje nimi lub dysponuje w niewielkim zakresie. 
Tabela 86. Samoocena umiejętności/postaw interpersonalnych dentystów

\begin{tabular}{|c|c|c|c|c|c|c|c|c|}
\hline \multirow[b]{2}{*}{$\begin{array}{l}\text { Umiejętności/ postawy } \\
\text { dentystów }\end{array}$} & \multicolumn{5}{|c|}{$\begin{array}{c}\text { Wskazania respondentów } \\
\text { (procent wskazań) }\end{array}$} & \multirow[b]{2}{*}{$\bar{x}$} & \multirow[b]{2}{*}{ Do } & \multirow[b]{2}{*}{ Me } \\
\hline & $\begin{array}{l}\text { brak } \\
\text { (1) }\end{array}$ & $\begin{array}{c}\mathrm{w} \\
\text { małym } \\
\text { stopniu } \\
(2)\end{array}$ & $\begin{array}{c}\text { średnio } \\
(3)\end{array}$ & dobrze & $\begin{array}{c}\text { bardzo } \\
\text { dobrze } \\
(5)\end{array}$ & & & \\
\hline Uczciwość wobec pacjentów & 0,00 & 0,00 & 3,35 & 24,88 & 71,77 & 4,68 & 5 & 5 \\
\hline $\begin{array}{l}\text { Dostosowanie sposobu mówienia do } \\
\text { możliwości pacjenta }\end{array}$ & 0,48 & 1,44 & 6,70 & 49,28 & 42,11 & 4,31 & 4 & 4 \\
\hline $\begin{array}{l}\text { Utrzymywanie dobrych relacji z pacjen- } \\
\text { tem w długim okresie }\end{array}$ & 0,00 & 0,48 & 6,70 & 54,55 & 38,28 & 4,31 & 4 & 4 \\
\hline $\begin{array}{l}\text { Nawiązywanie dobrego kontaktu z pac- } \\
\text { jentem w trakcie pierwszej wizyty }\end{array}$ & 0,48 & 1,44 & 10,05 & 52,15 & 35,89 & 4,22 & 4 & 4 \\
\hline Empatia & 0,00 & 0,96 & 11,48 & 56,46 & 31,10 & 4,18 & 4 & 4 \\
\hline $\begin{array}{l}\text { Zdolność przyznania się do błędu } \\
\text { przed współpracownikami czy pacjentami }\end{array}$ & 0,48 & 2,39 & 17,22 & 50,72 & 29,19 & 4,06 & 4 & 4 \\
\hline Aktywne słuchanie & 0,00 & 3,40 & 19,90 & 53,40 & 23,30 & 3,97 & 4 & 4 \\
\hline $\begin{array}{l}\text { Zachowanie dobrych relacji ze współpra- } \\
\text { cownikami }\end{array}$ & 2,87 & 1,91 & 16,75 & 57,89 & 20,57 & 3,91 & 4 & 4 \\
\hline $\begin{array}{l}\text { Radzenie sobie } \mathrm{z} \text { reklamacjami } \\
\text { składanymi przez pacjentów }\end{array}$ & 1,91 & 6,70 & 24,88 & 46,89 & 19,62 & 3,76 & 4 & 4 \\
\hline $\begin{array}{l}\text { Pozyskiwanie wiedzy od dystrybutorów } \\
\text { materiałów stomatologicznych }\end{array}$ & 1,44 & 6,70 & 27,27 & 45,93 & 18,66 & 3,74 & 4 & 4 \\
\hline Praca z dzieckiem-pacjentem & 6,70 & 7,18 & 19,62 & 40,19 & 26,32 & 3,72 & 4 & 4 \\
\hline Rozwiązywanie problemów & 0,48 & 4,81 & 37,50 & 42,31 & 14,90 & 3,66 & 4 & 4 \\
\hline Diagnozowanie problemów w gabinecie & 1,91 & 6,22 & 31,58 & 47,37 & 12,92 & 3,63 & 4 & 4 \\
\hline $\begin{array}{l}\text { Wykorzystywanie pozamedycznych } \\
\text { informacji od pacjentów do przekony- } \\
\text { wania ich do wyboru sposobu leczenia }\end{array}$ & 3,35 & 5,74 & 29,67 & 47,85 & 13,40 & 3,62 & 4 & 4 \\
\hline $\begin{array}{l}\text { Dostrzeganie odmiennych motywacji i } \\
\text { uzdolnień poszczególnych współpra- } \\
\text { cowników }\end{array}$ & 3,35 & 3,83 & 32,54 & 50,24 & 10,05 & 3,60 & 4 & 4 \\
\hline Zarządzanie finansami gabinetu & 4,33 & 8,17 & 33,17 & 39,90 & 14,42 & 3,52 & 4 & 4 \\
\hline $\begin{array}{l}\text { Umacnianie pewności siebie wśród } \\
\text { pracowników }\end{array}$ & 2,87 & 10,05 & 33,01 & 41,15 & 12,92 & 3,51 & 4 & 4 \\
\hline $\begin{array}{l}\text { Wskazanie najbardziej rentownych } \\
\text { pacjentów }\end{array}$ & 1,91 & 11,96 & 32,54 & 42,58 & 11,00 & 3,49 & 4 & 4 \\
\hline $\begin{array}{l}\text { Ustalanie standardów dla wykonywa- } \\
\text { nych przez pracowników zadań }\end{array}$ & 4,76 & 10,00 & 31,90 & 39,52 & 13,81 & 3,48 & 4 & 4 \\
\hline Mediacje w konflikcie & 3,35 & 7,18 & 38,28 & 40,19 & 11,00 & 3,48 & 4 & 4 \\
\hline $\begin{array}{l}\text { Nagradzanie skutecznych działań pra- } \\
\text { cowników }\end{array}$ & 4,76 & 11,02 & 30,14 & 42,11 & 11,96 & 3,45 & 4 & 4 \\
\hline Udzielanie rad pracownikom & 3,81 & 10,00 & 32,86 & 44,29 & 9,05 & 3,45 & 4 & 4 \\
\hline $\begin{array}{l}\text { Motywowanie pracowników do podno- } \\
\text { szenia kwalifikacji }\end{array}$ & 5,71 & 10,00 & 32,28 & 40,48 & 11,43 & 3,42 & 4 & 4 \\
\hline $\begin{array}{l}\text { Budowanie autorytetu osobistego przeło- } \\
\text { żonego }\end{array}$ & 6,28 & 7,25 & 39,61 & 37,68 & 9,18 & 3,36 & 3 & 3 \\
\hline $\begin{array}{l}\text { Wywieranie wpływu na decyzje rozmów- } \\
\text { ców }\end{array}$ & 2,87 & 11,48 & 41,63 & 36,84 & 7,18 & 3,34 & 3 & 3 \\
\hline
\end{tabular}




\begin{tabular}{|l|c|c|c|c|c|c|c|c|}
\hline Udzielanie konstruktywnej krytyki & 1,44 & 15,79 & 42,58 & 34,45 & 5,74 & 3,27 & 3 & 3 \\
\hline Delegowanie zadań na współpracowników & 8,10 & 13,81 & 38,10 & 30,95 & 9,05 & 3,19 & 3 & 3 \\
\hline $\begin{array}{l}\text { Nadzór i ocena zadań realizowanych } \\
\text { przez personel }\end{array}$ & 5,77 & 16,83 & 38,94 & 32,69 & 5,77 & 3,16 & 3 & 3 \\
\hline Identyfikowanie źródeł konfliktu w zespole & 9,13 & 16,35 & 35,58 & 33,65 & 5,29 & 3,10 & 3 & 3 \\
\hline Publiczne prezentacje & 14,42 & 17,29 & 28,37 & 29,33 & 11,00 & 3,04 & 4 & 3 \\
\hline $\begin{array}{l}\text { Konsekwentne karanie za pracę poniżej } \\
\text { możliwości }\end{array}$ & 12,50 & 34,62 & 37,98 & 9,62 & 5,29 & 2,61 & 3 & 3 \\
\hline
\end{tabular}

Zródło: opracowanie własne na podstawie przeprowadzonego badania.

Zestawienie pokazujące zróżnicowanie samooceny umiejętności interpersonalnych respondentów $\mathrm{z}$ uwzględnieniem ich stylu przywództwa przedstawia wykres 13.

Dentyści o Sylwetce A we wszystkich badanych obszarach (oprócz umiejętności pracy z dzieckiem i konsekwentnego karania pracowników za pracę poniżej możliwości) ocenili się wyżej, niż pozostałe grupy badanych.

Dentyści o Sylwetce C ocenili się lepiej niż dentyści o Sylwetce B we wszystkich zakresach, oprócz:

- umiejętności pozyskiwana wiedzy od przedstawicieli dystrybutorów materiałów stomatologicznych,

- pracy z dzieckiem-pacjentem,

- umiejętności wskazania najbardziej rentownych pacjentów gabinetu.

Jedynym obszarem, w którym dentyści o Sylwetce B ocenili się lepiej od pozostałych była umiejętność pracy z dzieckiem.

Konkludując, można powiedzieć, że dentystów o Sylwetce A (przedsiębiorców inicjatorów i realizatorów zmian) charakteryzuje - zgodnie z przeprowadzoną samooceną - wyższy poziom umiejętności interpersonalnych i intrapersonalnych na tle badanej grupy. Natomiast najniższe noty w zakresie omawianych umiejętności wystawili sobie dentyści o Sylwetce B (decydenci Druckera), a więc ta grupa, która w umiejętnościach stricte medycznych upatruje sukcesu gabinetu w przyszłości. 


\section{Wykres 13. Umiejętności interpersonalne a sylwetka respondenta}

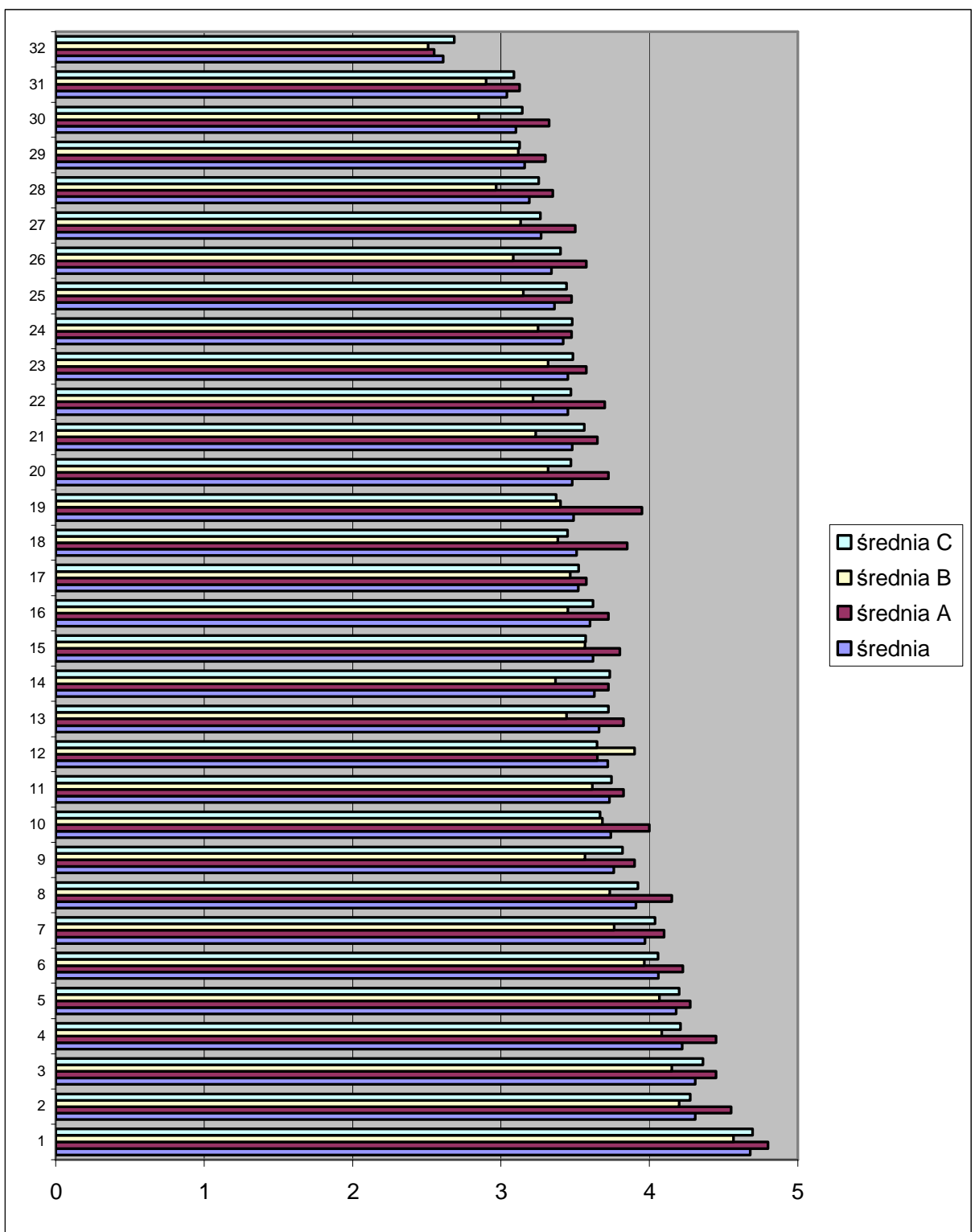

Źródło: opracowanie własne na podstawie przeprowadzonego badania.

Umiejętności i postawy: 1) Uczciwość wobec pacjentów, 2) Dostosowanie sposobu mówienia do możliwości pacjenta, 3) Utrzymywanie dobrych relacji z pacjentem w długim okresie, 4) Nawiązywanie dobrego kontaktu z pacjentem w trakcie pierwszej wizyty, 5) Zdolność wyczuwania emocji innych ludzi 6) Zdolność do przyznania się do błędu, 7) Umiejętność aktywnego słuchania, 8) Zachowanie dobrych relacji ze współpracownikami, 9) Radzenie sobie z reklamacjami składanymi przez pacjentów, 10) Pozyskiwanie wiedzy od przedstawicieli dystrybutorów materiałów stomatologicznych, 11) Umie- 
jętność jasnego i precyzyjnego komunikowania się, 12) Umiejętność pracy z dzieckiem-pacjentem, 13) Umiejętność rozwiązywania problemów, 14) Umiejętność diagnozowania problemów w gabinecie,

15) Wykorzystywanie pozamedycznych informacji od pacjentów do przekonywania ich do wyboru określonej opcji usługi, 16) Dostrzeganie odmiennych motywacji i uzdolnień poszczególnych członków personelu pomocniczego, 17) Zarządzanie finansami gabinetu, 18) Umacnianie pewności siebie wśród pracowników, 19) Wskazanie najbardziej rentownych pacjentów gabinetu, 20) Ustalanie standardów dla wykonywanych przez pracowników zadań, 21) Umiejętność mediacji, 22) Nagradzanie skutecznych działań pracowników, 23) Udzielanie rad pracownikom, 24) Motywowanie pracowników do podnoszenia kwalifikacji, 25) Budowanie autorytetu przełożonego, 26) Wywieranie wpływu na decyzje rozmówców, 27) Udzielanie konstruktywnej krytyki, 28) Delegowanie zadań na współpracowników, 29) Nadzór i ocena zadań realizowanych przez pracowników, 30) Identyfikowanie źródeł konfliktu w zespole pracowników, 31) Umiejętność publicznych prezentacji, 32) Konsekwentne karanie za pracę poniżej możliwości.

\subsection{SAMOOCENA W ZAKRESIE POSTAW PRORYNKOWYCH}

Do oceny postaw przedsiębiorczych lekarzy dentystów wykorzystano podejście funkcjonalne i zaproponowano ocenę: od ogólnej postawy zarządczej (związanej z podejmowaniem decyzji we wszystkich aspektach funkcjonowania gabinetu), przez postawy względem personelu po postawy względem pacjentów. W tabeli 87 przedstawione są wyniki samooceny lekarzy dentystów w zakresie działalności operacyjnej gabinetu stomatologicznego.

Tabela 87. Postawa lekarza dentysty w zarządzaniu gabinetem - badanie II

\begin{tabular}{|c|c|c|c|c|c|c|c|c|}
\hline \multirow[b]{2}{*}{ Postawa/ działanie w gabinecie } & \multicolumn{5}{|c|}{$\begin{array}{l}\text { Wskazania respondentów } \\
\text { (procent wskazań) }\end{array}$} & \multirow[b]{2}{*}{$\bar{x}$} & \multirow[b]{2}{*}{ Do } & \multirow[b]{2}{*}{ Me } \\
\hline & $\begin{array}{l}\text { nigdy } \\
\text { (1) }\end{array}$ & \begin{tabular}{c|} 
rzadko \\
(2)
\end{tabular} & $\begin{array}{l}\text { trudno } \\
\text { powie- } \\
\text { dzieć } \\
(3)\end{array}$ & $\begin{array}{l}\text { często } \\
\text { (4) }\end{array}$ & \begin{tabular}{|c|} 
zawsze \\
$(5)$
\end{tabular} & & & \\
\hline $\begin{array}{l}\text { Otwartość na nowe materiały i techniki } \\
\text { pracy i chętny udział w szkoleniach }\end{array}$ & 0,00 & 1,90 & 6,19 & 37,14 & 54,76 & 4,45 & 5 & 5 \\
\hline $\begin{array}{l}\text { Zwiększenie poziomu jakości obsługi } \\
\text { pacjentów należy traktować, jako inwes- } \\
\text { tycję w tworzenie lojalnych klientów }\end{array}$ & 1,90 & 2,86 & 5,71 & 45,24 & 44,29 & 4,27 & 4 & 4 \\
\hline $\begin{array}{l}\text { Wybór materiałów do pracy w gabinecie } \\
\text { jest warunkowany raczej jakością i mar- } \\
\text { ką, niż ceną }\end{array}$ & 1,44 & 1,91 & 12,92 & 42,11 & 41,63 & 4,21 & 4 & 4 \\
\hline $\begin{array}{l}\text { Przy podejmowaniu decyzji zarządczych } \\
\text { brane są pod uwagę sugestie pacjentów } \\
\text { związane z poprawą funkcjonowania } \\
\text { gabinetu }\end{array}$ & 4,33 & 3,85 & 25,48 & 50,96 & 15,38 & 3,69 & 4 & 4 \\
\hline $\begin{array}{l}\text { Stomatolog wiem najlepiej, jak powinien } \\
\text { funkcjonować gabinet }\end{array}$ & 8,10 & 11,90 & 41,90 & 34,29 & 3,81 & 3,14 & 3 & 3 \\
\hline $\begin{array}{l}\text { Z biznesowymi sprawami w prowadze- } \\
\text { niu gabinetu lekarz nie ma problemów }\end{array}$ & 6,73 & 22,12 & 34,13 & 25,96 & 11,06 & 3,13 & 3 & 3 \\
\hline $\begin{array}{l}\text { W codziennej pracy lekarz czuje, że bra- } \\
\text { kuje mu wiedzy biznesowej }\end{array}$ & 6,67 & 25,71 & 28,10 & 28,10 & 11,43 & 3,12 & $3 ; 4$ & 3 \\
\hline $\begin{array}{l}\text { Lekarz bierze udział w szkoleniach „nie- } \\
\text { medycznych” }\end{array}$ & 26,19 & 26,19 & 8,10 & 27,14 & 12,38 & 2,73 & 4 & 2 \\
\hline
\end{tabular}




\begin{tabular}{|l|c|c|c|c|c|c|c|c|}
\hline $\begin{array}{l}\text { W gabinecie jest opracowany plan } \\
\text { rozwoju (np. na najbliższe 2-3 lata) }\end{array}$ & 35,58 & 24,52 & 16,83 & 16,35 & 6,73 & 2,34 & 1 & 2 \\
\hline $\begin{array}{l}\text { Lekarz bierze udział w szkoleniach i kur- } \\
\text { sach, ale nie wprowadza nowych rozwią- } \\
\text { zań do swojej praktyki }\end{array}$ & 35,89 & 24,88 & 17,22 & 13,88 & 8,13 & 2,33 & 1 & 2 \\
\hline $\begin{array}{l}\text { Dążąc do obniżki kosztów w działaniu } \\
\text { gabinetu, lekarz decyduje się na zakup } \\
\text { tá́szych materiałów }\end{array}$ & 37,98 & 36,06 & 14,42 & 10,58 & 0,96 & 2,00 & 1 & 2 \\
\hline
\end{tabular}

Źródło: opracowanie własne na podstawie przeprowadzonego badania.

Biorąc pod uwagę myślenie i działanie lekarzy dentystów w biznesowym prowadzeniu spraw gabinetu, to ich samoocena w tym zakresie jest bardzo zróżnicowana - niemal w równych częściach wskazali, że nie mają z tym problemów, mają kłopoty, trudno im zająć stanowisko w tej sprawie. Podobnie głosy rozłożyły się w kwestii braku wiedzy pozamedycznej w prowadzeniu gabinetu (z większym naciskiem na brak takiej wiedzy - blisko $40 \%$ respondentów). Pomimo tak relatywnie niskiej samooceny $52,38 \%$ badanych nie szkoli się w zakresie pozamedycznych obszarów funkcjonowania gabinetu, wobec 39,52\%, którzy to robią (w tym 12,38\% bardzo często).

Najwyżej badani ocenili swoją otwartość na nowe materiały i techniki pracy oraz udział w szkoleniach - 91,90\% wskazań. Otwartość na innowacje jest symptomem przedsiębiorczości (potwierdza to wysoki odsetek osób, które wprowadzają nowe rozwiązania do pracy w gabinecie), a aktywność w zakresie uczestnictwa w szkoleniach można potraktować jako praktyczną realizację gabinetu jako organizacji uczącej się (co jest zbieżne $\mathrm{z}$ wynikami badania I). Przeszło połowa badanych wskazała, że najczęściej przy wyborze materiałów do pracy w gabinecie kieruje się raczej ich jakością i marką, niż ceną, co znalazło potwierdzenie w innym obszarze $-37,98 \%$ respondentów stwierdziło, że nigdy nie decyduje się na zakup tańszych materiałów stomatologicznych, dążąc do obniżki kosztów w funkcjonowaniu gabinetu, a 36,06\% że robi to czasami. Nieco ponad jeden procent badanych stwierdził, że robi to zawsze ${ }^{27}$. Zwiększenie jakości obsługi pacjentów wg 89,53\% respondentów należy traktować, jako inwestycję w tworzenie lojalnych klientów gabinetu, co można uznać za postawę świadomego full time marketera. Przeszło połowa badanych zadeklarowała, że wspiera personel pomocniczy w podnoszeniu kwalifikacji (wobec 6,19\%, którzy zadeklarowali, że nie robią tego nigdy).

Uwzględniając przyjętą typologię sylwetek (por. wykres 14), można wskazać, że dentyści o Sylwetce A w codziennym prowadzeniu spraw gabinetu

\footnotetext{
${ }^{27}$ Odpowiedzi te mogą być o tyle zastanawiające, że na rynku można wskazać materiały o bardzo zbliżonych parametrach, a zdecydowanie innej cenie. Dlatego trudno powiedzieć, czy zadeklarowane odpowiedzi można odnieść do racjonalnych zachowań rynkowych stomatologów.
} 
w obszarze pozamedycznym zdecydowanie, jako ważniejsze, niż pozostali respondenci, traktują kwestie:

- zwiększenia jakości obsługi pacjentów, jako inwestycji w tworzenie lojalnych klientów gabinetu,

- uwzględniania opinii pacjentów związanych z poprawą jakości obsługi przy podejmowaniu decyzji dotyczących zmian $w$ funkcjonowaniu gabinetu,

- udziału w szkoleniach pozwalających na poprawę funkcjonowania gabinetu w pozamedycznych obszarach,

- przygotowania planu rozwoju gabinetu,

co wyraźnie pokazuje ich proklientowską orientację.

Natomiast niżej, niż pozostali badani ocenili się w zakresie:

- trwania na stanowisku, że jako specjaliści zawsze wiedzą lepiej, jak powinien funkcjonować gabinet;

- odczuwania braku wiedzy pozamedycznej (np. związanej z efektywną komunikacją z pacjentem) w codziennej pracy,

- dążenia do obniżki kosztów przez zakup tańszych materiałów, co jest również potwierdzeniem ich orientacji na klienta w perspektywie biznesowej funkcjonowania gabinetu.

Respondenci o Sylwetce B we wszystkich obszarach ocenili się poniżej wskazań respondentów o Sylwetce $\mathrm{C}$, $\mathrm{z}$ wyjątkiem jednego obszaru: poczucia braku wiedzy w zakresie pozamedycznych aspektów funkcjonowania gabinetu (w tym aspekcie była to najniższa samoocena badania), co potwierdza, że dentyści o Sylwetce B w najmniejszym stopniu realizują orientację rynkową w prowadzeniu swoich gabinetów. Wskazuje to na ich niski potencjał w kreowaniu przewagi konkurencyjnej gabinetu $\mathrm{z}$ wykorzystaniem pozamedycznych instrumenttów. Tym samym można postawić tezę: że ich postawa jest bliższa administrowaniu niż zarządzaniu (nawet wg uproszczonego podejścia P.F. Druckera). 
Wykres 14. Postawy stomatologów w zarządzaniu gabinetem a typ sylwetki respondenta

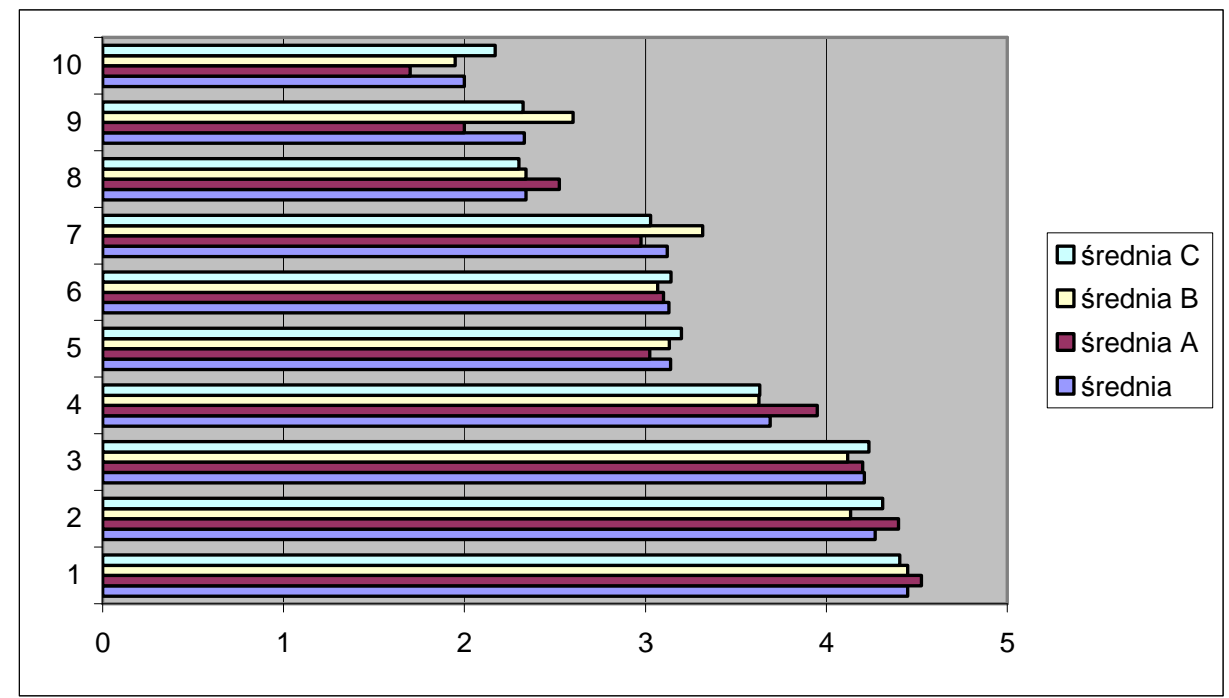

Źródło: opracowanie własne na podstawie przeprowadzonego badania.

Postawy: 1) Otwartość na nowe materiały i techniki pracy (co wpływa na udział w szkoleniach i kursach), 2) Przekonanie, że zwiększenie jakości obsługi pacjentów należy traktować jako inwestycję w tworzenie lojalnych klientów gabinetu, 3) Wybór materiałów do pracy w gabinecie uwarunkowany jest raczej ich jakością i marka, niż ceną, 4) Uwzględnianie przy podejmowaniu decyzji zarządczych sugestii pacjentów związanych z poprawą funkcjonowania gabinetu, 5) Przekonanie, że stomatolog wie najlepiej jak powinien funkcjonować gabinet, 6) Dentysta nie ma problemu z biznesowymi sprawami w prowadzeniu gabinetu, 7) $\mathrm{W}$ codziennej pracy stomatologowi brakuje wiedzy pozamedycznej (np. z zakresu zarządzania relacjami z pacjentami), 8) W gabinecie jest opracowywany plan rozwoju, 9) Stomatolog bierze udział w szkoleniach, ale nie wprowadza nowych rozwiązań do swojej pracy, 10) W dążeniu do obniżki kosztów w funkcjonowaniu gabinetu dentysta decyduje się na zakup tańszych materiałów stomatologicznych.

Pamiętając, że za kreowanie pozytywnych relacji na płaszczyźnie gabinet - pacjent odpowiadają właściwie wszyscy pracownicy gabinetu, warto podkreślić, że rolą stomatologa-przełożonego jest tworzenie takich warunków pracy, aby personel był z nich zadowolony (zgodnie z teorią Y McGregora), gdyż przyczyni się to do zwiększenia jego zaangażowania (por. punkt 3.1. w IV rozdziale), a w konsekwencji do utrzymania pozytywnych relacji z pacjentami i zatrzymania ich $w$ gabinecie. Poczucie zadowolenia personelu (w tym również stomatologa) związane z zaspokojeniem potrzeb w miejscu pracy, staje się warunkiem sine qua non zadowolenia pacjenta (por rysunek 7). $\mathrm{Z}$ drugiej strony zadowolenie pacjentów może być inspiracją do dalszej, lepszej pracy i źródłem satysfakcji personelu gabinetu (co pozwala zatrzymać pracownika w gabinecie na dłu- 
żej). Powstaje swoisty „krąg satysfakcji”, który przyczynia się do umacniania więzi na płaszczyźnie: gabinet - jego klienci (wewnętrzni i zewnętrzni). ${ }^{28}$

Rysunek 7. Związek między zatrzymaniem klienta a satysfakcją pracownika

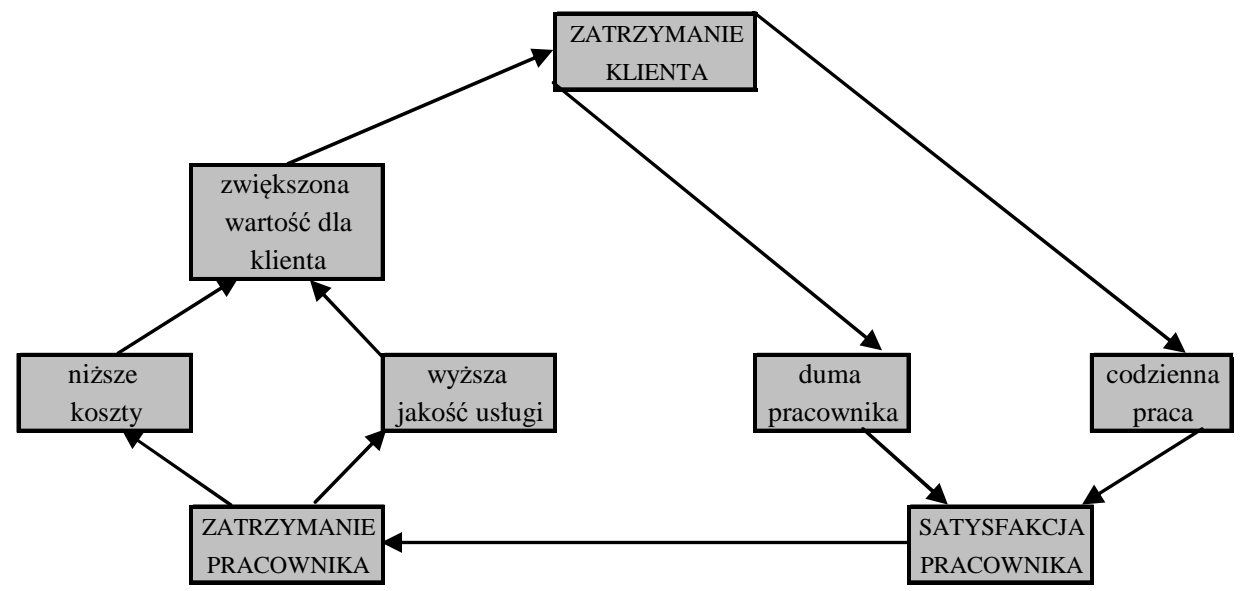

Źródło: Bain and Company w: Clark M., Payne A., Customer Retention: Does Employee Retention Hold a Key to Success, Marketing Education Group Proceedings 1993, nr 1 za: Otto J., Marketing relacji. Koncepcja i stosowanie”, Wydawnictwo C. H. Beck, Warszawa 2001, s. 193.

Szczegółowa samoocena postaw dentystów względem personelu pomocniczego $\mathrm{w}$ gabinecie przedstawiona jest $\mathrm{w}$ tabeli 88 . Zachowanie dobrych relacji ze współpracownikami (por. tabela 86 ) dla $66,51 \%$ badanych było ważne lub bardzo ważne wobec niespełna 5\%, dla których nie było to istotne (w ogóle lub mało). Stomatologom zależy, aby personel pomocniczy był dla nich partnerem w obsłudze pacjentów $(85,24 \%$ wskazań: zawsze lub często wobec $2,86 \%$ - nigdy) i dlatego $72,60 \%$ badanych podejmując decyzje, dotyczące pozamedycznych aspektów funkcjonowania gabinetu, bierze pod uwagę opinie personelu (wobec przeszło 13\%, którzy nigdy tego nie robią lub robią czasami). $\mathrm{Z}$ drugiej strony $28,57 \%$ dentystów zadeklarowało, że zawsze personel traktuje jak podwładnych, a 37,14\% - czasami, wobec 3,33\%, którzy twierdzą, że tego nie robią. $\mathrm{Z}$ tego względu nie można mówić o partycypacji personelu pomocniczego w zarządzaniu gabinetem (jedynie o - często zdecydowanym - głosie doradczym w sprawach organizacyjnych).

Badani zadeklarowali, że zależy im, aby personel podnosił swoje kwalifikacje był to priorytet wśród analizowanych aspektów - 85,17\% wskazań; co przejawia się w:

\footnotetext{
${ }^{28}$ Szerzej na ten temat w: Bukowska-Piestrzyńska A., Organizacja ... op. cit.
} 
- zachęcaniu personelu do udziału w szkoleniach (włącznie z udzielaniem czasu wolnego na ich odbycie), wskazywaniu literatury z zakresu obsługi pacjenta $-62,85 \%$ badanych robi to zawsze lub często wobec $12,86 \%$, którzy nie robią tego nigdy;

- finansowym wspieraniu personelu pomocniczego w podnoszeniu kwalifikacji $-54,88 \%$ badanych zadeklarowało, że robi to zawsze lub często (wobec $11,54 \%$, którzy nigdy tego nie robią).

Ponadto z tabeli 86 wynika, że w zakresie umiejętności motywowania personelu tylko co dziesiąty badany ocenił się bardzo dobrze, a 40,48\% - dobrze, wobec $15,71 \%$ dentystów, którzy uznali, że nie posiadają takich umiejętności lub posiadają je w niewielkim zakresie. Blisko połowa badanych czuje się dobrze w kierowaniu współpracownikami, ale dla $38,46 \%$ jest to wyzwanie, gdyż czują się mało pewnie w tym, co robią - oceniają swoje umiejętności interpersonalne $\mathrm{i}$ intrapersonalne jako niewystarczające.

Jedna trzecia badanych nie angażuje się w sprawy, którymi powinien zajmować się personel pomocniczy, a 52,63\% badanych deklaruje, że personel z każdym problemem decyzyjnym zwraca się do stomatologa, jako do przełożonego. W przypadku przeszło połowy badanych gabinetów trudno mówić o delegowaniu uprawnień do podejmowania decyzji na personel pomocniczy $-\mathrm{z}$ jednej strony może to wynikać z postawy stomatologa, który chce mieć pod kontrolą funkcjonowanie personelu, a $\mathrm{z}$ drugiej - $\mathrm{z}$ braku samodzielności pracowników. Dentyści ocenili się w tym zakresie relatywnie nisko (por. tabela 86), gdyż $40 \%$ deklaruje, że potrafi delegować zadania, $38,1 \%$, że nie wie, czy potrafi, a pozostali ocenili się słabo lub uznali, że nie posiadają takiej umiejętności w ogóle.

Swoje umiejętności nagradzania skutecznych działań pracowników (por. tabela 86) lekarze ocenili w większości dobrze i bardzo dobrze - 54,07\% wskazań, a 30\% - średnio (co różni wyniki badania I i II). Przejawia się to:

- chwaleniem za dobrą realizację zadań - 80,98\% respondentów robi to zawsze lub często (wobec 5,23\%, którzy nie robią tego lub robią rzadko),

- nagradzaniu za jakość pracy - 93,64\% wskazań (wobec 4,23\%, którzy nie robią tego w ogóle lub robią rzadko),

- uzależnianiu nagród od stażu pracy - 22,12\% wobec 53,37\%, którzy nie robią tego lub robią rzadko. 
Tabela 88. Postawa lekarza dentysty w kierowaniu personelem - badanie II

\begin{tabular}{|c|c|c|c|c|c|c|c|c|}
\hline \multirow[b]{2}{*}{ Postawa/ działanie wobec personelu } & \multicolumn{5}{|c|}{$\begin{array}{l}\text { Wskazania respondentów } \\
\text { (procent wskazań) }\end{array}$} & \multirow[b]{2}{*}{$\bar{x}$} & \multirow[b]{2}{*}{ Do } & \multirow[b]{2}{*}{ Me } \\
\hline & $\begin{array}{c}\text { nigdy } \\
\text { (1) }\end{array}$ & $\begin{array}{c}\text { rzadko } \\
(2)\end{array}$ & \begin{tabular}{|c|} 
trudno \\
powie- \\
dzieć \\
$(3)$
\end{tabular} & $\begin{array}{c}\text { często } \\
\text { (4) }\end{array}$ & $\begin{array}{c}\text { zawsze } \\
(5)\end{array}$ & & & \\
\hline $\begin{array}{l}\text { Dentyście zależy, aby personel podnosił } \\
\text { kwalifikacje zawodowe }\end{array}$ & 1,44 & 4,31 & 9,09 & 40,19 & 44,98 & 4,23 & 4 & 4 \\
\hline $\begin{array}{l}\text { Personel jest partnerem dentysty w obsłu- } \\
\text { dze pacjentów }\end{array}$ & 2,86 & 2,38 & 9,52 & 50,48 & 34,76 & 4,12 & 4 & 4 \\
\hline $\begin{array}{l}\text { Lekarz chwali personel za dobrą realizację } \\
\text { zadań }\end{array}$ & 1,90 & 3,33 & 13,81 & 50,48 & 30,48 & 4,04 & 4 & 4 \\
\hline $\begin{array}{l}\text { Nagrody w gabinecie zależą od jakości } \\
\text { pracy pracownika }\end{array}$ & 5,26 & 6,70 & 24,40 & 37,80 & 25,84 & 3,72 & 4 & 4 \\
\hline $\begin{array}{l}\text { Lekarz wspiera personel w podnoszeniu } \\
\text { kwalifikacji }\end{array}$ & 6,19 & 6,67 & 24,29 & 35,71 & 27,14 & 3,71 & 4 & 4 \\
\hline $\begin{array}{l}\text { Podejmując decyzje, dotyczące spraw } \\
\text { gabinetu (ale nie leczenia), lekarz bierze pod } \\
\text { uwagę sugestie personelu }\end{array}$ & 6,25 & 7,21 & 13,94 & 56,25 & 16,35 & 3,69 & 4 & 4 \\
\hline $\begin{array}{l}\text { Dentysta czuje się dobrze w kierowaniu } \\
\text { pracownikami }\end{array}$ & 4,31 & 12,44 & 34,93 & 37,32 & 11,00 & 3,38 & 4 & 3 \\
\hline $\begin{array}{l}\text { Personel z każdym problemem decyzyj- } \\
\text { nym zwraca się do dentysty }\end{array}$ & 6,70 & 15,79 & 24,88 & 39,71 & 12,92 & 3,36 & 4 & 4 \\
\hline $\begin{array}{l}\text { Lekarz wspiera finansowo personel } \\
\text { pomocniczy w podnoszeniu kwalifikacji }\end{array}$ & 11,54 & 15,87 & 19,71 & 32,21 & 20,67 & 3,35 & 4 & 4 \\
\hline $\begin{array}{l}\text { Dentysta angażuje się w sprawy/ decyz- } \\
\text { je, którymi po-winien zajmować się perso- } \\
\text { nel pomocniczy }\end{array}$ & 10,00 & 24,76 & 26,67 & 31,43 & 7,14 & 3,01 & 4 & 3 \\
\hline $\begin{array}{l}\text { Kierowanie personelem jest dla lekarza } \\
\text { wyzwaniem }\end{array}$ & 13,94 & 21,63 & 25,96 & 29,33 & 9,13 & 2,98 & 4 & 3 \\
\hline $\begin{array}{l}\text { Dentysta wskazuje personelowi (nawet naj- } \\
\text { mniejsze) niedociągnięcia w realizacji zadań }\end{array}$ & 7,14 & 30,95 & 28,10 & 28,57 & 5,24 & 2,94 & 2 & 3 \\
\hline $\begin{array}{l}\text { Dentysta jest osobą emocjonalną i okazuje } \\
\text { emocje (również negatywne) pracownikom }\end{array}$ & 18,57 & 32,38 & 21,90 & 20,95 & 6,19 & 2,64 & 2 & 2 \\
\hline Premie zależą od stażu pracy personelu & 29,33 & 24,04 & 24,52 & 18,75 & 3,37 & 2,43 & 1 & 2 \\
\hline $\begin{array}{l}\text { Dentysta personel pomocniczy traktuje, } \\
\text { jak swoich podwładnych }\end{array}$ & 28,57 & 37,14 & 16,19 & 14,76 & 3,33 & 2,27 & 2 & 2 \\
\hline
\end{tabular}

Źródło: opracowanie własne na podstawie przeprowadzonego badania.

Uwzględniając profil sylwetki dentysty (por. wykres 15), ponownie można zauważyć, że również w kierowaniu personelem lekarze dentyści o Sylwetce A wskazywali bardziej zdecydowane odpowiedzi, niż pozostali. 
Wykres 15. Postawy stomatologów w kierowaniu personelem a typ sylwetki respondenta

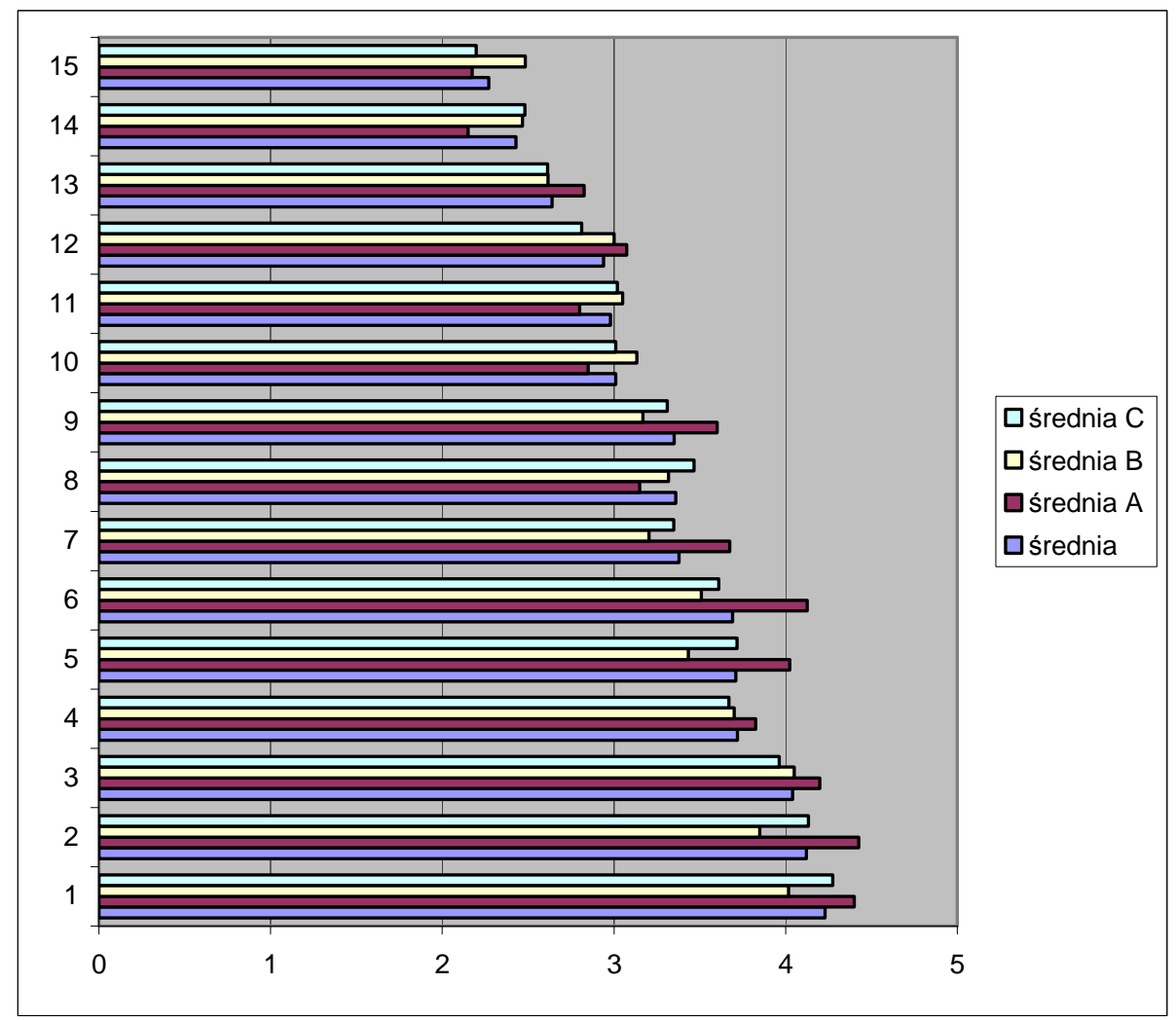

Źródło: opracowanie własne na podstawie przeprowadzonego badania.

Postawa dentysty w kierowaniu personelem: 1) Dentyście zależy, aby personel podnosił swoje kwalifikacje, 2) Personel pomocniczy jest dla dentysty partnerem w obsłudze pacjenta, 3) Personel jest chwalony za dobrą realizację zadań, 4) Nagrody dla personelu są uzależnione od jakości pracy, 5) Dentysta wspiera personel w podnoszeniu kwalifikacji np. werbalnie, udzielając wolnego czasu na naukę, 6) Dentysta, podejmując niemedyczne decyzje w gabinecie, bierze pod uwagę sugestie personelu, 7) Dentysta czuje się dobrze w roli przełożonego, 8) Personel pomocniczy z każdym problemem zwraca się do stomatologa, 9) Dentysta wspiera finansowo personel w podnoszeniu kwalifikacji, 10) Dentysta angażuje się w sprawy, za które odpowiada personel, 11) Kierowanie personelem jest dla dentysty wyzwaniem (np. jest za mało stanowczy, nie potrafi egzekwować obowiązków), 12) Stomatolog wskazuje personelowi wszystkie niedociągnięcia, 13) Dentysta jest osobą emocjonalną i okazuje emocje, 14) nagrody w gabinecie zależą od stażu pracy, 15) Dentysta traktuje personel, jak podwładnych.

Analiza odpowiedzi dentystów o Sylwetce A prowadzi do wniosku, że nie tylko dobrze się czują w kierowaniu personelem (nie odczuwają tego, jako wymagającego zadania), ale są otwarci na personel i tworzą warunki pracy sprzyjające zaangażowaniu personelu; np.: 
- personel pomocniczy z prośbą o podjęcie decyzji zwraca się do nich stosunkowo rzadko; ponadto nie angażują się w sprawy, którymi powinien zajmować się personel pomocniczy,

- personel traktują, jak partnerów, a nie podwładnych,

- przy nagradzaniu pracowników biorą pod uwagę jakość ich pracy,

- koncentrują się na postawach podwładnych - wspierają personel w podnoszeniu kwalifikacji (zarówno werbalnie, jak i finansowo).

Ponadto jak wynika $\mathrm{z}$ danych przedstawionych na wykresie 10 - poprawę komunikacji między pracownikami traktują, jako ważne wyzwanie, stojące przed współczesnym gabinetem stomatologicznym. Tym samym ich potencjał w kreowaniu przewagi konkurencyjnej gabinetu dzięki odpowiedniemu wykorzystywaniu zasobu ludzkiego można ocenić relatywnie wysoko.

Dentyści o Sylwetce B traktują personel raczej jako podwładnych (nie mają nawyku konsultacji swoich kroków ze współpracownikami), niż partnerów. W roli przełożonego personelu czują się najmniej komfortowo ze wszystkich badanych grup, m. in. ze względu na intrapersonalne ograniczenia traktują kierowanie personelem, jako wyzwanie; co przejawia się tym, że w wielu obszarach ocenili się zdecydowanie słabiej, niż pozostali, np. w zakresie: troski o podnoszenie kwalifikacji przez personel (przypomnijmy, że swoje umiejętności stricte zawodowe ta grupa respondentów oceniła najniżej na tle pozostałych dwóch grup - por. wykres 12). Dentyści o Sylwetce B w swojej ocenie nie są dobrymi przełożonymi (co przejawia się m. in. brakiem zaufania do współpracowników i ciągłym ich nadzorowaniem). Przejawy elastyczności w działaniu pracowników są na ogół tłumione, gdyż dentysta o Sylwetce B ceni sobie posłuszeństwo. Sytuacja taka może doprowadzić do bezwolności personelu i ograniczania się wyłącznie do wykonywania poleceń przełożonego (co może przyczynić się do spadku zaangażowania personelu i w konsekwencji zmniejszenia zadowolenia pacjentów z kontaktów z personelem gabinetu).

Dentyści o Sylwetce C relacje z podwładnymi mają zadowalające. Najwyżej spośród badanej grupy ocenili się w zakresie jednego czynnika: ,personel pomocniczy z każdym problemem decyzyjnym zwraca się do mnie", co może świadczyć o małej samodzielności personelu z jednej strony, a z drugiej - o wykreowaniu takich warunków pracy, w których wszystkie decyzje podejmuje przełożony (w praktyce choć dopuszcza do głosu podwładnych, to zawsze do niego należy decydujący głos). Dentysta stara się wykorzystywać cały potencjał podwładnego (dlatego dąży do rozwoju personelu) dla dobra gabinetu (a nie pracownika). 
Ostatnia kwestia, która była przedmiotem samooceny dentystów, to ich postawa względem pacjentów. W tabeli 89 przedstawione są wskazania respondentów dotyczące różnych aspektów relacji z pacjentami.

Tabela 89. Postawy lekarzy dentystów w kontaktach z pacjentami - badanie II

\begin{tabular}{|c|c|c|c|c|c|c|c|c|}
\hline \multirow{2}{*}{$\begin{array}{c}\text { Postawa/ } \\
\text { działanie } \\
\text { wobec pacjentów }\end{array}$} & \multicolumn{5}{|c|}{$\begin{array}{l}\text { Wskazania respondentów } \\
\text { (procent wskazań) }\end{array}$} & \multirow[b]{2}{*}{$\bar{x}$} & \multirow[b]{2}{*}{ Do } & \multirow[b]{2}{*}{ Me } \\
\hline & $\begin{array}{l}\text { nigdy } \\
\text { (1) }\end{array}$ & $\begin{array}{c}\text { rzadko } \\
(2)\end{array}$ & \begin{tabular}{|c} 
trudno \\
powie- \\
dzieć \\
$(3)$
\end{tabular} & \begin{tabular}{|c|} 
często \\
$(4)$
\end{tabular} & $\begin{array}{c}\text { zawsze } \\
(5)\end{array}$ & & & \\
\hline $\begin{array}{l}\text { Zwiększenie jakości obsługi pacjentów } \\
\text { należy traktować, jako inwestycję w } \\
\text { tworzenie lojalnych klientów gabinetu }\end{array}$ & 1,90 & 2,86 & 5,71 & 45,24 & 44,29 & 4,27 & 4 & 4 \\
\hline $\begin{array}{l}\text { Lekarz informuje pacjenta przed rozpo- } \\
\text { częciem leczenia o przewidywanym } \\
\text { koszcie zabiegu }\end{array}$ & 0,95 & 4,29 & 9,05 & 40,00 & 45,71 & 4,25 & 5 & 4 \\
\hline $\begin{array}{l}\text { Dla pacjentów najważniejszy jest sposób } \\
\text { traktowania przez personel }\end{array}$ & 0,48 & 2,86 & 15,71 & 48,57 & 32,38 & 4,10 & 4 & 4 \\
\hline $\begin{array}{l}\text { Z pacjentem lekarz rozmawia „twarzą } \mathrm{w} \\
\text { twarz” przed rozpoczęciem zabiegu, a nie } \\
\text { w trakcie }\end{array}$ & 2,38 & 7,14 & 15,24 & 32,86 & 42,38 & 4,06 & 5 & 4 \\
\hline $\begin{array}{l}\text { W gabinecie są wdrażane zmiany oraz } \\
\text { ulepszenia w zakresie obsługi }\end{array}$ & 0,48 & 3,33 & 13,33 & 57,62 & 25,24 & 4,04 & 4 & 4 \\
\hline $\begin{array}{l}\text { Pacjenci nie mają problemów z dodzwo- } \\
\text { nieniem się do gabinetu }\end{array}$ & 4,29 & 10,95 & 13,33 & 40,95 & 30,48 & 3,82 & 4 & 4 \\
\hline $\begin{array}{l}\text { Dla pacjentów najważniejsze jest wyposa- } \\
\text { żenie gabinetu i materiały, jakimi dentysta } \\
\text { pracuje }\end{array}$ & 4,29 & 25,24 & 28,10 & 33,81 & 8,57 & 3,17 & 4 & 3 \\
\hline $\begin{array}{l}\text { Lekarz jest osobą emocjonalną i okazuje } \\
\text { emocje pacjentom }\end{array}$ & 20,48 & 34,76 & 23,33 & 17,62 & 3,81 & 2,50 & 2 & 2 \\
\hline $\begin{array}{l}\text { Pacjenci otrzymują od dentysty maila/ } \\
\text { kartkę z życzeniami świątecznymi }\end{array}$ & 62,86 & 17,14 & 7,62 & 5,71 & 6,67 & 1,76 & 1 & 1 \\
\hline $\begin{array}{l}\text { Za przyprowadzenie nowego pacjenta obec- } \\
\text { ny otrzymuje rabat w trakcie kolejnej wizyty }\end{array}$ & 72,38 & 17,62 & 4,76 & 4,76 & 0,48 & 1,43 & 1 & 1 \\
\hline
\end{tabular}

Źródło: opracowanie własne na podstawie przeprowadzonego badania.

Jako punkt wyjścia do analizy należy przyjąć deklaracje 89,53\% respondentów dla których zwiększenie jakości obsługi należy traktować, jako inwestycję w tworzenie lojalnych klientów gabinetu (wobec 1,9\%, którzy się nie zgodzili z tym stanowiskiem). Dentyści zdają sobie sprawę, że dla pacjentów najważniejszy jest sposób traktowania przez personel gabinetu - 80,95\% (wobec 3,34\% - że nigdy lub czasami) i :

- 82,86\% badanych zadeklarowało, że w gabinecie wdrażane są ulepszenia w zakresie poprawy obsługi pacjenta (wobec $3,81 \%$ wskazań, że nie lub czasami), 
- $71,743 \%$ zadeklarowało, że pacjenci nie mają problemu z dodzwonieniem się do gabinetu,

- w zakresie komunikacji podejmowane są działania:

- w 85,71\% przypadków (zawsze lub często) pacjent jest informowany przed rozpoczęciem leczenia o jego przewidywanym koszcie;

- w 75,24\% przypadków rozmowa z pacjentem odbywa się „twarzą w twarz" przed rozpoczęciem leczenia (a nie, gdy pacjent leży na fotelu).

Warto zauważyć, że w gabinetach nie są (80,0\% wskazań) wysyłane kartki, maile z życzeniami do pacjentów (robi tak tylko 6,67\% badanych), a mógłby to być jeden $\mathrm{z}$ elementów utrzymywania pozytywnych relacji $\mathrm{z}$ pacjentami (w ramach obsługi po zakończonym leczeniu).

Uwzględniając typ sylwetki respondentów (por. wykres 16) można stwierdzić, że dentyści o Sylwetce A - częściej niż pozostali są przekonani, że zwiększenie jakości obsługi pacjentów to inwestycja w długookresowe relacje z pacjentami i dlatego przykładają wagę do wyposażenia gabinetu, a także wdrażają zmiany w zakresie poprawy jakości obsługi (np. wysyłając maile z życzeniami okolicznościowymi; dbając o to, by pacjenci nie mieli problemu z dodzwonieniem się do gabinetu).

Dentyści Sylwetce B byli najmniej przekonani co do tego, że zwiększenie jakości obsługi to inwestycja w przyszłość gabinetu, a także do tego, że dla pacjentów najważniejszy jest sposób traktowania ich przez personel. Niemniej jednak to oni częściej, niż pozostali informowali pacjentów o przewidywanym koszcie leczenia.

Dentyści o Sylwetce C zadeklarowali świadomość większą, niż pozostałe typy sylwetek, co to tego, że dla pacjentów najważniejszy jest sposób traktowania przez personel, ale w konkretnych zachowaniach proklientowskich ocenili się niżej, niż pozostali badani (np. rzadziej rozmawiają z pacjentem „twarzą w twarz" przed rozpoczęciem leczenia i informują pacjentów o przewidywanym koszcie usługi). 
Wykres 16. Postawy stomatologów w kontaktach z pacjentami a typ sylwetki respondenta

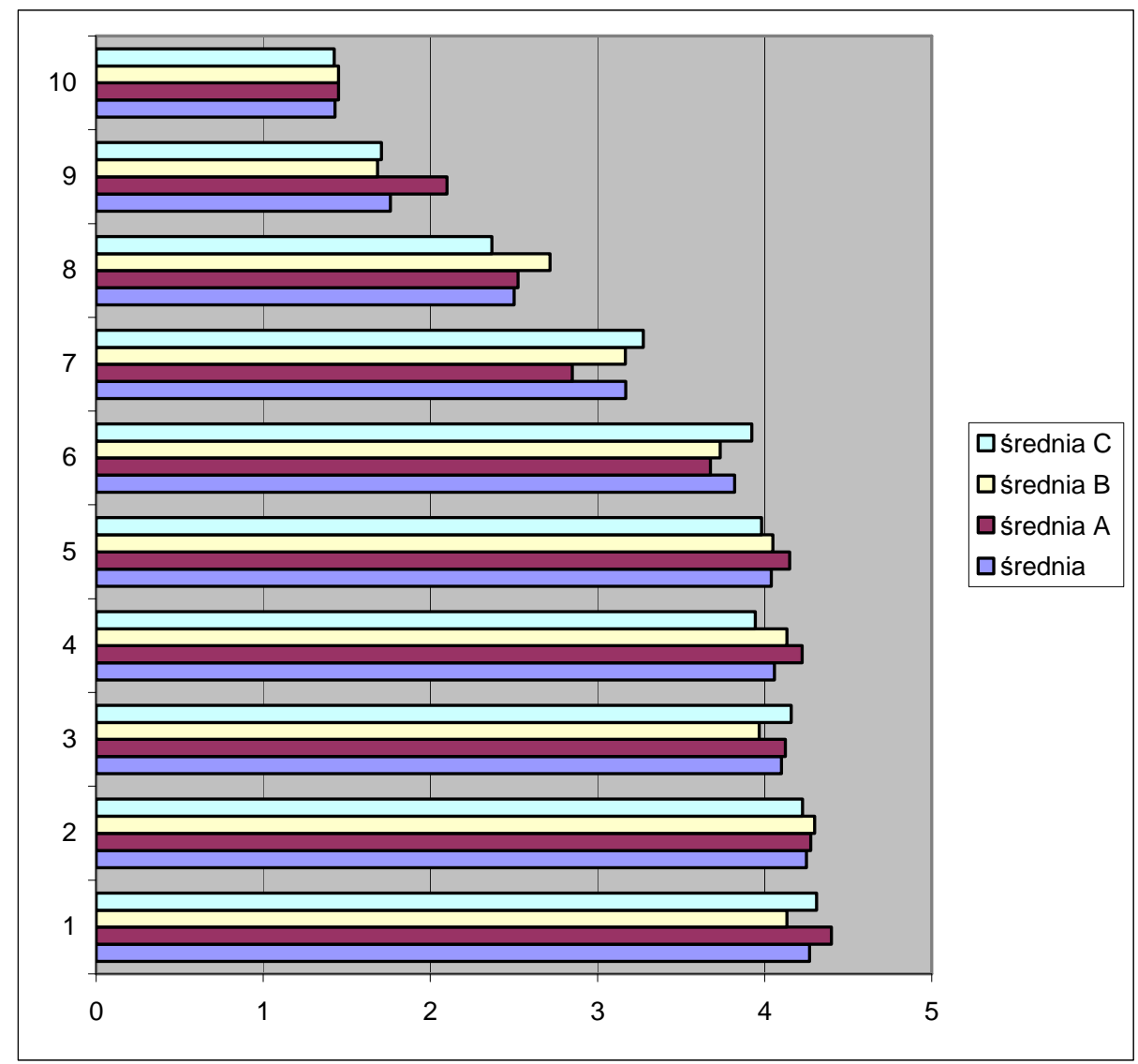

Źródło: opracowanie własne na podstawie przeprowadzonego badania.

Postawy respondentów wobec pacjentów: 1) Zwiększenie poziomu jakości obsługi pacjentów należy traktować, jako inwestycję w tworzenie lojalnych klientów gabinetu, 2) dentysta informuje pacjenta o przewidywanym koszcie przed rozpoczęciem leczenia, 3) Dentysta uważa, że dla pacjentów najważniejszy jest sposób traktowania przez personel, 4) Stomatolog z pacjentem rozmawia „twarzą w twarz" przed rozpoczęciem zabiegu (a nie gdy leży już na fotelu), 5) W gabinecie są wdrażane zmiany oraz ulepszenia $\mathrm{w}$ zakresie obsługi pacjenta, 6) W gabinecie zawsze ktoś odbiera telefon, 7) Dentysta uważa, ze dla pacjentów najważniejsze jest wyposażenie gabinetu i materiały, jakimi dentysta pracuje, 8) Dentysta jest osobą emocjonalną i okazuje emocje pacjentom, 9) Dentysta wysyła pacjentom kartki/maile z okazji świąt, 10) Dentysta udziela pacjentowi rabatu w trakcie wizyty za przyprowadzenie nowego pacjenta.

Reasumując, dentyści o Sylwetce A koncentrując się na instrumentach z zakresu relacji, tworzą $\mathrm{w}$ swoich gabinetach warunki najbardziej przyjazne pacjentom; tym samym można o nich powiedzieć, że dostrzegają w pozamedycznych działaniach potencjał do kreowania przewagi konkurencyjnej gabinetu (przejawiają Kirznerowską czujność). Natomiast dentyści o Sylwetce C, mając świado- 
mość oczekiwań pacjentów co do sposobu traktowania ich przez personel gabinetu, nie wykorzystują możliwości z zakresu komunikacji, aby podnosić poziom obsługi swoich klientów. Najmniej proklientowską postawę prezentują lekarze o Sylwetce B, którzy przede wszystkim w stricte medycznej działalności upatrują esencję funkcjonowania gabinetu stomatologicznego.

\section{WIEDZA AKADEMICKA \\ A DZIAŁANOŚĆ RYNKOWA DENTYSTÓW}

W wielu obszarach stricte biznesowego działania gabinetu (np. podejmowania działań marketingowych, zbierania danych o konkurentach) dentyści ocenili swoje umiejętności stosunkowo nisko, pomimo że przeszło połowa respondentów pracuje w zawodzie dłużej niż 15 lat (i można byłoby oczekiwać, że praktyka działania wpłynęła na ich umiejętności). Prawie $40 \%$ respondentów uznało, że brakuje im wiedzy pozamedycznej (np. z zakresu efektywnej komunikacji czy zarządzania relacjami z pacjentami) w codziennej pracy zawodowej. Badani widzą rosnącą rolę własnych umiejętności ${ }^{29}$ w biznesowym funkcjonowaniu gabinetu, ale sami w niewielkim stopniu wpływają na podniesienie ich poziomu przeszło 1/4 badanych nigdy nie brała udziału w szkoleniu z zakresu biznesowego funkcjonowania gabinetu, a kolejna czwarta część respondentów rzadko (tj. jeden czy dwa razy); tylko 12,38\% badanych zadeklarowało, że bierze udział w tego typu szkoleniach (por. tabela 87). Dlatego jako ciekawe poznawczo należy uznać wskazania respondentów w zakresie oczekiwań w stosunku do uczelni medycznych (por. tabela 90).

Przeszło $80 \%$ respondentów uznało, że uczelnie medyczne powinny kłaść większy nacisk na kształtowanie umiejętności interpersonalnych przyszłych dentystów (przede wszystkim w obszarze komunikacji). Przypomnijmy, że opinie lekarzy dentystów z badania I były zbliżone $-80 \%$ badanych zadeklarowało, że na studiach powinna być przekazywana tego typu wiedza, podczas gdy opinie studentów - badanie III w zakresie roli uczelni w przygotowaniu do prowadzenia prywatnego gabinetu były bardzo spolaryzowane - po $40 \%$ badanych studentów uznało, że uczelnia przygotowuje i nie przygotowuje do prowadzenia gabinetu. Wydaje się, że opinia dentystów - praktyków biznesu, którzy z pewnego dystansu mogą ocenić zdobytą na studiach wiedzę, jest bardziej miarodajna

\footnotetext{
${ }^{29}$ Przypomnijmy, że relatywnie nisko ocenili swoje pozamedyczne umiejętności związane z prowadzeniem gabinetu, np.: 1) umiejętność wprowadzania zmian w życiu zawodowym - 35,71\% oceniła średnio, a $6,19 \%$, że posiada je w małym stopniu lub w ogóle (por. tabela 85), 2) umiejętność planowania działań na najbliższy miesiąc - 36,71\% średnio, a 12,08\% w małym stopniu lub brak (por. tabela 85), 3) umiejętność identyfikowania źródeł konfliktu w zespole - 35,58\% średnio, a $25,48 \%$ w małym stopniu lub brak (por. tabela 86), 4) umiejętność wskazania najbardziej rentownych pacjentów gabinetu - 32,3\% średnio, a 13,87\% słabo lub brak (por. tabela 86), 5) umiejętność wykorzystania pozamedycznych informacji od pacjentów do przekonywania ich do wyboru określonej opcji usługi - 29,67\%, a 9,09\% słabo lub brak (por. tabela 86).
} 
w tym zakresie i może stanowić wskazówkę dla uczelni medycznych co do zakresu poszerzenia ich oferty edukacyjnej.

Tabela 90. Oczekiwania stomatologów względem uczelni medycznych (badanie II)

\begin{tabular}{|c|c|c|c|c|c|c|c|c|}
\hline \multirow[t]{2}{*}{ Stwierdzenie } & \multicolumn{5}{|c|}{$\begin{array}{l}\text { Wskazania respondentów } \\
\text { (procent wskazań) }\end{array}$} & \multirow[t]{2}{*}{$\bar{x}$} & \multirow[t]{2}{*}{ Do } & \multirow[t]{2}{*}{ Me } \\
\hline & \begin{tabular}{|c|} 
na \\
pewno \\
nie \\
$(1)$ \\
\end{tabular} & $\begin{array}{c}\text { raczej } \\
\text { nie } \\
(2) \\
\end{array}$ & $\begin{array}{c}\text { trudno } \\
\text { powie } \\
\text {-dzieć } \\
(3)\end{array}$ & $\begin{array}{c}\text { raczej } \\
\text { tak } \\
(4)\end{array}$ & $\begin{array}{c}\text { na } \\
\text { pewno } \\
\text { tak } \\
(5) \\
\end{array}$ & & & \\
\hline $\begin{array}{l}\text { W uczelniach medycznych powinna być } \\
\text { zwracana większa uwaga na umiejętność } \\
\text { komunikowania się z pacjentem } \\
\text { np. roszczeniowym, dzieckiem }\end{array}$ & 0,95 & 0,48 & 7,62 & 27,14 & 63,81 & 4,52 & 5 & 5 \\
\hline $\begin{array}{l}\text { Uczelnia powinna wyposażać studentów } \\
\text { w umiejętności negocjacyjne (przydatne do } \\
\text { rozmów z pacjentami i pracownikami NFZ) }\end{array}$ & 1,90 & 1,90 & 8,10 & 33,33 & 54,76 & 4,37 & 5 & 5 \\
\hline $\begin{array}{l}\text { Uczelnia powinna przygotowywać dentys- } \\
\text { tów do bycia przełożonym }\end{array}$ & 1,90 & 1,43 & 15,71 & 34,29 & 46,67 & 4,22 & 5 & 4 \\
\hline
\end{tabular}

Źródło: opracowanie własne na podstawie przeprowadzonego badania.

Przedstawione w tabeli 90 wyniki upoważniają do ponownego podkreślenia, że uczelnie medyczne - zmierzające w kierunku praktycznej realizacji idei Uniwersytetów Trzeciej Generacji - mogłyby rozważyć wprowadzenie modułów ekonomicznych do kształcenia studentów kierunków lekarsko-dentystycznych, jako przyszłych praktyków biznesu.

Uwzględnienie przyjętych typów sylwetek, pozwala na stwierdzenie, że najbardziej radykalni w wyrażaniu oczekiwań co do poszerzenia oferty uczelni o wiedzę biznesową byli respondenci o typie Sylwetki B (najniżej ocenili się pod tym względem); choć należy podkreślić, że różnice pomiędzy poszczególnymi sylwetkami były niewielkie i nieistotne statystycznie (por. wykres 17).

Wykres 17. Oczekiwania stomatologów w stosunku do uczelni medycznych a typ sylwetki respondenta

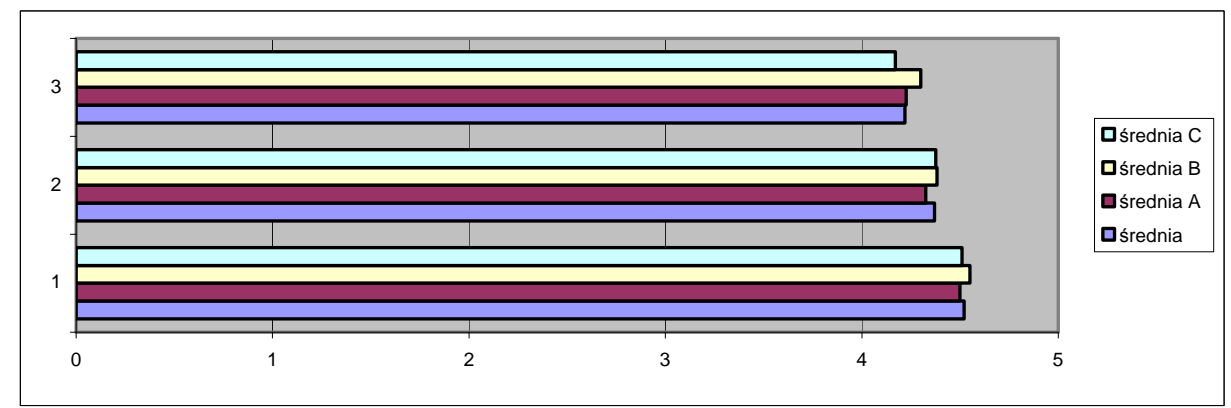

Źródło: opracowanie własne na podstawie przeprowadzonego badania.

Oczekiwania respondentów wobec uczelni medycznych: 1) Wyposażenie studenta w umiejętność komunikowania się pacjentem, 2) Wyposażenie studenta w umiejętności z zakresu negocjacji, 3) Przygotowanie studentów do bycia przełożonym personelu pomocniczego. 


\section{REASUMPCJA}

Przyjmując, że kompetencje przedsiębiorcze (w myśl uproszczonego podejścia P.F. Druckera), to „konglomerat zdolności, wiedzy, wykształcenia, doświadczenia, innych predyspozycji i cech osobowości”,30, w tym rozdziale zajęto się analizą umiejętności, postaw i zachowań dentystów w ich środowisku pracy (w kontekście funkcjonowania gabinetu, wobec personelu i pacjentów). Badani zostali podzieleni na trzy grupy (zgodnie z przeprowadzoną przez nich krótką diagnostyczną samooceną), zróżnicowane ze względu na charakter postaw przedsiębiorczych (powiązanych ze stylem przywództwa), jaki prezentują w gabinecie. Wnioski z badania są następujące:

- Dentyści o Sylwetce A (tj. prezentujący sylwetkę przedsiębiorcy inicjującego zmiany, powiązaną $\mathrm{z}$ przywództwem transformacyjnym) wykazali się największą otwartością na kwestie - szeroko pojętego - rynku. I tak:

- w zakresie umiejętności interpersonalnych we wszystkich badanych obszarach (oprócz umiejętności pracy z dzieckiem i konsekwentnego karania pracowników za pracę poniżej możliwości) ocenili się wyżej, niż pozostałe grupy badanych;

- w prowadzeniu gabinetu liczą się ze zdaniem swoich pracowników (traktują ich jak partnerów, którzy dzięki swojemu zaangażowaniu mogą wiele wnieść w funkcjonowanie gabinetu), często delegują uprawnienia na nich, a jako narzędzie motywacji obok pochwał stosują nagrody uzależnione od efektów pracy;

- w sytuacji, gdyby dentysta otwierał gabinet obok już istniejącego, respondenci o Sylwetce A podejmowaliby najbardziej zróżnicowane działania, miałyby one bardziej rynkowe nastawienie (np. działania z zakresu promocji) i związane byłyby $\mathrm{z}$ większym ryzykiem (np. zastosowanie wyższych cen niż konkurencja), niż działania dentystów o innych typach sylwetek;

- w sytuacji, gdyby obok ich gabinetu został otwarty inny - 70\% dentystów o Sylwetce A zwracałoby uwagę na działania konkurencji (a niemal połowa $\mathrm{z}$ nich odpowiedziałaby na działania konkurencji zmianą w swoim gabinecie), a odsetek wskazań „nie wiem”, co się dzieje w pobliżu mojego gabinetu był najniższy;

- dentysta o Sylwetce A jest zorientowany na pacjenta - jego wyleczenie i satysfakcję oraz dobrą atmosferę pracy;

- w lojalnych pacjentach widzą przyszłość gabinetu, dlatego podejmują działania zmierzające do poprawy jakości obsługi;

\footnotetext{
${ }^{30}$ Por. Nogalski B., Śniadecki J., Umiejętności menedżerskie $w$ zarzadzaniu przedsiębiorstwem, OPO Bydgoszcz 2001
} 
- jako czynniki konkurencyjności gabinetu przyszłości (ważniejsze, niż w pozostałych grupach) lekarze o Sylwetce A wskazali: dużą różnorodność usług i kwalifikacje interpersonalnych pracowników gabinetu.

- Sylwetkę B (odpowiadającą przedsiębiorcy decydentowi i powiązaną z przywództwem transakcyjnym) charakteryzowało m. in. to, że :

- samoocena w zakresie umiejętności interpersonalnych była najniższa pośród badanych grup, a jedynym obszarem, w którym ocenili się lepiej - była umiejętność pracy z dzieckiem;

- w sytuacji, gdyby dentysta otwierał swój gabinet w pobliżu istniejącego respondenci o Sylwetce B częściej, niż przeciętnie decydowaliby się na robienie tego samego, co konkurencja (co może świadczyć o niskim poziomie wiary we własne umiejętności tak stricte medyczne, jak i pozamedyczne);

- w sytuacji, gdy w pobliżu gabinetu respondenta pojawiłby się inny gabinet $40 \%$ respondentów o Sylwetce B obserwowałoby działania konkurencji, a niemal $1 / 3$ odpowiedziałaby działania konkurencji zmianami w swoim gabinecie; $w$ tej grupie co piąty badany nie wie, że w pobliżu otwiera się nowy gabinet;

- Sylwetka B od pozostałych respondentów różni się przede wszystkim tym, że zmiany w konkurencyjności gabinetów dostrzega w: rosnącym znaczeniu stosowanych materiałów stomatologicznych i kwalifikacji medycznych personelu pomocniczego;

- dentysta o Sylwetce B samodzielnie podejmuje decyzje (w myśl zasady: ,jako dentysta wiem najlepiej, co jest dobre dla mojego gabinetu”) i jako polecenia przekazuje pracownikom (których traktuje niemal przedmiotowo - jako środek do realizacji celów);

- dentysta o Sylwetce B jest zorientowany na pacjenta - jego wyleczenie oraz satysfakcję, a także rozwój własnych kwalifikacji medycznych.

- dentyści o Sylwetce C (łączący cechy przywódcy transformacyjnego i transakcyjnego, prezentujący postawę przedsiębiorcy organizatora zasobów) charakteryzują się tym, że:

- rozwój własnych kwalifikacji zawodowych (53,8\% wskazań) przedkładali nad wyleczenie pacjenta $(52,8 \%)$;

- w przypadku, gdyby stomatolog o Sylwetce C otwierał gabinet obok już istniejącego gabinetu, to jego zachowania byłyby zbliżone do działań podejmowanych zarówno przez dentystę o Sylwetce B (np. wprowadzanie szerszego wachlarza usług), jak i o sylwetce A (np. prowadzenie intensywnej promocji na danym terenie);

- wśród czynników ważnych dla konkurencyjności gabinetów przyszłości - silniej niż pozostałe typy sylwetek - uznali: nowoczesny sprzęt, renomę gabinetu, dużą grupę lojalnych klientów, lokalizację podmiotu; 
- w zakresie umiejętności intrapersonalnych lekarze dentyści o Sylwetce C lepiej, niż pozostali ocenili się w zakresie: wiedzy i umiejętności stricte zawodowych, wykorzystywania i w praktyce wiedzy zdobytej na szkoleniach, zwiększonej odporności na stres radzenie sobie z krytyką;

- w zakresie umiejętności interpersonalnych oceniają się niżej, niż dentyści o Sylwetce A i wyżej - niż B.

Potencjał dentystów o Sylwetce A w kreowaniu przewagi konkurencyjnej gabinetu (na wszystkich analizowanych płaszczyznach) należy ocenić jako relatywnie wysoki. Dentyści nie tylko wykorzystują pozamedyczne instrumenty oddziaływania na pacjentów, ale dobrze oceniają swoją umiejętności w zakresie zarządzania gabinetem. Sylwetka B rokuje powodzenie w sytuacjach prostych (wręcz biurokratycznych) ${ }^{31}$, natomiast w sytuacji, gdy będzie zmieniał się rynek usług stomatologicznych (czy to przez rosnącą podaż i/lub bardziej rynkowe zachowania innych gabinetów, czy zmiany w zakresie oczekiwań pacjentów) wydaje się być nierozwojową ${ }^{32}$. Brak lub złe rozpoznanie sytuacji rynkowej lub trzymanie się sprawdzonych wzorców z przeszłości (a innych - ze względu na niewystarczającą wiedzę biznesową - często nie ma) może zakończyć się utratą pozycji rynkowej podmiotu ${ }^{33}$. Nawet jeśli nie będzie związane $\mathrm{z}$ utratą dotychczasowych pacjentów (co jest możliwe ze względu na nieco instrumentalne ich traktowanie przez dentystów o Sylwetce B), to raczej trudno liczyć w takich warunkach na pozyskanie nowych.

W świetle przedstawionych rozważań można stwierdzić, że hipoteza mówiąca o tym, iż lekarze dentyści o sylwetce przedsiębiorcy inspiratora i inicjatora zmian - przywódcy transformacyjnego działają bardziej rynkowo, niż ci - o sylwetce przedsiębiorcy decydenta - przywódcy transakcyjnego, czy przedsiębiorcy organizatora - o mieszanym stylu przywództwa, została zweryfikowana pozytywnie. Ponadto można stwierdzić, że postawy i działania podejmowane $\mathrm{w}$ gabinetach lekarzy o Sylwetce A już dziś są bardziej proklientowskie (np. umiejętność utrzymywania dobrych relacji z pacjentem w długim okresie, odpowiedniego zachowania $w$ sytuacji ewentualnych reklamacji, wykorzystywania pozamedycznych informacji od pacjentów do przedstawienia im odpowiednich opcji usług), niż pozostałych, a dzięki otwartości na wiedzę pozamedyczną stwarzają warunki do szerszej implementacji marketingu relacji

\footnotetext{
${ }^{31}$ Avery G.C., Przywództwo w organizacji. Paradygmaty i studia przypadków, PWE, Warszawa 2009, s. 173 i nast.

${ }^{32} \mathrm{~W}$ literaturze forma ta jest określana jako przemijający styl przywództwa, choć ciągle jest stosowany w wielu podmiotach. Za: Ensley M.D., Pearce C.L., Hmieleski K.M., The moderating effect of environmental dynamism on the relationship between entrepreneur leadership behavior and new venture performance, "Journal of Business Venturing" 2006, vol. 21, s. 249.

${ }^{33}$ Czermiński A., Czerska M., Nogalski B., Rutka R., Apanowicz J., Zarządzanie organizacyjne, Dom Organizatora, Toruń 2001, s. 118.
} 
do tych gabinetów. Rysunek 8 przedstawia syntetyczne spojrzenie na cechy i umiejętności, którymi charakteryzują się lekarze dentyści działający jako przedsiębiorcy.

Rysunek 8. Drzewo kategorii cech i umiejętności lekarza dentysty jako przedsiębiorcy

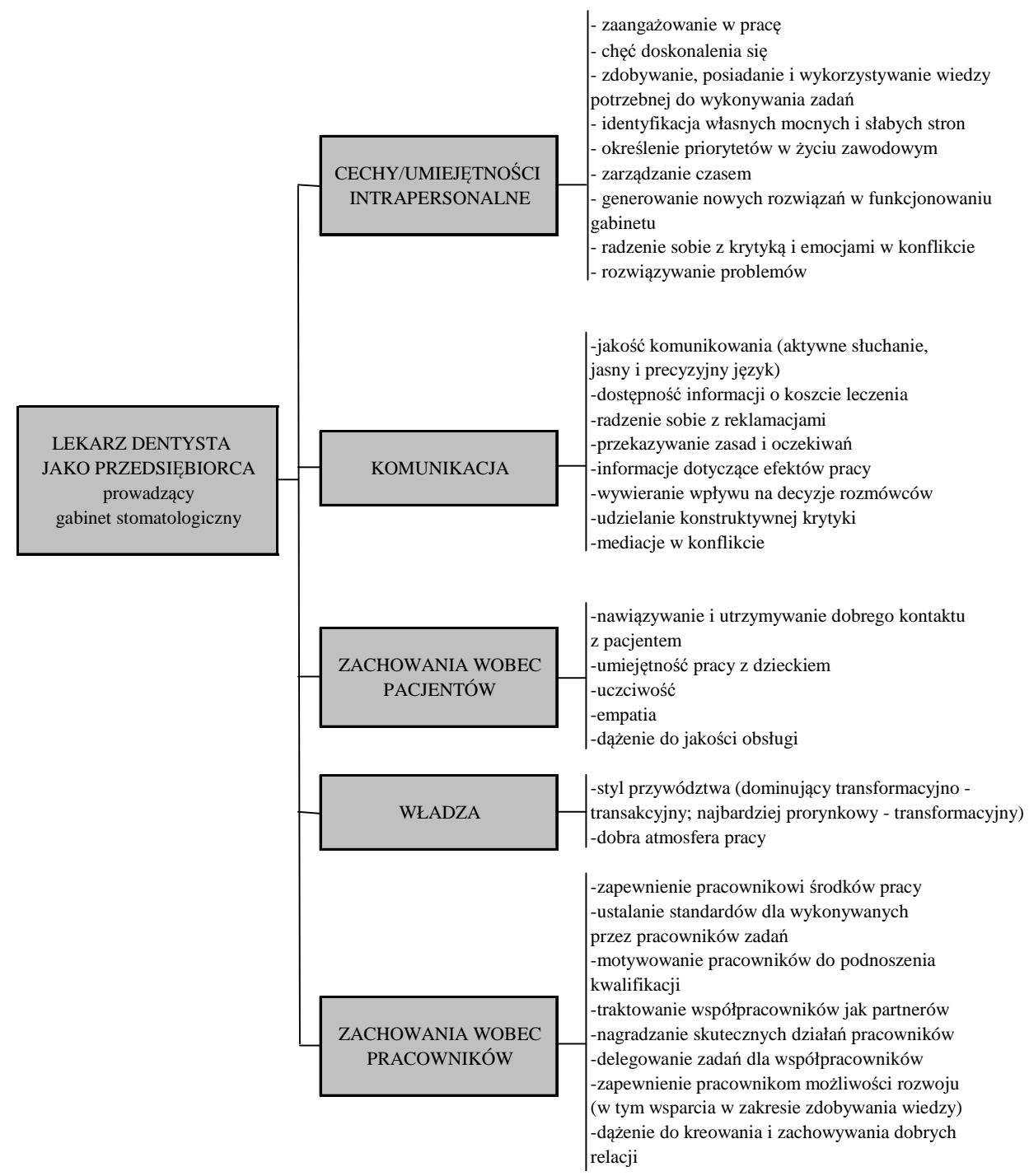

Źródło: opracowanie własne. 
Widoczne powiązania pomiędzy sylwetką lekarza dentysty a stosowanymi w gabinecie działaniami z zakresu marketingu, pozwalają na rekomendowanie praktyk ożywiania przedsiębiorczości (prezentowanych $\mathrm{w}$ literaturze przedmiotu, dotyczących budowania orientacji rynkowej podmiotu) $\mathrm{w}$ gabinetach stomatologicznych w celu zaspokajania - szeroko pojętych - potrzeb pacjentów i umacniania ich pozycji konkurencyjnej. 


\section{ZAKOŃCZENIE}

Nowoczesne organizacje staja się miejscem, w którym się przede wszystkim myśli, a dopiero później produkuje.

P. Płoszajski ${ }^{1}$

Gotowość przedsiębiorstw do zwrócenia uwagi na - inne niż tradycyjnie stosowane - instrumenty budowania przewagi konkurencyjnej staje się dziś jednym $\mathrm{z}$ warunków sprostania wyzwaniom, przed którymi stoją podmioty rynkowe, funkcjonujące $\mathrm{w}$ zmiennym otoczeniu ${ }^{2}$. $\mathrm{Z}$ tego względu $\mathrm{w}$ warunkach urynkowienia usług stomatologicznych i rosnących oczekiwań pacjentów w odniesieniu do świadczonych usług (w warstwie medycznej i pozamedycznej), lekarze dentyści stają przed wyzwaniem znalezienia prorynkowych sposobów działania, które pozwolą im na zdobycie i utrzymanie lub poprawę pozycji konkurencyjnej. Źródeł tych działań mogą upatrywać w posiadanych (lub możliwych do rozwinięcia) umiejętnościach wyróżniających - przedsiębiorczych, które stają się siłą kreatywną organizacji, pozwalają kreować nowe rozwiązania w funkcjonowaniu gabinetów, a tym samym umożliwiają prowadzenie gabinetu stomatologicznego, jako przedsiębiorstwa zarobkującego.

Biorąc pod uwagę fakt, że w Polsce wskaźnik nasycenia ${ }^{3}$ w odniesieniu do liczby praktykujących lekarzy dentystów jest istotnie niższy, niż w innych krajach Europy (por. tabela $1.20 \mathrm{w}$ załączniku 1), rysują się potencjalne możliwości rozwoju rynku usług stomatologicznych po stronie podażowej - liczba praktykujących lekarzy dentystów mogłaby się zwiększyć 2-krotnie, aby dostępność lekarzy dentystów w Polsce dorównała średniej w innych państwach europejskich. Tego rodzaju zmiany nie tylko wpłynęłyby na zwiększenie konkurencyjności na rynku, ale stanowiłyby również wyzwanie dla już praktykujących lekarzy (a tym samym wymuszałyby na nich podejmowanie działań przedsiębiorczych dla utrzymania się na rynku). Należy również zauważyć, że od lat udział wydatków na świadczenia stomatologiczne w kosztach świadczeń zdrowotnych NFZ ogółem maleje (por. tabela 41), a Polacy z dochodów własnych finansują ok. $80 \%$ wartości świadczeń stomatologicznych. Wartość rynku usług stomatologicznych sukcesywnie rośnie, dlatego dla lekarzy dentystów, prowadzących prywatne gabinety (a jest ich większość na rynku usług stomatologicznych), powinno być szczególnie istotne, aby nie tylko stricte medyczne aspekty wykonywanego zawodu, ale również osobista przedsię-

\footnotetext{
${ }^{1}$ Płoszajski P., Organizacja w przyszłości: przerażony kameleon, w: Borkowska S., Bohdziewicz P. (red.), Menedżer u progu XXIw., wyd. WSHE, Łódź 1998, s. 23.

${ }^{2}$ Obłój K., Strategia organizacji w poszukiwaniu ... op. cit.

${ }^{3}$ Definiowany jako liczba lekarzy dentystów przypadających na 10000 mieszkańców.
} 
biorczość (wyrażająca się np. w realizacji idei marketingu relacji w gabinecie), stanęła w centrum jego zainteresowań jako równoprawne narzędzie dostarczania wartości pacjentowi. Biorąc pod uwagę fakt, że sukces rynkowy przedsiębiorstwa zależy w dużej mierze od jego zdolności dostosowywania się do ciągłych zmian, to lekarze dentyści mogliby stać się Kirznerowskimi przedsiębiorcami - poszukującymi nowych formuł zwiększania (utrzymywania na dotychczasowym poziomie) uczestnictwa w wymianie rynkowej ${ }^{4}$.

Zgodnie z propozycją M. Bratnickiego przedsiębiorczość można postrzegać jako proces, w trakcie którego zapewnia się długotrwałość rynkową organizacji poprzez specyficzny sposób myślenia i działania jej uczestników, kreujących i wykorzystujących szanse rozwojowe ${ }^{5}$. Pojęcie przedsiębiorcy jest kategorią par excellance ekonomiczną (przedsiębiorca odpowiada na pytanie: co i dla kogo chce produkować/świadczyć usługę i powołuje przedsiębiorstwo do życia). Jednak - jak twierdzi M. Cassone - ,przedsiębiorca nie jest tylko arytmometrem", , który oblicza przy jakim zakresie świadczonych usług koszty krańcowe zrównają się z utargiem krańcowy. Po założeniu przedsiębiorstwa, musi ciągle reagować na zmieniające się warunki otoczenia, by podmiot mógł przetrwać na rynku i tu pojawia się jego funkcja wtórna - osoby zarządzającej przedsiębiorstwem (która może być realizowana również przez wynajętego menedżera). W pracy przedstawiono lekarza dentystę, jako przedsiębiorcę założyciela gabinetu (przedsiębiorstwa, które działa na rynku i jest poddawane wpływom otoczenia) i osobę, która jest odpowiedzialna za jego funkcjonowanie (przedsiębiorca Portera). Wskazano, że szansą dla komercyjnego gabinetu stomatologicznego na zachowanie homeostatycznej równowagi staje się rozpoznanie i zaspokojenie pozamedycznych potrzeb pacjentów ${ }^{7}$, a w konsekwencji nawiązanie $\mathrm{z}$ nimi długookresowej więzi (wpływającej nie tylko na dalsze korzystanie z usług stomatologa, ale również na rekomendowanie usług innym - potencjalnym - nabywcom). Instrumentem umożliwiającym wykorzystanie tej szansy staje się marketing relacji ${ }^{8}$, który wprowadzony i konsekwentnie reali-

\footnotetext{
${ }^{4} \mathrm{Z}$ wyników badania II można wnioskować, że lekarze dentyści o takiej sylwetce podejmowali najbardziej proklientowskie działania w swoich gabinetach.

${ }^{5}$ Bratnicki M., Przedsiębiorczość i przedsiębiorcy wspótczesnych organizacji, Wyd. AE w Katowicach, Katowice, 2002.

${ }^{6}$ Cassone M., The Entrepreneur. An Economic Theory, Barnes \& Noble Books, Totowa 1982.

${ }^{7}$ Pacjent „ocenia” lekarza w trakcie rozmowy nie tylko pod kątem jego umiejętności technicznych, ale również pod kątem jego umiejętności interpersonalnych. $\mathrm{Z}$ tego względu dentyści powinni zwrócić uwagę na ten wymiar swojej zawodowej postawy. Jest to o tyle istotne, że w opiece zdrowotnej ofertą usługową jest deklaracja (identyfikowana z konkretną osobą wykonawcy) gotowości i chęci do redukcji poczucia niepewności pacjenta w obszarze jego zdrowia (dlatego rośnie znaczenie zaufania w kreowaniu relacji: pacjent - dentysta).

${ }^{8} \mathrm{~W}$ pracy przyjęto, że marketing usług $\mathrm{w}$ gabinecie stomatologicznym dotyczy wszelkich aktywności ukierunkowanych na pacjenta, podejmowanych przez personel gabinetu, zmierzających do ciągłego uaktualniania wiedzy o jego potrzebach dla stworzenia optymalnej usługi (w wymiarze
} 
zowany w gabinecie może przyczynić się nie tylko do zacieśnienia współpracy z pacjentami, ale również do poprawy pozycji konkurencyjnej gabinetu.

Analiza piśmiennictwa z zakresu ekonomii, nauk o zarządzaniu oraz deontologii lekarskiej stanowiła podstawę wywodu teoretycznego pracy, a przeprowadzone - w czterech obszarach problemowych ${ }^{9}$ - badania własne pozwoliły na stworzenie materiału empirycznego. Tak szerokie potraktowanie tematu pozwoliło na pozyskanie interesujących poznawczo rezultatów w obszarze morfologii relacji: pacjent - lekarz dentysta oraz profilu sylwetki przedsiębiorczej dentysty. W pracy przyjęto założenie, że dychotomia funkcji medycznej i ekonomicznej pełnionych przez lekarza dentystę w prywatnym gabinecie będzie możliwa do uchwycenia dzięki analizie indukcyjnej i takie podejście zastosowano (z tego względu wnioski płynące z badań nie powinny być bezkrytycznie przenoszone na inne specjalności lekarskie ${ }^{10}$ ). Zaprezentowane wyniki badań dowodzą, że we współczesnych gabinetach stomatologicznych wykorzystywane są - czasami intuicyjnie - wybrane narzędzia marketingu w celu kształtowania relacji z pacjentami (wyniki badania I i II). Zakres ich aplikacji jest zróżnicowany, zależy zarówno od czynników egzogenicznych (np. etyka zawodu, zakres oczekiwań pacjenta, funkcjonowanie w pobliżu gabinetu innych podmiotów), jak i endogenicznych (np. poziom wiedzy dentysty w zakresie - szeroko pojętego - biznesowego funkcjonowania gabinetu, czy postawa przedsiębiorcza dentysty - wynikająca $\mathrm{z}$ motywów działania czy przejawiająca się $\mathrm{w}$ określonym stylu przywództwa). Wyniki badania pozwalają również na sformułowanie wniosku, iż lekarze dentyści (wyniki badania II) dostrzegają rosnącą rolę niemedycznych aspektów funkcjonowania gabinetu w poprawianiu jego konkurencyjności w przyszłości, a - podobnie jak w wynikach G. Zaltmana ${ }^{11}$ - materialne atrybuty usług mają znacząco mniejszy wpływ na preferencje nabywców usług

medycznym i pozamedycznym), w celu nawiązania partnerskich stosunków o trwałym charakterze, które będą wynikiem wzajemnego zrozumienia i zaufania. Ponadto te codzienne proklientowskie działania wpisują się w nurt przedsiębiorczości M.E. Portera i stanowią wyraz współczesnej koncepcji konkurencyjności gabinetów stomatologicznych.

${ }^{9}$ Określenie profilu lekarza dentysty - przedsiębiorcy i wskazanie działań rynkowych podejmowanych $\mathrm{w}$ gabinecie stomatologicznym było zrealizowane w ramach badania I, podobne podejście w odniesieniu do studentów kierunku lekarsko-densytycznego UM w Łodzi zastosowano w badaniu III. Wpływ sylwetki przedsiębiorczej (wyrażonej prezentowanym przez stomatologa stylem przywództwa) na podejmowane działania rynkowe był przedmiotem zainteresowania badania II. Oczekiwania pacjentów wobec personelu gabinetu i określenie sylwetki lekarza dentysty w ujęciu pozytywnym i normatywnym było przedmiotem zainteresowania badania IV.

${ }^{10}$ Stanowisko to jest zgodne z propozycją M. Ciesielskiego, który twierdzi, że w praktyce badawczej nauk o zarządzaniu powinno się formułować twierdzenia empiryczne o małej ogólności. Por. Ciesielski M., Problemy metodologii normatywnej $w$ naukach o zarzadzaniu, „Przegląd Organizacji”, $2012 \mathrm{nr}$ 10, s. 3.

${ }^{11}$ Smith S., Wheeler J., Managing ... op. cit., s. 56. 
stomatologicznych, niż elementy wynikające z kontaktów interpersonalnych z pracownikami gabinetu.

Z zasady Salus aegroti suprema lex wypływają wszystkie normy szczegółowe etyki zawodowej lekarza. Biorąc pod uwagę fakt, że marketing relacji stawia klienta w centrum uwagi, można wskazać na wspólny element działań z zakresu medycyny i marketingu - dążenie do dobra nabywcy usług zdrowotnych. Określenie miejsca marketingu relacji w funkcjonowaniu gabinetów stomatologicznych zostało przeprowadzone $\mathrm{z}$ zastosowaniem pozytywistycznego podejścia badawczego - rozpoznano postawy lekarzy dentystów wobec problematyki biznesowego funkcjonowania gabinetów, a także podejścia normatywnego - określono profil sylwetki lekarza dentysty przyszłości ${ }^{12}$ i wskazano determinanty konkurencyjności gabinetów stomatologicznych jutra ${ }^{13}$. Natomiast podejście interpretacyjne ${ }^{14}$ zostało wykorzystane do określenia sylwetki idealnego dentysty w oczach pacjentów (badanie IV) oraz gabinetu przyszłości w oczach studentów kierunku lekarsko-dentystycznego (badanie III).

Celem pracy było pokazanie przedsiębiorczej postawy stomatologów. Wymagało to kompleksowego podejścia, gdyż współczesna koncepcja przedsiębiorczości obejmuje kilka płaszczyzn ${ }^{15}$. I tak: w wymiarze podmiotowym przedsiębiorczości można wskazać, iż respondenci badania I i III najwyżej ocenili swoje zaangażowanie w prace $(93,9 \%$ lekarzy dentystów oceniło się dobrze i bardzo dobrze w tym zakresie). Ponadto lekarze dentyści - wyniki badania I - wysoko ocenili swoje umiejętności w zakresie wykorzystywania w praktyce wiedzy pozyskanej na szkoleniach (co potwierdza rolę lekarza, jako pracownika wiedzy - płaszczyzna edukacyjna przedsiębiorczości), a także określania priorytetów w życiu osobistym i zawodowym, co może świadczyć o umiejętności zachowywania życiowej równowagi (która w dłuższej perspektywie wpływa na zadowolenie z wykonywanej pracy i poczucie sukcesu życiowego).

\footnotetext{
${ }^{12}$ Respondenci badania I i III uznali, że lekarza dentystę powinno charakteryzować głównie: 1) wiedza stricte medyczna na wysokim poziomie, 2) przyjazne nastawienie wobec pacjentów i personelu, 3) zdrowa postawa moralna, 4) wysoki poziom inteligencji (zwłaszcza emocjonalnej).

Odmienne stanowisko dotyczyło skłonności do podejmowania ryzyka: stomatolodzy (badanie I) uznali, że wzorcowy dentysta powinien mieć odwagę do wprowadzania zmian i niewielką skłonność do podejmowania ryzyka, a studenci (badanie III) od idealnego stomatologa oczekują znacznej pewności siebie, kreatywności i skłonności do podejmowania ryzyka (a więc przedsiębiorczości Schumpeterowskiej).

${ }^{13}$ Respondenci badania II wskazali, że ważne będą przede wszystkim: 1) nowoczesny sprzęt,

2) kwalifikacje menedżerskie dentysty, 3) renoma gabinetu, 4) duża różnorodność usług, 5) ceny,

6) kwalifikacje menedżerskie dentysty, 7) duża grupa lojalnych klientów.

${ }^{14}$ Podejście to zostało zastosowane $\mathrm{m}$. in. pod wpływem słów Ł. Sułkowskiego, który uważa, że „zarządzanie na obecnym etapie rozwoju może dostarczać jedynie interpretacji, a nie praw czy teorii.” Por. Sułkowski Ł., Epistemologia nauk o zarzadzaniu, PWE, Warszawa 2005, s. 61.

${ }^{15}$ Kraśnicka T., Koncepcja rozwoju ... op. cit., s. 79 i nast.
} 
Wymiar edukacyjny przedsiębiorczości można odnaleźć w spojrzeniu na lekarza dentystę jako homo competens, czyli jednostkę, której zachowanie motywowane jest stworzeniem i wypełnianiem własnej listy kompetencji (obejmującej np. konieczność rozwoju stricte medycznego, umiejętności z zakresu skutecznej komunikacji i in.), co potwierdzają wyniki badania I, II i III (pokazujące, że podnoszenie kwalifikacji i rozwój zawodowy ${ }^{16}$ stanowią główne motywy działań respondentów).

W obszarze edukacji pojawiły się $\mathrm{w}$ pracy ciekawe wnioski dotyczące oczekiwań badanych, co do przygotowania w uczelni medycznej do prowadzenia prywatnego gabinetu: studenci mieli ambiwalentne odczucia związane z tym zagadnieniem - nieco ponad 40,0\% studentów zadeklarowało, że uczelnia przygotowuje ich do pracy we własnym gabinecie, a niewiele mniej, niż 40,0\% - że nie. Natomiast lekarze dentyści wykazali bardzo zdecydowaną postawę co do tego, że w uczelni medycznej powinny być przedstawiane zagadnienia z zakresu - szeroko pojętego - biznesowego funkcjonowania organizacji:

- blisko $80 \%$ dentystów z badania I zajęło stanowisko, że taka wiedza powinna być przekazywana,

- przeszło 90\% dentystów z badania II uznało, że w uczelni powinna być zwracana większa uwaga na umiejętności z zakresu komunikacji (np. postępowania z pacjentem roszczeniowym, negocjacji), a przeszło $80 \%$ zadeklarowało, że uczelnia powinna przygotowywać do bycia przełożonym.

Wyniki te pozwalają na pozytywną weryfikację hipotezy, mówiącej, iż: wśród lekarzy dentystów istnieje duże (powyżej 50\% lekarzy) zapotrzebowanie na wiedzę z zakresu biznesowego funkcjonowania gabinetów. Upoważnia to do stwierdzenia, iż uczelnie medyczne powinny rozważyć kształcenie postaw przedsiębiorczych studentów kierunku lekarsko-dentystycznego (które są charakterystyczne dla kapitału społecznego), aby poprawić przyszłe możliwości rynkowe swoich absolwentów.

W wymiarze psychologicznym i osobowym przedsiębiorczości stomatologów można sformułować pogląd, że wielu dentystów (dobrze widoczne jest to w badaniu I w badanej podgrupie o stażu krótszym niż 15 lat) cechuje zdolność do rozwiązywania rynkowych problemów (dzięki wyobrażeniom dotyczącym przyczyn określonych sytuacji), a także (wyniki badania I i Sylwetka A oraz Sylwetka C - organizator zasobów, podejmujący umiarkowane ryzyko - w ba-

\footnotetext{
${ }^{16}$ Podkreślmy, że własnych kompetencji, a niekoniecznie kompetencji personelu - w badaniu I 98,2\% respondentów zadeklarowało korzystanie ze szkoleń stricte medycznych i tylko 27,6\% członków ich personelu. W badaniu II respondenci o Sylwetce A (inspiratorzy i inicjatorzy zmian) deklarowali znaczne wsparcie dla personelu w zakresie podnoszenia kwalifikacji zawodowych, podczas gdy respondenci o Sylwetce B (koordynatorzy Walrasa) pozostawiali te kwestie niemal wyłącznie do dyspozycji personelu.
} 
daniu II) umiejętność znajdowania rozwiązań pojawiających się problemów bez dokładnego zrozumienia wszystkich elementów wpływających na kształtowanie danego zjawiska, czy stanu ekonomicznego. Z tego względu można przyjąć, że dzięki intuicji ${ }^{17}$ (umożliwiającej uzyskiwanie korzyści ze zmian w funkcjonowaniu podmiotu np. w zakresie obsługi pacjentów) lekarze dentyści są Schumeterowskimi przedsiębiorcami. Ponadto respondenci badania I wysoko ocenili swoją umiejętność identyfikowania własnych mocnych i słabych stron oraz myślenia alternatywnego, co potwierdza wcześniejszy wniosek. Słabsze noty wystawili sobie lekarze w badaniu I w zakresie radzenia sobie $\mathrm{z}$ negatywnymi odczuciami, czy postawami w kontaktach z innymi osobami, co przekłada się na ich kontakty z personelem gabinetu (np. respondenci badania II o Sylwetce B ocenili swoje umiejętności w tym zakresie bardzo nisko). Posiadane przez lekarzy dentystów - relatywnie wysoko przez nich ocenione - umiejętności interpersonalne i intrapersonalne (badanie I, II i III) oraz specyficzne dla zawodu cechy $^{18}$ umożliwiają im nawiązywanie relacji $\mathrm{z}$ pacjentami (co potwierdzają wyniki badania IV), tym samym hipotezę mówiącą o tym, iż osoby wykonujące zawód lekarza dentysty mają rozwinięte umiejętności interpersonalne (umożliwiające nawiązywanie relacji z klientami gabinetu) zweryfikowano pozytywnie. Przyjęta w pracy szczegółowa dezagregacja wyników badań, odnoszących się do postaw i umiejętności biznesowych dentystów (tak praktyków zawodu, jak i przyszłych adeptów), służyła lepszemu przedstawieniu umiejętności i postaw przedsiębiorczych i umożliwiła kompleksowy ogląd omawianych zagadnień.

Wymiar otoczenia, jako płaszczyzny działań przedsiębiorczych, był analizowany przede wszystkim $\mathrm{w}$ aspekcie kontaktów z pacjentami i lekarze - badanie I - jako swoje główne atuty wskazali: umiejętność utrzymywania dobrych relacji z pacjentami w długim okresie oraz nawiązywanie dobrego kontaktu z pacjentem w trakcie pierwszej wizyty, co wpływa na możliwość posiadania grupy lojalnych pacjentów. Również posiadanie dużej grupy lojalnych pacjentów respondenci badania I w rankingu atutów współczesnych gabinetów umieścili za kwalifikacjami medycznymi stomatologa i nowoczesnym sprzętem - a więc za czynnikami stricte medycznymi. Respondenci badania II dali temu czynnikowi 5 lokatę (za kwalifikacjami medycznymi stomatologa, nowoczesnością sprzętu, renomą gabinetu, różnorodnością usług), podobnie jak respondenci badania III (za kwalifikacjami medycznymi dentysty, nowoczesnością sprzętu i stosowanych materiałów stomatologicznych oraz renomą gabinetu),

17 Należy podkreślić rosnące zainteresowanie lekarzy dentystów problematyką biznesowego funkcjonowania gabinetu i odchodzenia przez nich od czysto intuicyjnego podejmowania decyzji do świadomego wykorzystywania instrumentów konkurowania (w tym stricte marketingowych) w prowadzonej działalności.

${ }^{18}$ Borkowska A., Czerw A., Psychologiczny portret ...op. cit., s. 25. 
dlatego wystąpiły przesłanki do podtrzymania hipotezy, postawionej we wstępie pracy, mówiącej, że trwałe relacje z pacjentami są postrzegane przez dentystów, jako podstawowy niemedyczny czynnik konkurencyjności gabinetów.

W wymiarze instytucjonalnym przedsiębiorczości zwrócono uwagę na umiejętności lekarzy dentystów w zakresie - szeroko pojętego - zarządzania personelem. W obu badaniach lekarzy dentystów - badaniu I i II samoocena respondentów w tym zakresie była najniższa (najsłabiej w ogóle wypadli stomatolodzy o Sylwetce B w badaniu II), np.:

- identyfikowania źródła konfliktu w zespole nie potrafi $40 \%$ badanych;

- umiejętność chwalenia pracowników na bardzo dobrym poziomie ma niespełna 1/4 badanych, a w ogóle - 1/10;

- umiejętność motywowania pracowników do podnoszenia kwalifikacji ok. $10 \%$ badanych oceniła u siebie bardzo dobrze, a przeszło 1/5 - słabo lub uznała, że jej nie posiada.

Wymiar instytucjonalny przedsiębiorczości można odnaleźć również w problematyce przedsiębiorczości rodzinnej. W badaniu III - 28\% badanych pochodziło z rodzin, w których najbliższy członek rodziny był stomatologiem. Podobny wynik uzyskano w odniesieniu do badania I - przeszło $20 \%$ badanych zadeklarowało, że dzieci pracują lub będą pracowały w zawodzie lekarza dentysty. Natomiast niespełna 5\% respondentów tego badania prowadzi gabinet należący wcześniej do członka rodziny (blisko 90\% zadeklarowało, że są założycielami gabinetów - co pokazuje zakres przedsiębiorczości założycielskiej). Jednym z celów cząstkowych pracy była odpowiedź na pytanie: „Czy intencje przedsiębiorcze studentów kierunku lekarsko-dentystycznego (wyrażone w tzw. ukrytej przedsiębiorczości) są wzmocnione przez uwarunkowania rodzinne (związane z tym, że rodzice/opiekunowie wykonują zawód stomatologa)?" Wyniki badania III pokazały, że blisko 2 razy więcej studentów z rodzin „bez lekarza dentysty w najbliższej rodzinie" zamierza po studiach otworzyć własny gabinet, niż studentów z ,rodzicem/opiekunem stomatologiem” (ta grupa w większości zadeklarowała podjęcie pracy w gabinecie rodzica/opiekuna). Tym samym nie można mówić o tym, by przedstawione uwarunkowania rodzinne wzmacniały postawę przedsiębiorczą studentów kierunku lekarskodentystycznego.

Przeprowadzone badania pozwalają na stwierdzenie, że: stomatolodzy są przedsiębiorczy $-81,3 \%$ respondentów badania I to właściciele gabinetów (reprezentują tzw. przedsiębiorczość założycielską); 35,7\% pracuje w więcej niż jednym gabinecie - może to być zarówno przejawem przedsiębiorczości wewnętrznej zgodnie z intencją: „pracuję więcej, bo chce więcej zarobic’”; ale również przedsiębiorczości zewnętrznej wymuszonej przepisami (głównie związanymi 
z wysokością składki ZUS dla pracownika i przedsiębiorcy). Niemniej jednak należy z całą stanowczością podkreślić, że w stomatologu lekarz ciągle wygrywa z przedsiębiorcą - w badaniu I i III przeszło 90\% respondentów wskazało, że wyleczenie i satysfakcja pacjentów są dla nich najważniejsze, w badaniu II $57 \%$ lekarzy dentystów wskazało, że głównym motywem wyboru zawodu była chęć pomocy drugiemu człowiekowi, w bada-niu IV - 73,5\% badanych pacjentów wskazało, że w ich ocenie wyleczenie pacjenta stanowi główny motyw pracy stomatologów (był to najwyżej oceniany czynnik motywacji do pracy). Otrzymane wyniki przeprowadzonych badań potwierdzają, iż lekarz dentysta (prowadzący własny gabinet stomatologiczny) jako człowiek gospodarujący nie jest klasycznym homo economicus, ale podmiotem o ograniczonej racjonalności $\mathrm{i}$ - z racji specyfiki wykonywanego zawodu - jest mu bliżej do sylwetki homo sociologicus, stawiającej przed sobą realizację - najpierw - celu medycznego, a później ekonomicznego funkcjonowania gabinetu. Tym samym hipotezę mówiącą o tym, iż wśród motywów wyboru zawodu lekarza dentysty dominuje chęć pomocy innym nad względami ekonomicznymi, należy uznać za zweryfikowaną pozytywnie.

W pracy wykazano również na płaszczyźnie teoretycznej - na podstawie dorob$\mathrm{ku}$ różnych przedstawicieli nurtu przedsiębiorczości (od R. Cantillona, przez J.B. Saya, J.A. Schumetera, F.H. Knighta, I.M. Kirzera, po P.F. Druckera), że lekarz dentysta w prowadzeniu gabinetu może przejawiać różne postawy przedsiębiorcze, a więc tym samym można określić go mianem przedsiębiorcy (por. tabela 4).

Jak już zostało powiedziane, jednym z przejawów działań przedsiębiorczych dentystów może być przeniesienie na grunt gabinetu idei marketingu relacji. Przeprowadzone badanie II pozwoliło na pozytywną weryfikację hipotezy mówiącej, że lekarz dentysta prezentujący sylwetkę przedsiębiorcy inspiratora i inicjatora zmian - przywódcy transformacyjnego, działa bardziej prorynkowo, niż ten, którego cechuje przedsiębiorczość w rozumieniu Walrasa czy Druckera (o transakcyjnym stylu przywództwa) lub przedsiębiorcę organizatora zasobów, podejmującego umiarkowane ryzyko (o mieszanym stylu przywództwa) ${ }^{19}$. Wyniki badania umożliwiły wskazanie wpływu prezentowanej przez stomatologa postawy przedsiębiorczej (zdefiniowanej przez styl przywództwa) na podejmowane przez niego $\mathrm{w}$ gabinecie działania rynkowe, zmierzające do utrzymania relacji z pacjentem. Lekarze dentyści - przedsiębiorcy inspiratorzy i inicjatorzy zmian wykazywali najbardziej prorynkowe nastawienie (w porównaniu $\mathrm{z}$ tymi o stylu transakcyjnym czy mieszanym), co przejawiało się m. in. w:

\footnotetext{
${ }^{19}$ We wstępie pracy omawiana hipoteza zawiera również przywództwo leseferystyczne, jednak ze względu na fakt, iż tylko dwie osoby zostały zakwalifikowane do tego typu sylwetki w pracy nie podjęto analizy w tym zakresie.
} 
- deklaracji podjęcia bardziej zróżnicowanych działań w sytuacji, gdyby otwierali gabinet obok już istniejącego;

- większej orientacji na zmiany zachodzące w otoczeniu gabinetu;

- wskazaniu czynników konkurencyjności gabinetu (dziś i w przyszłości) o orientacji rynkowej: zmiany w ofercie (zarówno w kierunku dywersyfikacji, jak i specjalizacji), kwalifikacje menedżerskie dentysty, bardzo dobra znajomość rynku i działań konkurentów, działania promocyjne;

- wyższej samoocenie w zakresie umiejętności interpersonalnych i intrapersonalnych na tle badanej grupy;

- przekonaniu, że zwiększenie jakości obsługi pacjentów to inwestycja w długookresowe relacje z pacjentami (dlatego przykładają wagę do wyposażenia gabinetu, a także wdrażają zmiany w zakresie poprawy jakości obsługi);

- tworzeniu w swoich gabinetach warunków najbardziej przyjaznych pacjentom.

Postawa lekarza dentysty (również pozostałych członków personelu gabinetu) ma istotny wpływ na poziom obsługi klienta i kształtowanie relacji z nim. L. Edvinsson i M.S. Malone ${ }^{20}$ podkreślają, że personel danego podmiotu może stanowić wartość dodaną organizacji (np. w gabinecie stomatologicznym wpływając na poziom pozamedycznych obszarów jakości usług i w efekcie możliwość nawiązywania relacji z pacjentami). Tym bardziej, że lekarz dentysta przez pacjentów jest często utożsamiany z samą usługą; siłę takiego przekazu wzmacnia ${ }^{21}$ :

- status eksperta - wiążący się ze specjalistyczną wiedzą, na którą powołuje się nadawca komunikatu kierowanego do pacjenta dla poparcia swojego twierdzenia;

- wiarygodność - która łączy się ze stopniem postrzegania źródła przekazu jako obiektywnego i uczciwego (dlatego szczególną rolę pełni zaufanie na płaszczyźnie lekarz - pacjent),

- umiejętność wzbudzenia sympatii - tzn. szczerość, poczucie humoru i naturalność, które zapewniają, że taka osoba sprawia pozytywne wrażenie na innych.

Dzięki wynikom badania IV udało się pokazać przedstawione wyżej powiązania - pacjenci zwracają uwagę nie tylko na profesjonalizm stricte medyczny

\footnotetext{
${ }^{20}$ Edvinsson L., Malone M.S., Kapitat ... op. cit., s. 27.

${ }^{21}$ Kelman H.C., Hovland C.I., Reistatement of the Communication in Delayed Measurement of Opinion Change, "Journal of Abnormal and Social Psychology", $1953 \mathrm{nr} 48$, s. 327 i nast. za: Kotler Ph., Shalowitz J., Stevens R.J., Marketing strategiczny ... op. cit., s. 523.
} 
stomatologa, ale również elementy związane z obsługą (i czynniki interpersonalne są dla nich ważniejsze, niż materialne).

Dbałość o jakość obsługi (zgodnie z oczekiwaniami nabywców), umożliwiająca nawiązywanie trwałych relacji z pacjentami, jest swoistym ultimum refugium w obliczu nasilającej się konkurencji na rynku usług stomatologicznych, z obopólną korzyścią i dla świadczących usługi, i dla pacjentów. Pacjenci (badanie IV) wracają do gabinetu, jeśli dentysta i personel pomocniczy spełniają ich oczekiwania (podstawowe to: doświadczenie personelu, rzetelność i dokładność lekarza w realizacji świadczenia stomatologicznego, poczucie bezpieczeństwa w gabinecie, dogodne terminy pracy gabinetu). Dentyści (badanie I) większości analizowanych czynników pozostania pacjenta w gabinecie, jako nabywcy usług stomatologicznych, przypisali mniejsze znaczenie, niż pacjenci (w wielu przypadkach nie są to różnice istotne statystycznie). Studenci (badanie III) lepiej, niż lekarze dentyści, określili oczekiwania pacjentów (lepiej też rozumieją rolę pacjenta jako współtwórcy usługi). Można powiedzieć, że dentyści rozpoznając intuicyjnie (bo respondenci nie prowadzili badania potrzeb pacjentów) pozamedyczne oczekiwania pacjentów, podejmują odpowiednie działania - z zakresu jakości obsługi - umożliwiające nawiązanie i utrzymanie relacji z pacjentem, choć nie są one realizowane na szeroką skalę (nawet w tych obszarach, które są ważne dla pacjentów). Ponadto lekarze dentyści nie w pełni wykorzystują potencjał komunikacji, jako świadomego narzędzia budowania więzi z pacjentami.

Na relacje z klientami można spojrzeć m. in. z poziomu ${ }^{22}$ : ponownych zakupów (wskaźnik retencji), skłonności do rekomendacji (NPS) oraz skłonności do zmiany firmy (wskaźnik utraty klientów). Zdecydowana większość pacjentów $(89,7 \%)$ nie tylko ponawia zakup świadczenia w gabinecie, ale powtarza je regularnie. Niemniej jednak tylko $1 / 3$ badanych pacjentów jest w pełni przekonana o słuszności powtarzania zakupów w gabinecie (dostrzega wartość, którą oferuje ten konkretny lekarz dentysta w tym konkretnym gabinecie), a kolejna trzecia część badanych ma w tym zakresie wątpliwości (11,9\% pacjentów jest przekonanych, że nie straciłoby dużo, przechodząc do innego gabinetu). Dlatego trudno mówić o zdecydowanych intencjach pacjentów do podtrzymywania współpracy z gabinetem. Potwierdza to fakt, że 64,9\% pacjentów nigdy nie zastanawiało się nad wyborem innego dentysty, a pozostali już tak. Spośród osób, które leczą się aktualnie u jakiegoś dentysty 80,3\% poleciłoby swojego lekarza komuś z rodzin/przyjaciół, a tylko 1,1\% - zdecydowanie nie (NPS dla całej grupy badanej wyniósł 79,2\%). Przedstawione wskaźniki pozwalają na stwierdzenie, że relatywnie wysoki wskaźnik retencji nie musi gwarantować utrzymania pacjenta, jako nabywcy usługi stomatologicznej w długim okresie.

\footnotetext{
${ }^{22}$ Kozielski R. (red.), Wskaźniki ... op. cit., Kraków 2008, s. 160.
} 
Powinno to zachęcać lekarzy dentystów do badania oczekiwań pacjentów oraz stopnia ich zaspokojenia, aby mogli podejmować działania w kierunku budowania prawdziwej (zamiast pozornej) lojalności pacjentów. Tym bardziej, że - jak pokazano w pracy - współczesne trendy (obecne w literaturze i praktyce działań przedsiębiorstw innych branż) nie są obce gabinetom stomatologicznym działającym zarobkowo (np. outsourcing funkcji pomocniczych, benchmarking) ${ }^{23}$. Analiza dokonana w pracy pozwala na pozytywną weryfikację hipotezy mówiącej o tym, iż relacje na płaszczyźnie pacjent - lekarz dentysta (mierzone wskaźnikiem retencji, wskaźnikiem utraty klientów i skłonności do rekomendacji) zależą od częstotliwości wizyt pacjenta w gabinecie (i im większa częstotliwość, tym głębsza relacja).

W prywatnych podmiotach leczniczych źródła przewagi konkurencyjnej ewoluują od stricte medycznych do opartych na biznesowych aspektach funkcjonowania gabinetu, szczególnie $\mathrm{w}$ zakresie relacji z pacjentami, które stają się unikatowym zasobem podmiotu, trudnym do przywłaszczenia i naśladowania, o długim okresie trwania. Ich budowa wymaga rozpoznania relatywnej ważności poszczególnych poziomów atrybutów usług stomatologicznych w oczach pacjentów, a następnie wprowadzenia odpowiednich zmian w obsłudze, co jest uwarunkowane zaangażowaniem wszystkich członków personelu gabinetu. Lekarz dentysta, jako przedsiębiorca nie może ograniczać się jedynie do obsługi takiej, jak w innych gabinetach, gdyż mogłoby to być niewystarczające do tego, by pozyskać i - w długim okresie - utrzymać pacjentów. Z tego względu stomatolog w obszarze pozamedycznych aspektów funkcjonowania gabinetu powinien działać w odmienny sposób - urzeczywistniać swoją własną koncepcję biznesowego działania.

Warto jeszcze raz podkreślić, że pozycja rynkowa gabinetów stomatologicznych nie wynika bezpośrednio z wielkości zgromadzonych zasobów materialnych. Przewaga jest związana z posiadaniem i wykorzystywaniem wyróżniających się kompetencji, budowanych przede wszystkim z zasobów niematerialnych (np. zgromadzonej wiedzy; pielęgnowanych relacji z pacjentami, dostawcami sprzętu i materiałów stomatologicznych). Rozwój przynoszących sukces kompetencji ściśle wiąże się z uczeniem się lekarzy dentystów (i pozostałych członków personelu gabinetu) ${ }^{24}$. W tym kontekście gabinet

\footnotetext{
${ }^{23} \mathrm{Z}$ drugiej strony należy przypomnieć o towarzyszącym wielu lekarzom dentystom braku przekonania co do możliwości pogodzenia niektórych inicjatyw z etyką lekarską - wynika ono najczęściej $\mathrm{z}$ tego, że stomatolog nie wie, czy można je pogodzić, a nie z tego, że na pewno jest przekonany o kolidowaniu tych dwóch obszarów. Spowodowane jest to przede wszystkim brakiem wiedzy o możliwościach rynkowego oddziaływania $(54,14 \%$ respondentów badania I zadeklarowało, że w małym stopniu lub nie dysponuje w ogóle wiedzą na temat możliwości wykorzystania marketingu w gabinecie, a 3,18\% badanych oceniło swoją wiedzę w tym zakresie jako bardzo dobrą).

${ }^{24}$ Morawski M., Zarzadzanie ... op. cit., s. 24.
} 
stomatologiczny można potraktować, jako organizację uczącą się, która w marketingu relacji (ujmowanym procesowo) dostrzega drogę w umacnianiu pozycji rynkowej (poprzez sieć wiernych klientów) ${ }^{25}$; tym samym tematyka podjęta $\mathrm{w}$ pracy wpisuje się w nurt teorii marketingu relacji w ujęciu sektorowym ${ }^{26}$.

Praca stanowi kompendium wiedzy o rynku usług stomatologicznych w Polsce i działaniach rynkowych stomatologów, jednak problematyka biznesowego funkcjonowania gabinetu stomatologicznego jest na tyle obszerna, że niektóre zagadnienia potraktowano marginalnie (lub nie podjęto ich w ogóle), aby skupić się na nawiązywaniu i utrzymywaniu relacji z pacjentami. W pracy udało się pokazać, że gabinet stomatologiczny podejmuje wiele działań zarządczych realizowanych w podmiotach innych branż (np. z zakresu przedsiębiorczości zarządczej, zarządzania wiedzą, zarządzania personelem, zarządzania jakością obsługi, reagowania na działania konkurencji itp.). Zmiany zachodzące na rynku usług stomatologicznych (np. w zakresie działania NFZ w obszarze kontraktowania i finansowania świadczeń stomatologicznych, rosnącej ekonomizacji kontaktów między lekarzem dentystą a pacjentem) pozostawiają otwartą furtkę do podejmowania dalszych poszukiwań badawczych. W pracy zostały nakreślone nowe kierunki badań, które mogą zostać podjęte w odniesieniu do usług stomatologicznych:

- eksploracja problematyki relacji z perspektywy pracowników gabinetów (i marketingu relacji $\mathrm{w}$ kontekście klientów wewnętrznych), wynikająca $\mathrm{z}$ niskiego poziomu samooceny lekarzy w zakresie umiejętności interpersonalnych w kontaktach z pracownikami (wyniki badania I i II),

- skupienie się na ekonomice funkcjonowania gabinetów i określenie wartości portfela klientów, jako efektu działań marketingowych podejmowanych przez lekarzy dentystów (jako kontynuacja problematyki badania I),

- określenie miejsca usług stomatologicznych w systemie opieki zdrowotnej, jako zadania publicznego i rekomendacje dla polityki zdrowotnej (jako wynik rozważań podjętych w III rozdziale),

- analiza rynku gabinetów stomatologicznych, zmierzająca do uchwycenia momentu pojawienia się tendencji do sprzedawania całych praktyk i podjęcie problemu wyceny (nie tylko majątkowej, ale i dochodowej) gabinetów (jako wynik rozważań II rozdziału).

Intencją autorki było, aby praca wpisała się w filozofię nurtu Uniwersytetu Trzeciej Generacji ${ }^{27}$ tzn. prezentowała nie tylko wiedzę teoretyczną i wyniki przeprowadzonych badań, ale również możliwości ich wykorzystania

\footnotetext{
${ }^{25}$ Chłodnicki M., Ustugi profesjonalne ... op. cit., s. 24.

${ }^{26}$ Por. Rayhmell J.M., Marketing in Service Sektor, Winthrop Publisher, Cambridge Mass., 1974.

${ }^{27}$ Wissena J.G., Uniwersytet ... op. cit., s. 43.
} 
w praktyce wybranych podmiotów rynkowych, jakimi są prywatne gabinety stomatologiczne. Dzięki m. in. postulatowi, by kształtować postawy przedsiębiorcze studentów kierunku lekarsko-dentystycznego, gdyż wpływają one na prorynkowe funkcjonowanie gabinetów stomatologicznych, udało się ten zamiar zrealizować. Pamiętając, że przedsiębiorczość jest zdolnością przystosowania się organizacji do zmian ( $w$ sposób przynoszący jej społecznoekonomiczną korzyść), można powiedzieć, że jest ona funkcją posiadanej i wykorzystywanej wiedzy o warunkach funkcjonowania podmiotu (w tym o nabywcach i konkurentach). Tym samym może znaleźć swój wyraz w marketingu relacji (który wymaga m. in. ciągłego analizowania zmieniających się oczekiwań nabywców i właściwego reagowania na nie). Lekarz dentysta, zastępując dotychczasowe rozwiązania lepszymi (np. w zakresie sposobu obsługi pacjentów przed rozpoczęciem leczenia), jest przedsiębiorcą innowatorem, a skupiając się na - przedstawionych w pracy - możliwościach tkwiących w marketingu relacji, może podwyższać efektywność operacyjną gabinetu (i poprawiać jego pozycję konkurencyjną). U części lekarzy dentystów (np. o Sylwetce A i C w badaniu II) i większości studentów kierunku lekarskodentystycznego można dostrzec znaczny potencjał do prorynkowej aktywności. $\mathrm{Z}$ tego względu można wnioskować, iż dualne tj. medyczno-marketingowe spojrzenie na gabinet stomatologiczny staje się koniecznością rynkową (jeśli dentysta - przedsiębiorca chce, by jego gabinet był konkurencyjny i dziś, i w przyszłości). 



\section{BIBLIOGRAFIA}

Adair J., Anatomia biznesu. Podejmowanie decyzji. Podstawowa umiejętność $w$ procesie zarzadzania, wyd. Studio EMKA, Warszawa 2001

Adamczyk J., Spoteczna odpowiedzialność przedsiębiorstw. Teoria i praktyka, PWE, Warszawa 2009

Adamczyk-Kloczkowska B., Wojna M., Czynniki wspierajace i osłabiajace konkurencję w systemie ochrony zdrowia, w: Ryć K., Skrzypczak Z. (red.), Ochrona zdrowia i gospodarka. Mechanizmy rynkowe $i$ gospodarka. Mechanizmy rynkowe a regulacje publiczne, Wydawnictwo Naukowe Wydziału Zarządzania Uniwersytetu Warszawskiego, Warszawa 2008

Agyeman-Budu E.A., Wevaert F., Investing in health care management: a way to Explorer the future value Outlook of the health care sector, "Corporate governance", $2006 \mathrm{nr} 4$

Ainsworth-Vaughn N., The discourse of medical encounters, w: Schiffrin D., Tannen D., Hamilton H. (red.), The Handbook of Discourse Analysis, Blackwell, Oxford 2001

Ajzen I., The theory of planned behavior, "Organizational Behavior and Human Decision Processes", 1991.t 50

Alaluf M., Stroobants M., Moviliza la competencia al obrero?, "Revista Europea de Formacion Profesional", 1994 nr 1 za: Dobska M., Rogoziński K. (red.), Podstawy zarzadzania zakładem opieki zdrowotnej, Wydawnictwo Naukowe PWN, Warszawa 2008

Aldana J.M., Piechulek H., AlSatir A., Client Satisfaction and Quality of Health Care, "Bulletin of the World Health Organization", $2001 \mathrm{nr} 6$

Aldlaigan A.H., Buttle F.A., SYSTRA-SQ: a new measure of bank service quality, "International Journal of Service Industry Management", $2002 \mathrm{nr} 4$

Alvarez S.A., Barney J.B., Discovery and Creation: Alternative Theories of Entrepreneurial Action, "Strategic Entrepreneurship Journal", 2007 vol. 1

Alvarez S.A., Introduction to Creativity, Imagination, and Opportunities, "Strategic Entrepreneurship Journal", 2008 vol. 2

Ambastha A., Momaya K., Competitiveness of firms: review of theory, frameworks, and models, "Singapore Management Review", 2004, vol. 26, nr 1

Anderson W., A Marketing View of Competition, ,Journal of Marketing”, 1937 nr 1(3)

Armstrong G., Kotler Ph., Saunders J., Wong V., Marketing. Podręcznik europejski, PWE, Warszawa 2002

Arrow K.J., Uncertainty and the Welfare Economics of Medical Care, "The American Economic Review”, December 1963, vol. LIII, nr 5

Austen-Tynda A., Kozłowski R., Burda-Świerz K., Istota $i$ znaczenie przywództwa dla ksztattowania konkurencyjności jednostki ochrony zdrowia, w: Frączkiewicz-Wronka A., Austen-Tynda A. (red.), Przywództwo w ochronie zdrowia. Idee i instrumenty, Wolters Kluwer Polska sp. z o.o., Warszawa 2009

Avery G.C., Przywództwo w organizacji. Paradygmaty i studia przypadków, PWE, Warszawa 2009

Backhouse R.E., Medea S.G., On the Definition of Economics, "Journal of Economic Perspectives", $2009 \mathrm{nr} 1$

Bain and Company w: Clark M., Payne A., Customer Retention: Does Employee Retention Hold a Key to Success, Marketing Education Group Proceedings $1993 \mathrm{nr} 1$ za: Otto J., Marketing relacji. Koncepcja i stosowanie, Wydawnictwo C.H.Beck, Warszawa 2001

Baker S., New Consumer Marketing: Managing a Living Demand System, West Sussex, England, John Wiley \&Sons, 2003

Bandura A., Self-efficacy: The exercise of control, Frejman\&Co, Nowy Jork 1997 
Bandura A., Cultivate self-efficacy for personal and organizational effectiveness, w: Locke A. (red.), Handbook of principles of organization behavior, Blackwell, Oxford 2000

Bank J., Zarzadzanie przez jakość, Wydawnictwo Felberg Sja, Warszawa 1999

Bansal H.S., Foyer P.A., Word of mouth processes within a services purchase decision context, "Journal of Service Research", $2000 \mathrm{nr} 2$

Barański J., Waszyński E., Steciwko A., Komunikowanie się lekarza z pacjentem, Wydawnictwo ASTRUM, Wrocław 2000

Barney J.B., Firm resources and sustained competitive advantage, "Journal of Management", 1991 vol. $17, \mathrm{nr} 1$

Barney J.B., Resource - based 'theorie' of competitive advantage: A ten-year retrospective on the resource-based wiev, "Journal of Managemenet", $2001 \mathrm{nr} 27$

Barney J.B., Clark D.N., Resource-Based Theory. Creating and Sustaining Competitive Advantage, Oxford University Press, Oxford, Nowy Jork 2009

Barney J.B., Wright P.M., On Becoming a Strategic Partner: The Role of Human Resources in Gaining Competitive Advantage, "Human Resource Management", 1998 vol. 37, nr 1

Bartkowiak G., Geneza i teoretyczna podstawa zarzadzania zasobami ludzkimi, w: Dobska M., Rogoziński K. (red.), Podstawy zarzadzania zakładem opieki zdrowotnej, Wydawnictwo Naukowe PWN, Warszawa 2008

Bass B., Leadership and Performance Beyond Expectations, "Free Press", Nowy Jork 1985

Bateson J.E.G., Managing Services Marketing, “The Dryden Press”, Orlando 1991

Beaver G., Jennings P., Managerial Competence and Competitive Advantage in the Small Business: An Alternative Perspective, w: Developing Core Competencies in Small Business for the $21^{\text {st }}$ Century, University of Vaasa, 1996

Belz G., Triumwirat ról wobec pytań o ewolucję modeli przywództwa, „Zeszyty Naukowe Uniwersytetu Ekonomicznego w Poznaniu” nr 187, Poznań 2011

Bernacik M., CEM - nowy wymiar orientacji na klienta, „Modern Marketing”, 2004 nr 1

Berry L.L., Relationship Marketing, w: Berry L.L., Shostack G.L., Upah G.D., Emerging Perspectives on Services Marketing, "American Marketing Association”, Chicago 1983

Bieniok H., Zarzadzanie mała firma, Wyd. AE w Katowicach, Katowice 1996

Binsztok A., Instrumenty marketingowe pozyskiwania, obstugi i utrzymania klienta $w$ komercyjnej firmie medycznej, w: Perechuda K., Kowalewski M., Zarzadzanie komercyjna firma medyczna, Wolters Kluwer business, Warszawa 2008

Bird B., Implementing Entrepreneurial Ideas: The Case for Intention, „Academy of Management Review", 1988 vol. 13, nr 3

Bitner M.J., Booms B.H., Tetreault M.S., The Service Ecounter: Diagnosing Favorable and Unfavorable Incidents, "Journal of Marketing", 1990, nr 1 za: Boguszewicz-Kreft M., Reakcja przedsiębiorstwa na błąd $w$ ustudze jako element marketingu partnerskiego, „Marketing i Rynek", $2004 \mathrm{nr} 6$

Bitner M.J., Hubert A.R., Encounter satisfaction versus overall satisfaction versus quality, w: R.T.Rust, L.R.Oliver (red.), Service Quality: New Directions in Theory and Practice, Sage, Londyn 1983

Bitner M.J., Zeithaml V.A., Service Marketing, McGraw-Hill, Nowy Jork 2003

Bjorkman T., Hansson L., Svensson B., Berglund I., What is important in psychiatric outpatient care? Quality of care the patient's perspective, "International Journal for Quality in Health Care",1995 nr4

Bladowski M., Depresja w środowisku lekarzy stomatologów, cz.I, „As Stomatologii”, $2010 \mathrm{nr} 1$ 
Bladowski M., Depresja w środowisku lekarzy stomatologów, cz.II. Skale pomiaru depresji, „As Stomatologii”, $2010 \mathrm{nr} 2$

Bladowski M., Zacharko-Klafft M., Depresja w środowisku lekarzy stomatologów, cz.III. Metody leczenia depresji, „As Stomatologii”, $2010 \mathrm{nr} 3$

Blattberg R.C., Hoch S.J., Database Models and Managerial Intuition, „Management Science“, $1990 \mathrm{nr}$ 36(8)

Blattberg R.C., Getz G., Thomas J.S., Customer Equity. Building and Managing Relationships as Valuable Assets, "Harvard Business School Press", Harvard 2001

Blaug M., Teoria ekonomii: ujęcie retrospektywne, Wydawnictwo Naukowe PWN, Warszawa 1994

Blois K., Analyzing Exchange Through the Use of Value Equations, „The Journal of Business \& Industrial Marketing", $2004 \mathrm{nr}$ 4-5

Bloemer J.M.M., Kasper H.D., The complex relationship between consumer satisfaction and Brand loyalty, "Journal of Economic Psychology", 1995 nr 16

Bławat F., Przedsiębiorca $w$ teorii przedsiębiorczości i praktyce matych firm, Gdańskie Towarzystwo Naukowe, Gdańsk 2003

Bober B., Rola informacji w procesie świadczenia ustugi szpitalnej - redukcja ryzyka decyzyjnego, w: Lewandowski R., Walkowiak R. (red.), Wspótczesne wyzwania strukturalne i menedżerskie w ochronie zdrowia. Problemy zarzadzania, OWSzIiZ im. prof. T. Kotarbińskiego, Olsztyn 2010

Bogusz J., Zasady deontologiczne zwiazane z postęami wiedzy ludzkiej, w: Kielanowski T. (red.), Etyka i deontologia lekarska, PZWL, Warszawa 1985

Bojar I., Wdowiak L., Zarzadzanie marketingowe w zakładach opieki zdrowotnej, „Zdrowie Publiczne", $2001 \mathrm{nr}$ 5-6

Bolton R.N., Drew. J.H., A longitudinal analysis of the impact of service changes on consumer attitudes, "Journal of Consumer Research", 1991 vol. 17

Borczyk D., Rozmawiamy nie tylko o pracy, ,Medical Tribune. Stomatologia”, 2010 nr 12

Borkowska A., Czerw A., Psychologiczny portret zawodu lekarza, w: Walkowiak R., Lewandowski R. (red.), Wspótczesne wyzwania strukturalne $i$ menedżerskie $w$ ochronie zdrowia. Problematyka zasobów i przekształceń, Wydawnictwo OWSzIiZ im. prof. T.Kotarbińskiego, Olsztyn 2010

Borkowska S., Bohdziewicz P. (red.), Menedżer u progu XXI wieku, wyd. WSHE, Łódź 1998

Borkowski J., Podstawy psychologii spotecznej, Dom Wydawniczy ELIPSA, Warszawa 2003

Borowiecki R., Romanowska M. (red.), Wywiad gospodarczy a konkurencyjność przedsiębiorstwa, Difin, Warszawa 2001

Borys T., Klient jako „poczatek” $i$,koniec” prowadzonej działalności, w: Borys T., Rogala P., Orientacja na klienta jako kryterium doskonatości, Prace Naukowe Uniwersytetu Ekonomicznego we Wrocławiu, nr 151, Wyd. UE, Wrocław 2011

Bowers K.S., Regher G., Balthazard C., Parker K., Intuition in the Context of Discovery, "Cognitive Psychology", $1990 \mathrm{nr} 22$

Brady M.K., Robertson C.J., Searching for a Consensus on the Antecedents Role of Service Quality and Satisfaction: An Exploratory Cross National Study, ,Journal of Business Research”, 2001 vol. 51

Bratnicki M., Konfiguracyjne ujęcie przedsiębiorczości organizacyjnej, „Ekonomika i Organizacja Przedsiębiorstwa", $2008 \mathrm{nr} 6$

Bratnicki M., Przedsiębiorczość i dynamika organizacji, „Organizacja i Kierowanie”, $2001 \mathrm{nr} 2$

Bratnicki M., Przedsiębiorczość i przedsiębiorcy wspótczesnych organizacji, Wyd. Akademii Ekonomicznej w Katowicach, Katowice, 2002 
Breyer F., Zweifel P., Kifmann M., Gesundheitsökonomie, Springer Verlag, Berlin, Heidelberg, Nowy Jork, 2003 za: Sowada C., Wptyw metod finansowania na zachowania lekarzy - aspekty ekonomiczne, zdrowotne i społeczne, „Zeszyty Naukowe Ochrony Zdrowia. Zdrowie Publiczne i Zarządzanie", $2005 \mathrm{nr}$ 1, t. III,

Brockner J., Siegel P.A., Daly J.P., Tyler T., Martin Ch., When Trust Matters: The Moderating Effect of Outcome Favorability, "Administrative Science Quarterly”, $1997 \mathrm{nr} 42$

Brooking A., Intellectual Capital: Core Assets for the Third Millennium Enterprise, International Thomson Business Press, Londyn 1988

Bryan L., Kay J., Dialogue: Can a Company Be Too Big? „The McKinsey Quarterly” 1999 nr 4

Brzeziński T., Tradycyjne zasady deontologii lekarskiej, w: Kielanowski T. (red.), Etyka i deontologia lekarska, PZWL, Warszawa 1985

Brzeziński M., Gorynia M., Hockuba Z., Ekonomia a inne nauki spoteczne na poczatku XXIw. Między imperializmem a kooperacja, „Ekonomista”, $2008 \mathrm{nr} 2$

Brzozowski P., Skala Wartości. Polska adaptacja Value Survey M.Rokeacha, COMPIS, Warszawa 1996

Bukowska-Piestrzyńska A., Communication with patients from the perspective of patients, dental surgeons and dentistry students - research results, ,e-Dentico”, $2013 \mathrm{nr} 1$

Bukowska-Piestrzyńska A., Emocje pracowników w gabinecie stomatologicznym, „e-Dentico”, $2012 \mathrm{nr} 5$

Bukowska-Piestrzyńska A., Organizacja i zarządzanie gabinetem stomatologicznym, Wyd. Czelej, Warszawa 2011

Bukowska-Piestrzyńska A., Obstuga klienta gabinetu stomatologicznego, Wyd. Czelej, Warszawa 2011

Bukowska-Piestrzyńska A., Finansowanie marketingu w ochronie zdrowia, CeDeWu.pl, Warszawa 2010

Bukowska-Piestrzyńska A., Określanie atrybutów ustug, „Ekonomika i Organizacja Przedsiębiorstwa", $2009 \mathrm{nr} 9$

Burns J.M., Leadership, Harper\&Row, Nowy Jork 1978

Busenitz L.W., Barney J.B., Differences between entrepreneurs and managers in large organizations: Biases and heuristics in strategic decision-making, "Journal of Business Venturing" 1997 vol. 12

Caers R., Du Bois C., Jegers M., De Gieter S., Schepers C., Peperma R., Principal-Agent Relationships on the Stewardship-Agency Axis, "Nonprofit Management \& Leadership", 2006 nr1

Cahill D.J., The Managerial Implications of the Learning Organization: A New Tool for Internal Marketing, "Journal of Services Marketing", 1995 vol. 9, nr 4 za: Kozielski R. (red.), Wskaźniki marketingowe, Oficyna a Wolters Kluwer business, Warszawa 2011, wyd. IV zmienione

Cantillon R., Assai sur la nature du commerce en general, za: Łuczak M., Przedsiębiorczość w zarzadzaniu firma, Wydawnictwo WSzE w Warszawie, Warszawa, 2003

Carbone L.P., Clued In: How to Keep Customers Coming Back Again and Again, FT Prentice Hall, Upper Saddle River, Nowy Jork 2004

Carbone L.P., Haeckel S.H., Engineering Customer Experiences, "Marketing Management", Winter 1994

Cardona P., Ray C., Zarządzanie poprzez misje, Oficyna Wolters Kluwer Business, Kraków 2009

Carroll A.B., A three dimensional conceptual model of corporate social performance, "Academy of Management Review", 1979 vol. 4, nr 4

Cassone M., The Entrepreneur. An Economic Theory, Barnes \& Noble Books, Totowa 1982 
Chamberlin E.H., The Theory of Monopolistic Competition, A Re-orientation of the Theory of Value, "Harvard University Press", wydanie 8, 1962 za: Czaja I., Przedsiębiorczość na rynku ustug medycznych procesie przeksztatceń organizacyjnych $i$ wtasnościowych $w$ Polsce, w: Rudawska I., Urbańczyk E., Ekonomiczno-organizacyjne problemy zarzadzania jednostkami stużby zdrowia, „Studia i materiały Polskiego Stowarzyszenia Zarządzania Wiedzą”, Bydgoszcz 2010

Chattopadhyay R., Ghosh A.K., Entrepreneurial Intention Model-Based quantitative Approach to Estimate Entrepreneurial Success, "Journal of Small Business and Entrepreneurship", 2008

Chłodnicki M., Ustugi profesjonalne - przez jakość do lojalności klientów, Wyd. AE w Poznaniu, Poznań 2004

Cholewicka-Goździk K., Istota zarzadzania jakościa, ,Problemy Jakości”, 2008, nr 6

Christopher M., Payne A., Ballantyne D., Relationship Marketing, Butterworth-Heinemann Ltd., Oxford 1991

Chryssides G.D., Kaler J.H., Wprowadzenie do etyki biznesu, PWN, Warszawa 1999

Ciesielski M., Problemy metodologii normatywnej $w$ naukach o zarzadzaniu, „Przegląd Organizacji”, $2012 \mathrm{nr} 10$

Cooper M.C., Ellram L.M., Characteristics of Chain Management and the Implications for Purchasing and Logistics Strategy, "International Journal of Logistics Management", $1993 \mathrm{nr} 2$

Copulsky J.R., Wolf M.J., Relationship Marketing. Positioning for the Future, "Journal of Business Strategy", $1990 \mathrm{nr}$ 7-8, vol. 11

Cortes R., Create emotional connections with consumers, "Caribbean Business" 30 September 2004

Cowles D., The Role of Trust in Consumer Relationships: Asking the Right Questions, "Management Decisions", 1997 vol. 35, nr 4

Coyle J., Bardi E., Langley C.J., Zarzadzanie logistyczne, PWE, Warszawa 2002

Cram T., The Power of Relationship Marketing, Pitman Publishing, Londyn 1994

Cunnington B., The Marketing Learning Identity, "Journal of Customer Marketing”, 1996 nr 5

Cyert R.M., March J.G., A Behavioural Theory of Firm, Blackwell Business, Cambridge 1992

Czaja I., Przedsiębiorczość na rynku ustug medycznych procesie przeksztatceń organizacyjnych $i$ własnościowych $w$ Polsce, w: Rudawska I., Urbańczyk E., Ekonomiczno-organizacyjne problemy zarzadzania jednostkami stużby zdrowia, „Studia i materiały Polskiego Stowarzyszenia Zarządzania Wiedzą", Bydgoszcz 2010

Czarniawska-Joerges B., Wolff R., Leaders, Managers, Entrepreneurs on and off the Organizational Stage, "Organization Studies", $1991 \mathrm{nr} 4$

Czermiński A., Czerska M., Nogalski B., Rutka R., Apanowicz J., Zarządzanie organizacyjne, Dom Organizatora, Torun 2001

Czerny J., Paradygmaty wspótczesnej filozofii nauki, Intermedia, Katowice 2005

Czubalski F., O wyborze zawodu lekarskiego, Warszawa 1931 , za: Gilewska-Dubis J., Etos zawodu lekarza $w$ relacji z pacjentem $w$ średniowiecznej medycynie europejskiej, w: Płonka-Syroka B. (red.), Relacje lekarz-pacjent $w$ aspekcie społecznym, historycznym i kulturowym, „Studia z dziejów kultury medycznej”, Katedra Etnologii i antropologii kulturowej Uniwersytetu Wrocławskiego, Wrocław 2005

Czubała A., Jonas A., Smoleń T., Wiktor J.W., Marketing ustug, Wolters Kluwer, Kraków 2006

Daszkowska M., Ustugi. Produkcja, rynek, marketing, Wydawnictwo Naukowe PWN, Warszawa 1998

De Rover R., San Bernardino of Siena and Saint'Antonio of Florence: The two great economic thinkers of the middle ages, Harvard Graduate School of Business Administration, Baker 
Library, Boston 1967, za: Jabłoński M., Klasyczne podejścia w identyfikacji kompetencji kierowniczych, „Organizacja i kierowanie”, $2009 \mathrm{nr} 4$

Definicja IBM, Are you to speed on knowledge management, HR Focus, 2000, vol. 77

den Hertog P., Co-producers of innovation: on the role of knowledge-intensive business services in innovation, w: Gadrey J., Gallouj F., Elgar E. (red.), Productivity, innovation and knowledge in services, New Economic and Socio-Economic Approaches, Cheltenham-Northampton 2002

Deshpande R., ,Forseeing” marketing, ,Journal of Marketing”, 1999 vol. 63

Dess J.G., Emmerson J., Economy P., Enterprising nonprofits, John\&Wiley Sons, Nowy Jork 2001

Deutsch M., Gerrard H.B., A study of normative and informational social influences upon individual judgement, "Journal of Abnormal Social Psychology", 1955 vol. 51

Dietl J., Gasparski W. (red.), Etyka biznesu, Wydawnictwo Naukowe PWN, Warszawa 1999

Dixon-Woods M., Dissemination of printed information for patients: a qualitative study of general practices, "Health Education Journal", $1998 \mathrm{nr} 1$

Dobiegała-Korona B., Kasiewicz S., Metody oceny konkurencyjności przedsiębiorstw, w: Kuciński K. (red.), Uwarunkowania konkurencyjności przedsiębiorstw w Polsce, „Materiały i Prace IFGN", tom LXXIX, Oficyna Wydawnicza SGH, Warszawa 2000

Dobrołowicz W., Przedsiębiorczość, w: Encyklopedia biznesu, t. I, Fundacja Innowacja, Warszawa 1995

Dobrowolska A., Dobrowolski W., Wptyw technologii informatycznej na jakość procesu ustugowego i na klienta, w: Borys T., Rogala P., Orientacja na klienta jako kryterium doskonałości, Prace Naukowe Uniwersytetu Ekonomicznego we Wrocławiu, nr 151, Wyd. UE, Wrocław 2011

Dobska M., Rogoziński K. (red.), Podstawy zarzadzania zakładem opiek zdrowotnej, Wydawnictwo Naukowe PWN, Warszawa 2008

Doctors for Health, WHO global strategy for changing medical education and medical practice for health for ali, WHO, Genewa 1996, s. 8 za: Rudawska I., Jakość relacji pacjent profesjonalista w sektorze ustug medycznych, „Problemy Jakości”, $2005 \mathrm{nr} 3$

Dokument roboczy uzupełniający Komunikat Komisji Europejskiej do Parlamentu Europejskiego, Rady Komitetu Ekonomiczno-Społecznego oraz Komitetu Regionów: Accompanying the Communication on „A single market for 21th century Europe”. Services of general interest, including social services of general interest: a new European commitment, COM (2007)725 final za: Skoczny T., Jurkowska A., Bernatt M., Charakter ustug świadczonych przez podmioty sektora pozarzadowego $w$ Polsce na tle definicji ustug ekonomicznych i nieekonomicznych w prawie wspólnotowym w szczególności w świetle zakresów Dyrektywy o ustugach na rynku wewnętrznym 2006/123/WE z uwzględnieniem orzecznictwa ETS, Warszawa 2008

Doney P.M., Canzon J.P., An examination of the nature of trust in buyer-seller relationship, "Journal of Marketing", 1997 vol. 61

Donnelley R.G., The Family Business, w: Aronoff C.E., Astrachan J.H., Ward J.L. (red.), Family Business Sourcebook, september 2002 za: Kowalewska A., Szut J., Sułkowski Ł, Marjański A., Definicja pojęcia firmy rodzinnej, w: Kowalewska A.(red.), Firmy rodzinne w polskiej gospodarce - szanse $i$ wyzwania, Wyd.Naukowe Technologii Eksploatacji - PIB, Warszawa 2009

Doyle P., Marketing wartości, FELBERG SJA, Warszawa 2003

Drucker P.F., Natchnienie i fart, czyli innowacja i przedsiębiorczość, Wydawnictwo Studio EMKA, Warszawa 2004

Drucker P.F., Managing Oneself, „Harvard Business School Publishing”, 1999

Drucker P.F., Społeczeństwo prokapitalistyczne, Wydawnictwo Naukowe PWN, Warszawa 1999

Drucker P.F., Praktyka zarządzania, Akademia Ekonomiczna w Krakowie, Kraków 1994 
Drucker P.F., Post - Capitalist Society, Harper Collins, Nowy Jork, 1993

Drucker P.F., Innowacje i przedsiębiorczość. Praktyka i zasady, PWE, Warszawa 1992

Dunaj B. (red.), Stownik wspótczesnego języka polskiego, Wyd. SMS, Kraków 2000

Dunning J.H., Towards a New Paradigm of Development: Implications for Determinants of International Business, "Transnational Corporations", $2006 \mathrm{nr} 1$

Durlik M., Zarzadzanie procesami leczenia w opiece zdrowotnej, w: Trocki M., Nowoczesne zarzadzanie w opiece zdrowotnej, Wydawnictwo Instytutu Przedsiębiorczości i Samorządności, Warszawa 2002

Duraj J., Papiernik-Wojdera M., Przedsiębiorczość i innowacyjność, Difin, Warszawa 2010

Dwyer F.R., Schurr P.H., Och S., Developing Buyer-Seller Relationships, "Journal of Marketing", $1987 \mathrm{nr} 51$

Dziuba D.T., Sektor informacyjny w badaniach ekonomicznych, Difin, Warszawa 2010

Edvardsson B., Gustafsson A., Roos I., Service portraits in service research - a critical review, "International Journal of Service Industry Management", 2005, nr 1

Edvinsson L., Malone M.S., Kapitat intelektualny, Wydawnictwo Naukowe PWN, Warszawa 2001

Eisingerich A.B., Ming L., Perceived service quality and customer trust in a professional service setting: What difference does customer education make? AMA Winter Educators' Conference Proceedings, $2007 \mathrm{nr} 18$

Ennew Ch., Banerjee A., Li D., Managing Word of mouth communication: empirical evidence, "International Journal of Bank Marketing", $2000 \mathrm{nr}$ 18/2

Ensley M.D., Pearce C.L., Hmieleski K.M., The moderating effect of environmental dynamism on the relationship between entrepreneur leadership behavior and new venture performance, "Journal of Business Venturing", 2006 vol. 21

Escher I., Możliwe sposoby ksztattowania oraz utrwalania pozytywnego kierunku marketingowej postawy pracowników, „Marketing i Rynek”, $2010 \mathrm{nr} 2$

Evans D.S., Leighton L.S., Some empirical aspects of entrepreneurship, "American Economic Review", 1989 vol. 79, nr 3

Evans R.G., Supplier-induced demand: some empirical evidence and implications, w: Perlman M. (red.), The Economics of Health and Medical Care, Macmillan, Londyn, 1974

Evason E, Whittington D., Patient satisfaction studies: problems and implications explored in a pilot study in Northern Ireland, "Health Education Journal", $1991 \mathrm{nr} 2$

Fazlagić A.J., Zarządzanie wiedza, Wyd. Millenium, Gniezno 2006

Fernald Jr. L.W., Solomon G.T., Tarabishy A., A new paradigm: Entrepreneurial leadership, "Southern Business Review", Spring 2005, nr 2

Ferrante F., Revealing Entrepreneurial Talent, "Small Business Economics”, 2005 t. 25, nr 2

Fey C.F., Birkinshaw J., External Sources of Knowledge, Governance Made and $R+D$ Performance, "Journal of Management", $2005 \mathrm{nr} 4$

Filek J., Społeczna Odpowiedzialność Biznesu. Tylko moda czy nowy model prowadzenia działalności gospodarczej? Urząd Ochrony Konkurencji i Konsumentów, Kraków 2006

Filipowicz G., Zarzadzanie kompetencjami zawodowymi, PWE, Warszawa 2004

Finkelstein S., Hambrick D.C., Strategic Leadership; Top Executives and their Effects on Organizations, West Publishing Company, Mineapolis/St. Paul 1996

Firma=etyka; pracownicy, dostawcy, spoteczeństwo, Zeszyt 1, Forum Odpowiedzialnego Biznesu, Warszawa 2009

Fisk R.P., Grove S.J., John J., Interactive Service Marketing, Houghton Miffilin Company, 2008

Fitzimmons J.A., Fitzsimmons M.J., Service Management. Operations, Strategy, Information Technology, McGraw-Hill International Edition, Nowy Jork 2008 
Flak O., Głód G., Konkurencyjność przedsiębiorstwa. Pojęcia, definicje, modele, część I, Wyd. Akademii Ekonomicznej w Katowicach, Katowice 2009

Fleischman S., Language and medicine, w: Schiffrin D., Tannen D., Hamilton H. (red.), The Handbook of Discourse Analysis, Blackwell, Oxford 2001

Fonfara K., Marketing partnerski na rynku przedsiębiorstw, PWE, Warszawa 1999

Fonfara K., Przedmowa do wydania polskiego, w: Gordon I.H., Relacje z klientem. Marketing partnerski, PWE, Warszawa 2001

Fornell C., A National Customer Satisfaction Barometr: The Swedish Experience, "Journal of Marketing", 1992 vol. 56, nr 1

Frączkiewicz-Wronka A., Austen A., Efektywne przywództwo w ochronie zdrowia - wyniki badań empirycznych, ,Zeszyty Naukowe UE w Poznaniu” nr 187, Poznań 2011

Frączkiewicz-Wronka A., Austen-Tynda A., Przywództwo w ochronie zdrowia. Idee i instrumenty, ABC a Wolters Kluwer business, Warszawa 2009

Frączkiewicz-Wronka A., Dostępność usług zdrowotnych - racjonalizacja czy wykluczenie, „Polityka Zdrowotna”, 2004 tom I

Frączkiewicz-Wronka A., Wronka M., Kotowski P., Koncentracja na zewnętrznym otoczeniu jednostki ochrony zdrowia - wyznaczanie kierunków działania przez przywódcę, w: Frączkiewicz-Wronka A., Austen-Tynda A. (red.), Przywództwo w ochronie zdrowia. Idee i instrumenty, Wolters Kluwer, Polska 2009

Frą́ J., Zarzadzanie jakościa ustug w opiece zdrowotnej, w: Rudawska I., Urbańczyk E., Ekonomiczno-organizacyjne problemy zarzadzania jednostkami stużby zdrowia, „Studia i materiały Polskiego Stowarzyszenia Zarządzania Wiedzą", Bydgoszcz 2010

Frishkoff P.A., Understanding Family Business, Austin Family Business Program, 15 April 1995, za: Kowalewska A., Szut J., Sułkowski Ł., Marjański A., Definicja pojęcia firmy rodzinnej, w: Kowalewska A.(red.), Firmy rodzinne $w$ polskiej gospodarce - szanse $i$ wyzwania, Wyd.Naukowe Technologii Eksploatacji - PIB, Warszawa 2009

Furtak R., Marketing partnerski na rynku ustug, PWE, Warszawa 2003

Gabryszak R., Kontrowersje wokót przedsiębiorczości, „Ekonomika i Organizacja Przedsiębiorstwa", $2005 \mathrm{nr} 6$

Galvao-Sobrinho C.R., Hippocraticc Ideale, Medical Ethics, and Practice of Medicine In the Early Middle Ages: The Legacy of the Hippocratic Oath, "Journal of the History Medicine", 1996 t. 51, za: Chmielnicki B., Oczekiwania pacjenta wobec lekarza w średniowiecznej medycynie europejskiej, w: Płonka-Syroka B. (red.), Relacje lekarz-pacjent $w$ aspekcie społecznym, historycznym $i$ kulturowym, „Studia z dziejów kultury medycznej”, Katedra Etnologii i antropologii kulturowej Uniwersytetu Wrocławskiego, Wrocław 2005

Garbarski L., Rutkowski I., Wrzosek W., Marketing. Punkt zwrotny nowoczesnej firmy, PWE, Warszawa 2000

Gartner W., Who is an Entrepreneur? Is the wrong question, "Entrepreneurship Theory and Practice", 1989 nr 5

Gathel R.J., The prevalence of dental fear and avoidance expanded adult and recent adolescent surveys, "Journal American Dental Association", 1989 nr 118

Gaurav K., Impact of Relationship Marketing Strategy on Customer Loyalty, "The Icfaian Journal of Marketing Research", $2008 \mathrm{nr} 11$

Gemme E.M., Retainig customers in a manager care market, "Marketing Health Services", 1997 t. 17, z. 3

George B., Sims P., McLean A., Mayer D., Przywództwo oparte na autentyczności, "Harvard Business Review", 2007 nr 12 (58)

Getzen T.E., Ekonomika zdrowia, PWN, Warszawa 2000 
Ghobadian A., Service quality concepts and models, "International Journal of Quality \& Reliability Management", $1994 \mathrm{nr} 9$

Gidens A., Socjologia, PWN, Warszawa 2004

Gieorgica J.P. (red.), Studia nad przedsiębiorczościa generacyjna, regionalna, ogólnopolska, Wyd. Uniwersytetu w Białymstoku, Białystok 2009

Gilly M.C., Graham J.L., Wolfinbarger M.F., Yale L.J., A Dyadic Study of Interpersonal Information Search, "Academy of Marketing Science", 1998 vol. 26, nr 2

Gilson L., Trust and the development of Health care as a social institution, "Social Science \& Medicine”, $2003 \mathrm{nr} 56$

Glinka B., Konecki K. (red.), Wspótczesne problemy socjologii organizacji i zarządzania. Wybrane zagadnienia, Wyd. UŁ, Łódź 2006

Glińska-Neweś A., Kulturowe uwarunkowania zarzadzania wiedza w przedsiębiorstwie, TNOiK, Toruń 2007

Głowacka M.D., Czajka P., Operatywne zarzqdzanie zakładem opieki zdrowotnej, w: Głowacka M.D., Galicki J., Mojs E. (red.), Zarzadzanie zakładem opieki zdrowotnej, ABC a Wolters Kluwer business, Warszawa 2009

Głuszek E. Zarzadzanie zasobami niematerialnymi, Wyd. AE im. O.Langego, Wrocław 2004

Goleman D., Emotional Intelligence: Why Il Can Matter More Than IQ, Bantam, Nowy Jork 1995

Golinowska S., Polityka społeczna państwa $w$ gospodarce rynkowej: studium ekonomiczne, Wydawnictwo Naukowe PWN, Warszawa 1997

Golinowska S., Rynek pracy w sektorze zdrowotnym - zaniedbany obszar zarzadzania, "Polityka Społeczna”, $2008 \mathrm{nr} 7$

Gonzales-Benito O., Gonzales-Benito P., Munoz-Gallego P.A., Role of Entrepreneurship and Market orientation in Firm's Success, "European Journal of Marketing", 2009 nr 3-4

Goodwin N., Leadership and the UK Health Service, ,Health Policy”, 2000 vol. 51

Gordon T., Pacjent jako partner, Instytut Wydawniczy PAX, Warszawa 1999

Gordon I.H., Relacje z klientem. Marketing partnerski, PWE, Warszawa 2001

Gordon I.H., Relationship Marketing. New Strategies, Techniques and Technologies to Win the Customers You Want and Keep Them Forever, John Wiley \& Sons, Toronto 1998

Gordon R.A., Howell J.E., Higher Education for Business, Garland, Nowy Jork 1959

Gorynia M. (red.), Luka konkurencyjna na poziomie przedsiębiorstwa a przystapienie Polski do Unii Europejskiej, Wyd. AE w Poznaniu, Poznań 2002

Griffin J., Customer Loyalty. How to Earn It, How to Keep It, Jossey-Bass Publishers, San Francisco 1997

Griffin R.W., Podstawy zarządzania organizacjami, PWN, Warszawa 1998

Grilo I., Irigoyen J.M., Entrepreneurship in the UE: To Wish and not to be, "Small Business Economics", 2006 t. 26, nr 4

Grönroos Ch., Service quality: the six criteria of good perceived service, „Review of Business",1988 nr3

Grönroos Ch., Service Management and Marketing. Managing the Moments of Truth in Service Competition's, Free Press, Lexington Books, Massachusetts, Toronto 1990

Grönroos Ch., Service Management and Marketing, Maxwell Macmillan International Edition, Nowy Jork 1990

Grönroos Ch., From Marketing-mix to Relationship Marketing: Towards a Paradigm Shift In Marketing, „Management Decisions”, $1994 \mathrm{nr} 3$

Grönroos Ch., Creating a relationship dialogue: communication, interaction and value, "The Marketing Review”, $2000 \mathrm{nr} 5$ 
Grossman G.M., Helman E., Innovation and Growth, MIT Press, Cambridge, Massachusetts1995

Gruca-Wójtowicz P., Jakość usług medycznych $w$ kontekście zróżnicowania oczekiwań stron zainteresowanych, „Problemy Jakości”, 2009 nr 3

Grudzewski W.M., Hejduk I.K., Innowacyjność w technice i technologii źródtem przewagi konkurencyjnej matych średnich przedsiębiorstw, Instytut Funkcjonowania Gospodarki Narodowej SGH, Warszawa 2002

Grudzewski W.M., Hejduk I.K., Sankowska A., Wańtuchowicz M., Zarzadzanie zaufaniem w organizacjach wirtualnych, Difin, Warszawa 2007

Gruszecki T., Wspótczesne teorie przedsiębiorstwa, Wydawnictwo Naukowe PWN, Warszawa 2002

Gruszecki T., Nagrody Nobla w ekonomii, Oficyna Wydawnicza Verba, Lublin 2001

Gruszecki T., Przedsiębiorca w teorii ekonomii, CEDOR, Warszawa 1994

Grygiel T., Wdowiak L., Frączak B., The increase of burnout symptoms among dentists in Poland between 2001 and 2010 - a survey, "eDentico", $2010 \mathrm{nr} 3$

Grzesiak S., Efektywność funkcjonowania przedsiębiorstwa - aspekty prakseologiczne i ekonomiczne, w: Przedsiębiorstwo na rynku. Gospodarka polska w procesie transformacji systemowej, materiały konferencyjne Uniwersytetu Szczecińskiego nr 17, Szczecin 1996

Gummesson E., Models of Professional Services Marketing, Stockholm 1979

Gummesson E., Letinen U., Grönroos Ch., Nordic Perspectives on Relationship Marketing, "European Journal of Marketing" vol. 31, 1997, za: Chłodnicki M., Ustugi profesjonalne przez jakość do lojalności klientów, Wyd.AE w Poznaniu, Poznań 2004

Gummesson E., Total Relationship Marketing, "Rethinking Marketing Management", ButterworthHeinemann, Oxford 1999

Gummesson E., Making relationship marketing operational, "International Journal of Service Industry Management”, 1994 t. 5, nr 5

Gupta V., MacMillan I., Surie G., Entrepreneurial Leadership: Developing and Measuring a Cross-cultural Construct, "Journal of Business Venturing", 2004 vol. 19

Hadrian P., Rawski M., Możliwości wykorzystania metody refleksji strategicznej w marketingu relacyjnym, „Marketing i Rynek”, $2009 \mathrm{nr} 10$

Hall M.A., Law, medicine and trust, "Stanford Law Review”, 2002 vol. 55, $\mathrm{nr} 2$

Hallowell E.M., The Human Moment At Work, „Harvard Business Review”, 1999 January-February

Haltiwanger J., Aggregate growth: what hale we learned from microeconomic evidence?, "Economics Department Working Papers", 2000

Hamel G., Prahalad C.K., Competing for the Future, "Harvard Business Review", 1994 lipiecsierpień

Hamel G., Prahald C.K., Przewaga konkurencyjna, Business Press, Warszawa 1999

Hammer M., Champy J., Reengineering w przedsiębiorstwie, Neuman Management Institute, Warszawa 1996

Hammer M., Transformacja firmy poprzez innowacje operacyjna, „Harvard Business Review",2004 nr5

Hamond J.S., Keeney R.L., Raiffa H., Myślowe pułapki, które prowadza do ztych decyzji, "Harvard Business Review. Polska”, $2005 \mathrm{nr} 1$

Hampden-Turner Ch., Trompenaars A., Siedem kultur kapitalizmu, Oficyna Ekonomiczna, Kraków 2000

Harris R.G., The Knowledge-Based Economy: Intellectual Origins and New Economic Perspectives, "International Journal of Management Reviews", 2001 vol. 3

Hartman J., Bioetyka dla lekarzy, Wolters Kluwer Polska, Warszawa 2009 
Hayek F.A., Wykorzystanie wiedzy w spoteczeństwie, w: Indywidualizm i porzadek ekonomiczny, Wydawnictwo ZNAK, Kraków1998

Haywood-Farmer J., A conceptual model of service quality, „International Journal of Operations and Productions Management", $1988 \mathrm{nr} 6$

Heszen-Niejodek I., Lekarz i pacjent. Badania psychologiczne, Wyd. UJ, Kraków 1992

Heszen-Klemens I., Psychologia medyczna. Główne kierunki badań, Wyd. Uniwersytetu Śląskiego, Katowice 1983

Hockuba Z., Pożegnanie z homo economicus, "Rzeczpospolita", 23.12.2008

Hocutt M.A., Relationship dissolution model: antecedens of relationship commitment and the likehood of dissolving a relationship, "International Journal of Service Industry Management", $1998 \mathrm{nr} 2$

Hofstede G., Hofstede G.J., Kultury i organizacje, PWE, Warszawa 2007

Holly R., Racjonalna polityka zdrowotna a procedury $i$ standardy medyczne $w$ systemie ochrony zdrowia, „Polityka Zdrowotna”, 2004 tom I

Hołub J., Kierunki rozwoju marketingu na rynku ustug medycznych, ,Przegląd Organizacji”, $2001 \mathrm{nr} 6$

Hooley G., Saunders J., Piercy N., Marketing Strategy \& Competitive Positioning, Prentice Hall, Harlow, Essex 1998

Hope E., Odpowiedzialność $w$ dziataniach public relations - zasady etyczne, w: Olędzki J., Tworzydło D. (red.), Public relations. Znaczenie społeczne i kierunki rozwoju, Wyższa Szkoła Informatyki i Zarządzania w Rzeszowie, Wydawnictwo Naukowe PWN, Warszawa 2006

Hougaard S., Bjerre M., Strategic relationship marketing, Springer, Berlin 2003

Huges M., Patient attitude to health education in general practice, "Health Education Journal", $1988 \mathrm{nr} 4$

Iacobucci D., Ostrom A.L., Grayson K.A., Distinguishing service quality and customer satisfaction: the voice of the consumer, ,Journal of Consumer Psychology”, 1995 vol. 3

Ibrahim Y., Doctor and patient questions as a measure of doctor-centeredness in UAE hospitals, "English for Specific Purposes", 2001 nr 20

Instytute of Medicine Committee on Quality of Health Care in America, Crossing the Quality Chasm: A new Health System for the 21 st Century, DC: National Academies Press, Washington 2001

Iwankiewicz-Rak B., Marketing organizacji niedochodowych. Wybrane problemy adaptacji $w$ warunkach polskich, Monografie i Opracowania $\mathrm{nr}$ 121, Wydawnictwo Akademii Ekonomicznej we Wrocławiu, Wrocław 1997

Jabłoński M., Klasyczne podejścia w identyfikacji kompetencji kierowniczych, „Organizacja i Kierowanie", $2009 \mathrm{nr} 1$

Jacobs P., The Economics of Health and Medical Care, Aspen Publishers, Gaithersburg in Maryland 1997

Javalgi R.G., Moberg Ch.R., Service loyalty: implications for service providers, "Journal of Services Marketing”, $1997 \mathrm{nr} 3$

Jenkins W., Competing in Times of Evolution and Revolution. An Essay on Long - Term Firm Survival, "Management Decision", $2005 \mathrm{nr} 1$

Jezior J., Społeczno-kulturowe i rynkowe czynniki kształtowania sytuacji pracy przedsiębiorców. Na podstawie badań matych firm $w$ woj. lubelskim, Wydawnictwo Uniwersytetu M. CurieSkłodowskiej, Lublin 2009

Johnson R., Clark G., Service Operations Management, Prentice Hall Coventry 2001

Johnson R., The determinants of service quality: satisfiers and dissatisfiers, „International Journal of Service Industry Management", $1995 \mathrm{nr} 5$ 
Jończak E., Problemy wyceny niebilansowego składnika aktywów niematerialnych - klientów, w: „Problemy wyceny w rachunkowości”, Prace Naukowe AE im. O.Langego we Wrocławiu, Wrocław 2001, nr 911

Jończyk J., Zarządzanie zasobami ludzkimi w zakładach opieki zdrowotnej, Difin, Warszawa 2008 Juchnowicz M. (red.), Kapitał ludzki a kształtowanie przedsiębiorczości, Poltext, Warszawa 2004

Juchnowicz M., Zarzadzanie kapitałem ludzkim a poziom zaangażowania pracowników, „Zarządzanie Zasobami Ludzkimi”, 2010 nr 3-4

Judge T., Piccolo R., Transformational and Transactional Leadership: A Meta-Analytic Test of Their Relative Validity, "Journal of Applied Psychology", $2004 \mathrm{nr} 5$ za: Belz G., Triumwirat ról wobec pytań o ewolucję modeli przywództwa, „Zeszyty Naukowe UE w Poznaniu” nr 187, Poznań 2011

Juran J.M., Gryna F.M., Jakość - projektowanie, analiza, Wydawnictwo Naukowo-Techniczne, Warszawa 1974

Kahnemen D., Tversky A., Prospect Theory: an analysis of Decision under Risk, "Econometrica", $1979 \mathrm{nr} 47$

Kalisiewicz D. (red. nacz.), Encyklopedia PWN, t. II, Wydawnictwo Naukowe PWN, Warszawa 1999

Kałuszyński M., Myślenie etyczne, Zakład Narodowy im. Ossolińskich, Wrocław 1980

Kamerschen D.R., McKenzie R.B., Nordinelli C., Ekonomia, Fundacja Gospodarcza „Solidarność“, Gdańsk 1990

Kamiński J., Nowa definicja marketingu AMA, „Marketing i Rynek”, 2009 nr 5

Kapała W., Drygas P., Marketing w ustugach medycznych. Marketing relacyjny, „Antidotum”, $2001 \mathrm{nr} 2$

Kapusta F., Przedsiębiorczość. Teoria i praktyka, Wydawnictwo Forum Naukowe, Poznań 2006

Karlof B., Strategia biznesu. Koncepcje i modele. Przewodnik, Biblioteka Menedżera i Bankowca, Warszawa 1992

Kasperkiewicz W., Procesy innowacyjne $w$ gospodarce rynkowej. Teoria i praktyka, Naukowe Wydawnictwo Piotrkowskie, Piotrków Trybunalski 2008

Katona G., Essays on Behavioral Economics, Institute for social Research, Ann Arbor 1980

Kazibudzki P., Kompetencje przedsiębiorcy-menedżera. Ideologia ksztattowania, Wydawnictwo My Book, Szczecin 2007

Kazibudzki P., Wzorzec kompetencji przedsiębiorcy przysztości i jego empiryczna walidacja, „Ekonomika i organizacja przedsiębiorstwa”, $2010 \mathrm{nr} 11$

Kątowski T., Zarys historii myśli ekonomicznej, Wyższa Szkoła Finansów i Administracji, Gdynia 2009

Kelly H.R., Knowledge and practice in firms, Dawidson, Dallas 2000

Kelman H.C., Hovland C.I., Reistatement of the Communication in Delayed Measurement of Opinion Change, "Journal of Abnormal and Social Psychology", $1953 \mathrm{nr} 48$, za: Kotler Ph., Shalowitz J., Stevens R.J., Marketing strategiczny w opiece zdrowotnej, Oficyna a Wolters Kluwer business, Warszawa 2011

Kenrick D.T., Neuberg S.L., Cialdini R.B., Psychologia spoteczna, GWP, Gdańsk 2002

Kielanowski T., Wprowadzenie do nauki o etyce i deontologii lekarskiej, w: Kielanowski T. (red.) Wybrane zagadnienia z etyki i deontologii lekarskiej, Warszawa 1980

Kieżun W., Sprawne zarzadzanie organizacja, Wyd. SGH, Warszawa 1997

King C., A framework for a service quality assurance system, "Quality Progress", 1997 nr 9

Kirzner I.M., Konkurencja i przedsiębiorczość, Fijorr Publishing, Warszawa 2010 
Klasik A., Przedsiębiorczość $i$ konkurencyjność a rozwój regionalny, Wyd. Akademii Ekonomicznej w Katowicach, Katowice 2006

Klimczak B., Lewicka-Strzałecka A. (red.), Etyka i ekonomia, Wyd. PTE, Warszawa 2007

Knight F.H., Risk, Uncertainly and Profit, Houghton\&Mifflin, Boston 1921 za: Piasecki B., Przedsiębiorczość i mała firma: teoria i praktyka, Wydawnictwo UŁ, Łódź 1998

Knosala R., Komputerowo zintegrowane zarzadzanie, WNT, Warszawa 2004

Kobyłko G., Morawski M. (red.), Przedsiębiorstwo zorientowane na wiedze, Difin, Warszawa 2006

Kogut B., Designing global strategies: Comparative and competitive value-added chains, "Sloan Management Review", 1985 vol. 24, nr 4

Kołodko G.W., Wędrujący świat, Prószyński i S-Ka, Warszawa 2008

Kopycińska D., Koncepcja społecznej odpowiedzialności firmy - poezja teorii i prozy życia, w: Gacparski W., Dietl J. (red.), Etyka biznesu w działaniu. Doświadczenia i perspektywy, Wydawnictwo Naukowe PWN, Warszawa 2001

Korbacz M., Janiszewska K., Zasady wspótpracy z firma świadczaca ustugi profesjonalne, w: K.Rogoziński (red.), Marketing ustug profesjonalnych, Wyd. AE w Poznaniu, Poznań 1999

Korsch B.M., Gozzi E.K., Francis V., Gaps in doctor-patient communication, "Pediatrics", $1968 \mathrm{nr} 42$

Kosak E., Motywacje stomatologów, „Magazyn Stomatologiczny”, $2000 \mathrm{nr} 1$

Kostro K., Kapitat społeczny w teorii ekonomicznej, „Gospodarka Narodowa”, 2005 nr 7-8

Kotler Ph., Levy S., Broadening the concept of marketing, ,Journal of Marketing”,1969 vol. 33, nr 1

Kotler Ph., Marketing Management, Prentice Hall, Inc., New Jersey 1994

Kotler Ph., Marketing: analiza, planowanie, wdrażanie, Wydawnictwo Felberg SJA, Warszawa 1999

Kotler Ph., Armstrong G., Saunders J., Wong V., Marketing. Podręcznik europejski, PWE, Warszawa 2002

Kotler Ph., Marketing, Dom Wydawniczy REBIS, Poznań 2005

Kotler Ph., Shalowitz J., Stevens R.J., Marketing strategiczny w opiece zdrowotnej, Oficyna a Wolters Kluwer business, Warszawa 2011

Kotter J.P., Co tak naprawdę robia przywódcy? Przywództwo, Wydawnictwo Helion, Gliwice 2005

Kowalewska A., Szut J., Sułkowski Ł., Marjański A., Definicja pojęcia firmy rodzinnej, w: Kowalewska A. (red.), Firmy rodzinne w polskiej gospodarce - szanse i wyzwania, Wyd. Naukowe Technologii Eksploatacji - PIB, Warszawa 2009

Kowalska K., Koordynowana opieka zdrowotna. Doświadczenia polskie i międzynarodowe, Wyd. Uniwersytetu Warszawskiego, Warszawa 2009

Kozielski R. (red.), Wskaźniki marketingowe, Oficyna a Wolters Kluwer business, Kraków 2008

Kozielski R. (red.), Wskaźniki marketingowe, Oficyna a Wolters Kluwer business, Warszawa 2011, wyd. IV zmienione

Koźmiński A.K., Zarządzanie $w$ warunkach niepewności, Wydawnictwo Naukowe PWN, Warszawa 2005

Kożuch B., Inwestycje zagraniczne a wzrost konkurencyjności regionu, w: Olesiński Z. (pod red.) Bezpośrednie inwestycje zagraniczne w Polsce, PWE, Warszawa 1998

Kożusznik B., Zachowania człowieka w organizacji, PWE, Warszawa 2007

Kraśnicka T., Koncepcje rozwoju przedsiębiorczości ekonomicznej i pozaekonomicznej, Wydawnictwo Akademii Ekonomicznej w Katowicach, Katowice 2002

Krause D.R., Handfield R.B., Tyler B.B., The Relationships Between Supplier Development, Commitment, Social Capital Accumulation and Performance Improvement, "Journal of Operations Management”, 2007 vol. 25 
Krawczyńska A., Trzmielak D., Jakość ustug medycznych, „Przegląd Organizacji”, 2001 nr 2

Kravitz R.L., Cope D.W., Bhrany V., Leake B., Internal medicine patients' expectations for care during office visits, "Journal of General Internal Medicine", 1994 vol. 9

Kravitz R.L. Callahan E.J., Paterniti D., Antonius D., Dunhan M., Lewis C.E., Prevalence and Sources of Patients' Unmet Expectations for care, “Annals of Internal Medicine”, $1996 \mathrm{nr} 125$

Kristiansen S., Indarti N., Entrepreneurial intention among Indonesian and Norwegian students, "Journal of Enterprising Culture", $2004 \mathrm{nr} 1$

Krupski R., Niemczyk J., Stańczyk-Hugiet E., Koncepcje strategii organizacji, PWE, Warszawa 2009

Krzakiewicz K., Kognitywne kompetencje menedżerów w aspekcie zarzqdzania strategicznego, „Zeszyty Naukowe UE w Poznaniu” nr 189, Poznań 2011

Krzyżanowska M., Marketing a inne sposoby budowania przewagi konkurencyjnej, „Marketing i Rynek", 2009 nr 1

Kukiełka-Pucher D., Dobkowska M., Pracownik emocjonalnie zaangażowany, „Manager”,2004 nr 5

Kunasz M., Przedsiębiorczość studentów studiów dziennych - wyniki badań, „Przegląd Organizacji”, $2008 \mathrm{nr} 1$

Kurczewska A., Intencje przedsiębiorcze, czyli co decyduje o przedsiębiorczości człowieka, „Przegląd Organizacji”, 2010 nr 10

Kwiatkowski S., Przedsiębiorczość intelektualna, Wydawnictwo Naukowe PWN, Warszawa 2000

Lalouschek J., Ärztliche Gesprächsausbildung. Eine diskursanalytische Studie zu Formen des ärztlichen Gesprächs, Radolfzell: Verlag für Gesprächsforschung, 2002 za: Stefaniak K., Władza i tożsamość w komunikacji lekarz - pacjent, Oficyna Wydawnicza ATUT, Wrocławskie wydawnictwo Oświatowe, Wrocław 2011

Lamin J.J., Strategiczne zarządzanie marketingowe, PWN, Warszawa 2001

Lange O., Ekonomia polityczna, PWN, Warszawa 1978

Langley G., BIIA Relationship Marketing Conference - Information quality and Customer Marketing, $1997 \mathrm{nr} 5$

Leary M., Wywieranie rażenia na innych. O sztuce autoprezentacji, GWP, Gdańsk 2000

Leibenstein H., Poza schematem ,homo oeconomicus”, PWN, Warszawa 1988

Leibenstein H., Beyond Economic Man: a New Foundation for Microeconomics, Harvard University Press, Cambridge, MA, 1976

Leonard L., Carbone B.L.P., Heeckel S.H., Managing the total customer, experience, "Sloan Management Review", $2002 \mathrm{nr} 3$

Leowski J., Polityka zdrowotna a zdrowie publiczne, CeDeWu, Warszawa 2009

Levin R., Is the dentist an entrepreneur?, ,Journal of American Dental Association”,2004 vol. 135, nr12

Ley P., Communicating with patients: Improving communication, satisfaction and compliance, Croom Helm, Londyn 1988

Ley P., Communication in the clinical setting, "British Journal of Orthodontics", $1973 \mathrm{nr} 1$

Liljander V., Roos I., Customer-relationship levels - from spurious to true relationship, "Journal of Services Marketing", $2002 \mathrm{nr} 7$

Liñán F., Chen Y.-W., Development and Cross-Cultural Application of a Specific Instrument to Measure Entrepreneurial Intentions, "Entrepreneurship Theory and Practice", 2009 nr 5

Little E., Marandi E., Relationship marketing management, Thomson 2003

Lovelock C., Services Marketing, Prentice-Hall, Englewood Cliffs, Nowy Jork, 1991 
Lucas R.E., On the Mechanics of Economic Development, "Journal of Monetary Economics", $1988 \mathrm{nr} 1$

Lumpkin G.T., Dess G.G., Linking two dimensions of entrepreneurial orientation to firm performance: The moderating role of environment and industry life cycle, "Journal of Business Venturing", $2001 \mathrm{nr} 16$

Luthans F., Youssef C.M., Human, social, and now positive psychological capital management: Investing in people for competitive advantage, "Organizational Dynamics", $2004 \mathrm{nr} 33$ za: Łaguna M., Nowe tendencje $w$ podejściu do szkoleń w organizacji w: Zawadzka A.M. (red.), Psychologia zarzadzania w organizacji, Wydawnictwo Naukowe PWN, Warszawa 2010

Macias J., Nowe koncepcje przewagi konkurencyjnej wspótczesnych przedsiębiorstw, „Przegląd Organizacji”, $2008 \mathrm{nr} 9$

Malach-Pines A., Sadeh A., Dvir D., Yafe-Yanai O., Entrepreneurs and managers: Similar yet different, "The International Journal of Organizational Analysis", $2002 \mathrm{nr} 2$

Malewska K., Zastosowanie koncepcji podejścia zasobowego $w$ praktyce zarzadzania strategicznego, w: Kruk H., Skrzeszewska K. (red.), Europejskie wymiary przedsiębiorczości, Akademia Morska, Gdynia 2008

Marconi J., Creating the Marketing Experience. New Strategies for Building Relationships with Your Target Market, Thomson, Mason, 2005

Marek Z., Niektóre przyczyny konfliktów między pacjentem a lekarzem, w: Kielanowski T. (red.), Etyka i deontologia lekarska, PZWL, Warszawa 1985

Masten A., Ordinary magic: resilience processes in development, “American Psychologist”, 2001 nr 56

Mastyk E., Organizacja w ruchu, Oficyna Ekonomiczna, Kraków 2003

Matecka M., Głowacka M.D., Jakubek E., Kompetencje spoteczne jako element kompetencji zawodo- wych menedżerów, w: Lewandowski R., Kautsch M. (red.), Przekształcenia strukturalne i spoteczne w ochronie zdrowia, seria „Przedsiębiorczość i Zarządzanie”, tom XIII, zeszyt 5, Łódź 2012

Maxwell J.C., Być liderem, Medium, Warszawa 1994

Maxwell R.S., Quality Assurance in Health, "British Medical Journal”, $1984 \mathrm{nr} 288$

Mayo A., Nohria N., Zeitgeist Leadership, „Harvard Business Review”, 2005 nr 10

Mazur J., Zarządzanie marketingiem ustug, Difin, Warszawa 2002

Mądrzycki T., Psychospoteczne prawidtowości ksztattowania się postaw, PZWS, Warszawa 1970

McClelland D., The achieving society, "The Free Press", Londyn 1961

McGowan P., Innowacja i przedsiębiorczość wnętrza, w: Stewart D. (red.), Praktyka kierowania, OWE, Warszawa 1994

Mechanic D., The functions and limitations of trust In the provision of medical Care, "Journal of Health Politics, Policy and Law", $1998 \mathrm{nr} 4$

Mersha T., Adlakha V., Attributes of service quality: the consumers perspective, „International Journal of Service Industry Management", $1991 \mathrm{nr} 3$

Micherda B., Analityczna funkcja rachunkowości, Wyd. Akademii Ekonomicznej w Krakowie, Kraków 2001

Mikuła B., Organizacje oparte na wiedzy, Wydawnictwo Akademii Ekonomicznej w Krakowie, Kraków 2006

Mirkiewicz J., Miłość jest najważniejszym lekarstwem - spagiryka, czyli poczatki nowożytnej farmakologii, w: Płonka-Syroka B. (red.), Relacje lekarz-pacjent $w$ aspekcie spotecznym, historycznym $i$ kulturowym, „Studia z dziejów kultury medycznej”, Katedra Etnologii i antropologii kulturowej Uniwersytetu Wrocławskiego, Wrocław 2005 
Misiński W., Modelowanie sytemu powszechnych ubezpieczeń zdrowotnych w Polsce, Wyd. Akademii Ekonomicznej im. O.Langego we Wrocławiu, Wrocław 2007

Mitręga M., Marketing relacji. Teoria i praktyka, CeDeWu, Warszawa 2005

Mohseni M., Lindstrom M., Social capital, trust in the health-care system and self-rated Health: The role of Access to Health care in a population-based study, "Social Science \& Medicine", $2007 \mathrm{nr} 64$

Money G., Economics, Medicine and Health Care, Englewood Cliffs, Nowy Jork, 2003

Moorman C., Deshpande R., Zaltman G., Factors affecting trust in market research relationship, "Journal of Marketing", 1993 vol. 57

Moorman C., Deshpande R., Zaltman G., Relationships Between Providers and Users of Market Research: The Role of Personal Trust, "Working Paper", nr 93 "Marketing Science Institute", Cambridge 1993, za: Furtak R., Marketing partnerski na rynku ustug, PWE, Warszawa 2003

Morawski M., Zarzadzanie profesjonalistami, PWE, Warszawa 2009

Morgan R.M., Hunt S.D., The Commitment-Trust Theory of Relationship Marketing, "Journal of Marketing", 1994 vol. 58

Mruk H., Marketing ustug profesjonalnych, „Marketing serwis”, $1996 \mathrm{nr} 8$

Mruk H., Przywództwo w zakładach opieki zdrowotnej, ABC a Wolters Kluwer business, Warszawa 2010

Mruk H., Sposoby konkurowania gabinetów lekarskich (stomatologicznych), „Poradnik Stomatologiczny", $2010 \mathrm{nr} 3$

Mudie P., Cottam A., Ustugi, zarzadzanie i marketing, Wydawnictwo Naukowe PWN, Warszawa 1998

Mueller S.L., Anisya T.S., Culture and Entrepreneurial Potential: a Nine Country Study of Locus of Control and Innovativeness, „Journal of Business Venturing”, 2001 t. 16, nr 1

Nahapiet J., Ghoshal S., Social Capital, Intellectual Capital, and the Organizational Advantage, "Academy of Management Review", 1998 vol. 23, nr 2

Narver J.C., Slater S.F., The effect of a market orientation on business profitability, "Journal of Marketing”, 1999 vol. 54

Nasiłowski M., Zarys historii myśli ekonomicznej, Wydawnictwo Key Text, Warszawa 2003

Näslund D., Olsson A., Karlsson S., Operationalizing the Concept of Value - an Action ResearchBased Model, "The Learning Organization", $2006 \mathrm{nr} 3$

Nawrocka A., Etos w zawodach medycznych, WAM, Kraków 2008

Newsome P.R., Wright G.H., A review of patient satisfaction, "British Dental Journal", 1999, vol. 186, nr 4 za: Rudawska I., Jakość relacji pacjent-profesjonalista $w$ sektorze ustug medycznych, „Problemy Jakości”, 2005 nr 3

Nicolaou N., Shane S., Cherkas L., Spector T.D., The Influence of Sensation Seeking in the Heritability of Entrepreneurship, "Strategic Entrepreneurship Journal", 2008 vol. 2

Niedbała E., Firmy rodzinne - obiekt badawczy, „Master of Business Administration”, $2002 \mathrm{nr} 5$

Niestrój E., Zarzadzanie marketingiem. Aspekty strategiczne, Wydawnictwo Naukowe PWN, Warszawa 1996

Niewiadomski P., Menedżer sprzedaży - model kluczowych kompetencji a efektywność działań, „Marketing i Rynek”, 2009 nr 9

Nieżurawski L., Pawłowska B., Witkowska J., Satysfakcja klienta: strategia - pomiar zarzadzanie, Wydawnictwo Naukowe Uniwersytetu im. M.Kopernika, Torun 2010

Noga A., Teorie przedsiębiorstw, PWE, Warszawa 2011

Nogalski B., Śniadecki J., Umiejętności menedżerskie w zarządzaniu przedsiębiorstwem, OPO Bydgoszcz 2001 
Nonaka I., Takeuchi H., Kreowanie wiedzy w organizacji, Polska Fundacja Promocji Kadr, Warszawa 2000

Norman R., Ramirez F., Designing interactive strategy from Value - chain to Value Constellation, John Wiley \& Sons, Nowy Jork, 1994

Norman R., Service Management, Strategy and Leadership In Service Business, J.Wiley\&Sons, Nowy Jork 1991

Northouse P.G., Leadership. Theory and Practice, Thousand Oaks, Londyn 2004

Nowakowski M. (red.), Biznes międzynarodowy, Key Text, Warszawa 2000

Obłój K., Strategia organizacji. W poszukiwaniu trwałej przewagi konkurencyjnej, PWE, Warszawa 2007

O'Conner Ch., Why marketing isn't working in the health care arena, "Journal of Health Care Marketing", 1982 vol. 2, nr 1

Oliver R.L., A Conceptual Model of Service Quality and Service Satisfaction: Compatible Goals, Different Concepts, "Advances in Sevices Marketing and Management", 1993 vol. 2

Opolski K., Dykowska G., Możdżonek M., Zarzadzanie przez jakość w ustugach zdrowotnych. Teoria i praktyka, CeDeWu, Warszawa 2003

O’Reilly Ch.A., Tushman M.L., Oburęczna firma, "Harvard Business Review Polska”, 2004, nr 7

Oleksyn T., Zarządzanie kompetencjami. Teoria i praktyka, Oficyna Ekonomiczna, Kraków 2006

Ornarowicz U., Menedżer XXI wieku, Oficyna Wydawnicza SGH, Warszawa 2008

Osbert-Pociecha G., Ambiwalencja zarządzania organizacja - zagrożenie czy szansa, „Przegląd Organizacji”, 2009 nr 6

Osbert-Pociecha G., Relacja między efektywnościa a elastycznością organizacji, Prace Naukowe Akademii Ekonomicznej nr 1183, Wrocław, 2007

Paluchowski W.J., Czy marketingowi potrzebna jest psychologia?, w: Rogoziński K. (red.), Marketing ustug profesjonalnych. Wpisanie marketingu $w$ strukturę organizacji ustugowej, materiał z IV konferencji 20-21 maja 2002, wyd. AE, Poznań 2002

Pałącki A., Zespołowe centra motywacji i kompetencji jako sposób kreowania i alokowania wiedzy w przedsiębiorstwie, praca doktorska niepublikowana, AF, Warszawa 2004 za: Noga A., Teorie przedsiębiorstw, PWE, Warszawa 2011

Parasuraman A., Measuring and monitoring service quality, w: Glyn W.J., Barnes J.G. (red.), Understanding Services Management, John Wiley \& Sons, Chichester 1995

Parasuraman A., Zeithaml V.A., Berry L.L., Reasons of expectations as a comparison standard in measuring service quality: implication for further research, "Journal of Marketing", $1994 \mathrm{nr} 58$

Parasuraman A., Zeithaml V.A., Berry L.L., A conceptual model of service quality and its implications for future research, "Journal of Marketing", $1985 \mathrm{nr} 49$

Parsons T., The sick role and the role of the physician reconsidered,"Health and Society”, $1975 \mathrm{nr} 53$

Pawłowski J., Diagnoza potencjału innowacyjności i konkurencyjności przedsiębiorstwa, „Przegląd Organizacji”, 2005, nr 5

Payne A., Marketing ustug, PWE, Warszawa 1996

Payne A., The Essence of Services Marketing, Prentice Hall, Londyn 1993

Peltier J.W., Boyt T., Obstetrical care and patient loyalty, "Marketing Health Services", 1999 t. 19

Penc J., Decyzje w zarządzaniu, Wyd. Profesjonalnej Szkoły Biznesu, Kraków 1995

Penc J., Nowoczesne kierowanie ludźmi. Wywieranie wptywu $i$ wspótdziatanie w organizacji, Difin, Warszawa 2007

Penc J., Role i umiejętności menedżerskie. Sekrety sukcesu i kariery, Difin, Warszawa 2005

Penc J., Zarzadzanie w warunkach globalizacji, Difin, Warszawa 2003 
Perechuda K., Coaching wiedzy medycznej jako instrument przewagi konkurencyjnej na rynku ustug medycznych, w: Perechuda K., Kowalewski M., Zarzadzanie komercyjna firma medyczna, Wolters Kluwer business, Warszawa 2008

Perechuda K., Dyfuz.ja wiedzy jawnej i niejawnej jako instrument sieciowego zarzqdzania gmina, „Współczesne Zarządzanie”, 2006 nr 2

Petera M.A., Barney J.B., Unraveling the Resource-based Triangle, "Managerial and Decision Economics", 2003 vol. 24, $\mathrm{nr} 4$

Petit P., The Roots of the New Economy: An Institutional Perspective, CEPREMAP/CNSR, Universite de Paris Sud (XI), 17-18 May 2000 za: Skrzypek E., Uwarunkowania jakości klienta w realiach nowej ekonomii, w: Borys T., Rogala P. (red.), Orientacja na klienta jako kryterium doskonatości, „Prace Naukowe Uniwersytetu Ekonomicznego we Wrocławiu” nr 151, Wrocław 2011

Philip G., Hazlett S.A., The measurement of service quality: a New P-C-P attributes model, "International Journal of Quality \& Reliability Management", $1997 \mathrm{nr} 3$

Philips F.S., Garman A.N., Bariers to entrepreneurship in healthcare organizations, „Journal of Health and Human Services Administration", 2006 vol.28, nr 4

Piasecki B., Ekonomika i zarządzanie mała firma, PWN, Warszawa 2001

Piasecki B., Przedsiębiorczość i mała firma: teoria i praktyka, Wydawnictwo UŁ, Łódź 1998

Pieluch T., Uwarunkowania rozwoju przedsiębiorczości, w: Kaleta A., Moszkowicz K., Woźniak L. (red.), Przedsiębiorczość i innowacyjność matych średnich przedsiębiorstw - wyzwania wspótczesności, Prace Naukowe Akademii Ekonomicznej im. O.Langego we Wrocławiu, nr 1030, Wrocław 2004

Pigla A., Społeczne i gospodarcze funkcjonowanie przedsiębiorstw rodzinnych, w: Listwan T., Mruk H., Zarzadzanie matymi i średnimi przedsiębiorstwami - problemy wspótczesne, Wyd. Forum Naukowe, Poznań 2009

Pine B.J., Gilmore J.H., The Experience Economy: Work is Theatre and Every Business a Stage, "Harvard Business School Press", Boston, 1999

Pitta D., Franzak F., Boundary Spinning Product Development in Consumer Markets - Learning Organization Insight, "Journal of Consumer Marketing", 1996, nr 5

Pluta-Olearnik M., Marketing ustug, PWE, Warszawa 1993

Płoszajski P., Organizacja w przyszłości: przerażony kameleon, w: Borkowska S., Bohdziewicz P. (red.), Menedżer u progu XXIw., wyd. WSH-E, Łódź 1998

Polanyi M., The Tacit Dimension, Anchor Books, Nowy Jork 1967

Polowczyk J., Podstawy ekonomii behawioralnej, „Przegląd Organizacji”, 2009, nr 12

Porter L., Leadership in economy and firms, Social-Library, Nowy Jork 2002

Porter M.E., Cometitive Advantage, Free Press, Nowy Jork 1985

Porter M.E., Porter o konkurencji, PWE, Warszawa 2001

Porter M.E., Strategia konkurencji. Metody analizy sektorów i konkurentów, Wydawnictwo MT Biznes sp. z o.o., Warszawa 2006

Poznański P., Konracka D., Skolimowska J., Gałczyński K., Zbylut J., Analiza gospodarki finansowej Kas Chorych $w$ aspekcie zapewnienia dostępności do wybranych świadczeń zdrowotnych, „Antidotum” 2000, nr 6

Quill T.E., Recognizing and Adjusting to Barriers In Doctor-Patient Communication, "Annals of Internal Medicine", $1989 \mathrm{nr} 111$

Rakowska A., Kompetencje kadry kierowniczej we wspótczesnych organizacjach, Wydawnictwo Uniwersytetu Marii Curie-Skłodowskiej, Lublin 2007 
Raport: Biały personel. Badania kwalifikacji i umiejętności pracowników w zakładach ochrony zdrowia w województwie tódzkim, WUP Łódź 2006

Raport: Działalność innowacyjna przedsiębiorstw z sektora ustug 2001-2003, GUS, Warszawa 2005

Ratyński W., Menedżerskie i organizatorskie metody zarzadzania, KODEKS sp. z o. o., Warszawa 2002

Ravald A., Grönroos Ch., The Value Concept and Relationship Marketing, "European Journal of Marketing”, $1996 \mathrm{nr} 2$

Rayhmell J.M., Marketing in Service Sector, Winthrop Publisher, Cambridge Mass, 1974

Reichheld F.F., Sasser Jr. W.E., Zero Defections: Quality Comes To Services, "Harvard Business Review", 1990

Reinhardt U.E., The Theory of Physician-Induced Demand. Reflections after a Decade, "Journal of Health Economics" 1985, t. 4

Robbins L.Ch., An Essay on the Nature and Significance of Economic Science, Macmillan, Londyn 1935

Rogoziński K., Nowy marketing ustug, Wyd. AE w Poznaniu, Poznań 1998

Rogoziński K., O marketingu - mimo wszystko inaczej, „Marketing i Rynek”, 1999 nr 1

Rogoziński K., Ustugi rynkowe, Wyd. AE w Poznaniu, Poznań 2000

Rogoziński K., O profesjonalizmie ksztattującym osobowość oraz jego wptywie na kulturę organizacji ustugowej, w: Rogoziński K. (red.) Marketing ustug profesjonalnych. Kultura organizacji - osobowość profesjonalisty, Wyd. AE w Poznaniu, Poznań 2001

Rogoziński K., Kompetencje menedżera organizacji ustugowej, w: Rogoziński K., Panasiuk A. (red.), Zarzadzanie organizacjami ustugowymi, Zeszyty Naukowe nr 229, Wydawnictwo UE w Poznaniu, Poznań 2012

Roig J.C.F., Garcia J.S., Tena M.A.M., Monzonis J.L., Customer Perceived Value in Banking Services, "International Journal of Bank Marketing", $2006 \mathrm{nr} 5$

Rollnick S., Miller W.R., Butler Ch.C., Wywiad motywujacy w opiece zdrowotnej, Wydawnictwo Szkoły Wyższej Psychologii Społecznej Academica, Warszawa 2010

Romanowska M., Kształtowanie postaw przedsiębiorczych na studiach ekonomicznych, w: Dietl J., Sapijaszka Z. (red.), Studia ekonomiczne - czy tylko wiedza i umiejętności?, Fundacja Edukacji Przedsiębiorczości, Łódź 2008

Ross G., Roos J., Measuring Your Company's Intellectual Performance, “Long Range Planning” 1997 nr 6, t. 30

Roter D.L., The enduring and evolving nature of the patient-physician relationship, "Patient Education and Counseling", $2000 \mathrm{nr} 39$

Rudawska E., Znaczenie relacji z klientami w procesie ksztattowania wartości przedsiębiorstwa, Uniwersytet Szczeciński, Rozprawy i Studia t. (DCCXC) 716, Szczecin 2008

Rudawska I., Między ekonomiq a deontologia lekarska - konflikt wartości na rynku ustug zdrowotnych, ,Antidotum”, $2002 \mathrm{nr} 6$

Rudawska I., Pacjent - klient na rynku ustug zdrowotnych, „Marketing i Rynek”, 2003 nr 1

Rudawska I., Koncepcja marketingu relacji w sektorze ustug zdrowotnych, „Ruch prawniczy, ekonomiczny i socjologiczny", 2004 zeszyt 4

Rudawska I., Kształtowanie zaangażowania $w$ relacjach ustugowych (na przyktadzie rynku ustug zdrowotnych), „Marketing i Rynek”, $2004 \mathrm{nr} 3$

Rudawska I., Jakość relacji pacjent - profesjonalista w sektorze ustug medycznych, „Problemy Jakości”, 2005 nr 3 
Rudawska I., Ekonomizacja relacji pacjent - ustugodawca w opiece zdrowotnej, Studia i rozprawy T.602, wyd. Uniwersytetu Szczecińskiego, Szczecin 2006

Rudawska I., Podstawy marketingu ustug zdrowotnych, w: Kautsch M. (red.), Zarzadzanie w opiece zdrowotnej. Nowe wyzwania, Wolters Kluwer Polska sp. z o.o., Warszawa 2010

Rudawska I., Szanse, granice i konsekwencje stosowania marketingu $w$ opiece zdrowotnej, w: Rudawska I., Urbańczyk E., Ekonomiczno-organizacyjne problemy zarządzania jednostkami stużby zdrowia, „Studia i materiały Polskiego Stowarzyszenia Zarządzania Wiedzą", Bydgoszcz 2010

Rydel M., Ronkowski C., Marketing partnerski, „Marketing i Rynek”, 1995 nr 9

Saam N.J., Asymmetry in information versus asymmetry in power: Implicite assumptions of agency theory?, "The Journal of Socio-Economics", $2007 \mathrm{nr} 36$

Sadowski Z., Podstawowe założenia strategii rozwoju Polski, „Ekonomista”, 1993 nr 12

Sagan A., Paradygmaty w marketingu - próba syntezy, „Marketing i Rynek”, 2012 nr 11

Saltman R.B., Busse R., Balancing regulation and entrepreneurialism In Europe's Health sektor: theory and practice, w: Salman R.B., Busse R., Mossialos E. (red.), Regulating Entrepreneurial Behavior In European Health Care Systems, European Observatory on Health Care Systems Series, Open University Press, Buckingham, Philadelphia 2002

Sandel M.J., Czego nie można kupić za pieniądze: moralne granice rynku, Kurhaus Publishing, Warszawa 2012

Sapilak B., Steciwko A., Melon M., Zespót wypalenia zawodowego - czy stoimy na przegranej pozycji?, „Lekarz”, $2006 \mathrm{nr} 9$

Say J.B., Traktat o ekonomii politycznej, PWN, Warszawa 1960

Scheaff R., Marketing for Health Services, Heinemann, Londyn 1991

von Schulenburg J-M., Greiner W., Gesundheitsökonomie, Mohr Siebeck, Tubingen 2000, w: Sowada C., Wptyw metod finansowania na zachowania lekarzy - aspekty ekonomiczne, zdrowotne $i$ spoteczne, „Zeszyty Naukowe Ochrony Zdrowia. Zdrowie Publiczne i Zarządzanie", $2005 \mathrm{nr}$ 1, t. III

Scheaff R., Marketing for Health Services, Heinemann, Londyn 1991

Schumpeter J.A., Theory of Economic Development: An Inquiry into Profits, Capital, Credit, Interest and the Business Cycle, Transaction Publishers, Londyn 2008

Schumpeter J.A., Kapitalizm, socjalizm, demokracja, PWN, Warszawa 1995

Schumpeter J.A., Teoria rozwoju gospodarczego, PWN, Warszawa 1960

Seligmann M.E.P., Optymizmu można się nauczyć, Media Rodzina of Poznań, Poznań 1999

Seyda B., Dzieje medycyny w zarysie, Warszawa 1973, za: Gilewska-Dubis J., Etos zawodu lekarza $w$ relacji z pacjentem $w$ średniowiecznej medycynie europejskiej, w: Płonka-Syroka B. (red.), Relacje lekarz-pacjent $w$ aspekcie spotecznym, historycznym i kulturowym, „Studia z dziejów kultury medycznej”, Katedra Etnologii i antropologii kulturowej Uniwersytetu Wrocławskiego, Wrocław 2005

Sęk H., Wypalenie zawodowe: przyczyny $i$ zapobieganie, Wydawnictwo Naukowe PWN, Warszawa 2004

Shalley Ch.E., Perry-Smith J.E., The Emergence of Team Creative cognition: the Role of Diverse Outside Ties, Sociocognitive Network Centrality, and Team Evolution, "Strategic Entrepreneurship Journal", 2008 vol. 2

Shapero A., Sokol L., Social Dinensions of Entrepreneurship, w: Kent C., Sexton D., Vespers K., The Encyclopedia of Entrepreneurship, Prentice-Hall: Englewood Cliffs, Nowy Jork 1982

Shaw C, Ivens J., Building Great Customer Experiences, Palgrave MacMillan, Basingstoke 2005 
Showers J.L., Chakrin L., Reducing Uncollectable Revenue from Residential Telephone Customers, Interfaces, $1991 \mathrm{nr} 11$

Siefer T., Du kommst später mal in die Firma! Psychosoziale Dynamik von Familienunternehmen”, Heidelberg 1996 za: Safin K., Przedsiębiorstwo rodzinne - istota i zachowania strategiczne, AE im. O. Langego we Wrocławiu, Wrocław 2007

Simon H.A., Administrative Behavior, Free Press, Nowy Jork 1947

Sitting D.F., Results of a content analysis of electronic messages (email) sent between patients and their physicians, "BMC Medical Informatics and Decision Making", $2003 \mathrm{nr} 3$

Skrzypek E., Jakość i efektywność, Wyd. UMCS, Lublin 2002

Skrzypek E., Kreatywność pracowników wiedzy i ich wptyw na innowacyjność przedsiębiorstw, w: Okoń-Horodyńska E., Wisła R. (red.) Kapitat intelektualny i jego ochrona, Instytut Wiedzy i Innowacji, Warszawa 2009

Skrzypek E., Uwarunkowania jakości klienta w realiach nowej ekonomii, w: Borys T., Rogala P. (red.), Orientacja na klienta jako kryterium doskonałości, „Prace Naukowe Uniwersytetu Ekonomicznego we Wrocławiu" nr 151, Wrocław 2011

Skuza B., Zarządzanie kapitatem intelektualnym na przykładzie Grupy Skania, w: Wawrzyniak B. (red.) Zarządzanie wiedza w przedsiębiorstwie, Wyd. WSzPiZ im. L. Koźmińskiego, Warszawa 2003

SMG/KRC, Wyniki badań dla Streetcom, prezentowane podczas konferencji „Word of Mouth The Power of Consumers”, 8.03.2007, za: Tkaczyk J., Wiarygodność źródet informacji a proces podejmowania decyzji przez konsumenta, w: Rudawska I., Soboń M. (red. nauk.), Przedsiębiorstwo i klient w gospodarce opartej na ustugach, Difin, Warszawa 2009

Smith A., Teoria uczuć moralnych, PWN, Warszawa 1989

Smith S., Wheeler J., Managing the Customer Experience, FT Prentice Hall, Pearson Education, Londyn 2002

Sobiech J., Warunki wyboru ekonomiczno-finansowych mechanizmów kierowania opieka zdrowotna, ,Zeszyty Naukowe” nr 109, Wyd. AE w Poznaniu, Poznań 1990

Sobol E. (red.), Nowy stownik języka polskiego, Wydawnictwo Naukowe PWN, Warszawa 2003

Sojki B. (red.), Zarządzanie produktem, PWE, Warszawa 2003

Sokołowska A., Społeczna odpowiedzialność małego przedsiębiorstwa - w kierunku uczciwego traktowania klienta, w: Borys T., Rogala P., Orientacja na klienta jako kryterium doskonatości, Prace Naukowe Uniwersytetu Ekonomicznego we Wrocławiu, nr 151, Wyd. UE, Wrocław 2011

Sokołowska M., Socjologia medycyny, PZWL, Warszawa 1986

Sokołowska M., Powstanie i rozwój socjologii medycyny w Polsce, w: Sokołowska M., Hołówka J., Ostrowska A. (red.), Socjologia a zdrowie, PWN, Warszawa 1976

Solomon M.R., Surprenant C., Czepiel J.A., Gutman E.G., A role theory perspective on dyadic interactions: the service encounter, "Journal of Marketing", $1985 \mathrm{nr} 1$

Sowada C., Wspótptacenie - szanse, zagrożenia i warunki szerszego zastosowania $w$ systemie powszechnego spotecznego ubezpieczenia zdrowotnego, „Zeszyty Naukowe Ochrony Zdrowia - Zdrowie Publiczne i Zarządzanie", 2004 t. II, nr 1

Sowińska A., Psychologiczne uwarunkowania skutecznego przywództwa, w: Frączkiewicz-Wronka A., Austen-Tynda A. (red.), Przywództwo w ochronie zdrowia. Idee i instrumenty, Wolters Kluwer Polska sp. z o.o., Warszawa 2009

Spencer L.M., Spencer S.M., Competence at work: models for superior performance, John Wiley\&Sons Inc., Nowy Jork 1993 
Srivastava R., Shervani T., Fahey L., Market - Based Assets and Shareholder Value: A Framework for Analysis, "Journal of Marketing", 1998 vol. 62

Stach P., Problemy konceptualizacji $i$ operacjonalizacji wartości dla klienta, „Przegląd Organizacji”, $2009 \mathrm{nr} 9$

Stachowicz-Stanuch A., Potęga wartości. Jak zbudować nieśmiertelna firmę, Wydawnictwo Helion, Gliwice 2007

Stajkovic A.D., Luthans F., Social cognitive theory and self-efficacy: going beyond traditional motivational and behavioral approaches, "Organizational Dynamics", $1998 \mathrm{nr} 26$

Stankiewicz M.J., Konkurencyjność przedsiębiorstwa. Budowanie konkurencyjności przedsiębiorstwa w warunkach globalizacji, Wydawnictwo TNOiK ,Dom Organizatora”, Toruń 2005

Stanton W.J., Fundamentals of Marketing, McGraw Hill, Nowy Jork 1981

Stańczak-Strumiłło K., Strumiłło J., Innowacje operacyjne $w$ jednostkach ochrony zdrowia, w: Lewandowski R., Walkowiak R., Kautsch M., Wspótczesne wyzwania menedżerskie w ochronie zdrowia, OWSzliZ im. prof. T. Kotarbińskiego, Olsztyn 2009

Stecewicz J., Stereotypy rozwoju a ekonomia, PWE, Warszawa 1991

Stefaniak K., Wtadza i tożsamość w komunikacji lekarz - pacjent, Oficyna Wydawnicza ATUT, Wrocławskie Wydawnictwo Oświatowe, Wrocław 2011

Stevenson H.H., Jarillo J.C., A paradigm of entrepreneurship: Entrepreneurial management, "Strategic Management Journal", $1990 \mathrm{nr} 11$ za: Oleksyn T., Zarzadzanie kompetencjami. Teoria i praktyka, Oficyna Ekonomiczna, Kraków 2006

Stewart T., The Wealth of Knowledge, Intellectual Capital and the Twenty-First Century Organization, Nicholas Brealey Publishing, Londyn 2001

Stewart W.H., Watson W.E., Carland J.C., Carland J.W., A Proclivity for entrepreneurship: A comparison of entrepreneurs, small business owners, and corporate managers, "Journal of Business Venturing", 1998 vol. 14

Stobińska K., Zarzadzanie wiedzq. Wyzwania dla zarzadzania zasobami ludzkimi, „Organizacja i Kierowanie", $2004 \mathrm{nr} 1$

Stoner J.A., Frejman R.E., Gilbert D.R., Kierowanie, PWE, Warszawa 2001

Storbacka K., Strandvik T., Grönroos Ch., Managing customer relationship for profit, „International Journal of Service Industry Management”, $1994 \mathrm{nr} 5$

Styś A., Olearnik J., Usługi w rozwoju społeczno-gospodarczym, PWE, Warszawa 1989

Suchecka J., Regulacje publiczne i prawne, równość sektorów w ochronie zdrowia, w: Ryć K., Skrzypczak Z., Ochrona zdrowia i gospodarka. Mechanizmy rynkowe a regulacje publiczne, Wyd. Nauk. WZ UW, Warszawa 2008

Sudoł S., Przedsiębiorczość - jej pojmowanie, typy i czynniki ją ksztattujące, „Problemy Zarządzania", $2008 \mathrm{nr} 2$

Sułkowski Ł., Organizacja a rodzina, więzi familijne w życiu gospodarczym, TNOiK, Torun 2004

Sułkowski Ł., Epistemologia nauk o zarzqdzaniu, Wydawnictwo Naukowe PWE, Warszawa 2005

Swink M., The Influence of User Charakteristics on Performance in a Logistic DSS Application, "Decision Science", $1995 \mathrm{nr}$ 26(4)

Synder C.R., Hope theory: Rainbows in the mind, "Psychological Inquiry", $2002 \mathrm{nr} 13$

Szasz T., Hollender M.H., A contribution to the philosophy of medicine: The Basic model's of the doctor-patient relationship, "Archives of Internal Medicine", $1956 \mathrm{nr} 97$

Szczepska M., Standaryzacja jakości opieki pielęgniarskiej, „Pielęgniarstwo”, 1996 nr 4

Sztompka P., Zaufanie. Fundament spoteczeństwa, Wydawnictwo ZNAK, Kraków 2007

Sztucki T., Marketing przedsiębiorcy i menedżera, Placet, Warszawa 2000 
Szulce H., Otoczenie firmy i jego wptyw na zarzadzanie marketingowe przedsiębiorstwem, w: Mruk H., Pilarczyk B., Szulce H., Marketing. Uwarunkowania i instrumenty, Wyd. Akademii Ekonomicznej w Poznaniu, Poznań 2007

Szymański W. (red.), Przedsiębiorstwo, rynek, konkurencja, Wyd. SGH, Warszawa 1995

Szymura-Tyc M., Marketing we wspótczesnych procesach tworzenia wartości dla klienta i przedsiębiorstwa, Wydawnictwo Akademii Ekonomicznej w Katowicach, Katowice 2005

Szymura-Tyc M., Zasoby $i$ kompetencje marketingowe przedsiębiorstwa, „Marketing i Rynek",2001 nr 5

Targalski J. (red.), Przedsiębiorczość i rozwój firmy, Wyd. AE w Krakowie, Kraków 1999

Tax S., Brown S., Chandreshekaran M., Customer Evaluations of Service Complaint Experiences: Implications for Relationship Marketing, ,Journal of Marketing”, 1998 vol. 62

Taylor E., Wstęp do ekonomiki, Spółdzielnia Wydawnicza „Żeglarz”, Gdynia 1947

Taylor F., The Principles of Scientific Management, Nowy Jork 1911 za: Dobska M., Rogoziński K. (red.), Podstawy zarzadzania zaktadem opieki zdrowotnej, Wydawnictwo Naukowe PWN, Warszawa 2008

Taylor-Gooby P., Trust, risk and health care reform, „Health, Risk \& Society”, 2006 nr 8

Teich S.T., Wan Z., Faddoul F.F., Relationship Between Broken Appointments and Dental Students' Clinical Experience Lewel, "Journal Dental Education", $2012 \mathrm{nr} 76$

Thakor M.V., Kumar A., What is a professional service? A conceptual review and bi-national investigation, "Journal of Services Marketing", $2000 \mathrm{nr} 1$

Thaler R.H., From Homo Economicus to Homo Sapiens, "Journal of Economic Perspectives", $2000 \mathrm{nr} 1$

Thom D.H., Hall M.A., Pawlson L.G., Measuring patient's trust in physicians when assessing quality of care, "Health Affairs" Milwood, 2004 vol. 23, nr 4

Thornton G., Biznes rodzinny, Helion, Gliwice 2004

Timmons J.A., New venture creation. Entrepreneurship for the 21st century, Irwion - McGrawHill, Singapore 1999, za: Glinka B., Kulturowe uwarunkowania przedsiębiorczości w Polsce, PWE, Warszawa 2008

Tobiasz-Adamczyk B., Relacje lekarz-pacjent $w$ perspektywie socjologii medycyny, Wyd. UJ, Kraków 2002

Toffler A., Trzecia fala, PIW, Warszawa 1985

Tounés A., L'intention entrepreneuriale des étudiants: les cas français, „La Revue des Sciences de Gestion, Direction et Gestion“, 2006 nr 219 za: Kurczewska A., Intencje przedsiębiorcze, czyli co decyduje o przedsiębiorczości człowieka, „Przegląd Organizacji”, 2010, nr 10

Townsend P.L., Gebhardt J.E., Quality in Action. 93 Lessons in Leadership, Participation and Measurement, J.Wiley\&Sons Inc. 1992, section 62, vocabulary za: Rogoziński K., Nowy marketing ustug, Wyd. AE w Poznaniu, Poznań 1998

Treacy M., Weirsem F., The Discipline of Market Leaders, Perseus Books, Nowy Jork 1995

Treacy M., Wiersman F., Customer Intimacy and other Value Disciplines, "Harvard Business Review", $1993 \mathrm{nr} 71$

Tzokas N., Saren M., Relationship Marketing In Consumer Markets from the Private to the Communal, Seminar on Relationship Marketing in an Era of Hyper Competition, Rotterdam 1996,

Ucbasaran D., Wright M., Westhead P., A longitudinal study of habitual entrepreneurs: starter and acquirers, "Entrepreneurship and Regional Development", 2003 vol. 15 
Ulaga W., Eggert A., Relationship Value and Relationship Quality. Broadening the Nomological Net-work of Business-to-Business Relationships, "European Journal of Marketing", 2006 vol. 40, $\mathrm{nr} 3-4$

Urban W., Siemieniako D., Lojalność klientów. Modele, motywacja i pomiar, Wydawnictwo Naukowe PWN, Warszawa 2008

Urbanek G., Wycena aktywów niematerialnych przedsiębiorstwa, PWE, Warszawa 2008

Urlich D., Nason S., Learning Capability, Oxford Press, Nowy Jork 1998

Vahabi M, Ferris L.E., Improving written patient education materials: a review of the evidence, "Health Education Journal", 1995 nr 1

Van Ossel G., Measuring Customer Satisfaction, w: van Looy B., van Dierdonck R., Gemmel P. (red.), Services Management. An Integrated Approach, Pitman Publishing, 1998

Vargo S.L., Lush R.F., The four service marketing myths-remnants of a good-based, manufacturing model, "Journal of Service Research", $2004 \mathrm{nr} 4$

Veblen T.B., Why is Economics Not an Evolutionary Science?, "The Quarterly Journal Economics", 1898 nr 12 w: Huebsh B.W. (red.), The Place of Science in Modern Civilization, Nowy Jork 1919

Von Mises L., Ludzkie działanie, Instytut Ludwiga von Milesa, Warszawa 2007

Wachowiak P., Profesjonalny menedżer. Umiejętność petnienia ról kierowniczych, Difin, Warszawa 2001

Wadhawa S., Rao K.S., Towards a Proactive Flexibility Management, "Global Journal of Flexible System Management", $2002 \mathrm{nr}$ 2-3

Wajda A., Organizacja i zarzadzanie, PWE, Warszawa 2003

Wajda A., Podstawy nauki o zarządzaniu organizacjami, Difin, Warszawa 2003

Walczak-Duraj D., Ład etyczny w gospodarce rynkowej. Doświadczenia polskiej transformacji, Wyd. UŁ, Łódź 2002

Walczak W., Miary $i$ kryteria oceny przedsiębiorczości, "Ekonomika i Organizacja Przedsiębiorstwa”, $2010 \mathrm{nr} 3$

Wądołowska K., Opinie o opiece zdrowotnej, CBOS, 2010

Wągrodzka A., Analiza wartości produktu dla nabywcy ustugi medycznej szpitala, „Marketing i Rynek", $2005 \mathrm{nr} 1$

Weick K.E., Making Sense of the Organization, Black Well, Oxford 2001

Westerbrook R.A., Produkt/consumption-based affective responses and postpurchase processes, "Journal of Marketing Research", August 1987 vol. 24

Whetten D.A., Cameron K.S., Developing Management Skills, Glenview, IL, Scott, Foresman za: Rakowska A., Sitko-Lutek A., Doskonalenie kompetencji menedżerskich, Wydawnictwo Naukowe PWN, Warszawa 2000

White S.S., Schneider B., Climbing the Commitment Ladder. The Role of Expectations Disconfirmation on Customers' Behavioral Intentions, "Journal of Service Research", 2000 vol.2, $\mathrm{nr} 3$

Wilk A., Przedsiębiorczość i przywództwo, „Przegląd Organizacji”, $2006 \mathrm{nr} 8$

Wilmańska-Sosnowska S., Lojalność klientów jako wyzwanie wspótczesnego marketingu, w: Gregor B. (red.), Marketing - handel - konsument $w$ globalnym spoteczeństwie informacyjnym, Acta Universitatis Lodziensis nr 179, Folia Oeconomica, Łódź 2004

Wilson A., The marketing of professional services, McGraw-Hill, Book Company Ltd., Londyn 1972 
Wilson F., Kickul J., Marlino D., Gender, Entrepreneurial Self-Efficacy, and Entrepreneurial Career Intentions: Implications for Entrepreneurship Education, "Entrepreneurship: Theory \& Practice", $2007 \mathrm{nr} 3$, t. 31

Winnicka-Popczyk A., Popczyk W., Firma rodzinna $w$ rozwiniętej gospodarce rynkowej, w: Jeżak J., Popczyk W., Winnicka-Popczyk A., Przedsiębiorstwo rodzinne, funkcjonowanie i rozwój, Difin, Warszawa 2004

Wissena J.G., Uniwersytet Trzeciej Generacji. Uczelnia XXIw., ZANTE, Warszawa 2009

Witczak H., Natura $i$ ksztattowanie systemu zarzadzania przedsiębiorstwem, Wydawnictwo Naukowe PWN, Warszawa 2008

de Witt B., Meyer R., Synteza strategii. Tworzenie przewagi konkurencyjnej przez analizowanie paradoksów, PWE, Warszawa 2007

Włodarczyk W.C., Reforma opieki zdrowotnej w Polsce, Studium polityki zdrowotnej, UWM Vesalius, Kraków 1998

Wojtyna A., Rola państwa we wspótczesnej ekonomii, „Ekonomista”, $1992 \mathrm{nr} 3$

Wojtyna A., Wspótczesna ekonomia - kontynuacja czy poszukiwanie nowego paradygmatu, „Ekonomista”, $2008 \mathrm{nr} 1$

Wolfe Ch. Jr., Markets or governments: choosing between imperfect alternatives, MIT Press, Cambridge 1994, za: Getzen T., Ekonomika zdrowia, Wydawnictwo Naukowe PWN, Warszawa 2000

Wrzosek W., Funkcjonowanie rynku, PWE, Warszawa 2002

Yang Z., Fang X., Online service quality dimensions and the relationships with satisfaction. A kontent analysis of customer reviews of securities brokerage services, „International Journal of Service Industry Management", $2004 \mathrm{nr} 3$

Young K., Narrative embodiments: Enclaves of the self In the realm of medicine, w: Schotter J., Gergen K.J. (red.), Texts of Identity, Sage, Londyn 1989

Yukl G.A., Leadership in Organization, 2nd ed., Nowy Jork 1998

Zaheer A., McEvil B., Peerone W., Does Trust Matter? Exploring the effects of interorganizational and interpersonal trust on performance, "Organization Science", 1998, vol. 9, $\mathrm{nr} 2$

Zahra S.A., Jennings D.F., Kuratko D., Antecedents and consequences of firm level entrepreneurship: The state of the field, "Entrepreneurship Theory \& Practice", $1999 \mathrm{nr} 24$

Zalaśkiewicz T., Przedsiębiorczość i podejmowanie ryzyka, w: Tyszka T. (red.), Psychologia ekonomiczna, GWP, Gdańsk 2004

Zaleznik A., Managers and leaders. Are they different?, "Harvard Business Review", 2004 nr 1 HBR OnPoint 8334 by Harvard Business School Publishing

Zaltman G., How Customer Think: Essentials Insights into the Mind of the Market, "Harvard Business School Press", Boston 2003

Zaltman G., Vertinsky I., Health service marketing: a suggested model, "Journal of Marketing", 1971 vol. 35

Zeithaml V.A., Bitner M.J., Services marketing, McGraw-Hill Companies Inc., Nowy Jork 1996

Zeithaml V.A., Bitner M.J., Services Marketing: Integrating Customer Focus across the Firm, McGraw-Hill, Nowy Jork, 2003

Zeithaml V.A., Parasurman A., Berry L.L., Delivering quality service, za: Rogoziński K., Nowy marketing ustug, Wyd. AE w Poznaniu, Poznań 1998

Zeithaml V.A., Parasuraman A., Berry L.L., Delivering Quality Service - balancing customer perceptions and expectations, „The Free Press”, Nowy Jork 1990

Zeithaml V.A., Consumer perceptions of Price, Quality, and Value: a Means-End Model and Synthesis of Evidence, "Journal of Marketing", $1988 \mathrm{nr} 3$ 
Zeller P., Produkt w ustugach edukacyjnych - sposób definiowania i konsekwencje dla dziatań marketingowych, w: Nowaczyk G., Lisiecki P. (red.), Marketingowe zarzadzanie szkoła wyższa, Wydawnictwo WSzB, Poznań 2006

Zienkowski L. (red.), Wiedza a wzrost gospodarczy, Wydawnictwo Naukowe SCHOLAR, Warszawa 2003

Zienkowski L., Co sprzyja rozwojowi gospodarczemu, Wydawnictwo Naukowe Scholar, Warszawa 2005

Znaniecki F., Ludzie teraźniejsi a cywilizacja przyszłości, Państwowe Wydawnictwo Naukowe, Warszawa 2001

Zweifel P., Manning W.G., Moral hazard and consumer incentives in health care, w: Culyer A.J., Newhouse J.P., Handbook of Health Economics, Nowy Jork 2000

Kodeks cywilny z dnia 23.04.1964r. (Dz. U. nr 16, poz. 93 z późn. zm.)

Ustawa o zakładach opieki zdrowotnej z 30.08.1991 r. (Dz. U. nr 91, poz. 408 z późn. zm.)

Ustawa o zawodzie lekarza i lekarza dentysty z 5.12.1996 r. (t. j. Dz. U. nr 277, poz. 1634 z 2011 r., brzmienie od 01.01.2013r.)

Ustawa o swobodzie działalności gospodarczej z 2.07.2004 r. (Dz. U. z 2010 r. nr 220, poz. 1447 i nr 239, poz. 1593)

Ustawa o świadczeniach opieki zdrowotnej finansowanych ze środków publicznych z 27.08.2004 r. (Dz. U. nr 164, poz. 1027 z 2008 r. z późn. zm.)

Ustawa o prawach pacjenta i Rzeczniku Praw Pacjenta z 6.11.2008r. (Dz. U. nr 52, poz. 417 z 2009r.)

Ustawa o systemie zarządzania emisjami gazów cieplarnianych i innych substancji z 17.07.2009r. (Dz. U. Nr 130, poz. 1070, z późn. zm.)

Ustawa o wyrobach medycznych z 20.05.2010 r. (Dz. U. nr 107, poz. 679 z 2010 r.)

Ustawa o działalności leczniczej z 15.04.2011 r. (Dz. U. nr 112, poz. 654 z 1.06.2011 r. z poźn. zm.)

Ustawa o zmianie ustawy o zawodach lekarza i lekarza dentysty z 28.04.2011 r. (Dz. U. nr 113, poz. 658 z 2011 r. z późn. zm.)

Rozporządzenia Ministra Zdrowia w sprawie świadczeń gwarantowanych z zakresu leczenia stomatologicznego z 30.08.2009 r. (Dz. U. nr 140, poz. 1144 z 2009 r. z późn. zm.)

Access to Health Care, www.ucatlas.ucsc.edu/access.php

Ashley-Cotleur K., Family Business and Relationship Marketing: The Impact of Relationship Marketing in Second Generation Family Business, Frostburg State University, www.usabe.org

Aspiracje zawodowe Polaków. Komunikat z badań, CBOS, Warszawa 2009, www.cbos.pl;

Biuletyny Statystyczne Ministerstwa Zdrowia przygotowywane przez Centrum Systemów Informacyjnych Ochrony Zdrowia za lata 2001-2011, www.csioz.gov.pl

Gummesson's 30 Rs (30 types of business relationship), www.audiencedialogue.net/30r.html

Hejduk I.K., Grudzewski W.M., Sankowska A., Wańtuchowicz M., W kierunku zarzadzania drugiej generacji - model diamentu czterech paradygmatów wspótczesnego przedsiębiorstwa, „E-mentor” 2010, nr 1(33), s. 39, www.e-mentor.edu.pl/czasopismo

Kasztelowicz P., Profesjonalna informacja medyczna w Internecie. Sieci indywidualne - czy moga być lekarstwem na zagrożenia wspótczesnego Internetu? www.am.torun.pl

Kowalewska A. (red.) Badanie firm rodzinnych. Raport końcowy, opracowany na zlecenie PARP, Warszawa 2009, www.parp.gov.pl

Kukliński A., Pawłowski K., Woźniak J., Kreatywna i innowacyjna Europa wobec wyzwań XXI wieku, Urząd Marszałkowski Województwa Małopolskiego Departament Polityki Regionalnej, Kraków 2009, www.politykarozwoju.obserwatoria:malopolska.pl

Prestiż zawodów. Komunikat z badań, CBOS, Warszawa 2009, www.cbos.pl 
Rachwał M., Znaczenie obstugi klienta $w$ osiaganiu przewagi konkurencyjnej, www.mfp.org.pl/publicystyka.php?id=19

Statut Instytutu Firm Rodzinnych, http://firmyrodzinne.pl/ index.php?option=com_content \&view=article

Staniszewski A., Bujnowska-Fedak M.M., Korzystanie z Internetu medycznego i ustug z zakresu e-zdrowia $w$ opinii publicznej Polaków w 2007r, 2009, www.img.custompublish.com/ getfile.php/670534.357.pyabxupqta/korzystanie1_results_Poland_2.pdf?-return

Wilmańska A. (red.), Raport o stanie sektora matych $i$ średnich przedsiębiorstw $w$ Polsce $w$ latach 2008-2009, PARP Warszawa 2010, http://www.parp.gov.pl

Wniosek dotyczacy zalecenia Parlamentu Europejskiego i Rady w sprawie kluczowych kompetencji $w$ исzеniu się przez całe życie, COM 548 z 2005, załącznik (pkt 7), www.eurlex.europa.eu/LexUriServ/LexUriServ.do?uri=OJ:C:2008:044:0084:0090:PL:PDF

www.diagnoza.com

www.rejestrzoz.gov.pl/RZOZ/

www.nfz.gov.pl. 



\section{Spis tabel}

Tabela 1. Pojęcie „konkurencyjności” w świetle wybranych pozycji przedmiotu 34

Tabela 2. Pojecie ,przedsiębiorczość” w świetle współczesnych, wybranych pozycji literatury przedmiotu

Tabela 3. Wybrane cechy zachowań przedsiębiorczych i administracyjnych organizacji ..............71

Tabela 4. Typologia pojęcia ,przedsiębiorca” i jego związek z współczesnym stomatologiem ... 77

Tabela 5. Respondenci badania I wg czasu jaki upłynął od ukończenia studiów ........................... 86

Tabela 6. Respondenci badania I wg czasu od jakiego pracują w obecnym gabinecie................... 86

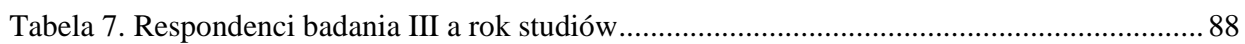

Tabela 8. Ranking intrapersonalnych motywacji lekarzy dentystów.............................................. 89

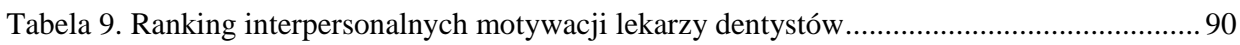

Tabela 10. Intrapersonalne motywacje studentów kierunku lekarsko-dentystycznego .................. 92

Tabela 11. Interpersonalne motywacje studentów kierunku lekarsko-dentystycznego ...................93

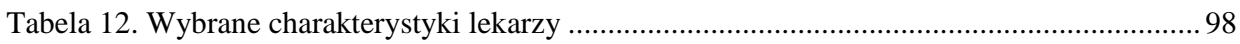

Tabela 13. Cechy charakterystyczne dla postaw przedsiębiorczych w świetle wybranych

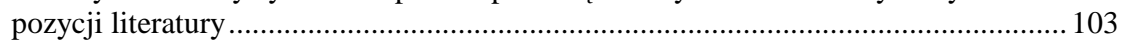

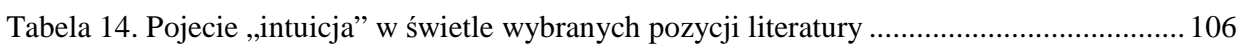

Tabela 15. Cechy charakterystyczne dla przedsiębiorcy i menedżera ......................................... 108

Tabela 16. Porównanie mentalności (osobowości) menedżera i lekarza ..................................... 115

Tabela 17. Pojęcie ,przywództwo” w świetle wybranych pozycji literatury przedmiotu............. 121

Tabela 18. Ranking umiejętności intrapersonalnych dentystów - wyniki samooceny …….......... 132

Tabela 19. Ranking umiejętności i postaw interpersonalnych dentystów - wyniki samooceny.. 133

Tabela 20. Ranking intrapersonalnych umiejętności studentów - wyniki studentów................... 136

Tabela 21. Ranking interpersonalnych umiejętności i postaw studentów - wynik samooceny ... 137

Tabela 22. Pojęcie ,przedsiębiorstwo rodzinne” w świetle wybranych pozycji literatury

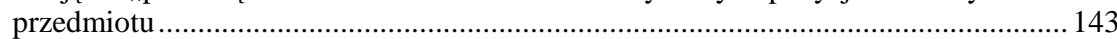

Tabela 23. Porównanie norm rodziny i norm przedsiębiorstwa .................................................. 145

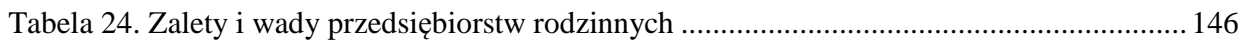

Tabela 25. Sposób zostania właścicielem gabinetu stomatologicznego przez dentystę

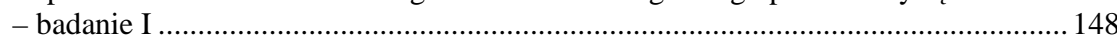

Tabela 26. Zatrudnienie dziecka stomatologa w gabinecie- badanie I ..................................... 149

Tabela 27. Zatrudnienie w gabinecie rodzica/opiekuna stomatologa ......................................... 149

Tabela 28. Planowane miejsce pracy po zakończeniu studiów wśród studentów nie mających w najbliższej rodzinie lekarza dentysty ............................................... 150

Tabela 29. Definicje usług prezentowane w wybranych pozycjach z zakresu marketingu........... 156

Tabela 30. Cechy jakości usług w świetle wybranych pozycji literatury ................................... 167

Tabela 31. Pojęcie ,zarządzanie wiedzą” w świetle wybranych pozycji literatury przedmiotu .. 185

Tabela 32. Udział w szkoleniach personelu w badanych gabinetach stomatologicznych............ 191

Tabela 33. Postawy respondentów a brak formalnej konieczności podnoszenia kwalifikacji ..... 194 
Tabela 34. Zagadnienia biznesowe a uczelnia medyczna - perspektywa lekarzy dentystów (badanie I)

Tabela 35. Zagadnienia biznesowe a uczelnia medyczna - perspektywa studentów kierunku lekarsko - dentystycznego (badanie III)

Tabela 36. Wielkość miejscowości w której funkcjonuje gabinet.

Tabela 37. Liczba gabinetów w pobliżu (w promieniu $5 \mathrm{~km}$ ) gabinetu respondenta 196

Tabela 38. Obawy respondentów związane z odejściem pacjenta do konkurencyjnego gabinetu

Tabela 39. Czas trwania relacji dentysta - pacjent. 198

Tabela 40. Rodzaj prowadzonej działalności w badanych gabinetach 198

Tabela 41. Udział wydatków na stomatologię w wydatkach NFZ w latach 2003-2013

Tabela 42. Pochodzenie środków finansowych za usługi stomatologiczne w gabinetach respondentów badania I.

Tabela 43. Sposób finansowania świadczenia stomatologicznego przez pacjentów .................... 200

Tabela 44. Ranking atutów gabinetów stomatologicznych - w oczach lekarzy dentystów. 201

Tabela 45. Ranking atutów współczesnego gabinetu stomatologicznego

- w oczach studentów.

Tabela 46. Gabinet stomatologiczny w oczach studentów - ujęcie normatywne. 205

Tabela 47. Determinanty wyboru materiałów stomatologicznych - w badaniu I. 206

Tabela 48. Ranking czynników wpływających na zmianę dostawcy materiałów (badanie I) ..... 207

Tabela 49. Zakres outsourcingu działań związanych z księgowością gabinetu - w badaniu I.... 207

Tabela 50. Osoby odpowiedzialne za pranie odzieży służbowej - w badaniu I 208

Tabela 51. Zakres outsourcingu działań związanych ze sprzątaniem w gabinecie - w badaniu I 208

Tabela 52. Miejsce przeprowadzenia sterylizacji narzędzi - w badaniu I 209

Tabela 53. Zmiany poziomu zatrudnienia w badanych gabinetach stomatologicznych - od początku działalności do dnia badania.

Tabela 54. Częstotliwość oceny personelu w badaniu I.

Tabela 55. Czynniki oceniane w pracy personelu - w badaniu I..

Tabela 56. Wykorzystywanie Internetu w gabinecie stomatologicznym wg lekarzy dentystów

Tabela 57. Internet w gabinecie stomatologicznym wg studentów

Tabela 58. Aktywność gabinetu stomatologicznego w sieci jako determinanta wyboru gabinetu przez pacjenta - wyniki badania IV

Tabela 59. Sukces zawodowy lekarza dentysty a jego płeć

Tabela 60. Pojęcie marketingu relacji w świetle wybranych pozycji literatury przedmiotu........ 232

Tabela 61. Pojęcie „,zaufanie” w świetle wybranych pozycji literatury przedmiotu 247

Tabela 62. Wpływ częstotliwości korzystania z usług stomatologicznych na oczekiwania wobec dentysty

Tabela 63. Oczekiwania pacjentów względem pracowników gabinetu w oczach studentów ..... 266

Tabela 64. Struktura wieku badanych pacjentów 269

Tabela 65. Częstotliwość korzystania z usług stomatologicznych przez pacjentów 269 
Tabela 66. Czas trwania kontaktów na płaszczyźnie: pacjent - dentysta 270

Tabela 67. Powody nie rezygnowania z usług gabinetu w perspektywie możliwości korzystania z usług innego gabinetu (badanie IV)

Tabela 68. Determinanty powrotu pacjenta do gabinetu w oczach dentystów

- wyniki badania I

Tabela 69. Oczekiwania pacjentów względem pracowników gabinetu w oczach studentów.......279

Tabela 70. Ranking działań podejmowanych w gabinetach (badanie I).....

Tabela 71. Działania jakie powinny być podejmowane w gabinecie stomatologicznym (badanie III).

Tabela 72. Częstotliwość korzystania z usług stomatologicznych a chęć rekomendowania gabinetu innym (badanie IV).

Tabela 73. Wskaźniki skłonności do zmiany usługodawcy (badanie IV).

Tabela 74. Częstotliwość korzystania z usług stomatologicznych a chęć rezygnacji z usług dotychczasowego dentysty (badanie IV)

Tabela 75. Typologia sylwetek związana ze stylem przywództwa respondentów badania II....... 302

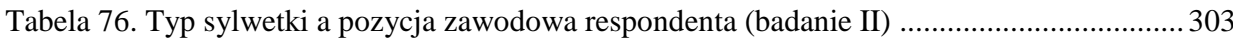

Tabela 77. Czas ukończenia studiów a typ sylwetki dentysty (badanie II) .....................................303

Tabela 78. Zawód lekarza dentysty w rodzinie respondenta a analizowane typy sylwetek.......... 304

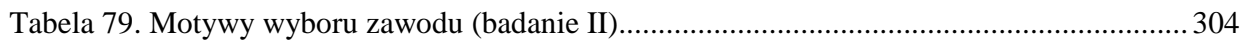

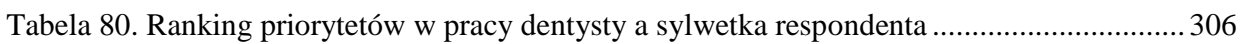

Tabela 81. Ranking działań podejmowanych przez respondentów badania II a otwieranie gabinetu obok już istniejącego.

Tabela 82. Ranking działań podejmowanych przez respondentów - obok powstaje nowy gabinet.

Tabela 83. Czynniki konkurencyjności gabinetu stomatologicznego a typ sylwetki respondenta

Tabela.84. Ranking wyzwań stojących przed gabinetami stomatologicznymi

- wyniki badania II

Tabela 85. Samoocena umiejętności intrapersonalnych dentystów

Tabela 86. Samoocena umiejętności/ postaw interpersonalnych dentystów..................................... 321

Tabela 87. Postawa lekarza dentysty w zarządzaniu gabinetem - badanie II ............................... 324

Tabela 88. Postawa lekarza dentysty w kierowaniu personelem - badanie II ............................. 330

Tabela 89. Postawy lekarzy dentystów w kontaktach z pacjentami - badanie II............................ 333

Tabela 90. Oczekiwania stomatologów względem uczelni medycznych (badanie II)................... 337 


\section{Spis wykresów}

Wykres 1. Intrapersonalne umiejętności lekarza dentysty - w ujęciu normatywnym

- wg stomatologów i studentów

Wykres 2. Interpersonalne umiejętności lekarza dentysty - w ujęciu normatywnym

- wg stomatologów i studentów

Wykres 3. Poczucie zagrożenia odejścia pacjenta do innego gabinetu a czas jaki upłynął od ukończenia studiów przez respondenta

Wykres 4. Atuty gabinetu stomatologicznego a płeć respondenta w badaniu I.

Wykres 5. Ranking atutów gabinetów stomatologicznych - spojrzenie lekarzy dentystów vs studentów stomatologii.

Wykres 6. Determinanty wyboru gabinetu i dalszego korzystania z jego usług w opinii pacjentów (średnia arytmetyczna ze wskazań) - wyniki badania IV

Wykres 7. Determinanty powrotu pacjenta do gabinetu w oczach pacjentów (badanie IV)

i lekarzy dentystów (badanie I) - średnia arytmetyczna ze wskazań respondentów .... 278

Wykres 8. Oczekiwania pacjentów wobec personelu gabinetu w oczach pacjentów (badanie IV) i studentów kierunku lekarsko-dentystycznego (badanie III) - średnia arytmetyczna ze wskazań respondentów.

Wykres 9. Proklientowskie działania gabinetu stomatologicznego - perspektywa stomatologa

(badanie I) i studenta kierunku lekarsko-dentystycznego (badanie III) - średnia

arytmetyczna ze wskazań respondentów.

Wykres 10. Średnia wskazań motywu wyboru zawodu a typ sylwetki respondenta (badanie II) 305

Wykres 11 . Wyzwania stojące przed współczesnymi gabinetami stomatologicznymi a sylwetki respondentów

Wykres 12. Umiejętności intrapersonalne a sylwetka respondenta sylwetki respondenta ......

Wykres 13. Umiejętności interpersonalne a sylwetka respondenta.

Wykres 14. Postawy stomatologów w zarządzaniu gabinetem a typ sylwetki respondenta......

Wykres 15. Postawy stomatologów w kierowaniu personelem a typ sylwetki respondenta

Wykres 16. Postawy stomatologów w kontaktach z pacjentami a typ sylwetki respondenta

Wykres 17 . Oczekiwania stomatologów w stosunku do uczelni medycznych a typ sylwetki respondenta

\section{Spis rysunków}

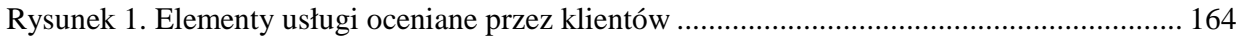

Rysunek 2. Fragment „łańcucha jakości” w gabinecie stomatologicznym ................................. 172

Rysunek 3. Miejsce marketingu relacji w tworzeniu jakości dla pacjenta ..................... 173

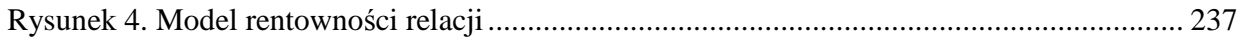

Rysunek 5. Powiązania pomiędzy jakością, obsługą klienta i marketingiem............................... 242

Rysunek 6. Model kreacji zaangażowania pacjenta w relację z usługodawcą ............................ 246

Rysunek 7. Związek między zatrzymaniem klienta a satysfakcją pracownika............................ 328

Rysunek 8. Drzewo kategorii cech i umiejętności lekarza dentysty jako przedsiębiorcy ..........341 


\section{ZALĄCZNIK NR 1}

\section{Zmiany w dostępności $w$ systemie ochrony zdrowia $w$ zakresie świadczeń stomatologicznych w Polsce w XXI w.}

Do przedstawienia zmian w zakresie dostępności do podmiotów oferujących świadczenia stomatologiczne w Polsce wykorzystano dane dostępne w zasobach Ministerstwa Zdrowia i Głównego Urzędu Statystycznego. Zostały one ujęte w czterech perspektywach:

- funkcja ochrony zdrowia (tabele 1.1 - 1.3),

- rodzaje specjalności stomatologicznych (tabele 1.4 - 1.9),

- dziedzina medyczna (tabele 1.10 - 1.14),

- lekarze dentyści (tabele 1.15 - 1.20).

Analizie poddano liczbę podmiotów świadczących określone usługi (liczbę zakładów i komórek) w ujęciu liczb bezwzględnych oraz w przeliczeniu na 10 tyś. mieszkańców (z podaniem województw o najwyższych i najniższych wartościach wskaźnika).

\section{CZĘŚĆ I. TRYB LECZENIA}

Analizując zmiany w funkcji ochrony zdrowia w okresie 2003-212, można skupić się na lecznictwie ambulatoryjnym i przychodniach stomatologicznych; dodatkowo $\mathrm{w}$ tabeli 1.3. ujęto zmiany w liczebności podmiotów dostarczających przedmioty protetyki stomatologicznej dla pacjentów ambulatoryjnych. $Z$ danych zawartych w tabe-lach $1.1-1.3$ wynika, że:

- liczba zakładów opieki zdrowotnej zajmujących się stomatologicznym leczeniem ambulatoryjnym (HC.1.3.2) wzrosła o 13,5\%; w odniesieniu do komórek organizacyjnych wzrost ten wyniósł $-17,6 \%$; średnie nasycenie ${ }^{1}$ wyniosło w 2010 r. - 4,2 (9,7 - największe w województwie mazowieckim, a najmniejsze w opolskim - 1,6) i wzrosło o 0,6 w porównaniu z 2003r.;

- liczba przychodni stomatologicznych (HP.3.2) wzrosła o 93\%; w odniesieniu do komórek organizacyjnych wzrost ten wyniósł - 47\%; średnie nasycenie wyniosło w 2010 r. - 10,0 (19,9 - największe w województwie mazowieckim, a najmniejsze w lubuskim 2,2 i podobnie, jak w poprzedniej analizowanej kate-

\footnotetext{
${ }^{1}$ Średnie nasycenie to liczba komórek organizacyjnych placówek ochrony zdrowia (np. poradni, oddziałów szpitalnych, pracowni itp.) przypadających na 10000 mieszkańców.
} 
gorii przez cały obserwowany okres nie zmieniły się województwa o najwyższej i najniższej wartości wskaźnika) i wzrosło o 3,2 w porównaniu z 2003 r.;

- liczba podmiotów dostarczających przedmioty protetyki stomatologicznej dla pacjentów ambulatoryjnych oraz wartość wskaźnika nasycenia (średnio - 0,1, maksymalnie - 0,2 w województwie łódzkim i śląskim, a minimalnie 0,0 - w województwie opolskim, podkarpackim i podlaskim) nie uległy zmianie w badanym okresie.

Tabela 1.1. Zmiany $w$ stomatologicznym leczeniu ambulatoryjnym w latach 2003-2012 LECZENIE AMBULATORYJNE - STOMATOLOGICZNE HC.1.3.2

\begin{tabular}{|c|c|c|c|c|c|}
\hline \multirow[t]{2}{*}{ Rok } & \multirow{2}{*}{$\begin{array}{l}\text { Liczba } \\
\text { zakładów }\end{array}$} & \multirow{2}{*}{$\begin{array}{l}\text { Liczba } \\
\text { Komórek }\end{array}$} & \multicolumn{3}{|c|}{ Komórki - nasycenie } \\
\hline & & & $\bar{x}$ & Max & Min \\
\hline 2003 & 4858 & 13811 & 3,6 & 8,7-mazow., 5,4-zachodniop. & 1,3-opol., 1,7 warm-maz. \\
\hline 2004 & 4990 & 14389 & 3,8 & $\begin{array}{l}\text { 8,9-mazow., 5,8-łódz., } \\
\text { zachodnio., }\end{array}$ & 1,3-opol., 1,7 warm-maz. \\
\hline 2005 & 5052 & 14662 & 3,8 & 8,9-mazow., 6,4-łódz., & $\begin{array}{l}\text { 1,3-opol., 1,8-lubus., } \\
\text { święt., warm-maz. }\end{array}$ \\
\hline 2006 & 5058 & 14884 & 3,9 & 9,2-mazow., 6,7-zachodniop. & 1,3-opol., 1,8-warm-maz \\
\hline 2007 & 5082 & 15021 & 3,9 & 9,4-mazow., 7,0-zachodniop. & 1,4-opol., 1,7-warm-maz \\
\hline 2008 & 5104 & 15224 & 4,0 & 9,5-mazow., 7,3-zachodniop. & $\begin{array}{l}\text { 1,3-opol., 1,8-lubus., } \\
\text { warm-maz }\end{array}$ \\
\hline 2009 & 5151 & 15472 & 4,0 & 9,5-mazow., 7,7-zachodniop. & 1,4-opol., 1,7-warm-maz \\
\hline 2010 & 5328 & 16242 & 4,2 & 9,7-mazow., 8,8-zachodniop. & 1,6-opol., 1,7-warm-maz \\
\hline 2011 & 5501 & b.d. & b.d. & b.d. & b.d. \\
\hline $\begin{array}{l}30.06 . \\
2012\end{array}$ & 5516 & b.d. & b.d. & b.d. & b.d. \\
\hline
\end{tabular}

Źródło: opracowanie własne na podstawie www.rejestrzoz.gov.pl/RZOZ/ (pozyskiwanie danych 15.09.2011 i 10.07.2012)

Legenda: 1) zakład - ZOZ zarejestrowany pod odrębnym numerem ksiąg rejestrowych w organach rejestrowych (może być zorganizowany w formie kilku/kilkunastu placówek tj. szpitali, przychodni, stacji pogotowia ratunkowego itp.); 2) komórka - komórka organizacyjna placówki ochrony zdrowia (np. poradnia, oddział szpitalny, pracownia itp.); 3)nasycenie - liczba komórek przypadających na 10000 mieszkańców.

Tabela 1.2. Zmiany w liczebności przychodni stomatologicznych w latach 2003-2012

\begin{tabular}{l|l|l|r|l|l|}
\hline \multicolumn{2}{l}{ PRZYCHODNIE STOMATOLOGICZNE HP.3.2 } \\
\hline Rok & Liczba & \multirow{2}{*}{$\begin{array}{l}\text { Liczba } \\
\text { kakładów }\end{array}$} & & \multicolumn{3}{|c|}{ Komórki - nasycenie } \\
\cline { 4 - 6 } & & $\bar{x}$ & \multicolumn{1}{c|}{ Max } & \multicolumn{1}{c|}{ Min } \\
\hline 2003 & 2324 & 26044 & 6,8 & 13,9 -mazow., 10,7-łódz. & 1,1-podlas., 1,7-lubus., \\
\hline 2004 & 3485 & 28089 & 7,3 & 15 -mazow., 12,7-łódz. & 1,2-podkarp., 1,8-lubus., \\
\hline 2005 & 3741 & 30458 & 8,0 & 16,1 -mazow., 14,9-łodz. & 1,3-podkarp., 1,7-lubus., \\
\hline 2006 & 3859 & 31857 & 8,3 & 16,9 -mazow., 15,5-łódz. & 1,4-podkarp., 1,8-lubus., \\
\hline 2007 & 3941 & 33077 & 8,7 & 17,7 -mazow., 15,8-łódz. & 1,7-podkarp., 1,8-lubus., \\
\hline 2008 & 4025 & 34504 & 9,0 & 18,6 -mazow., 16,3-łódz. & 1,8-lubus., 1,9-podkarp., \\
\hline 2009 & 4117 & 35380 & 9,3 & 19,0 -mazow., 16,7-łódz. & 2,0-podkarp., 2,1-lubus., \\
\hline 2010 & 4307 & 38255 & 10,0 & 19,9 mazow., 17,6-łódz. & 2,2-lubus., 2,4-podkarp., \\
\hline 2011 & 4481 & b.d & b.d. & b.d. & b.d. \\
\hline 30.06. & 4493 & b.d. & b.d. & b.d. & b.d. \\
2012 & & & & & \\
\hline
\end{tabular}

Źródło: jak pod tabelą 1.1.; Legenda: jak pod tabelą 1.1. 
Tabela 1.3. Zmiany w liczebności podmiotów dostarczających przedmioty protetyki stomatologicznej dla pacjentów ambulatoryjnych w latach 2003-2012

\begin{tabular}{|l|l|l|l|l|l|}
\hline \multicolumn{6}{|l|}{ DOSTARCZANIE PRODUKTOW MEDYCZNYCH DLA PACJENTÓW } \\
AMBULATORYJNYCH - Przedmioty protetyki stomatologicznej HC.5.2.5
\end{tabular}

Źródło: jak pod tabelą 1.1.; Legenda: jak pod tabelą 1.1.

\section{CZĘŚĆ II. RODZAJE SPECJALNOŚCI STOMATOLOGICZNYCH}

Analiza zmian w obszarze dostępności do podmiotów świadczących usługi o różnych specjalnościach stomatologicznych w latach 2003-2012 dotyczyła m. in.: chirurgii szczękowo-twarzowej (zarówno w obszarze lecznictwa szpitalnego, jak i w poradniach), ortodoncji, chorób błon przyzębia, protetyki, poradni stomatologicznych ogółem i dla dzieci. Z danych zawartych w tabelach $1.4-$ 1.10 wynika, że:

- liczba zakładów oferujących leczenie szpitalne na oddziałach chirurgii szczękowo-twarzowej (4630) wzrosła o 77\%; komórek organizacyjnych o 37\%, a łóżek o 6,6\%, choć średnie nasycenie w analizowanym okresie pozostało na niezmienionym poziomie - 0,1 (największe - 0,2 odnotowały województwa: dolnośląskie, lubelskie, łódzkie, mazowieckie, podlaskie, wielkopolskie, warmińsko-mazurskie; a najmniejsze - 0,0 - lubuskie i świętokrzyskie);

- liczba poradni stomatologicznych dla dzieci (1801) wzrosła o 46\%, a komórek o 42\%, średnie nasycenie wzrosło z 0,2 w 2003 r. do 0,4 w 2010 r. (maksymalne było $\mathrm{w}$ województwie mazowieckim - 1,4, a minimalne - 0,0 w lubelskim, lubuskim, opolskim i śląskim);

- liczba poradni chorób błon śluzowych przyzębia (1810) wzrosła o 43\%, a komórek o 39\%; średnie nasycenie w całym analizowanym okresie wynosiło 
0,2 (najwyższe było w województwach zachodniopomorskim i mazowieckim, a najniższe w kujawsko-pomorskim, małopolskim, podlaskim i warmińskomazurskim);

- liczba poradni ortodontycznych (1820) wzrosła o 36\%, a liczba komórek - o 34\%, natomiast nasycenie wynosiło w 2010 r. - 0,4 (maksymalne było w województwach: łódzkim, mazowieckim i zachodniopomorskim, a minimalne - 0,1 w podkarpackim, świętokrzyskim i warmińsko-mazurskim);

- liczba poradni protetyki stomatologicznej (1830) wzrosła o 32\%, a komórek o 29\%; średnie nasycenie w 2010 r. wynosiło 0,5 (najwyższą wartość miał ten wskaźnik w województwie zachodniopomorskim - 1,3, a najniższą w kujawskopomorskim, małopolskim, świętokrzyskim i warmińsko-mazurski - 0,1);

- liczba poradni chirurgii stomatologicznej (1840) wzrosła o 39\%, a komórek o $35 \%$, nasycenie wzrosło w latach $2004-2005$ z 0,3 do 0,4 i na tym poziomie utrzymało się do 2010 r. (maksymalny poziom wskaźnik miał w województwie mazowieckim i zachodniopomorskim - 1,1, a najniższy w województwach: kujawsko-pomorskim, opolskim, podlaskim i warmińsko-mazurskim - 0,1).

Tabela 1.4. Zmiany w liczebności oddziałów chirurgii szczękowo-twarzowej w latach 2003-2012

\begin{tabular}{|c|c|c|c|c|c|c|}
\hline \multicolumn{7}{|c|}{ LECZENIE SZPITALNE -ODDZIAŁ CHIRURGII SZCZEKOWO-TWARZOWEJ (4630) } \\
\hline \multirow[t]{2}{*}{ Rok } & \multirow{2}{*}{\begin{tabular}{|l|} 
Liczba \\
zakładów
\end{tabular}} & \multirow{2}{*}{\begin{tabular}{|l} 
Liczba \\
komórek
\end{tabular}} & \multirow{2}{*}{\begin{tabular}{|l|} 
Liczba \\
łóżek
\end{tabular}} & \multicolumn{3}{|c|}{ Łóżka - nasycenie } \\
\hline & & & & $\bar{x}$ & Max & Min \\
\hline 2003 & 27 & 30 & 513 & 0,1 & 0,3-łódz., & $\begin{array}{l}\text { 0,0-kujaw.-pom., lubusk., } \\
\text { świętok., }\end{array}$ \\
\hline 2004 & 29 & 34 & 518 & 0,1 & 0,3-łódz., & $\begin{array}{l}\text { 0,0-kujaw.-pom., lubusk., } \\
\text { świętok., }\end{array}$ \\
\hline 2005 & 32 & 37 & 550 & 0,1 & 0,3-łódz., & $\begin{array}{l}\text { 0,0-kujaw.-pom., lubusk., } \\
\text { świętok., }\end{array}$ \\
\hline 2006 & 34 & 39 & 551 & 0,1 & 0,3-łódz., & $\begin{array}{l}\text { 0,0-kujaw.-pom., lubusk., } \\
\text { świętok., }\end{array}$ \\
\hline 2007 & 36 & 41 & 561 & 0,1 & 0,3-łódz., & $\begin{array}{l}\text { 0,0-kujaw.-pom., lubusk., } \\
\text { świętok. }\end{array}$ \\
\hline 2008 & 33 & 34 & 494 & 0,1 & $\begin{array}{l}\text { 0,2-dolnośl., lubel., } \\
\text { łódz., mazow., podlas., } \\
\text { wielkop., }\end{array}$ & $\begin{array}{l}\text { 0,0-kujaw.-pom., lubusk., } \\
\text { świętok., }\end{array}$ \\
\hline 2009 & 34 & 35 & 491 & 0,1 & $\begin{array}{l}\text { 0,2-dolnośl., lubel., } \\
\text { łódz., mazow., podlas., } \\
\text { wielkop., }\end{array}$ & $\begin{array}{l}\text { 0,0-kujaw.-pom., lubusk., } \\
\text { swiętok., }\end{array}$ \\
\hline 2010 & 41 & 41 & 547 & 0,1 & $\begin{array}{l}\text { 0,2-dolnośl., lubel., } \\
\text { łódz., mazow., podlas., } \\
\text { wielkop., warm.-maz., }\end{array}$ & 0,0-lubus., świetok., \\
\hline 2011 & 47 & b.d. & b.d. & b.d. & b.d. & b.d. \\
\hline $\begin{array}{l}30.06 . \\
2012\end{array}$ & 48 & b.d. & b.d. & b.d. & b.d. & b.d. \\
\hline
\end{tabular}

Źródło: jak pod tabelą 1.1.; Legenda: jak pod tabelą 1.1. 
Tabela 1.5. Zmiany w liczebności poradni chirurgii stomatologicznej w latach 2003-2012 PORADNIA CHIRURGII STOMATOLOGICZNEJ (1840)

\begin{tabular}{|c|c|c|c|c|c|}
\hline \multirow[t]{2}{*}{ Rok } & \multirow{2}{*}{$\begin{array}{l}\text { Liczba } \\
\text { zakładów }\end{array}$} & \multirow{2}{*}{$\begin{array}{l}\text { Liczba } \\
\text { komórek }\end{array}$} & \multicolumn{3}{|c|}{ Komórki - nasycenie } \\
\hline & & & $\bar{x}$ & Max & Min \\
\hline 2003 & 1041 & 1203 & 0,3 & $\begin{array}{l}\text { 1,0-mazow., 0,6-łódz., } \\
\text { zachodniop. }\end{array}$ & $\begin{array}{l}\text { 0,0-kujaw.-pom., 0,1-lubel., opol., } \\
\text { podkarp., podlas., śląs., świętok., warm.- } \\
\text { mazur., }\end{array}$ \\
\hline 2004 & 1115 & 1287 & 0,3 & $\begin{array}{l}\text { 1,0-mazow., 0,7-łódz., } \\
\text { zachodniop. }\end{array}$ & $\begin{array}{l}\text { 0,0-kujaw.-pom., 0,1-lubel., lubusk., } \\
\text { opol., podkarp., podlas., śląs., świętok., } \\
\text { warm.-mazur., }\end{array}$ \\
\hline 2005 & 1176 & 1368 & 0,4 & $\begin{array}{l}\text { 1,0-mazow., 0,8-łódz., } \\
\text { zachodniop. }\end{array}$ & $\begin{array}{l}\text { 0,1-kujaw.-pom., lubusk., opol., } \\
\text { podkarp., podlas., śląs., świętok., warm.- } \\
\text { mazur., }\end{array}$ \\
\hline 2006 & 1207 & 1407 & 0,4 & $\begin{array}{l}\text { 1,0-mazow., 0,8-łódz., } \\
\text { zachodniop. }\end{array}$ & $\begin{array}{l}\text { 0,0-kujaw.-pom., 0,1-opol., podkarp., } \\
\text { podlas., warm.-maz., }\end{array}$ \\
\hline 2007 & 1217 & 1430 & 0,4 & $\begin{array}{l}\text { 1,1-mazow., } \\
\text { 0,9-zachodniop. }\end{array}$ & $\begin{array}{l}\text { 0,0-kujaw.-pom., 0,1-opol., podkarp., } \\
\text { podlas., warm.-maz., }\end{array}$ \\
\hline 2008 & 1258 & 1476 & 0,4 & $\begin{array}{l}\text { 1,1-mazow., } \\
\text { 1,0-zachodniop. }\end{array}$ & $\begin{array}{l}\text { 0,0-kujaw.-pom., 0,1-opol., podkarp., } \\
\text { podlas., warm.-maz., }\end{array}$ \\
\hline 2009 & 1289 & 1516 & 0,4 & $\begin{array}{l}\text { 1,1-mazow., } \\
\text { 1,0-zachodniop. }\end{array}$ & $\begin{array}{l}\text { 0,0-kujaw.-pom., } 0,1 \text {-opol., podkarp., } \\
\text { podlas., warm.-maz., }\end{array}$ \\
\hline 2010 & 1375 & 1627 & 0,4 & $\begin{array}{l}\text { 1,1-mazow., } \\
\text { zachodniop., } \\
\text { 0,9-łódz., }\end{array}$ & $\begin{array}{l}\text { 0,1-kujaw.-pom., opol., podlas., warm.- } \\
\text { maz. }\end{array}$ \\
\hline 2011 & 1448 & b.d. & b.d. & b.d. & b.d. \\
\hline $\begin{array}{l}30.06 . \\
2012\end{array}$ & 1450 & b.d. & b.d. & b.d. & b.d. \\
\hline
\end{tabular}

Źródło: jak pod tabelą 1.1.; Legenda: jak pod tabelą 1.1.

Tabela 1.6. Zmiany w liczebności poradni stomatologicznych dla dzieci w latach 2003-2012 PORADNIA STOMATOLOGICZNA DLA DZIECI (1801)

\begin{tabular}{|c|c|c|c|c|c|}
\hline \multirow[t]{2}{*}{ Rok } & \multirow{2}{*}{$\begin{array}{l}\text { Liczba } \\
\text { zakładów }\end{array}$} & \multirow{2}{*}{$\begin{array}{l}\text { Liczba } \\
\text { komórek }\end{array}$} & \multicolumn{3}{|c|}{ Komórki - nasycenie } \\
\hline & & & $\bar{x}$ & Max & Min \\
\hline 2003 & 709 & 949 & 0,2 & $\begin{array}{l}\text { 0,9-mazow., } \\
\text { 0,8-zachodniop. }\end{array}$ & $\begin{array}{l}\text { 0,0-lubel., lubus., opol., podkarp., śląs., } \\
\text { warm.-mazur. }\end{array}$ \\
\hline 2004 & 771 & 1017 & 0,3 & $\begin{array}{l}\text { 1,0-mazow., } \\
\text { 0,9-zachodniop., }\end{array}$ & $\begin{array}{l}\text { 0,0- lubel., lubus., opol., podkarp., śląs., } \\
\text { warm.-mazur. }\end{array}$ \\
\hline 2005 & 800 & 1066 & 0,3 & $\begin{array}{l}\text { 1,0-mazow., } \\
\text { 0,9-zachodniop., }\end{array}$ & 0,0- lubel., lubus., opol., śląs., warm.-mazur., \\
\hline 2006 & 873 & 1160 & 0,3 & $\begin{array}{l}\text { 1,1-mazow., } \\
\text { 1,0-zachodniop. }\end{array}$ & 0,0- lubel., lubus., opol., śląs., warm.-mazur. \\
\hline 2007 & 912 & 1223 & 0,3 & $\begin{array}{l}\text { 1,3-mazow., } \\
\text { 1,1-zachodniop., }\end{array}$ & 0,0-lubel., lubus., opol., śląs., warm.-mazur., \\
\hline 2008 & 923 & 1235 & 0,3 & $\begin{array}{l}\text { 1,3-mazow., } \\
\text { 1,1-zachodniop., }\end{array}$ & 0,0-lubel., lubus., opol., pomor., śląs. \\
\hline 2009 & 941 & 1264 & 0,3 & $\begin{array}{l}\text { 1,3-mazow., } \\
\text { 1,2-zachodniop., }\end{array}$ & 0,0-lubel., lubus., opol., pomor., śląs., \\
\hline 2010 & 995 & 1344 & 0,4 & $\begin{array}{l}\text { 1,4-mazow., } \\
\text { 1,3-zachodniop., }\end{array}$ & 0,0-lubel., lubus., opol., śląs. \\
\hline 2011 & 1034 & b.d. & b.d. & b.d. & b.d. \\
\hline $\begin{array}{l}30.06 . \\
2012\end{array}$ & 1035 & b.d. & b.d. & b.d. & b.d. \\
\hline
\end{tabular}

Źródło: jak pod tabelą 1.1.; Legenda: jak pod tabelą 1.1. 
Tabela 1.7. Zmiany w liczebności poradni chorób błon śluzowych przyzębia w latach 2003-2012

\begin{tabular}{|c|c|c|c|c|c|}
\hline \multicolumn{6}{|c|}{ PORADNIA CHORÓB BLON ŚLUZOWYCH PRZYZĘBIA (1810) } \\
\hline \multirow[t]{2}{*}{ Rok } & \multirow{2}{*}{$\begin{array}{l}\text { Liczba } \\
\text { zakładów }\end{array}$} & \multirow{2}{*}{\begin{tabular}{|l} 
Liczba \\
Komórek
\end{tabular}} & \multicolumn{3}{|c|}{ Komórki - nasycenie } \\
\hline & & & $\bar{x}$ & Max & Min \\
\hline 2003 & 584 & 681 & 0,2 & $\begin{array}{l}\text { 0,7-mazow., } \\
\text { 0,5-zachodniop., }\end{array}$ & $\begin{array}{l}\text { 0,0-kujaw.-pomor., lubus., małopol., } \\
\text { opol., podkarm., podlas., śląs., świętok., } \\
\text { warm.-mazur., }\end{array}$ \\
\hline 2004 & 625 & 732 & 0,2 & $\begin{array}{l}\text { 0,7-mazow., } \\
\text { 0,6-zachodniop., }\end{array}$ & $\begin{array}{l}\text { 0,0- kujaw.-pomor., lubus., małopol., } \\
\text { opol., podkarm., podlas., śląs., świętok., } \\
\text { warm.-mazur., }\end{array}$ \\
\hline 2005 & 665 & 784 & 0,2 & $\begin{array}{l}\text { 0,7-mazow., } \\
\text { 0,6-zachodniop., }\end{array}$ & $\begin{array}{l}\text { 0,0- kujaw.-pomor., lubus., małopol., } \\
\text { opol., podkarm., podlas., śląs., świętok., } \\
\text { warm.-mazur., }\end{array}$ \\
\hline 2006 & 689 & 811 & 0,2 & $\begin{array}{l}\text { 0,8-mazow., } \\
\text { 0,7-zachodniop., }\end{array}$ & $\begin{array}{l}\text { 0,0- kujaw.-pomor., lubus., małopol., } \\
\text { opol., podkarm., podlas., śląs., warm.- } \\
\text { mazur., }\end{array}$ \\
\hline 2007 & 694 & 826 & 0,2 & $\begin{array}{l}\text { 0,8-mazow., } \\
\text { 0,7-zachodniop., }\end{array}$ & $\begin{array}{l}\text { 0,0- kujaw.-pomor., lubus., małopol., } \\
\text { opol., podkarm., podlas., śląs., warm.- } \\
\text { mazur., }\end{array}$ \\
\hline 2008 & 728 & 863 & 0,2 & $\begin{array}{l}\text { 0,8-mazow., zachodniop., } \\
\text { 0,5 lódz., }\end{array}$ & $\begin{array}{l}\text { 0,0- kujaw.-pomor., lubus., małopol., } \\
\text { opol., podkarm., podlas., śląs., warm.- } \\
\text { mazur., }\end{array}$ \\
\hline 2009 & 752 & 885 & 0,2 & $\begin{array}{l}\text { 0,8-mazow., zachodniop., } \\
\text { 0,5 łódz., }\end{array}$ & $\begin{array}{l}\text { 0,0- kujaw.-pomor., lubus., małopol., } \\
\text { opol., podkarm., podlas., warm.-mazur., }\end{array}$ \\
\hline 2010 & 798 & 947 & 0,2 & $\begin{array}{l}\text { 1,0-zachodniop., } \\
\text { 0,8-mazow., }\end{array}$ & $\begin{array}{l}\text { 0,0- kujaw.-pomor., małopol., podlas., } \\
\text { warm.-mazur., }\end{array}$ \\
\hline 2011 & 835 & b.d. & b.d. & b.d. & b.d. \\
\hline $\begin{array}{l}30.06 . \\
2012\end{array}$ & 836 & b.d. & b.d. & b.d. & b.d. \\
\hline
\end{tabular}

Źródło: jak pod tabelą 1.1.; Legenda: jak pod tabelą 1.1.

Tabela 1.8. Zmiany w liczebności poradni ortodontycznych w latach 2003-2012

\begin{tabular}{|c|c|c|c|c|c|}
\hline \multicolumn{6}{|c|}{ PORADNIA ORTODONTYCZNA (1820) } \\
\hline \multirow[t]{2}{*}{ Rok } & \multirow{2}{*}{\begin{tabular}{|l|} 
Liczba \\
zakładów
\end{tabular}} & \multirow{2}{*}{$\begin{array}{l}\text { Liczba } \\
\text { komórek }\end{array}$} & \multicolumn{3}{|c|}{ Komórki -nasycenie } \\
\hline & & & $\bar{x}$ & Max & Min \\
\hline 2003 & 977 & 1108 & 0,3 & $\begin{array}{l}\text { 0,7-mazow., } \\
\text { 0,6-łódz., }\end{array}$ & $\begin{array}{l}\text { 0,0-warm.-mazur., } \\
\text { 0,1-opol., podkarp., świętok., }\end{array}$ \\
\hline 2004 & 1052 & 1203 & 0,3 & $\begin{array}{l}\text { 0,8-łódz., } \\
\text { 0,7-mazow., }\end{array}$ & $\begin{array}{l}\text { 0,0-warm.-mazur., } \\
\text { 0,1-opol., podkarp., świętok., }\end{array}$ \\
\hline 2005 & 1083 & 1260 & 0,3 & $\begin{array}{l}\text { 0,9-łódz., } \\
\text { 0,7-mazow., }\end{array}$ & $\begin{array}{l}\text { 0,0- warm.-mazur., } \\
\text { 0,1-opol., podkarp., świętok. }\end{array}$ \\
\hline 2006 & 1110 & 1290 & 0,3 & $\begin{array}{l}\text { 0,9-łódz., } \\
\text { 0,7-mazow., zachodniop., }\end{array}$ & $\begin{array}{l}\text { 0,0-warm.-mazur., } \\
0,1 \text {-opol., podkarp., świętok., podlas. }\end{array}$ \\
\hline 2007 & 1123 & 1312 & 0,3 & $\begin{array}{l}\text { 0,8-łódz., mazow., } \\
\text { 0,7-zachodniop., }\end{array}$ & $\begin{array}{l}\text { 0,0- warm.-mazur., } \\
\text { 0,1-opol., świętok. }\end{array}$ \\
\hline 2008 & 1174 & 1361 & 0,4 & 0,9-łódz., 0,8-mazow., & 0,1-opol., świętok., warm.-mazur., \\
\hline 2009 & 1208 & 1399 & 0,4 & $\begin{array}{l}\text { 0,9-łódz., } \\
\text { 0,8-mazow., zachodniop., }\end{array}$ & 0,1-opol., świętok., warm.-mazur., \\
\hline 2010 & 1279 & 1489 & 0,4 & $\begin{array}{l}\text { 0,9-1ódz, mazow., } \\
\text { zachodniop., }\end{array}$ & 0,1-podkarp., świętok., warm.-mazur., \\
\hline 2011 & 1326 & b.d. & b.d. & b.d. & b.d. \\
\hline $\begin{array}{l}30.06 . \\
2012\end{array}$ & 1329 & b.d. & b.d. & b.d. & b.d. \\
\hline
\end{tabular}

Źródło: jak pod tabelą 1.1.; Legenda: jak pod tabelą 1.1. 
Tabela 1.9. Zmiany w liczebności poradni protetyki stomatologicznej w latach 2003-2012

\begin{tabular}{|c|c|c|c|c|c|}
\hline \multicolumn{6}{|c|}{ PORADNIA PROTETYKI STOMATOLOGICZNEJ (1830) } \\
\hline \multirow[t]{2}{*}{ Rok } & \multirow{2}{*}{$\begin{array}{l}\text { Liczba } \\
\text { zakładów }\end{array}$} & \multirow{2}{*}{$\begin{array}{l}\text { Liczba } \\
\text { komórek }\end{array}$} & \multicolumn{3}{|c|}{ Komórki - nasycenie } \\
\hline & & & $\bar{x}$ & Max & Min \\
\hline 2003 & 1203 & 1407 & 0,4 & $\begin{array}{l}\text { 0,8-łódz., zachodniop., } \\
\text { 1,1-mazow., }\end{array}$ & $\begin{array}{l}\text { 0,0-podkarp.; 0,1-kujaw.-pom., } \\
\text { małopol., opol., podlas., śląs., } \\
\text { świętok., warm-maz., }\end{array}$ \\
\hline 2004 & 1290 & 1510 & 0,4 & $\begin{array}{l}\text { 1,1-mazow., } \\
\text { 1,0-łodz. }\end{array}$ & $\begin{array}{l}\text { 0,0-podkarp.; 0,1-kujaw.-pom., } \\
\text { małopol., opol., śląs., świętok., } \\
\text { warm.-maz., }\end{array}$ \\
\hline 2005 & 1354 & 1596 & 0,4 & $\begin{array}{l}\text { 1,1-mazow., łódz., } \\
\text { 0,9-zachodniop., }\end{array}$ & $\begin{array}{l}\text { 0,0-podkarp.; 0,1-kujaw.-pom., } \\
\text { małopol., opol., śląs., świętok., } \\
\text { warm.-maz., }\end{array}$ \\
\hline 2006 & 1370 & 1617 & 0,4 & $\begin{array}{l}\text { 1,1-mazow., łódz., } \\
\text { 1,0-zachodniop., }\end{array}$ & $\begin{array}{l}\text { 0,1- kujaw.-pom., małopol., opol., } \\
\text { podk., śląs., świętok., warm.-maz., }\end{array}$ \\
\hline 2007 & 1374 & 1631 & 0,4 & $\begin{array}{l}\text { 1,2-mazow., } \\
\text { 1,1-łódz., }\end{array}$ & $\begin{array}{l}\text { 0,1- kujaw.-pom., małopol., opol., } \\
\text { śląs., świętok., }\end{array}$ \\
\hline 2008 & 1413 & 1670 & 0,4 & $\begin{array}{l}\text { 1,2-mazow., } \\
\text { 1,1-łódz, zachodniop., }\end{array}$ & $\begin{array}{l}\text { 0,1- kujaw.-pom., małopol., opol., } \\
\text { podkarp., świętok, warm.-maz., }\end{array}$ \\
\hline 2009 & 1450 & 1713 & 0,4 & $\begin{array}{l}\text { 1,2-mazow., } \\
\text { 1,1-łódz, zachodniop., }\end{array}$ & $\begin{array}{l}\text { 0,1- kujaw.-pom., opol., podkarp., } \\
\text { świętok., warm.-maz., }\end{array}$ \\
\hline 2010 & 1532 & 1818 & 0,5 & $\begin{array}{l}\text { 1,3-zachodniop., } \\
\text { 1,2-łódz, mazow., }\end{array}$ & $\begin{array}{l}\text { 0,1- kujaw.-pom., małopol., } \\
\text { świętok., warm.-maz., }\end{array}$ \\
\hline 2011 & 1582 & b.d. & b.d. & b.d. & b.d. \\
\hline $\begin{array}{l}30.06 . \\
2012\end{array}$ & 1584 & b.d. & b.d. & b.d. & b.d. \\
\hline
\end{tabular}

Źródło: jak pod tabelą 1.1.; Legenda: jak pod tabelą 1.1.

\section{CZĘŚĆ III. DZIEDZINA MEDYCZNA}

Kolejne zestawienie materiału statystycznego dotyczącego podmiotów opieki zdrowotnej, jakie umożliwiał system Centralnego Systemu Informacyjnego Ochrony Zdrowia, był podział świadczeniodawców ze względu na reprezentowaną dziedzinę medyczną (por. tabela 1.11 - 1.16). I tak w latach 20032012:

- liczba zakładów opieki zdrowotnej świadczących usługi z zakresu ortodoncji (73) wzrosła o 48\%, a liczba komórek - o 43\%, natomiast średnie nasycenie z 0,5 do 0,7 (w 2010 r. najwyższą wartość miał ten wskaźnik w województwie mazowieckim - 1,6, a najniższą w opolskim, podkarpackim i podlaskim - 0,2);

- liczba zakładów opieki zdrowotnej świadczących usługi z zakresu periodontologii (74) wzrosła o 82\%, a komórek o $61 \%$, natomiast nasycenie z 0,4 w latach 2003-2004 do 0,6 w okresie 2008-2010 (największe było w województwie mazowieckim - 1,5, a najmniejsze w podlaskim - 0,0);

- jeśli chodzi o zakłady opieki zdrowotnej świadczących usługi z zakresu protetyki stomatologicznej (75), to ich liczba wzrosła o 39\%, a liczba komórek - o 33\%, co wpłynęło na wzrost nasycenia z 0,9 do 1,2 w 2010 r. (maksymalnie - 1,9 w województwie mazowieckim i minimalnie 0,3 w podkarpackim); 
- liczba zakładów opieki zdrowotnej zajmujących się stomatologią dziecięcą (76) wzrosła o 52\%, a komórek o $45 \%$, co wpłynęło na znaczna zmianę w poziomie nasycenia z 0,7 do $1,1 \mathrm{w} 2010$ r. (przy znacznym zróżnicowaniu między województwami: w województwie mazowieckim - 2,0, a podlaskim - 0,1 );

- liczba zakładów, w których można skorzystać ze świadczeń z zakresu stomatologii zachowawczej z endodoncją (77) wzrosła o 13,7\%, a komórek o 8\%, a nasycenie z 2,0 do 2,2 ( w 2010 r. wynosiło w województwie zachodniopomorskim 3,1, a opolskim - 1,1);

- w odniesieniu do zakładów opieki zdrowotnej zajmujących się chirurgią stomatologiczną (72) wzrost wyniósł 52,6\%, a komórek - 40,4\%, nasycenie wzrosło z 0,7 do 1,0 (w 2010 r. maksymalne było w województwie mazowieckim $-2,2$, a minimalne $\mathrm{w}$ opolskim i podlaskim $-0,2$ ).

Tabela 1.10. Zmiany w zakresie lecznictwa ortodontycznego w latach 2003-2012

\begin{tabular}{|c|c|c|c|c|c|}
\hline \multicolumn{6}{|c|}{73 ORTODONCJA } \\
\hline \multirow[t]{2}{*}{ Rok } & \multirow{2}{*}{$\begin{array}{l}\text { Liczba } \\
\text { zakładów }\end{array}$} & \multirow{2}{*}{$\begin{array}{l}\text { Liczba } \\
\text { komórek }\end{array}$} & \multicolumn{3}{|c|}{ Komórki - nasycenie } \\
\hline & & & $\bar{x}$ & Max & Min \\
\hline 2003 & 1314 & 1828 & 0,5 & $\begin{array}{l}\text { 1,3-mazow., } \\
\text { 0,7-łódz., }\end{array}$ & $\begin{array}{l}\text { 0,1-opol., podkarp., świętok., warm.- } \\
\text { mazur., }\end{array}$ \\
\hline 2004 & 1412 & 1973 & 0,5 & $\begin{array}{l}\text { 1,4-mazow., } \\
\text { 0,9-łódz., }\end{array}$ & $\begin{array}{l}\text { 0,1-opol., podkarp., świętok., warm.- } \\
\text { mazur., }\end{array}$ \\
\hline 2005 & 1490 & 2105 & 0,6 & $\begin{array}{l}\text { 1,4-mazow., } \\
\text { 1,0-łódz., }\end{array}$ & $\begin{array}{l}\text { 0,1-podkarp., opol.; } \\
\text { 0,2-podlas., świętok., warm.-mazur. }\end{array}$ \\
\hline 2006 & 1561 & 2214 & 0,6 & $\begin{array}{l}\text { 1,5-mazow., } \\
\text { 1,0-łódz., }\end{array}$ & $\begin{array}{l}\text { 0,1-podkarp.; } \\
\text { 0,2-opol., podlas., świętok.,warm.-mazur. }\end{array}$ \\
\hline 2007 & 1606 & 2302 & 0,6 & $\begin{array}{l}\text { 1,5-mazow., } \\
\text { 1,0-łódz., }\end{array}$ & $\begin{array}{l}\text { 0,1-podkarp., } \\
\text { 0,2-opol., podlas., świętok.,warm.-mazur. }\end{array}$ \\
\hline 2008 & 1676 & 2401 & 0,6 & $\begin{array}{l}\text { 1,6-mazow., } \\
\text { 1,0-łódz., }\end{array}$ & $\begin{array}{l}\text { 0,1-podkarp., } \\
\text { 0,2-opol., podlas., }\end{array}$ \\
\hline 2009 & 1733 & 2457 & 0,6 & $\begin{array}{l}\text { 1,6-mazow., } \\
\text { 1,0-łódz., }\end{array}$ & $\begin{array}{l}\text { 0,1-podkarp., } \\
\text { 0,2-opol., podlas., warm-mazur. }\end{array}$ \\
\hline 2010 & 1841 & 2617 & 0,7 & $\begin{array}{l}\text { 1,6-mazow., } \\
\text { 1,0-łódz., zachodniop., }\end{array}$ & 0,2-opol., podkarp., podlas., \\
\hline 2011 & 1941 & b.d. & b.d. & b.d. & b.d. \\
\hline $\begin{array}{l}30.06 . \\
2012\end{array}$ & 1946 & b.d. & b.d. & b.d. & b.d. \\
\hline
\end{tabular}

Źródło: jak pod tabelą 1.1.; Legenda: jak pod tabelą 1.1.

Tabela 1.11. Zmiany w zakresie lecznictwa periodontologicznego $w$ latach 2003-2012

\begin{tabular}{|c|c|c|c|c|c|}
\hline \multicolumn{6}{|c|}{74 PERIODONTOLOGIA } \\
\hline \multirow[t]{2}{*}{ Rok } & \multirow{2}{*}{$\begin{array}{l}\text { Liczba } \\
\text { zakładów }\end{array}$} & \multirow{2}{*}{\begin{tabular}{|l|} 
Liczba \\
komórek
\end{tabular}} & \multicolumn{3}{|c|}{ Komórki-nasycenie } \\
\hline & & & $\bar{x}$ & Max & Min \\
\hline 2003 & 944 & 1465 & 0,4 & $\begin{array}{l}\text { 1,1-mazow., } \\
\text { 0,5-lubel., łódz., śląs. }\end{array}$ & 0,0-opol., podk., podl. \\
\hline 2004 & 1037 & 1610 & 0,4 & $\begin{array}{l}\text { 1,2-mazow., } \\
\text { 0,5-lubel., łódz., śląs. }\end{array}$ & $\begin{array}{l}\text { 0,0-opol., podk., podl. } \\
\text { 0,1-kujaw.-pomor., małopol., }\end{array}$ \\
\hline 2005 & 1169 & 1807 & 0,5 & $\begin{array}{l}\text { 1,3-mazow., } \\
\text { 0,6-lubel., łódz., śląs. }\end{array}$ & \begin{tabular}{|l|} 
0,0-podkarp., podlas., \\
0,1-małopol.,, opol.,
\end{tabular} \\
\hline 2006 & 1268 & 1954 & 0,5 & 1,4-mazow.,0,7-lubel., & 0,0-podkarp., podlas.; 0,1-opo \\
\hline
\end{tabular}




\begin{tabular}{|l|l|l|l|l|l|}
\hline 2007 & 1316 & 2044 & 0,5 & 1,5 -mazow.,0,7-lubel., & 0,0-podkarp., podlas., 0,1-opol., \\
\hline 2008 & 1397 & 2134 & 0,6 & $\begin{array}{l}1,5 \text {-mazow., } \\
\text { 0,7-lubel., łódz., śląs. }\end{array}$ & $\begin{array}{l}\text { 0,0-podlas., } \\
\text { 0,1-opol., podkarp. }\end{array}$ \\
\hline 2009 & 1472 & 2201 & 0,6 & $\begin{array}{l}\text { 1,5-mazow., 0,7-lubel., łódz., } \\
\text { śląs., zachodniop., }\end{array}$ & $\begin{array}{l}\text { 0,0-podlas., } \\
\text { 0,1-opol., podkarp., }\end{array}$ \\
\hline 2010 & 1584 & 2359 & 0,6 & $\begin{array}{l}1,5-\text { mazow., } \\
\text { 0,8-lubel., śląs., zachodniop., }\end{array}$ & $\begin{array}{l}\text { 0,0-podlas., } \\
\text { 0,1-opol., podkarp. }\end{array}$ \\
\hline 2011 & 1712 & b.d. & b.d. & b.d. & b.d. \\
\hline $\begin{array}{l}30.06 . \\
2012\end{array}$ & 1719 & b.d. & b.d. & b.d. & b.d. \\
\hline
\end{tabular}

Źródło: jak pod tabelą 1.1.; Legenda: jak pod tabelą 1.1.

Tabela 1.12. Zmiany w zakresie protetyki stomatologicznej w latach 2003-2012

\begin{tabular}{|c|c|c|c|c|c|}
\hline \multicolumn{6}{|c|}{75 PROTETYKA STOMATOLOGICZNA } \\
\hline \multirow{2}{*}{ Rok } & \multirow{2}{*}{\begin{tabular}{|l|} 
Liczba \\
zakładów
\end{tabular}} & \multirow{2}{*}{\begin{tabular}{|l|} 
Liczba \\
komórek
\end{tabular}} & \multicolumn{3}{|c|}{ Komórki - nasycenie } \\
\hline & & & $\bar{x}$ & Max & Min \\
\hline 2003 & 2388 & 3466 & 0,9 & 1,7-mazow., 1,2-śląs., & 0,1-podkarp., 0,2-opol., podlas., \\
\hline 2004 & 2556 & 3725 & 1,0 & 1,8-mazow., 1,3-łódz., śląs., & 0,1-podkarp., 0,2-opol., podlas., \\
\hline 2005 & 2719 & 3997 & 1,0 & 1,8-mazow., 1,5-łódz., & 0,1-podkarp., 0,3-opol., podlas., \\
\hline 2006 & 2799 & 4111 & 1,1 & 1,9-mazow., 1,5-łódz., & 0,1-podkarp., 0,3-opol., podlas., \\
\hline 2007 & 2831 & 4188 & 1,1 & 1,9-mazow., 1,5-łódz., śląs., & 0,1-podkarp., 0,3-opol., podlas. \\
\hline 2008 & 2909 & 4258 & 1,1 & 1,9-mazow., 1,5-łódz., śląs., & 0,2-podkarp., 0,3-opol., podlas., \\
\hline 2009 & 2980 & 4336 & 1,1 & 1,9-mazow., 1,5-łódz., śląs., & 0,2-podkarp., 0,3-opol., \\
\hline 2010 & 3149 & 4596 & 1,2 & 1,9-mazow., 1,6-śląs., & 0,3-podkarp., 0,4-opol., podlas., \\
\hline 2011 & 3300 & b.d. & b.d. & b.d. & b.d. \\
\hline $\begin{array}{l}30.06 . \\
2012\end{array}$ & 3310 & b.d. & b.d. & b.d. & b.d. \\
\hline
\end{tabular}

Źródło: jak pod tabelą 1.1.; Legenda: jak pod tabelą 1.1.

Tabela 1.13. Zmiany $w$ zakresie stomatologii zachowawczej $\mathrm{z}$ endodoncją $\mathrm{w}$ latach 2003-2012 77 STOMATOLOGIA ZACHOWAWCZA Z ENDODONCJA

\begin{tabular}{|c|c|c|c|c|c|}
\hline \multirow[t]{2}{*}{ Rok } & \multirow{2}{*}{$\begin{array}{l}\text { Liczba } \\
\text { zakładó } \\
\text { w }\end{array}$} & \multirow{2}{*}{$\begin{array}{l}\text { Liczba } \\
\text { Komórek }\end{array}$} & \multicolumn{3}{|c|}{ Komórki - nasycenie } \\
\hline & & & $\bar{x}$ & Max & Min \\
\hline 2003 & 4765 & 7642 & 2,0 & \begin{tabular}{|l} 
2,7-śląs., \\
2,6-mazow.,
\end{tabular} & $\begin{array}{l}\text { 1,0-opol.; 1,4-kujaw.-pomor., lubus., } \\
\text { pomor., świętok., warm.-mazur., }\end{array}$ \\
\hline 2004 & 4898 & 7802 & 2,0 & $\begin{array}{l}\text { 2,7-śląs., } \\
\text { 2,6-łódz., mazow., }\end{array}$ & $\begin{array}{l}\text { 1,0-opol.; 1,4-kujaw.-pomor., lubus., } \\
\text { pomor., święt., warm.-mazur. }\end{array}$ \\
\hline 2005 & 4956 & 7782 & 2,0 & $\begin{array}{l}\text { 2,7-zachodniop., } \\
\text { 2,6-łódz., mazow., śląs. }\end{array}$ & $\begin{array}{l}\text { 1,0-opol., } \\
\text { 1,2-lubus., }\end{array}$ \\
\hline 2006 & 4969 & 7773 & 2,0 & $\begin{array}{l}\text { 2,7-zachodniop., } \\
\text { 2,6-łódz, mazow., śląs. }\end{array}$ & $\begin{array}{l}\text { 1,0-opol., } \\
\text { 1,3-lubus., }\end{array}$ \\
\hline 2007 & 4981 & 7798 & 2,0 & $\begin{array}{l}\text { 2,8-zachodniop., } \\
\text { 2,6-mazow., śląs., }\end{array}$ & $\begin{array}{l}\text { 1,1-opol., } \\
\text { 1,3-lubus., }\end{array}$ \\
\hline 2008 & 5008 & 7830 & 2,0 & $\begin{array}{l}\text { 2,8-zachodniop., } \\
\text { 2,6-łódz., mazow., śląs., }\end{array}$ & $\begin{array}{l}\text { 1,0-opol., } \\
\text { 1,4-warm.-mazur., }\end{array}$ \\
\hline 2009 & 5059 & 7931 & 2,1 & $\begin{array}{l}\text { 2,9-zachodniop., } \\
\text { 2,7-śląs., }\end{array}$ & $\begin{array}{l}\text { 1,0-opol., } \\
\text { 1,3-lubus., }\end{array}$ \\
\hline 2010 & 5233 & 8257 & 2,2 & $\begin{array}{l}\text { 3,1-zachodniop., } \\
\text { 2,8-śląs., }\end{array}$ & $\begin{array}{l}\text { 1,1-opol., } \\
\text { 1,4-warm.-mazur., }\end{array}$ \\
\hline 2011 & 5403 & b.d. & b.d. & b.d. & b.d. \\
\hline $\begin{array}{l}30.06 . \\
2012\end{array}$ & 5417 & b.d. & b.d. & b.d. & b.d. \\
\hline
\end{tabular}

Źródło: jak pod tabelą 1.1.; Legenda: jak pod tabelą 1.1. 
Tabela 1.14. Zmiany w zakresie chirurgii stomatologicznej w latach 2003-2012

\begin{tabular}{|c|c|c|c|c|c|}
\hline \multicolumn{6}{|c|}{72 CHIRURGIA STOMATOLOGICZNA } \\
\hline \multirow[t]{2}{*}{ Rok } & \multirow{2}{*}{$\begin{array}{l}\text { Liczba } \\
\text { zakładów }\end{array}$} & \multirow{2}{*}{\begin{tabular}{|l|} 
Liczba \\
komórek
\end{tabular}} & \multicolumn{3}{|c|}{ Komórki - nasycenie } \\
\hline & & & $\bar{x}$ & Max & Min \\
\hline 2003 & 1754 & 2676 & 0,7 & $\begin{array}{l}\text { 1,9-mazow., } \\
\text { 0,8-świętok., wielko., }\end{array}$ & $\begin{array}{l}\text { 0,1-opol., podkarp., } \\
\text { podlas., }\end{array}$ \\
\hline 2004 & 1889 & 2883 & 0,8 & $\begin{array}{l}\text { 1,9-mazow., } \\
\text { 0,9-łódz., wielkop., }\end{array}$ & $\begin{array}{l}\text { 0,1-opol., podkarp., } \\
\text { podlas., }\end{array}$ \\
\hline 2005 & 2038 & 3118 & 0,8 & $\begin{array}{l}\text { 1,9-mazow., 1,0-lubel., łódz., świętok, } \\
\text { wielkop., }\end{array}$ & $\begin{array}{l}\text { 0,1-opol., podkarp., } \\
\text { podlas., }\end{array}$ \\
\hline 2006 & 2127 & 3249 & 0,8 & $\begin{array}{l}\text { 2,0-mazow., } \\
\text { 1,1-łódz., }\end{array}$ & 0,1-podkarp., podlas., \\
\hline 2007 & 2178 & 3347 & 0,9 & $\begin{array}{l}\text { 2,1-mazow., } \\
\text { 1,1-łódz, świętok., }\end{array}$ & $\begin{array}{l}\text { 0,1-podlas., } \\
\text { 0,2-opol., podkarp. }\end{array}$ \\
\hline 2008 & 2258 & 3439 & 0,9 & $\begin{array}{l}\text { 2,1-mazow., } \\
\text { 1,1-lubel, łódz., świętok., zachodniop., }\end{array}$ & $\begin{array}{l}\text { 0,1-podlas., } \\
\text { 0,2-opol., podkarp. }\end{array}$ \\
\hline 2009 & 2333 & 3518 & 0,9 & $\begin{array}{l}\text { 2,1-mazow., } \\
\text { 1,1-lubel., łódz., świętok., zachodniop., }\end{array}$ & $\begin{array}{l}\text { 0,1-podlas., } \\
\text { 0,2-opol., podkarp., }\end{array}$ \\
\hline 2010 & 2506 & 3758 & 1,0 & $\begin{array}{l}\text { 2,2-mazow., } \\
\text { 1,3-zachodniop., }\end{array}$ & $\begin{array}{l}\text { 0,2-opol., podlas., } \\
\text { 0,3-kujaw.-pomor., } \\
\text { podkarp. }\end{array}$ \\
\hline 2011 & 2667 & b.d. & b.d. & b.d. & b.d. \\
\hline $\begin{array}{l}30.06 . \\
2012\end{array}$ & 2676 & b.d. & b.d. & b.d. & b.d. \\
\hline
\end{tabular}

Źródło: jak pod tabelą 1.1.; Legenda: jak pod tabelą 1.1.

\section{CZĘŚĆ IV. LEKARZE DENTYŚCI}

Podejmując się analizy dostępności do usług stomatologicznych w Polsce nie sposób pominąć liczby lekarzy dentystów. Kwalifikowane kadry są zasadniczym elementem kapitału intelektualnego systemu opieki zdrowotnej, a ich jakość w dużej mierze decyduje o jakości udzielanych świadczeń (a w konsekwencji o bezpieczeństwie, zadowoleniu i satysfakcji pacjentów). Część eksperttów utożsamia wręcz kwalifikacje lekarzy z jakością świadczeń zdrowotnych ${ }^{2}$.

Przedstawione poniżej zmiany w liczbie lekarzy dentystów w XXI w. obejmują personel medyczny uprawniony do wykonywania zawodu, personel medyczny zatrudniony wg podstawowego miejsca zatrudnienia ( $w$ tym również w publicznych placówkach zdrowotnych i zgodnie z prezentowaną specjalizacją) oraz zarejestrowane praktyki lekarzy dentystów (z podziałem na indywidualne i grupowe). Przedstawione jest także zestawienie danych dotyczących Polski na tle kilku wybranych państw UE.

$\mathrm{Z}$ danych zawartych $\mathrm{w}$ tabeli 1.15 wynika, że liczba osób uprawnionych do wykonywania zawodu lekarza dentysty w latach $2000-2010^{3}$ wzrosła o $10,85 \%$, co wpłynęło na wskaźnik nasycenia - wzrósł z 8,5 w 2001 r. do 9,8 w 2010 r;

\footnotetext{
${ }^{2}$ Niżankowski R., Jaki system specjalizacji lekarskich?, „Zdrowie i Zarządzanie”, 2000, tom II, nr 5

${ }^{3}$ Dane bez MON, MSWiA, MS.
} 
jednak jeśli uwzględni się, że w 2010 r. 16,14\% lekarzy dentystów uprawnionych do wykonywania zawodu nie wykonywało go, to wskaźnik nasycenia wynosi - 8,2, a uwzględnienie stażystów (w 2010 r. - 951 osób) obniża wartość wskaźnika do poziomu - 7,97.

Porównując sytuację Polski z innymi państwami europejskimi (por. tabela 1.20), można zauważyć, że w zakresie liczby lekarzy uprawnionych do wykonywania zawodu lekarza dentysty w przeliczeniu na 10 tyś. mieszkańców sytuacja w kraju jest zbliżona do innych państw. Jednak przyglądając się wskaźnikowi nasycenia odnoszącemu się do dentystów aktywnych zawodowo, czy praktykujących Polska wypada gorzej, niż pozostałych siedem państw uwzględnionych $\mathrm{w}$ tabeli. Pamiętając, że wpływ na ten stan mają lekarze stażyści (nie uwzględniani w tych statystykach) można się zastanowić dlaczego osób nie pracujących w zawodzie jest tak dużo? Czy absolwenci studiów nie byli $\mathrm{w}$ stanie z przyczyn związanych z problemami w dostaniu się na staż ze względu na zbyt małą liczbę miejsc w porównaniu z liczbą chętnych, czy merytorycznych (niski poziom wiedzy) stać się aktywnymi zawodowo dentystami? Czy nie marnuje się $\mathrm{w}$ ten sposób potencjału uczelni wyższych i pieniędzy publicznych? (a kolejne uczelnie uruchamiają kierunki lekarskodentystyczne) Czy powody rynkowe np. bariera w postaci braku środków na otwarcie własnego gabinetu, stają się przyczyna takiej sytuacji? Czy też dane statystyczne nie do końca oddają rynkową rzeczywistość w tym zakresie (wielu dentystów podkreśla rosnącą konkurencję i mcdonaldyzację usług stomatologgicznych)? Czy i jakie są powody nie podejmowania pracy $\mathrm{w}$ zawodzie? $\mathrm{W}$ pracy nie podjęto próby odpowiedzi na te pytania, ale wydają się one ciekawe poznawczo i rysują nowe pole dociekań.

Ciekawa sytuacja dotyczy Węgier, które wskaźniki nasycenia mają na relatywnie niskim poziomie, ale są pierwszym w Europie i drugim (po Meksyku) eksporterem usług stomatologicznych. Okazuje się, że nawet relatywnie niska liczba lekarzy może obsługiwać nie tylko pacjentów krajowych, ale również zagranicznych. Działania takie są podejmowane również w Polsce np. turystyka medyczna z Londynu do UM w Łodzi, lecz dotyczą one stosunkowo niewielkiej liczby dentystów, choć rynek ten z roku na rok rośnie.

Dane zawarte w tabeli 1.16 wyraźnie pokazują wysoki stopień sfeminizowania zawodu (ok. $80 \%$ w całym analizowanym okresie) oraz wyraźnie malejący wskaźnik nasycenia - uwzględniający podstawowe miejsce zatrudnienia stomatologa. Jeszcze głębszy spadek wartości wskaźnika można zaobserwować w odniesieniu do lekarzy zatrudnionych w publicznych podmiotach ochrony zdrowia (por. tabela 1.17) - z 1,2 w 2002 r. do 0,5 w 2010 r. (zróżnicowanie między województwami w $2010 \mathrm{r}$. było na poziomie 1,1: od 1,2 w województwie łódzkim do $0,1 \mathrm{w}$ województwie lubuskim i warmińsko-mazurskim). 
Biorąc pod uwagę zmiany w zakresie liczby dentystów ze specjalizacją (por. tabela 1.18), można zauważyć wzrost w okresie 2000-2010. Jednak bardziej szczegółowa analiza danych zmusza do negatywnej oceny roku $2010 \mathrm{w}$ zakresie liczby lekarzy dentystów pracujących w placówkach ochrony zdrowia wg podstawowego miejsca zatrudnienia, gdyż uwzględniając okres 1992-2010 wyższa była tylko od tej liczby w roku 2000, w pozostałych latach przyjmowała niższe wartości - nawet o 20\%. Tendencję rosnącą wskazywała liczba specjalistów w zakresie ortodoncji i periodontologii, natomiast pozostałe specjalności (chirurgia stomatologiczna, chirurgia szczękowo-twarzowa, protetyka, stomatologia dziecięca, stomatologia zachowawcza) charakteryzuje malejąca liczba dentystów (wg podstawowego miejsca zatrudnienia).

$\mathrm{Z}$ danych zamieszczonych w tabeli 1.19 wynika, że w latach 2006-2010 wzrosła liczba indywidualnych (o 13\%) i grupowych (o 26\%) praktyk dentystycznych oraz świadczonych w miejscu wezwania (24-krotny wzrost), natomiast liczba indywidualnych praktyk specjalistycznych zmalała $\mathrm{w}$ niewielkim zakresie (spadek o $0,7 \%$ ).

Tabela 1.15. Personel medyczny uprawniony do wykonywania zawodu

\begin{tabular}{|l|l|l|l|l|l|l|}
\hline \multirow{3}{*}{ rok } & \multirow{2}{*}{$\begin{array}{l}\text { dentyści } \\
\text { ogółem }\end{array}$} & \multicolumn{2}{|l|}{$\begin{array}{l}\text { Liczba dentystów na } \\
\text { 10 tys. mieszkańców }\end{array}$} & $\begin{array}{l}\text { dentyści nie } \\
\text { wykonujący } \\
\text { zawodu }\end{array}$ & \\
\cline { 3 - 7 } & & Ogółem & max. & min. & & \\
\hline 2001 & 32732 & 8,5 & $11,4-$ pomor. & $4,1-$ lubus. & b.d. & b.d. \\
\hline 2002 & 34409 & 9,0 & $11,7-$ pomor. & $6,0-$ opol. & b.d. & b.d. \\
\hline 2003 & 32655 & 8,6 & $11,2-$ mazow. & $5,9-$ kuj.-pomor. & b.d. & b.d. \\
\hline 2004 & 33957 & 8,9 & $11,7-$ mazow. & $5,9-$ kuj.-pomor. & b.d. & b.d. \\
\hline 2005 & 34379 & 9,0 & $12,1-$ mazow. & $5,3-$ warm.-mazur. & b.d. & b.d. \\
\hline 2006 & 34373 & 9,2 & $12,2-$ mazow. & $6,1-$ kuj.-pomor. & 4775 & 965 \\
\hline 2007 & 35464 & 9,3 & $12,1-$ mazow. & $6,0-$ kuj.-pomor. & 5657 & 870 \\
\hline 2008 & 36196 & 9,5 & $12,4-$ mazow. & $6,1-$ kuj.-pomor. & 5837 & 929 \\
\hline 2009 & 36945 & 9,7 & $12,6-$ mazow. & $6,1-$ kuj.-pomor. & 5302 & 1005 \\
\hline 2010 & 37616 & 9,8 & $12,8-$ mazow. & $6,2-$ kuj.-pomor. & 6071 & 951 \\
\hline 2011 & 38335 & 9,9 & $12,9-$ mazow. & $6,2-$ kuj-pomor. & 5871 & 981 \\
\hline
\end{tabular}

Zródło: opracowanie własne na podstawie Biuletynów Statystycznych Ministerstwa Zdrowia przygotowywanych przez Centrum Systemów Informacyjnych Ochrony Zdrowia za lata 20012011, www.csioz.gov.pl 
Tabela 1.16. Personel ochrony zdrowia - lekarze dentyści wg podstawowego miejsca zatrudnienia ${ }^{4}$

\begin{tabular}{|c|c|c|c|c|}
\hline \multirow[t]{2}{*}{ Rok } & \multicolumn{3}{|c|}{ Lekarze dentyści } & \multirow{2}{*}{$\begin{array}{l}\text { Lekarze dentyści na } 10 \text { tys } \\
\text { mieszkańców }\end{array}$} \\
\hline & ogółem & w tym: kobiety & $\%$ & \\
\hline 1980 & 16834 & 13771 & 81,80 & 4,7 \\
\hline 1990 & 18205 & 14532 & 79,82 & 4,8 \\
\hline 1995 & 17805 & 14192 & 79,71 & 4,6 \\
\hline 1997 & 17624 & 13819 & 78,41 & 4,6 \\
\hline 1998 & 17323 & 13544 & 78,19 & 4,5 \\
\hline 1999 & 13260 & 10275 & 77,49 & 3,4 \\
\hline 2000 & 11758 & 8911 & 75,79 & 3,1 \\
\hline 2004 & 10081 & 7461 & 74,01 & 2,6 \\
\hline 2005 & 11881 & 911 & 76,69 & 3,1 \\
\hline 2007 & 12930 & 9953 & 76,98 & 3,4 \\
\hline 2008 & 12765 & 9803 & 76,80 & 3,3 \\
\hline 2009 & 11855 & 9209 & 77,68 & 3,1 \\
\hline 2010 & 12326 & 9580 & 77,72 & 3,2 \\
\hline 2011 & 12989 & 10030 & 77,22 & 3,4 \\
\hline
\end{tabular}

Źródło: dane MZ w Roczniku Statystycznym GUS

Tabela 1.17. Personel ochrony zdrowia - lekarze dentyści pracujący w publicznych zakładach opieki zdrowotnej wg podstawowego miejsca zatrudnienia ${ }^{5}$

\begin{tabular}{|c|c|c|c|c|}
\hline \multirow[t]{2}{*}{ Rok } & \multirow{2}{*}{$\begin{array}{l}\text { dentyści } \\
\text { ogółem }\end{array}$} & \multicolumn{3}{|c|}{ Liczba dentystów na 10 tys. mieszkańców } \\
\hline & & Ogółem & $\max$. & $\min$. \\
\hline 2002 & 4497 & 1,2 & b.d. & b.d. \\
\hline 2003 & 4082 & 1,1 & 2,3- łódzkie & 0,2 - lubus. \\
\hline 2004 & 3040 & 0,8 & 1,6 - łódzkie & 0,2 - lubus., opol., warm.-mazur., \\
\hline 2005 & 2349 & 0,6 & 1,5 - łódzkie & 0,1 - lubus., wielkop. \\
\hline 2006 & 2244 & 0,6 & 1,5 - łódzkie & 0,1 - lubus., opol., podlas., warm.-mazur., \\
\hline 2007 & 2088 & 0,5 & 1,4- łódzkie & $0,1-$ lubus. \\
\hline 2008 & 1968 & 0,5 & 1,6 - łódzkie & 0,1 - lubus., warm.-mazur. \\
\hline 2009 & 1810 & 0,5 & 1,0 - łódzkie & $0,1-$ lubus., wielkop. \\
\hline 2010 & 1826 & 0,5 & 1,2- łódzkie & 0,1 - lubus., warm-mazur. \\
\hline 2011 & 1860 & 0,5 & 1,3- łódzkie & 0,1 - podlas., śląs., wielko. \\
\hline
\end{tabular}

Źródło: opracowanie własne na podstawie Biuletynów Statystycznych Ministerstwa Zdrowia przygotowywanych przez Centrum Systemów Informacyjnych Ochrony Zdrowia za lata 20012011, www.csioz.gov.pl

Tabela 1.18. Specjaliści - lekarze dentyści pracujący w placówkach ochrony zdrowia wg podstawowego miejsca zatrudnienia ${ }^{6}$ (dane bez MON, MSWiA, MS)

\begin{tabular}{|l|l|l|l|l|l|l|l|l|l|l|}
\hline Rok & Ogół. & Ch.stom & $\begin{array}{l}\text { Ch.szcz- } \\
\text { twarz }\end{array}$ & Ortod & Period & Prot & $\begin{array}{l}\text { Stom. } \\
\text { dziec }\end{array}$ & $\begin{array}{l}\text { Stom. } \\
\text { zach }\end{array}$ & $\begin{array}{l}\text { Stom. } \\
\text { ogólna }\end{array}$ & $\begin{array}{l}\text { Dent. } \\
\text { ze } \\
\text { spec/ } \\
\text { dent.og }\end{array}$ \\
\hline 1992 & 8510 & 752 & 149 & 416 & 60 & 723 & 646 & 1221 & 4445 & $51,2 \%$ \\
\hline 1995 & 9174 & 869 & 131 & 390 & 127 & 672 & 606 & 1120 & 5168 & $51,5 \%$ \\
\hline 1998 & 9264 & 815 & 190 & 410 & 114 & 663 & 424 & 857 & 5672 & $53,5 \%$ \\
\hline 2000 & 6319 & 590 & 145 & 367 & 103 & 508 & 254 & 570 & 3637 & $53,7 \%$ \\
\hline
\end{tabular}

\footnotetext{
${ }^{4}$ Dane bez MON, MSWiA, MS.

${ }^{5}$ Dane bez MON, MSWiA, MS.

${ }^{6}$ Dane bez MON, MSWiA, MS.
} 


\begin{tabular}{|l|l|l|l|l|l|l|l|l|l|l|}
\hline 2003 & 8642 & 790 & 179 & 572 & 182 & 654 & 304 & 640 & 5176 & $80,5 \%$ \\
\hline 2004 & 8456 & 701 & 138 & 572 & 167 & 618 & 294 & 590 & 5224 & $83,9 \%$ \\
\hline 2005 & 7617 & 635 & 131 & 519 & 136 & 559 & 249 & 507 & 4759 & $64,1 \%$ \\
\hline 2006 & 7542 & 657 & 151 & 573 & 138 & 560 & 255 & 550 & 4576 & $61,9 \%$ \\
\hline 2007 & 7720 & 628 & 143 & 588 & 149 & b.d. & 276 & b.d. & 4643 & $59,7 \%$ \\
\hline 2008 & 7860 & 684 & 146 & 620 & 151 & b.d. & 275 & b.d. & 4682 & $61,6 \%$ \\
\hline 2009 & 9196 & 646 & 152 & 539 & 174 & b.d. & 272 & b.d. & 4400 & $77,6 \%$ \\
\hline 2010 & 7346 & 695 & 133 & 535 & 170 & b.d. & 267 & b.d. & 4264 & $59,6 \%$ \\
\hline
\end{tabular}

Źródło: opracowanie własne na podstawie Biuletynów Statystycznych Ministerstwa Zdrowia przygotowywanych przez Centrum Systemów Informacyjnych Ochrony Zdrowia za lata 20012011, www.csioz.gov.pl i dane MZ w Roczniku Statystycznym GUS

Tabela 1.19. Liczba zarejestrowanych praktyk dentystów

\begin{tabular}{|l|l|l|l|l|}
\hline Rok & Indywidualne & $\begin{array}{l}\text { Indywidualne } \\
\text { specjalistyczne }\end{array}$ & grupowe & $\begin{array}{l}\text { Świadczone w } \\
\text { miejscu wezwania }\end{array}$ \\
\hline 2006 & 12567 & 8386 & 443 & 38 \\
\hline 2007 & 12908 & 8372 & 452 & 5 \\
\hline 2008 & 13115 & 8149 & 571 & 201 \\
\hline 2009 & 13550 & 8255 & 583 & 497 \\
\hline 2010 & 14196 & 8329 & 558 & 915 \\
\hline
\end{tabular}

Źródło: opracowanie własne na podstawie Biuletynów Statystycznych Ministerstwa Zdrowia przygotowywanych przez Centrum Systemów Informacyjnych Ochrony Zdrowia za lata 20012011, www.csioz.gov.pl

Tabela 1.20. Wskaźniki nasycenia w wybranych państwach UE w 2007 r. i 2010 r.

\begin{tabular}{|l|l|l|l|l|}
\hline Państwo & \multirow{2}{*}{ rok } & \multicolumn{3}{|l|}{$\begin{array}{l}\text { liczba lekarzy dentystów przypadająca } \\
\text { na 10 tys. mieszkańców }\end{array}$} \\
\cline { 3 - 5 } & & $\begin{array}{l}\text { Personel medyczny } \\
\text { uprawniony do } \\
\text { wykonywania zawodu }\end{array}$ & $\begin{array}{l}\text { Dentyści aktywni } \\
\text { zawodowo }\end{array}$ & $\begin{array}{l}\text { Dentyści } \\
\text { praktykujący }\end{array}$ \\
\hline Polska & 2007 & 9,3 & 3,8 & 3,5 \\
\cline { 2 - 5 } & 2010 & 9,8 & 3,6 & 3,3 \\
\hline Niemcy & 2007 & 10,2 & 8,0 & 7,7 \\
\cline { 2 - 5 } & 2010 & 10,6 & 8,3 & 7,9 \\
\hline Węgry & 2007 & 6,9 & b.d. & 4,0 \\
\cline { 2 - 5 } & 2010 & 7,4 & b.d. & 5,3 \\
\hline Finlandia & 2007 & 12,1 & 8,3 & 7,8 \\
\cline { 2 - 5 } & 2009 & 12,3 & 8,2 & 7,4 \\
\hline \multirow{3}{*}{ Dania } & 2007 & 14,2 & 8,9 & 8,4 \\
\cline { 2 - 5 } & 2009 & 14,0 & 8,2 & 7,5 \\
\hline Czechy & 2007 & b.d & b.d. & 6,9 \\
\cline { 2 - 5 } & 2010 & b.d. & b.d. & 7,2 \\
\hline \multirow{2}{*}{ Wielka } & 2007 & b.d. & b.d. & 4,9 \\
\cline { 2 - 5 } Brytania & 2010 & b.d. & b.d. & 5,2 \\
\hline Francja & 2007 & b.d. & 7,0 & b.d. \\
\cline { 2 - 5 } & 2010 & b.d. & 6,9 & b.d. \\
\hline
\end{tabular}

Źródło: opracowanie własne na podstawie www.stats.oecd.org (14.12.2012) 


\section{ZAŁĄCZNIK NR 2 \\ Determinanty wyboru gabinetu przez pacjenta - wyniki badania IV}

Badanie IV miało na celu określenie potrzeb pacjentów w zakresie obsługi w gabinecie stomatologicznym oraz oceny kontaktów pacjent - personel gabinetu. Poniżej przedstawione są zagregowane wyniki z przeprowadzonego badania $\mathrm{IV}^{1} \mathrm{w}$ zakresie czynników wpływających na decyzję pacjenta o wyborze gabinetu stomatologicznego (por. tabela 2.1) i oczekiwań pacjentów względem personelu gabinetu (tabela 2.2), a także czynników wpływających na decyzje pacjenta o kontynuowaniu korzystania z usług gabinetu (tabela 2.3) i ocen postaw lekarzy dentystów i ich gabinetów przez pacjentów (tabela 2.4).

Tabela 2.1. Ranking czynników decydujących o wyborze gabinetu przez pacjenta

\begin{tabular}{|c|c|c|c|c|c|c|c|c|c|}
\hline \multirow[b]{2}{*}{$\begin{array}{l}\text { Czynnik } \\
\text { decyzyjny }\end{array}$} & \multicolumn{5}{|c|}{$\begin{array}{c}\text { Wskazania respondentów } \\
\text { (procent odpowiedzi) }\end{array}$} & \multirow[b]{2}{*}{$\bar{x}$} & \multirow[b]{2}{*}{ Do } & \multirow[b]{2}{*}{ Me } & \multirow[b]{2}{*}{$\mathbf{S}(\mathbf{x})$} \\
\hline & $\begin{array}{l}\text { na } \\
\text { pewno } \\
\text { nie } \\
(1)\end{array}$ & $\begin{array}{l}\text { raczej } \\
\text { nie } \\
(2) \\
\end{array}$ & $\begin{array}{l}\text { trudno } \\
\text { powie- } \\
\text { dzieć } \\
\text { (3) }\end{array}$ & $\begin{array}{l}\text { raczej } \\
\text { tak } \\
\text { (4) }\end{array}$ & $\begin{array}{l}\text { na } \\
\text { pewno } \\
\text { tak } \\
(5)\end{array}$ & & & & \\
\hline $\begin{array}{l}\text { Doświadczony } \\
\text { personel }\end{array}$ & 0,7 & 3,3 & 7,0 & 33,1 & 55,9 & 4,40 & 5 & 5 & 0,82 \\
\hline $\begin{array}{l}\text { Dogodne terminy } \\
\text { wizyt }\end{array}$ & 3,6 & 6,5 & 7,6 & 32,7 & 49,5 & 4,18 & 5 & 4 & 1,06 \\
\hline $\begin{array}{l}\text { Rekomendacje } \\
\text { rodziny, } \\
\text { przyjaciół }\end{array}$ & 4,2 & 4,2 & 6,4 & 42,6 & 42,6 & 4,15 & $\begin{array}{l}4 ; \\
5\end{array}$ & 4 & 1,01 \\
\hline $\begin{array}{l}\text { Dogodne godziny } \\
\text { pracy gabinetu }\end{array}$ & 4,8 & 3,7 & 8,1 & 39,1 & 44,3 & 4,14 & 5 & 4 & 1,04 \\
\hline $\begin{array}{l}\text { Łatwość w } \\
\text { umówieniu się na } \\
\text { wizytę np. } \\
\text { telefonicznie }\end{array}$ & 5,9 & 9,2 & 7,3 & 30,8 & 46,9 & 4,04 & 5 & 4 & 1,20 \\
\hline Renoma gabinetu & 3,8 & 8,0 & 15,7 & 35,6 & 36,8 & 3,93 & 5 & 4 & 1,09 \\
\hline $\begin{array}{l}\text { Lokalizacja } \\
\text { gabinetu }\end{array}$ & 7,8 & 14,6 & 12,7 & 35,4 & 29,5 & 3,64 & 4 & 4 & 1,26 \\
\hline $\begin{array}{l}\text { Niskie ceny usług } \\
\text { w gabinecie }\end{array}$ & 7,2 & 17,8 & 20,1 & 25,0 & 29,9 & 3,53 & 5 & 4 & 1,28 \\
\hline Łatwość dojazdu & 12,8 & 10,9 & 17,4 & 33,2 & 25,7 & 3,48 & 4 & 4 & 1,33 \\
\hline $\begin{array}{l}\text { Duża różnorod- } \\
\text { ność usług }\end{array}$ & 8,8 & 16,1 & 20,3 & 37,2 & 17,6 & 3,39 & 4 & 4 & 1,20 \\
\hline $\begin{array}{l}\text { Wygląd zewnę- } \\
\text { trzny gabinetu } \\
\text { podmiotu }\end{array}$ & 18,8 & 18,8 & 26,4 & 25,3 & 10,7 & 2,9 & 3 & 3 & 1,27 \\
\hline $\begin{array}{l}\text { Zabezpieczenie } \\
\text { miejsc parkingo- } \\
\text { wych dla pacjent- } \\
\text { tów }\end{array}$ & 29,1 & 26,1 & 20,3 & 15,3 & 9,2 & 2,49 & 1 & 2 & 1,30 \\
\hline
\end{tabular}

\footnotetext{
${ }^{1}$ Wartość wskazań średniej arytmetycznej, dominanty i mediany dla badanych kryteriów w badaniu IV była zbliżona (lub identyczna), co pozwala wnioskować, że miał on rozkład normalny.
} 


\begin{tabular}{|c|c|c|c|c|c|c|c|c|c|}
\hline Młody personel & 24,9 & 30,0 & 26,5 & 12,1 & 6,6 & 2,46 & 2 & 2 & 1,18 \\
\hline $\begin{array}{l}\text { Niższe ceny usług } \\
\text { w godzinach } \\
\text { południowych }\end{array}$ & 28,6 & 27,8 & 24,1 & 11,2 & 8,3 & 2,43 & 2 & 2 & 1,24 \\
\hline $\begin{array}{l}\text { Oferowana przez } \\
\text { gabinet „karta } \\
\text { stałego pacjenta” } \\
\text { (umożliwiająca } \\
\text { np. 5\% zniżkę na } \\
\text { świadczenia) }\end{array}$ & 31,0 & 26,1 & 20,7 & 14,2 & 8,0 & 2,42 & 2 & 2 & 1,28 \\
\hline $\begin{array}{l}\text { Wysokie ceny } \\
\text { usług }\end{array}$ & 42,5 & 27,6 & 19,3 & 6,3 & 4,3 & 2,02 & 1 & 2 & 1,12 \\
\hline $\begin{array}{l}\text { Możliwość } \\
\text { umówienia wizyty } \\
\text { mailem }\end{array}$ & 47,7 & 29,8 & 10,9 & 7,8 & 3,9 & 1,9 & 1 & 2 & 1,11 \\
\hline $\begin{array}{l}\text { Opinie internau- } \\
\text { tów na portalach } \\
\text { społecznościow. }\end{array}$ & 52,1 & 23,2 & 15,1 & 6,9 & 2,7 & 1,85 & 1 & 1 & 1,08 \\
\hline $\begin{array}{l}\text { Reklama w } \\
\text { gazecie lokalnej }\end{array}$ & 51,2 & 35,7 & 9,3 & 3,9 & 0,0 & 1,66 & 1 & 1 & 0,80 \\
\hline $\begin{array}{l}\text { Oferta na } \\
\text { grouponie, } \\
\text { MyDeal'u itp. }\end{array}$ & 59,9 & 24,2 & 11,5 & 3,2 & 1,2 & 1,62 & 1 & 1 & 0,90 \\
\hline $\begin{array}{l}\text { Aktywność } \\
\text { stomatologa na } \\
\text { facebooku, nk, } \\
\text { innym portalu } \\
\text { społecznościow. }\end{array}$ & 72,2 & 20,1 & 7,3 & 0,0 & 0,4 & 1,36 & 1 & 1 & 0,65 \\
\hline
\end{tabular}

Źródło: opracowanie własne na podstawie przeprowadzonego badania.

Tabela 2.2. Ranking oczekiwań pacjentów względem dentysty

\begin{tabular}{|c|c|c|c|c|c|c|c|c|c|}
\hline \multirow[b]{2}{*}{ Oczekiwania } & \multicolumn{5}{|c|}{$\begin{array}{c}\text { Wskazania respondentów } \\
\text { (procent odpowiedzi) }\end{array}$} & \multirow[b]{2}{*}{$\bar{x}$} & \multirow[b]{2}{*}{ Do } & \multirow[b]{2}{*}{ Me } & \multirow[b]{2}{*}{$\mathbf{S}(\mathbf{x})$} \\
\hline & $\begin{array}{l}\text { na } \\
\text { pewno } \\
\text { nie } \\
(1)\end{array}$ & $\begin{array}{l}\text { raczej } \\
\text { nie } \\
(2)\end{array}$ & $\begin{array}{l}\text { trudno } \\
\text { powie- } \\
\text { dzieć } \\
\text { (3) }\end{array}$ & $\begin{array}{l}\text { raczej } \\
\text { tak } \\
\text { (4) }\end{array}$ & $\begin{array}{l}\text { na } \\
\text { pewno } \\
\text { tak } \\
(5)\end{array}$ & & & & \\
\hline $\begin{array}{lr}\text { Dentysta } & \text { powi- } \\
\text { nien } & \text { wykonać } \\
\text { usługe w sposób } \\
\text { rzetelny i dokład- } \\
\text { ny }\end{array}$ & 0,4 & 0,0 & 0,7 & 9,1 & 89,8 & 4,88 & 5 & 5 & 0,41 \\
\hline $\begin{array}{l}\text { Pracownicy gabi- } \\
\text { netu powinni dys- } \\
\text { ponować profes- } \\
\text { jonalna wiedzą } \\
\text { i kwalifikacjami }\end{array}$ & 0,4 & 0,4 & 1,1 & 15,6 & 82,5 & 4,80 & 5 & 5 & 0,50 \\
\hline $\begin{array}{l}\text { Dentysta powi- } \\
\text { nien } \\
\text { zaufanie swbudzać } \\
\text { postępowaniem }\end{array}$ & 0,0 & 1,1 & 1,8 & 21,3 & 75,8 & 4,72 & 5 & 5 & 0,55 \\
\hline $\begin{array}{l}\text { Personel powi- } \\
\text { nien dawać pac- } \\
\text { jentowi poczucie } \\
\text { bezpieczeństwa }\end{array}$ & 0,4 & 2,2 & 2,2 & 26,4 & 69,0 & 4,61 & 5 & 5 & 0,67 \\
\hline $\begin{array}{l}\text { Pracownicy gabi- } \\
\text { netu powinni być } \\
\text { uprzejmi }\end{array}$ & 0,7 & 0,7 & 4,0 & 27,4 & 67,2 & 4,59 & 5 & 5 & 0,67 \\
\hline $\begin{array}{l}\text { Informacja w trak- } \\
\text { cie leczenia po- } \\
\text { winna być wy- } \\
\text { czerpujaca }\end{array}$ & 0,4 & 2,2 & 4,7 & 28,9 & 63,9 & 4,54 & 5 & 5 & 0,72 \\
\hline
\end{tabular}




\begin{tabular}{|c|c|c|c|c|c|c|c|c|c|}
\hline $\begin{array}{l}\text { Personel powi- } \\
\text { nien szybko rea- } \\
\text { gować na po- } \\
\text { trzeby pacjenta }\end{array}$ & 0,4 & 2,6 & 8,9 & 36,8 & 51,3 & 4,36 & 5 & 5 & 0,78 \\
\hline $\begin{array}{l}\text { Wizyty powinny } \\
\text { rozpoczynać } \\
\text { punktualnie }\end{array}$ & 0,7 & 0,7 & 7,3 & 45,6 & 45,6 & 4,35 & 4 & 4 & 0,71 \\
\hline $\begin{array}{l}\text { Personel gabinetu } \\
\text { powinien rozu- } \\
\text { mieć obawy pac- } \\
\text { jenta związane z } \\
\text { wizytą w gabine- } \\
\text { cie }\end{array}$ & 0,8 & 3,0 & 9,4 & 35,3 & 51,5 & 4,34 & 5 & 5 & 0,83 \\
\hline $\begin{array}{l}\text { Dentysta powi- } \\
\text { nien starać się } \\
\text { rozpoznać po- } \\
\text { trzeby pacjenta } \\
\text { (np. w zakresie } \\
\text { stomatologii } \\
\text { estetycznej) }\end{array}$ & 0,4 & 4,9 & 9,9 & 34,9 & 50,7 & 4,32 & 5 & 5 & 0,84 \\
\hline $\begin{array}{l}\text { Dentysta powi- } \\
\text { nien rozmawiać } \mathrm{z} \\
\text { pacjentem o jego } \\
\text { problemach zdro- } \\
\text { wotnych i profi- } \\
\text { laktyce }\end{array}$ & 1,1 & 2,9 & 12,7 & 30,2 & 53,1 & 4,31 & 5 & 5 & 0,88 \\
\hline $\begin{array}{l}\text { Dentysta powi- } \\
\text { nien rozmawiać } z \\
\text { pacjentem jas- } \\
\text { nym językiem }\end{array}$ & 0,7 & 3,6 & 9,8 & 41,5 & 44,4 & 4,25 & 5 & 4 & 0,83 \\
\hline $\begin{array}{l}\text { Pracownicy gabi- } \\
\text { netu powinni być } \\
\text { schludnie ubrani }\end{array}$ & 1,1 & 2,6 & 10,0 & 46,5 & 39,8 & 4,21 & 4 & 4 & 0,81 \\
\hline $\begin{array}{l}\text { Dentysta nie po- } \\
\text { winien ,naciskać” } \\
\text { na pacjenta, aby } \\
\text { zdecydował się na } \\
\text { droższe leczenie }\end{array}$ & 3,7 & 7,0 & 11,5 & 31,1 & 46,7 & 4,10 & 5 & 4 & 1,09 \\
\hline $\begin{array}{l}\text { Dentysta powi- } \\
\text { nien zwracać się } \\
\text { do pacjenta per- } \\
\text { sonalnie (np. po } \\
\text { imieniu), a nie } \\
\text { bezosobowo }\end{array}$ & 5,5 & 17,6 & 33,1 & 26,1 & 17,6 & 3,33 & 3 & 3 & 1,12 \\
\hline $\begin{array}{l}\text { Gabinet powinien } \\
\text { przypominać o } \\
\text { terminie wizyty } \\
\text { SMSem }\end{array}$ & 17,8 & 27,9 & 21,6 & 20,8 & 11,9 & 2,81 & 2 & 3 & 1,28 \\
\hline
\end{tabular}

Zródło: opracowanie własne na podstawie przeprowadzonego badania.

Tabela 2.3.Ranking czynników skłaniajacych pacjenta do powrotu do gabinetu

\begin{tabular}{|c|c|c|c|c|c|c|c|c|c|}
\hline \multirow[b]{2}{*}{$\begin{array}{l}\text { Czynnik } \\
\text { decyzyjny }\end{array}$} & \multicolumn{5}{|c|}{$\begin{array}{c}\text { Wskazania respondenta } \\
\text { odpowiedzi) }\end{array}$} & \multirow[b]{2}{*}{$\bar{x}$} & \multirow[b]{2}{*}{ Do } & \multirow[b]{2}{*}{ Me } & \multirow[b]{2}{*}{$\mathbf{S}(\mathbf{x})$} \\
\hline & $\begin{array}{l}\text { na } \\
\text { pewno } \\
\text { nie } \\
(1) \\
\end{array}$ & $\begin{array}{l}\text { raczej } \\
\text { nie } \\
\text { (2) }\end{array}$ & $\begin{array}{l}\text { trudno } \\
\text { powie- } \\
\text { dzieć } \\
\text { (3) }\end{array}$ & $\begin{array}{l}\text { raczej } \\
\text { tak } \\
\text { (4) } \\
\end{array}$ & $\begin{array}{l}\text { na } \\
\text { pewno } \\
\text { tak } \\
(5) \\
\end{array}$ & & & & \\
\hline $\begin{array}{l}\text { Wiedza i kwali- } \\
\text { fikacje dentysty }\end{array}$ & 0,4 & 0,4 & 1,5 & 21,2 & 76,5 & 4,73 & 5 & 5 & 0,54 \\
\hline $\begin{array}{lr}\text { Zdolność } & \text { wyko- } \\
\text { nywania } & \text { świad- } \\
\text { czenia w } & \text { rzetelny } \\
\text { i dokładny } & \text { sposób }\end{array}$ & 0,0 & 0,0 & 2,9 & 26,5 & 70,6 & 4,68 & 5 & 5 & 0,53 \\
\hline $\begin{array}{l}\text { Zaufanie, jakie } \\
\text { wzbudza dentysta }\end{array}$ & 1,5 & 0,7 & 2,5 & 31,3 & 64,0 & 4,56 & 5 & 5 & 0,72 \\
\hline $\begin{array}{l}\text { Doświadczony } \\
\text { personel }\end{array}$ & 1,1 & 1,1 & 3,6 & 33,9 & 60,2 & 4,51 & 5 & 5 & 0,72 \\
\hline $\begin{array}{l}\text { Konieczność } \\
\text { dokończenia } \\
\text { leczenia }\end{array}$ & 0,0 & 5,3 & 6,1 & 27,8 & 60,8 & 4,44 & 5 & 5 & 0,83 \\
\hline
\end{tabular}




\begin{tabular}{|c|c|c|c|c|c|c|c|c|c|}
\hline $\begin{array}{l}\text { Nowoczesny } \\
\text { sprzęt }\end{array}$ & 0,4 & 1,5 & 7,1 & 35,7 & 55,3 & 4,44 & 5 & 5 & 0,73 \\
\hline $\begin{array}{l}\text { Uprzejmość per- } \\
\text { sonelu }\end{array}$ & 0,8 & 0,8 & 6,8 & 39,5 & 53,3 & 4,42 & 5 & 5 & 0,72 \\
\hline $\begin{array}{l}\text { Poczucie } \text { bez- } \\
\text { pieczeństwa, jakie } \\
\text { pacjent ma w } \\
\text { gabinecie }\end{array}$ & 2,2 & 4,7 & 6,2 & 31,3 & 55,6 & 4,33 & 5 & 5 & 0,95 \\
\hline $\begin{array}{l}\text { Dogodne terminy } \\
\text { wizyt }\end{array}$ & 1,5 & 4,8 & 7,7 & 35,5 & 50,5 & 4,29 & 5 & 5 & 0,91 \\
\hline $\begin{array}{l}\text { Szybkość reakcji } \\
\text { personelu n na } \\
\text { potrzeby pacjenta }\end{array}$ & 0,4 & 1,5 & 12,0 & 47,7 & 38,3 & 4,22 & 4 & 4 & 0,74 \\
\hline $\begin{array}{l}\text { Wyczerpująca } \\
\text { informacja } \\
\text { trakcie leczenia }\end{array}$ & 0,7 & 6,6 & 11,0 & 34,2 & 47,4 & 4,21 & 5 & 4 & 0,94 \\
\hline $\begin{array}{l}\text { Latwość w umó- } \\
\text { wieniu się na wi- } \\
\text { zyte (np. telefo- } \\
\text { nicznie, mailowo) }\end{array}$ & 2,6 & 9,2 & 6,6 & 33,2 & 48,3 & 4,15 & 5 & 4 & 1,06 \\
\hline $\begin{array}{l}\text { Umiejętność po- } \\
\text { zyskania zaufania } \\
\text { pacjenta }\end{array}$ & 0,4 & 2,6 & 16,9 & 43,1 & 37,1 & 4,14 & 4 & 4 & 0,81 \\
\hline Przystepne ceny & 3,4 & 6,0 & 18,5 & 31,4 & 40,8 & 4,0 & 5 & 4 & 1,07 \\
\hline Renoma gabinetu & 2,6 & 8,6 & 16,8 & 33,6 & 38,4 & 3,97 & 5 & 4 & 1,06 \\
\hline $\begin{array}{l}\text { Podejmowanie } \\
\text { wysiłków przez } \\
\text { dentyste w celu } \\
\text { poznania } \\
\text { potrzeb }\end{array}$ & 0,4 & 5,7 & 21,5 & 43,8 & 28,7 & 3,95 & 4 & 4 & 0,87 \\
\hline $\begin{array}{l}\text { Punktualność } \\
\text { rozpoczynania } \\
\text { wizyt }\end{array}$ & 1,5 & 9,7 & 13,5 & 43,4 & 31,8 & 3,94 & 4 & 4 & 0,99 \\
\hline $\begin{array}{l}\text { Wygląd } \\
\text { nettrny i wew- } \\
\text { nętrzny podmiotu }\end{array}$ & 2,3 & 7,1 & 18,8 & 45,5 & 26,3 & 3,86 & 4 & 4 & 0,97 \\
\hline Niskie ceny usług & 3,8 & 15,4 & 20,3 & 28,6 & 32,0 & 3,7 & 5 & 4 & 1,18 \\
\hline $\begin{array}{l}\text { Duża różno- } \\
\text { rodność usług }\end{array}$ & 4,6 & 9,2 & 21,5 & 41,8 & 23,0 & 3,69 & 4 & 4 & 1,07 \\
\hline $\begin{array}{l}\text { Lokalizacja } \\
\text { gabinetu }\end{array}$ & 5,6 & 12,2 & 20,0 & 37,8 & 24,4 & 3,63 & 4 & 4 & 1,14 \\
\hline $\begin{array}{l}\text { Empatyczna } \\
\text { postawa dentysty }\end{array}$ & 4,7 & 7,4 & 31,0 & 34,1 & 22,9 & 3,63 & 4 & 4 & 1,06 \\
\hline $\begin{array}{l}\text { Regularne roz- } \\
\text { mowy dentysty z } \\
\text { pacjentem o jego } \\
\text { problemach zdro- } \\
\text { wotnych i profi- } \\
\text { laktyce }\end{array}$ & 6,4 & 18,0 & 28,1 & 27,0 & 20,6 & 3,37 & 3 & 3 & 1,18 \\
\hline Młody personel & 15,7 & 28,0 & 32,8 & 14,2 & 9,3 & 2,74 & 3 & 3 & 1,16 \\
\hline \begin{tabular}{lr}
\multicolumn{2}{l}{ Zabezpieczenie } \\
miejsc & parkin- \\
gowych & dla \\
pacjentów & przed \\
gabinetem &
\end{tabular} & 26,0 & 26,8 & 19,2 & 18,1 & 9,8 & 2,59 & 2 & 2 & 1,31 \\
\hline $\begin{array}{l}\text { Posiadanie karty, } \\
\text { stałego pacjenta" } \\
\text { (umożliwiajacej } \\
\text { np. 5\% zniżkę na } \\
\text { świadczenia) }\end{array}$ & 33,7 & 29,9 & 13,3 & 13,3 & 9,8 & 2,36 & 1 & 2 & 1,33 \\
\hline $\begin{array}{l}\text { Przypominanie } \\
\text { o terminie wizyty } \\
\text { SMSem }\end{array}$ & 25,4 & 26,5 & 16,8 & 12,7 & 8,6 & 2,32 & 1 & 2 & 1,31 \\
\hline $\begin{array}{l}\text { Wykorzystywa- } \\
\text { nie gadżetów } \\
\text { reklamowych (np. } \\
\text { długopisów, } \\
\text { kalendarzy) }\end{array}$ & 41,0 & 38,3 & 12,4 & 5,6 & 2,6 & 1,91 & 1 & 2 & 1,00 \\
\hline $\begin{array}{l}\text { Leczenie się „u } \\
\text { rodziny” }\end{array}$ & 60,2 & 19,9 & 8,4 & 4,6 & 6,5 & 1,76 & 1 & 1 & 1,19 \\
\hline
\end{tabular}

Źódło: opracowanie własne na podstawie przeprowadzonego badania. 
Tabela 2.4. Opinie pacjentów na temat personelu gabinetu

\begin{tabular}{|c|c|c|c|c|c|c|c|c|c|}
\hline \multirow[b]{2}{*}{$\begin{array}{l}\text { Wyszczegól- } \\
\text { nienie }\end{array}$} & \multicolumn{5}{|c|}{$\begin{array}{c}\text { Wskazania respondentów } \\
\text { (procent odpowiedzi) }\end{array}$} & \multirow[b]{2}{*}{$\bar{x}$} & \multirow[b]{2}{*}{ Do } & \multirow[b]{2}{*}{ Me } & \multirow[b]{2}{*}{$\mathbf{S}(\mathbf{x})$} \\
\hline & $\begin{array}{l}\text { na } \\
\text { pewno } \\
\text { nie } \\
(1)\end{array}$ & $\begin{array}{l}\text { raczej } \\
\text { nie } \\
\text { (2) }\end{array}$ & $\begin{array}{l}\text { trudno } \\
\text { powie- } \\
\text { dzieć } \\
\text { (3) }\end{array}$ & $\begin{array}{l}\text { raczej } \\
\text { tak } \\
\text { (4) }\end{array}$ & $\begin{array}{l}\text { na } \\
\text { pewno } \\
\text { tak } \\
(5)\end{array}$ & & & & \\
\hline $\begin{array}{l}\text { Zawsze jestem } \\
\text { traktowany z sza- } \\
\text { cunkiem przez } \\
\text { pracowników }\end{array}$ & 1,4 & 1,4 & 8,0 & 40,9 & 48,2 & 4,33 & 5 & 4 & 0,8 \\
\hline $\begin{array}{l}\text { Pracownicy } \\
\text { życzliwie traktują } \\
\text { moje sugestie i } \\
\text { uwagi }\end{array}$ & 1,1 & 4,0 & 16,4 & 47,4 & 31,0 & 4,03 & 4 & 4 & 0,86 \\
\hline $\begin{array}{l}\text { Pracownicy w } \\
\text { sposób rzetelny } \\
\text { przedstawiają mi } \\
\text { korzyści, których } \\
\text { dostarczy mi } \\
\text { określona usługa }\end{array}$ & 1,5 & 9,6 & 16,9 & 46,3 & 25,7 & 3,85 & 4 & 4 & 0,96 \\
\hline $\begin{array}{l}\text { Dentysta zawsze } \\
\text { stara się znaleźć } \\
\text { wariant oferty naj- } \\
\text { lepiej dopasowany } \\
\text { do potrzeb pacjen- } \\
\text { ta (medycznie, fi- } \\
\text { nansowo, } \\
\text { czasowo) }\end{array}$ & 1,8 & 6,5 & 21,7 & 44,9 & 25,0 & 3,85 & 4 & 4 & 0,93 \\
\hline $\begin{array}{l}\text { Pracownicy potra- } \\
\text { fią w jasny sposób } \\
\text { przekazać pacjent- } \\
\text { towi wiedzę doty- } \\
\text { czącą specyfiki } \\
\text { usługi }\end{array}$ & 2,2 & 8,5 & 16,2 & 48,3 & 24,7 & 3,85 & 4 & 4 & 0,96 \\
\hline $\begin{array}{l}\text { Pracownicy gabi- } \\
\text { netu zachęcają } \\
\text { pacjenta do peł- } \\
\text { nego opisania po- } \\
\text { trzeb związanych } \\
\text { z usługą }\end{array}$ & 2,6 & 18,7 & 26,0 & 35,5 & 17,2 & 3,46 & 4 & 4 & 1,06 \\
\hline $\begin{array}{l}\text { Stomatologa inte- } \\
\text { resują tylko zęby } \\
\text { pacjenta (a nie on } \\
\text { jako człowiek) }\end{array}$ & 10,8 & 25,7 & 32,8 & 20,9 & 9,7 & 2,93 & 3 & 3 & 1,13 \\
\hline $\begin{array}{l}\text { Gdyby stomato- } \\
\text { log wiedział o } \\
\text { pacjencie więcej, } \\
\text { ich relacje byłyby } \\
\text { bardziej korzystne }\end{array}$ & 13,8 & 28,4 & 38,1 & 13,8 & 6,0 & 2,70 & 3 & 3 & 1,06 \\
\hline $\begin{array}{l}\text { Pracownicy gabi- } \\
\text { netu poświęcają } \\
\text { więcej czasu na } \\
\text { to, aby skłonić } \\
\text { pacjenta do sko- } \\
\text { rzystania z usługi, } \\
\text { niż na dosiady- } \\
\text { waniu się o jego } \\
\text { potrzebach }\end{array}$ & 12,7 & 39,2 & 28,4 & 14,2 & 5,6 & 2,61 & 2 & 2 & 1,06 \\
\hline $\begin{array}{l}\text { Czasem czuję się } \\
\text { bezradny wobec } \\
\text { postawy dentysty } \\
\text { dotyczącej } \\
\text { drogiego leczenia }\end{array}$ & 18,9 & 36,3 & 23,3 & 18,9 & 2,6 & 2,50 & 2 & 2 & 1,08 \\
\hline $\begin{array}{l}\text { Stomatologa } \\
\text { interesują tylko } \\
\text { pieniądze pacjenta } \\
\text { (a nie jego proble- } \\
\text { my zdrowotne) }\end{array}$ & 25,3 & 40,1 & 23,8 & 7,1 & 3,7 & 2,24 & 2 & 2 & 1,03 \\
\hline
\end{tabular}

Źródło: opracowanie własne na podstawie przeprowadzonego badania 
